\title{
LUIZA YABIKU
}

\section{PEDESTRE:}

MODALIDADE DE TRANSPORTE NA CIDADE UMA VISÃO ERGONÔMICA 


\section{LUIZA YABIKU}

\section{PEDESTRE:}

\section{MODALIDADE DE TRANSPORTE NA CIDADE UMA VISÃO ERGONÔMICA}

Tese apresentada à Faculdade de Arquitetura e Urbanismo da Universidade de São Paulo, para obtenção do Título de Doutor em Arquitetura e Urbanismo.

Área de Concentração: Tecnologia da Arquitetura

Orientador: Prof. Dr. José Jorge Boueri 
AUTORIZO A REPRODUÇÃO E DIVULGAÇÃO TOTAL OU PARCIAL DESTE TRABALHO, POR QUALQUER MEIO CONVENCIONAL OU ELETRÔNICO, PARA FINS DE ESTUDO E PESQUISA, DESDE QUE CITADA A FONTE.

\section{ASSINATURA:}

E-MAIL: luizayabiku@uol.com.br

Yabiku, Luiza

Y12m Pedestre: modalidade de transporte na cidade, uma visão ergonômica / Luiza Yabiku. - - São Paulo, 2006. 423 p. : il.

Tese (Doutorado - Área de Concentração: Tecnologia da Arquitetura) - FAUUSP.

Orientador: José Jorge Boueri Filho.

1. Circulação de pedestres 2. Ergonomia 3. Calçadas 4. Acidentes de trânsito I. Título 


\section{DEDICATÓRIA}

Dedico este trabalho aos meus filhos Ceci e Ubiratan, meus inesgotáveis fontes de energia. Aos meus pais (in memorian), a minha irmã Nina (in memorian) e ao meu amigo Eng ${ }^{\circ}$ Alberto Luiz Otero Reys (in memorian), pelos incentivos em vida e valiosas inspirações eterna. 


\section{AGRADECIMENTOS}

Ao professor e orientador:

Prof. Dr. Arqº JOSÉ JORGE BOUERI,

Pela valiosa orientação científica e metodológica e a confiança depositada em mim.

Aos professores:

Dra. ANDREINA NIGRIELLO

Dra. ÉLIDE MONZEGLIO (in memorian)

Dr. GERALDO GOMES SERRA

Dr. JOÃO BEZERRA DE MENEZES

Dr. NILSON FRANCO MARTINS

Pelo incentivo e colaboração.

Aos funcionários da FAUUSP, em especial da Secretaria e das Bibliotecas.

Ao Arq. e Adv. JOSÉ IGNACIO SEQUEIRA DE ALMEIDA,

Pela valiosa colaboração com a revisão de textos, preciosos comentários e sugestões.

À Prefeitura Municipal de São Paulo:

Eng. MARCO ANTONIO ROMANO

Eng. RUI VILANI

À CET - Companhia de Engenharia de Trânsito de São Paulo:

Eng LUIS ÁLVARO DE TOLEDO BARROS JR.

Eng SUN HSING MING

Eng. PAULO S. CARDONE

Eng. WAGNER PALHARES

Arq ${ }^{a}$ NANCY REIS SCHNEIDER

Arq ${ }^{a}$ KATIA MOHERDAUI VESPUCCI

Eng $^{\circ}$ PAULO SEITI UETA

À DERSA - Desenvolvimento Rodoviário S. A.

Analista de Documentação Sra CARMEM TONIOLO

À ABRASPE - Associação Brasileira de Pedestres:

Eng JOSÉ EDUARDO DAROS

Á ABRAMET - Associação Brasileira de Medicina de Tráfego:

DI MARCO ANTONIO PIRITO

Dra. MARIA BRUNETTI KAISER PIRITO

Dr ALBERTO SABBAG

Ao METRO - Companhia do Metropolitano de São Paulo:

Arqa. JEANE METRAN

Aos meus apoios técnicos:

JULIANA NAKAMURA

REINALDO TOSHINARU SHIRAI

Pela inestimável colaboração.

E a todos os familiares, amigos e colegas, pelo incentivo nas horas mais amargas. 


\title{
PEDESTRE: \\ MODALIDADE DE TRANSPORTE NA CIDADE UMA VISÃO ERGONÔMICA
}

\begin{abstract}
RESUMO
Esta tese tem por objetivo verificar a aplicabilidade da metodologia proposta pelo HCM-2000 (Highway Capacity Manual/ano 2000) para a determinação dos Níveis de Serviço nas Instalações para Pedestres. A tese apresenta a avaliação da qualidade de serviço das instalações para pedestres como instrumento que possibilite a inserção da escala do pedestre dentro da escala dos projetos viários e urbanos.

A visão ergonômica (o ajuste das instalações para o ser humano) é fundamental para a caracterização da escala do pedestre. A metodologia tem a sua aplicabilidade comprovada, com o estudo de caso na cidade de São Paulo. O campo experimental da pesquisa foi a Zona Leste de São Paulo, devido as suas peculiaridades de espaço com potencial de ocupação e adensamento, com conseqüente exposição de pedestres aos acidentes.

Com base nesta tese foram levantadas oito proposições para a cidade de São Paulo, que fazem parte deste trabalho.
\end{abstract}

\section{PEDESTRIAN: \\ A MEAN OF TRANSPORTATION IN THE CITY AN ERGONOMIC VIEW}

\begin{abstract}
This thesis purpose to verify the HCM 2000 (Highway Capacity Manual 2000) purposed methodology - which evaluates the pedestrian's facilities Level-of-Service in São Paulo city pedestrian' s facilities. This thesis also introduces an evaluation from Level-of-Service determinations as a mean to insert the pedestrian scale into the urban projects scales.

The ergonomics view (the human being's facilities adjustment) is essential to characterize the pedestrian scale. A study of case in São Paulo City confirmed this methodology appliance. This research took place in São Paulo's East Side due to its potential peculiarities and high density occupation, which expose the pedestrians to several hazardous of accidents.

Based in this research, there were elaborate eight proposals for São Paulo city.
\end{abstract}




\section{PEDESTRE: \\ MODALIDADE DE TRANSPORTE NA CIDADE UMA VISÃO ERGONÔMICA}

\section{SUMÁRIO}

\section{INTRODUÇÃO}

Cap. I ASPECTOS ERGONÔMICOS DO CAMINHAR

1. A FISIOLOGIA DO CAMINHAR

2. CARACTERÍSTICAS DOS PEDESTRES

3. PEDESTRES ESPECIAIS

4. O COMPORTAMENTO DO PEDESTRE NO ESPAÇO

URBANO

5. SÍNTESE DO CAPÍTULO

6. BIBLIOGRAFIA REFERENCIADA

I-89

Cap. II O PEDESTRE E A CIDADE

1. OS PASSOS DA CIVILIZAÇÃO

II-3

2. A LEGITIMAÇÃO DE PROPRIEDADE DO PEDESTRE

3. OS PASSOS DA LEGISLAÇÃO DAS CALÇADAS NA CIDADE DE SÃO PAULO.

4.TIPOLOGIA DAS CALÇADAS DE SÃO PAULO II-30

5. SÍNTESE DO CAPÍTULO

6. BIBLIOGRAFIA REFERENCIADA

Cap. III O PEDESTRE E A SEGURANÇA

1. O ATROPELAMENTO

III-4

2. CUSTO DE ACIDENTE COM PEDESTRE

III-32

3. MEDIDAS DE SEGURANÇA

III-36

4. SÍNTESE DO CAPÍTULO

III-53

5. BIBLIOGRAFIA REFERENCIADA

III-55

Cap. IV DESEMPENHO E NÍVEL DE SERVIÇO DAS

INSTALAÇÕES PARA PEDESTRES

1. CONCEITOS E DETERMINAÇÕES DE NÍVEL DE IV-4

SERVIÇO

2. CARACTERÍSTICAS DOS PEDESTRES

3. MEDIÇÃO DE DESEMPENHO E NÍVEL DE SERVIÇO

IV-10

4. ANÁLISE DE CAPACIDADE E NÍVEL DE SERVIÇO

IV-14

5. FORMULÁRIOS E MEMÓRIA DE CÁLCULO

IV-27

6. LIMITAÇÕES DA METODOLOGIA E CONSIDERAÇÕES

IV-51

EM RELAÇÃO AO TRÂNSITO DA CIDADE DE SÃO PAULO

7. SÍNTESE DO CAPÍTULO

IV-61

8. BIBLIOGRAFIA REFERENCIADA 
Cap. V ESTUDO DE CASO:

AVALIAÇÃO DE NÍVEL DE SERVIÇO E ADEQUAÇÃO ERGONÔMICA DAS INSTALAÇÕES PARA PEDESTRES NA CIDADE DE SÃO PAULO

1. SELEÇÃO DOS LOCAIS A SEREM ANALISADOS

2. PESQUISA E ANÁLISE DOS LOCAIS SELECIONADOS

3. SÍNTESE DO CAPÍTULO

4. BIBLIOGRAFIA REFERENCIADA

Cap. VI CONCLUSÕES E PROPOSTAS CONCLUSÕES

PROPOSTAS

\section{BIBLIOGRAFIA}

LISTA DE TABELAS

LISTA DE QUADROS

LISTA DE FIGURAS

LISTA DE GRÁFICOS

LISTA DE EQUAÇÕES 


\section{LISTA DE EQUAÇÕES}

\section{CAPÍTULO IV:}

Equação 1: Relação entre densidade, velocidade e o fluxo de pedestres $\quad$ IV- 7

Equação 2: Relação entre densidade, velocidade e espaço de pedestre $\quad$ IV-7

Equação 3: Cálculo do número de pedestre num pelotão $\quad$ IV- 24

$\begin{array}{ll}\text { Equação 4: Largura efetiva do passeio } & \text { IV- } 28\end{array}$

$\begin{array}{ll}\text { Equação 5: Cálculo de fluxo de pedestre } & \text { IV- } 32\end{array}$

Equação 6: Número total de bicicletas na mesma direção $\quad$ IV- 36

Equação 7: Cálculo do número total de eventos $\quad$ IV- 36

$\begin{array}{ll}\text { Equação 8: Tempo médio de espera numa travessia } & \text { IV- } 38\end{array}$

Equação 9: Cálculo de tempo-espaço disponível numa intersecção $\quad$ IV- 41

$\begin{array}{ll}\text { Equação 10: Cálculo de tempo de retenção } & \text { IV- } 42\end{array}$

Equação 11: Cálculo de tempo de espera na área de retenção IV- 42

Equação 12: Cálculo de tempo-espaço disponível IV-43

Equação 13: Cálculo de área de circulação para pedestre IV-43

$\begin{array}{ll}\text { Equação 14: Tempo-espaço de uma travessia } & \text { IV- } 43\end{array}$

Equação 15: Número de pedestres atravessando durante o intervalo do ciclo $\quad$ IV- 44

Equação 16: Cálculo de tempo total de travessia $\quad$ IV- 44

Equação 17: Cálculo de tempo total ocupado em travessia $\quad$ IV- 45

Equação 18: Cálculo do espaço de circulação por pedestre IV- 45

Equação 19: Cálculo de tempo-espaço ocupado por veículo em conversão IV- 45

$\begin{array}{ll}\text { Equação 20: Cálculo da brecha crítica para um pedestre } & \text { IV- } 47\end{array}$

$\begin{array}{ll}\text { Equação 21: Distribuição espacial de pedestres } & \text { IV- } 47\end{array}$

Equação 22: Tamanho de um típico pelotão de pedestre IV- 47 
Equação 23: Brecha crítica para um grupo

IV- 48

Equação 24: Tempo médio de espera para travessia

IV- 48

Equação 25: Velocidade média de caminhar numa seção inteira

IV- 49 


\section{LISTA DE FIGURAS}

TÍTULO

Pág.

\section{CAPÍTULO I:}

I- 1 Representação esquemática das fases de atividade dos membros I- 4 inferiores no decurso do duplo passo.

I- 2 Fases de apoio e de oscilação.

I- 6

I- 3 Pontos de aplicação dos esforços, na planta do pé.

I- 7

I- 4 Reações do piso no decurso do caminhar.

I- 10

I- 5 Movimentos do centro de gravidade no decurso de um caminhar

I- 12 normal.

I- 6 Relação de altura do quadril com a velocidade de progressão

I- 15

I- 7 Relação entre a altura do quadril e a retração dos membros inferiores. I- 15

I- 8 A subida por uma escada.

I- 19

I- 9 Modificações de atividades eletromiográficas no decurso de uma caminhada ascendente e descendente.

I- 10 Acesso em rampas para o desenho universal.

I- 22

I- 11 Força exercida pelo pé sobre o piso.

I- 24

I- 12 Coeficiente de atrito entre dois sólidos.

I- 25

I- 13 A elipse do corpo humano.

I- 29

I- 14 Envoltórias de preservação espacial.

I- 31

I- 15 Classificação das distâncias sociais.

I- 34

I- 16 Definição de zona de passo e zona sensorial. I- 35

I- 17 Definição de tempo de reação.

I- 18 Tipos de filas para pedestres. I- 39

I- 19 Área de ocupação em elevadores. I- 40

I- 20 Elipse do corpo e Zonas de proteção, em filas. I- 41

I- 21 Zona de contato. I- 41

I- 22 Zona de não contato. I- 42

I- 23 Zona de conforto pessoal. I- 42

I- 24 Zona de circulação livre. I- 43

I- 25 Dimensionamento para pessoas portando bagagens. I- 53

I- 26 Dimensionamento para pessoas portando equipamento de I- 54 acessibilidade.

I- 27 Travessia de pedestres. I- 57

I- 28 Ausência de pavimentação e calçadas. I- 58

I- 29 Calçadas estreitas. I- 58

I- 30 Calçadas em mal estado de conservação. I- 59

I- 31 Algumas placas de Sinais de Regulamentação. I- 77

I- 32 Ciclovia em via urbana, bem delimitada. I- 79

I- 33 Outra tomada da mesma ciclovia, acima citada. I- 79 


\section{CAPÍTULO II:}

II- 1 A Acrópole em Atenas. $\quad$ II- 5

II- 2 Edificação antiga com passagem para pedestre.

II- 3 Antigo bairro judeu. Cobertura para pedestres.

II- 4 Divisão da calçada em três faixas. II- 30

II- 5 Aplicação da divisão de calçada em área comercial. $\quad$ II- 31

II- 6 Aplicação da divisão de calçada em área residencial.

II- 7 Piso de concreto moldado in loco, estampado. II- 34

II- 8 Exemplo de pavimento em placa de concreto, "inteligente”. II- 35

II- 9 Exemplo de bloco de concreto intertravado. II- 36

II- 10 Exemplo de uma calçada em ladrilho hidráulico. II- 37

II- 11 Mosaico português em assentamento numa calçada a beira mar. II- 38

II- 12 Simulação de uma avenida sem interferência aérea. II- 41

II- 13 Simulação de uma rua sem os postes de fiação aérea II- 42

II- 14 Simulação de uma rua sem a interferência aérea.

II- 15 Simulação de uma via sem a fiação aérea, interferindo no II- 43 paisagismo.

II- 16 Perfil de uma via, com a galeria técnica no subsolo. II- 43

II- 17 Exemplo de uma galeria técnica (perfil circular). II- 43

\section{CAPÍTULO III:}

$\begin{array}{lll}\text { III- } 1 \text { Distância de Parada } & \text { III- } 8\end{array}$

III- 2 Plataforma ou prolongamento das calçadas III- 43

III- 3 Ilustração de um redutor de velocidade ("lombada” ou "rampa") tipo III- 45 I e II.

$\begin{array}{lll}\text { III- } 4 & \text { Sonorizador } & \text { III- } 47\end{array}$

III- 5 Almofadas III- 48

III- 6 Platôs ou Interseções Elevadas $\quad$ III- 50

III- 7 Ilustração de uma "chicana” urbana III- 51

III- 8 Estreitamento de pista, reduzindo a velocidade III- 51

III- 9 Ilustrações de mini rotatória e ilha ao longo da via. III- 52 


\section{CAPÍTULO IV:}

IV- 1 Elipse do corpo e área para caminhar requerido para um pedestre IV-10

a) Elipse do corpo do pedestre

b) Espaço requerido para o pedestre caminhar

IV- 2 Nível de Serviço numa via de pedestre

IV- 17

IV- 3 Nível de Serviço nas áreas de filas

IV- 18

IV- 4 Fluxo de pelotões ocorre quando pedestres se aglomeram para um

IV- 21 propósito

IV- 5 Larguras variáveis para obstáculos fixos

IV- 28

IV- 6

Intersecções em esquina e movimentos de pedestres

IV- 40

IV- 7

Condição 1: Travessia na rua não preferencial

IV- 40

IV- 8

Condição 2: Travessia na rua preferencial

IV- 41

IV- 9

Travessia de Pedestre Iluminada

IV- 65

IV- 10

Travessia com Segurança

IV- 66

IV- 11 Viaduto do Chá

IV- 66

IV -12

Passarela para Pedestres

IV- 67

IV- 13 Complexo de Passarelas

IV- 67

IV-14 Segregação de Pista para Pedestre

IV- 68

IV-15 Calçadão no Centro da Cidade

IV- 68

\section{CAPÍTULO V:}

V- 1 "Pontos de Articulação". RMSP. Julho/99 V- 5

V- 2 "Densidade Populacional, Emprego e Viagens". RMSP. Julho/99 V- 6

V- 3 "Densidade de Viagens por Motivo Não Residencial”. V-7 RMSP.Julho/99

V- 4 Localização dos "Pontos de Articulação”. RMSP. Julho/99 V-13

V- 5 "Pontos de Articulação". RMSP. Bolsão 3 e 4. Julho/99 V- 17

V- 6 Mapa de localização dos “campi” da USP, na Cidade de São Paulo V- 20

V- 7 Mapa da USP Leste, Gleba $1 \quad$ V- 20

V- 8 Mapa da USP Leste, Gleba $2 \quad$ V- 21

V- 9 Maquete do campus, Gleba $1 . \quad$ V- 21

V-10 Configuração geográfica do GET - $3 \quad$ V-23

V-11 Travessia de Pedestres na av. Alcântara Machado. Visão V-32 panorâmica.

V-12 Travessia de Pedestres na av. Alcântara Machado. Detalhe da V-33 travessia.

V-13 Esquema da travessia da av. Alcântara Machado. V- 34

V-14 Viaduto Guadalajara. Vista panorâmica. V- 36

V- 15 Viaduto Guadalajara. Detalhe da calçada. V- 36

V-16 Esquema da travessia do viaduto Guadalajara. V- 37 
V-17 Cruzamento das avenidas Celso Garcia e Salim F. Maluf. Visão V-40 panorâmica.

V-18 Cruzamento das avenidas Celso Garcia e Salim F. Maluf. Detalhe V- 40 1.

V-19 Cruzamento das avenidas Celso Garcia e Salim F. Maluf. Detalhe V- 41 2.

V- 20 Cruzamento das avenidas Celso Garcia e Salim F. Maluf. Detalhe V- 41 3.

V- 21 Esquema de travessia no cruzamento nas avenidas Celso Garcia e V-42 Salim Maluf

V- 22 Cruzamento da av. Alcântara Machado com a r. Hipódromo. Vista V-47 panorâmica.

V-23 Cruzamento da av. Alcântara Machado com a r. Hipódromo. V-47 Detalhe da travessia na av. Alcântara Machado.

V- 24 Cruzamento da av. Alcântara Machado com a r. Hipódromo. V-48 Detalhe 1.

V- 25 Cruzamento da av. Alcântara Machado com a r. Hipódromo. V-48 Detalhe 2.

V-26 Esquema da travessia na av. Alcântara Machado. V-49

V- 27 Viaduto Bresser. Vista panorâmica. V- 53

V- 28 Viaduto Bresser. Detalhe da travessia de pedestres V- 53/54

V- 29 Esquema de travessia no viaduto Bresser $\quad$ V- 54

V-30 Cruzamento das ruas Acurui/ Antônio de Barros/ Emília Marengo. V- 57 Vista panorâmica

V-31 Esquema das travessias no cruzamento das ruas Acurui/ Antônio V-57 de Barros/ Emília Marengo

V- 32 Ponte Tatuapé. Vista panorâmica. $\quad$ V- 61

V- 33 Ponte Tatuapé. Detalhe da calçada. V- 61

V-34 Esquema de travessia da ponte do Tatuapé. V- 62

V- 35 Travessia da rua Montesima. Cabeceira Água Rasa. V- 65

V- 36 Travessia da rua Montesima. Cabeceira Vila Prudente. V- 65

V- 37 Travessia da rua Montesima. Detalhe $1 . \quad$ V-66

V- 38 Travessia da rua Montesima. Detalhe 2. V-66

V- 39 Esquema da travessia da rua Montesima. $\quad$ V- 67

$\begin{array}{lll}\text { V- } 40 \text { Ponte Aricanduva. Vista panorâmica. } & \text { V- } 70\end{array}$

$\begin{array}{lll}\text { V- } 41 \text { Ponte Aricanduva. Detalhe da calçada. } & \text { V- } 70\end{array}$

V- 42 Ponte Aricanduva. Detalhe do retorno para pedestre. V-71

V-43 Ponte Aricanduva. Outro ângulo do detalhe do retorno para V-71 pedestres.

V- 44 Ponte Aricanduva. Detalhe da travessia no sentido bairro-centro. V- 72

V-45 Esquema da travessia na ponte Aricanduva. V- 72

V-46 Cruzamento das ruas Cantagalo com Gonçalo Nunes. Vista V-75 panorâmica.

V- 47 Cruzamento das ruas Cantagalo com Gonçalo Nunes. Detalhe. V- 75

V-48 Esquema das travessias no cruzamento das ruas Cantagalo com V-76 Gonçalo Nunes

V- 49 Travessia na av. João XXIII. Vista panorâmica. $\quad$ V- 80

V- 50 Travessia na av. João XXIII. Detalhe da travessia. $\quad$ V- 80

V- 51 Travessia na av. João XXIII. Outro ângulo. V- 81 
V-52 Esquema da travessia na av. João XXIII.

V-53 Travessia no cruzamento das ruas Amador Bueno da Veiga e V- 84 Maria Carlota.

V-54 Travessia no cruzamento das ruas Amador Bueno da Veiga e V-84 Maria Carlota.

Outro ângulo.

V-55 Esquema de travessia das ruas Amador Bueno da Veiga e Maria V- 85 Carlota

V- 56 Travessia das ruas Amador Bueno da Veiga, Izabel e Samuel V- 88 Jorge Ribeiro.

Vista panorâmica.

V-57 Travessia das ruas Amador Bueno da Veiga, Izabel e Samuel V- 89 Jorge Ribeiro.

Detalhe 1.

V-58 Travessia das ruas Amador Bueno da Veiga, Izabel e Samuel V- 89 Jorge Ribeiro.

Detalhe 2

V-59 Travessia das ruas Amador Bueno da Veiga, Izabel e Samuel V-90 Jorge Ribeiro.

Ãngulo de Visão da rua Izabel.

V-50 Travessia das ruas Amador Bueno da Veiga, Izabel e Samuel V-90 Jorge Ribeiro.

Visão da rua Samuel Jorge Ribeiro.

V- 61 Esquema das travessias das ruas Amador Bueno da Veiga. Izaabel V-91 e Samuel Jorge Ribeiro.

V-62 Viaduto Cangaíba. Vista geral. V-95

V-63 Viaduto Cangaíba. Vista do viaduto e a passagem de pedestre. V-96

V- 64 Viaduto Cangaíba. Detalhe da ocupação do entorno do viaduto. V-96

V- 65 Viaduto Cangaíba. Outro ângulo do viaduto. V- 97

$\begin{array}{lll}\text { V- } 66 & \text { Esquema da travessia do viaduto Cangaíba. } & \text { V- } 98\end{array}$

V- 67 Travessia de pedestre na av. São Miguel. Vista $1 . \quad$ V-100

V- 68 Travessia de pedestre na av. São Miguel. Vista $2 . \quad$ V-101

V- 69 Travessia de pedestre na av. São Miguel. Detalhe da vista $2 . \quad$ V- 101

V- 70 Esquema da travessia de pedestre na av. São Miguel/ r. Vigília/ r. V- 102 Luis Asson

V- 71 Travessia na av. São Miguel/r. Benfica de Minas/r. São Celso V- 104

V-72 Esquema de travessia na av. São Miguel/r. Benfica de Minas/ r. V-104 São Celso 


\section{LISTA DE GRÁFICOS}

CAPÍTULO I:

I- 1 Curva de crescimento: altura e peso. Sexo masculino, de 2 a $20 \quad$ I 66 anos de idade.

I- 2 Curva de crescimento: altura e peso. Sexo feminino, de 2 a $20 \quad$ I- 67 anos de idade.

\section{CAPÍTULO III:}

$\begin{array}{lll}\text { III- } 1 & \text { Relação entre a velocidade, fluxo e a densidade de pedestres } & \text { III- } 7\end{array}$

III- 2 Velocidade x Sobrevivência III- 12

III- 3 Distribuição das Mortes por Tipo de Usuário da Via, em 2005, no III- 20 Município de São Paulo

III- 4 Sexo das Vítimas de Acidentes de Trânsito em 2005. Município de III- 30 São Paulo

\section{CAPÍTULO IV:}

$\begin{array}{lll}\text { IV- } 1 & \text { Relação entre velocidade de pedestre e a densidade } & \text { IV- } 7\end{array}$

IV- 2 Relação entre fluxo de pedestres e espaço IV- 8

IV- 3 Relação velocidade de caminhar e o fluxo de pedestre IV- 9

IV- 4 Relação entre velocidade do pedestre e o espaço IV- 9

IV- 5 Distribuição típica da velocidade de caminhar num fluxo livre $\quad$ IV- 12

IV- 6 Fluxo de tráfego numa travessia: probabilidade de conflito IV- 15

IV- 7 Variação de fluxo de pedestre, minuto a minuto IV- 19

IV- 8 Relação entre pelotões e fluxo médio IV- 21

\section{CAPÍTULO V:}

V- 1 Distribuição das Mortes de Pedestres por GETs (2005) V- 18

V- 2 NS das Instalações para Pedestres próximos dos "Pontos de V- 119 Articulação" 


\section{LISTA DE QUADROS}

$\mathbf{N}^{\mathbf{o}}$

TÍTULO

Pág.

CAPÍTULO II:

II- 1 Critérios para a largura da calçada e da escolha do pavimento de II- 33 acordo com o tipo de via. 


\section{LISTA DE TABELAS}

\section{CAPÍTULO I:}

I- 1 Cadência de caminhar e comprimento de passos. I- 16

I- 2 Dimensionamento de rampas. I- 22

I- 3 Coeficiente de atrito estático (fs) e dinâmico (fa) e índices de I- 25 dureza de diferentes revestimentos.

$\begin{array}{lll}\text { I- } 4 \text { Redução da capacidade de visão por idade. } & \text { I- } 50\end{array}$

I- 5 Tempo necessário para um idoso fazer a travessia com segurança. I- 55

I- 6 Comportamento do pedestre em relação ao espaço disponível I- 81

\section{CAPÍTULO III:}

III- 1 Velocidade dos pedestres caminhando III- 5

III- 2 Velocidade de adultos correndo III- 5

III- 3 Velocidade de adultos correndo III- 5

III- 4 Média do fluxo livre de velocidade de pedestre $\quad$ III- 6

III- 5 Velocidade e distância de parada para veículo leve e pesado. III- 9 Asfalto rugoso e seco.

III- 6 Velocidade e distância de parada para veículo leve e pesado. III- 9 Asfalto rugoso e molhado.

III- 7 Velocidade e distância de parada para veículo leve e pesado. III- 9 Asfalto liso e seco.

III- 8 Velocidade e distância de parada para veículo leve e pesado. III- 10 Asfalto liso e seco.

III- 9 Número de Dias entre a Data da Ocorrência do Acidente e a Data III- 13 da Morte, em 2005, no Município de São Paulo.

III- 10 Lesões mais comuns em acidentes com pedestres. III- 13

ÍII- 11 Lesões causadas aos idosos no atropelamento. III- 15

III- 12 Circunstâncias de atropelamento de menores de 15 anos III- 16

III- 13 Situações dos menores, vítimas de atropelamento.

III- 14 Principais tipos de lesões encontrados nas necropsias de menores $\quad$ III- 17

III- 15 Intervalo de tempo ente o acidente e o óbito III- 18

III- 16 Evolução da Divisão modal, na região Metropolitana de São Paulo III- 19

III- 17 Distribuição Mensal das Mortes por Atropelamento, em 2005, III- 21 Município de São Paulo

III- 18 Distribuição das vítimas de acidentes de trânsito atendidas em III- 22 23/07 a 23/08/2001. PSIOT da HCFMUSP

III- 19 Distribuição de vítimas de acidentes de trânsito atendidas, por III- 23 gênero, em 23/07 a 23/08/2001. PSIOT da HCFMUSP. 
III- 20 Morte por atropelamento, nas regiões administrativas de São III- 24 Paulo, em retrospectiva anual

III- 21 Morte por atropelamento, por faixa etária, em 2002/2003/2004. III- 25

III- 22 Morte por atropelamento, por faixa etária e por região III- 26 administrativa, em 2004

III- 23 Morte por atropelamento, por faixa etária e por região III- 26 administrativa, em 2003.

III- 24 Morte por atropelamento, por faixa etária e por região III- 27 administrativa, em 2002.

III- 25 Morte por atropelamento, por ano, por nível de escolaridade. III- 28

III- 26 Morte por atropelamento, por ano, por sexo. III- 29

III- 27 População total do município de São Paulo, de 2000 a $2004 . \quad$ III- 29

III- 28 População total por grupo de idade e sexo, no município de São III- 29 Paulo, em 2004.

III- 29 Custo de um acidente, valores de abril de $2003 . \quad$ III- 33

III- 30 Custo de um acidente, valor de $1994 . \quad$ III- 34

III- 31 Distância de Visibilidade, numa rodovia, no período noturno. III- 35

\section{CAPÍTULO IV:}

IV- 1 Dados de entrada requeridos e valores representativos para IV- 22 pedestres

IV- 2 Largura representativa para calçadas

IV- 23

IV- 3 Raios de curvatura de esquinas representativos

IV- 23

IV- 4

Média de fluxo livre de velocidade de pedestre

IV- 25

IV- 5 Valores representativos para travessia

IV- 25

IV- 6 Nível de Serviço para volume de pedestres numa calçada

IV- 26

IV- 7 Largura de obstáculos nas calçadas

IV- 30

IV- 8 Critério de NS para fluxos médios em passeios e calçadas

IV- 32

IV- 9 Critérios de NS ajustados para pelotões em passeios e calçadas

IV- 33

IV- 10 Os critérios de NS para escadas

IV- 34

IV- 11

Critérios de NS para fluxo de pedestres em travessia

IV- 34

IV- 12

Critérios de NS para áreas de filas para pedestres

IV- 35

IV- 13

compartilhados

IV-14 NS para pedestres em intersecções sinalizadas

IV- 37

IV-15 NS para pedestres numa intersecção não sinalizada

IV- 38

IV-16 NS de calçadas para pedestres em ruas urbanas

IV- 49

IV-17 Programação sobre o tempo de vermelho intermitente para

IV- 50

pedestre

IV- 63 


\section{CAPÍTULO V:}

V- 1 Morte por atropelamento, nas regiões administrativas de São V-14 Paulo, em retrospectiva anual.

V- 2 Relação de "Pontos de Articulação" com Número de Mortos por V-15 Atropelamento.

V- 3 Estações de Metrô, compreendidas na região do GET $3 . \quad$ V- 24

V- 4 Estações de trem (CBTU) compreendido na região do GET $3 \quad$ V- 24

V- 5 Terminais de ônibus urbano, compreendido na região do GET 3. V- 24

V- 6 Relação de Centros Comerciais, compreendidos na região do GET V- 25 3

V- 7 Relação de “shoppings centers”, na região do GET $3 \quad$ V- 25

V- 8 Relação de Hipermercados, na região do GET $3 \quad$ V- 25

V- 9 Relação de Parques e Clubes, na região do GET $3 \quad$ V- 26

V-10 Relação de Faculdades e Universidades, na região do GET 3 V- 26

V-11 Relação de Hospitais, na região do GET 3 V- 27

V-12 Relação de Cemitérios, na região do GET $3 \quad$ V- 27

V-13 Correspondência entre "Pontos de Articulação" e locais com V- 28 complexidade no trânsito de pedestres.

V- 14 Cálculo de Tempo de Amarelo V- 30

V-15 Cálculo de Tempo de Vermelho Geral V- 30

V-16 Cálculo de Tempo de Verde de Segurança V- 30

V-17 Cálculo de Tempo Verde Mínimo de Travessia V- 31

IV- 8 Critério de NS para Fluxos Médios em Passeios e Calçadas V- 31

IV-14 NS para Pedestres em Interseções Sinalizadas V-31 


\section{PEDESTRE: \\ MODALIDADE DE TRANSPORTE NA CIDADE \\ UMA VISÃO ERGONÔMICA}

\section{INTRODUÇÃO}

A qualidade de vida no trânsito está ligada ao processo de construção da cidade, à criação do espaço urbano. A decisão do uso do solo é tomada pela atividade de planejamento urbano que define a forma da cidade. O tipo de uso do solo gerará deslocamentos, cuja natureza e quantidade serão função das características das habitações e sua população, área ocupada, densidade e renda de seus habitantes, quantidade e idades. A decisão fundamental que condiciona o padrão dos deslocamentos é gerada pelo uso do solo permitido. Os deslocamentos, conjunto de viagens e caminhadas, serão atendidos pelo sistema de transportes e trânsito viário.

O trânsito é uma organização dentro de uma dada sociedade, que administra interesses diversos e desigualdades surgidas, gerando um elemento básico inevitável: o Conflito. Há dois tipos de Conflitos. O Conflito Físico, pois o trânsito é uma disputa pelo espaço físico, na impossibilidade de se acomodar simultaneamente, no mesmo espaço, os movimentos gerados pelas atividades das pessoas, e que reflete uma disputa pelo tempo e acesso aos equipamentos urbanos. O Conflito Político, pois reflete os interesses diversos das pessoas no trânsito, que por sua vez estão ligados a sua posição no processo produtivo da cidade.

O Conflito também pode ser explicada pelo Movimento. O Movimento gera poluição sonora e atmosférica. Os Movimentos precisam ser ordenados, precisam de regulamentações, sinalizações, semáforos, etc, gerando a poluição ambiental. Analogamente otimizar o Movimento significa aumentar a velocidade do trânsito, 
facilitando a circulação dos veículos pelo sistema viário, o que aumenta a insegurança na circulação, principalmente para os pedestres, as crianças e os idosos.

Assim a qualidade de vida é afetada pela própria ocupação do espaço urbano e das conseqüências advindas pelos deslocamentos devido a essa ocupação.

A convivência pacífica entre as partes integrantes do Conflito é resgatar a qualidade de vida dos cidadãos.

As primeiras restrições ao trânsito conhecidas foram determinadas por Júlio César (que além de grande estrategista de guerras via-se obrigado a dedicar-se na administração do caótico e turbulento trânsito de Roma) que proibiu o tráfego de veículos com rodas no centro de Roma durante certas horas do dia. Em Roma também havia ruas de "mão única” e estacionamentos fora da via, especialmente construídos para as carroças.

No final do século XIX a invenção do automóvel e o aumento de sua circulação nas cidades trouxeram os primeiros problemas modernos de trânsito e, conseqüentemente a legislação a respeito. Assim, em 1868, em Londres surgiu o primeiro semáforo com as cores verde e vermelho. Em 1896, em Londres ocorreu o primeiro acidente fatal resultado de um atropelamento e em Nova York ocorreu em 1899.

A partir do século XX o trânsito vai generalizar-se como um problema urbano, à medida que as cidades crescem e o trânsito faz parte da questão urbana.

A mecanização das indústrias automobilísticas, reduzindo os custos, e a disponibilidade de combustível, tornou o automóvel acessível ao cidadão comum, deixando explícito o partido que o planejamento viário e urbano tomou.

O planejamento das cidades, os projetos de edificações, dos espaços públicos e dos sistemas viários e até os comércios, são levados a efeito pensando-se na funcionalidade dos veículos. 
Porém, ao raiar do século XXI, a prioridade é a inclusão social e o desenho universal. A escala humana deve ser levada em conta ao se projetar um equipamento, uma edificação ou planejar a cidade.

Inserir a escala humana num projeto de grande magnitude, como o planejamento urbano, é um desafio. Há várias metodologias a fim de cumprir esta finalidade.

Esta tese pretende apresentar a avaliação da qualidade de serviço das instalações para pedestres como instrumento que possibilite a inserção da escala do pedestre dentro da escala dos projetos viários e urbanos.

Para esta avaliação será testada e verificada a aplicabilidade da metodologia proposta pelo HCM-2000 (Highway Capacity Manual/ano 2000), de determinação dos Níveis de Serviço nas Instalações para Pedestres. São Paulo. O campo experimental da pesquisa foi a Zona Leste de São Paulo, devido as suas peculiaridades de espaço com potencial de ocupação e adensamento, com conseqüente exposição de pedestres aos acidentes.

Com a demonstração da validade do uso desta metodologia na avaliação de qualidade de serviço nas instalações para pedestres, pretende-se que os Níveis de Serviços sejam utilizados como parâmetros a serem levados em conta no planejamento urbano e viário, além de servir como avaliação de qualidade de vida dos cidadãos.

\section{RESUMO DA ESTRUTURA, CONTEÚDO E METODOLOGIA}

\section{CAPÍTULO I}

\section{ASPECTOS ERGONÔMICOS DO CAMINHAR}

\section{Conteúdo:}

Este capítulo apresenta o personagem central da tese: O Pedestre; e a sua principal atividade: $\mathrm{O}$ ato de Caminhar. Identifica o mecanismo do caminhar e suas correlações com o desempenho do pedestre. As percepções do espaço do pedestre, 
suas relações com o espaço do outro, o comportamento individual e o coletivo do pedestre no espaço urbano são discutidos, bem como são destacados os pedestres especiais, como os idosos e as crianças. Há ainda referências às crianças ciclistas, devido à grande presença destas junto às crianças pedestres.

\section{Metodologia:}

A pesquisa bibliográfica consistiu na coleta e compilação de diversas e importantes informações necessárias ao conhecimento da atividade caminhar. Foram pesquisados livros de Ergonomia, Engenharia e “sites” pertinentes a esse assunto.

\section{CAPÍTULO II}

\section{O PEDESTRE E A CIDADE}

\section{Conteúdo:}

Este capítulo apresenta breve revisão histórica sobre o pedestre na civilização ocidental, um resumo dos pensamentos de personalidades que advogam o direito de propriedade da cidade aos pedestres e uma retrospectiva da legislação pertinente a calçadas na cidade de São Paulo até a data recente, inclusive as novas propostas para as calçadas visando à acessibilidade universal.

\section{Metodologia:}

O material bibliográfico levantado possibilitou o registro técnico de diversos conceitos e pensamentos necessários à fundamentação dos estudos realizados. Uma investigação retrospectiva na legislação de São Paulo para o uso da calçada conduziu a importantes fatos e decisões, que culminam com o novo decreto sobre a calçada de desenho universal. 


\section{CAPÍTULO III}

\section{O PEDESTRE E A SEGURANÇA}

\section{Conteúdo:}

Este capítulo apresenta a anatomia do atropelamento e as condições para a sobrevivência, assim como o custo desses acidentes e as medidas mitigadoras para sua redução. São focalizados os atropelamentos com os pedestres idosos e crianças, assim como os índices retrospectivos de mortes por atropelamento no município de São Paulo. Dentro das medidas de segurança são apresentadas as propostas “Zona 30" e "Traffic Calming”.

\section{Metodologia:}

Neste capítulo a pesquisa bibliográfica atingiu vastas áreas, de engenharia de trânsito, aos boletins de acidentes e dissertações e teses sobre o assunto. Experiências internacionais foram consultadas a respeito das intervenções urbanas para diminuir a velocidade dos veículos no sistema viário.

\section{CAPÍTULO IV}

\section{DESEMPENHO E NÍVEL DE SERVIÇO DAS INSTALAÇÕES PARA}

\section{PEDESTRES}

Conteúdo:

Este capítulo apresenta o método de avaliação do nível de serviço para instalações para pedestres. Esta metodologia foi lançada no compêndio da Highway Capacity Manual, do ano 2000. Concomitantemente há inserções de pesquisas de outros autores, assim como as divergências com o sistema de gerenciamento de trânsito no 
município de São Paulo.

A implantação de uma instalação para pedestres não deve ser somente a expressão de uma política vertical, mas também visar atender as necessidades do público alvo. Projetar implica em instrumentalizar-se técnica e esteticamente, incluindo-se o ajuste ao cliente e uma avaliação crítica do seu uso e satisfação.

\section{Metodologia:}

Basicamente este capítulo estuda o Manual do HCM 2000, porém acrescentando os comentários pertinentes referidos ao Código de Trânsito Brasileiro e Sistema Operacional da Companhia de Engenharia de Trânsito de São Paulo.

\section{CAPÍTULO V}

\section{ESTUDO DE CASO}

\section{AVALIAÇÃO DE NÍVEL DE SERVIÇO E ADEQUAÇÃO ERGONÔMICA DAS INSTALAÇÕES PARA PEDESTRES NA CIDADE DE SÃO PAULO}

Conteúdo:

Este capítulo apresenta a pesquisa de avaliação de Nível de Serviço das Instalações para Pedestres, utilizando a pesquisa recomendada pelo HCM/2000. Concomitantemente foram levantadas avaliações de satisfação dos usuários das instalações, com pesquisa qualitativa direta. Foram analisadas e avaliadas as instalações e configuradas as considerações finais com recomendações elaboradas a partir deste experimento.

\section{Metodologia:}

O campo experimental da pesquisa foi a Zona Leste, selecionado a partir do cruzamento das informações sobre os "Pontos de Articulação” e suas localizações na 
Cidade de São Paulo e as mortes de Pedestres no Município de São Paulo. Para o conhecimento da área de interesse é elaborado um levantamento de dados sócioeconômicos, caracterização do seu sistema viário e pólos geradores de trânsito. Com o levantamento de pontos críticos para pedestres, elaborados pela Companhia de Engenharia de Trânsito de São Paulo, situados nas proximidades dos "Pontos de Articulação” é levado a efeito a pesquisa e análise de campo, com a metodologia preconizada pela HCM 2000 e com a pesquisa qualitativa sobre a satisfação do usuário das instalações para pedestres.

\section{CAPÍTULO VI}

\section{CONCLUSÃO E PROPOSTAS}

\section{Conteúdo:}

Este capítulo expõe as conclusões desta tese, elaboradas a partir do desenvolvimento dos capítulos anteriores. Com base nesta tese foram levantadas oito propostas para a cidade de São Paulo, que fazem parte deste capítulo.

\section{Metodologia:}

A partir das conclusões das análises do Nível de Serviço das instalações para pedestres e das pesquisas qualitativas foram elaboradas as conclusões e propostas. A metodologia da análise das instalações para pedestres pelo Nível de Serviço tem a sua aplicabilidade comprovada com o estudo de caso, na cidade de São Paulo. 


\section{CAPÍTULO I}

\section{ASPECTOS ERGONÔMICOS DO CAMINHAR}

Apresentação:

Este capítulo apresenta o personagem central da tese: O Pedestre; e a sua principal atividade: $\mathrm{O}$ ato de Caminhar. Identifica o mecanismo do caminhar e suas correlações com o desempenho do pedestre. As percepções do espaço do pedestre, suas relações com o espaço do outro, o comportamento individual e o coletivo do pedestre no espaço urbano são discutidos, bem como são destacados os pedestres especiais, como os idosos e as crianças. Há ainda referências às crianças ciclistas, devido à grande presença destas junto às crianças pedestres. 


\section{CAPITULO I}

\section{ASPECTOS ERGONÔMICOS DO CAMINHAR}

\section{Sumário:}

1. A FISIOLOGIA DO CAMINHAR

1.1 Progressão e Equilíbrio do Corpo

1.2 Fases da Atividade nos Membros Inferiores

1.3 O Caminhar nas Condições Variáveis

2. CARACTERÍSTICAS DOS PEDESTRES

2.1 Dimensões do Corpo Humano - A Elipse do Corpo

2.2 A Percepção Pessoal do Espaço - A Zona de Proteção do Corpo

2.3 Zonas Espaciais de Locomoção

2.4 Percepção Espacial em Filas

\section{PEDESTRES ESPECIAIS}

3.1 O Pedestre Idoso

3.1.1 O idoso e os acidentes

3.1.2 A idade legal da pessoa idosa

3.1.3 Antropometria dos idosos

3.1.4 O idoso caminhando

3.2 O Pedestre Criança

3.2.1 Período etário da criança

3.2.2 Antropometria da criança

3.2.3 Os pés e os calçados da criança

3.2.4 Fisiologia da criança

3.2.5 Orientação para um caminhar seguro da criança

3.2.6 A criança e a bicicleta.

4. O COMPORTAMENTO DO PEDESTRE NO ESPAÇO URBANO

5. SÍNTESE DO CAPÍTULO

6. BIBLIOGRAFIA REFERENCIADA 


\section{ASPECTOS ERGONÔMICOS DO CAMINHAR}

\section{A FISIOLOGIA DO CAMINHAR}

O conhecimento do pedestre inicia-se com o conhecimento do corpo humano. A capacidade de movimentação está intimamente relacionada com as dimensões físicas do corpo humano. A locomoção integra os movimentos do conjunto do corpo humano. $\mathrm{O}$ caminhar se expressa por fenômenos mecânicos cuja complexidade decorre da interação de todos os segmentos corporais.

O caminhar pode ser definido como um constante deslocamento, sustentada pela atividade alternada dos dois membros inferiores, com o tronco permanentemente em equilíbrio. Também pode ser reconhecido como uma contínua luta entre o equilíbrio e o desequilíbrio. Caminhar implica em movimentar um complexo sistema bio-neuromecânico, com perfeita interação entre nervos, músculos e sensores biológicos na retomada contínua do equilíbrio postural.

\subsection{Progressão e Equilíbrio do Corpo}

A fisiologia do caminhar é explicada tecnicamente por Scherrer em "Physiologie du travail" [SCHERRER(1967)], e Fruin em "Pedestrian, planning and design" [FRUIN(1971)], além de outros autores, citados no decorrer deste capítulo, cujos trabalhos serviram também para compor a presente abordagem.

O caminhar pode ser entendido como o deslocamento consistente, uma translação do conjunto do corpo. Resulta da atividade alternada dos dois membros inferiores conjugada com o equilíbrio dinâmico do tronco sobre a bacia. Mecanicamente essa alternância dos dois membros inferiores é compreendida como passos.

A figura abaixo (figura I-1) representa esquematicamente as fases dos passos. 


\section{Figura I-1. Representação esquemática das fases da atividade dos membros inferiores no decurso do duplo passo}

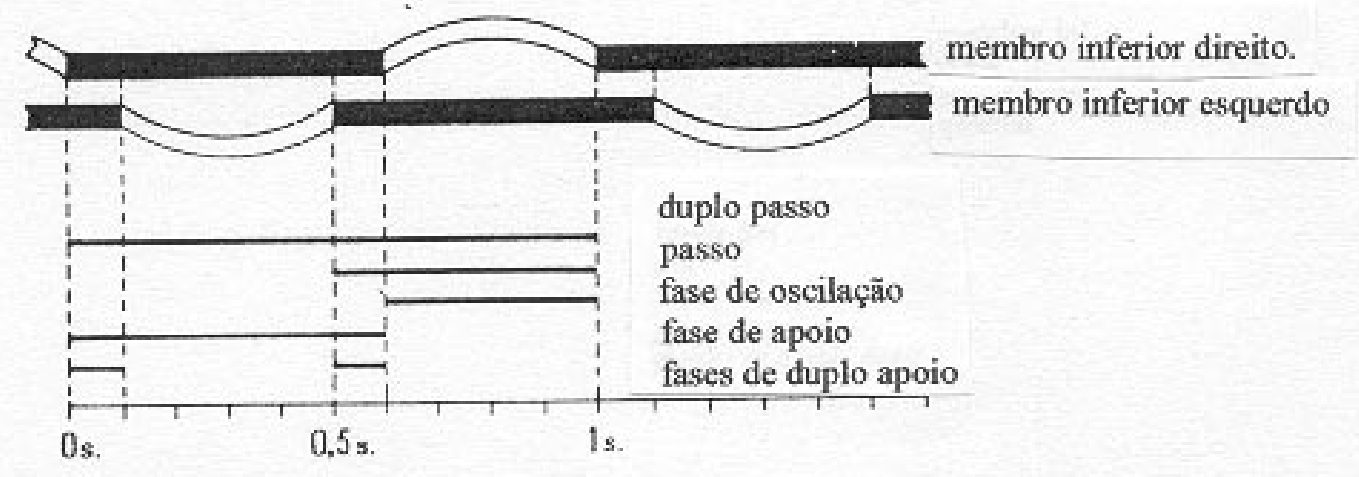

Fonte: J. Scherrer.”Physiologie du travail”. [SCHERRER(1967)]

No passo enquanto um dos pés sustenta o peso total do corpo (fase de apoio), o outro oscila e vai avançar sobre o lugar do precedente (fase de oscilação). Existe um lapso de tempo durante o qual os dois pés estão simultaneamente ocupando a fase de apoio (fase de duplo apoio). Esta é uma característica do caminhar dos bípedes e que diferencia o caminhar do correr.

O duplo passo é o intervalo de tempo no decurso do qual um dos membros inferiores apresenta uma fase de apoio e uma fase de oscilação, simplificando, o duplo passo é a repetição do fenômeno com o mesmo pé. Este é o período do fenômeno, quando as duas pernas retornam à mesma posição relativa ao início do fenômeno. Portanto, o passo simples, ou passo, não representa senão um semi-período.

O comprimento do passo é a distância que separa um ponto fixo do mesmo pé entre dois apoios sucessivos.

Para uma pessoa de 58,7 kg e 1,67 m de altura e comprimento de pernas de 0,87 $\mathrm{m}$, o caminhar no plano com uma cadência de 121 passos/minuto, aproximadamente 2,0 passos/segundo, com passos de $75 \mathrm{~cm}(0,75 \mathrm{~m})$ de comprimento, resulta numa velocidade média de $5,45 \mathrm{~km} / \mathrm{h}$ ou $1,5 \mathrm{~m} / \mathrm{s}$. 
$\overline{\text { No decurso do duplo passo a articulação coxo-femural é a responsável pelo avançar, que }}$ resulta na progressão do corpo no sentido do deslocamento, gerando os movimentos da articulação coxo-femural perturbam as condições de equilíbrio da bacia e das partes subjacentes. A progressão é acompanhada de movimentos complexos solicitados por exigência de ordem postural. Isto afeta particularmente o tronco, que mantém sua posição em relação à bacia, graças às oscilações nos diferentes planos do espaço.

O caminhar não pode ser executado sem que as exigências conjuntas da progressão e do equilíbrio sejam satisfeitas. Aqui entram as atividades dos músculos que, harmoniosamente, coordenam os segmentos corporais. Para isso eles necessitam da intervenção de mecanismos nervosos variados que, implicados na reação postural, devem asseguram os movimentos alternados dos membros inferiores.

\subsection{Fases da Atividade nos Membros Inferiores}

A atividade dos membros inferiores é descrita considerando a duração de um duplo passo (um período). Por convenção arbitrária, descrevem-se as fases iniciando o duplo passo com a fase de apoio do membro inferior direito.

\section{Fase de apoio.}

A fase de apoio do membro inferior direito começa no instante em que o calcanhar direito inicia contacto com o piso. Durante um curto intervalo de tempo os dois pés estão em contacto com o piso. É a primeira fase do duplo apoio, cuja duração é cerca de um quarto da duração da fase de oscilação e quando o membro inferior esquerdo começa oscilar, iniciando a fase aérea.

A perna direita está, neste instante, inclinada a 25 graus, em relação à sua vertical; o joelho está ligeiramente flexionado, assim como o tornozelo. (figura I-2) 
Figura I-2: Fases de apoio e de oscilação

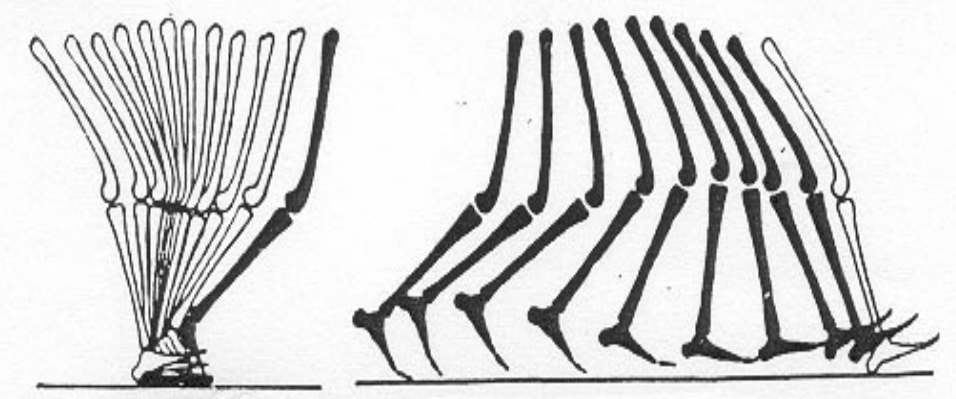

Fonte: J. Scherrer."Physiologie du travail". [SCHERRER(1967)] As posições sucessivas do membro inferior correspondente à fase de apoio estão representadas em branco, a fase de oscilação está em preto.

No decurso da fase de apoio, a perna exerce uma ação de frenagem seguida de uma ação de propulsão. A ação de frenagem aparece no momento que o calcanhar toca o piso, percorre verticalmente até o quadril passando pelo tornozelo; o joelho se estende e o quadril descreve uma curva de raio crescente e o corpo atinge sua altura máxima quando a perna passa para a posição vertical. Daí, até o pé inteiro tocar o piso, a perna se inclina progressivamente, exercendo, então, uma ação de propulsão.

Durante o período de frenagem, o apoio se faz sobre o calcanhar, ao redor do qual o membro inferior realiza seu deslocamento. O joelho acentua progressivamente sua extensão e os pés aplicam-se progressivamente sobre o piso. O quadril descreve, em conseqüência, uma curva de raio crescente e o corpo mantém a sua altura máxima quando o membro passa para a posição vertical.

Durante o período de propulsão, o apoio se desloca do calcanhar até a parte anterior do pé: o pé "se desenrola" do calcanhar à ponta dos dedos (figura I-3). A extensão do joelho determina a flexão da planta do pé. 
Figura I-3: Pontos de aplicação dos esforços, na planta do pé.

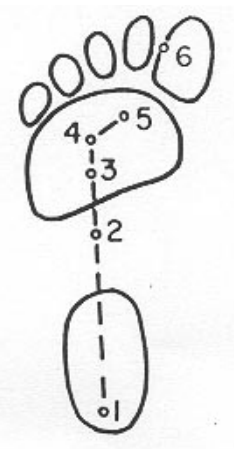

Fonte: J. Scherrer."Physiologie du travail". [SCHERRER(1967)]

$\mathrm{Na}$ fase de apoio, o pé se apóia a partir do calcanhar (1) ao dedão (6).

O joelho recomeça a flexionar quando a perna está inclinada a 25 graus e a extensão do tornozelo atinge cerca da metade de seu valor máximo. $\mathrm{O}$ alongamento da perna, que varia durante toda a duração da fase de apoio, passa por um máximo determinado, principalmente, pelo aumento do ângulo entre o pé e a perna.

A fase de apoio do membro inferior direito chega ao fim quando a ponta do pé direito deixa o piso. No mesmo instante termina a segunda fase de duplo passo, começando o fim da oscilação do membro inferior esquerdo, que tem a mesma duração que a primeira.

\section{Fase de oscilação}

A fase de oscilação começa quando a perna direita deixa o piso para oscilar, movendose para frente. O joelho direito, já ligeiramente flexionado quando a perna deixa o piso, acentua progressivamente sua flexão até o instante em que a coxa passa pela posição vertical.

Inicia-se a extensão do joelho, que estará completa no momento que a coxa avança para frente, com contração de suas flexões e está inclinada de 25 graus em torno da vertical. Quanto à articulação do tornozelo, ela passa da flexão dorsal para depois retomar pouco a pouco a sua posição inicial. Enfim, a articulação do quadril descreve uma curva 
ascendente, em seguida descendente e avança no comprimento do passo. A fase de oscilação chega ao fim quando o calcanhar direito retoma o contacto com o piso. A fase de oscilação é sempre menor que a fase de apoio.

Contrariamente à idéia corrente, os movimentos de oscilação dos membros inferiores não podem ser comparados aos do modelo pendular.

\section{Propulsão e frenagem}

Na locomoção, a força necessária à progressão provém de uma impulsão exercida pelo membro inferior (o membro inferior direito, por exemplo), no decurso do segundo período da fase de apoio. A impulsão é produzida pelo alongamento da perna sob efeito da contração dos músculos extensores. A reação é fornecida pelo piso, cujo atrito fixa o pé e permite que se faça o movimento do quadril com a perna em questão. Mais precisamente, o membro inferior oscilante (no exemplo o membro inferior direito), partilha com o tronco a quantidade de movimento que lhe será comunicada para a impulsão da perna em questão. Da inclinação progressiva desta última, em relação ao piso, resulta que, a partir de um dado instante, o centro de gravidade geral do corpo se projeta adiante da superfície de sustentação. O equilíbrio está comprometido e permanece enquanto a perna oscilante não retoma contato com o piso. É necessário que a quantidade de movimento devido à propulsão seja neutralizada. Uma ação de frenagem deve ser exercida para o membro esquerdo. Aqui, como vimos anteriormente, tem início a fase de apoio. O equilíbrio é restabelecido graças à inclinação, atrasando a perna esquerda. Os músculos extensores das pernas estão sempre ativos, mesmo nos movimentos lentos.

Assim, a progressão resulta de um jogo repetido de perda e recuperação do equilíbrio. 
O centro de gravidade do corpo deve manter-se acima da perna apoiada no piso. A análise mecânica detalhada tem sido difícil devido aos inúmeros segmentos corporais envolvidos e postos em jogo e às múltiplas forças agentes. Neste capítulo não é tratado o importante papel dos membros superiores, pertinente ao estudo das cadeias articulares, mas apresenta-se uma abordagem geral considerando o sistema de forças externas.

No caminhar é importante o efeito da força que o piso exerce sobre o corpo. O piso age como reação que se opõe à pressão sobre ele (tanto devido ao peso como pela ação muscular), e age sobre a massa corporal total.

Pode-se vê-los registrado graças à plataforma de forças. (figura I-4). Plataforma de forças é uma técnica de medição, constituída de uma plataforma na altura do piso que registra por meios elétricos as forças exteriores exercidas pelo piso e os pés.

A componente anterior-posterior ou sagital, da reação, também chamada de força de fricção, é particularmente importante, pois determina as condições de frenagem e da propulsão (o que possibilita a progressão), e, como conseqüência, os riscos de queda, comum como se verá adiante. Constata-se que ela oscila no decurso da fase de apoio, entre um valor negativo mínimo e um valor positivo máximo, da ordem de $-9 \mathrm{~kg} \mathrm{a}+9$ $\mathrm{kg}$ dentro do exemplo considerado. 
Figura I-4. Reações do piso no decurso do caminhar.

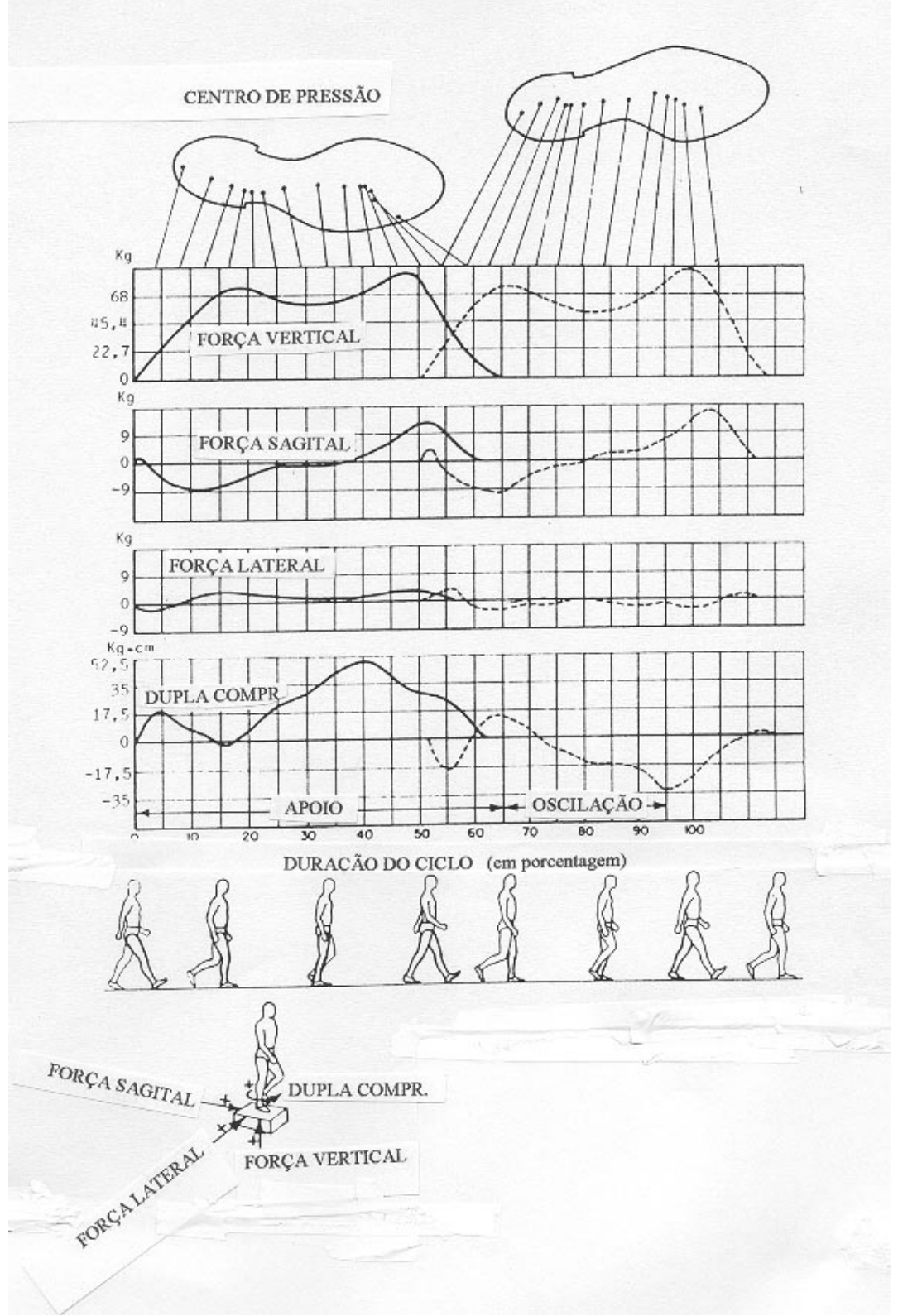

Fonte: J. Scherrer.”Physiologie du travail”. [SCHERRER(1967)]

A medida direta de todas as reações exercida pelo piso, dupla compressão, pode ser realizada graças a uma plataforma de forças. Marcam-se as reações durante o duplo passo. A força vertical oscila durante a fase de apoio simples ao redor do valor correspondente ao peso do corpo.

\section{Movimentos do corpo}

Os movimentos dos membros inferiores, que caracterizam a sucessão dos passos, complicam-se devido às oscilações dentro dos outros segmentos corporais. Com efeito, as forças de propulsão e de frenagem são transmitidas ao tronco por intermédio da 
articulação de quadril. O tronco, assim como a bacia, responde pelo movimento de rotação, exercendo ritmos dentro dos diferentes planos de espaço. O deslocamento do tronco perturba, por sua vez, as condições de equilíbrio da cabeça, que participa de todas as oscilações do tronco. Enfim, os braços se movimentam balançando, ação que corrige os efeitos da torção do tronco. O tronco age na oscilação regular, manifestandose nos planos sagital, frontal e transversal.

\section{Oscilações verticais.}

A subida do corpo é devida à componente vertical da força desenvolvida pelo membro inferior de apoio no momento de sua extensão. A descida do corpo, que a sucede, sobrevém devido à ação do peso, o qual pode ser mediado pelas extensões da perna de apoio. Estas oscilações verticais apresentam seu máximo e seu mínimo durante um passo simples.

\section{Oscilações laterais.}

No decurso de um duplo passo, o apoio do corpo é pressionado sucessivamente sobre um membro inferior depois sobre o outro. Portanto, para manter o centro de gravidade acima da base de sustentação, o tronco está sempre à direita ou à esquerda da linha mediana do corpo. Essas oscilações laterais são comunicadas ao tronco pela componente vertical devido à extensão do membro de apoio e existem no período da duração do duplo passo.

Movimentos de torção.

A rotação do tronco, dentro de um plano horizontal, é igualmente produzida pela inclinação dos membros de apoio: o membro inferior em fase de oscilação comunica à bacia uma rotação adiante e o membro inferior em fase de apoio comunica uma rotação atrasada. Estas rotações da bacia dentro do plano transversal são devidas, numa parte, à 
componentes horizontais, que se desenvolve dentro de período de propulsão e de frenagem; e por outra parte, pela produção da quantidade de movimento do membro inferior na fase oscilante. Na figura I-5 observa-se os planos dos movimentos, a partir do centro de gravidade geral.

\section{Figura I-5. Movimentos do centro de gravidade no decurso de um caminhar normal}
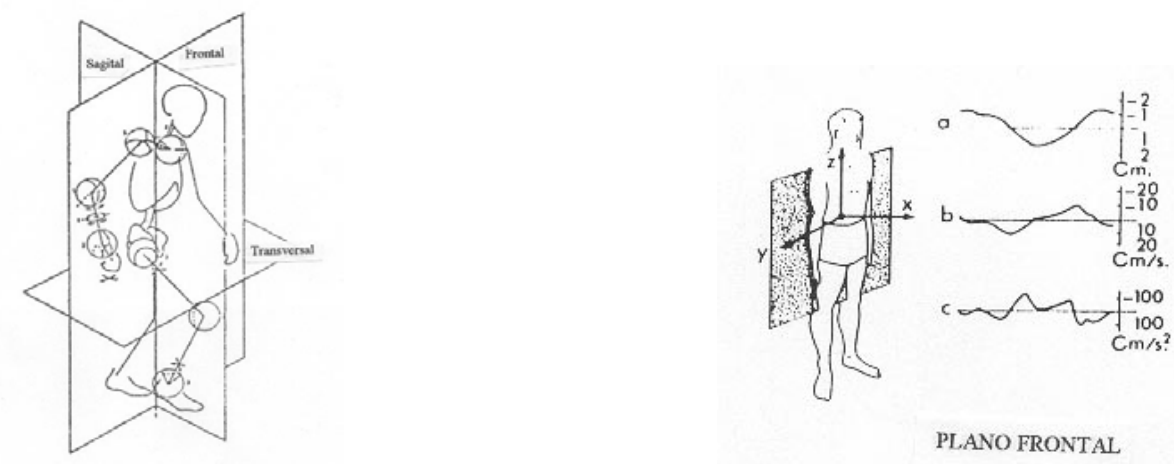

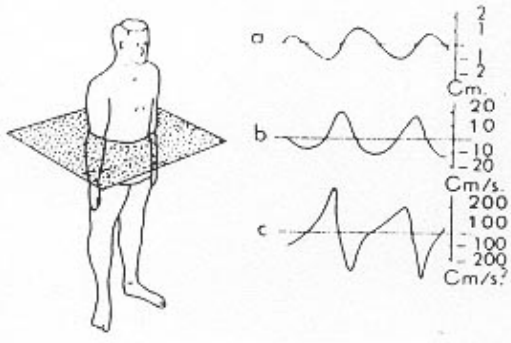

PLANO TRANSVERSAL

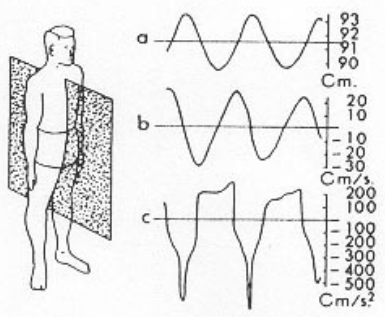

PLANO SAGITAL

Fonte: J. Scherrer.”Physiologie du travail”. [SCHERRER(1967)]

Fonte: J.Boueri,“Antropometria Aplicada à Arquitetura, Urbanismo e Desenho Industrial”. [BOUERI (1999)].

O deslocamento do centro de gravidade do corpo (a), sua velocidade (b) e sua aceleração (c) são representados por sua oscilação vertical (plano sagital), lateral (plano frontal) e antero-posterior (plano transversal). $\mathrm{O}$ deslocamento do centro de gravidade é deduzido do movimento dos diferentes segmentos corporais, registrados pela cronofotografia dentro de três planos de referência. As velocidades e acelerações são determinadas por meio de cálculos.

Para uma velocidade de progressão de $5,45 \mathrm{~km} / \mathrm{h}(1,5 \mathrm{~m} / \mathrm{s})$ e 121 passos/minuto $(2,0$ passos/s), as oscilações verticais têm uma amplitude de $0,04 \mathrm{~m}$, as oscilações laterais 


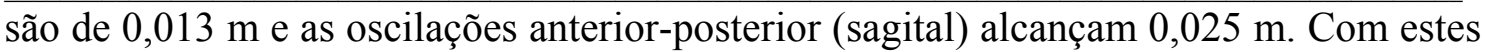
dados, pode-se calcular o trabalho mecânico efetuado a cada passo. Sendo aproximadamente $6 \mathrm{kgm}$ por passo para uma pessoa de $65 \mathrm{~kg}$, resulta em 0,09 $\mathrm{kgm} / \mathrm{pas} / \mathrm{kg}$ de peso corporal. $\mathrm{O}$ trabalho assim calculado é relativo àquela velocidade de progressão dada e à pessoa descrita. Para um passo de $0,78 \mathrm{~m}$ o trabalho mecânico é de mais de $7.700 \mathrm{kgm}$, efetuado para cada quilometro $(1.000 \mathrm{~m})$ percorrido.

Assim, em termos de calorias, no caminhar com velocidade normal, perde-se em torno de 100 cal por $1,6 \mathrm{~km}(1.600 \mathrm{~m})$ percorrido, ou perde-se $0,5 \mathrm{~kg}$ andando $56 \mathrm{~km}$ ou $56.000 \mathrm{~m}$ (35 milhas).

\section{Atividade muscular num caminhar normal}

Há vários músculos envolvidos no ato de caminhar, mas aqueles essenciais da locomoção são os do quadril, do joelho e do tornozelo.

A importância do estudo dos músculos é esclarecer os resultados da análise mecânica do duplo passo. Na transição das fases de oscilação e de apoio, seis dos sete grupos musculares considerados estão assentados na atividade elétrica (extensão do quadril, abdutor do quadril, adutor do quadril, flexão do joelho, extensão do joelho, extensão do tornozelo, flexão do tornozelo). Só o glúteo médio permanece ativo no meio da fase de apoio. Os demais músculos cessam de se contrair dentro do primeiro terço desta fase. A atividade dos músculos das extensões do tornozelo não começa senão no meio da fase de apoio. Eles constituem, dentre outros, o grupo mais ativo dentro da caminhar normal. $\mathrm{Na}$ transição entre as fases de apoio e de oscilação, os adutores da coxa manifestam certa atividade. No decurso da oscilação, o músculo tibial anterior contrai-se algumas vezes de forma enérgica. Interessante observar a existência de uma contração, que sobrevém das extensões do tronco ao início e ao fim da fase de apoio. 
A organização da atividade muscular, num caminhar normal, parece ser extremamente complexa, pelo fato de necessitar acumulação de progressão em equilíbrio, com inúmeros fatores suscetíveis de modificá-la. Particularmente: a velocidade de progressão, o peso carregado, e a natureza da inclinação do piso, como será visto adiante. Independentemente destas variações, uma característica de ordem geral deve ser sublinhada. A atividade muscular é periódica, mas relativamente descontínua no decurso do duplo passo. A descontinuidade é resultado da inércia das massas corporais que regularizam o movimento.

\subsection{O Caminhar nas Condições Variadas}

As características de caminhar, descritas anteriormente, são de caminhar normal no plano. Toda mudança interveniente no sistema de forças exteriores resulta em modificações, mais ou menos importantes, tanto sob a ótica de fenômenos mecânicos, quanto sob a natureza da atividade muscular. São os efeitos das variações da velocidade de progressão, das condições de equilíbrio corporal e a natureza do solo, que serão apresentados a seguir.

\section{Velocidade de progressão.}

O caminhar rápido distingue-se do caminhar lento pelo aumento de inclinação do tronco, pela diminuição das oscilações laterais do tronco e aumento de oscilações dos membros superiores. Estas modificações dos movimentos do corpo são, evidentemente, conseqüência das modificações da atividade dos membros inferiores. Constata-se também: redução do tempo de duplo apoio, aumento do comprimento do passo, da cadência (número de passos por minuto) e da velocidade. Estas modificações não são 
$\overline{\text { independentes uma das outras. Algumas delas estão ligadas à altura do quadril no }}$ decurso do movimento, a altura do quadril reduz-se no caminhar rápido.(figura I-6).

Figura I-6. Relação da altura do quadril com a velocidade de progressão.

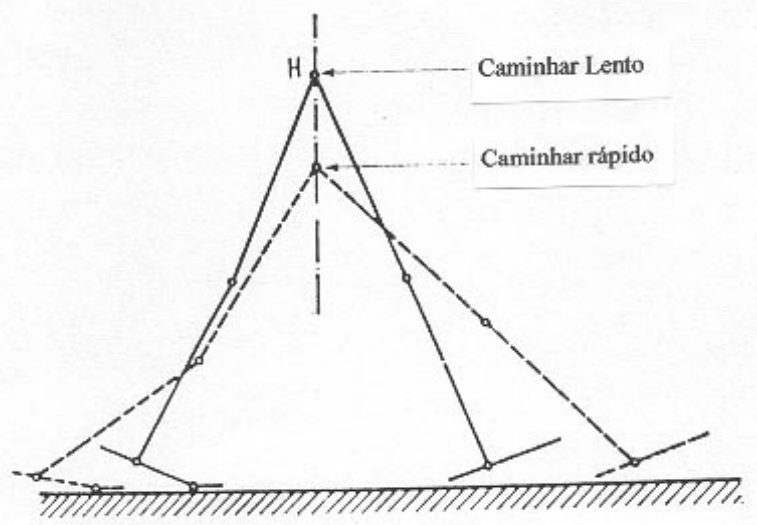

Fonte: J. Scherrer. "Physiologie du Travail". [SCHERRER(1967)]

Note-se que o caminhar mais rápido corresponde a altura do quadril $(\mathrm{H})$ mais baixo.

Quanto maior a redução da altura do quadril, maior a inclinação dos membros inferiores em relação ao piso, e maior o comprimento do passo (figura I-7). Assim, aumentando a inclinação do membro de apoio, inicia-se sua aceleração quando começa a oscilar. Em outras palavras, as forças de propulsão e de frenagem aumentam em razão da inclinação do membro inferior de apoio, aumentando a sua velocidade. O comprimento do passo aumenta com a cadência até alcançar 150 passos por minuto; em seguida tende a diminuir.

Figura I-7.Relação entre a altura do quadril e a retração dos membros inferiores.

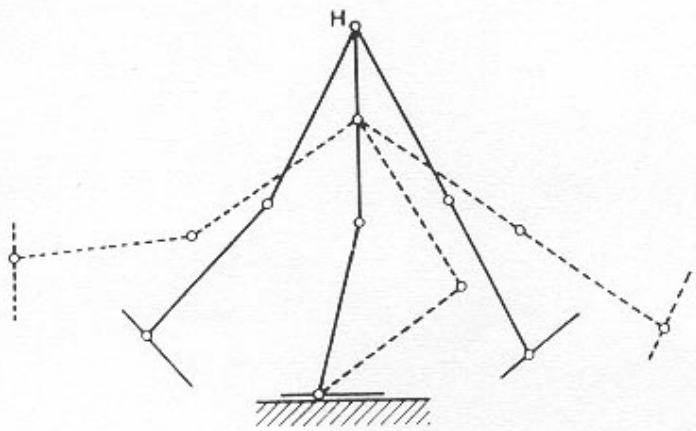

Fonte: J. Scherrer. “Physiologie du Travail”. [SCHERRER(1967)] 
$\overline{\text { Se não houver nenhum fato particular, a pessoa adota espontaneamente uma cadência } \mathrm{e}}$ um comprimento de passo que lhe são peculiares. A peculiaridade dos passos está sujeita a variações importantes (tabela I-1). Não depende somente das características antropométricas da pessoa, mas também da ausência ou não da fadiga (o comprimento do membro inferior, em particular), dos fatores psicológicos e étnicos. Em terreno plano e uniforme, a cadência ótima, medida em laboratório, é determinada entre $3,8 \mathrm{~km} / \mathrm{h}$ $(1,06 \mathrm{~m} / \mathrm{s})$ a $4,6 \mathrm{~km} / \mathrm{h}(1,28 \mathrm{~m} / \mathrm{s})$.

Há diferenças no caminhar observado em relação à idade e ao sexo do pedestre. As diferenças do caminhar entre homens e mulheres são devidas às proporções anatômicas de suas respectivas pélvis (ou quadris). A maior flexibilidade do quadril das mulheres, movendo para frente e para trás, resulta maior rotação, para um dado comprimento de passo. Com a idade, o efeito de redução do grau de rotação do quadril, tanto para o homem como para a mulher, reduz o comprimento do passo e assim também reduz a velocidade do caminhar.

Tabela I-1. Cadência de caminhar e comprimento de passos. Observações obtidas a partir de um grupo de 936 pessoas em Nova York.

\begin{tabular}{llcl}
\hline Cadência & $\begin{array}{l}\text { Limites } \\
(\text { Passos/min)* }\end{array}$ & $\begin{array}{l}\text { Participação Percentual } \\
\text { dentro da amostra }(\%)\end{array}$ & $\begin{array}{l}\text { Comprimento } \\
\text { dos passos }\end{array}$ \\
\hline Muito lento & $78,0-100,0$ & 10 & Muito curto \\
Lento & $100,1-107,0$ & 20 & Curto \\
Normal & $107,1-117,6$ & 40 & Normal \\
Rápido & $117,7-125,0$ & 20 & Longo \\
Muito rápido & $125,1-144,0$ & 10 & Muito longo \\
\hline
\end{tabular}

Média

112,5

Fonte: Scherrer. "Physiologie du Travail" [SCHERRER(1967)]

(*) Por ser medida em campo foi mantida a grandeza temporal em minutos. 


\section{Modificações das condições de equilíbrio corporal}

Quando as condições do equilíbrio estático do corpo são modificadas, há uma nova reorganização da massa corporal e das contrações musculares responsáveis pela postura. As características do caminhar serão modificadas por esta razão e eventualmente a velocidade de progressão será alterada.

O caminhar normal pode alterar-se com as seguintes interferências: tipo de calçado, carregamento de pesos e declividade do piso.

\section{Influência dos calçados.}

Os calçados influem no caminhar, devido ao salto do sapato, assim como a aderência da sola no piso e o peso próprio do calçado. A altura do salto modifica a atividade postural: quanto maior o salto do sapato, menor é a projeção horizontal do pé sobre o piso e há redução do desenvolvimento do pé no piso. O comprimento do passo diminui, igualmente pelo fato de a perna não se estender no início da fase de apoio.

A natureza da sola do sapato também influencia, pois as solas mais flexíveis favorecem o desenvolvimento das passadas. A flexibilidade do calçado, no calcanhar, também é importante, pois permite a mobilidade do tornozelo, elemento importante nos calçados de montaria e das botas.

O peso ou leveza do calçado interfere na fase de oscilação, quando a perna realiza seu movimento aéreo.

A aderência da sola no piso depende da qualidade de ambos (sola e piso).

Quando o coeficiente de atrito for maior que o componente horizontal da força de frenagem (ou propulsão), então há risco de derrapagem ou até de queda. 


\section{Interferência do carregamento de peso.}

A forma geral do passo permanece a mesma, porém o tempo de duração do passo é reduzido. Nota-se também a diminuição do comprimento do passo e acréscimo de tempo na fase de apoio, notadamente no duplo apoio. Quanto aos movimentos verticais, estes diminuem devido à redução do comprimento do passo. As outras oscilações dependem da modalidade do carregamento. Parecem ter pouco efeito pelo transporte sobre o ombro, pois a posição do centro de gravidade do conjunto é então pouco modificada. Sob este ponto de vista, o carregamento sobre o ombro é o mais favorável às pessoas. As medições comparativas de consumo de oxigênio confirmam este ponto de vista, o procedimento de carregamento mais energeticamente econômico repartir simetricamente a carga sobre os dois ombros.

Porém, na prática, é a característica dos carregamentos (dimensões, embalagens, peso, etc) que determinam o modo de carregá-los.

\section{Interferência da declividade do piso}

Aqui se avalia o desempenho do caminhar nas rampas e nas escadas.

Subir ou descer escada é bem diferente de caminhar no plano. A locomoção na escada é mais restrita devido aos riscos à segurança e às restrições impostas pelo comprimento e altura dos degraus. O consumo de energia para subir escada é cerca de 10 a 15 vezes maior que a energia necessária para andar na equivalente distância horizontal, e surpreendentemente cerca de 1/3 (um terço) maior para descer.

Quando subimos escada o centro de gravidade do corpo desloca-se para frente e a perna a frente é elevada, colocando-se no primeiro degrau para apoiar o corpo e preveni-lo de eventual queda à frente. Tanto a perna à frente como a outra fazem a propulsão, assim a ação de levantar a perna é coordenada numa combinação de esforços para ascender. A 
$\overline{\text { perna de trás é então levantada, movimentada e colocada no segundo degrau, seguindo- }}$ se com a repetição da ação.

Na descida, o centro de gravidade deve manter-se atrás, devido ao aumento de perigo de queda. $\mathrm{O}$ ato de descer requer menos energia que para subir e a velocidade para descer é cerca de 1/3 (um terço) maior que a velocidade necessária para subir, porém uma concentração maior é requerida no ato de descer para controlar a ação da gravidade sobre o corpo. Isso requer maior cuidado ao baixar o peso para apoiar o pé no degrau abaixo.

Uma oscilação do corpo em torno de $10 \mathrm{~cm}$ ocorre quando o peso é deslocado de um pé para o outro.

\section{Subir (ou descer) a escada}

A necessidade de deslocamento vertical do peso do corpo se traduz pela importante modificação da atividade dos membros inferiores, e dos movimentos que acompanham o corpo. Assim, a fase de duplo apoio é mais prolongada, assim como a fase de oscilação é menos ampla. As oscilações verticais do tronco desaparecem, salvo quando a velocidade do caminhar é rápida, mas há um exagerado balanço lateral do corpo (figura I-8).

Figura I-8. A subida por uma escada.

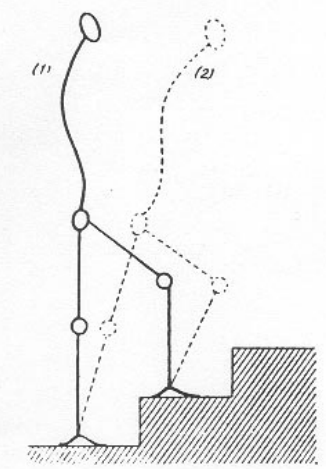

Fonte: Scherrer. "Physiologie du Travail" [SCHERRER(1967)]. 


\section{Subir (ou descer) uma rampa}

A rampa ou plano inclinado apresenta uma condição mista entre andar no plano e subir uma escada. O duplo apoio é mais prolongado, as oscilações do corpo são atenuadas. A inclinação do corpo exige uma atividade extra de sustentação, comparada à escada com mesma inclinação. A figura I-9 permite constatar importantes modificações relativas, que afetam os extensores dos joelhos e as flexões e as extensões dos pés (dados obtidos por observações por eletromiografia).

A eletromiografia é um procedimento utilizado para registrar um fenômeno elétrico que está relacionado com a contração muscular. A contração muscular e a produção de força são provocadas pela mudança relativa de posição de várias moléculas ou filamento no interior do arranjo muscular. O deslizamento destes filamentos é provocado por um fenômeno elétrico conhecido como potencial de ação. A eletromiografia consiste em registrar os padrões de mudança no potencial de ação. Este procedimento é muito aplicado na biomecânica, para determinar a ativação de determinados grupos musculares durante as diversas fases de uma tarefa motora; na análise da postura e de tarefas, com a determinação da fadiga muscular sendo uma poderosa ferramenta para estudos de ergonomia. 


\section{Figura I-9. Modificações de atividades eletromiográficas no decurso de uma caminhada ascendente e descendente.}
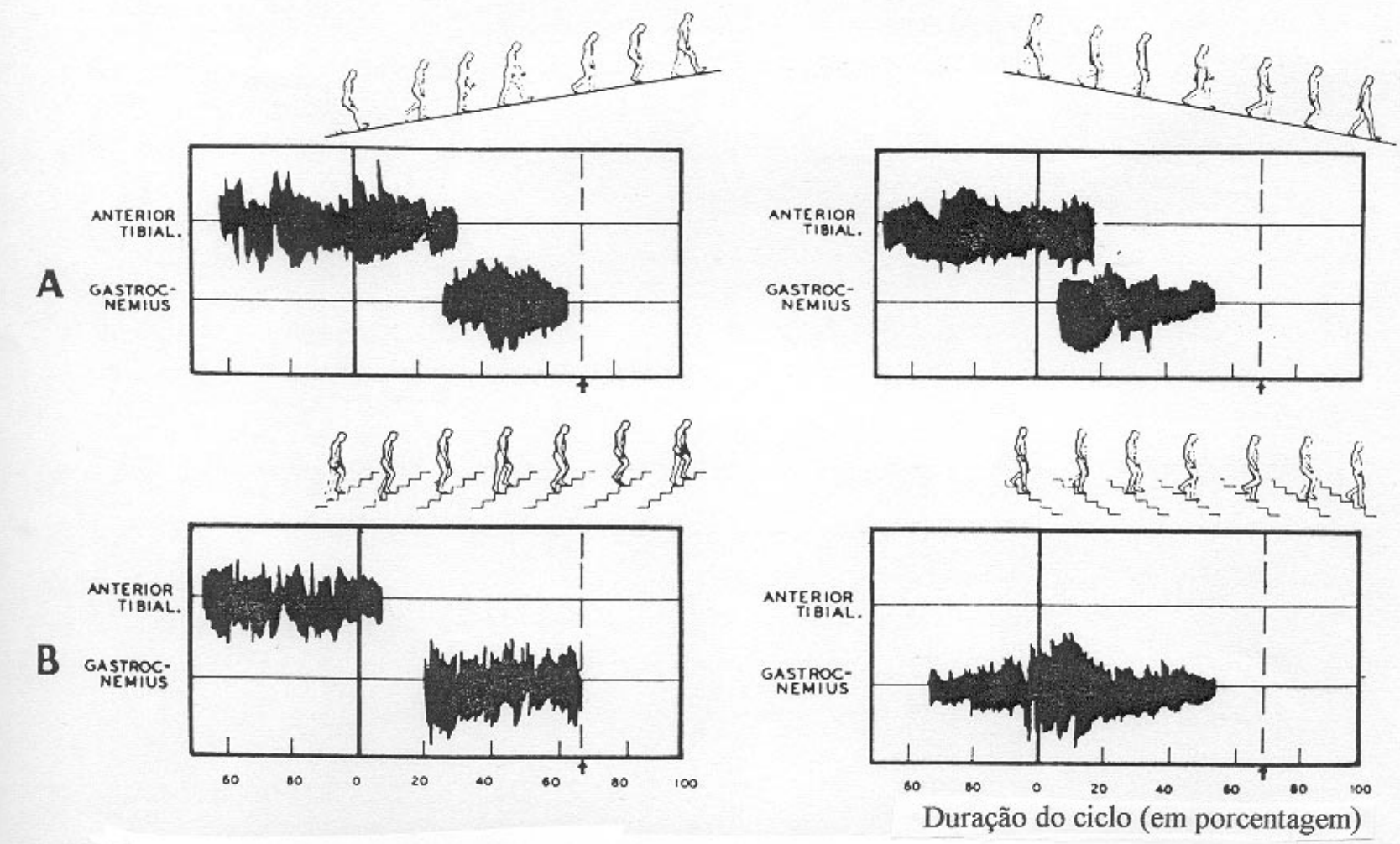

Fonte: J. Scherrer Physiologie du Travail [SCHERRER(1967)].

As atividades de flexão e extensão dos pés são comparadas para um caminhar sobre um plano inclinado (A) e sobre uma escada (B), ascendente e descendente. A inclinação é de $10^{\circ}$. A cadência é espontânea.

O ciclo começa com o início da fase de apoio e uma flecha marca o fim do processo.

A análise destes resultados sugere que:

a) Caminhada ascendente é mais penosa que caminhada no plano.

.b) As escadas são preferíveis aos planos inclinados, para um mesmo ângulo de inclinação.

O consumo de oxigênio confirma estas sugestões, que permitem fixar as características das escadas e dos planos inclinados para os quais o caminhar é mais produtivo. Para as 
escadas sugere-se $17 \mathrm{~cm}$ de altura para espelho e de $29 \mathrm{~cm}$ de profundidade para $\mathrm{o}$ degrau.

A NBR 9050/2004, que trata da acessibilidade de pessoas portadoras de deficiências [ABNT(2004)], propõe o uso de rampas, porém com declividades específicas, conforme o comprimento da rampa, como segue na tabela I-2.

Tabela I-2. Dimensionamento de rampas

\begin{tabular}{|c|c|c|c|}
\hline $\begin{array}{l}\text { Inclinação } \\
\text { admissível de cada } \\
\text { segmento de rampa } \\
(\%)\end{array}$ & $\begin{array}{l}\text { Desníveis máximos } \\
\text { de cada segmento } \\
\text { de rampas } \\
(\mathrm{m})\end{array}$ & $\begin{array}{l}\text { Números máximos } \\
\text { de segmentos de } \\
\text { rampas }\end{array}$ & $\begin{array}{c}\text { Comprimentos } \\
\text { máximos de cada } \\
\text { segmento de rampa } \\
(\mathrm{m})\end{array}$ \\
\hline $5,00 \quad(1: 20)$ & 1,500 & --- & 30,00 \\
\hline $6,25(1: 16)$ & 1,000 & 14 & 16,00 \\
\hline $8,33 \quad(1: 12)$ & 1,200 & 12 & 19,20 \\
\hline $10,00 \quad(1: 10)$ & 0,900 & 10 & 10,8 \\
& 0,274 & 08 & 2,74 \\
\hline $12,50 \quad(1: 8)$ & 0,500 & 06 & 7,00 \\
\hline
\end{tabular}

Fonte: NBR 9050. "Acessibilidade de pessoas portadoras de deficiências a edificações, espaço, mobiliário e equipamento urbano". [ABNT(2004)].

Para o desenho universal, segundo Panero [PANERO(1979)], recomenda-se como medida básica para uma rampa (figura I-10):

Figura 10. Acesso em rampas para o desenho universal

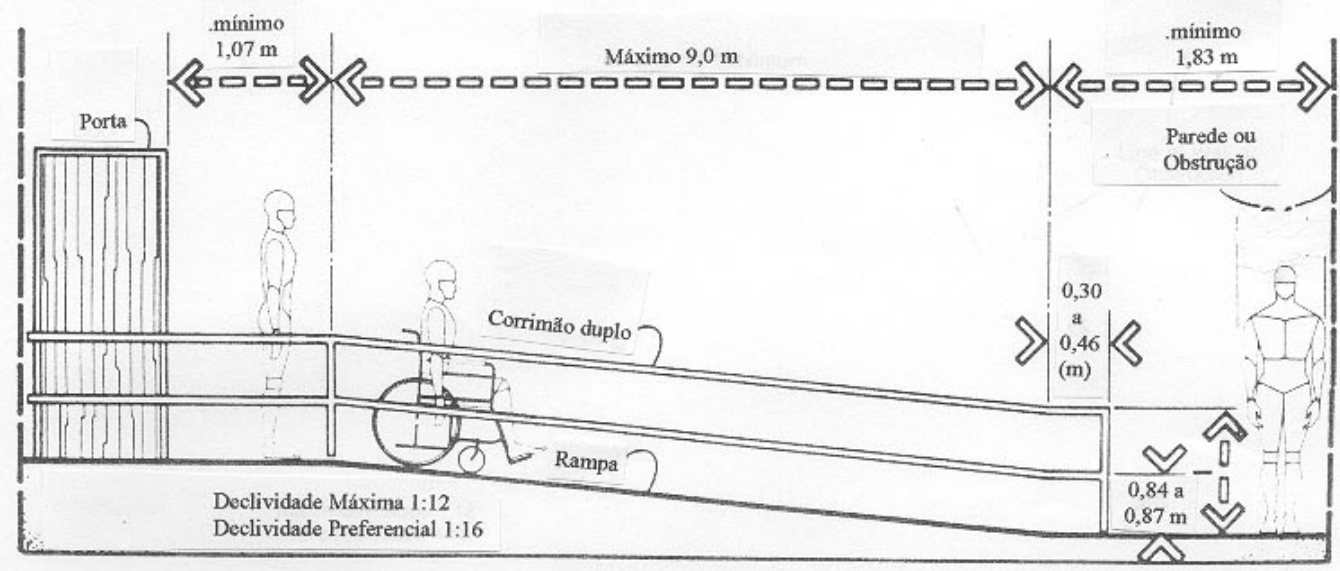

Fonte: Panero. "Human Dimension \& Interior Space". [PANERO(1979)] 


\section{Interferência do piso na segurança e no conforto.}

Diversos fatores ligados à natureza ou ao estado do piso são conhecidos por influir no conforto e na dificuldade do caminhar. Assim, o estado da superfície do piso pode ser plano ou irregular ou craquelado, escorregadio ou aderente. Sua composição pode ser duro ou flexível, móvel ou compacto. A complexidade destes fenômenos mecânicos torna a análise difícil e exige estudo fisiológico minucioso.

Os dois fatores mais importantes, do ponto de vista ergonômico, são a aderência e a dureza. A aderência entre o piso e o calçado varia conforme a natureza das superfícies em contacto: o valor do coeficiente de atrito depende das possibilidades de progressão e dos riscos de queda. A dureza do piso varia igualmente conforme o material: o valor do módulo de elasticidade condiciona o conforto do caminhar.

\section{Aderência e segurança}

A propulsão, assim como a frenagem, aparece quando a força $(\mathrm{F})$ exercida pelo pé sobre o piso, sofre uma força reativa $(\mathrm{R})$ igual e de sinal contrário aplicada pelo piso no pé.

Em resumo, exprime-se pela fórmula:

$$
\mathrm{Fs}=\mathrm{Rs} \quad \mathrm{e} \quad \mathrm{Ft}=\mathrm{Rt}
$$

Onde Rt é a reação tangencial ou força de atrito,ou força de resistência ao escorregamento e Rs é a reação normal (figura I-11). 
Figura I-11. Força exercida pelo pé sobre o piso.
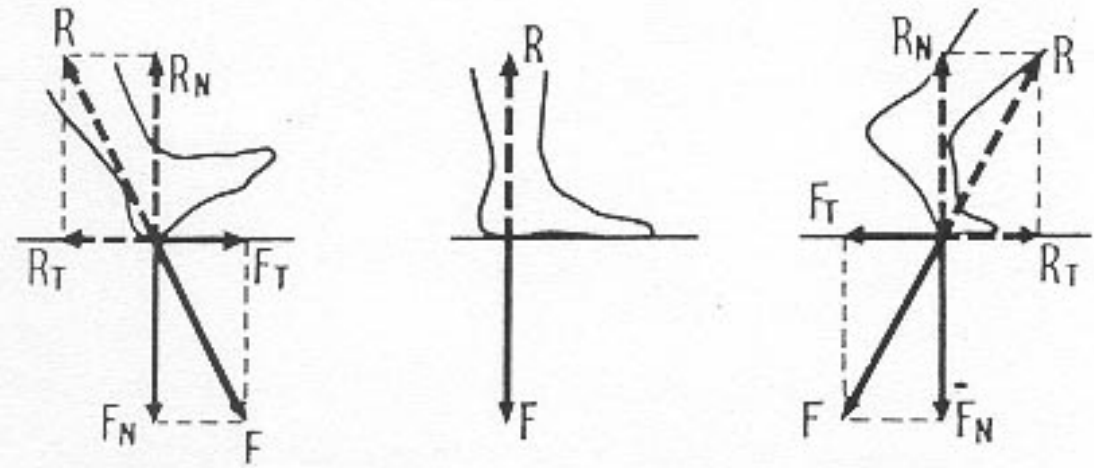

Fonte: J. Scherrer Physiologie du Travail [SCHERRER(1967)]

A ação (F) e a reação (.R) são representadas no caso de frenagem, da propulsão e da posição vertical do membro inferior.

A força de atrito limita as possibilidades de frenagem ou de propulsão. Este independe das dimensões da superfície de apoio e é proporcional à componente normal. Assim:

$$
R \mathrm{t}=\mathrm{fRs} \quad \text { ou } \quad \mathrm{f}=\frac{R t}{R s}=\operatorname{tg} \delta
$$

Onde:

f é o coeficiente de atrito (de escorregamento)

$\delta=$ ângulo de atrito

$R \mathrm{t}=$ força de resistência ao atrito

$R \mathrm{~s}=$ reação normal.

O valor da força de atrito depende, portanto, do valor do coeficiente de atrito (figura I12).

Este varia conforme a natureza das superfícies em contacto (tabela I-3).

Quando a sola recebe um movimento de escorregamento em relação ao piso, o coeficiente de atrito varia. Pode-se distinguir o coeficiente de atrito estático do coeficiente de atrito dinâmico. O coeficiente de atrito tende a diminuir quando a velocidade de escorregamento aumenta. 
Figura I-12. Coeficiente de atrito entre dois sólidos.

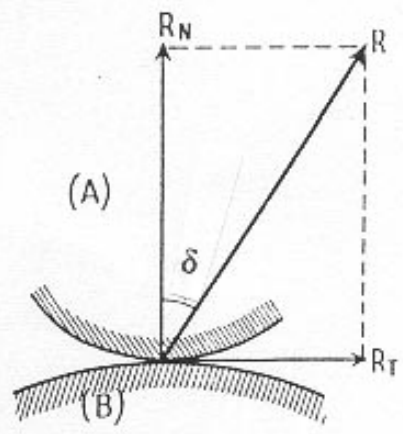

Fonte: J. Scherrer Physiologie du Travail [SCHERRER(1967)]

No caso geral um sólido (A) em contacto com um sólido (B), fixo, é susceptível aos movimentos de escorregamento, de rolamento e de rodopiar. Dentro dos limites de aproximação consideraremos apenas o movimento de escorregamento.

\section{Tabela I-3. Coeficiente de atrito estático (fs) e dinâmico (fa) e índices de dureza de diferentes revestimentos.}

\begin{tabular}{|c|c|c|c|c|c|c|c|c|c|}
\hline \multirow[t]{3}{*}{ Material } & \multirow{3}{*}{$\begin{array}{c}\text { Índice } \\
\text { de } \\
\text { dureza }\end{array}$} & \multicolumn{4}{|c|}{ Solado de couro } & \multicolumn{4}{|c|}{ Solado de borracha } \\
\hline & & \multicolumn{2}{|c|}{ Superfície seca } & \multicolumn{2}{|c|}{ Superfície úmida } & \multicolumn{2}{|c|}{ Superfície seca } & \multicolumn{2}{|c|}{ Superfície úmida } \\
\hline & & .fs & fa & $\mathrm{fs}$ & $\mathrm{fa}$ & fs & $\mathrm{Fa}$ & .fs &. $\mathrm{fa}$ \\
\hline Asfalto & 100 & 0,54 & 0,45 & - & - & 0,74 & 0,71 & - & - \\
\hline $\begin{array}{ll}\text { Peça } & \text { de } \\
\text { vinil }\end{array}$ & 77 & 0,46 & 0,39 & 0,30 & 0,11 & 0,58 & 0,54 & 0,63 & 0,47 \\
\hline Borracha & 19 & 0,45 & 0,63 & 0,43 & 0,27 & 0,44 & 0,63 & 0,87 & 0,50 \\
\hline $\begin{array}{ll}\begin{array}{l}\text { Folha } \\
\text { vinil }\end{array} & \text { de } \\
\end{array}$ & 25 & 0,43 & 0,39 & 0,78 & 0,29 & 0,48 & 0,67 & 0,82 & 0,61 \\
\hline $\begin{array}{ll}\begin{array}{l}\text { Peça } \\
\text { cortiça }\end{array} & \text { de } \\
\end{array}$ & 38 & 0,42 & 0,34 & 0,78 & 0,55 & 0,53 & 0,50 & 1,00 & 0,98 \\
\hline Linóleo & 65 & 0,27 & 0,25 & - & - & 0,42 & 0,36 & - & - \\
\hline $\begin{array}{l}\text { Madeira } \\
\text { envernizada }\end{array}$ & 40 a 50 & 0,31 & 0,25 & - & - & 0,50 & 0,40 & - & - \\
\hline
\end{tabular}

Fonte: J. Scherrer Physiologie du Travail [SCHERRER(1967)]

Como já foi visto, o equilíbrio é perdido no momento em que a perna de apoio deixa o piso e é recuperado quando a perna oscila retomando contacto com o piso. A componente horizontal da força aplicada pelo pé, quando este toca o piso, é dirigida à frente e deve estar equilibrada pela força de atrito de mesma grandeza e de sinal oposto. Assim, se a força de atrito é menor que a força horizontal aplicado pelo pé, este 
escorrega sobre o piso e a pessoa cai. Em outros termos, se $\mathrm{f}>\frac{F t}{F s}$, a pessoa não escorrega, se o contrário ela cai.

Para um tipo de sola conhecido podem-se definir os mais seguros revestimentos. Para um dado tipo de piso, conhecido o seu estado (seco, úmido, encerado), é possível precisar o material e a textura das solas antiderrapantes.

\section{Dureza do piso e conforto}

Um sólido, qualquer que seja seu material, nunca é perfeitamente rígido. Submetido a uma determinada força, sofre deformações que são acompanhadas pelas reações opostas às forças atuantes. $\mathrm{O}$ esmagamento de um piso devido às forças de propulsão ou de frenagem é um exemplo. No caso das deformações elásticas, o módulo de Young ou módulo de elasticidade é o coeficiente de proporcionalidade, que relaciona a deformação e as forças deformantes: para dada força, quanto maior o módulo de elasticidade, maior é a deformação. A noção de dureza ou flexibilidade de um piso reporta à noção física de elasticidade: os índices de dureza dos pisos, habitualmente considerados, são expressões, mais ou menos fiéis, de inverso do módulo de elasticidade.

As pessoas reagem à dureza do piso sobre os quais caminham. Assim, a diferença entre um revestimento em asfalto e um revestimento de borracha é percebida em termos de conforto.

A classificação da dureza dos pisos, estabelecida em testes puramente físicos, corresponde aproximadamente àquela que pode ser baseada na intensidade de atividade muscular, salvo no concernente à borracha. $\mathrm{O}$ revestimento em borracha provoca um efeito interessante, uma sensação de mal estar durante o caminhar, pois seu coeficiente de dureza é baixo. Esta discrepância se explica pelo valor muito elevado de seu 
coeficiente de atrito dinâmico. A reação oposta pelo piso à força aplicada pelo pé, no momento que este deixa o piso, é fortemente aumentada, necessitando uma atividade muscular extra.

Um revestimento em folhas de vinil sobre uma base de feltro oferece melhor conforto, enquanto um piso em asfalto oferece um desempenho pior. 


\section{CARACTERÍSTICAS DOS PEDESTRES}

O projeto do ambiente envolvendo pedestres requer conhecimento básico de características das relações humanas e suas capacidades.

As dimensões físicas de um corpo determinam a largura das portas, passeios, afetam a capacidade prática de movimentação em escadas, calçadas, etc. Porém, o fator psicológico de evitar contactos corporais com outras pessoas afeta o espaçamento entre elas em ambientes onde há oportunidades de multidão. A mobilidade exibe diferentes características em termos de superfícies e declividades, exigindo atenção para estes projetos no concernente à segurança e energia consumida para sua utilização.

\subsection{Dimensões do Corpo Humano - A Elipse do Corpo}

A profundidade do corpo e a largura dos ombros são as medidas primárias utilizadas nos projetos de espaços e instalações para pedestres.

A largura dos ombros é um fator que afeta a capacidade técnica de portas, corredores, escadas e equipamentos mecânicos como elevadores e escadas rolantes.Muitas instalações são projetadas para permitir que duas ou mais pessoas possam passar por elas, mas na prática a largura tem sido insuficiente para este propósito, limitando suas conveniências e capacidade. Observa-se que um único pedestre, com bagagem ou pacotes, pode restringir tanto o acesso como a locomoção de outros pedestres.

Seguindo estas premissas o pesquisador J. J. Fruin [FRUIN(1971)], após compilação de inúmeras observações das dimensões do corpo humano, concluiu por uma elipse associada ao corpo humano. Esta elipse tem o eixo longitudinal (ombro) de 0,60 m e o transversal (profundidade) de 0,50 m. Estas medidas equivalem a uma área de $0,30 \mathrm{~m}^{2}$ 
por pessoa (figura I-13). No cálculo de uma instalação para pedestre, uma área de 0,75

$\mathrm{m}^{2}$ é usada como uma zona de proteção para cada pedestre.

A título de comparação em Boueri [BOUERI(1999)] tem-se que a largura máxima do corpo humano no $95^{\prime}\left(95^{\circ}\right.$ percentil $)$, para homens é de $0,578 \mathrm{~m}$; e a profundidade máxima do corpo para homens no $95^{\prime}\left(95^{\circ}\right.$ percentil $)$ é de $0,330 \mathrm{~m}$.

Esta elipse leva em conta tanto o fato de muitos pedestres carregarem artigos pessoais, como sua natural preferência de evitar contactos entre corpos e oscilação própria do corpo ao se deslocar. Esta oscilação observada ao caminhar, também é observada enquanto parado. Apesar de ficar parado aparentar uma atividade estática, o corpo oscila (mexe-se) e há um arrastar de pés para ajudar o retorno do sangue ao cérebro e descansar os músculos das pernas. A elipse do corpo é uma forma simples e conveniente de visualização de muitas situações envolvendo confinamento de pedestres.

Figura I-13. A elipse do corpo humano

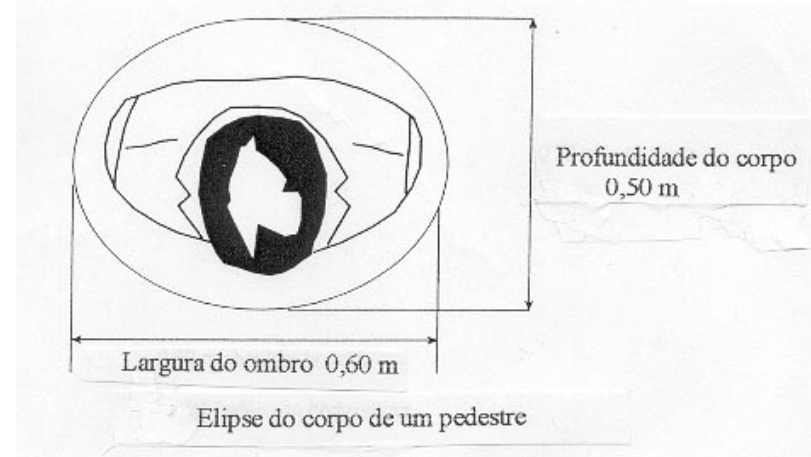

Fonte: HCM 2000.[TRANSPORTATION(2000)].

2.2 A Percepção Pessoal do Espaço - A Zona de Proteção do Corpo

O ser humano valoriza o espaço pessoal. O pedestre tem seu próprio conceito de apropriação do espaço. É a percepção de um “território" próprio relacionado à imagem do corpo humano. Se puder escolher livremente, o pedestre adotará um espaçamento que evitará contactos com outros, exceto em casos excepcionais, tais como em 
elevadores, quando aceita que a sua lei de liberdade deve ficar suspensa temporariamente.

Pedestres caminhando em calçadas ou passeios, o fazem segundo uma zona de proteção concebida e hierarquizada por idade, "status", sexo, e portadores de deficiência. As regras territoriais de conduzir-se, nem sempre são percebidas pelos próprios pedestres, mas suas preferências são de interesse do projetista, para dimensionar visando o conforto do usuário e a capacidade destas instalações (tais como cinemas, elevadores, escadas, etc).

Porém, o comportamento dos pedestres varia com a cultura dos países. Algumas sociedades do oriente e oriente médio aceitam maiores proximidades espaciais e um grau maior de contactos pessoais que normalmente são tolerados no ocidente. A preferência por um espaçamento maior por estes últimos é visto por aqueles como uma forma de altivez e intenção de não se comunicar, conforme lemos em Boueri [BOUERI(1999)].

O conceito de percepção pessoal do espaço é muito importante para o dimensionamento de qualquer instalação para seres humanos, pois respeita a pessoa, na sua cultura e etnia. Iniciado por Hall, em "The Hidden Dimension" [HALL(1966)], esse conceito é estudado nos trabalho de Fruin em "Pedestrian - Planning and design" [FRUIN(1971)], Boueri "Antropometria Aplicada à Arquitetura, Urbanismo e Desenho Industrial"BOUERI(1999)], Panero "Human Dimension \&Interior Space" [PANERO(1979)], HCM 2000 (Highway Capacity Manual 2000) [TRANSPORTATION(2000)], Itiro Iida "Ergonomia" [IIDA(1990)], enfim todos os projetistas preocupados com o bem estar das pessoas, adotam esta importante variável. 
Hall [HALL(1966)] aborda o comportamento das pessoas, no sentido de preservação da individualidade, levando-o a classificar as necessidades espaciais individuais em quatro categorias: distâncias públicas; distâncias sociais; distâncias pessoais e distâncias íntimas, ilustradas conforme a figura I-14. Estas classificações são baseadas nas mudanças sensoriais devido à alteração das características da visão, do olfato, da receptividade térmicas, da audição e capacidade de se tocarem a distâncias variadas, e são envoltórias dimensionais, com raios de atuação tendo por centro o próprio indivíduo. Estas observações foram efetuadas levando-se em conta o critério de conforto pessoal.

Figura I-14. Envoltórias de Preservação Espacial

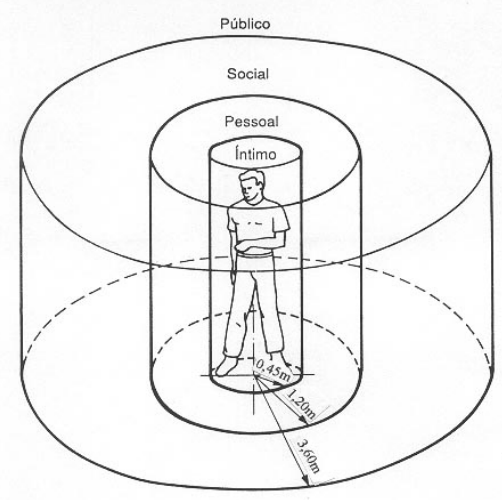

Fonte: Itiro Iida. "Ergonomia”. [IIDA(1990)]

O limite da envolvente sensorial de 7,5 m foi classificado como a distância pública. Para além desta distância pouco detalhe pessoal da outra pessoa pode ser detectado. A comunicação oral se dá em voz alta, e dá-se ênfase aos gestos e movimentos.

Na distância pública (de 3,6 m a 7,5 m) a comunicação oral pode ter um tom mais baixo e não há necessidade de tantos gestuais e movimentação corporal. Expressões faciais, tais como o sorriso, podem ser detectadas, mas não os detalhes como a cor dos olhos, a textura da pele e as condições dos dentes; mas é possível perceber alguns detalhes da 
roupa e outros aspectos pessoais. Esta é a zona de "fuga", onde a pessoa pode tomar atitudes evasivas ou defensivas.

A distância social vai de 1,2 m a 3,6 m. A partir de 3,6 m para menos se inicia a zona de envolvimento pessoal e potencial vulnerabilidade. Historicamente pode-se comparar com a distância dos contendores ao iniciarem uma luta com espadas.

Esta é uma distância para formalismos. Alongando os braços e estendendo o corpo é possível passar um objeto de uma pessoa a outra. Os detalhes da face ainda não são distinguíveis, mas as condições da roupa e outros aspectos pessoais podem ser detectados. É provável que não possa distinguir o calor e odor da outra pessoa.

O envolvimento pessoal é facilitado entre $1,2 \mathrm{~m}$ a 2,1 $\mathrm{m}$. É possível fazer contacto entre as pessoas com o esticar dos braços, mas não é possível agarrar ou agredir. É uma distância para conversações sociais e para pessoas trabalhando. Detalhes da face podem ser detectados, inclusive a textura da pele, e as condições dos cabelos. Geralmente é o limite onde pode ser pressentido o hálito ou odores e o calor da pessoa.

A distância pessoal está entre $0,45 \mathrm{~m}$ e 1,20 m. A partir de 1,2 $\mathrm{m}$ de distância é fácil tocar as mãos da outra pessoa, bastando estender os braços. Aqui temos o "círculo da confiança”, onde é possível agarrar ou agredir a pessoa. Os detalhes mais complexos, como as condições dos dentes ou a sua higiene, podem ser detectados a essa distância. Ocasionalmente o hálito e o uso de água-de-colônia podem ser percebidos.

De $0,45 \mathrm{~m}$ a $0,75 \mathrm{~m}$ de distância, o contacto entre corpos pode ser evitado, mas os contactos podem ser feitos facilmente por pequena extensão das extremidades. Esta é a distância que provavelmente alguém usará para esperar numa fila. Detalhes pessoais de higiene, assim como o hálito e odor do corpo podem ser facilmente percebidos. 
A distância íntima está compreendida entre $0,45 \mathrm{~m}$ ou menos. Neste limite $\mathrm{o}$ envolvimento sensorial fica intensificado. Os sons, calor e odor das pessoas são totalmente percebidos e torna-se difícil evitar o contacto involuntário dos corpos. Em ambientes lotados fazem-se necessários códigos de condutas especiais para não haver mal entendidos. A visibilidade é desconfortável e pode provocar distúrbios psíquicos involuntários em algumas pessoas.

O espaço é percebido diferentemente pelas pessoas, e dele tem diversas sensações dependendo das distâncias de separação entre elas.(figura I-15). Quando o critério do conforto não foi enfatizado, as zonas de proteção limitaram-se entre 0,23 a $0,26 \mathrm{~m}^{2}$ de área, uma área um pouco menor que a da elipse recomendada pelas observações de Fruin $\left(0,30 \mathrm{~m}^{2}\right)$ [FRUIN(1971)].

Quando o conforto pessoal foi enfatizado houve grande variação na zona de proteção do corpo tanto para homens como para mulheres. A zona de proteção ao redor das mulheres variou entre 0,37 a $0,46 \mathrm{~m}^{2}$ de área, e para os homens cerca de 0,74 a $0,84 \mathrm{~m}^{2}$. A zona de proteção maior selecionada pelos homens em relação àquela selecionada pelas mulheres foi interpretada como devido ao potencial agressividade dos homens. Isto seria a separação "alcance dos braços". Como ponto de referência, um guardachuva aberto para mulheres, $0,76 \mathrm{~m}$ de diâmetro, cobre uma área de cerca de $0,46 \mathrm{~m}^{2}$, e um guarda-chuva aberto para homens, com 1,09 m de diâmetro, uma área de 0,93 m². 
Figura I-15. Classificação das distâncias sociais.

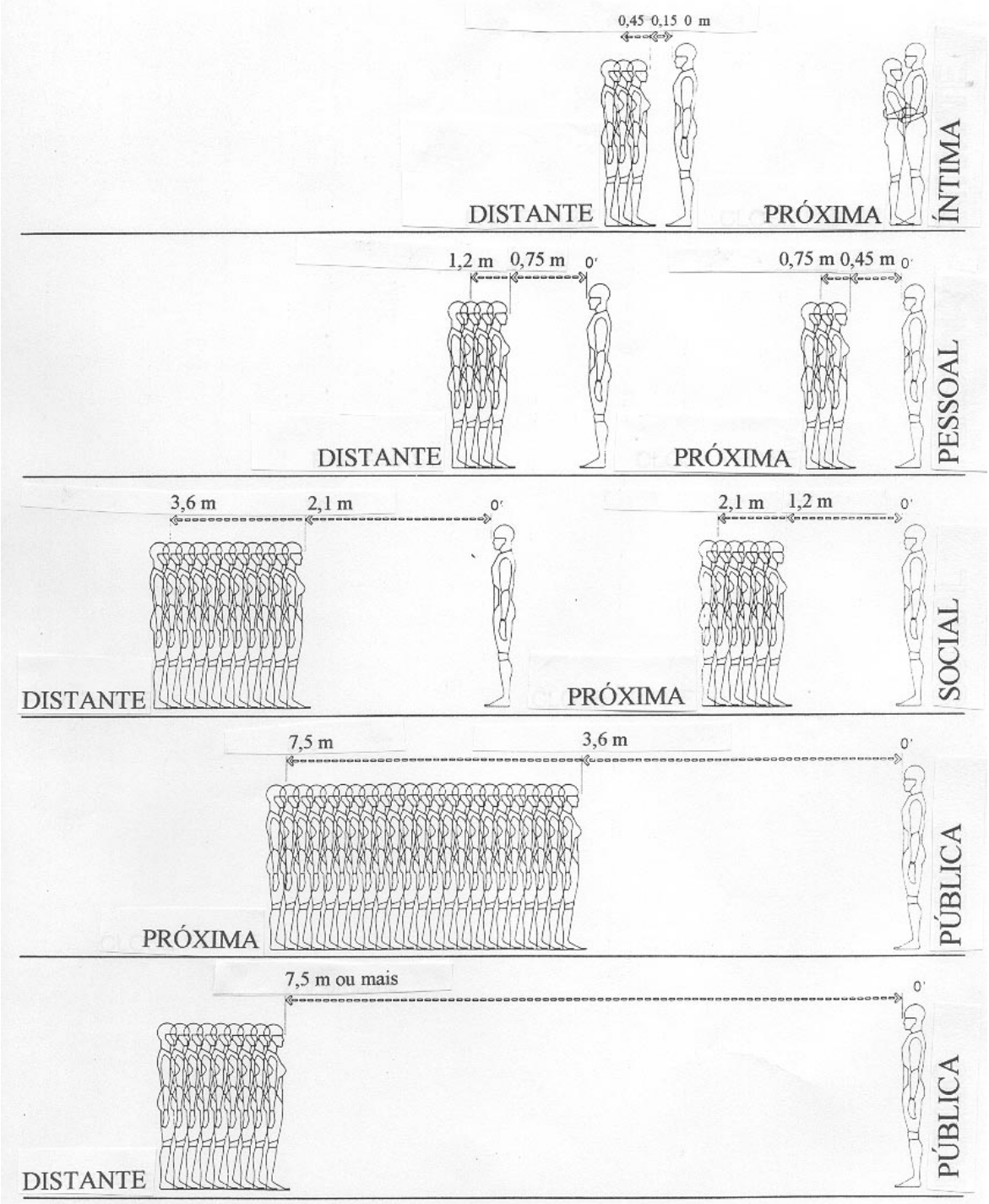

Fonte:Boueri:"Antropometria Aplicada à Arquitetura, Urbanismo e Desenho Industrial" [BOUERI(1999)].

Experiências semelhantes, efetuadas em prisões, revelaram que normalmente prisioneiros masculinos podem permitir um raio de aproximação maior que $0,46 \mathrm{~m}$ ou o equivalente de uma zona com área de $0,65 \mathrm{~m}^{2}$. Os prisioneiros potencialmente mais agressivos preferem uma área 4 vezes maior.

As áreas de confinamento devem ser bem estudadas para se preservar a saúde mental e física dos envolvidos. 


\subsection{Zonas Espaciais de Locomoção}

O conceito de zona de proteção também se estende a outras atividades do ser humano.

Os motoristas numa rodovia estabelecem uma ampla zona de proteção, incluindo a sua imagem mental das extremidades de seu veículo, além do espaço total requerido para uma parada segura do veículo. Penetrar nesta zona, por aproximação de outro veículo é fortemente ressentido. Assim também, a locomoção humana normal requer uma zona tão ampla quanto mais dinâmica a situação, conforme observada em 2.2.

O espaço requerido para locomoção pode ser dividido em zona de passo, a área requerida para os pés se movimentarem, e a zona sensorial, área requerida pelo pedestre para percepção, evolução e reação (figura I-16).

\section{Figura I-16. Definição de zona de passo e zona sensorial}

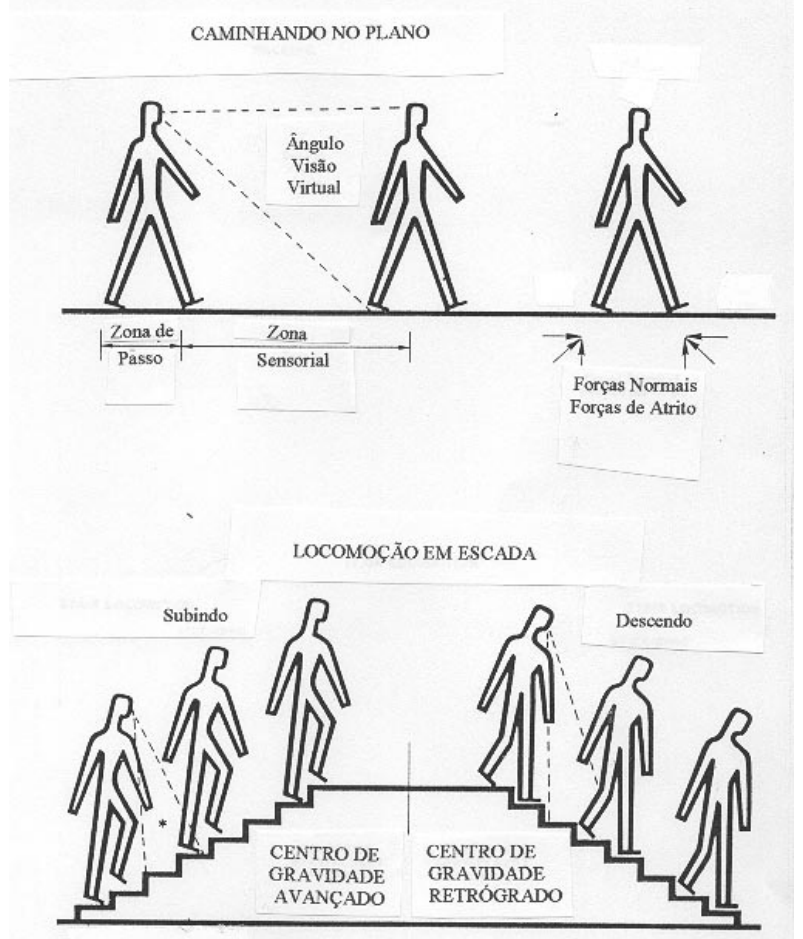

Fonte: Fruin. "Pedestrian, planning and design"FRUIN(1971)].

O tamanho da zona de passo depende da idade, sexo e condições físicas do pedestre, tem sido apresentado como tendo relação linear direta com a velocidade. 
Tanto a zona de passo como a zona sensorial pode ser afetada pela influência externa, tais como as condições do terreno e a do trânsito. O tamanho dos passos do pedestre pode ser medido, mas a zona sensorial requer compreensão de muitas percepções humanas e psicológicas.

Por razões de segurança pessoal, por convenções sociais, a fim de evitar constrangimento, ou somente para apreciar a paisagem, o pedestre está constantemente monitorando um largo limite de estímulos sensoriais.

Seus ouvidos podem alertá-lo sobre a buzina de um veículo, seu toque ao escorregamento ou terrenos irregulares, uma miríade de informações, incluindo sinais de trânsito, ou colisões em curso com outros pedestres. Estes estímulos sensoriais devem ser processados, e o pedestre deve reagir a tempo de evitar o perigo.

A capacidade de visão e o julgamento de distâncias podem ter um efeito significante nas atividades do pedestre. O termo "visão locomotora" descreve uma série de características visuais especializadas conectadas com a definição de velocidade, distância e direção durante o caminhar. Alguns pedestres usam esta visão para refazer mentalmente seu trajeto, variar sua velocidade e ajustar seu passo e velocidade para evitar colisões e efetuar ultrapassagens. A observação de pedestres com deficiência visual confirma a importância da visão na locomoção. Estes se locomovem mais lentamente, sobem escadas com mais cuidado, e freqüentemente param para se reorientarem.

Em algumas situações até pessoas com visão normal podem sofrer restrições visuais.

O olho humano é capaz de detectar detalhes, com precisão, dentro de um pequeno cone de visão, de cerca de 3 a 5 graus. Aspectos menos acurados são possíveis num cone de visão em torno 12 graus; mais além a visão torna-se menos detalhada e o limite de 
conforto visual é um cone com cerca de 60 a 70 graus. Os pedestres usam um cone de visão com menor amplitude quando caminham com cuidado, como subir ou descer escadas ou entrar num elevador. Em geral, o pedestre precisa manter uma distância mínima em torno de 2,0 $\mathrm{m}$ do pedestre da frente para ter uma visão segura deste, da cabeça aos seus pés.

Adotando este espaçamento, com determinada velocidade, a possibilidade de atropelar o pedestre da frente fica diminuído.

O tempo de reação, ou seja, o tempo entre o estímulo visual e a subseqüente reação física, é um elemento da zona sensorial humana. Entre motoristas foi encontrado um lapso de tempo entre 4 a 5 décimos de segundos entre o sinal visual e aplicar o pé no freio a fim se parar o veículo.(Figura I-17). Este tempo de reação olho-pé aumenta com a idade. O tempo de reação é um dos fatores intervenientes no caminhar e deve ser abordado ao se projetar equipamentos mecânicos como elevadores e escadas rolantes. O maior tempo de reação entre os idosos aumenta o tempo para acessar um elevador, por exemplo, diminuindo a capacidade efetiva deste elevador. Numa locomoção com velocidade livre, o pedestre definirá uma zona clara à sua frente, que lhe dará tempo suficiente para reagir e tomar medidas evasivas de ação.

\section{Figura I-17. Definição de tempo de reação}

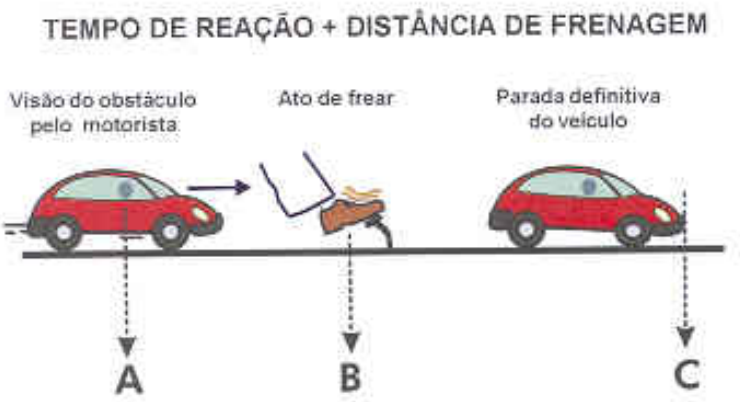

Fonte:Arquivo da autora. [YABIKU(1999)] 


\subsection{Percepção Espacial em Filas}

As filas podem ser generalizadas como sendo qualquer forma do pedestre esperar de pé numa relativa posição estacionária por algum período de tempo.

As filas podem ser de dois tipos: a linear ou ordenada, com convenção de primeiro que vem é o primeiro na frente (compras de ingresso, atendimento nas repartições, bancos, etc); ou a fila em massa, sem ordem ou organização. Estas filas são aquelas em que pedestres esperam em pé, com limitados movimentos dentro da área (pontos de ônibus, sala de espera de cinemas, etc). (Figuras I-18).

Filas lineares ou ordenadas, nas filas de ônibus têm-se observados um espaçamento inter-pessoal de 0,48 a $0,50 \mathrm{~m}$, com pequenas variações. Pedestres com bagagens ou pertences nas mãos, para comprar passagens, ocupam mais espaço, pois muitos deles colocam suas bagagens entre seus pés ou ao seu lado. Numa fila normal de compra de bilhetes com 1,5 $\mathrm{m}$ de fila, as pessoas ocupavam de $0,70 \mathrm{~m}^{2}$ a $0,80 \mathrm{~m}^{2}$ por pessoa. Movimentar-se através dessa fila é possível, mas na base do "com licença”.

Instalações que congregam inúmeras pessoas em pé, formando multidões, têm sido causas de fatalidades, por exemplo, estádios de esportes, casa noturnas, etc. Apesar de se projetarem boas instalações, o controle de multidões é difícil e o pânico favorece o surgimento de forças de esmagamento corpo a corpo (quando a área para cada pedestre variar entre 0,09 a $0,14 \mathrm{~m}^{2}$ ).

O aproximado limite de ocupação humana num espaço confinado é apresentado na figura I-19, representando o grau de confinamento em elevadores. 


\section{Figura I-18. Tipos de Filas para Pedestres}

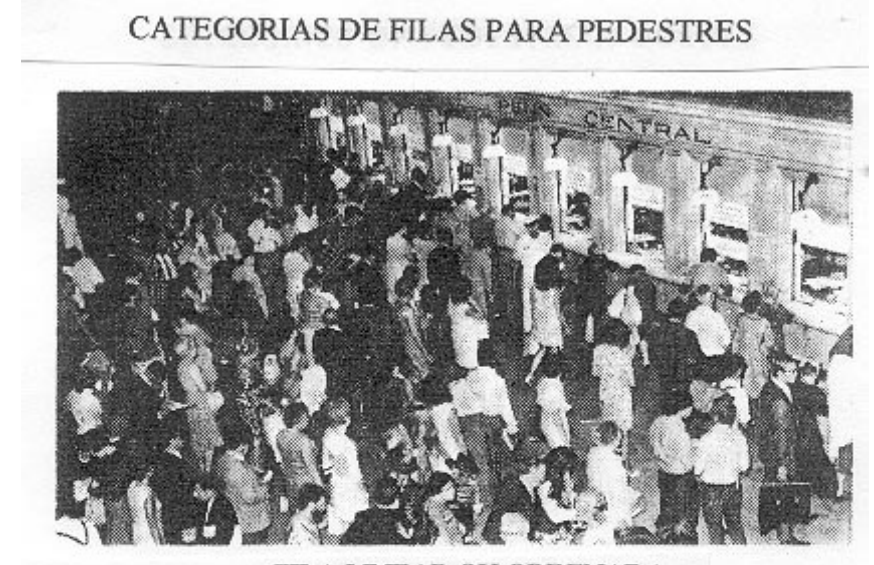

FILA LINEAR OU ORDENADA

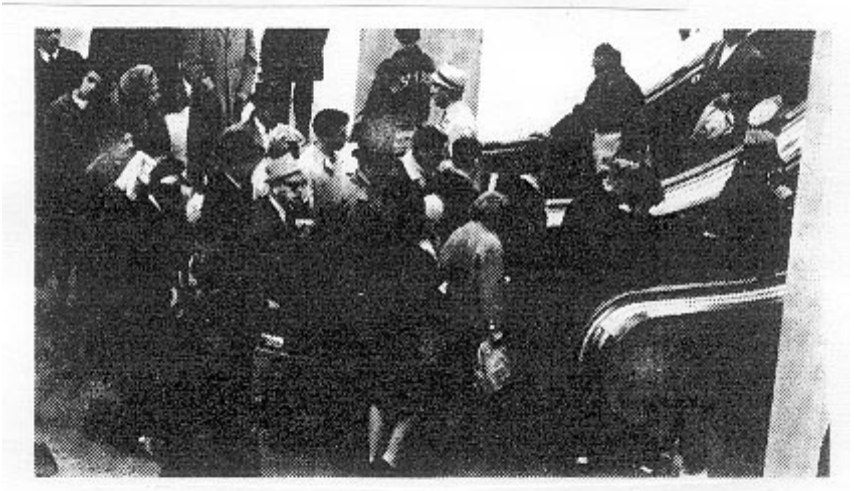

FILA EM MASSA - SEM CIRCULAÇÃO

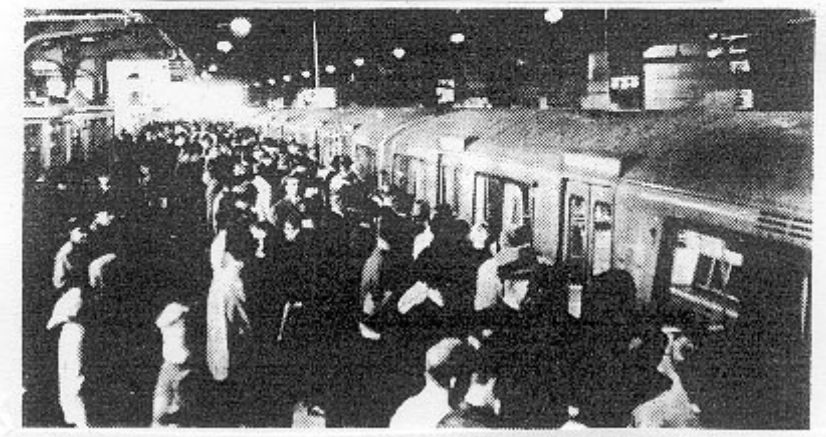

FILA EM MASSA - COM CIRCULAÇÃO

Fonte: Fruin. "Pedestrian, planning and design" [FRUIN(1971)]. 


\section{Figura I-19. Área de ocupação em elevadores} OCUPAÇÃO EM ELEVADORES

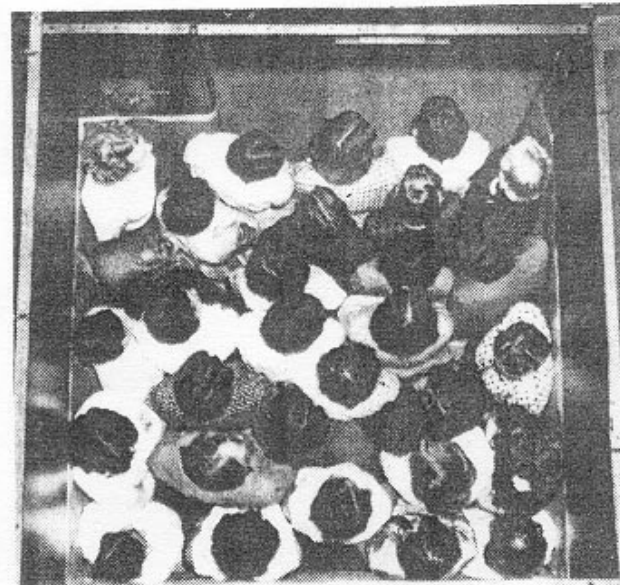

OCUPAÇ̃̃O SÓ POR MULHERES

Aproximadamente $0,14 \mathrm{~m}^{2}$ por pessoa

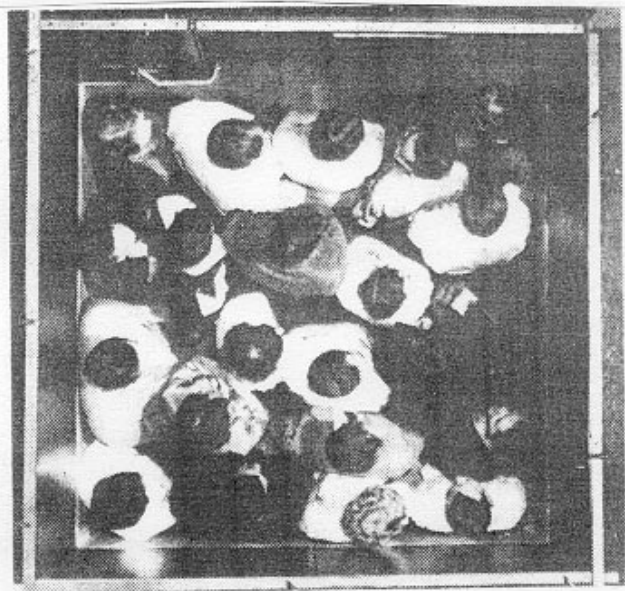

OCUPAÇ̃̃O MISTA

Aproximadamente $0,17 \mathrm{~m}^{2}$ por pessoa

Fonte: Fruin. "Pedestrian, planning and design" [FRUIN(1971)]

A primeira foto apresenta mulheres ocupando totalmente o elevador com cerca de 0,14 $\mathrm{m}^{2}$ por pessoa. A segunda ocupação mista com cerca de $0,17 \mathrm{~m}^{2}$ por pessoa. Estas pessoas estavam usando roupas leves de verão, e não portavam pacotes ou acessórios pessoais. É inevitável o contacto entre corpos, e a mobilidade dentro da área confinada torna-se impossível. Elevadores são considerados situações especiais em que pedestres se submetem ao desconforto temporariamente. 
A elipse descrita anteriormente torna-se um método útil para ilustrar as densidades das filas e sintetizar a mobilidade em áreas de filas. As figuras I-20, I-21, I-22, I-23 e I-24 ilustram os vários níveis de ocupação da área pelos pedestres, assumindo espaçamento inter-pessoal uniforme e zonas de proteção do corpo.

Figura I-20. Elipse do corpo e Zonas de Proteção em Filas

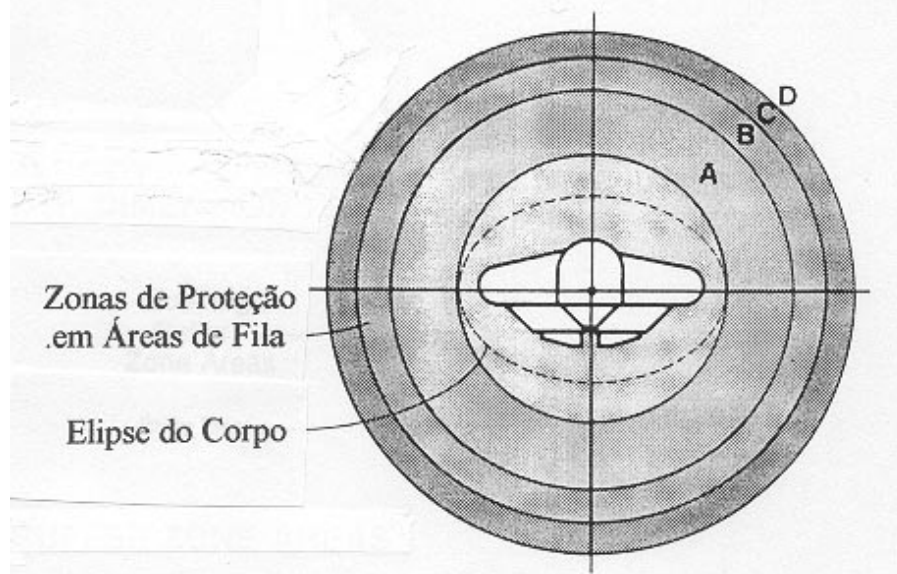

Fonte: Panero. "Human Dimension \& Interior Space”. [PANERO(1979)]

Figura I-21. Zona de Contato

\section{A - ZONA DE CONTATO}

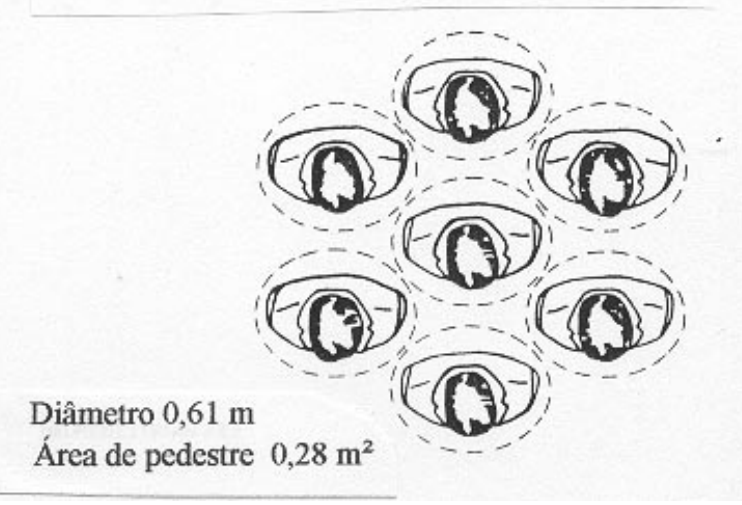

Fonte: Fruin. "Pedestrian, planning and design" [FRUIN(1971)]

Nesta figura I-21 simulou-se um grupo de pedestres igualmente espaçados numa zona de proteção individual de $0,61 \mathrm{~m}$ de diâmetro. Isto resulta numa área de fila com 0,28 $\mathrm{m}^{2}$ por pessoa, e pode ser chamado de limite de zona de contacto, porque abaixo desta área de ocupação, freqüentemente é inevitável o contacto entre as pessoas. Não há 
$\overline{\text { possibilidade para circulação dentro da zona e os movimentos podem ser restritos a }}$ arrastar de pés, avançando para frente. Ela representa um elevador cheio ou à frente de uma escada rolante ou travessia de pedestre.

\section{Figura I-22. Zona de Não Contato}

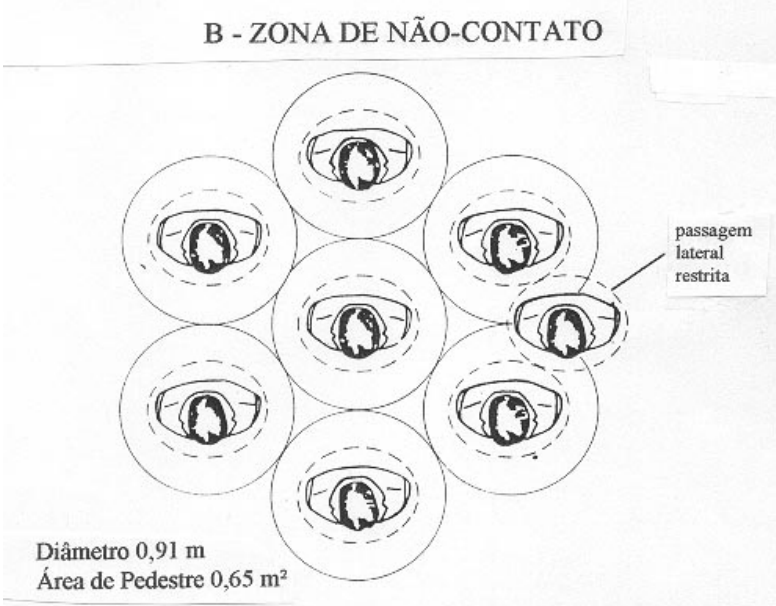

Fonte: Fruin. "Pedestrian, planning and design" [FRUIN(1971)]

Na figura I-22 a zona de proteção tem-se expandido para 0,91 m e uma área de 0,65 $\mathrm{m}^{2}$ de área. Esta pode ser considerada a zona de não contacto, porque o contacto pode ser evitado entre 0,28 a $0,65 \mathrm{~m}^{2}$ por pessoa, e uma movimentação interna não perturba a fila. A movimentação da fila pode ser feita em grupo e produz a máxima capacidade de fluxo nas escadas e calçadas.

Figura I-23. Zona de Conforto Pessoal

\section{C - ZONA DE CONFORTO PESSOAL}

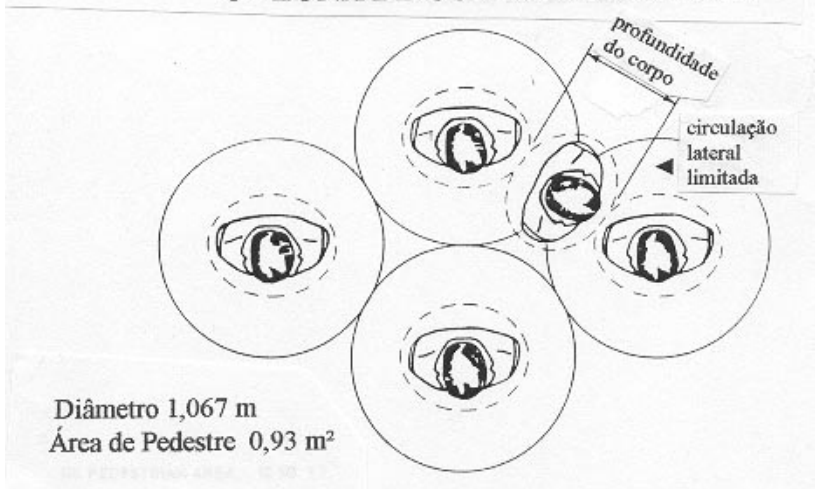

Fonte: Fruin. "Pedestrian, planning and design" [FRUIN(1971)] 
A figura I-23 ilustra a expansão da zona de proteção do corpo para 1,067 $\mathrm{m}$ de diâmetro e $0,93 \mathrm{~m}^{2}$ de área. Esta pode ser considerada a zona de conforto pessoal, desde que 0,65 a $0,93 \mathrm{~m}^{2}$ de área esteja dentro do limite de separação espacial e é a área ocupada que as pessoas selecionam quando há ênfase ao conforto. Nesse espaçamento a circulação entre as pessoas é livremente satisfeita.

\section{Figura I-24. Zona de Circulação Livre}

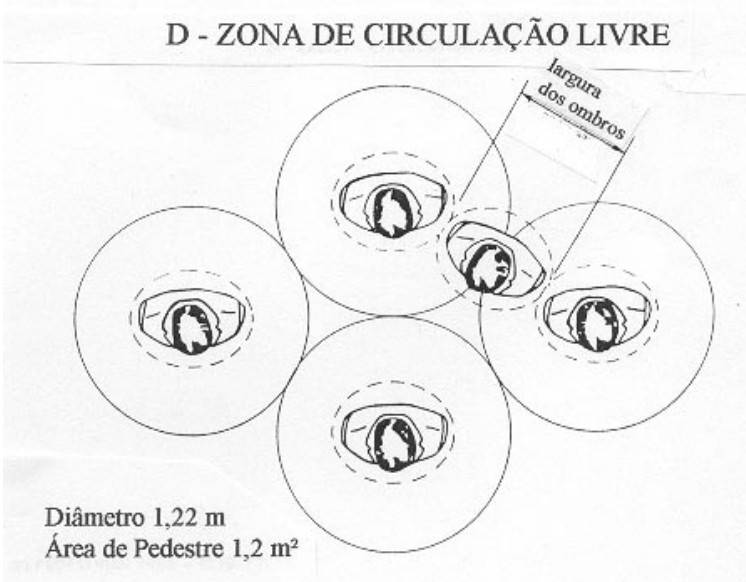

Fonte: Fruin. "Pedestrian, planning and design" [FRUIN(1971)]

A figura I-24, a zona de proteção foi expandida para 1,22 $\mathrm{m}$ de diâmetro e a 1,20 $\mathrm{m}^{2}$ de área. Esta pode ser denominada de zona de circulação livre, pois a circulação dentro da área de fila, com a média de ocupação de 0,93 a 1,2 $\mathrm{m}^{2}$ por pessoa, é possível sem perturbar outros.

Representa a síntese da ocupação espacial, com o nível de serviço padrão para as filas.

Os processos de chegada são determinantes para o uso das instalações para os pedestres.

Os processos de chegada devem ser claramente compreendidos pelo projetista antes da execução da obra. Há dois tipos básicos de chegada: processo em massa e processo intermitente.

Um exemplo do processo padrão de chegada em massa ocorre depois de um evento esportivo, quando há um êxodo imediato de espectadores, ou numa plataforma de 
terminal de metrô ou trem, quando descarrega multidão de passageiros em poucos minutos. Nos processos de chegada em massa, temporariamente, excede-se a capacidade da instalação para pedestre, pelo impacto de sua excessiva demanda num curto espaço de tempo. Instalações sujeitas a esse processo de chegada sempre funcionam no limite de sua capacidade prática, indiferente ao projeto, até o fim do serviço. A avaliação qualitativa do processo de chegada em massa é baseada no tempo de serviço e das adequadas filas de suas seções. Por exemplo, o critério mínimo de projeto para a plataforma de trem (ou metrô), sujeito à chegada em massa, é tornar desimpedida totalmente a plataforma até a chegada da próxima composição.

Padrão de chegada intermitente é a típica chegada a uma instalação de pedestres, tais como um grande terminal, ou prédio de escritório, com inúmeras fontes de demanda. Estas instalações tendem a ser um regulador de trânsito, mas estão sujeitas às ondas de curto período, ou micro-picos de volumes de tráfego, consideravelmente maiores que a média ou intervalos de curto período em que esse volume cai abaixo da média.

Distinguir o processo de chegada pode ser importante para o projetista, pois a média do período de projeto, não reflete o padrão real de chegada, podendo produzir uma inadequada e inconveniente instalação. 


\section{PEDESTRES ESPECIAIS}

Neste item será apresentada a físiologia dos idosos e crianças devido à forte presença destes segmentos nas áreas urbanas. Os portadores de necessidades especiais não serão objetos deste item, pois há uma grande amplitude de características específicas de cada tipo de necessidade especial. Lembre-se que o Decreto $\mathrm{n}^{\circ} 5.296$, de 02 de dezembro de 2004, que regulamenta as Leis $\mathrm{n}^{\mathrm{o}} 10.048 / 2000$, que dá prioridade de atendimento às pessoas que especifica, e $\mathrm{n}^{\mathrm{o}} 10.098$ / 2000, que estabelece normas gerais e critérios básicos para a promoção da acessibilidade das pessoas portadoras de deficiência ou com mobilidade reduzida, torna efetivas as medidas que permitem a acessibilidade universal, especificamente nos Capítulos IV-Da implementação da acessibilidade arquitetônica e urbanística; Capítulo V-Da acessibilidade aos serviços de transportes coletivos e Capítulo VIII-Do programa nacional de acessibilidade. A recomendação é a utilização das Normas Brasileiras - ABNT.

\subsection{O Pedestre Idoso}

3.1.1. O idoso e os acidentes.

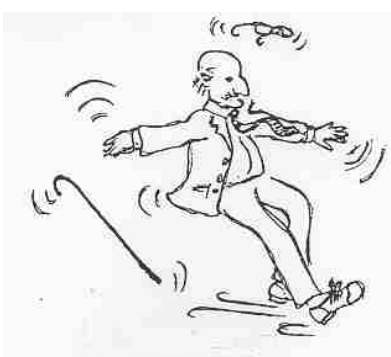

A participação do idoso no contingente de pedestres é significativa, pois àqueles que sempre foram pedestres, somam-se outros que perderam a mobilidade por automóveis, quer por opção, quer por perda da licença de dirigir. 


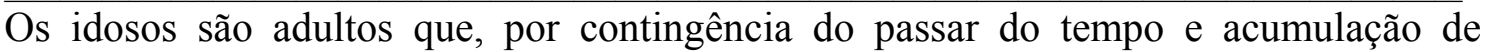
enfermidades, têm reduzido a sua agilidade, a sua motricidade e as percepções sensoriais. Devido a estas perdas o pedestre idoso torna-se mais vulnerável dentro do sistema viário e urbano. Os acidentes comprovam esta fragilidade.

Conforme Minayo [MINAYO(2005)], "Os acidentes de transporte e as quedas são as duas causas básicas de morte e fazem confluência entre violências e acidentes, pois as quedas podem ser atribuídas a vários fatores: fragilidade física, uso de medicamentos que costumam provocar algum tipo de alteração no equilíbrio, na visão ou estão associados à presença de enfermidades como a osteoporose. No entanto esses problemas costumam também ser fruto de omissão e de negligências quanto à assistência nos lares e nas comunidades em que os idosos vivem. As mortes, as lesões e os traumas provocados pelos meios de transporte e pelas quedas dificilmente podem ser atribuídos apenas a causas acidentais. Pelo contrário precisam ser incluídos em qualquer política pública que busque superar as violências cometidas contra idosos”.

No Brasil cerca de 93.000 idosos por ano são internados, sendo 53\% por motivo de quedas, $27 \%$ devido à violência e agressões e $20 \%$ por acidentes de trânsito.

Conquanto os acidentes de trânsito e transporte sejam as primeiras causas externas específicas de mortes de idosos, as quedas são as principais, na internação desse grupo populacional.

Freqüentemente as lesões e os traumas provocados por quedas em idosos, ocorrem em casa entre o quarto e o banheiro; ou nas vias públicas, nas travessias, ao subirem nos ônibus ou ao locomoverem dentro deles. As quedas associam-se, na maioria das vezes a enfermidades como a osteoporose, instabilidade visual e postural típicas da idade e a negligências de que são vítimas. Há uma expectativa de que para cada 3 (três) queda 
não fatais haverá 1 (uma) queda fatal. A fratura do colo do fêmur é a principal causa de hospitalização e metade dos idosos que sofrem esse tipo de lesão falece dentro de um ano. Grande parte dos que sobrevivem fica totalmente dependente dos cuidados de outras pessoas.

No município de São Paulo, segundo a Companhia de Engenharia de Tráfego [CET(2005)], dos 714 mortos no primeiro semestre de 2005, 52\% foram por atropelamento. Destes quase 30\% tinham mais de 60 anos.

Segundo Etienne Grandjean [GRANDJEAN(1973)], o avanço da idade traz mutações no corpo, representado normalmente por reduções em medidas, capacidade motora (morosidade nas funções e redução da atenção) e atividade mental (perda de memória e redução de cognição).

As maiores enfermidades são as derivadas formas de reumatismos, caracterizados pelos sintomas de artrites nas mãos e pés, reduzindo a capacidade de distendê-los e reduzindo a destreza para atividades manuais; artrites da coluna vertebral, restringindo movimentos lombares; artrites nas articulações dos quadris e joelhos, dificultando o caminhar. Freqüentemente surgem depressões, agravando e causando a solidão.

As pessoas freqüentemente começam a sentir o peso da idade com a chegada da aposentadoria e/ou a morte do cônjuge. A dificuldade de encontrar novos propósitos na vida leva a um declínio no seu poder mental.

Todas estas considerações levam a crer que o envelhecimento é um estágio de vida muito triste. Porém não se pode generalizar.

Há idosos que vivem esta idade com alegria, são produtivos, encontrando novas propostas de vida, conforme Yabiku [YABIKU(2000)]. 


\subsubsection{A idade legal da pessoa idosa.}

Atualmente os idosos não podem ser generalizados num todo uniforme, mas classificados por fases de atividades, conforme Lilian Laux [LAUX(1996)]:

- Jovem idoso na faixa etária entre 65 a 74 anos

- Idoso na faixa etária entre 75 a 84 anos

- Idoso idoso na faixa etária a partir de 85 anos

Conforme Yabiku [YABIKU(2000)] a definição da idade limite inferior para a pessoa idosa é importante do ponto de vista legal e previdenciário. Há algumas controvérsias em relação à idade de 60 ou 65 anos, conforme os éditos surgidos.

A terceira idade é uma expressão cunhada pela Organização Mundial da Saúde, em 1957, com grande aceitação, nos últimos anos, no Brasil. Com este termo pretende-se referir, mais respeitosamente, às pessoas com mais de 60 anos.

A Assembléia Mundial sobre o Envelhecimento, realizada em 1982 pela ONU, em Viena, mencionou a idade de 60 anos, como limite inferior da pessoa idosa.

No Brasil a Lei Federal $n^{\circ} 10.741$, de $1^{\circ}$ de outubro de 2003, cria o Estatuto dos Idosos, incorporando a lei anterior $\mathrm{n}^{\circ} 8.842 / 94$, que dispunha sobre a Política Nacional do Idoso. Nelas lê-se: “considera-se o idoso, para efeitos desta Lei, a pessoa maior de sessenta anos de idade". O Decreto $\mathrm{n}^{\mathrm{o}}$ 5.109, de 17 de junho de 2004 trata da regulamentação desta Lei, sobrepondo-se aos decretos de $n^{0} 4.227$ de 13 de maio de 2002 e no $^{\mathrm{o}} 4.287$, de 27 de junho de 2002.

A OIT - Organização Internacional do Trabalho, através da Convenção n ${ }^{\circ} 102$ (Da Seguridade Social / Genebra, 28 de junho de 1952), adotou o critério cronológico, e tem como idoso o maior de 65 anos. Este mesmo critério foi adotado pela OMS Organização Mundial da Saúde. 
O Município de São Paulo criou, em 1984, o Conselho Municipal da Condição do Idoso. Nesta carta a idade limite inferior foi de 65 anos. Em 1986 foi criado o Conselho Estadual do Idoso no Estado de São Paulo, seguindo o mesmo limite de idade-65 anos. Estes dois Conselhos foram criados anteriormente à promulgação da Lei Federal (1994), e seguiu as recomendações da Organização Mundial da Saúde.

Segundo o IBGE, 65 anos é o início da terceira idade nos países desenvolvidos e 60 anos para os países em desenvolvimentos.

O Código de Trânsito Brasileiro [CTB(1997)] não define a idade máxima para requerer ou renovar a carteira de habilitação. Porém, na Resolução CONTRAN nº 007/98 regulamenta os exames médicos, para renovação da carteira de habilitação, de 5 em 5 anos até completar-se 65 anos, passando então para 3 em 3 anos, esta obrigatoriedade.

\subsubsection{Antropometria do idoso.}

Com base em Kelly e Kroemer [KELLY;KROEMER(1990)], em síntese, são as seguintes reduções de medidas antropométricas, para a pessoa idosa, concernente ao ato de caminhar:

- Força do joelho: para grupos de 70 a 86 anos, a flexão de joelhos variam de $56 \%$ a 78\% da flexibilidade do grupo jovem (20-35 anos), dependendo da posição do joelho.

- Postura (desequilíbrio postural): pesquisadores encontraram desequilíbrio postural aos 71-75 anos para homens, podendo ser o dobro dos observados aos 31-35 anos. Há relatos de que estas medidas correlacionam-se com a gordura do corpo e a força de apreensão das mãos. 
Também foi encontrado desequilíbrio postural entre as mulheres: os grupos mais idosos (70-80 anos), demonstraram um desequilíbrio de $0,43 \%$ da base de apoio, comparada com o desequilíbrio de $0,23 \%$ demonstrado pelo grupo mais jovem (20-30 anos).

Quanto à força de apreensão, Czaja [CZAJA(1990)], observa que na média, há o decréscimo da massa muscular com a idade, que resulta do decréscimo tanto da quantidade como do tamanho das fibras musculares. Além disso, a capacidade média máxima do sistema cardiovascular, de distribuir oxigênio para o trabalho muscular, é reduzida, relativamente cedo no processo de envelhecimento.Traduzindo isto em desempenho, há estimativa expedita de que, em torno de 40 anos, a média de força muscular seja cerca de $95 \%$ da máxima inicial nos últimos $20 \mathrm{seg}$. Aos 50 anos esta força cai para cerca de $85 \%$ e aos 65 anos somente $75 \%$ do esforço inicial é ainda disponível.

Kelly e Kroemer [KELLY;KROEMER(1990)], por seu turno observam que a força de apreensão declina $16 \%$ aos 60 anos, da força máxima durante 20 seg. Outros autores relatam um declínio de $40 \%$, dos 30 aos 80 anos, quando medidos seccionalmente e declínio de $60 \%$ quando medidos longitudinalmente. Outros autores relatam declínio de $29 \%$ e alguns não observaram mudança com a idade.

Considera-se que um terço da população trabalhadora sofre da visão. Isso afeta mais com o envelhecimento, conforme a estatística observada por Tilley [TILLEY(1993)] (tabela I-4).

Tabela I-4. Redução da capacidade de visão, por idade

\begin{tabular}{||c|c|}
\hline IDADE & VISÃO (\%) \\
\hline 20 & 100 \\
\hline 40 & 90 \\
\hline 60 & 74 \\
\hline 80 & 47 \\
\hline
\end{tabular}

Fonte : Alvin R. Tilley “The measure of man and woman”. [TILLEY(1993)] 
Basicamente, a perda de percepções sensoriais (visão, audição) inicia-se a partir de 60 a 65 anos.

O efeito da alteração da percepção de cores atinge a população com mais de 75 anos. A capacidade de percepção de cores diminui com a idade, por causa do amarelamento do cristalino. Conseqüentemente os idosos têm mais dificuldades em distinguirem verdes, azuis e violetas.

Além disso, os olhos focalizam mais lentamente. Conforme relato de Kelly e Kroemer [KELLY;KROEMER(1990)] após os 75 anos as pessoas pesquisadas apresentaram o tempo de reação dos olhos o dobro com a idade, em relação ao jovem de 35 a 45 anos. Foi observado também que há perda de brilho dos olhos, quase duplicando com a idade. Observou-se também que aos 40 anos requer-se 2 vezes mais de luz que aos 20 anos. Com 60 anos requer-se 5 a 6 vezes mais luz que aos 20 anos. Sugere-se aumentar a iluminação ambiente por cerca de $20 \%$. Os idosos necessitam detalhes mais acentuados, bem contornados e mais largos.

Com o avançar da idade também a audição para sons de altas freqüências, são perdidas, mas é possível serem corrigidas com próteses auditivas. O paladar e olfato perdem a sensibilidade com a idade. $\mathrm{O}$ idoso tende a usar mais sal, pimenta e sabores fortes. Isto conduz a outras patologias, como o aumento da hipertensão, dos colesteróis, dos problemas cardíacos e tendências a diabetes e obesidades.

A perda de cognição afeta basicamente as pessoas em torno de 70 anos.

\subsubsection{O idoso caminhando.}

A velocidade média de um conjunto de pedestres jovens, composto de homens e mulheres, é normalmente assumida como $1,4 \mathrm{~m} / \mathrm{s}$. A presença de idosos neste conjunto 


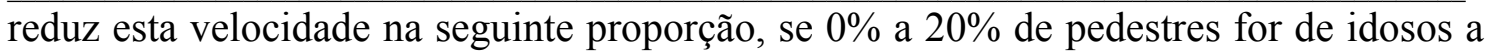
velocidade pode ser assumida como $1,2 \mathrm{~m} / \mathrm{s}$, Se os idosos constituírem mais de $20 \%$ a velocidade recomendada é de $1,0 \mathrm{~m} / \mathrm{s}$. Para cada acréscimo de $10 \%$ ou mais de idosos, deve-se reduzir a velocidade em $0,1 \%$. Porém, a presença do idoso não é o fator mais restritivo no desenvolvimento da velocidade dos pedestres. $O$ elemento que mais restringe a velocidade é a densidade (número de pedestres por metro quadrado).

Sendo o idoso uma presença constante e crescente no meio social, sendo um usuário assíduo dos equipamentos públicos, sendo a sua natureza fragilizada, expondo-o a acidentes, suas necessidades devem ser levadas em consideração, no momento de dimensionar os equipamentos, as praças e os passeios, senão por respeito à idade ao menos em nome dos consumidores e dos direitos humanos.

Os responsáveis em projetar, executar e administrar o espaço público devem aplicar os princípios de acessibilidade universal, para que todos possam usufruir desses espaços, sem constrangimentos. Uma pessoa portando malas ou bagagens, de fato torna-se alguém com mobilidade reduzida temporariamente, exigindo dimensionamento maior que aqueles que não estejam portando volumes (figura I-25)

O dimensionamento adequado ou a instalação de equipamentos de ajuda podem não ser tão dispendioso no contexto geral.

A superfície do piso é importante. O revestimento deve ser plano, não deslizante e em bom estado o tempo todo.

No Brasil a NBR 9050 / 2004 [ABNT(2004)], trata deste assunto. 


\section{Figura I-25. Dimensionamento para pessoas portando bagagens}

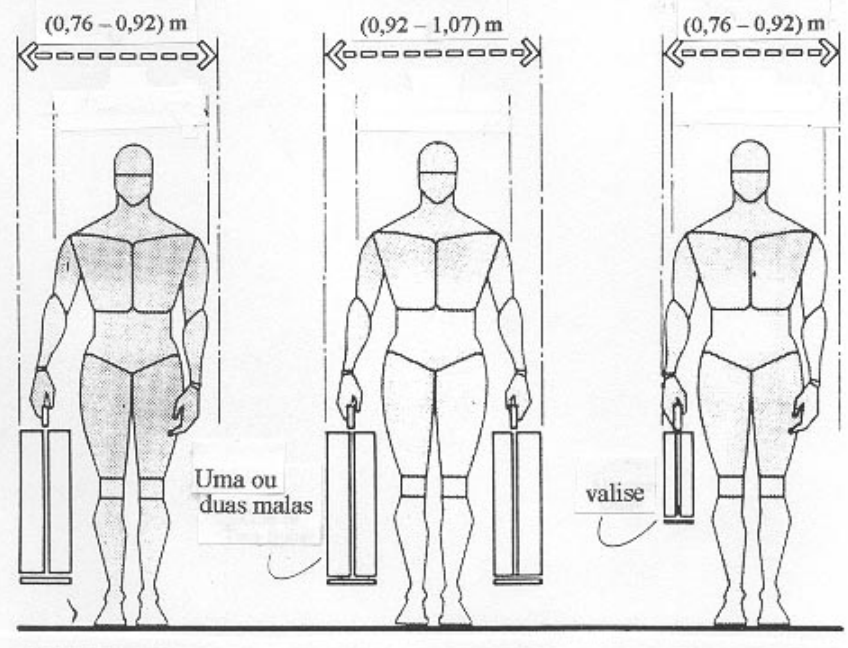

LARGURA PARA PESSOAS PORTANDO MALAS OU BAGAGENS

Fonte: Panero. "Human Dimension \& Interior Space". [PANERO(1979)].

Outros exemplos: as pessoas com uma bengala ou usando muletas ocupam uma largura mínima de 0,75 a $0,90 \mathrm{~m}$; as pessoas com cão-guia ou com um acompanhante necessitam de 1,10 a 1,20 m; e uma pessoa empurrando um carrinho ocupa 1,70 m no sentido transversal, conforme figura I-26. 


\section{Figura I-26. Dimensionamento para pessoas portando equipamentos de} acessibilidade

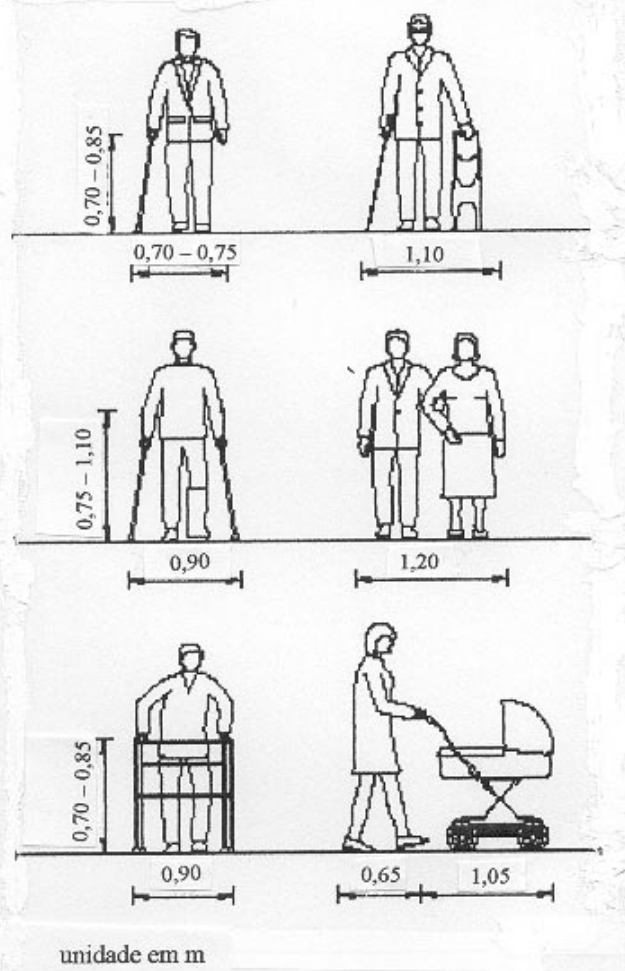

Fonte: Angelo. “Accessibilité des voires”. [ANGELO(1999)]

Conforme pesquisa de Yabiku [YABIKU(2000)], referente ao motorista de terceira idade da cidade de São Paulo, enquanto pedestre, foi observado que o maior obstáculo que este enfrenta é o tempo dos semáforos nas travessias. Dos idosos entrevistados $56 \%$ considerou o tempo verde muito pouco e $44 \%$ considerou razoável; o tempo de amarelo (ou intermediário) foi considerado pouco para 52\% e razoável para $44 \%$ e $4 \%$ ficaram indiferentes. O tempo vermelho foi considerado muito longo para $32 \%$ e novamente $44 \%$ considerou razoável, e para o restante foi indiferente. O tempo de vermelho (e do amarelo) reflete o tempo de espera para a travessia.

De fato, o tempo de travessia (tempo verde) adotado pela Municipalidade de São Paulo é muito pouco para aqueles que desenvolvem baixa velocidade de caminhar. Considerando a velocidade de $1,2 \mathrm{~m} / \mathrm{s}$ como a velocidade média entre idosos, 
caminhando solitariamente (excluindo a condição de pelotão, que é o mais comum nas travessias, mas que interferem no desenvolvimento da velocidade individual), pode-se calcular, numa primeira aproximação, o tempo necessário para o idoso fazer a travessia, segundo a fórmula espaço $=$ velocidade $\mathrm{x}$ tempo, adotando os comprimentos de travessias mais comuns da cidade de São Paulo e comparando com o tempo adotado nestas travessias. (tabela I-5)

Tabela I-5. Tempo de verde para travessia com segurança.

\begin{tabular}{|c|c|c|}
\hline \multirow{2}{*}{$\begin{array}{c}\text { Comprimento de travessia } \\
\text { (largura da via em metros) }\end{array}$} & \multicolumn{2}{|c|}{$\begin{array}{c}\text { Tempo de verde } \\
\text { (em segundos) }\end{array}$} \\
\cline { 2 - 3 } & Regulamentado & $\begin{array}{c}\text { Necessário para o idoso } \\
(\mathrm{v}=1,2 \mathrm{~m} / \mathrm{s})\end{array}$ \\
\hline 5,5 a 8,0 & 3,0 & 6,7 \\
\hline 8,0 a 14,0 & 4,0 & 11,7 \\
\hline 14,0 a 18,0 & 5,0 & 15,0 \\
\hline$>18,0$ & 6,0 & $>15,0$ \\
\hline
\end{tabular}

Fonte: Yabiku. "O Pedestre”. [YABIKU(1999)].

Outra questão responsável por acidentes de queda dos idosos, fora de suas habitações, refere-se aos atos de subir e descer dos coletivos e de se deslocar dentro deles. Para isto a ABNT com a NBR 14022 (revisto em 2005/6), “Acessibilidade à pessoa portadora de deficiência em ônibus e trolebus, para atendimento urbano e intermunicipal". [ABNT(1997/2006)] normatizou o piso baixo ou elementos técnicos que propiciem o acesso mais compatível para adentrar ou sair do coletivo. Em relação à frenagem e aceleração do coletivo, o motorista deve ser bem treinado para não executar movimentos bruscos que desequilibram os usuários que estiverem em pé ou em movimentação dentro do veículo. 


\subsection{O Pedestre Criança.}

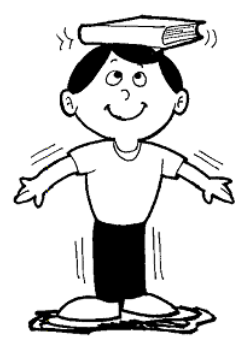

Dentre os segmentos que compõe os pedestres, as crianças formam o contingente mais encantador, mais alegre e barulhento, porém aquele que requer mais atenção pela sua especificidade.

As crianças não têm conhecimento de trânsito, de seus perigos e quais os cuidados a serem tomados. Há inúmeras armadilhas urbanas depondo com a segurança das crianças, conforme figuras I-27, I-28, I-29 e I-30.

O mais importante é que o seu sistema físico e psicológico está em formação. A grande impetuosidade infantil (movida pela energia de seu corpo), aliada a insipiente formação dos órgãos sensores, expõe a criança a inúmeros perigos, não apenas no sistema viário. O circuito da criança no sistema viário é limitado à residência - escola - praça de esportes ou lazer (clubes, cinemas, shoppings próximos, etc). Para preservar a segurança das crianças são realizadas intervenções urbanas pontuais, a fim de reduzir a velocidade dos veículos, associado a uma adequada circulação de pedestres.

Porém, para uma convivência mais segura do sistema viário e urbano com a criança, o mais eficaz ainda é a informação correta dos responsáveis pela criança (pais, professores, policiais, atendentes de vendas, a sociedade em geral).

A grande dificuldade dessa relação, é que o adulto geralmente ignora as limitações físicas das crianças, responsabilizando-as de negligência e má educação, como se fossem adultos em escala menor. 
$\overline{\text { Há um outro segmento de crianças que ocupa o espaço urbano, notadamente as praças e }}$ ruas e avenidas de grande movimento, como forma de trabalho informal, vendendo pequenas mercadorias (guloseimas, etc) ou fazendo insipientes malabarismos.

Conquanto o trabalho infantil seja proibido no Brasil, pelo Estatuto da Criança e Adolescente (Lei $\mathrm{n}^{\mathrm{o}} 8069$ de 13 de julho de 1990), e a sua erradicação esteja progressivamente bem sucedida, em 2001 ainda cerca de 5 milhões de crianças entre 5 e 17 anos trabalhavam, sendo que $40 \%$ destes (2,2 milhões) tinham menos de 14 anos, conforme dados do IBGE. Pelo Estatuto 16 anos é a idade mínima para o ingresso no mercado de trabalho. Em 15 anos o Brasil conseguiu reduzir pela metade o número de crianças de 5 a 17 anos exploradas nas lavouras, carvoarias, nos lixões e na produção de calçados, conforme relatado em MINAYO [MINAYO-GOMEZ(1997)]. Porém os trabalhos informais, aliados à mendicância entre as crianças é um fenômeno aparentemente crescente nas grandes cidades do Brasil. Não há estatística com estas crianças. Mas sem dúvida elas correm riscos de atropelamentos nas vias públicas. E acima de tudo são crianças e estão em fase de crescimento e desenvolvimento.

Figura I-27. Travessia de pedestre

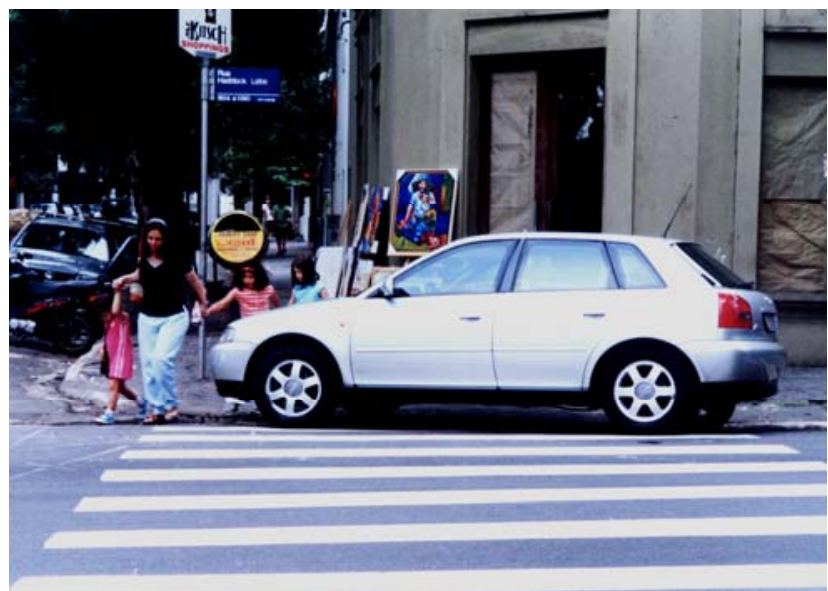

O desrespeito à faixa de pedestre pelos veículos, contradiz a segurança que esta passagem deveria proporcionar. Isto confunde a criança.

Fonte: arquivo da autora [YABIKU(1999)] 
Figura I-28. Ausência de pavimentação e calçadas.

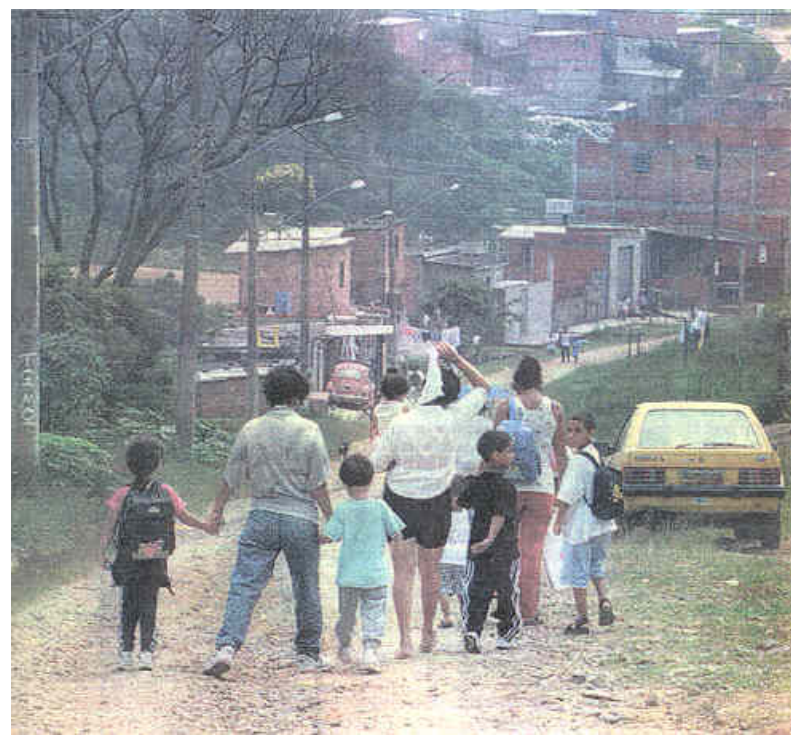

As crianças da periferia são obrigadas a andar por longas distâncias para estudar e as ruas nem sempre são pavimentadas, nem dispõe de calçadas.

Fonte: arquivo da autora [YABIKU(1999)]

Figura I-29. Calçadas estreitas.

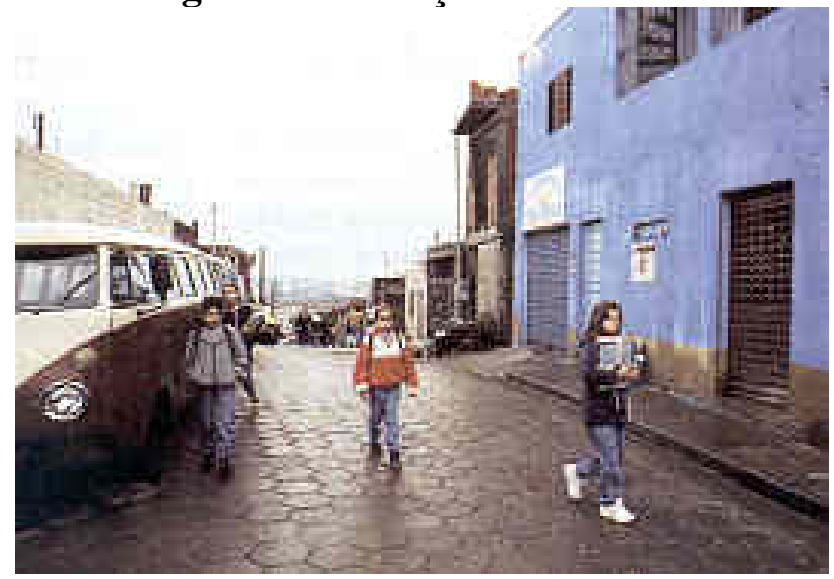

Em bairro popular (geralmente loteamento irregular) as calçadas tendem a ser estreitas e as crianças são obrigadas a utilizar a rua para ir à escola.

Fonte: arquivo da autora [YABIKU(1999)] 
Figura I-30. Calçadas em mal estado de conservação.

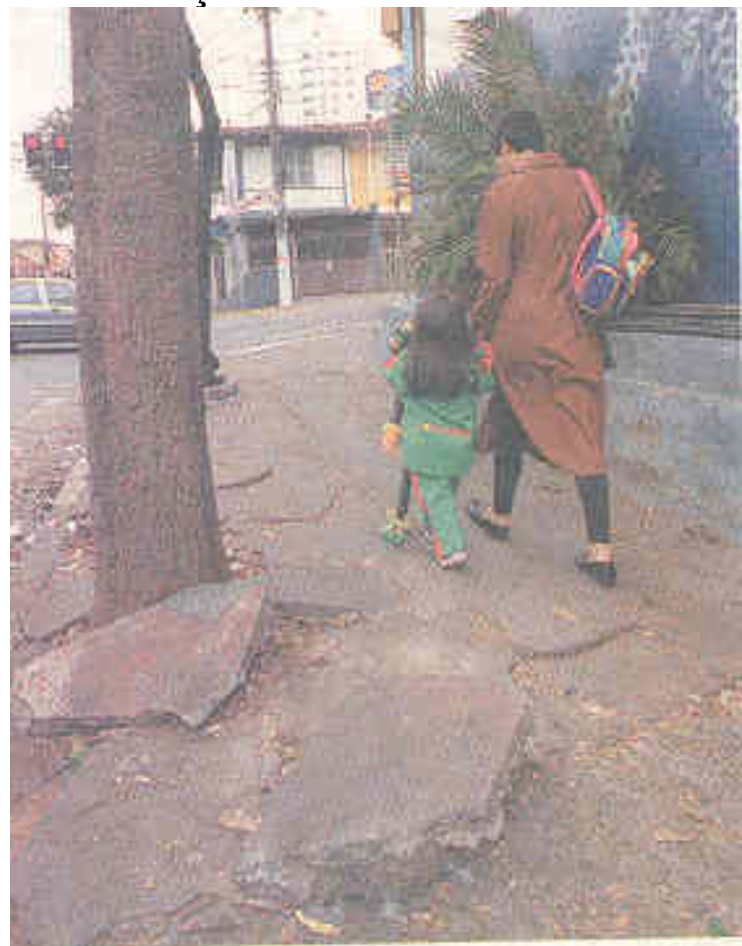

Em bairro central da cidade o estado das calçadas também não é favorável a caminhadas, somente a obrigação de ir à escola justifica correr riscos.

Fonte: arquivo da autora [YABIKU(1999)]

\subsubsection{Período etário da criança.}

O Estatuto da Criança e do Adolescente define "a criança como a pessoa até 12 anos de idade incompleto e adolescente a pessoa entre 12 e 18 anos de idade”.

Mas, conforme o desenvolvimento da criança ela tem bem demarcadas as fases de seu crescimento:

- Recém-nascido: de 0 a 28 dias

- Lactente: de 29 dias a 1 ano e 11 meses

- Pré-escolar: de 2 anos a 6 anos

- Escolar: de 7 anos a 9 anos

- Adolescente: de 10 anos a 19 anos. 


\subsubsection{Antropometria da criança}

O ser humano compartilha com todos os outros animais o processo biológico do crescimento e desenvolvimento, porém apresenta uma característica particular - o tempo prolongado necessário à sua maturação durante toda a infância e adolescência.

O crescimento, assim como o desenvolvimento da criança, é um processo contínuo e cada etapa deste processo se apóia na fase precedente e condiciona a seguinte. Todo este processo está sob os efeitos de determinantes sociais, econômicos e culturais que ampliam, restringem ou mesmo anulam tais ou quais aspectos do crescimento e desenvolvimento da criança.

O crescimento é o resultado da divisão celular e do aumento do tamanho das células, com conseqüente aumento de massa corpórea que pode ser identificada como "unidade de massa" em determinada "unidade de tempo". O crescimento refere-se ao aspecto quantitativo das proporções do organismo, ou seja, trata-se das mudanças das dimensões corpóreas, como peso, altura, perímetro cefálico, etc.

Desenvolvimento fundamenta-se no ganho da capacidade, não há "unidade mensurável" mas há "unidade de tempo". O desenvolvimento refere-se às mudanças qualitativas, tais como aquisição e aperfeiçoamento de capacidades e funções, que permitem às crianças realizarem novas atividades, progressivamente mais complexos e com habilidades cada vez maiores.

O crescimento e o desenvolvimento da criança se constituem-se como processos integrados e indissociáveis, porém, enquanto o crescimento termina em determinada idade, quando o ser humano atinge sua maturidade biológica, o desenvolvimento é um processo que o acompanha através de toda sua existência. 
No crescimento físico, em condições normais, cada tecido e cada órgão cresce segundo grau, padrão e velocidades próprios. Assim as dimensões externas, os tecidos muscular e ósseo, volume sanguíneo, órgãos dos aparelhos respiratórios, circulatório e digestivo, rim e baço, não são processos biológicos uniformes por unidade de tempo, apresentando períodos de aceleração e outros de desaceleração. [EPM (2003)]

As maiores velocidades de crescimento, avaliadas por meio de medidas do peso e da estatura, ocorrem nos períodos de zero a dois anos de idade e na adolescência. No primeiro ano de vida a criança que nasce com cerca de $3,0 \mathrm{~kg}$, dobra seu peso até os seis meses de idade e triplica aos 12 meses. Sua estatura, em torno de $0,50 \mathrm{~m}$ ao nascer aumenta $0,15 \mathrm{~m}$ até os seis meses de idade e $0,25 \mathrm{~m}$ no final do primeiro ano.

O crescimento no primeiro ano de vida reflete, sobretudo, as condições de nascimento, gestação, tamanho da mãe e tende a ser constante até os 18 meses de vida, quando então se aproxima do potencial genético (podendo acelerar ou desacelerar seu crescimento nesse período), mantendo-se no mesmo percentil até os 10 ou 12 anos, isto é, antes de iniciar a puberdade. Em geral, o pré-escolar e o escolar apresentam um ganho anual de 2,5 a $3,5 \mathrm{~kg}$ de peso.

Uma característica desse crescimento é que, dos seis meses de idade até a puberdade, as extremidades crescem mais rapidamente do que o tronco, de forma que o ponto médio da altura desloca-se do umbigo para a sínfise púbica. Assim, as relações entre os segmentos superior e inferior e entre a envergadura e a estatura vão sofrendo modificações no decorrer desse processo, estabilizando-se somente após a puberdade. Ainda que as medidas dos segmentos corporais não sejam tomadas rotineiramente, trazem informações valiosas e são indispensáveis para avaliação dos distúrbios de crescimento, pois às diferentes causas desses distúrbios podem se associar, ou não, 
$\overline{\text { alterações nas proporções corporais. A seguir, apresentamos as relações entre segmento }}$ superior (SS) e segmento inferior (SI) e entre a envergadura (Env) e Estatura (Est) nas diferentes faixas etárias.[EPM(2003)].

- $\mathrm{SS} / \mathrm{SI}=1,7$ ao nascer; 1,3 aos três anos; 1,0 após sete anos;

- Env - Est $=-3 \mathrm{~cm}$ até sete anos; 0 dos oito aos 12 anos; +1 e +4 aos 14 anos, no sexo feminino e masculino, respectivamente.

Quanto ao comprimento, do primeiro ao segundo ano de vida, a criança cresce em torno de $0,12 \mathrm{~m}$; dos dois aos três anos, cresce $0,08 \mathrm{~m}$ e entre três e quatro anos cresce $0,07 \mathrm{~m}$. A partir dos quatro anos até o início da puberdade o ritmo médio de crescimento é de 0,04 a 0,06 $\mathrm{m}$ ao ano, tornando-se tanto mais lento quanto mais próximo ao início do estirão puberal.

Crescimento Neural - refere-se ao crescimento do cérebro, cerebelo e estruturas afins, sendo representado pelo perímetro cefálico (PC) que apresenta uma intensa velocidade nos dois primeiros anos de vida. O PC aumenta cerca de $0,20 \mathrm{~m}$ do nascimento aos 18 anos, dos quais $75 \%$ até os dois anos de idade. Ao nascimento, o PC tem 34 a $36 \mathrm{~cm}$, sendo que, no primeiro ano de vida, cresce $0,12 \mathrm{~m}: 0,02 \mathrm{~m} / \mathrm{mes}$ no primeiro trimestre, $0,01 \mathrm{~m} / \mathrm{mes}$ no segundo trimestre e $0,05 \mathrm{~m} / \mathrm{mes}$ no segundo semestre.

Fatores do crescimento - a vulnerabilidade do processo de crescimento não só se expressa nas deficiências energético-proteicas, que podem se apresentar por falta de aporte suficiente ou pela presença de patologias, mas também nas privações psicossociais, constituindo-se em processo extremamente sensível a todos os tipos de agravos. Os fatores que atuam no crescimento da criança estão, resumidamente, apresentados a seguir: 
Fatores exógenos ou extrínsecos - Dos fatores exógenos destacam-se fatores socioeconômicos, ambientais e nutricionais sendo que, até os dois anos de idade, estes fatores influenciam o crescimento de forma mais determinante do que os fatores endógenos.

Fatores endógenos ou intrínsecos - Os fatores endógenos, que incluem herança genética, sexo, etnia, fatores hormonais, começam a interferir de forma mais expressiva no crescimento, a partir dos dois anos. A partir dessa idade, o hormônio de crescimento (GH) torna-se o principal responsável pelo ritmo de crescimento. Antes dos dois anos, os fatores hormonais (hormônios tireoidianos, cortisol, glucagom, insulina) atuam de maneira igualitária.

Avaliação do Crescimento - O crescimento pode ser avaliado por métodos clínicos, físicos, bioquímicos e antropométricos. Os métodos clínicos têm como base a anamnese e o exame físico e são usados em conjunto com os métodos físicos (radiologia), bioquímicos (dosagens de ferro, proteínas, cálcio, fósforo, etc) e antropométricos.

Dados antropométricos - Os dados antropométricos são de grande utilidade na avaliação do crescimento, desde que as seguintes etapas sejam adequadamente cumpridas: registro exato da idade e sexo da criança, tomada periódica e precisa das medidas e adoção de curva de referência. As medidas mais utilizadas para avaliação do crescimento são:

- peso

- comprimento ou altura

- relação peso/altura

- perímetros cefálico, torácico, braquial

- segmentos corpóreos: envergadura, segmento superior e inferior 
As curvas de referência, teoricamente, deveriam se confundir com o padrão de normalidade dos indivíduos examinados, isto é, deveriam ser construídas a partir de medidas observadas em indivíduos bem nutridos e com potencial genético de crescimento idêntico ao dos examinados. Na prática, dadas às diminutas diferenças que parecem separar, pelo menos nos primeiros anos de vida, o crescimento dos diferentes grupos étnicos quando favoráveis às condições ambientais, aceita-se que as curvas de referência, desde que construídas a partir de populações cujo crescimento físico se dê livre de impedimentos ambientais e de acordo com as recomendações técnicas, podem ser utilizadas como aproximações válidas do que seria a normalidade. A mais utilizada é a do National Center for Health Statistics (NCHS). Gráficos (I-1) e (I-2) [ABATE(2004)]

A curva do NCHS foi construída a partir dos dados de dois grandes estudos:1929/75 crianças de zero a 24 meses (867 crianças brancas) e o de 1962/74, resultado de três pesquisas, das quais fizeram parte crianças de dois a 18 anos (20.000 indivíduos). A Organização Mundial de Saúde recomenda a utilização desta curva como referência internacional. Assim, o Ministério da Saúde do Brasil adotou esta curva no cartão de acompanhamento da criança. O importante é definir o objetivo na utilização da curva de referência, lembrando que a avaliação individual, deverá considerar um conjunto de dados obtidos a partir da anamnese, exame físico e, quando necessário, de exames subsidiários.

O crescimento da criança tem caráter complexo, tanto no aspecto dos fatores que interferem com maior ou menor intensidade em determinadas faixas etárias, como na velocidade e diferentes particularidades com que cada órgão e sistema adquirem funções maduras. As formas de avaliar o crescimento partem de comparações 
$\overline{\text { populacionais, até chegar ao indivíduo onde ritmo, características, velocidades de }}$ crescimento são únicas para atingir seu objetivo final que é tornar-se adulto. 
Gráfico (I-1) Curva de crescimento: altura e peso. Sexo masculino, de 2 a 20 anos de idade.

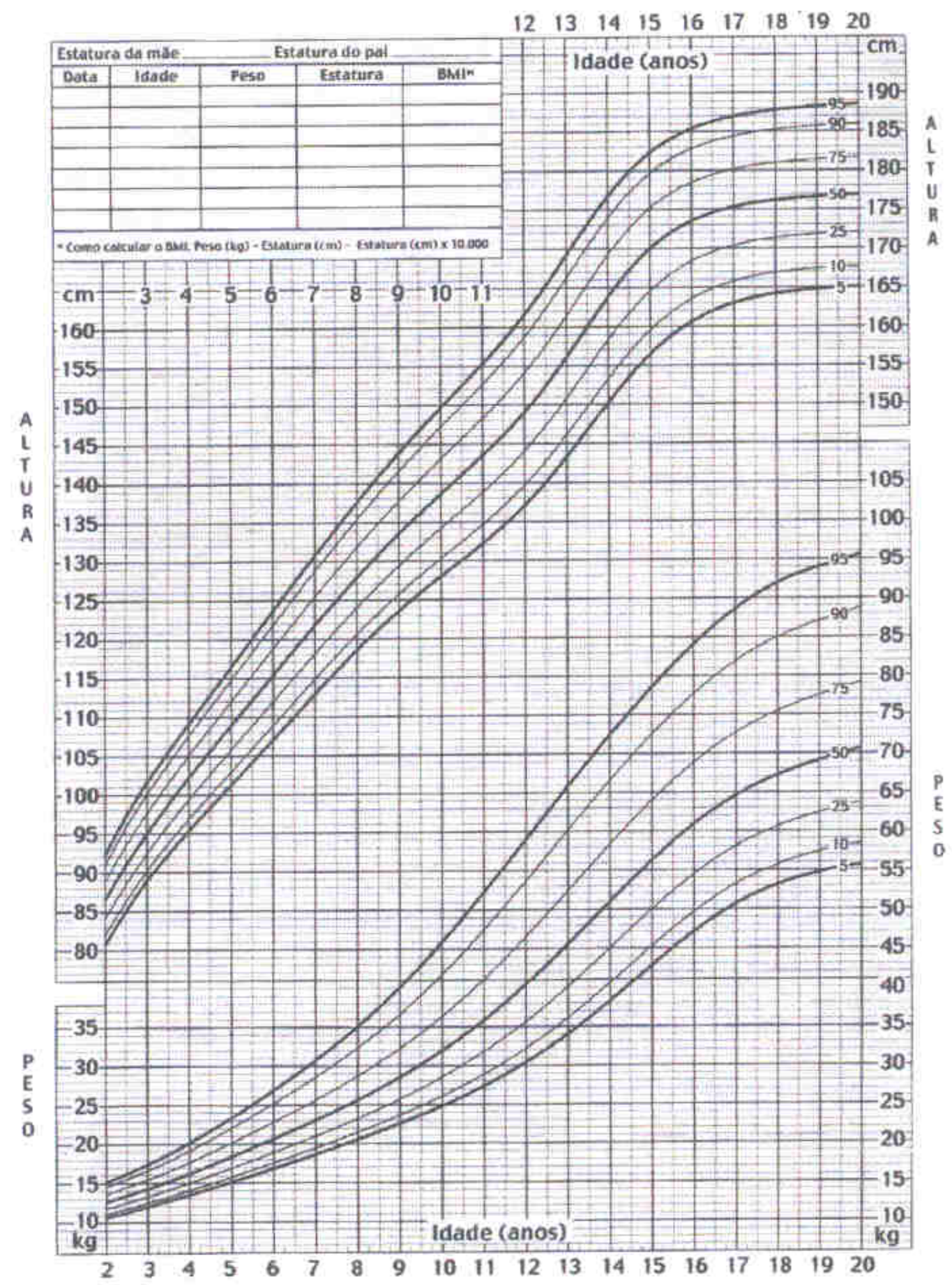

Fonte: National Center for Health Statistics (NCHS), EUA, em [ABATE (2004)] 
Gráfico (I-2) Curva de crescimento: altura e peso. Sexo feminino, de 2 a 20 anos de idade.

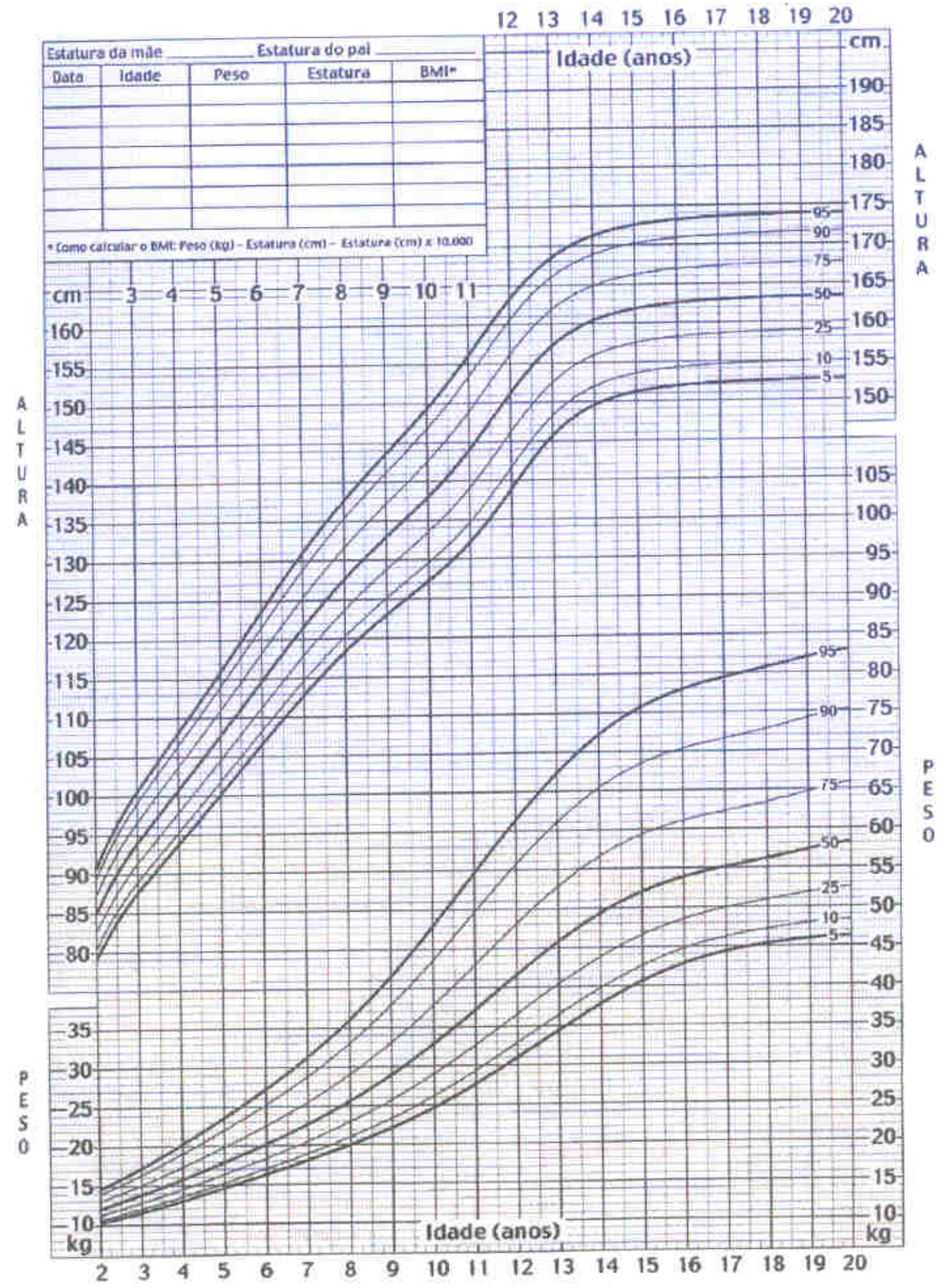

Fonte: National Center for Health Statistics (NCHS), EUA, em [ABATE (2004)] 


\subsubsection{Os pés e os calçados das crianças}

Para a criança pedestre o crescimento dos pés e o uso de um calçado adequado são fatores importantes. Os pés, com seus frágeis ossos em crescimento, necessitam de apoio e estabilidade.

Durante os dois primeiros anos de vida os pés da criança são menos definidos e possuem mais cartilagens e tecido do que ossos, cujo processo de ossificação tem início mais tarde. No entanto é nessa fase que a criança começa a caminhar, desenvolvendo o seu ciclo biomecânico. Nesta etapa, a acomodação dos pés nos calçados necessita muita atenção. As crianças novas tendem a encolher os dedos dificultando a confirmação da acomodação, o que causará desconforto e também poderá impedir o fortalecimento dos pés da criança, por não poder mover os dedos. Além do espaço na caixa dos dedos devese verificar se os pés da criança assentam sem sair na parte mais larga do sapato e que o pé não escorrega no calcanhar. [SILVA(2005)]

Durante o crescimento da criança a arcada do pé não está ainda desenvolvida, mas isto não significa que a criança possui "pé chato", pois à medida que o pé se desenvolve, os 26 ossos que compõe o pé começam a desenvolver gradualmente para o lado medial criando a arcada longitudinalmente, a arcada surge quando o tecido gordo começa lentamente a desaparecer. Nesta fase as crianças tendem a escolher o calçado pela moda e não pela funcionalidade, dispondo-se a sacrifícios com os pés.

O ritmo normal de crescimento dos pés varia ente $2,5 \mathrm{~cm}$ a $5,0 \mathrm{~cm}$ por ano, durante a puberdade ( 8 a 13 anos) e 2,5 $\mathrm{cm}$ a $15,0 \mathrm{~cm}$ por ano durante a adolescência. (Foi mantido a unidade $\mathrm{cm}$ da pesquisa do autor Paulo Silva) [SILVA(2005)]. 
O rápido crescimento dos pés das crianças faz muitos pais comprarem calçados maiores que seus pés, para permitir os pés crescerem e os calçados durarem mais. Este fato pode trazer lesões e desalinhamento no desenvolvimento dos pés e pernas da criança.

Recomendações:

- Verificar o tamanho dos calçados constantemente certificando-se que não estejam apertados e procure averiguar os desgastes anormais. O ideal é a vistoria a cada três meses.

- Observe a criança caminhar descalça; se apontar os dedos para dentro, fora, tocar joelho com joelho ou qualquer outra anomalia consulte um médico ortopedista.

- O calçado preferível é aquele com cadarço ou velcro para ajustar numa pressão adequada aos pés.

- A sola deve ser flexível e estável. A caixa dos dedos deve ser redonda e possuir espaço suficiente para a criança mexer todos os dedos livremente.

- O contraforte deve ser forte e estável de forma a evitar movimentos mediais/laterais.

- Evitar calçados com salto alto. O pé deve estar posicionado como se a criança estivesse descalça.

- Evitar utilizar calçado de uma criança para outra, pois este calçado pode estar com acomodação viciada e cada pé precisa de acomodação específica.

- Cuidado ao administrar medicação contra fungos e bolhas nos pés. A medicação forte pode queimar ou machucar a pele. 


\subsubsection{Fisiologia da criança.}

A fisiologia da criança difere da fisiologia do adulto, basicamente, porque ela está em formação. Apesar de ter todos os órgãos completos, estes não estão em plena capacitação. As partes sensorial e psíquica são as mais sensíveis e potencialmente vulneráveis às crianças, expondo-as a situações de perigo, mesmo não sendo percebido por elas. Assim Schneider e Robin [SCHNEIDER;ROBIN(2003)], abordaram a questão conforme resumido em tópicos, abaixo.

A visão: uma criança não enxerga como um adulto.

-seu campo de visão é estreito, ela vê unicamente à sua frente.

- por causa de seu pequeno tamanho, ela não pode ver acima dos automóveis estacionados, e também não é vista pelos motoristas.

- ela não vê se não contrastes, assim ela leva cerca de 4 segundos para distinguir se um automóvel está rodando ou parando,

- ela confunde "tamanho" e "distância": um automóvel lhe parece mais distante que um caminhão.

- ela confunde "ver" e "ser visto" e, conseqüentemente, não se preocupa em se mostrar. A audição: uma criança não entende como um adulto.

- não detecta bem de onde vem o som.

- se distrai com os ruídos decorrentes da via.

- não entende senão os ruídos que lhe interessam (por exemplo, o chamado de alguém).

A relação causa-efeito: uma criança não compreende bem.

- assim ela não pensa na "distância de parar" de um veículo: ela acredita que um automóvel para instantaneamente, quando o motorista pisa o freio. 
Distância, Tempo, Velocidade: uma criança não é capaz de avaliá-los corretamente.

- a criança não tem noção de profundidade, não conseguindo distinguir o longe de muito longe (ao olhar para cima o avião e o semáforo estão no mesmo plano).

A síntese global: uma criança não sabe pensar e reagir a muitas coisas de uma vez.

- é difícil a ela observar ao mesmo tempo a passagem para pedestres, a sinalização do "homenzinho verde", os automóveis, etc.

A satisfação de suas necessidades: uma criança procura abordar a satisfação de suas próprias necessidades.

- para elas, brincar, mexer, estar na hora da escola ou em casa, divertir-se com seus pais do outro lado da rua ou rebater sua bola é mais importante que observar a circulação; para fazer aquilo que ela objetive fazer, uma criança é capaz de se jogar contra um automóvel que entra na sua visão, mas que lhe contrarie seu caminho.

A morte: uma criança não teme a morte.

- para ela a morte é como um jogo; ela brinca de morrer, depois se levanta e está de novo vivo. A criança, portanto, não tem medo de morrer, mas tem mais receio da bronca que vai levar se ela obrigar os automóveis a pararem: ela vai, portanto, correr com o objetivo de não atrapalhar.

O ambiente seguro: uma criança tem sempre a impressão de estar em segurança.

- por exemplo, ela pensa que nada pode acontecer se estiver próximo a seus pais ou se adultos estão perto delas, ou se estão perto de sua casa ou de sua escola.

As falsas "imagens" da criança: os objetos não têm o mesmo significado que têm para os adultos.

- a rua, para elas é um espaço para brincar sob o controle dos pais. 
- o automóvel: elas têm confiança neles, pois eles se assemelham a seres humanos (faróis $=$ olhos, etc $)$.

- a passagem para pedestres, impropriamente chamada de "protegida", não o é, trata-se de um lugar onde ela deve acautelar-se, não é um lugar amigável.

A “imitação": uma criança imita sempre os adultos.

Mais ainda que os adultos, a criança "imita": ela pensa que se os outros atravessaram, ela pode passar também, sem levar em conta que em alguns segundos a situação muda; e se elas estão de mãos dadas, as crianças se confortam mutuamente dentro da idéia da ausência de perigo.

3.2.5 Orientação para um caminhar seguro da criança.

As causas dos acidentes. Explicar bem às crianças que as causas dos acidentes são conhecidas e quando suprimidas as causas, suprimem-se os acidentes.

Não inverter as responsabilidades. Jamais perder a ocasião de dizer à criança que o excesso de prudência que lhe é pedido, é motivado pelo comportamento perigoso e ilegal de uma parte dos automobilistas.

Seriedade. A rua não é um jogo: não há como adotar uma abordagem lúdica para lhes ensinar a segurança.

O exemplo. Pais, professores; sejam exemplos quando vocês acompanham as crianças. Exijam, por exemplo, que cada criança do grupo veja constantemente os dois lados da travessia.

A passagem de pedestre. Não diga jamais "passagem protegida": centenas de pedestres são mortos todos os anos sobre as passagens de pedestres. Fazer da passagem de pedestre o único meio seguro, é impedir aos pedestres de atravessar 
noutro lugar qualquer, o que é eleger o inadequado, pois as vias locais nem sempre tem estas travessias, e a travessia é uma acessibilidade para todos. Portanto, às criança devem-se ensinar também, como atravessar nas ruas não equipadas com passagens para pedestres.

O lugar do policial. Não é pedagógico, nem para automobilistas, nem para as crianças, colocar um policial sobre a passagem de pedestre: isso habitua as crianças a atravessarem sem a vigilância e os automobilistas a pararem somente se houver um policial sobre a passagem de pedestre. Por outro lado, se o policial está sobre a calçada, ele pode apitar aos automobilistas que não pararem para ceder a passagem aos pedestres conforme o Art 70 do Código de Trânsito Brasileiro [CTB(1997)], e além de poder fazer observação a uma criança sobre algum erro cometido ao fazer a travessia.

Os pontos importantes a serem ensinados:

Antes de atravessar a rua: mostrar-se. Se o automóvel não está muito próximo, dar um passo adiante, em frente aos automóveis, que deverão estar parando, para se tornar visível (mostrar-se); parar um momento, e só depois continuar a travessia quando os automóveis pararem de verdade, ou se não houver nenhum automóvel.

Não se lançar na corrente, para atravessar, nem se arrastar demais: atravessar com passo de alerta e vendo constantemente os dois lados, para vigiar os automóveis.

A figura do pedestre verde e vermelho. Quando a figura passa a verde: ficar desconfiado e esperar que os automóveis parem completamente, antes de iniciar a travessia. Quando a figura passa para vermelho, se já estamos atravessando, saiba 
que, legalmente, o pedestre tem o direito de continuar, e que dispõe de menos de cinco a seis segundos antes de o semáforo passar ao verde para os automóveis.

Seja visível. Usar vestimentas chamativas, e se possível amarelas ou brancas no inverno, acompanhados de suspensórios ou faixas retro reflexivos costurados.

A distância de frenagem e o tempo de reação. É uma noção indispensável explicar à criança, mesmo pequenas, porque elas acreditam que os veículos param instantaneamente.

O álcool. A criança aprende e cresce rápido, ela observa e forja uma opinião mais ou menos definitiva, para as idéias recorrentes, que entende e para os hábitos ou tradições comportamentais que constatam na sua vida diária. Portanto, é importante dizer, desde a mais tenra idade, que uma pequena dose de vinho, ou cerveja ou qualquer outra bebida alcoólica é perigosa para a condução: dá euforia, diminuição dos reflexos, aumento do tempo de reação e adormecimento precoce.

\subsubsection{A criança e a bicicleta}
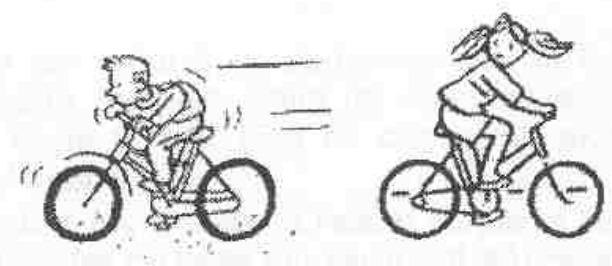

A circulação das crianças e adolescentes em bicicletas é notória e intensiva, apesar de seu trajeto ser normalmente de curta distância, resumindo se ao circuito de casa escola - lazer. Mas com a velocidade desenvolvida, a impetuosidade das crianças, e sua natural imaturidade (descritas neste capítulo), os acidentes são comuns e às vezes fatais. 
Conforme Robin [ROBIN(2005)], os acidentes de bicicletas, mais freqüentes, com crianças são as colisões perpendiculares com os veículos motorizados: nas saídas das propriedades ou das vias particulares (condomínios) para os mais jovens $(6-9$ anos), ou nos cruzamentos para os mais velhos (9 - 14 anos), freqüentemente devido ao desrespeito a parada obrigatória ou a de ceder a passagem. A seguir são aqueles com jovens ciclistas manobrando à esquerda, notadamente as crianças entre 12 a 14 anos.

Seguem algumas recomendações visando a segurança das crianças em bicicletas.

Saída de uma propriedade privada. Colocar uma larga cancela atravessando a saída da propriedade, isto habituará a criança a prestar atenção a este lugar.

Cruzamentos. Orientar as crianças a parar ao sinal do "PARE" e a desacelerar ao sinal de "Dê a Preferência". Verificar, freqüentemente, se os dois freios da bicicleta funcionam bem e que a criança, com seus pequenos dedos, pode agarrar e apertar facilmente os cabos; senão, mudar os cabos.

Virar à esquerda num cruzamento. No caso de um cruzamento de ruas não muito largas e com pouco trânsito, a criança pode ir se colocando à esquerda, sinalizando a intenção da manobra estendendo o braço esquerdo. Com cautela, olhando à esquerda e para trás concretizar a conversão à esquerda.

Se o cruzamento for de ruas largas e com fluxo de trânsito mais intenso, então a conversão à esquerda deverá ser feita indiretamente, em duas etapas. Permanecer à direita, atravessar o cruzamento e parar à direita, ao lado dos veículos que esperam para atravessar. A seguir atravessar no momento mais conveniente. Outra solução para o pequeno ciclista é descer da bicicleta e atravessar o cruzamento com os pedestres, mantendo a bicicleta à mão. 
A rotatória. Indicar à criança os pontos perigosos (sobretudo as saídas de veículos que cortam a sua trajetória). Numa grande rotatória orientar para que circule bem à direita, mas numa rotatória pequena circular longe da borda direita, pois os motoristas podem supor que o ciclista pretende sair da rotatória e "empurrá-lo" para a direita, cortando a sua trajetória. Lembrar que na rotatória a velocidade dos automóveis é mais baixa, mas os ciclistas devem seguir esta velocidade, o que não é fácil, em vista de que está fazendo um trajeto em curva.

A Sinalização. Orientar para que obedeçam as sinalizações. "PARE", "Dê a Preferência", "Proibido Virar a Esquerda", "Proibido Trânsito de Bicicletas", "Duplo Sentido de Circulação", Parar no Semáforo Vermelho, etc. A figura (28) ilustra algumas placas de sinalização do Código de Trânsito Brasileiro [CTB(1997)], que o jovem ciclista deve conhecer.

Circular na cidade. Não passar rente aos automóveis nos estacionamentos, nem junto aos pedestres. Deixar ao menos um metro à direita, como medida de segurança, no caso de algum movimento imprevisto.

Rua de pedestre (calçadão) e passeios. Não circular nos calçadões a menos que aja uma ciclovia, devidamente marcada, separando o trânsito de pedestres e ciclistas.

Andar em grupo ou em pelotão. É interessante e divertido, porém por medida de segurança formar pequenos grupos de 2 ou 3, com algumas dezenas de metros separando os grupos.

Ser visto. Usar vestes que tenham elementos ou faixas refletivas ou vestes claras (branca, amarela, etc). 
Figura 31. Algumas placas de Sinais de Regulamentação

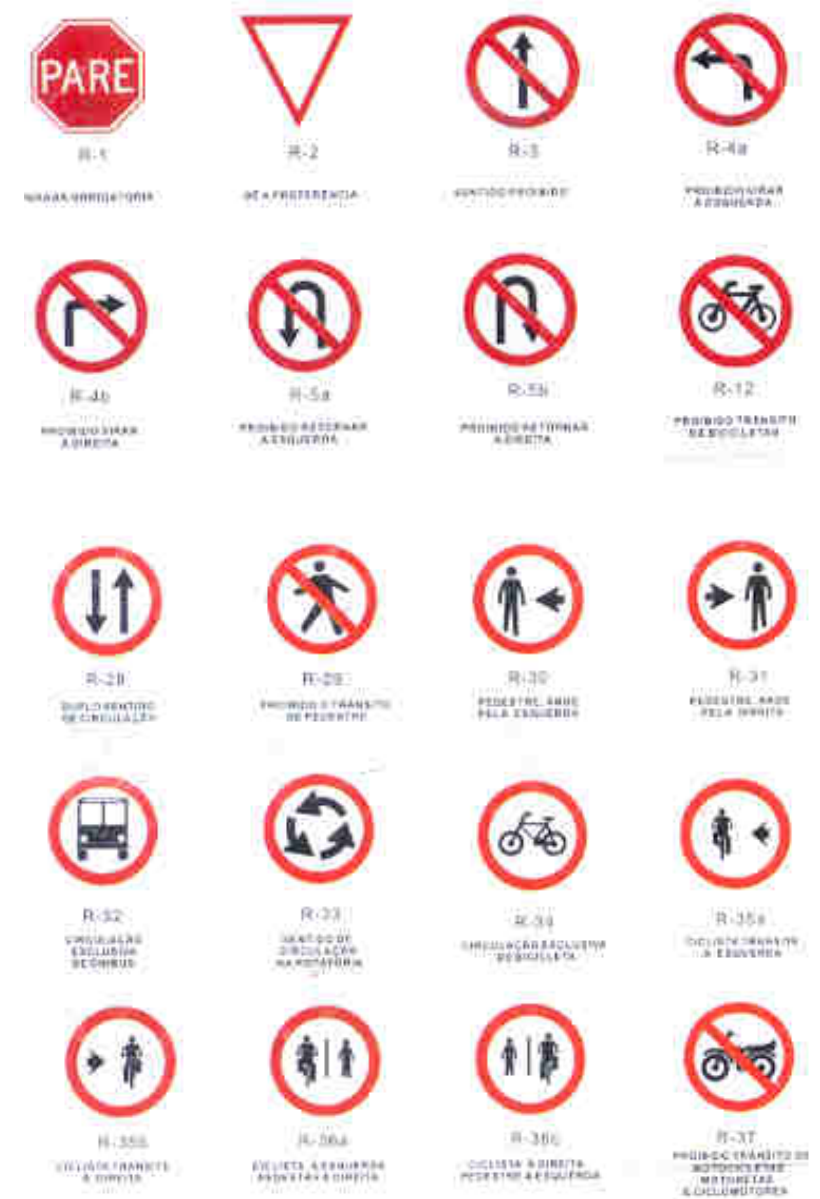

Fonte: Código de Trânsito Brasileiro. [CTB(1997)]

Manutenção da bicicleta. Aprender a mudar o cabo de freio, a regular os freios, lubrificar os cabos, a fixar um catadióptricos e a trocar lâmpada. Manter as correntes da bicicleta limpas e lubrificadas. Calibrar os pneus.

Exercícios de habilidades. Treinar pequenas habilidades é até necessários, para utilizá-las em situações emergenciais. Por exemplo:

1. soltar a mão esquerda do guidão para agarrar um objeto (garrafa de plástico) sobre uma mesa e colocá-lo mais adiante: isto pode ajudar a estender o braço esquerdo para indicar que vai fazer conversão. 
2. Rodar em diversos tipos de pisos irregulares, pedriscos, gramas, etc. Com esta habilidade a criança pode se salvar quando tiver que desviar dos veículos em situação de colisão.

3. Ultrapassar a guia da calçada. Este gesto pode salvar a criança ciclista quando estiver numa situação difícil, por exemplo, quando acuada por um caminhão que vai virar à direita.

\section{Recomendações}

No Brasil os acessórios obrigatórios para a bicicleta são: refletor dianteiro, traseiro, de rodas e pedais; campainhas e espelho retrovisor. Este último é de uso controverso, pois muitos acreditam que é mais importante para a segurança do ciclista olhar para frente do que olhar para trás, além disso, a imprecisão causada pela vibração da bicicleta causa grande imprecisão na imagem do espelho.

Para a segurança das crianças ciclistas recomenda-se:

-Reduzir drasticamente a velocidade dos veículos nas instalações apropriadas como rotatórias, lombadas, viadutos, etc.

- O ideal seria a implantação de ciclovias, ligando as casas e as escolas.

- A separação de pistas para os veículos a motor e as bicicletas é a solução mais segura para as crianças. A pista para a bicicleta pode ser uma instalação sobre a calçada ou passeio, se esta for larga o suficiente. Nos cruzamentos os veículos a motor que fazem a conversão à direita podem ver o ciclista sobre a pista, porém estas pistas devem ser devidamente sinalizadas. As calçadas e passeios devem ser bem demarcados separando as pistas de bicicletas e dos pedestres. 
- Uma faixa para ciclistas delimitada no leito carroçável, devidamente demarcada com faixa de separação de trânsito e sinalização horizontal.

Esta solução só é aceitável para as ruas de baixo volume de trânsito e para ciclistas adultos. Para as crianças é perigoso, pois os veículos transitam rente aos ciclistas e no caso de crianças, estas são muito vulneráveis e podem desequilibrar-se com facilidade de suas bicicletas. Além disso, nos cruzamentos os caminhões e os veículos que fazem a conversão à direita não têm boa visão das crianças-ciclistas que se encontram no aguardo à direita. As figuras I-29 e I-30 exemplificam uma ciclovia bem demarcada numa via urbana.

\section{Figura I-32 Ciclovia em via urbana, bem delimitada}

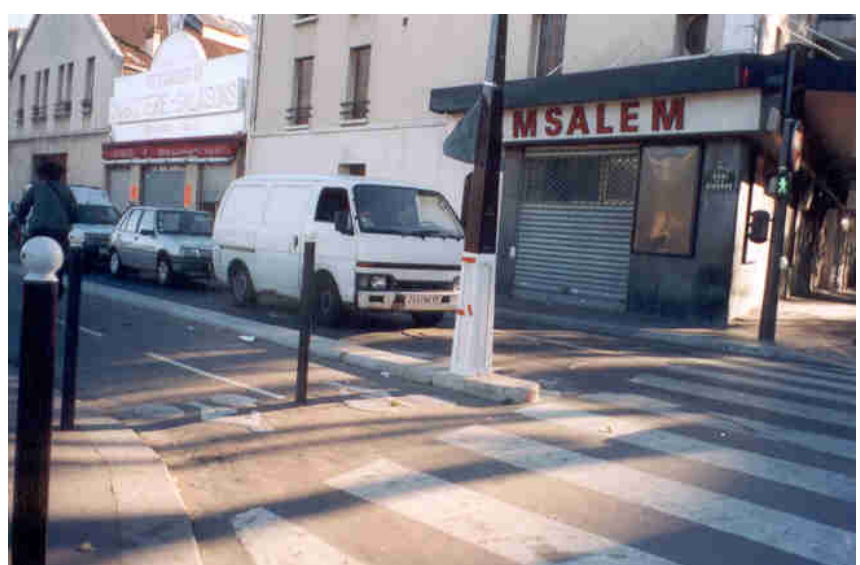

Fonte: Arquivo da autora. Paris. [YABIKU(1999)]

Figura I-33. Outra tomada da mesma ciclovia acima citada

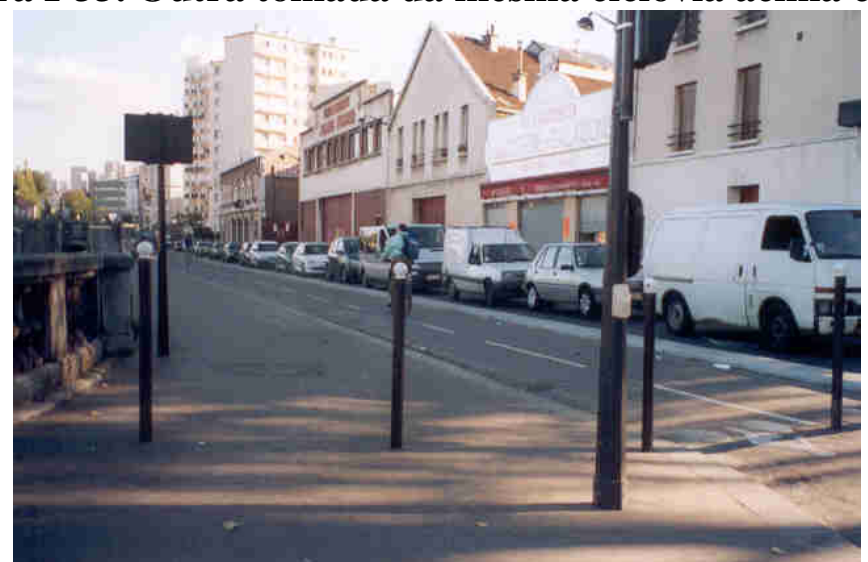

Fonte: Arquivo da autora. Paris. [YABIKU(1999)] 
- A circulação em contra fluxo, nas vias de sentido único, de baixo volume de trânsito e onde a velocidade é baixa, tem a vantagem de se ter uma boa visão dos veículos que vem, mas devem ser bem sinalizados com placas. Há muitos acidentes nestas circunstâncias.

- Aconselhar o uso de tênis ou calçado de sola que não escorregue no pedal e tenha aplicativo retro-reflexivo.

- Ao comprar a bicicleta os pais devem adequar o tamanho à estatura da criança. Ela estará adequada quando a criança for capaz de apoiar os pés inteiros no chão, mesmo estando sentada no banco. O ideal é que com o pé apoiado no pedal, a perna da criança fique levemente dobrada (isto evita sobrecarga nos joelhos ao pedalar) Verificar se tem adesivos refletores nos paralamas dianteiros e traseiros e nos pedais.

- Finalmente a recomendação maior: o uso do capacete. A vantagem deste é a proteção da cabeça nas colisões com veículos, ou em caso de quedas, o que tem salvado vidas e reduzido as deficiências físicas. O inconveniente é que costuma-se transferir para a parte mais vulnerável (os ciclistas) a responsabilidade de se proteger da imprudência dos automobilistas. Além disso, os capacetes apresentados não são muitos anatômicos às crianças e, normalmente, ficam folgados na cabeça, mesmo quando fortemente atados ao queixo. O capacete ideal, bem ventilado e com a proteção da nuca acolchoada, estará na posição correta quando cobrir todas as partes superiores da testa, protegendo-a assim contra impactos importantes. No Brasil o uso do capacete não é obrigatório, mas é recomendável. O capacete também deve possuir adesivos refletivos. 


\section{O COMPORTAMENTO DO PEDESTRE NO ESPAÇO URBANO}

Dependendo da área disponível, o pedestre desenvolve um tipo de comportamento, conforme observado por Pushkarev [PUSHKAREV(1975)], e adaptado por CET [CET(1978)], conforme tabela I-6.

Tabela I-6. Comportamento do pedestre em relação ao espaço disponível

\begin{tabular}{|c|c|c|c|c|c|c|}
\hline $\begin{array}{l}\text { Superfície } \\
\text { média } \\
\text { por } \\
\text { pessoa } \\
\left(\mathbf{m}^{2}\right) \\
\end{array}$ & Fluxo & $\begin{array}{l}\text { Velocidade } \\
\text { média }\end{array}$ & $\begin{array}{l}\text { Escolha da } \\
\text { velocidade }\end{array}$ & $\begin{array}{l}\text { Movimento } \\
\text { contrário } \\
\text { ou cruzado }\end{array}$ & Conflitos & Ultrapassagem \\
\hline 0,2 a 0,5 & Errático & Arrastada & Nenhuma & Impossível & $\begin{array}{l}\text { Contato físico } \\
\text { inevitável }\end{array}$ & Impossível \\
\hline 0,5 a 0,7 & $\begin{array}{l}\text { Tende ao } \\
\text { máximo } \\
\text { para } \\
\text { correntes } \\
\text { de pressão } \\
\end{array}$ & Arrastada & Nenhuma & Muito difícil & $\begin{array}{l}\text { Provável } \\
\text { contato físico } \\
\text { conflitos } \\
\text { inevitáveis }\end{array}$ & Impossível \\
\hline 0,7 a 1,1 & $\begin{array}{l}\text { Tende ao } \\
\text { máximo } \\
\text { para } \\
\text { correntes } \\
\text { em regime } \\
\text { relaxado }\end{array}$ & $\begin{array}{l}\text { Mais ou } \\
\text { menos } 67 \% \\
\text { daquela do } \\
\text { fluxo livre }\end{array}$ & $\begin{array}{l}\text { Praticamente } \\
\text { nenhuma }\end{array}$ & $\begin{array}{l}\text { Severamente } \\
\text { restrito, com } \\
\text { colisão }\end{array}$ & $\begin{array}{l}\text { Provável } \\
\text { contato físico: } \\
\text { conflitos } \\
\text { inevitáveis }\end{array}$ & Impossível \\
\hline 1,1 a 1,5 & $\begin{array}{l}65 \text { a } 80 \% \\
\text { da } \\
\text { capacidade } \\
\text { máxima }\end{array}$ & $\begin{array}{l}\text { Mais ou } \\
\text { menos } 75 \% \\
\text { daquela de } \\
\text { fluxo livre }\end{array}$ & $\begin{array}{l}\text { Restrita, } \\
\text { necessário } \\
\text { reajuste } \\
\text { constante }\end{array}$ & $\begin{array}{l}\text { Severamente } \\
\text { restrito, com } \\
\text { conflitos }\end{array}$ & Inevitáveis & $\begin{array}{l}\text { Difícil sem } \\
\text { contato físico }\end{array}$ \\
\hline 1,5 a 1,8 & $\begin{array}{l}50 \text { a } 70 \% \\
\text { da } \\
\text { capacidade } \\
\text { média }\end{array}$ & $\begin{array}{l}\text { Mais ou } \\
\text { menos } 80 \% \\
\text { daquela de } \\
\text { fluxo livre }\end{array}$ & $\begin{array}{l}\text { Restrita, a não } \\
\text { ser para os } \\
\text { lentos }\end{array}$ & $\begin{array}{l}\text { Restrito, } \\
\text { com } \\
\text { colisões }\end{array}$ & $\begin{array}{l}\text { Altamente } \\
\text { prováveis }\end{array}$ & $\begin{array}{l}\text { Difícil sem } \\
\text { contato físico }\end{array}$ \\
\hline 1,8 a 2,5 & $\begin{array}{l}\text { Mais ou } \\
\text { menos } \\
50 \% \text { da } \\
\text { capacidade } \\
\text { máxima }\end{array}$ & $\begin{array}{l}\text { Mais que } \\
80 \% \\
\text { daquela de } \\
\text { fluxo livre }\end{array}$ & $\begin{array}{l}\text { Parcialmente } \\
\text { restrita }\end{array}$ & $\begin{array}{l}\text { Possível } \\
\text { com } \\
\text { conflitos }\end{array}$ & $\begin{array}{l}\text { Altamente } \\
\text { provável }\end{array}$ & $\begin{array}{l}\text { Difícil sem } \\
\text { manobras } \\
\text { abruptas }\end{array}$ \\
\hline 2,5 a 4,0 & $\begin{array}{l}\text { Mais ou } \\
\text { menos } \\
33 \% \text { da } \\
\text { capacidade } \\
\text { máxima }\end{array}$ & $\begin{array}{l}\text { Próxima à } \\
\text { de fluxo } \\
\text { livre }\end{array}$ & $\begin{array}{l}\text { Ocasionalmente } \\
\text { restrita }\end{array}$ & $\begin{array}{l}\text { Possível, } \\
\text { com } \\
\text { conflitos } \\
\text { ocasionais }\end{array}$ & $\begin{array}{l}\text { Provavelmente } \\
50 \% \text { do tempo }\end{array}$ & $\begin{array}{l}\text { Possível com } \\
\text { interferência }\end{array}$ \\
\hline $\begin{array}{l}\text { Mais de } \\
\mathbf{4 , 0}\end{array}$ & $\begin{array}{l}\text { Menos que } \\
20 \% \text { da } \\
\text { capacidade } \\
\text { máxima }\end{array}$ & À escolha & Sem restrições & Livre & $\begin{array}{l}\text { Necessário } \\
\text { manobrar para } \\
\text { evitar } \\
\text { conflitos }\end{array}$ & $\begin{array}{l}\text { Livre com } \\
\text { alguma } \\
\text { manobra }\end{array}$ \\
\hline
\end{tabular}

Fonte: CET. "Boletim Técnico 17 Área de Pedestres” [CET(1978)]. 
Ainda, segundo o Boletim Técnico 17, a CET [CET(1978)] observou que os pedestres desenvolvem um comportamento social, em relação ao espaço urbano, que é de certa forma, um comportamento universal de todos os caminhantes.

$1^{\text {o }}$ - Os pedestres preferem caminhar sempre no mesmo nível, evitando passagens subterrâneas e passarelas, por mais bem projetadas e seguras. Tais dispositivos constituem desvios do trajeto natural, freqüentemente aumentando o tempo de percurso, a distância para percorrer e o dispêndio de energia.

Numa travessia segura ao nível do solo, mesmo somando-se o tempo de espera, esta será feita com $30 \%$ de tempo menor e $1 / 5$ de dispêndio de energia daquela que seria gasta no caso de uma travessia por passagem inferior ou elevada.

$2^{\circ}$ - Os pedestres tendem a escolher as mínimas distâncias; não apenas entre dois pontos afastados, como também em trajetos pequenos como, por exemplo, para atravessarem a rua. Assim, a localização das faixas para pedestres, passarelas e passagens subterrâneas deve ser avaliada de acordo com esta característica de conveniência do pedestre, para que tenham utilização efetiva. Além disso, a própria disposição relativa das ruas de pedestres deve levar este fator em conta, já que elas são propostas para canalizar o trânsito de pedestres.

$3^{o}$ - A maioria das viagens de pedestres em grandes centros é de curto percurso (geralmente alguns quarteirões), usualmente ligando o estacionamento ao edifício, o terminal de transportes ao edifício e vice-versa e, ainda, ligando um edifício a outro.

Para estas viagens curtas o deslocamento a pé é, efetivamente, o mais indicado, pela disponibilidade, custo irrisório, liberdade de direção e de escolha de itinerário, etc. 
$4^{\circ}$ - Os padrões de distâncias a percorrer a pé são, em geral, semelhantes para cidades de portes semelhantes. Esta observação facilita o projeto de equipamentos urbanos que dependem deste tipo de dado, já que é possível usar experiências obtidas em outras localidades.

$5^{\circ}$ - O ser humano geralmente estabelece uma região em torno de si, destinado a servir de proteção contra contatos físicos diretos indesejados com outros elementos e para acomodar os seus membros e os balanços naturais do deslocamento. De modo a prever este espaço disponível recomenda-se usar uma faixa de $0,60 \mathrm{~m}$ de largura para o projeto de instalações para pedestres.

Em condições de fluxo livre, os pedestres preferem evitar contato físico com outros, adotando um espaçamento inter-pessoal maior (zona de passo e zona sensorial). Este espaçamento também determina a facilidade de ultrapassagem sobre os mais lentos e a capacidade de se desviar de obstáculos físicos. A zona de proteção é aproximadamente $0,60 \mathrm{~m}$ no eixo longitudinal e $0,50 \mathrm{~m}$ no transversal.

$6^{\text {0 }}$ - O ângulo visual e a percepção sensorial definem o chamado "envelope sensorial", que é uma região tridimensional de observação do pedestre. As informações captadas neste "envelope" orientam o pedestre em seu deslocamento, fazendo-o posicionar-se convenientemente na via e com relação aos fluxos de pedestres e de veículos; fornecem dados para a escolha de velocidade de deslocamento mais adequada e estabelecem as características para as medidas evasivas, de forma a serem evitados os obstáculos.

O conhecimento destes dados orienta o projeto das instalações físicas, da sinalização e do posicionamento dos obstáculos físicos que podem interferir no tráfego dos pedestres. $7^{\circ}$ - O pedestre não utiliza toda a largura da calçada durante seu percurso. Dessa forma não precisa ficar se deslocando lateralmente para evitar obstáculos fixos. Em geral, 
mantém-se afastado, no mínimo 0,45 $\mathrm{m}$ das paredes e muros, a não ser no caso de concentração de multidões. Da mesma forma, mantém-se afastado no mínimo $0,45 \mathrm{~m}$ das vitrines, ao passar por elas. A partir da guia da calçada, a distância mantida é de, no mínimo $0,35 \mathrm{~m}$ no caso de deslocamento ao longo da via e até $0,60 \mathrm{~m}$, no caso de existirem hidrantes, postes e latas de lixo.

Também devem ser levadas em conta as bancas de jornal e demais obstáculos. Pode-se definir uma "largura efetiva de calçada" que é a largura total menos a largura devida à existência de obstáculos. Esta é a dimensão a ser usada nos projetos, para cálculos de capacidade de escoamento.

$8^{\circ}$ - As viagens que têm por motivo as compras apresentam como características o maior número de travessias por viagens, velocidade de caminhar mais baixo, o menor grau de atenção dispensado pelo pedestre (a obstáculos, aos veículos, etc) e a execução de movimentos imprevisíveis. Deste modo, estas viagens são mais perigosas para os próprios pedestres.

$9^{\circ}$ - Todo elemento que se interponha no seu deslocamento, representa um obstáculo a mais no seu trajeto (passarelas, escadas, elevadores, calçadas, etc).

$10^{\circ}$ - Os dispositivos para o tráfego de veículos são os mais sérios obstáculos ao seu deslocamento (ruas, avenidas, viadutos, estradas, etc). 
A ABRASPE, Associação Brasileira de Pedestres [ABRASPE(1998)], faz as seguintes recomendações para um caminhar seguro, que chamou de "Regras de Sobrevivência do Pedestre".

1. Ande sempre pela calçada, ou pelo acostamento, até encontrar um lugar seguro e com boa visibilidade para atravessar a via;

2. Evite andar pelo meio fio, para não ser atingido por acessórios laterais do veículo;

3 Pare, Olhe, e Escute com atenção o trânsito, permanecendo na calçada ou no acostamento, até entender bem como os veículos estão se movimentando, principalmente em avenidas e rodovias onde eles desenvolvem alta velocidade;

4. Seja esperto: nas vias sem sinalização para pedestre, somente inicie a travessia quando a distância dos veículos permitir você realizá-la, caminhando com naturalidade;

5. Peça ajuda, caso não tenha entendido a sinalização ou sinta-se inseguro para atravessar a via;

6. Use a própria cabeça: não siga outras pessoas que atravessam correndo, achando que elas são espertas e sabem o que fazem;

7. Procure não atravessar em frente a veículos estacionados;

8. Respeite o sinal e use as faixas de pedestres, ou as passarelas, quando possível, porém, não confie cegamente na sinalização, observando se os veículos estão parados, ou quase parando, antes de atravessar;

9. Atravesse em trajetória perpendicular à via, nunca em diagonal, mantendo-se atento ao trânsito até alcançar o outro lado e, caso sinta insegurança, levante o braço com a palma da mão voltada para os motoristas; 
10. Use material refletivo no vestuário ou segure um objeto branco na mão, deixando-o bem à vista, quando andar a noite, pois o motorista não vê você, a não ser que use roupa clara que reflita a luz do farol;

11. Ajude as crianças, os idosos e as pessoas com mobilidade reduzida a atravessarem a via, levantando o braço durante a travessia, pois sua responsabilidade é muito grande nesse caso;

12. Caminhe pelo acostamento ou quando não houver, bem na lateral da pista, tanto nas estradas, como em vias sem calçadas, sempre de frente para os veículos, ainda que as luzes o incomodem. 


\section{SÍNTESE DO CAPÍTULO}

Neste capítulo a abordagem da prática do caminhar como um modo de transporte, uma intermodalidade, onde o veículo é o pedestre, a principal questão é conhecer o mecanismo do ato de caminhar bem como o relacionamento do pedestre com o ambiente, com os demais pedestres e consigo mesmo.

A fisiologia do caminhar (item 1) esclarece este mecanismo e nos surpreende com o grande desafio que o homem primitivo teve ao colocar-se de pé e andar. O ato de caminhar, uma alternância entre o equilíbrio e o desequilíbrio, é uma luta constante contra a força da gravidade, tendo apenas o peso para impulsionar a força de atrito e deslocar-se para frente, ou para trás, ou de lado, etc.

No item 2, foram configuradas as características próprias dos pedestres. Diferentemente dos veículos puramente mecânicos, o pedestre pensa, deseja, evita gastar energia, cansa, corre, arrisca-se, é impaciente, não tolera gente desconhecida muito próxima a ele, sente e suporta o aperto da multidão. O pedestre coloca várias envoltórias de aproximação social que o protege ou lhe dá mais segurança.

Os pedestres especiais, como os idosos e crianças foram focalizados no item 3 . O pedestre idoso tem natural redução na velocidade de caminhar, além dos reflexos e sentidos. Porém os acidentes, principalmente de quedas, em vias públicas ou ao adentrar ou sair e locomover-se dentro de um coletivo, não são apenas culpa de doenças, remédios, mas de negligências do poder público no sentido de não manterem os equipamentos urbanos em bom estado. Quando o pedestre é uma criança, devem-se despender cuidados redobrados, pois é um ser impetuoso e em formação, arrisca-se, desconhece o perigo e é frágil. As particularidades da formação das crianças foram 
levantadas, visando sustentar uma orientação mais segura, para não haver solicitação acima da capacidade de compreensão das crianças.

No universo dos pedestres crianças há íntima convivência com os ciclistas crianças. As recomendações para estes jovens ciclistas são relatadas para promover-se mais segurança.

O item 4 é dedicado ao comportamento dos pedestres no espaço urbano. Aqui o comportamento é de pedestres como parte de uma coletividade. As individualidades dos itens anteriores aqui tomam caráter de comportamento social. Até como "regras de sobrevivência dos pedestres".

O conhecimento do mecanismo do ato de caminhar, assim como o tipo de "veículo", que é o pedestre, suas ações e reações ao ambiente, são de vital importância para os urbanistas e projetistas do sistema viário os terem como parâmetros para projetarem com mais funcionalidade e acessibilidade. Os equipamentos e instalações de uso com predominância de idosos e crianças demandam atenção pela especificidade de suas necessidades. É importante a compreensão da universalidade do tema.

Para o pedestre é importante conhecer-se, através de um trabalho científico, para integrar-se nesse universo de pedestres anônimos e poder reivindicar seu "status" dentro da cidade. Os equipamentos, as instalações, as praças, os passeios e calçadas devem atender as suas necessidades. 


\section{BIBLIOGRAFIA REFERENCIADA}

ABATE, Tânia Piestzschke. "Ergonomia da Criança. Aspectos ergonômicos da criança e o projeto da pré-escola no Estado de São Paulo". Dissertação de Mestrado. FAUUSP.2004.

ABNT. "Acessibilidade de pessoas portadoras de deficiência a edificações, espaço, mobiliário e equipamento urbano”. NBR 9050. Set. 2004.

ABNT. "Acessibilidade à pessoa portadora de deficiência em ônibus e trolebus, para atendimento urbano e intermunicipal". NBR 14022. Dez 1997 / 2006.

ABRASPE. “Manual de Orientação do Pedestre”. São Paulo. 1998.

ANGELO, Cléon. “Accessibilité des voires”. ANLH asbl.Paris .1999.

BOUERI, José Jorge."Antropometria Aplicada à Arquitetura, Urbanismo e Desenho Industrial”. FAUUSP. São Paulo. 1999.

CET. "Boletim Técnico no 8, 17,19 -Áreas de Pedestres". Companhia de Engenharia de Trânsito. São Paulo.1978.

CET. "Mortes em Acidentes de Trânsito no Município de São Paulo". Companhia de Engenharia de Trânsito. São Paulo. 2005.

CTB.“Código de Trânsito Brasileiro". Diário Oficial da União. Imprensa Nacional. Brasília D.F. 1997.

CZAJA, Sara J. "Human Factors Research Needs for an Aging Population”. National Research Council. Washington D.C. 1990.

EPM, Curso de Pediatria. "O crescimento da Criança". Disponível em www.virtual.epm.br/material/tis.2003. Acessado em 9/2/2006.

FRUIN, John J. “Pedestrian-Planning and Design”. New York. DC. 1971.

GRANDJEAN, Etienne. "Ergonomics of the home". London.1973.

HALL, Edward T. “A Dimensão Oculta”. Rio de Janeiro. 1966.

IIDA, Itiro. "Ergonomia. Projeto e Produção". Editora Blucher. São Paulo.1990.

KELLY, P.L; KROEMER, K. H. E. "Anthropometry of the Elderly: Status and Recommendations". The Journal of Human Factors, 32(5).1990

LAUX, Lila. “Aging Techniques”. U.S. West Technologies. Washington D. C.1996. 
MINAYO-GOMEZ, Carlos. "Crianças e adolescentes trabalhadores: um compromisso para a saúde coletiva". Caderno da Saúde Pública.1997.Disponível em http://www.scielo.br. Acessado em 9/02/2006.

MINAYO, Maria Cecília de Souza. "Violência contra idosos". Revista Ciência \& Saúde Coletiva. Ministério da Justiça. Brasília. 2005.

PANERO, Julius; ZELNIK, Martin. "Human Dimension \& Interior Space". Whitney Library of Design. London. 1979.

PUSHKAREV, B; ZUPAN, J. “Urban Space for Pedestrian”. MIT Press. 1975.

ROBIN, Jacques. “La sécurité de l' enfant à biciclette”. INPSE. France. 2005.

SCHERRER, J. "Physiologie du Travail-Ergonomie". Masson\&C Editeurs. Paris.1967.

SCHNEIDER, Bernard; ROBIN, Jacques. 'L' enfant dans la rue”. Paris. 2003.

SILVA, Paulo. "Calçado para Crianças". 2005. Disponível em http://calcadodesportivo.no.sapo.pt. Acessado em 9/02/2006.

TILLEY, Alvin R. “The measure of man and woman”. Human Factors in Design.1993.

TRANSPORTATION, Research Board. "HCM 2000". National Research Council Washington, D.C.2000

YABIKU, Luiza. "O Pedestre”. Apostila do curso de Capacitação para Médicos Peritos Examinadores. ABRAMET. São Paulo. 1999.

YABIKU, Luiza. "Os Motoristas de Terceira Idade e as Condições Não Amigáveis da Direção Veicular. O caso dos motoristas de terceira idade na cidade de São Paulo". Dissertação de Mestrado. FAUUSP. 2000. 


\section{CAPÍTULO II}

\section{O PEDESTRE E A CIDADE}

Apresentação:

Este capítulo apresenta breve revisão histórica sobre o pedestre na civilização ocidental, um resumo dos pensamentos de personalidades que advogam o direito de propriedade da cidade aos pedestres e uma retrospectiva da legislação pertinente a calçadas na cidade de São Paulo até a data recente, inclusive as novas propostas para as calçadas visando à acessibilidade universal. 


\section{CAPÍTULO II}

O PEDESTRE E A CIDADE

Sumário:

1. OS PASSOS DA CIVILIZAÇÃO

2. A LEGITIMAÇÃO DE PROPRIEDADE DO PEDESTRE

3. OS PASSOS DA LEGISLAÇÃO DAS CALÇADAS NA CIDADE DE SÃO PAULO

4. TIPOLOGIA DAS CALÇADAS DE SÃO PAULO

4.1 Dimensionamento e especificação das calçadas

4.2 Principais características dos pisos recomendados

4.3 Diretrizes de projeto das calçadas

4.4 Estruturação do subsolo de São Paulo

5. SÍNTESE DO CAPÍTULO

6. BIBLIOGRAFIA REFERENCIADA 


\section{O Pedestre e a Cidade}

\section{OS PASSOS DA CIVILIZAÇÃO}

Os homens primitivos (cerca de 500 mil anos a 250 mil anos $\mathrm{AC}$ ), eram caçadores e coletores, acampavam próximo às fontes de água e alimentos, seja a caça como os frutos de árvores e arbustos. Os homens mais ágeis tornavam-se os líderes e guardiões do grupo. Agrupavam-se então em lugares abrigados e suficientemente próximos para poderem ser alcançados facilmente ao primeiro sinal de perigo. Fabricavam as armas rudimentares, para a sua defesa e que também serviam para a construção de melhores formas de habitação. Gordon Childe em "O que aconteceu na história". [CHILDE(1966)].

Talvez a menos de 10 mil anos AC, algumas sociedades começaram a aumentar o suprimento de alimentos, cultivando plantas e criando animais domésticos. A nova economia produtora diferencia-se da fase anterior, que se denomina barbarismo. É a Idade Neolítica, Segunda Idade da Pedra ou Idade da Pedra Polida.

Cerca de 5 mil anos AC ocorre a transformação de algumas aldeias marginais em cidades. Há produção de alimentos excedentes, superior às necessidades domésticas, concentrando estes excedentes para manter uma nova população urbana de artesãos especializados, comerciantes, sacerdotes, funcionários. Surge a escrita como subproduto necessário dessa revolução urbana, que penetra na civilização e dá início ao registro histórico (culturas egípcia, hindu, e outras). Aqui as primeiras cidades verdadeiramente organizadas são fundadas em torno de uma monarquia de orientação religiosa, apoiada pela grande subserviência popular. O advento da agricultura organizada e domesticação de animais permitiram expansão das cidades.

Normalmente a cidade era murada e os templos, casas e palácios eram situados dentro do muro. A lavoura localizava-se fora dos muros. O caçador de outrora tornou-se um 
soldado pedestre, protegendo as leis, administrando, mantendo a justiça e expandindo o domínio da monarquia.

Atenção cuidadosa era dada à localização da cidade, para poder ser defendida facilmente. A preferência era dada aos topos das montanhas, penínsulas e ilhas. Porém quando o local era de estratégia comercial e a topografia natural era falha construíam-se artefatos de defesa artificial (altos muros, torres de observação, etc). Em alguns casos, o portentoso muro de defesa tornava-se uma restrição ao desenvolvimento da cidade, forçando o adensamento das residências, construindo-se edificações que mesclavam o comércio, as oficinas e as residências.

Os primeiros 2 mil anos de civilização coincidem com o que os arqueólogos chamam de Idade do Bronze, porque o cobre e o bronze eram metais utilizados para ferramentas e armas. Crescem as populações urbana industrial e comercial.

Em cerca de 1200 AC inicia a produção de ferro fundido, dando início a primeira Idade de Ferro. No Oriente Médio surge o alfabeto que popularizou a escrita. Surge também a moeda facilitando as transações comerciais a varejo. Há notável crescimento da população, pelo menos no Mediterrâneo. Isto acontece, porém, em última análise, ao custo do empobrecimento relativo ou escravização dos trabalhadores agrícolas e artesãos.

As grandes cidades da história foram edificadas tanto para servir os pedestres como para inspirá-los a uma vida social e religiosa, conforme observa John Fruin. [FRUIN(1971)]. O assentamento e os arranjos das edificações e monumentos gregos são exemplos disso. As concepções de edificação, estátuas (ornamentos) e paisagem formavam uma unidade visual, mas sem interferência nas suas grandiosidades individuais. A forma dos edifícios, a localização e a topografia natural eram usadas para atingir os objetivos de inspiração social e religiosa. 
A Acrópole é um exemplo de desenho do espaço para a escala humana, sem introduzir a descontinuidade de conflitos visual ou elementos físicos. Figura (II-1).

Figura II-1. A Acrópole em Atenas, na segunda metade do século $5^{\circ} \mathrm{AC}$. $\mathrm{O}$ Parthenon ao centro e o Erechtheum à esquerda.

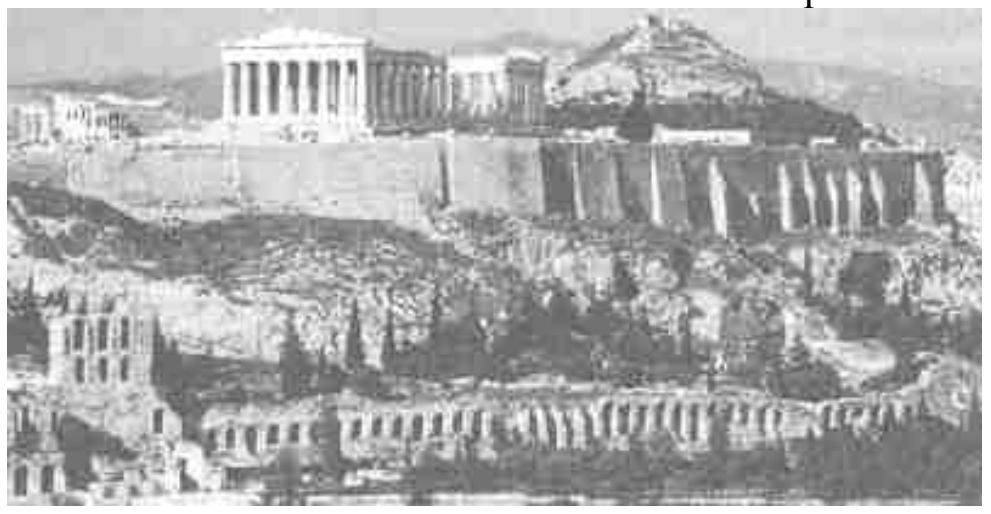

Fonte: Enciclopédia Britânica. [ENCICLOPEDIA(1973)].

Esta escala é interrompida com as antigas cidades romanas e hebréias, causada pela introdução do veículo. Júlio César decretou que carruagens pesadas eram proibidas de circular dentro do centro da cidade depois do entardecer.

O fórum de Pompéia continha uma extensa via para pedestres. Grandes barreiras de pedras, em locais estratégicos, bloqueavam a entrada dos veículos.

O Talmud, livro de leis hebraicas, decreta que áreas especiais deveriam ser dispostas ao longo da rua principal, para os pedestres poderem descarregar suas cargas e descansarem. Estas áreas deveriam ser claramente demarcadas e separadas dos veículos por pontaletes de metal ou barreiras de pedras.

A necessidade de comunicação e interação nas cidades medievais foi solucionada reorganizando-se seu planejamento, provendo-se uma praça central para pedestres. Foi desenhado um espaço aberto para servir e complementar a vista da catedral e outras importantes edificações localizadas ao redor. A praça servia de mercado a um lugar para pronunciamentos públicos, de atos religiosos a ocasiões festivas e recreativas. O 
tamanho das praças era uma função do número de pessoas que vinham em peso a esses propósitos.

O conforto humano e a conveniência de pedestres não passavam despercebidos pelos planejadores medievais. Pedestres eram protegidos pelas galerias (figura II-2), dosséis (abrigos), figura (II-3), colunas e pórticos. As cidades antigas de Bolonha tinham $32 \mathrm{~km}$ (20 milhas) de rede de calçadas cobertas por pórticos que providenciavam uma sombra fresca e seca, para pedestres no verão e eram caminhos livres de neve no inverno. $\mathrm{O}$ sistema de Bolonha de cobrir as calçadas foi muito admirado por famosos escritores e filósofos, que contavam como eram agradáveis os passeios e convivência social que despertavam. A cobertura e as calçadas elevadas são algumas recentes propostas para os pedestres, mas que já faziam sua aparição na arquitetura medieval.[FRUIN(1971)].

Figura II-2. Edificação antiga, ainda remanescente, com passagem para pedestre.

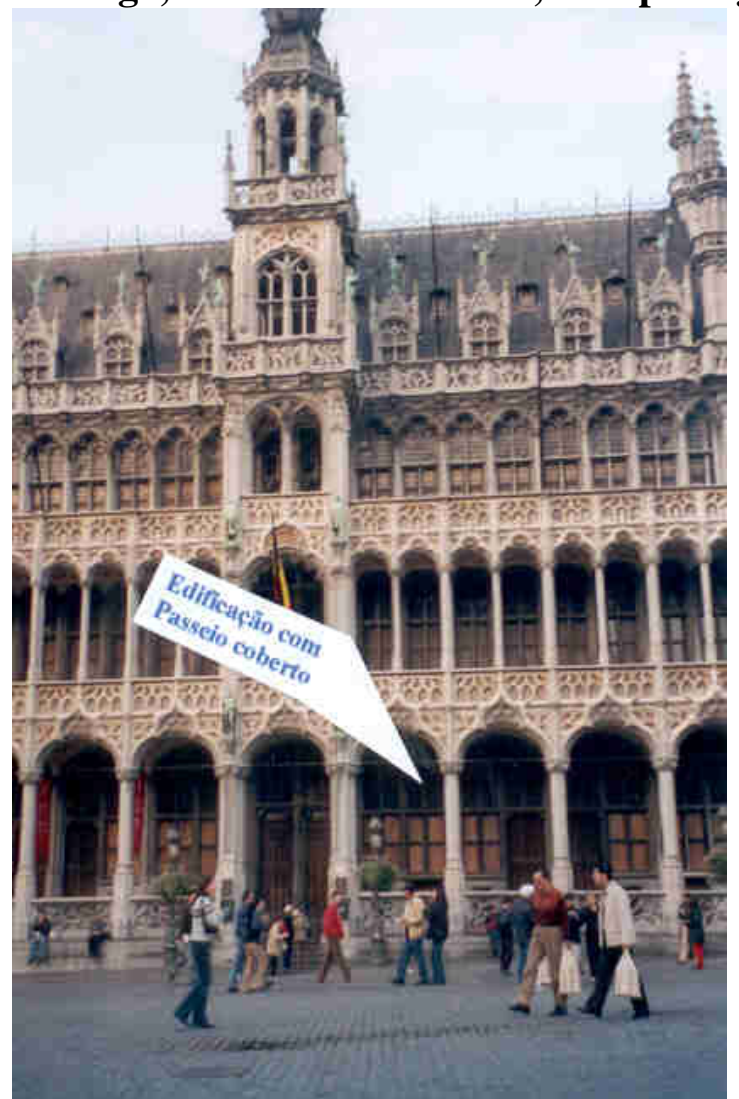

Fonte: Arquivo da autora.[YABIKU(1999)]. 


\section{Figura II-3. Antigo bairro judeu, em Veneza, ainda conservado, com habitação} (misto de residência, oficina e loja) com cobertura para pedestre.

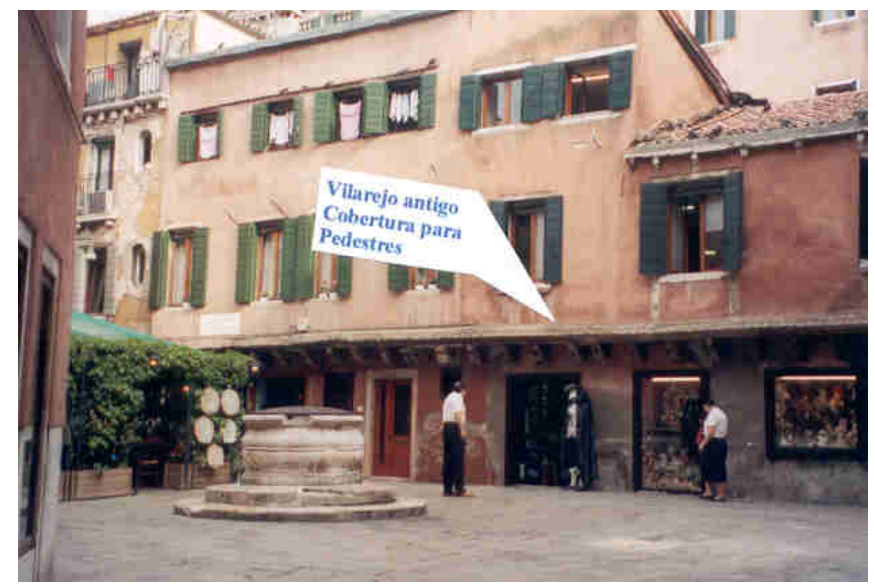

Fonte: Arquivo da autora [YABIKU(1999)].

O grande mestre renascentista Leonardo da Vinci considerava o valor da separação física do trânsito de pedestre e do veicular. Ele planejava a cidade com o dobro de redes de ruas, uma elevada para pedestres e outro ao nível da rua, de terra, para servir aos veículos. Da Vinci, o engenheiro, considerava que o mais eficiente sistema de tráfego para ambos (pedestres e veículos) requeria a separação, com redes contínuas para cada um. Da Vinci, o artista, reconhecia que os requisitos da estética visual poderiam ser mais bem satisfeitos pela perspectiva humana distinta apresentando-o acima do ambiente da cidade.

Os planejadores da idade média já reconheciam que a área dos pisos da edificação poderia ser uma função da largura das ruas. Cidades medievais limitavam as alturas das edificações para duas vezes a largura da rua.

Da Vinci era da opinião que a razão de um para um era mais desejável. [FRUIN(1971)]. Isto contrasta com algumas modernas cidades onde pavimento e largura de calçadas tem permanecido remanescente por séculos, enquanto as edificações têm aumentado suas alturas enormemente. Em vários casos o espaço das calçadas tinha realmente sido reduzido durante esse tempo para facilitar os movimentos dos veículos. 
$\overline{\text { Os artesãos do passado adornavam os passeios e ruas com texturas nos pavimentos }} \mathrm{e}$ mosaicos, com propostas tanto prático como estético. As ruas pavimentadas de pedra da velha Milão eram pavimentadas em tal forma que conduziam as rodas para longe dos passeios, assim prevenindo as colisões entre veículos e pedestres.

Estas pequenas evidências denotam as preocupações com os pedestres nas cidades desde os tempos remotos.

Assim sendo, a instalação do espaço público não é uma invenção moderna: apareceu ao mesmo tempo em que surgiram as cidades. As cidades eram pensadas como formas e volumes de construção, criando possibilidades para que as pessoas articulassem suas vidas com mais ou menos facilidade.

As ruas e as praças eram essenciais: formavam as ligações entre as habitações, eram os laços de encontros entre as entradas das construções com os passeios, os jardins e as fontes e eram indispensáveis para caminhar.

As árvores serviam para delimitar um território: separavam o espaço dos pedestres com o das carroças e as carruagens.

Historicamente, as instalações sempre foram intimamente ligadas à tecnologia ou a determinadas situações:

- Na Idade Média, apareceram os primeiros regulamentos urbanos (“códigos de obras”), após os grandes incêndios.

- Na Renascença, a prosperidade das cidades faz surgir um controle maior dos espaços e dos cenários urbanos.

- Com as sucessivas aglomerações urbanas, o uso das vias intensificou-se, consumindo a capacidade viária, deteriorando os espaços urbanos, tornando pouco eficiente o sistema de circulação, e até servindo como condutores de doenças e pragas. Surgiu, então, a necessidade de planejamento e ordenação das vias. Conforme relatado por Akemi 
Sakaguchi [SAKAGUCHI(1998)], o modelo de circulação viária adotada até hoje segue

o modelo de circulação sanguínea. Isto ocorreu no século XVII (1628-Estudo Anatômico do Movimento do Coração e do Sangue em Animais. Sir Willian Harvey), quando surgiu o conceito de sangue e sua circulação no corpo humano (vias principais, arteriais, congestionamentos, estrangulamentos, etc). Surgem leis que impõem aos proprietários pavimentarem as margens das novas vias, com uma largura de três pés, logo abaixo de suas habitações, dando origem às calçadas atuais.

- Na época clássica, são realizadas as grandes instalações de prestígio; os parques e as praças são construídos segundo projetos geométricos e decorados com possantes fontes e estátuas portentosas, presentes mais como parte um cenário decorativo que conjunto de elementos funcionais.

- No século XIX, ocorre a expansão das cidades e do número de habitantes, é a era da industrialização nascente. Os bulevares e as avenidas são contornados por largas calçadas, reservadas à circulação dos pedestres; surgem os quarteirões. Os elementos de mobiliário urbano prosperam garantindo a vida de conforto nas cidades: os lampiões a gás propiciando a segurança aos cidadãos; a população pode apreciar os concertos de música e manifestações teatrais nos coretos que abrigam os espetáculos ao ar livre; há preocupação em alinhar as árvores, formando um novo cenário à cidade.

- O Século XX é marcado pela especialização de espaço. A circulação dos automóveis ocupa o espaço público de forma predominante. Surgem regras e convenções para organizar a circulação dos veículos e das pessoas. Os semáforos com três cores (verde, amarelo e vermelho), setas dando a direção de circulação, preferências, painéis com códigos de sinalização vertical e outros dispositivos fazem suas aparições no cenário urbano. 
- Hoje a circulação é mais densa e o aumento do número de automóveis submete as vias num crescente congestionamento. A rede viária (ruas e calçadas) é pensada em termos de equilíbrio das vias, fluidez do tráfego e da segurança. As ruas e as praças são dedicadas aos estacionamentos; os mobiliários urbanos e a publicidade ocupam as vias públicas.

- A cidade-automóvel. A cidade é adaptada ao automóvel.

Os espaços públicos são dedicados essencialmente às ligações de trânsito ou de passagem, perdendo-se as qualidades de hospitalidade e de sociabilidade.

Portanto, as premissas originais de elo entre as relações sociais, os bulevares e as ruas que convidavam a passeios, hoje são temas de romances.

No entanto, a circulação e os transportes contaminam-se com problemas: congestionamento, acidentes, violência e poluição. A cidade torna-se um complexo de atividades, justapondo zonas especializadas de habitação, comércio e lazer.

O tecido social se esgarça, há nova expansão de habitantes nas periferias e novas vias ligando as partes e assim conduzindo mais comércio, lazer e serviços, que sobrecarregam com mais acidentes, congestionamentos, violências e poluição.

Na luta por romper com essa sistemática os excluídos, as crianças, os idosos, os portadores de mobilidade reduzida, simplesmente reivindicam seu direito ao espaço público. A acessibilidade universal discute as prioridades e privilégios e tenta retomar o equilíbrio entre as vias e os passeios. 


\section{A LEGITIMAÇÃO DE PROPRIEDADE DO PEDESTRE}

A retomada de posse da cidade pelos pedestres é uma temática discutida e refletida por vários pensadores modernos e contemporâneos.

Walter Benjamin [BENJAMIN(1987)], nos anos 30, já questionou este tema, quando colocou na paisagem urbana a figura do "flaneur", aquele que apropriadamente percola as vias, os guetos, os "boulevares", as praças. Em "As Passagens" ele define o "flaneur" como:

"O "flaneur" é o que está no centro do mundo - na multidão - e o que está, ao mesmo tempo, protegido, dissimulando-se, ao abrigo dos olhares".

"O "flaneur" é um estudioso da natureza humana. Sob a aparência de um olhar desatento e distraído, esconde-se alguém cuja volúpia reside na decifração dos sinais e das imagens: algo que pode ser revelado por uma palavra deixada ao acaso, na expressão capaz de fascinar o olhar de um pintor, um ruído que espera o ouvido de um músico atento."

“O "flaneur” procura um refúgio na multidão. A multidão é o véu através do qual a vida familiar se move para o "flaneur", em fantasmagoria"

Esta figura do "flaneur" encontra eco em Milton Santos [SANTOS(1996)] em "A Natureza do Espaço", quando este reflete sobre a velocidade e coloca que agora, estamos descobrindo que, nas cidades, o tempo que comanda, ou que vai comandar, é o tempo dos homens "lentos". "A força é dos "lentos" e não dos que detêm a velocidade. Quem, na cidade, tem mobilidade (e pode percorrê-la e esquadrinhá-la) acaba por ver pouco, da cidade e do mundo. Os homens "lentos", para quem tais imagens são miragens, não podem, por muito tempo, estar em fase com esse imaginário perverso e acabam descobrindo as fabulações". 
Em Carta de Atenas [LE CORBUSIER(1993)], produzido pelo IV CIAM (IV

Congresso Internacional de Arquitetura Moderna), realizado em julho/agosto de 1933 e só publicada em 1942 por Le Corbusier cita 5 funções para uma boa cidade: 1.Habitação, 2. Recreio, 3. Trabalho, 4. Circulação, 5. Patrimônio Histórico.

Nos parágrafos 59 a 64 fica clara a preocupação do espaço do pedestre convivendo com os veículos automotores. Le Corbusier cita, especificamente para o sistema viário, as seguintes recomendações:

1. Cruzamento em nível.

2. Vias em função de veículo e velocidades.

3. O pedestre deve poder seguir por trajetos diversos daqueles dos automóveis.

4. As ruas devem ser diferenciadas de acordo com suas destinações: residência, passeios, trânsito, vias principais.

5. Zonas de vegetação devem isolar os leitos de grande circulação.

Conquanto a idéia principal fosse devolver a cidade a seus habitantes, o conceito da Cidade Funcional e do Homem Ideal traz um distanciamento do homem e do sistema viário, justamente devido à demarcação da função. A especialização de vias para pedestres segregados da via para veículos automotores, aumentando a segurança dos primeiros, mas que, com o passar do tempo, implicou a hierarquização e os privilégios dos veículos automotores. Le Corbusier pretendia eliminar as diferenças e conflitos da cidade moderna, porém essas diferenças e conflitos é que tornam as cidades lugares mais sedutores e constantes desafios aos urbanistas, engenheiros e seus tão diversos habitantes.

Kevin Lynch [LYNCH(1985)], em "Buena Forma de la Ciudad", deixa implícito seu cuidado com a acessibilidade, mobilidade e comunicação entre pessoas, e que os equipamentos, edificações e manutenções devem privilegiar a justiça e eqüidade entre 
os homens. Cita as 7 qualidades que uma cidade deve ter para ser considerada uma cidade em boa forma:

1. Vitalidade: o grau em que a forma de assentamento sustenta as formas vitais, os requisitos e capacidade biológica dos seres humanos; antes de tudo, como proteção à sobrevivência da espécie.

2. Sentido: O grau no qual o assentamento pode ser claramente percebido, mentalmente diferenciado e estruturado no tempo e no espaço por seus residentes, é o grau em que essa estrutura mental conecta com seus valores e conceitos; o ajuste entre o entorno, nossas capacidades mentais e sensoriais, e nossas construções culturais.

3. Adequação: O grau em que a forma e a capacidade dos espaços, dos canais e dos equipamentos de um assentamento se ajusta ao tipo e quantidade de atividade que realizam, ou que as pessoas desejam realizar, isto é, a adequação dos contextos de conduta, incluindo a sua adaptabilidade às ações futuras.

4. Acesso: A capacidade de se chegar a outras pessoas, atividades, recursos, serviços, informação ou lugares, incluindo a quantidade e diversidades dos elementos que se possam alcançar.

5. Controle: O grau em que o uso e o acesso a espaços e atividades, e a sua criação, reparação, modificação e direção são controlados por aqueles que o usam, trabalham ou residem nos mesmos.

6. Eficácia: O custo, em termos de outras coisas valorizadas de criar e de manter o assentamento, para qualquer grau de consecução das dimensões ambientais enumeradas. 7. Justiça: A forma em que os benefícios e custos ambientais se distribuem entre as pessoas, seguindo algum princípio concreto, como a eqüidade, a necessidade, o valor intrínseco, a possibilidade de pagar, o esforço realizado, a contribuição potencial ou o poder. A justiça é o critério que equilibra as ganâncias entre os distintos valores. 
Jane Jacobs [JACOBS(2003)], em "Morte e Vida de Grandes Cidades", escrito em 1961, inicia seu livro com o capítulo "A natureza peculiar das cidades", dedicando-o às calçadas, como a força agregadora da cidade. Ela descreve o relacionamento entre os habitantes, as pessoas que circulam no bairro e que fazem e mantêm a cidade viva. A autora observa que o que mata ou torna indiferente a cidade e o que o torna saudável é algo independente de melhorias, embelezamento, etc. O que é vivo é a possibilidade de vivenciar, caminhar, escutar, ter relacionamentos de vizinhanças, e estes se ajudarem mutuamente. A arquitetura exemplar não basta se esta propiciar nichos sombrios onde a marginalidade se instala. A função da calçada é específica, pois ela é o suporte dos serviços (padarias, lojas, etc), que são as gerenciadoras dos quarteirões. Ela é incisiva ao argumentar que os parques e as praças não têm serventia se as crianças, os idosos e as pessoas não permanecerem neles.

“A História da Arte como História da Cidade"de Giulio Carlo Argan [ARGAN(1993)], pode ser resumido pelo seguinte parágrafo:

"A cidade é o melhor aparato de mediação entre cultura de classe e cultura de massa, aquela que, mais do que qualquer outra coisa garantirá o caráter democrático daquela que será a nova estrutura da sociedade e da cultura, a massa".

Trata-se de conservar ou restituir ao indivíduo a capacidade de interpretar, utilizar o ambiente urbano, de maneira diferente das prescrições implícitas no projeto de quem o determinou; dar-lhe a possibilidade de não se assimilar, mas de reagir ativamente ao ambiente. O problema consiste em dar elasticidade à cidade, entendida como sistema de informação. Incontestavelmente, a cidade é feita de coisas, mas essas coisas nós as vemos, oferecem-se como imagem à nossa percepção, e uma coisa é viver na dimensão livre e mutável das imagens, outra é viver na dimensão estreita, imutável, opressiva, cheia de arestas, das coisas. É essa passagem que a cidade moderna deve realizar, a 
passagem da concretização, da dureza das coisas, à mobilidade e mutabilidade das imagens.

"Há uma cidade de grandes estruturas que tem uma duração de anos ou de séculos. E há a cidade de um dia, a cidade que dá a imediata impressão de ser feita de imagem, de sensações, de impulsos mentais; a que realmente se vê e que não é dada pelas arquiteturas imóveis, mas pelos automóveis, pelas pessoas, pelas infinitas notícias que são transmitidas através da publicidade e dos outros canais de comunicação. É uma distinção de tempos, longos e curtos. Esta distinção é aquela que a arquitetura clássica legitima: a distinção entre estrutura e decoração, sendo a estrutura a realidade duradoura a que se calcula em séculos, e a decoração a realidade que muda e se exprime em anos, em dias até mesmo em horas".

Milton Santos [SANTOS(1996)] em "A Natureza do Espaço", citado acima em Walter Benjamin, coloca a importância das cidades para o homem contemporâneo. Nas cidades modernas os lugares se mundializaram. Todos os capitais, todos os trabalhos, todas as técnicas e formas de organização podem aí se instalar, conviver, prosperar. Nos tempos de hoje, a cidade grande é o espaço onde os fracos podem subsistir. A cidade é o lugar onde há mais mobilidade e mais encontros. A anarquia atual da cidade grande lhe assegura um maior número de deslocamentos, enquanto a geração de relações interpessoais é ainda mais intensa. $\mathrm{O}$ movimento é potencializado nos países subdesenvolvidos, graças à enorme gama de situações pessoais de renda, ao tamanho desmesurado das metrópoles e ao menor coeficiente de "racionalidade" na operação da máquina urbana.

"Durante séculos, acreditávamos que os homens mais velozes detinham a inteligência do Mundo. A literatura que glorifica a potência incluiu a velocidade como essa força mágica que permitiu à Europa civilizar-se primeiro e empurrar, depois, a sua civilização 
para o resto do mundo. Agora, estamos descobrindo que, nas cidades, o tempo que comanda, ou que vai comandar, é o tempo dos homens lentos. Na grande cidade, hoje, o que se dá é tudo ao contrário. A força é dos "lentos" e não dos que detêm a velocidade. Quem, na cidade, tem mobilidade (e pode percorrê-la e esquadrinhá-la) acaba por ver pouco, da cidade e do mundo. Sua comunhão com as imagens, freqüentemente préfabricada, é a sua perdição. Seu conforto, que não deseja perder, vem exatamente do convívio com essas imagens. Os homens "lentos", para quem tais imagens são miragens, não podem, por muito tempo, estar em fase com esse imaginário perverso e acabam descobrindo as fabulações".

Para os homens lentos deslocar-se na cidade trata-se de uma busca do futuro sonhado, como carência a satisfazer (carência de todos os tipos de consumo, material, imaterial, político, participação e cidadania). Esse futuro é imaginado ou entrevisto na abundância do outro e nas possibilidades apresentadas pelo Mundo e percebidos no Lugar. O consumo imaginado e não atendido, produz um desconforto criador. O choque entre cultura objetiva e cultura subjetiva torna-se instrumento da produção de uma nova consciência.

Já em "Pensando o Espaço do Homem”, Milton Santos \{SANTOS(1986)] reflete sobre o espaço, o tempo, a paisagem e o espaço social.

“O espaço presente é a acumulação dos fatos passados. O passado passou e o presente é real, mas a atualidade do espaço tem algo de singular: ela é formada de momentos que foram, estando agora cristalizados como objetos geográficos atuais. O momento passado está morto como "tempo", mas não como "espaço", o momento passado estará sempre aqui e participa da vida atual como forma indispensável à realização social”.

Quanto à paisagem, esta compreende dois elementos:

1) Os objetos naturais, que não são obra do homem nem jamais foram tocados por ele. 
2) Os objetos sociais, testemunhos do trabalho humano no passado, como no presente.

A paisagem não tem nada de fixo, de imóvel. Cada vez que a sociedade passa por um processo de mudança, a economia, as relações sociais e políticas também mudam, em ritmos e intensidades variados. A mesma coisa acontece em relação ao espaço e a paisagem que se transforma para se adaptar às novas necessidades da sociedade. As alterações por que passa a paisagem são apenas parciais. De um lado alguns dos seus elementos não mudam, enquanto a sociedade evolui. São as testemunhas do passado. Por outro lado, muitas mudanças sociais não provocam necessariamente ou automaticamente modificações na paisagem.

Desta forma a paisagem é algo temível. A semantização geral dos objetos agrega um significado equívoco, fazendo da paisagem uma espécie de mentira funcional. Os locais de trabalho, de estudo, de lazer, o quadro de nossa vida quotidiana, são concebidos como mercadorias, para seduzir e atrair o consumidor. Isso torna a leitura da paisagem extremamente difícil. Os objetos individuais apresentam multiplicidade, e o que se procura não é uma lei dos objetos. Os objetos não passam de objetivações e individualizações. O que interessa é a lei do movimento geral da sociedade, pois é pelo movimento geral da sociedade que se apreende o movimento geral do espaço.

O espaço social é definido por três conceitos gerais: a forma, a estrutura e a função. Isto significa que todo espaço social pode ser objeto de uma análise formal, estrutural e funcional. A interpretação de um espaço ou de sua evolução só é possível através de uma análise global que possa combinar simultaneamente estas três categorias analíticas. Nos grupos sociais primitivos as formas saíam da estrutura social quase sem mediação. Hoje isto não existe mais. Em vista da complexidade da divisão do trabalho, a produção do espaço é o resultado de múltiplas determinações cuja origem se situa em níveis 
diferentes e em escalas variáveis, indo do simples lugar à dimensão internacional. As formas deixaram de ter um papel exclusivamente funcional.

Para interpretar corretamente o espaço é preciso descobrir e afastar todos os símbolos destinados a fazer sombra à capacidade humana de apreensão da realidade. Isto quer dizer que não é suficiente interpretar a paisagem nos seus movimentos, nem trabalhar exclusivamente sobre os elementos que a compõem. A noção de tempo é fundamental. A sociedade é atual, mas a paisagem, pelas suas formas, é composta de atualidades de hoje e do passado. A noção de escala é igualmente importante, pois se o espaço é total, a paisagem não o é. Não se pode falar de paisagem total, pois o processo social de produção é espacialmente seletivo.

Yi-Fu Tuan [TUAN(1983)], geógrafo de origem chinesa, escreveu em 1983 "Espaço e Lugar. A perspectiva da experiência", onde ao refletir sobre tempo, espaço, lugar e distância, centraliza o homem como a principal figura que determina desde a expansão física de uma civilização, ao adensamento de uma cidade. As dimensões de tempo e espaço, carregadas de emoções e desejos, subvertem os conceitos matemáticos destas dimensões, subjugando-os ao seu critério particular.

“O espaço é o ambiente que permite o movimento, e o lugar é o ambiente com significado, sejam estes signos tácteis, visuais ou memoriais, com sensações, sentimentos ou experiências. A subjetividade da noção de liberdade de movimentos confunde-se com o desejo pessoal. Os camponeses do início da era industrial ansiavam por sair de suas vastas terras e das grandes casas e partiram para as cidades efervescentes, repletas de oportunidades de um novo estilo de vida. Os chineses conquistaram o grande continente asiático partindo das regiões semi-áridas do norte, descendo para o sul, para as densas florestas cheias de brumas e água”. 
$\overline{\text { Conforme Yi Fu Tuan [TUAN(1983)] o espaço é organizado de acordo com as relações }}$ do nosso corpo; os pontos cardeais e a noção de frente, trás, esquerdo e direito. Mas precisamos de referências conhecidas, para sentirmos seguros e locomovermos neste lugar. As distâncias têm conotações de graus de acessibilidade e também preocupações. Os seres humanos estão interessados em outras pessoas e nos objetos importantes em suas vidas. Isto nos dá a noção do "Aqui" e "Lá".

Espaço e espaciosidade são termos intimamente relacionados, como são a densidade de população e a aglomeração. Porém a convivência com espaços amplos e espaços delimitados (quaisquer que sejam estas delimitações), é julgada pelas pessoas conforme seu referencial cultural. Assim territórios amplos podem significar ausências de pessoas queridas, ou expectativas de novas relações, do que existe "Lá". Aglomerações podem ser aconchego e segurança, mas também implicam um relacionamento estressante. $\mathrm{O}$ espaço recomendado pela Associação Norte-Americana de Saúde Pública é de 32 metros quadrados, por pessoa, como padrão recomendável. Mas há tribos e culturas que habitam em conglomerados, convivendo harmoniosamente em um ajuntamento de pessoas, onde não há recantos individualizados.

A experiência de espaço e tempo é principalmente subconsciente. $\mathrm{O}$ conceito de tempo prevalece ao da distância. A distância, ao contrário do comprimento, não é um conceito espacial puro, implica tempo. Assim a relação do "Aqui" e "Lá", traduz-se e, "Agora" e "Então". "Então" tanto pode referir-se ao passado como ao futuro.

O lugar é qualquer objeto estável que capta nossa atenção. A atenção pode ser de longa duração, carregada de emoção, ou fugazes e distraídas. Mas de qualquer forma ela aconteceu. Os lugares podem ser criados a partir de valores nomeados, quer sejam culturais, estéticos ou formas de juntar pessoas. Assim têm-se museus, praças, parques, 
shoppings, monumentos, bairros e cidades, que atraem pessoas não relacionadas a elas, mas com a finalidade de afeiçoarem-se ao lugar, pelo valor atribuído a ele.

Gordon Cullen [CULLEN(1983)] conceitua a paisagem urbana, na escala do homem, da visão individual e não a do paisagista, do urbanista ou do engenheiro construtor.

A paisagem urbana é retratada como sendo o impacto visual da cidade sobre os seus habitantes ou visitantes. Um conjunto de edifícios adquire um poder de atração visual a que dificilmente poderá almejar um edifício isolado. Alguém transitando por entre o conjunto de edificações tem reações e sensações, sentindo que há vida própria por entre estas construções.

Uma cidade é uma ocorrência emocionante ao meio-ambiente. No entanto a emoção e a animação procuradas nas cidades não surgem automaticamente das soluções científicas fornecidas pela Técnica. Aceitam-se essas soluções, mas sem permitir que atuem como vínculo principal. Aliás, isso nem seria possível, já que qualquer solução científica se baseia no aproveitamento ótimo de fatores médios (média de comportamentos, médias de clima, etc). Quando se olha para uma coisa vê-se por acréscimo uma quantidade de outras coisas. O meio-ambiente suscita reações emocionais dependentes ou não da pessoal vontade. Este processo pode ser interpretado sob três aspectos:

1. ÓPTICA. "Visão Serial". O cérebro humano reage ao contraste, isto é, às diferenças entre as coisas, e ao ser estimulado simultaneamente por duas imagens apercebe-se da existência de um contraste bem marcado. Neste caso a cidade torna-se visível num sentido mais profundo: anima-se de vida pelo vigor e dramaticidade dos seus contrastes. Se ao nível científico ou comercial a cidade constitui um todo, numa perspectiva visual temos dois pontos de vista a considerar: a imagem existente e a imagem emergente. De um modo geral, aparecem aos transeuntes como uma sucessão de acontecimentos fortuitos, e a 
sua ligação não passa de mera coincidência. Contudo, tal ligação deve ser tomada como mais um aspecto de arte do relacionamento, colocado ao serviço da imaginação humana, com vista a fazer da unidade um todo coerente e dramático. Pelo processo de manipulação, teremos conseguido criar, a partir da realidade inerte, uma situação intensamente emotiva.

2. LOCAL. "Aqui" e "Lá". Este segundo ponto trata das reações perante a nossa posição no espaço. As percepções de que estou Aqui, e vou para Lá, integra-se numa ordem de experiências ligadas às sensações provocadas por espaços abertos e espaços fechados, que nas suas manifestações mórbidas são a ágorafobia e claustrofobia.

Uma vez que o nosso corpo tem o hábito de relacionar-se instintiva e continuamente com o meio-ambiente, o sentido de localizar não pode ser ignorado e entra, forçosamente, na planificação do ambiente.

3. CONTEÚDO. Trata-se da própria constituição da cidade: a sua cor, textura, estilo, escala, a natureza, a personalidade e tudo que a individualiza.

Afora estes três conceitos fundamentais, algumas percepções espaciais são consideradas como a APROPRIAÇÃO DO ESPAÇO.

Num mundo de conceitos bem definidos as vias destinam-se ao trânsito de pessoas e coisas e os edifícios às relações sociais e de trabalho. Mas como a maioria das pessoas faz exatamente o que lhe convém e quando lhe convém, verifica-se que também o exterior está ocupado para fins sociais e comerciais.

Assim tem-se as vias apropriadas por uma ocupação estática, para vendas de mercadorias, feiras livres, camelôs, a extensão de mesas de bares e restaurantes, lazer. 
$\overline{\text { Uma forma de apropriação pelo movimento, é a via ocupada por pedestres que }}$ caminham ao longo desta, dirigindo-se a determinados locais, e pessoas esperando o transporte coletivo.

A apropriação como recinto é uma síntese da polaridade entre pés e pneus, isto é, entre a circulação de pessoas e de veículos. É a unidade base duma certa morfologia urbana. Fora dele, o ruído e o ritmo apressado da comunicação impessoal, um vai e vem; no interior, o sossego e a tranqüilidade de sentir que o largo, a pracinha ou o pátio têm escala humana. O recinto é o objetivo da circulação, o local para onde o trânsito nos conduz. Sem ele o trânsito torna-se absurdo.

O PAVIMENTO. Existem dois aspectos relacionados com o direito de reunião: o primeiro aplica-se aos habitantes da cidade, e o segundo aos edifícios que a compõe.

Visualmente a maior perda sofrida é a neutralização do pavimento, do espaço entre as construções, que deixou de constituir uma superfície de ligação para se transformar numa superfície de separação. Transformou-se também, de uma superfície particularizada a uma superfície generalizada.

A primeira reação de quem se apercebe do valor do pavimento como um cenário potencial é de ornamentá-lo, porém o pavimento deve contribuir com o seu próprio caráter e personalidade, aliar a funcionalidade aos aspectos sociais e estéticos, compondo um ambiente amigável.

ILUMINAÇÃO PÚBLICA. As instalações elétricas não podem ser pensadas apenas como um grande advento da tecnologia e aplicadas como decoração ostensiva, mas devem cumprir sua função de dar segurança e articular o tecido urbano.

PUBLICIDADE DE RUA. Os anúncios e publicidade nas ruas são as contribuições mais importantes do século XX para a paisagem urbana. Os quatros grandes argumentos utilizados para contrariar a publicidade de rua são: 
1. Os anúncios são incongruentes e contrários ao bem-estar das populações.

2. Invadem os espaços públicos e os habitantes não têm outro remédio senão reparar neles.

3. Banalizam o ambiente e degradam o gosto popular.

4. Distraem os condutores e usuários da via.

Analisando estes argumentos Cullen [CULLEN(1983)] diz:

1. A publicidade é aceito como um fator normal da vida da cidade. Qual seria a incongruência se considerarmos que a cidade é uma paisagem construída pelo homem?

2. É inteiramente verdade que a publicidade invade espaços públicos, mas parece difícil encontrar outros locais onde se possa convenientemente localizá-los.

3. A publicidade vem degradar o gosto popular, mas tem um grande mérito, a sua vitalidade.

4. Os anúncios distraem os condutores. Quando isto acontece, são de fato prejudiciais e o urbanista deve levá-los em consideração.

A PAREDE. Qualquer atividade conforma-se com os limites do mais apropriado, e neste caso o tratamento que se dá às paredes é semelhante.

O controle adequado parece residir na ênfase que se quer dar ou na reavaliação que se pretende fazer, de uma função. Atualmente a variedade de métodos construtivos de que se dispõe permite encarar o desafio do vazio sob perspectivas diferentes e mais apropriadas.

DESNÍVEIS. A arte de jogar com diferentes níveis é uma parte importante da arte da paisagem urbana. Desníveis no terreno podem ocorrer naturalmente resultante de um perfil do local, ou artificialmente, surgido das solicitações que o urbanista deve satisfazer. Mas seja qual for a sua origem, as reações pessoais aos níveis são de tensões particulares percebidas em relação à posição de cada um no mundo. Estar em cima 
equivale a privilégio e autoridade. Abaixo é traduzido como intimidade, aconchego. $\mathrm{O}$ jogo dos desníveis traduz elegância, surpresas e conivências.

John J. Fruin [FRUIN(1971)] é o precursor no estudo do pedestre, cientificamente, como uma modalidade de deslocamento. Seu livro "Pedestrian, planning and design" [FRUIN(1971)], foi fruto da sua tese de doutorado, em Planejamento de Transportes, no Instituto Politécnico de Brooklyn. Aliando a engenharia de tráfego ao conhecimento da natureza e fisiologia humana, Fruin observou, calculou e expôs uma metodologia para determinar o nível de conforto e segurança das instalações para pedestres. A velocidade, o tempo, a densidade e a fluidez de escoamento de trânsito de pedestres foram equacionados à semelhança dos deslocamentos de veículos automotores, porém com a peculiaridade do pedestre que tem livre arbítrio de mobilidade em quatros direções, característica que um veículo automotor não tem, além de que os corpos respondem mais rapidamente que os veículos, o que os tornam imprevisíveis.

Em seu livro ele conta uma cena que realmente o impressionou, e que o levou a ter grande convicção de que deve ser dado um máximo de espaço possível aos pedestres, nos equipamentos a seu serviço. O fato ocorreu no maior terminal de linhas de trem suburbanas de Nova York, após uma forte nevasca que interrompeu os serviços de saída. Milhares de passageiros amontoaram-se numa área ampla, mas restrita. Uma entrada comum na plataforma de trem. Uma "onda de choque" percorreu através da multidão como se fosse uma simples e unificada massa, literalmente levantando as pessoas de seus pés. A polícia tentou controlar a multidão revertendo a onda para trás, mas nada parava a onda, ainda bem que a polícia não utilizou as armas de fogo. Mais trens chegava e as pessoas não podiam desembarcar. Instalou-se o caos, mas felizmente não ocorreu nenhum acidente grave. A situação poderia ter sido pior se a plataforma 
fosse menor, e as pessoas poderiam cair nos trilhos, e seria menos conturbado se a

plataforma fosse mais larga, e o sistema de saída previsse essas emergências. 


\section{OS PASSOS DA LEGISLAÇÃO DAS CALÇADAS NA CIDADE DE}

\section{SÃO PAULO.}

Os cuidados com os passeios e calçadas no município de São Paulo, tomam forma com as medidas baixadas pela autoridade municipal. Assim a primeira lei data de 1896, isto é há 110 anos atrás, três anos antes da Proclamação da República. Com a Libertação dos Escravos pela Lei Áurea, em 1888, São Paulo atrai muitos imigrantes europeus. Em 1895 a população de São Paulo era de 130 mil habitantes, dos quais 71 mil eram estrangeiros, chegando-se a 240 mil habitantes em 1900.

Os imigrantes, notadamente italianos, vão compor a classe operária na nascente indústria paulistana. Surgem bairros operários nos arredores de São Paulo, Brás, Bexiga e Moóca, assim como bairros aristocráticos como os Campos Elísios.

Assim temos as legislações municipais testemunhando a progressão da complexidade da cidade no tempo:

Lei $n^{0}$ 209, de 11/03/1896. Obriga a construção de passeios e fechos de terreno.

Coronel Rodovalho, presidente da Câmara Municipal.

Lei $n^{0} 460$, de 17/04/1900. Autoriza o prefeito a alterar o alargamento dos passeios atualmente existentes.

Prefeito Antônio da Silva Prado

Lei $\mathbf{n}^{0}$ 570, de 07/05/1902. Obriga os proprietários dos prédios completarem o alargamento.

Prefeito Antônio da Silva Prado

O empresário e político Conselheiro Antônio da Silva Prado foi o primeiro prefeito após a Proclamação da República, mas ainda nomeado pelo Marechal Deodoro da Fonseca (os quatro seguintes foram eleitos). 
Coube a ele a urbanização e reformas civis, dando uma feição européia à cidade de São Paulo. Arborizou ruas e avenidas, remodelou o Jardim da Luz, inaugurou a iluminação elétrica em alguns pontos da cidade, o fornecimento da energia elétrica, em 1900 inaugurou a $1^{\text {a }}$ linha de bondes elétricos, abriu a avenida Angélica e construiu o Teatro Municipal em 1911.

Lei $n^{0}$ 4.256, de 01/07/1952. Proíbe expor ou depositar materiais, mercadorias ou objetos nos passeios das vias públicas do município.

Prefeito Armando de Arruda Pereira.

Lei $n^{0}$ 5.039, de 14/09/1956. Os proprietários de imóveis edificados ou não situados em vias públicas dotadas de guias e sarjetas são obrigados a construir ou reconstruir os respectivos passeios e mantê-los em perfeito estado de conservação.

Elias Shammass, presidente da Câmara Municipal.

Lei $\mathrm{n}^{0}$ 6.933, de 26/08/1966. Proíbe estacionamento de veículos sobre passeios e calçadas.

Prefeito José Vicente de Faria Lima.

Lei $\mathbf{n}^{\mathbf{0}}$ 7.644, de 28/10/71. Os terrenos não edificados, situados na zona urbana do município, com frente para vias e logradouros públicos, dotados de calçamento ou guias e sarjetas, serão obrigatoriamente fechados nos respectivos alinhamentos com muros de alvenaria.

Prefeito José Carlos de Figueiredo Ferraz.

Lei $\mathbf{n}^{0}$ 10.508, de 04/05/1988. Dispõe sobre a limpeza nos imóveis, o fechamento de terrenos não edificados e a construção de passeios.

Prefeito Jânio da Silva Quadros

Lei $\mathbf{n}^{0}$ 10.667, de 28/10/1988. Dispõe sobre a permissão de uso de passeio público fronteiriço a bares e restaurantes..., para colocação de mesas e cadeiras. 
Prefeito Jânio da Silva Quadros.

Lei $\mathbf{n}^{0}$ 11.210, 20/05/92. Dispõe sobre a colocação de lixeiras nos passeios públicos.

Prefeita Luiza Erundina,

Lei $\mathbf{n}^{0}$ 11.509, de 13/04/1994. Determina o uso de pisos drenantes em passeios públicos, estacionamentos descobertos, ruas de pouco movimento de veículos e vias de circulação de pedestres.

Prefeito Miguel Colassuono.

Lei $n^{0}$ 11.656, de 18/10/1994. Dispõe sobre a obrigatoriedade de demarcação, pelos postos de serviço e abastecimento de combustíveis, de faixa para passagem de pedestres nas calçadas.

Prefeito Paulo Salim Maluf.

Lei $\mathbf{n}^{0}$ 12.002, 23/01/1996. Dispõe sobre a permissão de uso de passeio público fronteiriço a bares e restaurantes para colocação de mesas e cadeiras.

Prefeito Paulo Salim Maluf.

Lei $n^{0}$ 12.260, de 11/12/1996. Disciplina o uso de calçadas nas proximidades das faixas de pedestres.

Prefeito Paulo Salim Maluf.

Lei $n^{0}$ 12.271, de 19/12/1996. Dispõe sobre a instalação de guaritas de segurança.

Prefeito Paulo Salim Maluf.

Lei $\mathbf{n}^{\mathbf{0}}$ 13.310, de 31/01/2002. Os responsáveis por imóveis edificados ou não lindeiros a vias e logradouros públicos dotados de guias e sarjetas, devem zelar para que, ao oferecerem vagas nos respectivos recuos para estacionamento ou parada de veículos, estes não venham a ocupar ainda que parcialmente o passeio correspondente.

Prefeita Marta Suplicy. 
Lei $n^{0}$ 13.614, de 02 / 07/ 2003. Estabelece as diretrizes para a utilização de vias municipais para a implantação e instalação de equipamentos de infra-estrutura urbana. Fomenta o compartilhamento de redes no município como forma de reduzir o impacto das obras sobre os munícipes, bem como estimula a construção de galerias técnicas.

Prefeita Marta Suplicy.

Decreto $n^{0}$ 45.904, de 19/05/2005. Regulamenta o artigo $6^{\circ}$, da Lei $n^{0} 13.885$, de 25/08/2004(*), no que se refere à padronização dos passeios públicos do Município de São Paulo.

Prefeito José Serra.

(*) Lei $\mathbf{n}^{\mathbf{0}}$ 13.885, de 25/08/2004. Estabelece norma complementar ao Plano Diretor Estratégico, institui os Planos Regionais Estratégicos das Subprefeituras, dispõe sobre o parcelamento, disciplina e ordena o Uso e Ocupação do Solo do Município de São Paulo.

Prefeita Marta Suplicy 


\section{TIPOLOGIA DAS CALÇADAS DE SÃO PAULO.}

\subsection{Dimensionamento e especificação das calçadas}

As calçadas são as bases de um caminhar seguro, confortável e saudável. A sua conservação deveria ser de extrema fiscalização, para não correrem o risco de se tornarem palcos de acidentes com prejudiciais danos físicos.

O decreto $\mathrm{n}^{\mathrm{o}}$ 45.904/2005 [SÃO PAULO(2005)], para calçadas e passeios contempla a acessibilidade universal. Entre as medidas mais significativas temos:

- Uma área livre para a circulação de pedestres, com largura mínima de 1,20 m, desobstruída de mobiliário urbano ou qualquer outra interferência, com superfície firme, regular, estável e não escorregadia sob qualquer condição. Figuras (II-4), (II-5) e (II-6)

- Uma faixa de serviço, com largura mínima de $0,70 \mathrm{~m}$, onde se permite a colocação de objetos, elementos do mobiliário urbano e construções integrantes da paisagem urbanos, implantados mediante a autorização do Poder Público. Figuras (II-4), (II-5) e (II-6)

- Uma faixa de acesso destinada à acomodação de interferências temporárias, como mesas e cadeiras, projeção de anúncios, sendo necessária autorização da Prefeitura e recomendável para passeios com mais de 2,0 $\mathrm{m}$ de largura, de forma a não interferir na faixa livre. Não há especificação de largura para esta faixa, desde que garantidas as dimensões das faixas livres e de serviços. Figuras (II-4), (II-5) e (II-6).

Figura II-4

Divisão da calçada em três faixas

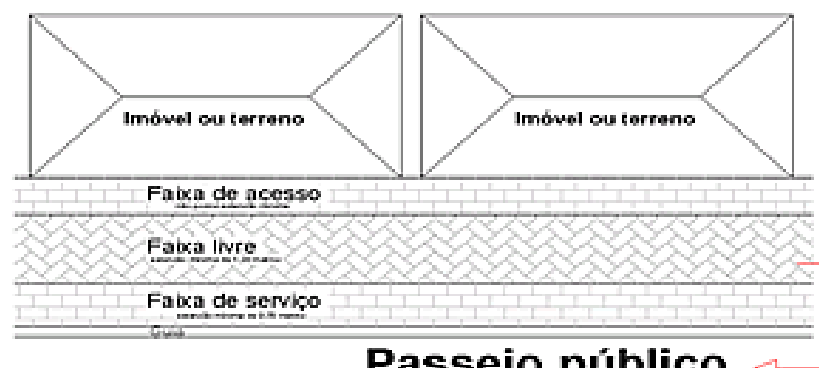

Passeio público

Fonte: PMSP. Decreto no 45.904. [SÃO PAULO(2005)]. 
Figura II-5. Aplicação da divisão de calçada em área comercial.

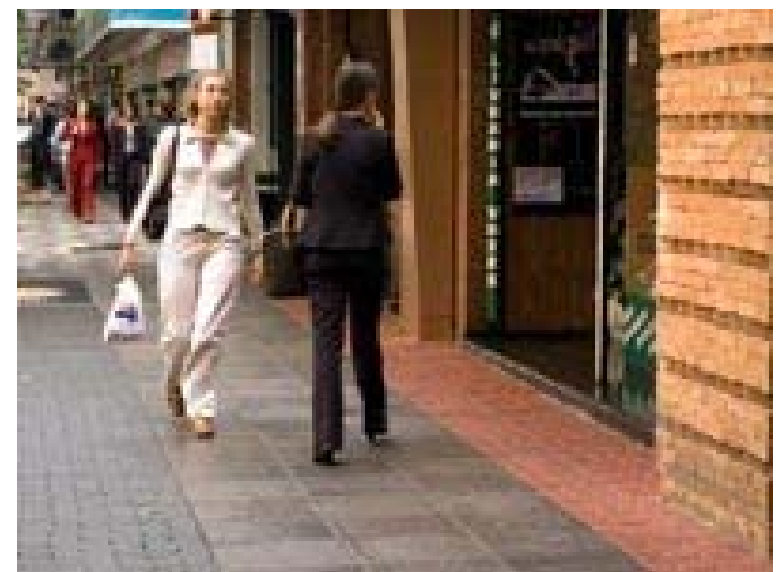

Fonte: ABCP. Galeria de fotos.[ABCP(2005)]

Figura II-6. Aplicação de divisão de calçada em área residencial.

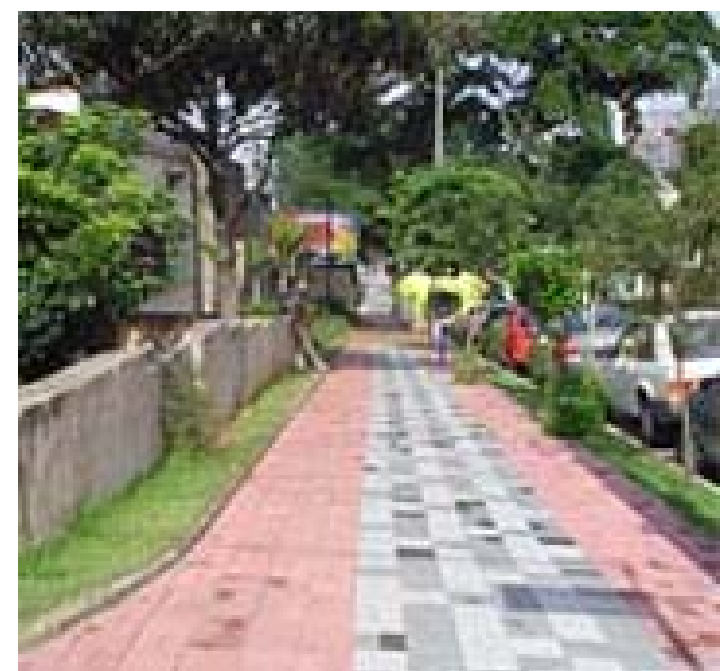

Fonte: ABCP. Galeria de fotos.[ABCP(2005)]

- A inclinação longitudinal do passeio deve acompanhar o "greide" da rua, não superior a $8,33 \%$.

- A inclinação transversal constante não deve ser superior a $2 \%$.

- Os padrões do calçamento poderão ser escolhidos entre:

- concreto pré-moldado ou moldado in loco (cimentado), com juntas ou em placas, acabamentos desempenado, texturado ou estampado. 
- bloco de concreto intertravado.

· ladrilho hidráulico.

- pisos de pedras naturais (granitos e basalto) e mosaicos portugueses poderão ser adotados pelo munícipe em situações especiais, tais como passeios contíguos às áreas de lazer, de permanência e de pedestres, desde que fora da faixa livre, mediante autorização específica de consulta prévia da Prefeitura.

Outra exceção que precisa de consulta prévia da Prefeitura são as calçadas em áreas com declividade acentuada.

Segue quadro que resume os critérios para a escolha do pavimento (quadro II-1). 

UMA VISÃO ERGONOMICA

\section{Quadro II-1. Critérios para a largura da calçada e da escolha do pavimento, de acordo com o tipo de via .}

\begin{tabular}{|c|c|c|c|c|c|}
\hline \multirow[b]{2}{*}{ Tipo de Via } & \multicolumn{2}{|c|}{ Largura da calçada } & \multicolumn{3}{|c|}{ Tipo de pavimento } \\
\hline & $\begin{array}{l}\text { Mínima } \\
(\mathrm{m})\end{array}$ & $\begin{array}{l}\text { Recomendada } \\
\text { (m) }\end{array}$ & $\begin{array}{l}\text { Área de Faixa } \\
\text { Livre }\end{array}$ & $\begin{array}{l}\text { Área da faixa de } \\
\text { acesso e serviço }\end{array}$ & Vegetação \\
\hline Local & 1,20 & 1,50 & $\begin{array}{ll}\text { Todos } & \text { os } \\
\text { pavimentos } & \\
\text { recomendados } & \text { no } \\
\text { decreto } & \\
\end{array}$ & $\begin{array}{l}\text { Gramado ou piso } \\
\text { drenante }\end{array}$ & $\begin{array}{l}\text { Arborização } \\
\text { conforme consulta } \\
\text { à SVMA * }\end{array}$ \\
\hline Coletora & 2,00 & 2,50 & $\begin{array}{ll}\text { Todos } & \text { os } \\
\text { pavimentos } & \\
\text { recomendados } & \text { no } \\
\text { decreto } & \\
\end{array}$ & $\begin{array}{l}\text { Gramado ou piso } \\
\text { drenante }\end{array}$ & $\begin{array}{l}\text { Arborização } \\
\text { conforme consulta } \\
\text { à SVMA * }\end{array}$ \\
\hline $\begin{array}{l}\text { Coletora } \\
\text { com } \\
\text { Comércio }\end{array}$ & 2,50 & $\begin{array}{l}\text { Dimensiona } \\
\text { do para } \\
\text { absorver o } \\
\text { fluxo de } \\
\text { pedestres }\end{array}$ & $\begin{array}{l}\text { Concreto pré- } \\
\text { moldado } \\
\text { placas, bloco de } \\
\text { concreto } \\
\text { intertravado, } \\
\text { ladrilho hidráulico }\end{array}$ & $\begin{array}{l}\text { Concreto em placas } \\
\text { ou bloco } \\
\text { intertravado na } \\
\text { faixa de serviço e } \\
\text { piso drenante ou } \\
\text { permeável junto à } \\
\text { faixa de acesso. }\end{array}$ & $\begin{array}{lr}\text { A área excedente } \\
\text { junto aos imóveis } \\
\text { poderá } \\
\text { utilizado ser } \\
\text { instalações ra } \\
\text { mesas e cadeiras, } \\
\text { mediante emissão } \\
\text { de Termo de } \\
\text { Permissão } \\
\text { Uso** }\end{array}$ \\
\hline Estrutural & 3,00 & 3,50 & $\begin{array}{l}\text { Concreto pré- } \\
\text { moldado } \\
\text { placas, bloco de } \\
\text { concreto } \\
\text { intertravado, } \\
\text { ladrilho hidráulico } \\
\end{array}$ & $\begin{array}{l}\text { Concreto em placas } \\
\text { ou bloco } \\
\text { intertravado na } \\
\text { faixa de serviço e } \\
\text { piso drenante ou } \\
\text { permeável junto à } \\
\text { faixa de acesso. }\end{array}$ & $\begin{array}{l}\text { Arborização } \\
\text { conforme consulta } \\
\text { à SVMA * }\end{array}$ \\
\hline $\begin{array}{l}\text { Estrutural } \\
\text { com } \\
\text { comércio }\end{array}$ & 3,50 & $\begin{array}{l}\text { Dimensiona } \\
\text { do para } \\
\text { absorver o } \\
\text { fluxo de } \\
\text { pedestres }\end{array}$ & $\begin{array}{l}\text { Concreto pré- } \\
\text { moldado } \\
\text { placas, bloco de } \\
\text { concreto } \\
\text { intertravado, } \\
\text { ladrilho hidráulico }\end{array}$ & $\begin{array}{l}\text { Concreto em placas } \\
\text { ou bloco } \\
\text { intertravado na } \\
\text { faixa de serviço e } \\
\text { piso drenante ou } \\
\text { permeável junto à } \\
\text { faixa de acesso. }\end{array}$ & $\begin{array}{lr}\text { A área } & \text { excedente } \\
\text { junto aos imóveis } \\
\text { poderá r rer } \\
\text { utilizado rara } \\
\text { instalações re } \\
\text { mesas e cadeiras, } \\
\text { mediante emissão } \\
\text { de Termo de } \\
\text { Permissão } \\
\text { Uso** }\end{array}$ \\
\hline
\end{tabular}

*SVMA Secretaria do Verde e Meio Ambiente da Prefeitura de São Paulo.

** Termo de Permissão de Uso emitido pela Prefeitura de São Paulo.

Fonte: PMSP. Decreto n ${ }^{\circ}$ 45.904. [SÃO PAULO(2005)].

\subsection{Principais características dos pisos recomendados}

\section{Pisos em Concreto}

\section{Pisos em concreto moldado in loco}

O piso de concreto moldado in loco pode ter acabamento "vassourado" ou apresentar

estampas coloridas. O processo de "estampar" o piso consiste no uso de ferramentas adequadas que dão formas para estamparia e produtos de acabamentos especiais para 


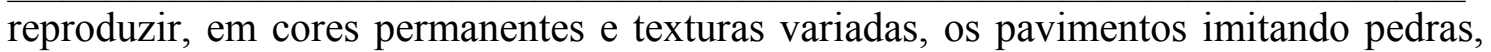
tijolos e cerâmicas, a um custo inferior ao dos materiais naturais e com maior rapidez na execução. O produto apresenta grande durabilidade, visto que a matéria prima principal é o concreto. Exemplo na figura (II-7). A base do piso em terra compactada, com camada separadora de brita; a armadura deve ser feita com telas soldadas. O pavimento recebe um tratamento superficial, executado no mesmo instante em que é feita a concretagem, enquanto ainda não atingir o início do processo de "pega".

Vantagens para este tipo de piso:

- permite imitar vários tipos de materiais, de uma forma econômica e rápida.

- tem alta resistência, durabilidade e plasticidade.

- facilita o dimensionamento de acordo com o projeto.

- possibilita racionalidade no uso, evitando desperdícios e formação de entulhos.

- apresenta alta produtividade.

\section{Figura II-7. Piso de concreto moldado in loco, estampado. No detalhe fase de aplicação da estamparia}

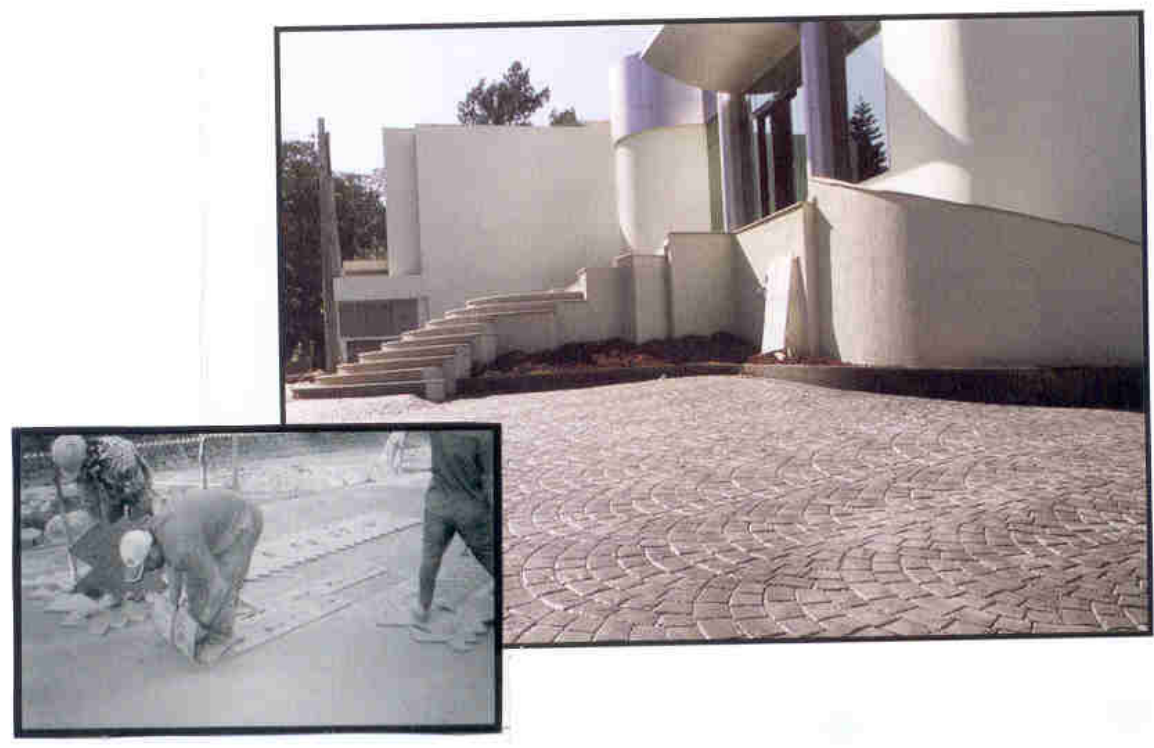

Fonte: ABCP. Galeria de fotos.[ABCP(2005)] 


\section{Pisos em concreto pré-moldado}

- Placas de concreto removíveis “inteligentes”

São placas assentadas em areia enriquecida com cimento e podem ser retiradas e recolocadas sem quebrar, gerando economia por muitos anos. Admitem variedade de tamanho, texturas e cores, características compatíveis com as necessidades dos projetos. Quando o projeto prevê enterramento de fios, cabos e tubulações das concessionárias no subsolo, as placas podem ser apoiadas sobre alvéolos que facilitam a passagem de fios, sempre que for necessário fazer uma ampliação de rede ou executar uma nova instalação. Figura (II-8). São placas assentadas em areia enriquecida com cimento e podem ser retiradas e recolocadas sem quebrar, gerando economia por muitos anos.

Figura II-8. Exemplo de pavimento em placa de concreto, “inteligente”.
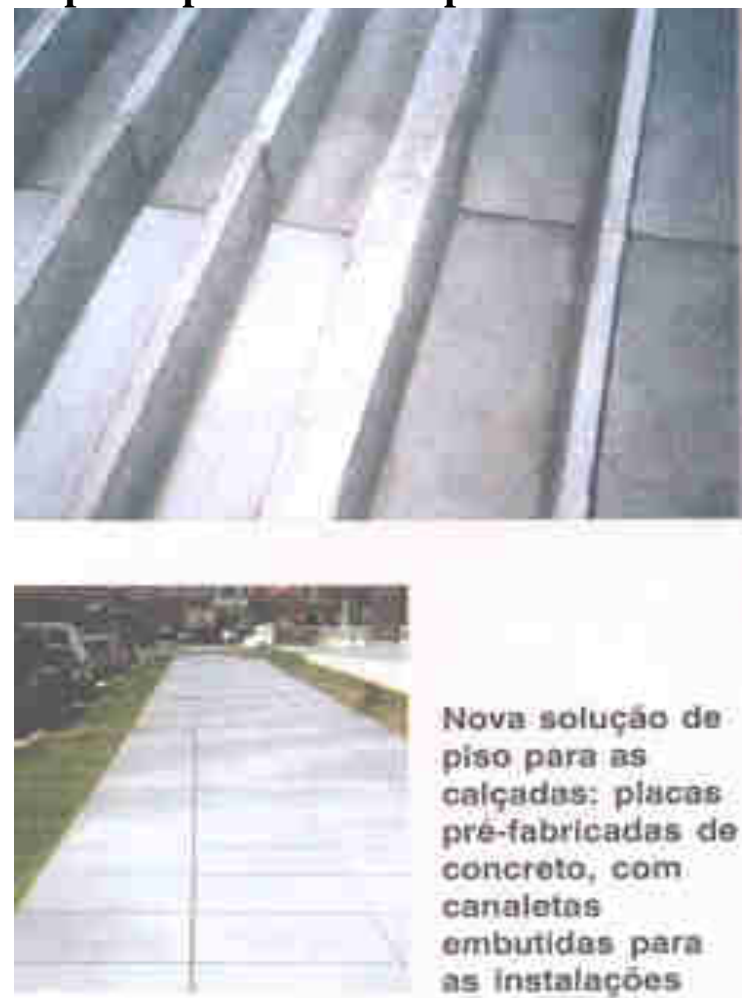

Nova soluçáo de piso para as calçadas: placas pre-fabricadas de concreto, com canaletas embutidas para as instalaçóes

Fonte: ABCP. Galeria de fotos.[ABCP(2005)]

\section{Blocos intertravados}

São peças de concreto pré-moldados que se mantêm travadas por meio de contenção lateral e por atritos entre os elementos. Figura (II-9). 
Estes blocos intertravados são fabricados especialmente para essa finalidade e assentados um a um, no local definitivo e diretamente sobre a base, encaixados em espaços limitados por guias ou meios-fios de concreto. Sobre a base devidamente compactada e nivelada, lançado uma camada de 0,03 a $0,05 \mathrm{~m}$ de areia ou pó de pedra, onde são assentados os blocos um a um, com espaçamento de 0,002 a 0,003 m entre um e outro. Estes espaços são preenchidos com areia e o conjunto é compactado com placa ou rolo vibratório.

Vantagens para este tipo de piso:

- execução mais rápida

- custo relativamente mais reduzido

- utilização imediata

- facilidade de remoção ou deslocamento quando necessário, sem perda de material.

- excelente aspecto visual

Figura II-9. Exemplo de blocos de concreto intertravado. No detalhe $o$ assentamento das peças.

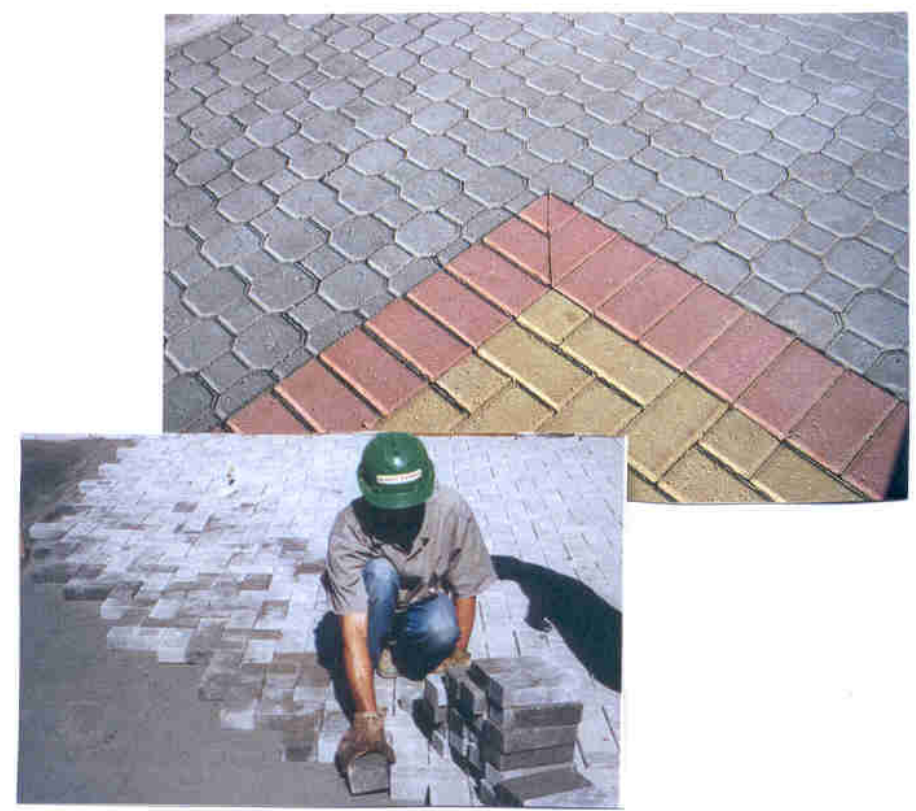

Fonte: ABCP. Galeria de fotos.[ABCP(2005)] 


\section{Ladrilho hidráulico}

Ladrilhos hidráulicos são placas de concreto de alta resistência ao desgaste, quadradas $(0,20 \times 0,20 \mathrm{~m})$, fabricadas com argamassa de cimento e areia, com uma fina camada superficial prensada, na qual se utilizam cimentos brancos e corantes. Nesta camada são feitos desenhos normalmente em relevo, o que torna as peças antiderrapantes.

A argamassa de cimento (1:3 em volume) para fixar o ladrilho deve ser nivelada por faixas sarrafeadas. Sobre a superfície plana e áspera aplicam-se as peças de ladrilhos bem saturadas de água. Para fixar e nivelá-las adequadamente bate-se com uma manopla.

É material de fácil limpeza, bastando utilizar-se de água e sabão. Sua execução é pontual e permite liberação ao uso em 24 horas. Com durabilidade mínima de 5 anos, sua manutenção e reposição são simplificadas, pois apenas requerem a substituição da peça danificada. A superfície plana e com sulcos proporciona facilidade de trânsito e efeito antiderrapante. A drenagem é superficial.

A figura (II-10) ilustra uma das inúmeras maneiras de formar uma decorativa calçada.

Figura II-10. Exemplo de uma calçada em ladrilho hidráulico.

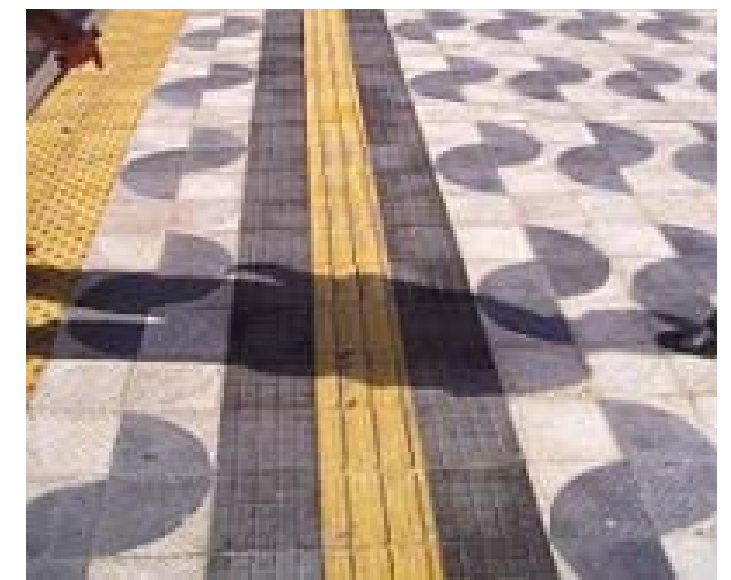

Fonte: ABCP. Galeria de fotos.[ABCP(2005)] 


\section{Mosaico Português}

São calçadas arranjadas com pedras de 0,05 a $0,08 \mathrm{~m}$, de formato irregular. O material não suporta muito peso e sua manutenção e reposição requerem muitos cuidados, sendo inadequada para "remendos". As pedras são assentadas com auxílio de soquetes de madeira sobre colchão de areia, justapostas e rejuntadas.

O mosaico português e as peças de granito apicoado ou legigado são permitidos exclusivamente para áreas de permanência e circulação de pedestres, próximo a áreas de lazer, mediante aprovação da Prefeitura, desde que fora da faixa livre. Figura (II-11).

\section{Figura II-11. Mosaico português em assentamento numa calçada à beira mar.}

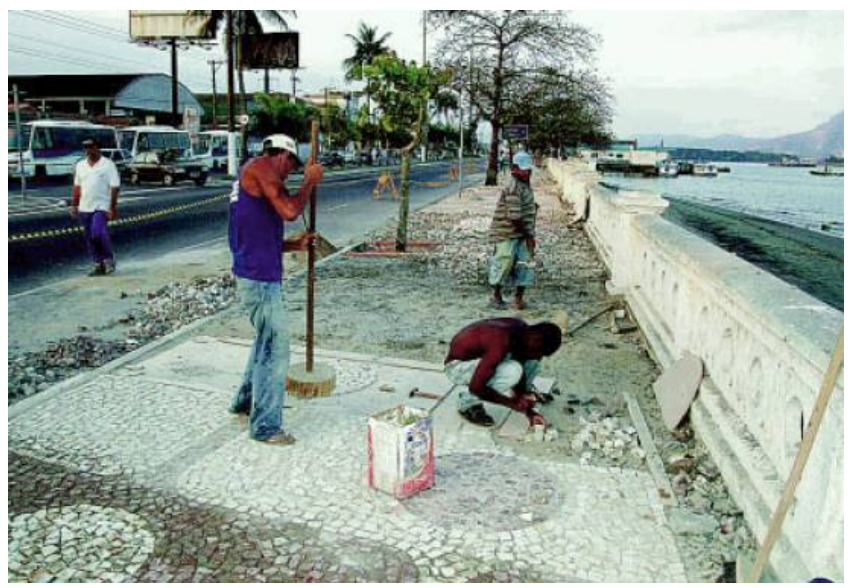

Fonte: "Histórias e Lendas de Santos".[SANTOS(2004)]

4.3 Diretrizes de projeto das calçadas

Além dos requisitos do Decreto nº 45.904 / 2005 [SÃO PAULO(2005)], a legislação do Município de São Paulo contempla outras importantes condições que definem o perfil urbanístico das calçadas na cidade.

- Os elementos de mobiliário temporário (mesas, cadeiras e toldos) continuam regulamentados pelas leis $n^{\circ} 12.002$ e 12.260 de 1996. 
Lei 12.002/96 permite a colocação de mesas, cadeiras e toldos nos passeios públicos fronteiriços a bares, confeitarias, restaurantes, lanchonetes e assemelhados, determinando que:

- a instalação do mobiliário no passeio não poderá bloquear, obstruir ou dificultar o acesso de veículos, o livre trânsito de pedestres e em especial de deficientes físicos, nem a visibilidade dos motoristas na confluência de vias.

- qualquer que seja a largura da calçada dever-se-á respeitar a faixa mínima de 1,10m para permitir o livre e seguro trânsito de pedestres.

- fica proibida a colocação, nestas calçadas, de amplificadores, caixas acústicas, altofalantes ou qualquer aparelhos que produzam som, bem como quiosques ou estandes de venda.

Lei $12.260 / 96$ proíbe a utilização das calçadas, situadas nas proximidades das faixas de pedestres do Município de São Paulo, para o desenvolvimento de qualquer atividade, econômica ou não, inclusive prestação de serviços de qualquer natureza, devendo apenas ser utilizadas pelos pedestres.

- A lei municipal $\mathrm{n}^{0} 10.508$ de 1988 dá a responsabilidade ao proprietário do terreno ou imóvel em frente, da construção, manutenção e reparo da respectiva calçada, sempre que a via dispuser de guia e sarjeta, bem como trata da implantação de mobiliário, da utilização dos passeios e da aplicação das respectivas penalidades.

- Continuidade

Os passeios deverão ser contínuos, sem mudança abrupta de nível ou inclinação que dificultem o trânsito seguro dos pedestres, observado quando possível os níveis imediatos dos passeios vizinhos já executados.

- Escoamento de águas pluviais 
$\overline{\text { Os lançamentos de águas pluviais devem ser feitos por meio de condutores, passando }}$ por baixo da calçada e chegando até a sarjeta.

\section{- Declividade}

Os passeios das vias com declividade superior a $12 \%$ deverão ser subdivididos longitudinalmente em trechos com declividade máxima de $12 \%$ e a interligação entre as subdivisões poderá ser executada em degraus com altura máxima de $0,175 \mathrm{~m}$ e largura mínima de 0,28 m no sentido longitudinal.

- Desnível

O eventual desnível entre o passeio e o terreno lindeiro (rampas de acesso, degrau ou nivelamento) deverá ser acomodado no interior do imóvel, depois do limite da fachada. Nenhum degrau pode ser feito no passeio.

- As Interferências

O sistema de posteamento e correspondentes redes aéreas de energia e comunicação concentram uma série de interferências que, além de gerarem campos elétro-magnéticos próximos às pessoas, facilitarem ligações clandestinas ("gambiarras" ou "gatos") e agravarem a poluição visual, são fator de risco de acidentes com os postes "plantados" no caminho do pedestre.

A Lei $n^{\circ} 13.614$ /2003 privilegia as instalações subterrâneas das fiações e os métodos não destrutivos; e as instalações aéreas só seriam aprovadas quando comprovada a impraticabilidade da instalação subterrânea.

As galerias técnicas, situadas abaixo das vias, permitem fácil acesso para inspeções. Sua construção pode ser pelo método destrutivo (“cut \& cover”) ou método menos destrutivo (destruição do pavimento feito apenas no início e fim dos trechos da obra, com perfuração do túnel direcional). Dentro deste túnel é implantada a galeria, propriamente dita, com "prateleiras" ao longo desta, onde são "deitados" os cabos e 
fiações de cada empresa operadora de serviços. Isto permite melhor racionalização do uso do subsolo, o que implica melhor controle no uso da coisa pública por parte do poder concedente, que é a municipalidade.

O ganho em estética, praticidade, funcionalidade, acessibilidade e segurança são fatores favoráveis para a implantação dessas instalações. As figuras (II-12), (II-13), (II-14) e (II-15) são ilustrações de situações simuladas de vias com aterramento dos cabos de fiação. A figura (II-16) é a ilustração de um perfil de uma via com calçada técnica. A figura (II-17) representa uma das soluções para a galeria técnica, no caso uma galeria circular (podem ser em perfil quadrado, etc.).

Figura II-12. Simulação de uma avenida sem interferência aérea
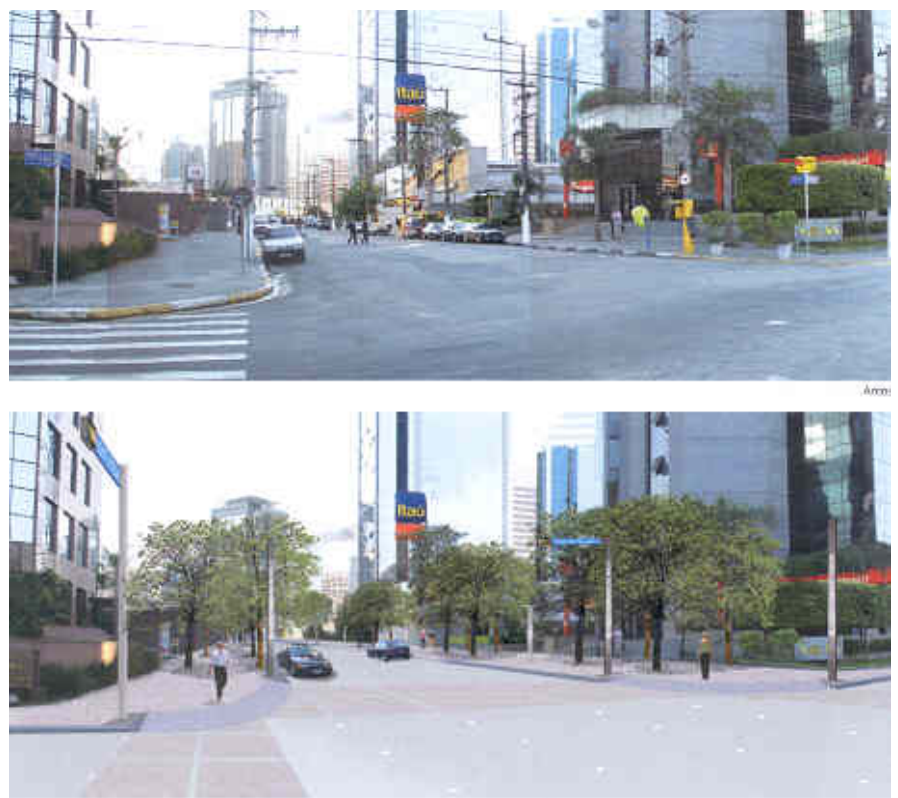

Fonte: Movimento Colméia.[COLMEIA(2003)] 
Figura II-13. Simulação de uma rua sem os postes de fiação aérea.
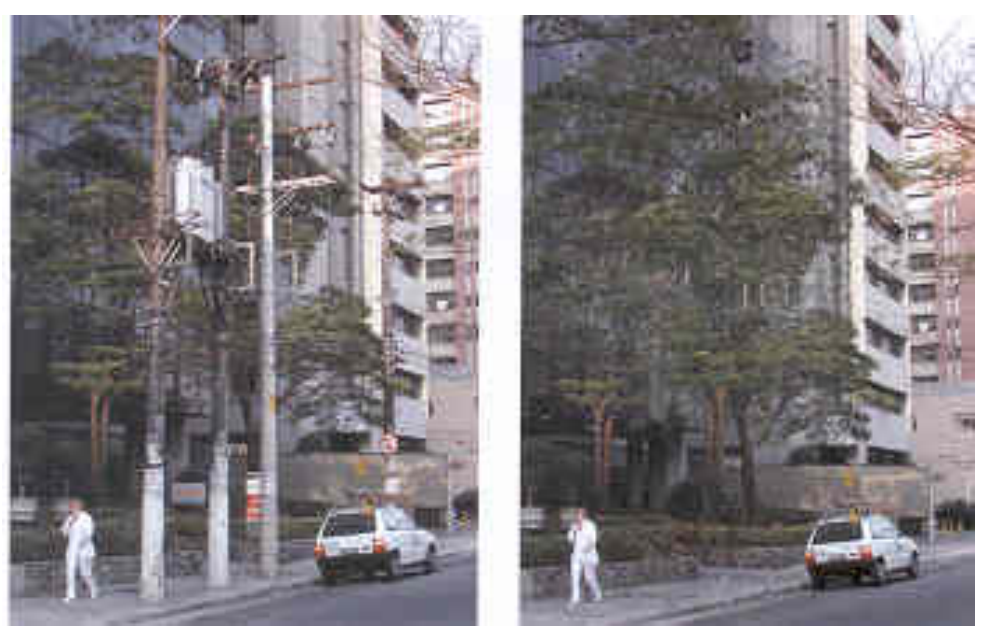

Fonte: Movimento Colméia.[COLMEIA(2003)]

Figura II-14. Simulação de uma rua sem a interferência aérea.

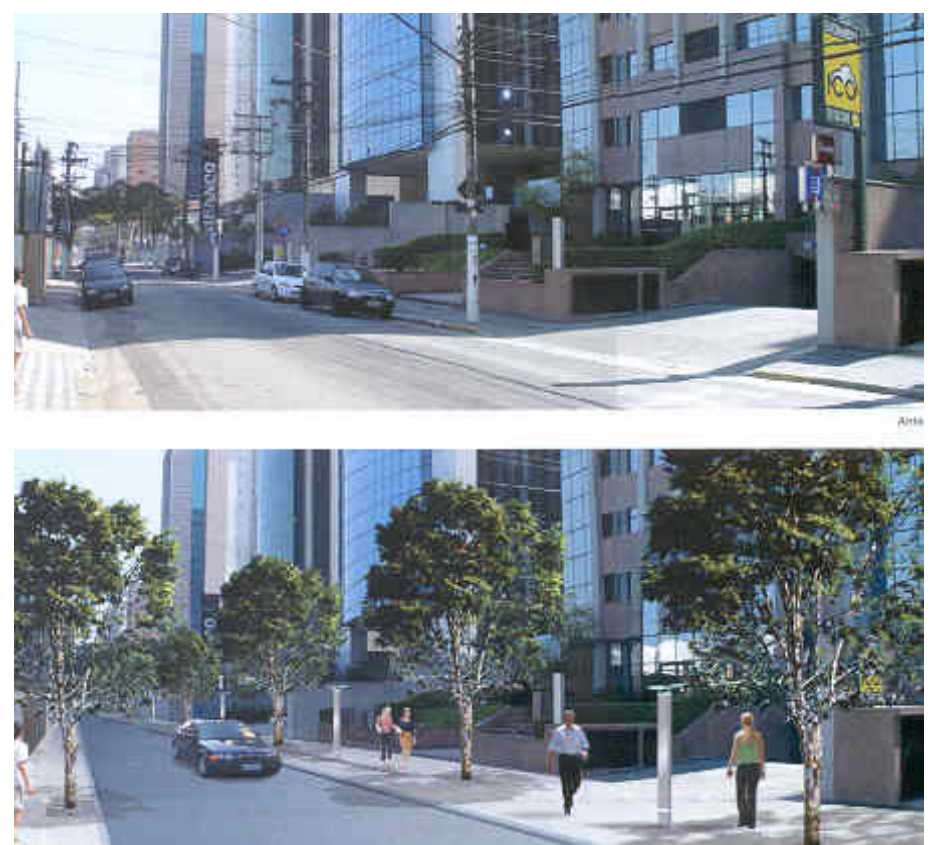

Fonte: Movimento Colméia.[COLMEIA(2003)] 
Figura II-15. Simulação de uma via sem a fiação aérea, interferindo no paisagismo.
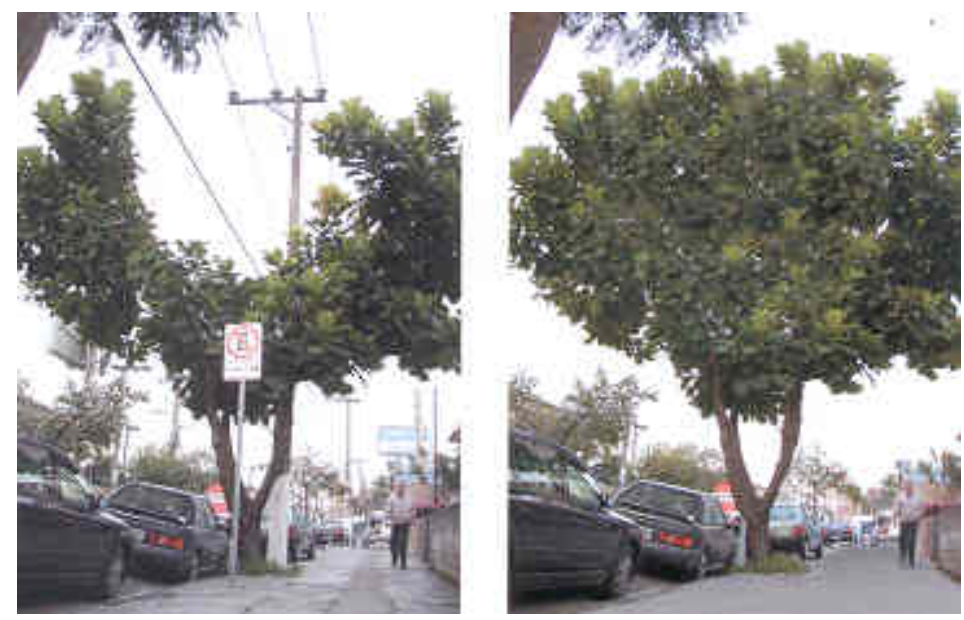

Fonte: Movimento Colméia.[COLMEIA(2003)]

Figura II-16. Perfil de uma via, com a galeria técnica no subsolo.

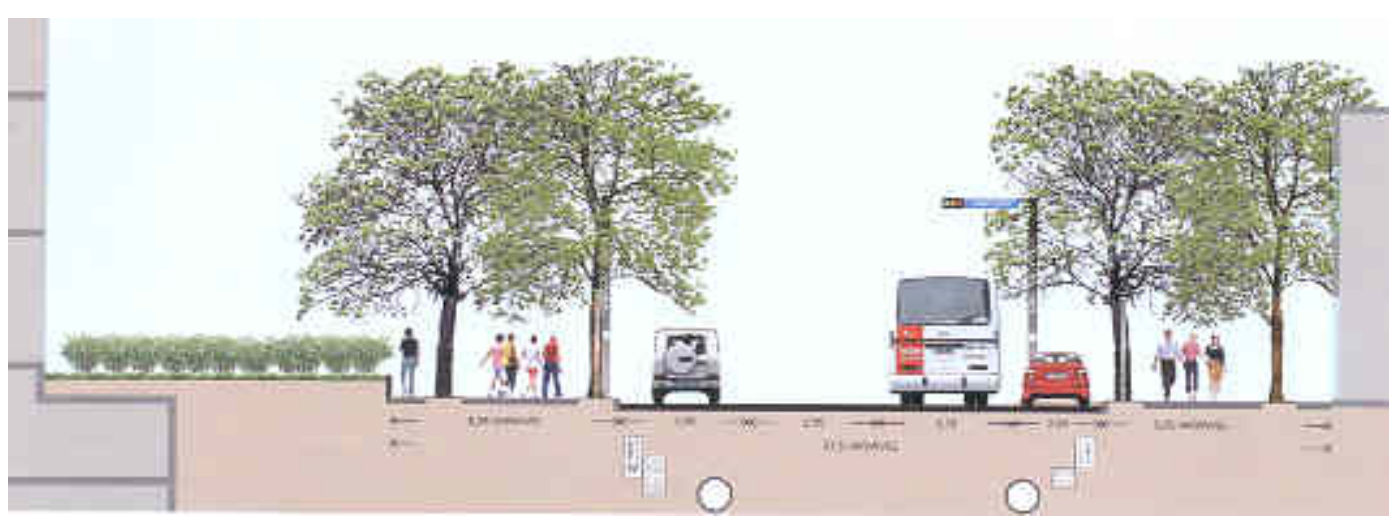

Fonte: Movimento Colméia.[COLMEIA(2003)]

Figura II-17. Exemplo de uma galeria técnica (perfil circular)

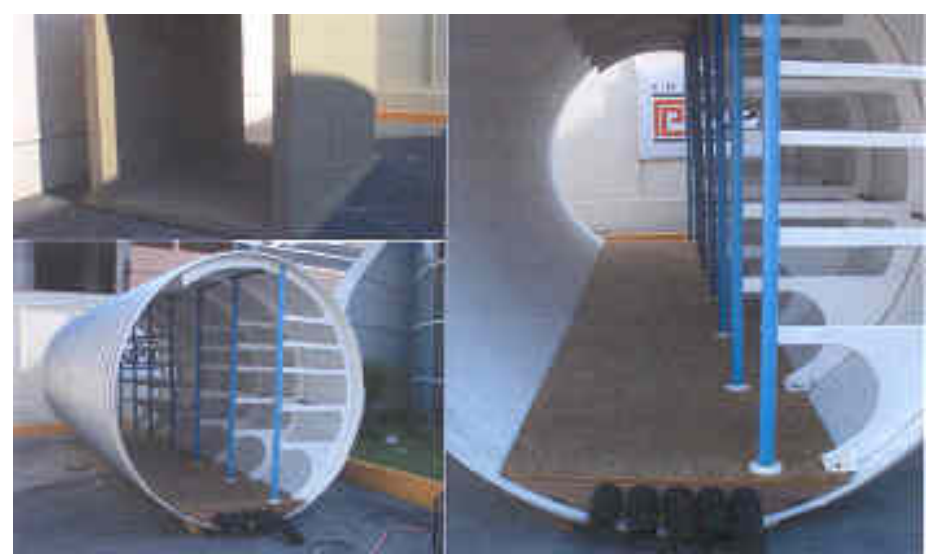

Fonte: Movimento Colméia.[COLMEIA(2003)] 
Os pontos negativos destas calçadas técnicas são:

- as fases da obra, perturbações ruidosas e dinâmicas.

- as tampas de caixas de inspeção e visitas são de padrões diferentes das placas que constituem o calçamento.

- pode haver reposição inadequada do pavimento (caberia à municipalidade fiscalizar a adequada reposição do pavimento).

- eventualmente haverá necessidade de equipamentos aflorados (armários, transformadores, respiros, etc).

\subsection{Estruturação do subsolo de São Paulo}

Todos os aspectos de praticidade, eficiência e segurança que os materiais e técnicas descritos podem oferecer para melhorar a qualidade das calçadas para os pedestres, no entanto, deparam com uma adversidade que se arrasta há anos, qual seja a falta de um mapa unificado do subsolo da cidade de São Paulo.

Conforme o artigo "Subsolo carece de Mapa Unificado", do Jornal do Engenheiro, \{MISLEH(2006)], o subterrâneo da cidade de São Paulo é uma complexidade de aproximadamente 100 mil quilômetros de cabeamentos, galerias e outras instalações, cujo ordenamento não é acompanhado adequadamente na rede existente. Não há cadastro único de todo o emaranhado de tubulações, fios e cabos, pois no município nem toda a infra-estrutura enterrada é conhecida. A região mais complicada é o centro expandido cujo adensamento é maior e onde se encontram até dutos abandonados e pedaços de obras perdidos. Isso se deve ao processo centenário de ocupação desse espaço, que ocorreu sem uma coordenação geral.

O perigo deste desconhecimento é o risco de uma concessionária interferir em redes vizinhas. A empresa concessionária de eletricidade, por exemplo, pode ter a carga 
interrompida e uma região inteira da cidade pode ficar sem energia. Se outra empresa A perfuração uma tubulação de gás pode significar até risco de explosão; o rompimento de uma adutora pode comprometer o fornecimento de água para milhões de pessoas e concentrar desperdício de água que não se tem; a ruptura de um coletor de esgoto põe em risco a saúde pública.

A solução geralmente adotada tem sido o intercâmbio de cadastros entre as concessionárias e previsão de ações conjuntas. Em médio prazo cogita-se sobre a formação de uma entidade que congregasse todas as companhias e, de forma simplificada, centralizasse as informações de suas redes. Embora a idéia pareça simples, o mapeamento unificado é apenas parte da solução, pois não basta juntar os cadastros, há que se compatibilizar linguagens e softwares. A Prefeitura de São Paulo elabora a base cadastral com financiamento do BNDES (Banco Nacional de Desenvolvimento Econômico e Social). É o início para ordenar o subsolo da cidade de São Paulo, conforme eng. Marcos Romano em [MISLEH(2006)]. 


\section{SÍNTESE DO CAPÍTULO}

As cidades originariamente foram concebidas para os homens pedestres que, no máximo, conduziam cargas em carroças de tração animal. Com a evolução das carroças em carruagens, bigas e outras formas para a condução de pessoas e coisas aliadas ao aumento de sua freqüência nas vias, os veículos passaram a ter primazia nas vias. Mais tarde, com a mecanização e o uso de combustíveis as máquinas alcançaram velocidades muito superiores à tração animal. Nesse quadro, os pedestres foram segregados das vias, com a adoção de um sistema de calçadas, normalmente à margem das vias, para sua circulação. Regras, códigos, signos foram inventados para compatibilizar estes dois modos de translação, mecânico, com veículos, e a pé, pelos pedestres.

As calçadas e passeios passaram a ser o reduto natural dos pedestres, embora não exclusivo, pois por vezes compartilhados (mobiliário urbano, sinalização, serviços) e nem sempre amigáveis. As visões das cidades pelos pedestres foram laboratórios para muitos pensadores, filósofos, urbanistas, pesquisadores e intelectuais. Estes concluíram pela legitimidade de posse da cidade aos pedestres e não apenas o direito às calçadas. A qualidade de vida da cidade depende da qualidade de circulação e mobilidade de sua gente.

A ascensão da cidade de São Paulo, saindo da economia cafeeira e escravocrata para a emergente industrialização e mão de obra imigrante, necessitou de urgentes leis para domesticar a cidade que se agigantava. Neste contexto os pedestres foram literalmente colocados à margem. Neste início do século XXI, surgem novas diretrizes para disciplinar as calçadas paulistanas. Com as novas possibilidades tecnológicas e com as inovadoras propostas urbanísticas, pretende-se que as calçadas sejam resgatadas aos pedestres em condições de acessibilidade universal. Leis e Decretos foram produzidos 
para viabilizar para tal empreendimento, incluindo o ofício prático da escolha do material e detalhes de projetos das calçadas.

Todos os tipos de pedestres, com suas velocidades relativas baixas, estarão esquadrinhando a cidade, perscrutando a pulsação de vida e assim resgatando seu direito ancestral de caminhar. Barreiras arquitetônicas deverão ser reduzidas e confinadas ao mínimo, incluindo-se aquelas vinculadas à prestação de serviços públicos. Apesar de dificuldades inerentes de um município que cresceu sem controle centralizado, que ignora o que existe no seu subsolo, o esforço da municipalidade aliado ao das concessionárias tem rendido frutos, que animam a formação de um mapeamento unificado em espaço de tempo que se espera não esteja muito distante.

A inserção da modalidade caminhar no trânsito urbano com qualidade é não somente uma possibilidade, como uma realidade próxima. A acessibilidade universal é o estágio maior da conquista do homem. 


\section{BIBLIOGRAFIA REFERENCIADA.}

ABCP. "Galeria de fotos". 2005. Disponível no site www.abcp.org.br. Acessado em $15 / 02 / 2006$.

ARGAN, Giulio Carlo. "A História da Arte como História da Cidade”. Martins Fontes. São Paulo.1993.

BENJAMIN, Walter. "Passage”. Editions du Seuil. Paris 1987.

CHILDE, Gordon. “O que aconteceu na história”. Ed, Zahar.São Paulo.1966

COLMEIA. "Repensando a Vila Olímpia”. Movimento Colméia. São Paulo. 2003.

CULLEN, Gordon. "Paisagem Urbana”. Edições 70. Lisboa. 1983.

ENCICLOPEDIA BRITANICA. "Micropedia Volume 1”. 1973.

FRUIN, John J. “Pedestrian. Planning and Design”. New York. 1971.

JACOBS, Jane. "Morte e Vida de Grandes Cidades". Ed Martins Fontes. 2003.

LE CORBUSIER. "Carta de Atenas / Le Corbusier”. Hucitec. São Paulo. 1993.

LYNCH, Kevin. “Buena Forma de la Ciudad”. Editora Gili. Barcelona.1985

MISLEH, Soraia. "Subsolo carece de Mapa Unificado". Jornal do Engenheiro. Fevereiro. 2006.

SÃO PAULO, Prefeitura Municipal. "Decreto no 45.904 / 2005". Diário Oficial do Município.São Paulo. Maio 2005.

SÃO PAULO, Prefeitura Municipal.’Programa Passeio Livre".2005. Disponível no site http://portal.prefeitura.sp.gov.br. Acessado em 15/02/2006.

SAKAGUCHI, Maria Akemi. "Da medicina ao urbanismo, as origens do primado da mobilidade". Dissertação de Mestrado. FAUUSP. 1998.

SANTOS, Milton. "A Natureza do Espaço. Técnica e Tempo. Razão e Emoção". HUCITEC. São Paulo. 1996.

SANTOS, Milton. "Pensando o Espaço do Homem”. HUCITEC. São Paulo. 1986.

SANTOS, Prefeitura Municipal.“História e Lendas de Santos”.2004. Disponível no site http://www.novomilenio.inf.br/santos/h0264.htm.Acessado em 17/02/2006. 
TUAN, Yi-Fu. "Espaço e Lugar. A Perspectiva da Experiência”. DIFEL.São Paulo. 1983.

YABIKU, Luiza. "O Pedestre". Apostila do curso de Capacitação para Médicos Peritos Examinadores. ABRAMET. São Paulo. 1999. 


\section{O PEDESTRE E A SEGURANÇA}

\section{Apresentação:}

Este capítulo apresenta a anatomia do atropelamento e as condições para a sobrevivência, assim como o custo desses acidentes e as medidas mitigadoras para sua redução. São focalizados os atropelamentos com os pedestres idosos e crianças, assim como os índices retrospectivos de mortes por atropelamento no município de São Paulo. Dentro das medidas de segurança são apresentadas as propostas “Zona 30” e “Traffic Calming”. 


\section{CAPÍTULO III}

\section{O PEDESTRE E A SEGURANÇA}

\section{Sumário:}

1. O ATROPELAMENTO

1.1 Anatomia do Atropelamento

1.2 Probabilidade de Sobrevivência

1.3 Atropelamento de Pedestres Idosos

1.4 Atropelamento de Pedestres Crianças

1.5 Morte por Atropelamento na Cidade de São Paulo

\section{CUSTO DE ACIDENTE COM PEDESTRE}

2.1 Custo de Atropelamento

2.2 Custo de Quedas em Vias Públicas

3. MEDIDAS DE SEGURANÇA

3.1 Comportamento dos Pedestres

3.2 Intervenções Urbanas

3.2.1 "Zona 30"

3.2.2 "Traffic calming”

4. SÍNTESE DO CAPÍTULO

5. BIBLIOGRAFIA REFERENCIADA 


\section{O PEDESTRE E A SEGURANÇA}

Conquanto caminhar seja em ato inerente ao homem, independente de credo, poder aquisitivo ou cultura, também significa exposição a acidentes. A própria ação de dar passos está relacionada a uma constante luta entre equilíbrio e desequilíbrio; a progressão de passadas dá-se com a participação do piso onde se realiza, cujas características (rugosidade, umidade, declividade), interfere na segurança de uma caminhada; a condição do pedestre (idade, saúde, pressa, desatenção, atividade, tipos de calçados) também interfere na segurança. Também as condições de tempo (dia, noite, entardecer, chuva, neblina) participam do contexto do caminhar. Alguma perturbação na dinâmica dessas relações pode levar o pedestre a sofrer uma queda, que pode ter ou não conseqüências graves. No Capítulo I já foi explanado sobre a questão dos Pedestres Idosos, que sofrem com maior freqüência com as quedas.

Mas o grande vilão que atua fortemente contra a segurança do pedestre é o veículo automotor. Isto porque este desenvolve velocidade muito acima da velocidade do pedestre e possui massa inercial muito maior, características decisivas para desfavorecer o pedestre em qualquer situação de confronto com o veículo. Define-se este confronto como “acidente por atropelamento” (atropelar é um verbo com o radical “tropel”, o que remete os acidentes de confronto dos pedestres com os cavalos, quando este era a forma de transporte mais veloz). 


\section{O ATROPELAMENTO.}

\subsection{Anatomia do Atropelamento}

O primeiro acidente fatal resultado de um atropelamento foi registrado na Inglaterra em

7 de agosto de 1896. Nos Estados Unidos a morte por atropelamento ocorreu pela primeira vez em Nova York em setembro de 1899. Não há registro semelhante no Brasil, mas o primeiro acidente de automóvel constatado foi em 1897 na cidade de Rio de Janeiro, sendo o veículo importado pertencente ao abolicionista José do Patrocínio e o condutor era o jovem poeta Olavo Bilac, que sem ser habilitado, bateu o veículo numa árvore, ao fazer uma curva. Ambos salvaram-se, ilesos. [DETRAN(2004)]

O atropelamento é o confronto entre o veículo automotor e o pedestre, com ou sem impacto, quando os dois estiverem no mesmo local, no mesmo instante. Mesmo que a velocidade de um deles seja zero no impacto, dependendo da velocidade que o outro estiver desenvolvendo poderá haver lesão para aquele de menor massa inercial. Pode-se considerar que causa do atropelamento seja a entrada de um deles na zona sensorial do outro. A zona sensorial do veículo é maior que a do pedestre, não apenas devido à sua maior massa inercial, como em função dos equipamentos sensores que porta.

Ao avistar um veículo automotor, o pedestre pode reagir de forma imprevisível. Há pedestres que param imediatamente, alguns recolhendo alguns passos atrás, aguardando, outros há que andam mais rápido ou correm para transpor a distância, antes da chegada do veículo na sua zona sensorial. Nesta última alternativa o pedestre só conseguirá evitar o confronto se for mais rápido que o veículo em sair da zona de confronto (palco da disputa de espaço). Nesta situação a característica do pedestre é fundamental: se idosos, crianças, homens ou mulheres, se em boa forma física ou não, etc. 
A seguir são apresentadas tabelas contendo as velocidades características dos segmentos, individualmente, tabelas (III-1), (III-2), (III-3), e velocidade de caminhar em grupo, na tabela (III-4)

Tabela (III-1).Velocidade dos pedestres caminhando

\begin{tabular}{|l|c||}
\hline \multicolumn{1}{|c|}{ Idade } & $\begin{array}{c}\text { Velocidade } \\
(\mathrm{m} / \mathrm{s})\end{array}$ \\
\hline De 5 a 9 anos & 1,8 \\
\hline De 10 a 14 anos & 1,7 \\
\hline De 15 a 19 anos & 1,6 \\
\hline De 20 a 24 anos & 1,6 \\
\hline De 25 a 34 anos & 1,6 \\
\hline De 35 a 44 anos & 1,6 \\
\hline De 45 a 54 anos & 1,6 \\
\hline De 55 a 64 anos & 1,6 \\
\hline Mais de 65 anos & 1,4 \\
\hline
\end{tabular}

Fonte:PULIDO. "La reconstrucción de accidentes de transito enfocada a peatones”[PULIDO(2001)].

Tabela (III-2). Velocidade de crianças correndo

\begin{tabular}{||l|c|}
\hline \multicolumn{1}{|c|}{ Idade } & $\begin{array}{c}\text { Velocidade } \\
(\mathrm{m} / \mathrm{s})\end{array}$ \\
\hline 5 anos & 3,4 \\
\hline 6 anos & 3,7 \\
\hline 7 anos & 3,8 \\
\hline 8 anos & 4,1 \\
\hline 9 anos & 4,4 \\
\hline 10 anos & 4,4 \\
\hline 11 anos & 4,6 \\
\hline
\end{tabular}

Fonte:PULIDO. "La reconstrucción de accidentes de transito enfocada a peatones”.[PULIDO(2001)]

Tabela (III-3). Velocidade de adultos correndo

\begin{tabular}{||l|c||}
\hline \multicolumn{1}{|c|}{ Idade } & $\begin{array}{c}\text { Velocidade } \\
(\mathrm{m} / \mathrm{s})\end{array}$ \\
\hline 20 anos & 3,5 \\
\hline 30 anos & 3,3 \\
\hline 40 anos & 2,8 \\
\hline 50 anos & 2,8 \\
\hline 60 anos & 2,8 \\
\hline
\end{tabular}

Fonte: PULIDO.“La reconstrucción de accidentes de transito enfocada a peatones”.[PULIDO(2001)] 


\section{Tabela (III-4). Média do fluxo livre de velocidade de pedestres}

\begin{tabular}{||l|l|l||}
\hline Fluxo de homens & $94 \mathrm{~m} / \mathrm{min}$ & $1,6 \mathrm{~m} / \mathrm{seg}$ \\
\hline Fluxo de mulheres & $77 \mathrm{~m} / \mathrm{min}$ & $1,3 \mathrm{~m} / \mathrm{seg}$ \\
\hline Fluxo misto & $81 \mathrm{~m} / \mathrm{min}$ & $1,4 \mathrm{~m} / \mathrm{seg}$ \\
\hline
\end{tabular}

Fonte: Fruin.“Pedestrian, planning and design”. [FRUIN(1971)]

Observou-se que a redução por causa da idade não é muito significativa, estando em torno de $14 \%$; de $84 \mathrm{~m} / \mathrm{min}$ (1,4 m/seg), para a idade de 20 a 25 anos, reduz-se para 66 m/min (1,1 m/seg) para 81 a 87 anos, para o trânsito livre.

Porém, ao se observar uma concentração de pedestres em trânsito, constatou-se em Highway Capacity Manual [TRANSPORTATION(2000)] que a velocidade de andar do pedestre é maior dependendo da proporcionalidade de idosos pedestres (65 anos ou mais) na população de caminhantes, conforme já relatado no item relativo a pedestres idosos. Se variar de 0 a 20\% de pedestres idosos, a média da velocidade de caminhar é de $1,2 \mathrm{~m} / \mathrm{s}$ nas vias de pedestres. Se a população de idosos for mais de $20 \%$ do total de pedestres a média de velocidade decresce para 1,0m/s. Se a via sofrer acréscimo de $10 \%$ ou mais, a velocidade é reduzida em $0,1 \mathrm{~m} / \mathrm{s}$ para o caminhar. Nas calçadas, a velocidade do fluxo livre de pedestres é de aproximadamente 1,5m/s. Há vários outros condicionantes que podem reduzir a média de velocidade do pedestre, tais como a alta porcentagem de crianças pequenas que caminham devagar na corrente de pedestres.

No entanto, a densidade é o elemento que mais restringe a velocidade, que decresce em função da ocupação, conforme o gráfico (III-1). 


\section{Gráfico III-1. Relação entre a velocidade, fluxo e a densidade de pedestres}

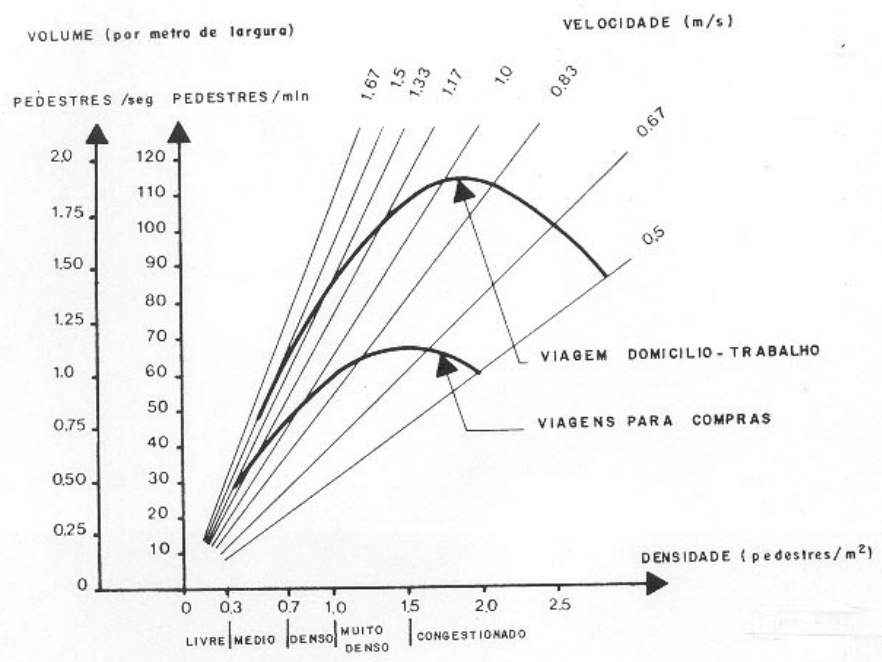

Fonte: CET. “Boletim Técnico 17. Área de Pedestres” [CET(1978)].

Deste gráfico podemos deduzir que:

a) para um dado volume de pedestres, à medida que aumenta a densidade, a velocidade de deslocamento diminui;

b) para uma dada velocidade, à medida que aumenta o volume, a densidade aumenta;

c) para um dado volume, mantendo-se a velocidade, a densidade de pedestres aumenta à medida que a largura da via diminui.

O veículo automotor, ao ser freado, requer a uma distância de parada, que é a distância efetiva em que o veículo vai parar e resulta da soma das distâncias de reação e de frenagem. Figura (III-1). Se o pedestre estiver dentro desta “distância de parada”, possivelmente será atropelado. A velocidade do pedestre, andando ou correndo, será relevante para sair ou não entrar nesta área. Em outras palavras, esta distância é a distância de segurança para os pedestres manterem-se longe do perigo. 


\section{Figura (III-1) Distância de Parada}

\section{TEMPO DE REAÇĀO + DISTÂNCIA DE FRENAGEM}

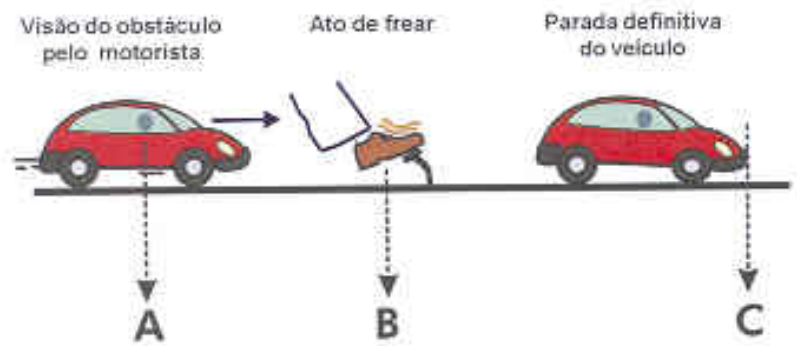

Fonte: Arquivo da autora [YABIKU(1999)].

A distância de parada é a distância percorrida pelo veículo no momento de reação do motorista ao avistar o obstáculo ou pessoa, mais a distância percorrida durante a freada (ou frenagem). A distância de parada depende de alguns fatores:

- da velocidade em que se encontra o veículo ao avistar o obstáculo (ou pessoa).

- do tempo de reação do condutor.

- tipos de pavimentos, rugosos ou lisos.

- das condições atmosféricas (tempo seco ou chuvoso).

- da inclinação da via, se plana, descida ou subida.

- do estado dos freios.

A tipologia do pavimento e as condições atmosféricas condicionam diretamente o grau de aderência dos pneus ao solo (contato entre pneus e pavimento da via). A aderência máxima encontra-se numa via plana e seca. Quando a pista está molhada a aderência é reduzida pela metade, portanto a distância de frenagem é dobrada. Em condições de muita chuva e pista lisa o veículo pode aquaplanar, isto é deslizar sem controle, pois a aderência é próxima de zero.

Para um motorista atento, com tempo de reação de um segundo, num local plano, com pneus em bom estado e freios bem regulados, foram observadas as seguintes distâncias 
de paradas apresentadas nas tabelas (III-5) pavimento em asfalto rugoso e seco, (III-6) asfalto rugoso e molhado, (III-7) asfalto liso e seco e (III-8) asfalto liso molhado.

Observação: a unidade de velocidade dos veículos automotores será citada em $\mathrm{km} / \mathrm{h}$, como é reconhecida na prática. Os demais serão na unidade métrica kg, m, s.

\section{Tabela (III-5).Velocidade e distância de parada para veículos leve e pesado. Asfalto rugoso e seco}

\begin{tabular}{|c|c|c|c|c|c|c|}
\hline \multirow{2}{*}{$\begin{array}{c}\text { Velocidade } \\
(\mathrm{km} / \mathrm{h})\end{array}$} & \multicolumn{3}{|c|}{ Veículo leve } & \multicolumn{3}{c|}{$\begin{array}{c}\text { Veículo pesado } \\
\text { (caminhão, ônibus, etc) }\end{array}$} \\
\cline { 2 - 7 } & \multicolumn{2}{|c|}{ Distância de Parada $(\mathrm{m})$} & \multicolumn{3}{c|}{ Distância de Parada (m) } \\
\cline { 2 - 7 } & Reação & Frenagem & Total & Reação & Frenagem & Total \\
\hline 40 & 11 & 8 & 19 & 11 & 11 & 22 \\
\hline 60 & 17 & 17 & 34 & 17 & 24 & 41 \\
\hline 80 & 22 & 30 & 52 & 22 & 41 & 63 \\
\hline 100 & 28 & 48 & 76 & 28 & 62 & 90 \\
\hline
\end{tabular}

Fonte: Atico Dotta. “O Condutor Defensivo”. [DOTTA(2000)]

Tabela (III-6).Velocidade e distância de parada para veículos leve e pesado. Asfalto rugoso e molhado

\begin{tabular}{|c|c|c|c|c|c|c|}
\hline \multirow{2}{*}{$\begin{array}{c}\text { Velocidade } \\
(\mathrm{km} / \mathrm{h})\end{array}$} & \multicolumn{3}{|c|}{ Veículo leve } & \multicolumn{3}{c|}{$\begin{array}{c}\text { Veículo pesado } \\
\text { (caminhão, ônibus, etc) }\end{array}$} \\
\cline { 2 - 7 } & \multicolumn{2}{|c|}{ Distância de Parada (m) } & \multicolumn{3}{c|}{ Distância de Parada (m) } \\
\cline { 2 - 7 } & Reação & Frenagem & Total & Reação & Frenagem & Total \\
\hline 40 & 11 & 12 & 23 & 11 & 16 & 27 \\
\hline 60 & 17 & 28 & 45 & 17 & 35 & 52 \\
\hline 80 & 22 & 49 & 71 & 22 & 61 & 83 \\
\hline 100 & 28 & 77 & 105 & 28 & 94 & 122 \\
\hline
\end{tabular}

Fonte: Atico Dotta. “O Condutor Defensivo”. [DOTTA(2000)]

Tabela (III-7).Velocidade e distância de parada para veículos leve e pesado. Asfalto liso e seco

\begin{tabular}{|c|c|c|c|c|c|c|}
\hline \multirow{2}{*}{$\begin{array}{c}\text { Velocidade } \\
(\mathrm{km} / \mathrm{h})\end{array}$} & \multicolumn{3}{|c|}{ Veículo leve } & \multicolumn{3}{c|}{$\begin{array}{c}\text { Veículo pesado } \\
\text { (caminhão, ônibus, etc) }\end{array}$} \\
\cline { 2 - 7 } & \multicolumn{2}{|c|}{ Distância de Parada $(\mathrm{m})$} & \multicolumn{3}{c|}{ Distância de Parada (m) } \\
\cline { 2 - 7 } & Reação & Frenagem & Total & Reação & Frenagem & Total \\
\hline 40 & 11 & 10 & 21 & 11 & 14 & 25 \\
\hline 60 & 17 & 23 & 40 & 17 & 31 & 48 \\
\hline 80 & 22 & 41 & 63 & 22 & 55 & 77 \\
\hline 100 & 28 & 64 & 92 & 28 & 82 & 110 \\
\hline
\end{tabular}

Fonte: Atico Dotta. “O Condutor Defensivo”. [DOTTA(2000)] 


\section{Tabela (III-8).Velocidade e distância de parada para veículos leve e pesado. Asfalto liso e molhado}

\begin{tabular}{|c|c|c|c|c|c|c|}
\hline \multirow{2}{*}{$\begin{array}{c}\text { Velocidade } \\
(\mathrm{km} / \mathrm{h})\end{array}$} & \multicolumn{3}{|c|}{ Veículo leve } & \multicolumn{3}{c|}{$\begin{array}{c}\text { Veículo pesado } \\
\text { (caminhão, ônibus, etc) }\end{array}$} \\
\cline { 2 - 7 } & \multicolumn{3}{|c|}{ Distância de Parada $(\mathrm{m})$} & \multicolumn{2}{c|}{ Distância de Parada (m) } \\
\cline { 2 - 7 } & Reação & Frenagem & Total & Reação & Frenagem & Total \\
\hline 40 & 11 & 15 & 26 & 11 & 20 & 31 \\
\hline 60 & 17 & 34 & 51 & 17 & 42 & 59 \\
\hline 80 & 22 & 62 & 84 & 22 & 74 & 96 \\
\hline 100 & 28 & 96 & 124 & 28 & 114 & 142 \\
\hline
\end{tabular}

Fonte: Atico Dotta.“O Condutor Defensivo”. [DOTTA(2000)]

Estas tabelas não indicam a luminosidade do local, que seria um fator interveniente muito complexo para ser medido, mas que refletiria a condição de visibilidade tanto do pedestre pelo motorista como do veículo pelo pedestre. Mas estas tabelas foram elaboradas a partir de medições que iniciaram após o motorista visualizar o pedestre. Por meio destas tabelas verifica-se que numa situação menos favorável a acidentes (veículo leve a $40 \mathrm{~km} / \mathrm{h}$, numa pista de asfalto rugoso e seco) o veículo pararia após 19 m de visualização do pedestre. Na condição extrema para promoção de acidente (veículo leve a $100 \mathrm{~km} / \mathrm{h}$ ou veículo pesado a $100 \mathrm{~km} / \mathrm{h}$, num asfalto liso e molhado) o veículo leve precisaria de $124 \mathrm{~m}$ para parar (velocidade = zero), e o veículo pesado precisaria de $142 \mathrm{~m}$. A velocidade é o principal fator para atropelamento, pois a distância percorrida pelo veículo até parar é muito significativa. Antes de parar é possível ocorrer o confronto com o pedestre.

A visualização do veículo pelo pedestre também está sujeita a várias condicionantes, mas a principal é a iluminação da via. Ao final do dia ou à noite os faróis dos veículos ofuscam a visão, impedindo o pedestre de avaliar com segurança a distância em que se encontra o veículo. Lembrando que, conforme apresentado no capítulo I (Antropometria do idoso), desta tese, em relação à visão que possuía aos 20 anos, a pessoa, aos 60 anos terá sua visão reduzida a $74 \%$, e que aos 80 anos a terá reduzida a 47\%, necessitando 
corrigi-la com eficientes óculos. Nesse mesmo capítulo há relato de que os olhos focalizam mais lentamente com a idade, sendo que após os 75 anos as pessoas apresentam o dobro do tempo de reação dos olhos em relação ao jovem de 35 a 45 anos. Observou-se também que aos 40 anos requer-se 2 vezes mais luz que aos 20 anos. Com 60 anos requer-se 5 a 6 vezes mais luz que aos 20 anos. Estes argumentos estão fortemente relacionados às causas de atropelamento de idosos. Os idosos, devido a natural deficiência proveniente pelo envelhecimento, têm mais dificuldades para visualizar o veículo. A iluminação das vias é parte da solução para atender estes casos, além da redução de velocidade dos veículos em áreas de circulação de pedestres. O motorista precisa dispor de muito espaço para frear seu veículo a tempo de não atropelar. Não há dúvida que a melhor e mais rápida visualização de ambas as partes contribui para reduzir o possível confronto entre os atores do confronto.

\subsection{Probabilidade de Sobrevivência}

À simples visão do pedestre pelo motorista e sua conseqüente reação para redução de velocidade até parar o veículo, não garantem que não haverá atropelamento. No caso do confronto ocorrer com o veículo em velocidade alta, reduz-se a probabilidade de sobrevivência conforme apresentado no gráfico III-2- Velocidade x Sobrevivência.

Conforme registrado em “Curiosidades” no site do DETRAN - SP [DETRAN(2004)], o impacto de um veículo a $80 \mathrm{~km} / \mathrm{h}$ equivale ao de uma queda livre de $25 \mathrm{~m}$. A $60 \mathrm{~km} / \mathrm{h}$ o impacto equivalerá a uma queda de um prédio de 4 andares. Mesmo a $20 \mathrm{~km} / \mathrm{h}$ o impacto resulta numa força equivalente a 15 vezes o peso da pessoa atingida. Isto ilustra a terrível força de destruição que a velocidade provoca. Não por acaso os atropelamentos levam a conseqüências severas. 


\section{Gráfico III-2. Velocidade x Sobrevivência}
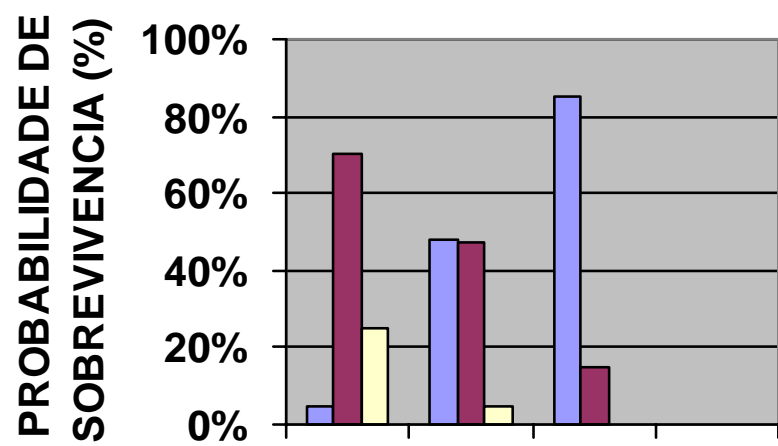

\section{$\square$ MORTO $\square$ FERIDO \\ $\square$ ILESO}

\section{$\begin{array}{lll}32 & 48 & 64\end{array}$}

$\mathrm{km} / \mathrm{h} \mathrm{km} / \mathrm{h} \mathrm{km} / \mathrm{h}$

\section{VELOCIDADE (km/h)}

Fonte: DAROS. “O risco de atropelamento” [DAROS(2004)]

Esta afirmação é constatada na estatística levantada pela CET-SP em "Morte em Acidentes de Trânsito no Município de São Paulo”, com o número de dias entre a data da ocorrência do acidente e a data da morte da vítima de atropelamento, em 2005. [CET(2005)]. (Tabela III-9).

Por esta estatística observa-se que 77\% das mortes se dão nos 5 primeiros dias após o atropelamento, sendo que cerca de $52 \%$ morrem no mesmo dia do acidente e $12 \%$ no dia seguinte. Tal é a gravidade de um atropelamento.

Quanto à probabilidade de lesões sofridas pelo pedestre atropelado em função da velocidade dos veículos automotores no ato do atropelamento é apresentado na tabela (III-10). 
Tabela III-9. Número de Dias entre a Data da Ocorrência do Acidente e a Data da Morte, em 2005, no Município de São Paulo

\begin{tabular}{|c|c|c|}
\hline Número de Dias & Pedestres Mortos & Participação Porcentual \\
\hline 0 & 388 & $51,94 \%$ \\
\hline 1 & 92 & $12,31 \%$ \\
\hline 2 & 33 & $4,41 \%$ \\
\hline 3 & 25 & $3,33 \%$ \\
\hline 4 & 20 & $2,67 \%$ \\
\hline 5 & 17 & $2,26 \%$ \\
\hline 6 & 11 & $1,46 \%$ \\
\hline 7 & 9 & $1,19 \%$ \\
\hline 8 & 5 & $0,65 \%$ \\
\hline 9 & 9 & $1,19 \%$ \\
\hline 10 & 12 & $1,60 \%$ \\
\hline 11 & 10 & $1,32 \%$ \\
\hline 12 & 2 & $0,28 \%$ \\
\hline 13 & 4 & $0,55 \%$ \\
\hline 14 & 3 & $0,42 \%$ \\
\hline 15 & 4 & $0,55 \%$ \\
\hline 16 & 0 & 0 \\
\hline 17 & 1 & $0,15 \%$ \\
\hline 18 & 2 & $0,28 \%$ \\
\hline 19 & 2 & $0,28 \%$ \\
\hline 20 & 2 & $0,28 \%$ \\
\hline 21 & 3 & $0,42 \%$ \\
\hline 22 & 1 & $0,15 \%$ \\
\hline 23 & 2 & $0,28 \%$ \\
\hline 24 & 1 & $0,15 \%$ \\
\hline 25 & 5 & $0,65 \%$ \\
\hline 26 & 1 & $0,15 \%$ \\
\hline 27 & 3 & $0,42 \%$ \\
\hline 28 & 1 & $0,15 \%$ \\
\hline 29 & 1 & $0,15 \%$ \\
\hline 30 & 3 & $0,43 \%$ \\
\hline Mais de 30 & 43 & $5,76 \%$ \\
\hline Sem Informação & 32 & $4,28 \%$ \\
\hline Total & 747 & $100 \%$ \\
\hline
\end{tabular}

Fonte: CET. “Morte em Acidente de Trânsito no Município de São Paulo”. [CET(2005)]

Tabela (III-10) Lesões mais comuns em acidentes com pedestres.

\begin{tabular}{|c|l|}
\hline Velocidade (km/h) & \multicolumn{1}{c|}{ Lesões em Pedestres } \\
\hline 40 & Lesões nos membros inferiores \\
\hline Entre 40 e 60 & Lesões no tórax e cabeça \\
\hline Mais de 60 & Morte com lesões severas \\
\hline
\end{tabular}

Fonte: PULIDO.“La reconstrucción de accidentes de transito enfocada a peatones"[PULIDO(2001)] 


\subsection{Atropelamento de Pedestres Idosos}

Quando o pedestre atropelado é uma pessoa idosa, as preocupações com seu estado de saúde são mais significativa. Uma ampla pesquisa realizada em Oxfordshire publicada em The Journal of Trauma [MCCOY; JOHNSTONE;DUTHIE(1989)] relata que muito se fala na vulnerabilidade das pessoas idosas para traumas, mas a pesquisa revelou ser mais significativa a fragilidade na sua recuperação. As lesões que em grupos mais jovens podem ser consideradas sérias, mas não ameaçadoras de vida, nos idosos implicam aumento de tempo de internamento em hospitais e alto risco de mortalidade. O aumento do tempo de internamento é mais significante entre pedestres idosos, onde há uma incidência de fraturas múltiplas nos membros inferiores. Os pedestres portadores de lesões severas têm seu tempo de internamento médio de 16 noites para aqueles acima de 65 anos e 5 noites para os abaixo de 65 anos. A fragilidade do idoso pode ser observada até nos traumas menores, por todo esse procedimento como conseqüência do acidente.

Isso reflete não a gravidade da lesão, mas a fragilidade na recuperação da lesão, o que representa dores e padecimento, para o pedestre idoso, e dispêndio de dinheiro para o poder público.

Em "Morte de idosos por atropelamento: uma proposta de educação para segurança da terceira idade no trânsito” [CET(1994)], a equipe de pesquisadores da CETSP relata que os pedestres de 60 a 90 anos de idade estão em primeiro lugar como vítimas de atropelamento, seguido ou não de morte. As lesões causadas têm os seguintes percentuais de distribuição (tabela III-11): 
Tabela III-11. Lesões causadas aos idosos no atropelamento

\begin{tabular}{l|c}
\hline \multicolumn{1}{c|}{ Tipo de Lesão } & $\begin{array}{c}\text { Incidência em } \\
\text { Porcentagem }\end{array}$ \\
\hline -Segmento cefálico & $78 \%$ \\
-Extremidades inferiores (principalmente pernas) & $51 \%$ \\
- Extremidades superiores (principalmente braços) & $28 \%$ \\
- Tórax & $23 \%$ \\
- Cintura pélvica & $18 \%$ \\
- Abdômen & $16 \%$ \\
- Coluna vertebral & $07 \%$ \\
\hline TOTAL & $221 \%$ \\
\hline
\end{tabular}

Fonte: CET."Morte de idosos por atropelamento: uma proposta de educação para segurança da terceira idade no trânsito" [CET(1994 )].

Esse percentual superior a $100 \%$ demonstra e enfatiza a alta incidência de lesões múltiplas, atribuíveis não apenas às condições físicas do idoso.

\subsection{Atropelamento de Pedestres Crianças}

As circunstâncias do atropelamento das crianças são diferentes das ocorridas com adultos. Conforme tese apresentada pela dra. Renata D. Waksman [WAKSMAN(1995)], em pesquisa de morte em crianças menores de quinze anos, os atropelamentos ocorrem nos dias de semana (de segunda a sexta feira) em $58 \%$ dos casos, e $42 \%$ aos sábados, domingos e feriados. A situação é diferente quando morrem envolvidos em acidentes de veículos, quando estão dentro de veículos (43\% de segunda a sexta-feira e $57 \%$ aos sábados, domingos e feriados). Neste segundo caso a criança foi um participante passivo, uma conseqüência de ações dos adultos. No primeiro caso a participação da criança é fundamental. Conforme a mesma pesquisa as circunstâncias em que ocorreram os atropelamentos seguem segundo a tabela (III-12). 
Tabela III-12. Circunstâncias de atropelamento de menores de 15 anos.

\begin{tabular}{l|c}
\hline \multicolumn{1}{c|}{ CIRCUNSTÂNCIAS } & INCIDÊNCIA (\%) \\
\hline Menor atravessou a rua sem olhar & 33 \\
Menor correu para a rua & 29 \\
Veículo a motor desgovernou e subiu na calçada & 17 \\
Menor soltou da mão do responsável e correu para a rua & 5 \\
Atropelamento do responsável e do menor & 3 \\
Ignorado & 13 \\
\hline Total & 100 \\
\hline
\end{tabular}

Fonte: Renata D. Waksman. "Características epidemiológicas dos acidentes fatais de transportes em menores de quinze anos”. [WAKSMAN(1995)].

Quanto a situação da criança no momento da ocorrência de atropelamento, Waksman observou a seguinte relação, tabela (III-13):

Tabela III-13. Situação dos menores, vítimas de atropelamento.

\begin{tabular}{l|c}
\hline \multicolumn{1}{c|}{ SITUAÇÃO DA VÍTIMA } & INCIDÊNCIA (\%) \\
\hline Sozinha & 46 \\
Acompanhada por outro menor & 22 \\
Acompanhada por outro maior & 19 \\
Ignorado & 13 \\
\hline Total & 100 \\
\hline
\end{tabular}

Fonte: Renata D. Waksman. "Características epidemiológicas dos acidentes fatais de transportes em menores de quinze anos”. [WAKSMAN(1995)].

Em quase 20\% dos casos, o menor estava acompanhado pela mãe, pai ou outra pessoa maior de idade, o que salienta o fato de que estas pessoas podem ser consideradas imprudentes e até negligentes. No capítulo I desta tese, foi apresentado em "A fisiologia da criança” que a criança difere fisiologicamente do adulto porque está em formação. Apesar de ter todos os órgãos completos, estes não estão em plena capacitação. As partes sensorial e psíquica são as mais sensíveis e potencialmente vulneráveis das crianças, expondo-as a situações de perigo, mesmo não sendo percebido por elas. A visão, especialmente, está em estado de maturação. Seu campo de visão é estreito, assim sendo ela vê unicamente à sua frente. A criança não vê com clareza os contrastes, assim ela leva cerca de 4 segundos para distinguir se um automóvel está rodando ou parando. 
Também não desenvolveu ainda a capacidade de avaliação de profundidade, do perto e do longe; assim a criança confunde "tamanho" e "distância”: um automóvel lhe parece mais distante que um caminhão.

Sobretudo, o seu pequeno porte a dificulta “ver” por cima dos automóveis estacionados, além de também não poder “ser vista” pelos motoristas.

As crianças acompanhadas de outras menores invariavelmente brincam, possivelmente correndo, saltando, chutando coisas pelo chão, como que jogando futebol, lançando coisas pelo ar, como que jogando volei ou basquete. Assim, é importante que, além dos adultos próximos a elas (policiais, vendedores de barraquinhas, jornaleiros, etc) as alertem sobre os perigos na rua, a municipalidade deve monitorar o sistema viário próximo às escolas, principalmente reduzindo a velocidade dos veículos.

Waksman também analisou os dados de necropsia dos menores vítimas de acidentes, tendo relatado o resultado na tabela III-14.

Tabela III-14. Principais tipos de lesões encontrados nas necropsias de menores.

\begin{tabular}{l|c}
\hline \multicolumn{1}{c|}{ TIPOS DE LESÕES } & INCIDÊNCIA (\%) \\
\hline Segmento cefálico & 45 \\
Abdômen & 20 \\
Membros & 19 \\
Tórax & 16 \\
\hline Total & 100 \\
\hline
\end{tabular}

Fonte: Renata D. Waksman. "Características epidemiológicas dos acidentes fatais de transportes em menores de quinze anos”. [WAKSMAN(1995)].

Lesões de cabeça e pescoço lideram a lista de causas básicas que levam a óbito nos acidentes com pedestres crianças. A preponderância destes tipos de lesões é explicada pela altura das crianças em relação aos veículos. Ainda segundo Waksman, mesmo nos atropelamentos com os veículos automotores desenvolvendo baixa velocidade, podem ocorrer lesões graves, como compressão de vísceras sólidas, contusões pulmonares, lesões de cérebro e fígado e contusões renais. [WAKSMAN(1995)]. 
A fatalidade do atropelamento é avaliada pelo intervalo de tempo entre o Acidente e o

Óbito. Assim Waksman tabelou os registros de óbitos das crianças atropeladas.Tabela III-15.

Tabela III-15. Intervalo de Tempo entre o Acidente e o Óbito

\begin{tabular}{l|c}
\hline \multicolumn{1}{c|}{ INTERVALO DE TEMPO } & INCIDÊNCIA (\%) \\
\hline Morte no local & 17 \\
Morte a caminho do hospital & 9 \\
Internação menor que 24 horas & 38 \\
Internação entre 24 a 48 horas & 11 \\
Internação superior a 48 horas & 14 \\
Sem informação & 11 \\
\hline Total & 100 \\
\hline
\end{tabular}

Fonte: Renata D. Waksman. "Características epidemiológicas dos acidentes fatais de transportes em menores de quinze anos”. [WAKSMAN(1995)].

Conforme esta tabela $27 \%$ das crianças entrou em óbito precocemente, sem beneficiarse do socorro médico, o que demonstra a extrema gravidade do acidente. Outra leitura desta tabela apresenta um atendimento pré-hospitalar muito bom, já que só perderam 9\% dos pacientes. Porém, a gravidade das lesões levou quase $40 \%$ das crianças ao óbito em menos de um dia, o que representa impacto estressante e sofrimentos, tanto para os pequenos pacientes como para a família, que nada puderam fazer em tão curto espaço de tempo.

As crianças sobreviventes de atropelamentos sofrem seqüelas, por vezes graves, que as incapacitam para o resto de suas vidas, ou comprometem seus projetos de vida, conforme relato em “Avaliação das Seqüelas e suas Repercussões Sociais em Adolescentes Vítimas de Acidentes de Trânsito” [FRANÇOSO(2004)].

1.5 Morte por Atropelamento na Cidade de São Paulo

A Cidade de São Paulo é uma das mais importantes do País por suas atividades econômicas. Com seus 10,7 milhões de habitantes São Paulo é o núcleo de uma região 
metropolitana com população de 17,8 milhões e que gera em torno de $18,5 \%$ do PIB brasileiro. Seu crescimento explosivo colocou-a como a quarta cidade no ranking mundial, atrás apenas de Tóquio, Bombain e Cidade do México. Como cidade mundial está ao lado de Seul, São Francisco, Toronto, Sidney, Bruxelas, Moscou, Madri e Cidade do México, abaixo apenas de um grupo seleto liderado por Nova York. [ALMEIDA(2006)]. Com uma infraestrutura bem servida (transportes, luz, comunicações, saneamento) os negócios, serviços e indústrias prosperaram no passado e permanecem em crescimento, gerando empregos. Os deslocamentos diários dentro da cidade atestam esta efervescência. Conforme dados do Censo da Companhia do Metropolitano [METRO(1999)] em 1997, na região Metropolitana de São Paulo, 34,4\% das viagens foram realizados a pé e $65,6 \%$ motorizados, sendo que destes $50,8 \%$ em coletivos e 49,2\% em veículos individuais.Tabela (III-16).

Tabela III-16 Evolução da Divisão Modal, na Região Metropolitana de São Paulo.

\begin{tabular}{|c|c|c|c|c|c|c|}
\hline \multirow[b]{2}{*}{ MODO } & \multicolumn{2}{|c|}{1977} & \multicolumn{2}{|c|}{1987} & \multicolumn{2}{|c|}{1997} \\
\hline & $\begin{array}{l}\text { Viagens } \\
\text { (x1000) }\end{array}$ & $\%$ & $\begin{array}{l}\text { Viagens } \\
\text { (x1000) }\end{array}$ & $\%$ & $\begin{array}{l}\text { Viagens } \\
\text { (x1000) }\end{array}$ & $\%$ \\
\hline Coletivo & 9.759 & 61,00 & 10.343 & 54,97 & 10.473 & 50,79 \\
\hline Individual & 6.240 & 39,00 & 8.473 & 45,03 & 10.147 & 49,21 \\
\hline Motorizado & 15.999 & 74,77 & 18.816 & 63,98 & 20.620 & 65,60 \\
\hline À pé & 5.400 & 25,23 & 10.591 & 36,02 & 10.812 & 34,40 \\
\hline TOTAL & 21.399 & 100,00 & 29.407 & 100,00 & 31.432 & 100,00 \\
\hline
\end{tabular}

Fonte: METRÔ. “Síntese das Informações Domiciliar e Linha de Contorno”. [METRO(1999)]

A leitura desta tabela demonstra uma tendência para $1 / 3$ das viagens a pé e 2/3 motorizados, o que remete à preocupação com os acidentes de atropelamentos. Uma poderosa massa de pedestres movimentando-se conjuntamente com mais que o dobro de 
sua massa em veículos automotores mais velozes. É de se esperar que, em algum momento, um confronto acontecerá. Esta constatação pode ser observada no gráfico III3. Distribuição das Mortes por Tipo de Usuário da Via, em 2005, apresentado pela CET-SP, no relatório “Morte em Acidentes de Trânsito no Município de São Paulo”. [CET(2005)].

\section{Gráfico III-3. Distribuição das Mortes por Tipo de Usuário da Via, em 2005 no Município de São Paulo}

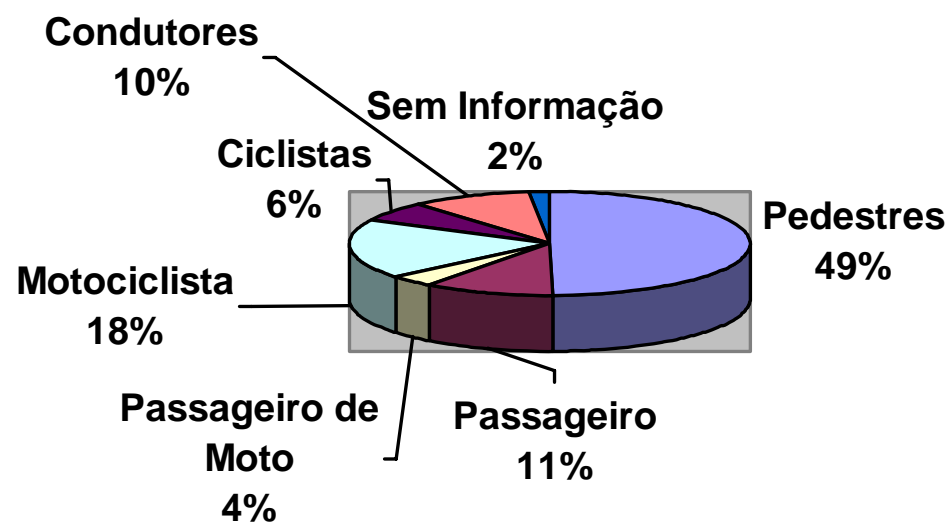

\begin{tabular}{|l|}
\hline$\square$ Pedestres \\
$\square$ Passageiros \\
$\square$ Passageiros de Moto \\
$\square$ Motociclistas \\
$\square$ Ciclistas \\
$\square$ Condutores \\
$\square$ Sem Informação \\
\hline
\end{tabular}

Fonte: CET. “Morte em Acidente de Trânsito no Município de São Paulo”. [CET(2005)]

A sazonalidade das mortes por atropelamento durante o ano de 2005 é apresentado na tabela III-17.Distribuição Mensal das Mortes por Atropelamento, em 2005. [CET(2005)], onde observa-se que há uma certa uniformidade na distribuição dos atropelamentos ao longo dos meses do ano, em torno de 62 eventos. As maiores freqüências estão nos meses de junho (78 mortes) e dezembro (73 mortes); e o menor mês é janeiro, com 44 mortes. Junho é início do inverno, e os dias são mais frios e escurecem mais cedo o que podem provocar desatenção por parte dos motoristas, e os pedestres também perdem a visibilidade dos veículos. Dezembro devido às festas natalinas e comemorações de fim de ano há mais exposição de pedestres, por motivo de 
compras; e muitos motoristas (e pedestres) alcoolizados circulando no fim do dia. Janeiro, por ser mês de férias de verão por parte dos escolares, coincide também com as férias por parte de muitos trabalhadores, daí diminuir a exposição da massa de pedestres no trânsito.

Tabela III-17. Distribuição Mensal das Mortes por Atropelamento, em 2005 Município de São Paulo

\begin{tabular}{|l|c|}
\hline Mês do Ano & Pedestre Morto \\
\hline Janeiro & 44 \\
\hline Fevereiro & 60 \\
\hline Março & 63 \\
\hline Abril & 57 \\
\hline Maio & 69 \\
\hline Junho & 78 \\
\hline Julho & 66 \\
\hline Agosto & 63 \\
\hline Setembro & 58 \\
\hline Outubro & 57 \\
\hline Novembro & 60 \\
\hline Dezembro & 73 \\
\hline TOTAL & 748 \\
\hline
\end{tabular}

Fonte: CET. “Morte em Acidente de Trânsito no Município de São Paulo”. [CET(2005)]

O Hospital das Clínicas da Faculdade de Medicina da Universidade de São Paulo (HCFMUSP), referência em atendimento emergencial no Brasil, apresentou a relação de um mês (23/07 a 23/08 de 2001), no atendimento do Pronto Socorro do Instituto de Ortopedia e Traumatismo (PSIOT), tabela III-18 Distribuição das vítimas de acidentes de trânsito atendidas, conforme relata a Dra. Júlia Maria D’ Andréa Greve. [GREVE(2006)]. 


\section{Tabela III-18 Distribuição das vítimas de acidentes de trânsito atendidas em 23/07 a 23/08/2001 no PSIOT da HCFMUSP}

\begin{tabular}{|c|c|c|}
\hline Tipo de Acidente & $\begin{array}{c}\text { Número de } \\
\text { Atendimentos }\end{array}$ & $\begin{array}{c}\text { Participação } \\
(\%)\end{array}$ \\
\hline Colisão & 183 & $33,4 \%$ \\
\hline Queda & 122 & $22,3 \%$ \\
\hline Atropelamento & 116 & $21,2 \%$ \\
\hline Queda em veículo em movimento & 70 & $12,8 \%$ \\
\hline Queda em veículo parado & 24 & $4,4 \%$ \\
\hline Queda dentro de veículo & 11 & $2,0 \%$ \\
\hline Capotamento & 4 & $0,7 \%$ \\
\hline Não declarado & 18 & $3,2 \%$ \\
\hline Total & 548 & $100 \%$ \\
\hline
\end{tabular}

Fonte: Júlia M. D.Greve. “Acidentes nas Calçadas”. [GREVE(2006)]

Observa-se que as colisões entre veículos predominam na ocorrência de vítimas, porém os acidentes que envolvem pedestres são mais diversificados e, no conjunto, representam maior número (queda, atropelamento, queda de veículo em movimento, queda em veículo parado, queda dentro de veículo), totalizando 62,6\% dos atendimentos. As quedas em veículos estão relacionadas com transportes coletivos e motocicletas. Se forem considerados como “acidentes com pedestre” somente aquele que não envolvem veículo o resultado não será menos dramático, pois somados, queda e atropelamento totalizam $43,5 \%$ dos atendimentos.

Em relação ao gênero, a tabela III-19 Distribuição de vítimas de acidentes de trânsito atendidas por gênero, apresenta informações importantes sobre o comportamento das pessoas. 


\section{Tabela III-19 Distribuição de vítimas de acidentes de trânsito atendidas, por gênero, em 23/07 a 23/08/2001. PSIOT da HCFMUSP.}

\begin{tabular}{|l|r|r|r|r|r|}
\hline \multirow{2}{*}{ Tipo de Acidente } & \multirow{2}{*}{$\begin{array}{c}\text { Atendimento } \\
\text { por } \\
\text { acidente }\end{array}$} & \multicolumn{2}{|c|}{ Mulher } & \multicolumn{2}{c|}{ Homem } \\
\cline { 5 - 7 } & 116 & 41 & $35 \%$ & 75 & $65 \%$ \\
\hline Atropelamento & 183 & 38 & $20 \%$ & 145 & $80 \%$ \\
\hline Colisão & 70 & 7 & $10 \%$ & 63 & $90 \%$ \\
\hline Queda veículo em movimento & 122 & 75 & $61 \%$ & 47 & $39 \%$ \\
\hline Queda de pedestre & 11 & 5 & $45 \%$ & 6 & $55 \%$ \\
\hline Queda dentro de veículo & 24 & 12 & $50 \%$ & 12 & $50 \%$ \\
\hline Queda em veículo parado & 526 & 178 & $34 \%$ & 348 & $66 \%$ \\
\hline Total & & & Participação & Atendim. & Participação \\
\hline
\end{tabular}

Fonte: Júlia M. D.Greve. “Acidentes nas Calçadas”. [GREVE(2006)]

A distribuição por gênero mostra que as mulheres se acidentam mais apenas nas quedas sem envolvimento com veículos; nas quedas dentro dos veículos ou quando estes estão parados, as quedas envolvem indistintamente homens e mulheres, em iguais condições; mas em todos os demais tipos de acidentes os homens são mais comprometidos. Se as quedas dentro dos veículos ou em veículos parados referirem-se aos transportes coletivos têm-se, então, um grande desrespeito aos passageiros. Os condutores dos veículos devem certificar-se de que os passageiros estão devidamente acomodados para então prosseguir a viagem. Pela leitura da estatística não se trata de fragilidade física dos pedestres, mas de desequilíbrio destes, pois os veículos só estão realmente imóveis quando desligados; veículos parados com motor ligado apresentam movimentos de balanço na sua estrutura.

Em relação aos mortos por atropelamento os dados do Município de São Paulo, “Sumário de Dados” [PRO-AIM(2005)] (*) apresenta-nos dados, conforme tabelas (III20), (III-21), (III-22), (III-23), (III-24), (III-25) e (III-26).

(*) PRO-AIM, Programa de Aprimoramento das Informações de Mortalidade no Município de São Paulo. 
Tabela III-20. Morte por atropelamento, nas regiões administrativa de São Paulo, em retrospectiva anual.

\begin{tabular}{|l|c|c|c|c|}
\hline $\begin{array}{l}\text { Região Ano } \\
\text { Administrativa }\end{array}$ & Ano 2002 & Ano 2003 & Ano 2004 & $\begin{array}{c}\text { População } \\
\text { Total } \\
(2004)^{*}\end{array}$ \\
\hline Centro Oeste & $\mathbf{5 7}$ & $\mathbf{6 7}$ & $\mathbf{5 4}$ & 1.294 .720 \\
\hline Leste & $\mathbf{1 2 2}$ & $\mathbf{1 0 5}$ & $\mathbf{1 1 8}$ & 1.882 .362 \\
\hline Norte & $\mathbf{1 2 0}$ & $\mathbf{1 1 9}$ & $\mathbf{1 0 9}$ & 2.092 .360 \\
\hline Sudeste & $\mathbf{1 1 7}$ & $\mathbf{1 2 0}$ & $\mathbf{1 3 5}$ & 2.530 .920 \\
\hline Sul & $\mathbf{9 0}$ & $\mathbf{8 3}$ & $\mathbf{9 7}$ & 2.255 .452 \\
\hline Endereço Ignorado & $\mathbf{9 1}$ & $\mathbf{9 6}$ & $\mathbf{6 5}$ & ---- \\
\hline Total & $\mathbf{5 9 7}$ & $\mathbf{5 9 0}$ & $\mathbf{5 7 8}$ & 10.055 .814 \\
\hline
\end{tabular}

Fonte: Município de São Paulo. Sumário de Dados.[PRO-AIM(2005)]

* Sumário de Dados.Valores obtidos a partir do Censo Demográfico 2000, do IBGE.

Pode-se observar que o número de mortes por atropelamento diminuiu apenas 3\% em 3 anos. As regiões Leste e Sudeste são as detentoras de maiores números de mortes por atropelamento, sendo responsáveis por quase 50\% das mortes totais. Coincidentemente, é onde prevalece o maior número de habitantes, o que resume a massa exposta e a carência de uma política de comunicação e prevenção de acidentes.

Apesar de que no Censo de Mobilidade Urbana da Companhia do Metropolitano de São Paulo [METRO(1999)] ter detectado que 30\% da deslocamento ser feita à pé na região central, o índice de mortalidade é pequeno na região Centro Oeste, que inclui a região central. A região central tem a velocidade de veículos reduzida e bem fiscalizada, além de amplas áreas de passeios (calçadões). 
Tabela III-21. Morte por atropelamento, anual, por faixa etária.

\begin{tabular}{|l|c|c|c|}
\hline Faixa etária & Ano 2002 & Ano 2003 & Ano 2004 \\
\hline $1-4$ anos & 11 & 10 & 10 \\
\hline $5-9$ anos & 17 & 16 & 14 \\
\hline $10-14$ anos & 21 & 18 & 19 \\
\hline $15-19$ anos & 33 & 32 & 28 \\
\hline $20-29$ anos & 78 & 72 & 76 \\
\hline $30-39$ anos & 100 & 92 & 79 \\
\hline $40-49$ anos & 86 & 90 & 106 \\
\hline $50-59$ anos & 84 & 75 & 75 \\
\hline $60-69$ anos & 52 & 77 & 62 \\
\hline $70-79$ anos & 65 & 60 & 62 \\
\hline+80 anos & 31 & 26 & 35 \\
\hline Ignorado & 19 & 22 & 12 \\
\hline Total & 597 & 590 & 578 \\
\hline
\end{tabular}

Fonte: Município de São Paulo. Sumário de Dados. [PRO-AIM(2005)].

Pela leitura desta tabela deduz-se que há uma tendência ao longo dos três anos em manterem-se os índices de atropelamentos por faixa etária: entre adolescentes (1 a 19 anos) em torno de $12 \%$, idosos (60 a 80 anos ou mais) em torno de $30 \%$, e adultos em fase economicamente ativa (20 a 59 anos), em torno de $58 \%$. A previsibilidade de que adultos economicamente ativos estarem mais predispostos a atropelamentos é natural, pois representam a grande maioria da massa exposta no trânsito. A porcentagem de idosos mortos também é significativa, devido à fragilidade na recuperação das lesões acima citada. As crianças e adolescentes normalmente estão acompanhados de adultos, quando em seu deslocamento, mas $12 \%$ das mortes por atropelamento serem pessoas tão jovens, representa uma grande perda para o futuro, por motivo que poderia ser evitado. 
Tabela III-22.Morte por atropelamento, por faixa etária e por região administrativa, em 2004

\begin{tabular}{|l|c|r|r|r|r|}
\hline \multirow{2}{*}{ Faixa etária } & \multicolumn{5}{|c|}{ Região Administrativa } \\
\cline { 2 - 6 } & Centro-Oeste & Leste & Norte & Sudeste & Sul \\
\hline $1-4$ anos & --- & --- & 3 & 2 & 5 \\
\hline $5-9$ anos & --- & 5 & 6 & 2 & 1 \\
\hline $10-14$ anos & 2 & 7 & 3 & 4 & 2 \\
\hline $15-19$ anos & 5 & 7 & 4 & 5 & 7 \\
\hline $20-29$ anos & 5 & 19 & 16 & 20 & 9 \\
\hline $30-39$ anos & 7 & 15 & 12 & 15 & 19 \\
\hline $40-49$ anos & 10 & 22 & 14 & 22 & 18 \\
\hline $50-59$ anos & 8 & 13 & 16 & 18 & 11 \\
\hline $60-69$ anos & 6 & 12 & 10 & 18 & 11 \\
\hline $70-79$ anos & 8 & 12 & 12 & 23 & 7 \\
\hline+80 anos & 3 & 6 & 13 & 6 & 7 \\
\hline Total & 54 & 118 & 109 & 135 & 97 \\
\hline
\end{tabular}

Fonte: Município de São Paulo. Sumário de Dados. [PRO-AIM(2005)].

Tabela III-23. Morte por atropelamento, por faixa etária e por região administrativa, em 2003.

\begin{tabular}{|l|r|r|r|r|r|}
\hline \multirow{2}{*}{ Faixa etária } & \multicolumn{5}{|c|}{ Região Administrativa } \\
\cline { 2 - 6 } & Centro-Oeste & Leste & Norte & Sudeste & Sul \\
\hline $1-4$ anos & 2 & 1 & 4 & 1 & 2 \\
\hline $5-9$ anos & 1 & 6 & 4 & 2 & 3 \\
\hline $10-14$ anos & 1 & 6 & 4 & 2 & 5 \\
\hline $15-19$ anos & 6 & 5 & 10 & 5 & 4 \\
\hline $20-29$ anos & 10 & 10 & 16 & 11 & 13 \\
\hline $30-39$ anos & 9 & 17 & 21 & 16 & 13 \\
\hline $40-49$ anos & 8 & 18 & 13 & 18 & 13 \\
\hline $50-59$ anos & 3 & 16 & 13 & 18 & 12 \\
\hline $60-69$ anos & 11 & 18 & 11 & 23 & 6 \\
\hline $70-79$ anos & 9 & 7 & 12 & 18 & 12 \\
\hline+80 anos & 7 & 1 & 11 & 6 & --- \\
\hline Total & 67 & 105 & 119 & 120 & 83 \\
\hline
\end{tabular}

Fonte: Município de São Paulo. Sumário de Dados. [PRO-AIM(2005)]. 


\section{Tabela III-24.Morte por atropelamento, por faixa etária e por região administrativa, em 2002.}

\begin{tabular}{|l|c|r|r|r|r|}
\hline \multirow{2}{*}{ Faixa etária } & \multicolumn{5}{|c|}{ Região Administrativa } \\
\cline { 2 - 6 } & Centro-Oeste & Leste & Norte & Sudeste & Sul \\
\hline $1-4$ anos & --- & 4 & 2 & 2 & 3 \\
\hline $5-9$ anos & --- & 5 & 4 & 2 & 4 \\
\hline $10-14$ anos & 1 & 8 & 3 & 4 & 6 \\
\hline $15-19$ anos & 1 & 14 & 5 & 6 & 4 \\
\hline $20-29$ anos & 12 & 16 & 12 & 18 & 14 \\
\hline $30-39$ anos & 7 & 25 & 18 & 16 & 14 \\
\hline $40-49$ anos & 9 & 19 & 17 & 10 & 12 \\
\hline $50-59$ anos & 9 & 16 & 24 & 8 & 13 \\
\hline $60-69$ anos & 3 & 6 & 11 & 16 & 10 \\
\hline $70-79$ anos & 9 & 8 & 16 & 25 & 5 \\
\hline+80 anos & 6 & 1 & 8 & 10 & 5 \\
\hline Total & 57 & 122 & 120 & 117 & 90 \\
\hline
\end{tabular}

Fonte: Município de São Paulo. Sumário de Dados. [PRO-AIM(2005)].

A interpretação destas tabelas apresenta uma interessante reversão de fatos. A região Sudeste que em 2002 representava a $3^{\text {a }}$ colocada no "ranking" das mortes por atropelamento, passou a $1^{\text {a }}$ colocada nos anos seguintes. A região norte sofreu uma deflação em 2004, passando à terceira colocação, após permanecer em $2^{\circ}$ lugar nos dois anos anteriores. A região leste, que predominava em 2002, passou a segunda colocação em 2004. As regiões sul e centro-oeste permanecem em penúltimo e último lugar, respectivamente.

A leitura destes fatos aponta que há carência na política pública de prevenção de atropelamentos, notadamente nas regiões sudeste, leste e norte.

Em relação à faixa etária as regiões mantêm a relação de $30 \%$ de idosos mortos por atropelamento, crianças até 19 anos em 10\% a 15\% (região sudeste). A manutenção deste padrão nas regiões dá-nos a pista de que o comportamento e hábitos da população de São Paulo são uniformes em todas as suas regiões, e que não há política para 
prevenção de atropelamentos eficientes, nem mesmo, regionalizando a gestão de trânsito de São Paulo.

As estatísticas de mortes por atropelamento, conforme a ocupação das vítimas, relatadas pela CET-SP, “Mortes em Acidentes de Trânsito no Município de São Paulo”, [CET(2005)] apresenta a grande maioria das vítimas como sendo os Aposentados (18,8\%), que pode ser interpretado como o rebaixamento do poder aquisitivo do trabalhador após a sua aposentadoria, o que demanda em acréscimo na massa de pedestres, com conseqüência a sua exposição ao atropelamento. Esta constatação foi observada na pesquisa desenvolvida por Yabiku “Os motoristas de terceira idade e as condições não amigáveis da direção veicular” [Yabiku(2000)], quando pessoas de terceira idade relataram que pararam de dirigir por medidas econômicas: ou doaram seu veículo aos filhos ou netos, que necessitavam do veículo e não tinham condições de adquiri-lo; ou tiveram que vendê-lo por não ter possibilidades de arcarem com as despesas de manutenção (combustíveis, seguros, revisões mecânicas).

Tabela III-25. Morte por atropelamento, por ano, por nível de escolaridade.

\begin{tabular}{|l|c|c|c|}
\hline Escolaridade & Ano 2002 & Ano 2003 & Ano 2004 \\
\hline Nenhum & 48 & 41 & 34 \\
\hline De 1 a 3 anos & 72 & 79 & 65 \\
\hline De 4 a 7 anos & 225 & 197 & 209 \\
\hline De 8 a 11 anos & 82 & 102 & 120 \\
\hline De 12 e mais & 25 & 24 & 36 \\
\hline Ignorado & 121 & 108 & 73 \\
\hline Não informado & 24 & 39 & 41 \\
\hline Total & $\mathbf{5 9 7}$ & $\mathbf{5 9 0}$ & $\mathbf{5 7 8}$ \\
\hline
\end{tabular}

Fonte: Município de São Paulo. Sumário de Dados [PRO-AIM(2005)]

Em termos de escolaridade, predominam os atropelados com apenas o primeiro grau (de 4 a 11 anos de escola). Isto reforça a importância do ensino transversal de educação no trânsito, para o primeiro grau. Esta é a fase de maior fixação cognitiva da criança. 
Os conhecimentos de "caminhar defensivo" (ou até direção defensiva) apreendidos na infância serão úteis na fase adulta do cidadão.

Tabela III-26. Morte por atropelamento, por ano, por sexo

\begin{tabular}{|l|c|c|c|}
\hline Sexo do atropelado & Ano 2002 & Ano 2003 & Ano 2004 \\
\hline Masculino & 446 & 440 & 416 \\
\hline Feminino & 151 & 150 & 162 \\
\hline Total & $\mathbf{5 9 7}$ & $\mathbf{5 9 0}$ & $\mathbf{5 7 8}$ \\
\hline
\end{tabular}

Fonte: Município de São Paulo. Sumário de Dados [PRO-AIM(2005)]

Tabela III-27. População Total do Município de São Paulo, de 2000 a 2004.

\begin{tabular}{|c|c|c|c|c|}
\hline Ano 2000 & Ano 2001 & Ano 2002 & Ano 2003 & Ano 2004 \\
\hline & & & & \\
10.434 .252 & 10.525 .697 & 10.617 .943 & 10.710 .997 & 10.804 .867 \\
\hline
\end{tabular}

Fonte: Secretaria Municipal de Planejamento. "Dados Sócio Econômicos”. Município de São Paulo. Disponível em www.prefeitura.sp.gov.br. Acessado em nov/2005.

Tabela III-28.População Total, por Grupo de Idade e Sexo no Município de São Paulo, em 2004.

\begin{tabular}{l|rrr}
\hline \multicolumn{1}{c|}{$\begin{array}{c}\text { GRUPO POR } \\
\text { IDADE }\end{array}$} & MASCULINO & FEMININO & TOTAL \\
\hline 0 a 9 anos & 910.468 & 877.494 & 1.787 .962 \\
10 a 17 anos & 674.391 & 664.372 & 1.338 .763 \\
18 a 24 anos & 646.266 & 674.073 & 1.320 .339 \\
25 a 50 anos & 2.427 .619 & 2.741 .949 & 5.169 .568 \\
60 anos e mais & 428.839 & 634.289 & 1.063 .128 \\
\hline Total & 5.087 .583 & 5.592 .177 & 10.679 .760 \\
\hline
\end{tabular}

Fonte: SEADE. "Demografia”. Fundação Sistema Estadual de Análise de Dados”. Disponível em www.seade.gov.br/produtos. Acessado em nov/2005.

Conforme apresentado nas tabelas III- 20, e III- 27 e III-28, constata-se divergência entre os números de população em 2004, apresentados pelo PRO-AIM, da Prefeitura de São Paulo [PRO-AIM(2005)], pela Secretaria de Planejamento da Prefeitura de São Paulo [PLANEJAMENTO(2005)], e os dados da SEADE, do Estado de São Paulo [SEADE(2005)]. Estes desencontros de dados referem-se às metodologias diferentes aplicadas nas pesquisas destas entidades. Para esta avaliação do cenário de mortes por 
atropelamentos a refinação desses dados não representa impacto, pois o cenário será determinado qualitativamente. Assim sendo, pode-se observar que, apesar da população feminina entre 0 a 59 anos estar próxima da população masculina, a proporção de homens mortos por atropelamento é aproximadamente três vezes à de mulheres. Uma constatação semelhante foi observada pela pesquisa do CET-SP em "Mortes em Acidentes de Trânsito no Município de São Paulo” [CET(2005)], sendo os pedestres mortos do sexo feminino de 15,2\% contra 42,4\% das vítimas de sexo masculino, conforme pode-se avaliar no Gráfico III-4. Sexo das Vítimas de Acidentes de Trânsito em 2005.

Gráfico III-4. Sexo das Vítimas de Acidentes de Trânsito em 2005. Município de São Paulo

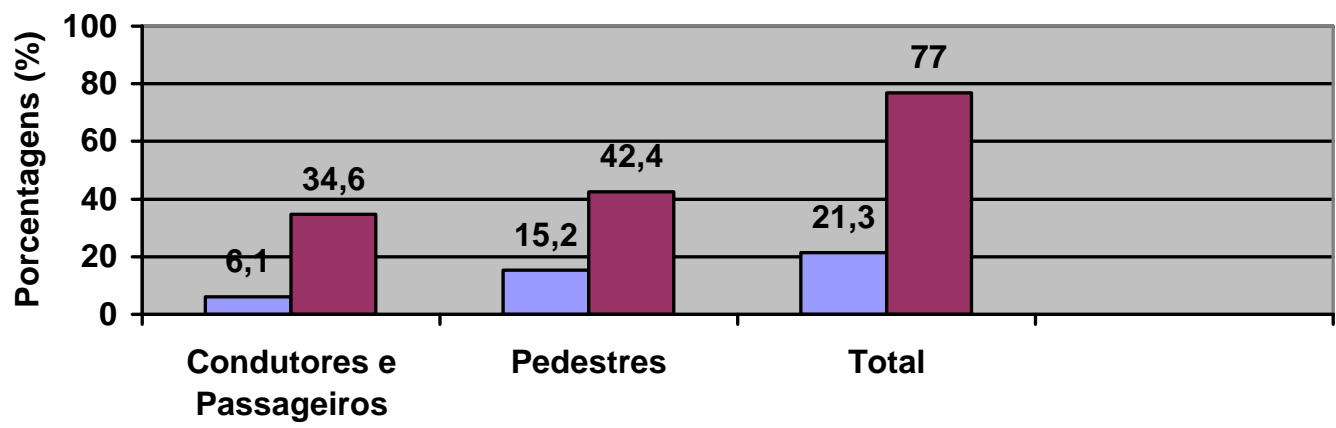

Sexo das Vítimas

Fonte: CET. “Mortes em Acidentes de Trânsito no Município de São Paulo”. [CET(2005)].

Observa-se que este padrão mantém-se ao longo de 2002 a 2005, porém Waksman, já havia observado este padrão em 1995, entre os menores de 15 anos. [WAKSMAN(1995)]. Há indícios de que as mulheres desenvolvem um comportamento defensivo desde a infância, em detrimento à ousadia dos meninos.

Na população adulta, além do comportamento defensivo, a interpretação deste fato remete ao comportamento e hábitos da população. As mulheres estão no mercado de trabalho e instituições de ensino em mesma ou maior quantidade que os homens, 
expondo-se assim à probabilidade de atropelamento em igualdade de condições (conforme dados do SEADE, 55,1\% é a participação feminina no mercado de trabalho registrado.[SEADE(2005)]. Porém é hábito as mulheres portarem bolsas e sacolas de compras, além do uso de sapatos de salto altos. Como visto no capítulo I estes são fatores restritivos para o desenvolvimento de velocidade de caminhar. Assim, as mulheres arriscam-se menos ao confronto com veículos automotores. Resguardam-se sabendo que "não vai dar tempo".

Já entre a população idosa, constata-se que a população feminina com mais de 60 anos é cerca de 1,5 vezes maior que a masculina. Será que as mortes por atropelamento de homens economicamente ativos contribuíram para estes dados na idade madura? Na publicação “Síntese dos Indicadores Sociais - 2002”, o IBGE [IBGE(2003)] assinala que "A alta incidência de mortes de jovens do sexo masculino contribui para a diferença de quase oito anos entre as expectativas de vida de homens e mulheres que, em 2000, era de 72,6 anos para as mulheres e de 64,8 anos para os homens.” A “Síntese” refere-se a mortes por causas externas ou mortes violentas em geral, incluindo-se aí os acidentes de trânsito.

Portanto há que rever a política de segurança voltada aos pedestres. 


\section{CUSTO DE ACIDENTE COM PEDESTRE}

\subsection{Custo de atropelamento}

Dentro do universo dos acidentes, o custo de um atropelamento é um segmento que, destacando-se dos acidentes envolvendo veículos automotores, ainda não foi devidamente calculado.

O IPEA - Instituto de Pesquisa Econômica Aplicada realizou uma ampla pesquisa, iniciada em 2001 e finalizada em 2003, sobre os custos de acidentes de trânsito "IMPACTOS SOCIAIS E ECONÔMICOS DOS ACIDENTES DE TRÂNSITO NAS AGLOMERAÇÕES URBANAS”.[IPEA(2003)]. Esta pesquisa foi realizada nas aglomerações urbanas de São Paulo, Belém, Recife e Porto Alegre.

Os custos dos acidentes analisados incluem tratamentos e reabilitações das vítimas, a recuperação ou reposição dos bens materiais danificados, os custos administrativos dos serviços públicos envolvidos e as perdas econômicas e previdenciárias ocorridos.

Custos considerados:

Perda de produção

Danos aos veículos

Médico-hospitalar

Processos judiciais

Congestionamento

Previdenciário

Resgate de vítimas

Remoção de veículos

Danos ao mobiliário urbano e à propriedade de terceiros

Meio de transportes 
Danos à sinalização

Atendimento policial e dos agentes de trânsito

Impacto familiar

Conforme esta pesquisa o custo total dos acidentes de trânsito, por ano, nas aglomerações urbanas brasileiras é $\mathrm{R} \$ 5,3$ bilhões (valores de abril/2003), incluindo as áreas urbanas, excluindo acidentes em rodovias, fora de aglomerações urbanas. Neste custo a parte referente aos custos médico-hospitalares corresponde a $\mathrm{R} \$ 1,7$ bilhões. $\mathrm{O}$ custo unitário de acidente está representado na tabela III-29.

Tabela III-29.Custo de um acidente, valores de abril 2003

\begin{tabular}{|c|c|c|}
\hline Tipo de acidente & Quantidade & \multicolumn{1}{c|}{ Custo (R\$) } \\
\hline Sem vítima & 1 & $3.262,00$ \\
\hline Com vítima & 1 & $17.460,00$ \\
\hline Com morte & 1 & $144.143,00$ \\
\hline
\end{tabular}

Fonte: IPEA “IMPACTOS SOCIAIS E ECONÔMICOS DOS ACIDENTES DE TRÂNSITO NAS AGLOMERAÇÕES URBANAS”.[IPEA(2003)].

Em resumo: 1 acidente com vítima custa 11 vezes mais que um acidente sem vítima; e com morte custa cerca de 44 vezes mais que um acidente sem vítima.

São dados que evidenciam o impacto econômico causado pelos acidentes de trânsito, que crescem significativamente à medida que aumenta a severidade dos acidentes de trânsito.

Por outro lado, o trabalho da CET-SP "Morte de Idosos por Atropelamento: uma proposta de educação para segurança de terceira idade no trânsito”, [CET(1994)], 9 anos anterior à pesquisa do IPEA, relata os dados do BID - Banco Interamericano de Desenvolvimento, segundo o qual o Brasil gasta US\$ 1,5 bilhão por ano em conseqüência dos acidentes de trânsito. Deste custo, 7\% são arcados pela Previdência Social, o que equivale a um gasto de cerca de US\$ 100 milhões com assistência médica, auxílios, pensões e aposentadorias. A perda de produção equivale a 60\% , cerca de US\$ 
900 milhões. Outros 33\% cerca de US\$ 500 milhões referem-se às despesas com substituição de veículos.

Desta mesma fonte do BID, temos os custos por acidente, na tabela III-30.

Tabela III-30.Custo de um acidente, valores de 1994.

\begin{tabular}{|c|c|c|}
\hline Tipo de acidente & Quantidade & Custo (US\$) \\
\hline Sem vítima & 1 & 1.400 \\
\hline Com vítima & 1 & 5.000 \\
\hline Atropelamento & 1 & 8.300 \\
\hline
\end{tabular}

Fonte: CET."Morte de idosos por atropelamento: uma proposta de educação para segurança da terceira idade no trânsito" [CET(1994 )].

Supondo-se a moeda norte-americana (US\$) como uma base monetária de valor fixo para cálculos, convertendo-se os valores encontrados pelo IPEA para o dolar de abril de 2003 (índice $=2,888$ ), tem-se um custo anual dos acidentes no Brasil com valor correspondente a US\$ 1,8 bilhão; para um acidente sem vítima o valor de US\$ 1,13 mil e um acidente com vítima US\$ 6,0 mil. Estes valores estão próximos da estimativa do BID. Considerando o período de 9 anos, o valor teve pouca variação. Para um acidente com morte, o custo do IPEA convertido em dólar será de US\$ 49,9 mil; mantida a proporção de que um acidente com morte custando 44 vezes um acidente sem vítima, o correspondente ao valor do BID será US\$ 61,6; um valor consideravelmente mais alto que o do IPEA.

Pode-se considerar confiável o custo de US\$ 8,3 mil para um atropelamento avaliado pelo BID. Porém é um valor significativamente superior ao valor de um acidente com vítima. A explicação está na possibilidade de que as lesões nos pedestres são mais graves que aquelas sofridas pelos ocupantes de veículos automotores, que estão protegidos pelo arcabouço do veículo. Às lesões graves seguem-se tempo e tratamento de recuperação mais prolongados, além de possíveis tratamentos fisioterápicos, quando não houver incapacitação da vítima para uma vida normal. Para as leis americanas a 
proteção é total e vitalícia, a penalidade é severa e grande parte da população tem seguro de vida, o que onera o custo do acidente. Talvez para as condições brasileiras haja uma redução neste valor. É necessária uma pesquisa aprofundada, nas mesmas condições da pesquisa do IPEA, para obter-se um valor confiável para o custo de um atropelamento.

\subsection{Custo de quedas em vias públicas}

Segundo pesquisas O/D (origem e destino) realizadas em algumas cidades brasileiras, pelo IPEA em "IMPACTOS SOCIAIS E ECONÔMICOS DOS ACIDENTES DE TRÂNSITO NAS AGLOMERAÇÕES URBANAS”.[IPEA(2003)], mais de 30\% de deslocamentos realizados em áreas urbanas são feitos a pé.

O IPEA pesquisou as quedas sofridas pelos pedestres nas calçadas e passeios públicos, sem envolvimento de veículos automotores. A pesquisa domiciliar, realizada em 354 aglomerações em São Paulo, totalizou 1426 moradores entrevistados e revelou a freqüência de quedas e seus custos, a saber:

9 quedas/1000 habitantes, ao custo de R\$ 2,5 mil/queda.

A incidência de queda de pedestres em vias públicas e seus custos mostram que os acidentes com pedestres sem envolvimento de veículos produzem perdas econômicas consideráveis.

Embora os valores encontrados estejam sujeitos a variações significativas, dado o pequeno número de casos identificados, a pesquisa mostra a importância da formulação específica de políticas voltadas para a segurança de pedestres, principais vítimas de atropelamentos e de danos por quedas, por meio da melhoria de calçadas, de sinalização, da implantação de passarelas e faixas de travessias. 


\section{MEDIDAS DE SEGURANÇA.}

\subsection{Comportamento dos pedestres.}

O Pedestre nunca deve arriscar-se a uma situação de confronto com veículos automotores, pois a probabilidade de atropelamento é grande e as conseqüências recairão sobre ele. A recomendação é conduzir-se segundo as “regras de sobrevivência”, citadas no capítulo I.

Para evitar atropelamento à noite recomenda-se que os pedestres utilizem vestimentas claras e visíveis (é uma das “regras de sobrevivência”). Ressalte-se, no entanto, que recente pesquisa de cores demonstra que nem todas as gamas de cores claras são suficientemente visíveis para evitar atropelamento, conforme Tabela III-31. Distância de Visibilidade, numa rodovia, no período noturno.

Tabela III-31. Distância de Visibilidade, numa rodovia, no período noturno.

\begin{tabular}{||c|c||}
\hline DISTÂNCIA (M) & CORES \\
\hline 20 & Azul \\
\hline 30 & Vermelho \\
\hline 40 & Amarelo \\
\hline 60 & Branco \\
\hline 80 & \\
\hline 150 & Refletivo \\
\hline 160 & \\
\hline
\end{tabular}

Fonte: DAROS.”O risco de atropelamento” [DAROS(2004)]

Sob este aspecto são recomendáveis: o uso de roupas com alguns detalhes em elementos refletivos, tais como tiras cruzadas no tórax, detalhes em bonés, tênis ou sapatos com detalhes refletivos (já existente para crianças), bicicletas com detalhes luminosos e refletivos, ou mesmo o porte de lanternas acesas para pedestres e ciclistas. 


\subsection{Intervenções urbanas.}

A solução mais eficiente para evitar o atropelamento é a redução de velocidade dos veículos automotores, principalmente nas áreas onde houver intensa circulação de pedestres. São os casos dos pólos geradores de tráfego de pedestres, tais como as instituições de ensino (escolas, universidades, etc), locais de lazer (“shoppings centers”, clubes esportivos, etc), terminais de ônibus, estações de metrôs, etc.

A redução de velocidades em determinadas áreas é possível com utilização de equipamentos ou fiscalização ostensiva. Também com intervenções urbanas é possível atingir essa meta, aplicando-se procedimentos como “traffic calming” ou “zona 30”, que se resumem em priorizar a circulação de pedestres sem impedir a circulação de veículos automotores.

A “zona 30", um procedimento implantado basicamente na Europa, contorna uma área de interesse e promove redução de velocidades com os mesmos instrumentais que o “traffic calming”, o “traffic calming” propriamente dito consiste em procedimentos de intervenções urbanas para redução de velocidade, podendo ser pontuais, localizados apenas em algumas vias que possibilitem essa intervenção.

\subsubsection{A “zona 30”}

Uma “Zona 30” é um conjunto de ruas na cidade onde a velocidade está limitada a 30 km/h, com características especiais. Segundo o Código de Trânsito Brasileiro [CTB(1997)] nas vias locais, se não houver sinalização regulamentadora, a velocidade máxima é de $30 \mathrm{~km} / \mathrm{h}$. Porém a proposta da “Zona 30” é demarcar claramente um bolsão onde a prioridade são: os pedestres, as crianças, as bicicletas. Nesse bolsão os 
automóveis são um componente da circulação, submisso à ordem de proteção e segurança dos componentes prioritários.

O sistema viário passa por intervenções urbanísticas, a fim de reduzir a velocidade dos veículos (automóveis, ônibus, caminhões leves, etc.), dar visibilidade ao conjunto de usuários e acentuar a presença livre de pedestres, sejam adultos ou crianças, com ou sem bicicletas. É possível instalar uma “Zona 30” dentro de um quarteirão começando no centro da cidade, dentro de zonas residenciais, em uma zona escolar, dentro de uma zona alongada englobando um itinerário de ciclovia. Países como a Holanda e Alemanha instauraram “Zonas 30” em diversas de suas cidades.

Uma “Zona 30 escolar” é, em geral, limitada para as vias de tráfego importante: no interior do contorno poligonal, que compreende a escola, todas as ruas são limitadas a 30 km/h., pois “as crianças estão em toda a parte” e não somente no portão de saída da escola.

\section{A circulação}

Uma “Zona 30” não é uma “área para pedestre”: os veículos podem acessá-la sem algum constrangimento em particular, pois afora a velocidade, não é imposta qualquer outra restrição. O estacionamento é possível, salvo se outras razões particulares exijam sua regulamentação. Uma velocidade baixa (30 km/h) não gera mais congestionamento que velocidades mais altas: entre 30 e $70 \mathrm{~km} / \mathrm{h}$ o escoamento de trânsito é o mesmo, pois quanto mais rápido, mais aumenta a distância entre automóveis. De outra parte, mesmo nas ruas de $50 \mathrm{~km} / \mathrm{h}$, há sempre razões para desacelerar: sinal vermelho, cruzamentos simples ou congestionamentos de trânsito; é comum que a velocidade seja mais próxima de 20 a 30 km/h, o que é comparável à velocidade em “Zona 30”. 


\section{A velocidade}

Como em qualquer outra rua, os pedestres podem atravessar e os motoristas têm que ceder a passagem (art. 38, parágrafo único do Código de Trânsito Brasileiro), mas na “Zona 30” é mais fácil para os pedestres atravessarem e mais fácil para os motoristas pararem: é preciso saber que a parada de um veículo necessita abordar um tempo de reação do condutor (cerca de um segundo) depois um tempo de frenagem do veículo, proporcional ao quadrado da velocidade (por exemplo, à velocidade de $60 \mathrm{~km} / \mathrm{h}$, a distância de frenagem não é duas vezes mais distante que a $30 \mathrm{~km} / \mathrm{h}$, mas quatro vezes maior!). Com efeito, se uma pessoa surgir repentinamente a cerca de $12 \mathrm{~m}$ de um veículo em movimento à velocidade de $30 \mathrm{~km} / \mathrm{h}$, será possível pará-lo totalmente e evitar o confronto. No entanto, se o veículo estiver a $50 \mathrm{~km} / \mathrm{h}$ haverá tempo justo de reagir, mas ainda não suficiente para começar a frear. A $50 \mathrm{~km} / \mathrm{h}$, portanto, o choque ocorrerá, sendo o resultado mais provável a morte do pedestre.

A organização do sistema viário na zona 30.

Não é suficiente colocar uma faixa “Zona 30” para ter uma “Zona 30”. Uma “Zona 30” tem o aspecto de uma rua pacífica onde o ambiente não convida a desenvolver velocidade. Algumas vezes ocorre o caso naturalmente em certas ruas, mas o mais freqüente, sobretudo nas entradas, é a necessidade de executar arranjos específicos, que não significam serem onerosas: avanços das calçadas de quando em quando, chicanas e plantação de árvores não despendem altos custos.

É desaconselhável marcar as passagens de pedestres dentro da zona 30, pois os pedestres devem poder atravessar não importa onde. Porém nas entradas e saídas, uma passagem zebrada, em relevo, marcará bem a transição. Pode-se conjugar, com vantagem, essa passagem com um estreitamento da calçada ou colocar uma ilha central, 
deixando-se duas meias-calçadas estreitas. É preferível não se estabelecer sentido único nas ruas de “Zonas 30”. Entretanto, é comum de quando em quando alternar o sentido de circulação, a fim de dissolver o trânsito nos quarteirões. Quanto aos cruzamentos, devem ser trabalhados como ocasiões de desacelerar; em conseqüência, não se colocam semáforos de três cores, nem se define prioridade a uma rua. A solução geral para os cruzamentos é, portanto, a prioridade à direita. Para bem marcar o cruzamento, é aconselhável executar avanços em “orelha” (“tapers”). Mas pode-se também nos cruzamentos na “Zona 30”, implantar uma rotatória ou minirotatória (tornando difícil para caminhões ultrapassarem) ou executar um cruzamento em platô (sobrelevado de 10 a 15 cm), na área de conflito.

Outras vantagens da “Zona 30”.

Uma velocidade mais baixa diminui o estresse dos residentes, torna o quarteirão mais pacífico e melhora a segurança. Os efeitos benéficos se fazem também sentir sobre os ruídos que diminuem bastante: uma velocidade regular, baixa, sem aceleração brusca, abaixa o nível de ruído dos automóveis (motor, pneus, etc). Se passarem menos automóveis, a poluição será consideravelmente diminuída. A implantação de uma zona 30 é freqüentemente uma oportunidade de embelezar a rua, plantando árvores, por exemplo.

Isso sem contar com a inevitável interação amistosa que surge entre os moradores e transeuntes, o que favorece a vizinhança. 


\subsection{2 “Traffic Calming”}

O conceito de áreas ambientais, da década de 60, gerou a implantação de manejos e intervenções urbanas, que passaram a ser chamadas de "traffic calming". A idéia foi limitar o grau de liberdade do condutor em relação à velocidade e induzir procedimentos de condução do veículo, permitindo o compartilhamento mais equilibrado dos espaços urbanos. Isto remete ao conceito de qualidade de vida nos centros urbanos, que não está ligado apenas às moradias e serviços, mas também às características de sua vizinhança, principalmente nas vias próximas. Assim, determinouse que a velocidade dos veículos deveria ser próxima da velocidade do passo humano e os procedimentos na condução do veículo não deveriam transmitir sensação de insegurança para os pedestres, em espaços residenciais e comerciais. Dentro do sistema viário pretende-se integrar diversos meios de transporte, coletivos e individuais, de forma a garantir a eficiência global, sem que se dificulte o fluxo de pedestres ou ocorra a segregação de espaços devido a barreiras virtuais causadas pelo tráfego de veículo, caracterizado pela alta velocidade e altos volumes de trânsito.

Em sentido mais amplo pode-se abordar o conceito de "traffic calming" sob três objetivos básicos:

1. Redução de acidentes na interface veículos / pedestres.

2. Redução dos níveis de poluição ambiental.

3. Resgate de áreas para o uso de pedestres.

Para atingir estes objetivos são aplicáveis dois tipos de medidas, não excludentes:

1. Medidas que objetivam a redução de velocidade dos veículos por ação direta ou por indução. 
2. Medidas que criam um ambiente diferenciado, induzindo o motorista a uma forma mais prudente de condução.

Estas medidas podem ser tanto de ordem física (lombadas, estreitamento de pista, etc) como regulamentadoras (placas, faixas, etc).

As medidas regulamentadoras estão previstas no Código de Trânsito Brasileiro [CTB(1997)], e a sua aplicação é de competência do órgão integrante do Sistema Nacional de Trânsito com circunscrição sobre a via.

Algumas medidas físicas são apresentadas a seguir:

\section{Plataforma ou prolongamentos das calçadas.}

As travessias podem ser sobrelevadas à altura das calçadas, como que avançando a calçada no leito viário, reduzindo a velocidade dos veículos, pois a sobrelevação será um obstáculo a transpor, o que privilegia a segurança do pedestre. Em São Paulo o seu uso é muito limitado, pois foram implantados somente em alguns locais próximos a hospitais, “shopping”, etc. Deve ser sinalizado para alertar os motoristas, e também aos pedestres, pois a sinalização semafórica continua valendo, como se fosse uma travessia ou cruzamento normal. Somente há redução forçada de velocidade na passagem dos veículos, quando autorizados pelo respectivo sinal verde, a prosseguir em marcha. Permite que pedestres e cadeiras de rodas atravessem a via sem qualquer mudança de nível. Figura III-2.Plataforma ou prolongamento das calçadas.

Fatores positivos:

- dispositivo mais eficaz na redução da velocidade.

- o perfil plano cria condições mais seguras para a travessia de pedestres.

Fatores negativos: 
- exige cuidado no projeto para deficientes visuais.

- requer construção parcial da via.

- não discrimina as classes de veículos e podem tornar-se impopulares junto a operadores de transportes públicos, além de dificultar a operação de veículos de emergência.

Figura III-2. Plataformas ou prolongamento das calçadas

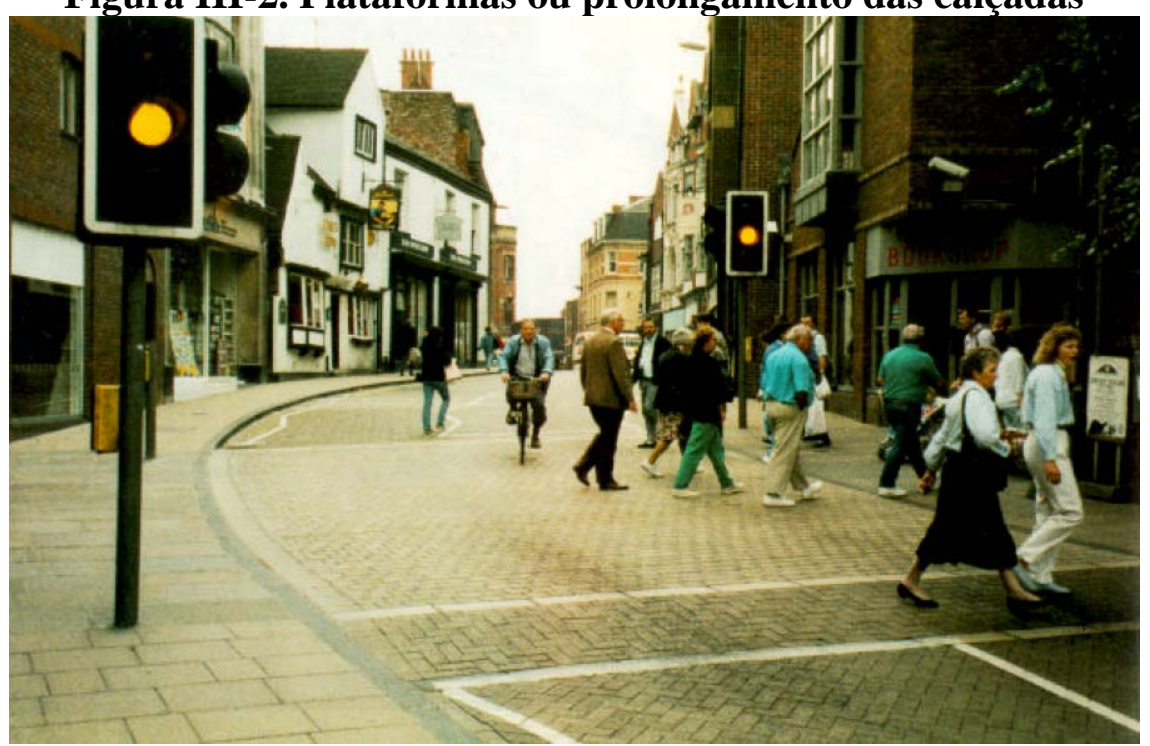

Fonte: BHTRANS.“ Manual de Medidas Moderadoras de Tráfego”. [BHTRANS(2006)]

Os redutores de velocidade

Os redutores de velocidade não são intervenções aleatórias. São dispositivos normalizados (Resolução 039/98, disciplina o parágrafo único do artigo 94 do Código de Trânsito Brasileiro) no que se refere às dimensões geométricas, e são reguladores de velocidade no que se refere à sua utilização. $\mathrm{O}$ artigo $2^{\circ}$ desta Resolução diz: "As ondulações transversais devem ser utilizadas em locais onde se pretenda reduzir a velocidade do veículo, de forma imperativa, principalmente naqueles onde há grande movimentação de pedestres”. Esta resolução apresenta padrões de ondulações (também conhecidas por "lombadas" ou “rampas”), veja figura (III-3), e sonorizadores (ou 
“costelas de burro” ou “tábua de lavadeiras”). Tanto as ondulações (lombadas) como os sonorizadores devem ser precedidos de sinalizações verticais indicativas e demarcados com faixas refletivas.

\section{As Ondulações:}

As ondulações (lombadas) são recomendadas, no Brasil, em locais cujo índice de acidentes são significativos ou que caracterizem riscos potenciais de acidentes; em áreas urbanas com ausência de rampas com declividade superior a 6\% ao longo do trecho. Quanto ao volume de trânsito, recomenda-se sua aplicação em vias com volume de trânsito inferior a 600 veículos por hora, durante os períodos de pico, podendo a autoridade de trânsito admitir volumes mais elevados, em locais com grande movimentação de pedestres. Em relação à velocidade é recomendado para velocidades entre $20 \mathrm{~km} / \mathrm{h}$ e $30 \mathrm{~km} / \mathrm{h}$, conforme a especificação da "lombada” (tipo I e tipo II).

As ondulações tipo I admitem largura igual à da pista (mantendo-se as condições de drenagem superficial), têm comprimento de $1,50 \mathrm{~m}$ e altura até $0,08 \mathrm{~m}$. O tipo II admite a largura igual à da pista (salvaguardando as condições de drenagem superficial), comprimento de 3,70 $\mathrm{m}$ e altura até $0,10 \mathrm{~m}$.

Fatores positivos:

- dispositivo mais eficaz na redução de velocidade.

- fácil instalação, não requer repavimentação ou reconstrução da via.

- aplicável na maioria dos locais.

Fatores negativos:

- por si só, não contribui para mudança da característica da via.

- não discrimina as classes de veículos e pode tornar-se impopular junto aos operadores de transportes públicos, além de dificultar a operação de veículos de emergência. 


\section{Figura III-3. Ilustrações de redutor de velocidade (“lombada” ou "rampa”) tipo I e II}

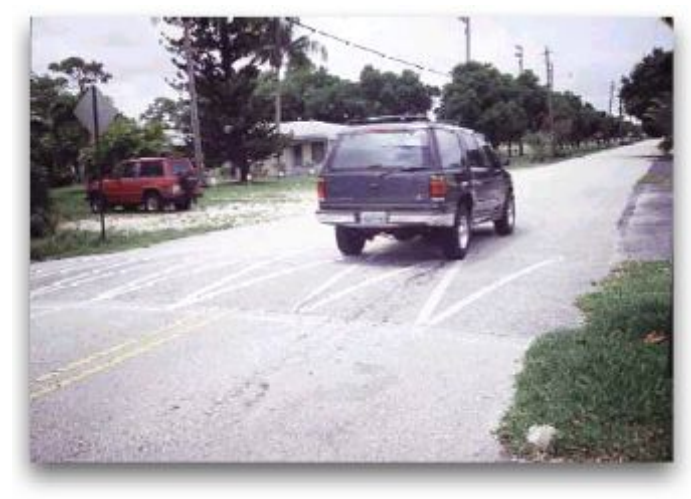

“Lombada” tipo I

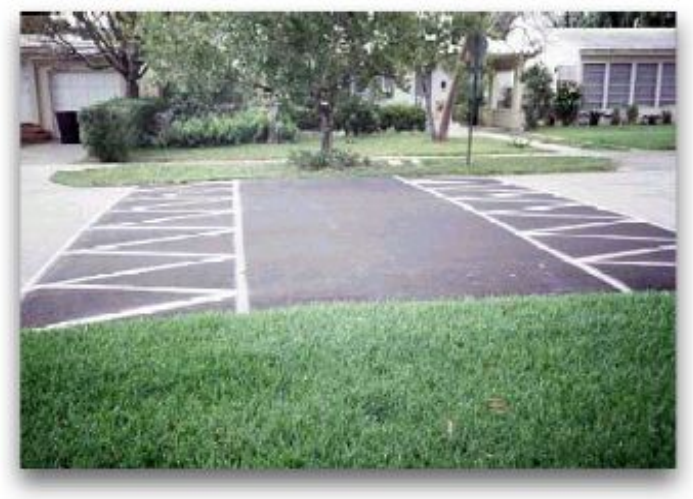

“Lombada” tipo II

Fonte: Arquivo da autora. [YABIKU(1999)].

Nas “Zonas 30” européias, são admitidos dois tipos de redutores (lombadas): o trapezoidal e o circular (chamado de lombada de burro). Ambos têm altura de 10 cm (aproximadamente). Atuam em conjunto com a largura da calçada. O redutor trapezoidal tem um platô superior, que mede entre 2,50 m à 4,0 m e, de cada lado, rampas de $7 \%$ à 10\%. O redutor circular tem 4 m de diâmetro.

Os redutores são autorizados em aglomerações, nas ruas onde o volume diário médio de trânsito é inferior a 3.000 veículos. Não devem ser implantados nas ruas com declive superior a 4\%, nem nas ruas por onde passe linha regular de ônibus, nem a menos de 40 m de uma curva fechada. É obrigatório limitar a velocidade a $30 \mathrm{~km} / \mathrm{h}$ nas proximidades do redutor.

\section{Os Sonorizadores:}

Os sonorizadores são pequenas áreas elevadas de um lado ao outro da pista de rolamento (em ângulo de $90^{\circ}$ em relação à direção de tráfego), que, normalmente, são utilizados para “despertar” os motoristas (muito útil em rodovias) devido à trepidação e ruído que estes dispositivos provocam no veículo. Este procedimento acaba funcionando também como redutor de velocidade. 
Estes dispositivos devem atender às seguintes especificações: largura do dispositivo igual à da pista, mantendo-se as condições de drenagem superficial; com largura da régua de 0,08 m; espaçamento entre réguas de $0,08 \mathrm{~m}$; comprimento de 5,00m e altura da régua de 0,025m. Estes têm a finalidade de reduzirem a velocidade para 20 a 30 $\mathrm{km} / \mathrm{h}$, e não são recomendados para locais por onde circulem linhas regulares de transporte coletivo. (Figura III-4).

Fatores positivos:

- fácil implantação, não requer reconstrução da via.

- mais apropriado para entradas em áreas mais adensadas ou, em caso de estradas, em trechos da via muitos longos e planos, próximo à ocupação urbana.

Fatores negativos:

- as barras de trepidação são consideradas ineficazes na redução de velocidade. As velocidades podem aumentar à medida que os motoristas percebam que o efeito do sonorizador pode ser reduzido quando os dispositivos são transpostos a velocidades mais altas.

- aumento dos níveis de ruídos e de vibrações em áreas residenciais.

- baixa aderência das barras de trepidação. 
Figura III-4. Sonorizador

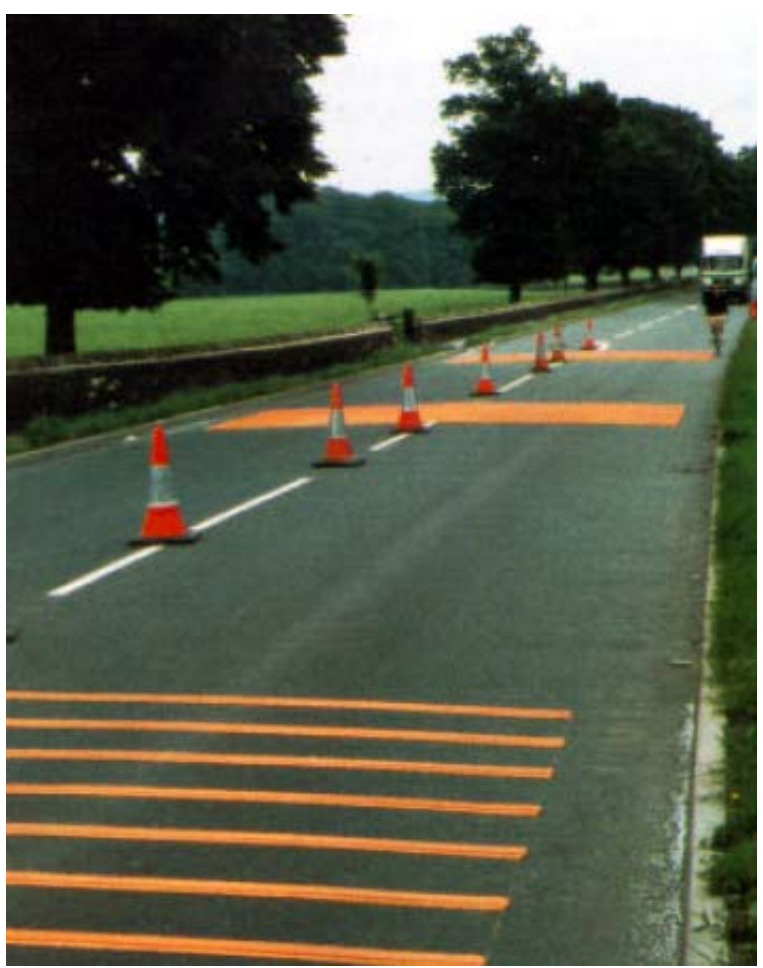

Fonte: BHTRANS.“ Manual de Medidas Moderadoras de Tráfego”. [BHTRANS(2006)]

\section{As Almofadas:}

As almofadas ou speed cushions são porções elevadas da via, colocadas em ângulo reto em relação à direção do trânsito, sendo que o perfil plano estende-se sobre parte da faixa de trânsito, com largura menor que a bitola de um ônibus convencional, mas maior que a bitola média dos veículos leves. Desta forma os ônibus e veículos pesados não são afetados. Este dispositivo melhora a segurança através da redução da velocidade sem impor restrições de velocidade para ônibus, caminhões e veículos de emergências. Podem ser instalados ou um único dispositivo, um par, três lado a lado, dependendo da largura da via.(Figura III-5).

Fatores positivos:

- tráfego relativamente livre para ônibus e ambulâncias.

- evita problemas de drenagem. 
- fácil instalação.

- custo mais baixo, pois não exigem reconstrução da via, nem dispositivos especiais de drenagem.

Fatores negativos:

- veículos com rodas traseiras duplas podem ser afetados pelas almofadas.

- este dispositivo não afeta a velocidade de motocicletas.

As almofadas são indicadas para as ruas com menos de 6.000 veículos/dia. Sua largura deve estar entre 1,75 m (se houver muitos caminhões e ônibus) a 1,90 m, (se poucos caminhões e ônibus). Sua altura está entre 0,06 e 0,07 m. As rampas, antes e depois, estão compreendidas entre 0,45 e 0,50 m, as rampas laterais entre 0,30 e 0,35 m. Devese implantar obrigatoriamente uma por sentido de circulação e devem estar face a face. É recomendável limitar a velocidade em $30 \mathrm{~km} / \mathrm{h}$ nas proximidades das almofadas.

Figura III-5. Almofadas

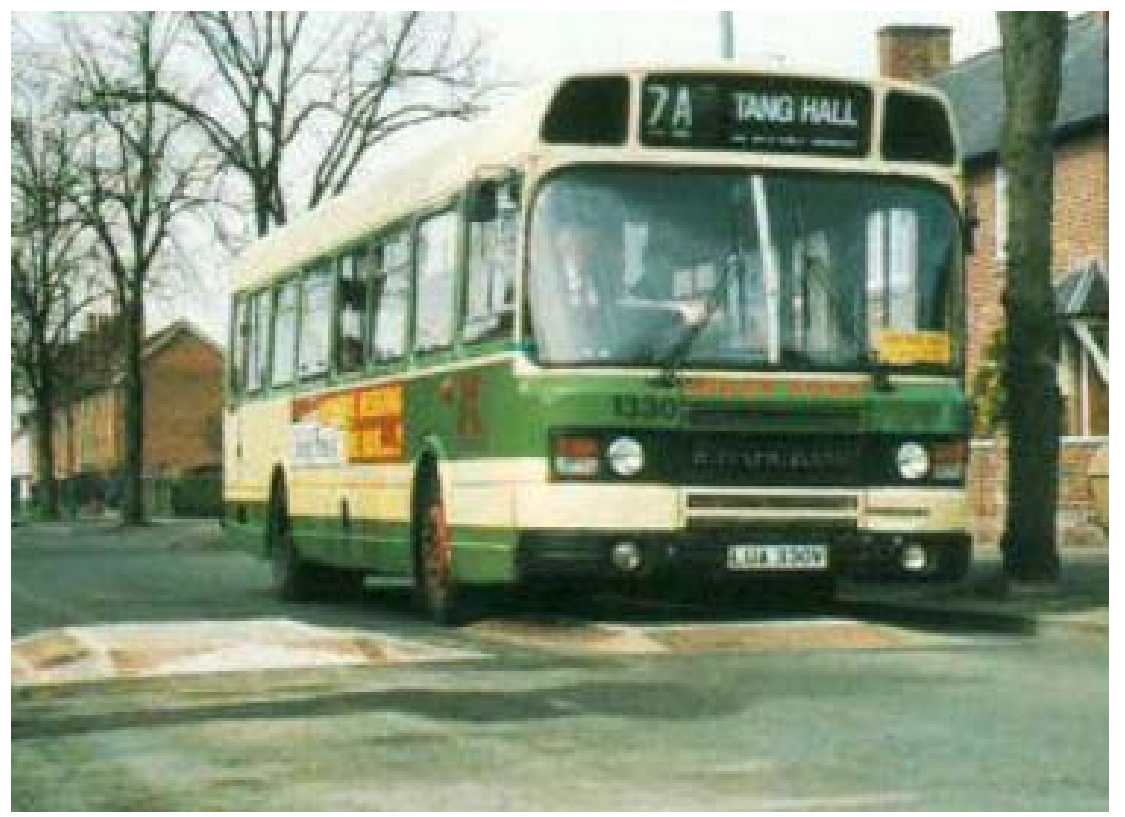

Fonte: BHTRANS.“ Manual de Medidas Moderadoras de Tráfego”. [BHTRANS(2006)] 


\section{Os Platôs ou Interseções Elevadas:}

É uma seção elevada da via da mesma altura da calçada, compreendendo toda a interseção, construída com perfil e rampas. O platô pode ser implantado em trechos de vias, neste caso sobre um a extensão maior que a de uma ondulação (lombada). (Figura III-6).

Fatores positivos:

- dispositivos mais eficaz na redução de velocidade.

- mais adequado para rotas de transporte coletivo do que as ondulações.

- cria condições mais seguras para travessia de pedestres.

Fatores negativos:

- exige cuidado no projeto para deficientes visuais.

- requer reconstrução parcial da via.

Para os platôs não há limite de trânsito (salvo nas vias expressas ou congêneres) Sua largura é de 10 a $30 \mathrm{~m}$ em cima do platô. Sua altura é aquela da borda menos 0,02 m, sem contudo ultrapassar 0,15 m. Atuam como conjunto com a largura da calçada. As rampas têm inclinação de 5\%, devem estar pavimentadas ou asfaltadas, a fim de garantir que estejam bem assentadas. É recomendável limitar a velocidade nas proximidades em $30 \mathrm{~km} / \mathrm{h}$. 
Figura III-6. Platôs ou Interseções Elevadas

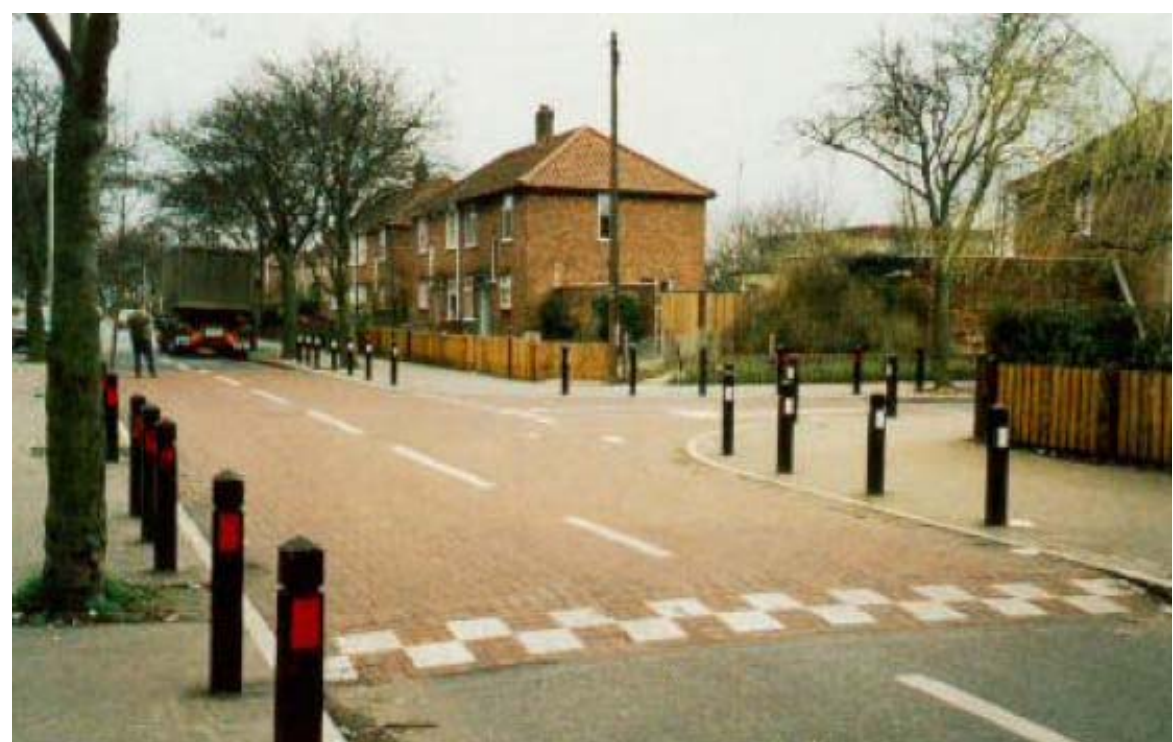

Fonte: BHTRANS.“ Manual de Medidas Moderadoras de Tráfego”. [BHTRANS(2006)]

\section{As “chicanas".}

As “chicanas”, ou deflexões horizontais, são dispositivos que implicam desvios na trajetória dos veículos. Apresentam pequeno raio de giro, induzindo o motorista a reduzir a velocidade e a conduzir com mais prudência. Altera o panorama visual provocando uma alteração radical nas características das vias, É uma solução de custo médio e exige estudo prévio para compatibilizar os raios geométricos com a tipologia dos veículos (veículos grandes, como os ônibus, têm dificuldades em realizar trajeto em raios pequenos). (Figura III-7). 


\section{Figura III-7. Ilustração de uma “chicana” urbana}

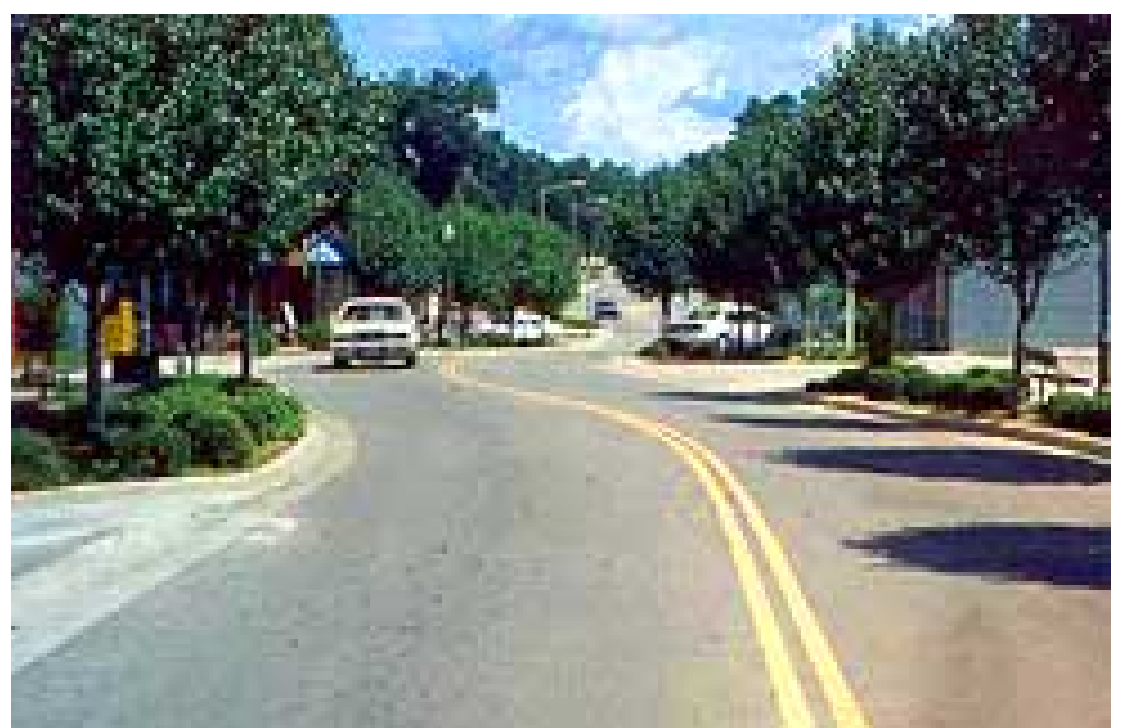

Fonte: Arquivo da autora. [YABIKU(1999)].

\section{O estreitamento da pista}

Estreitamento ou estrangulamento da pista são reduções da largura da via em todo o seu comprimento, sem alterar a sua linearidade, induzindo a uma condução mais cautelosa, reduzindo a velocidade e impedindo a ultrapassagem. (Figura III-8)

Figura III- 8. Estreitamento de pista, reduzindo a velocidade.

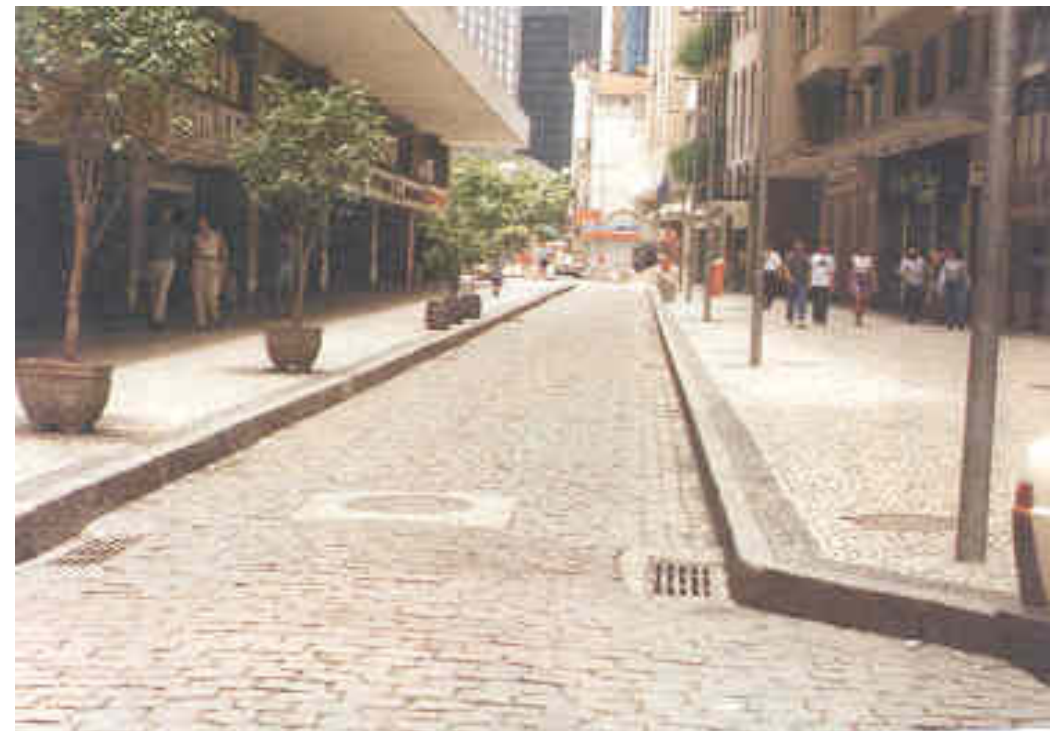

Fonte: Arquivo da autora. [YABIKU(1999)]. 


\section{As mini-rotatórias e ilhas na via}

Outra forma de induzir a redução de velocidade é a implantação de pequenas rotatórias ou ilhas ao longo da via, não sendo necessariamente um cruzamento, apenas com a finalidade de “quebrar” uma linearidade geométrica da via que induza o motorista a desenvolver alta velocidade, como o exemplo da figura III-9.

Figura III-9. Ilustrações de mini-rotatória e ilha ao longo da via.

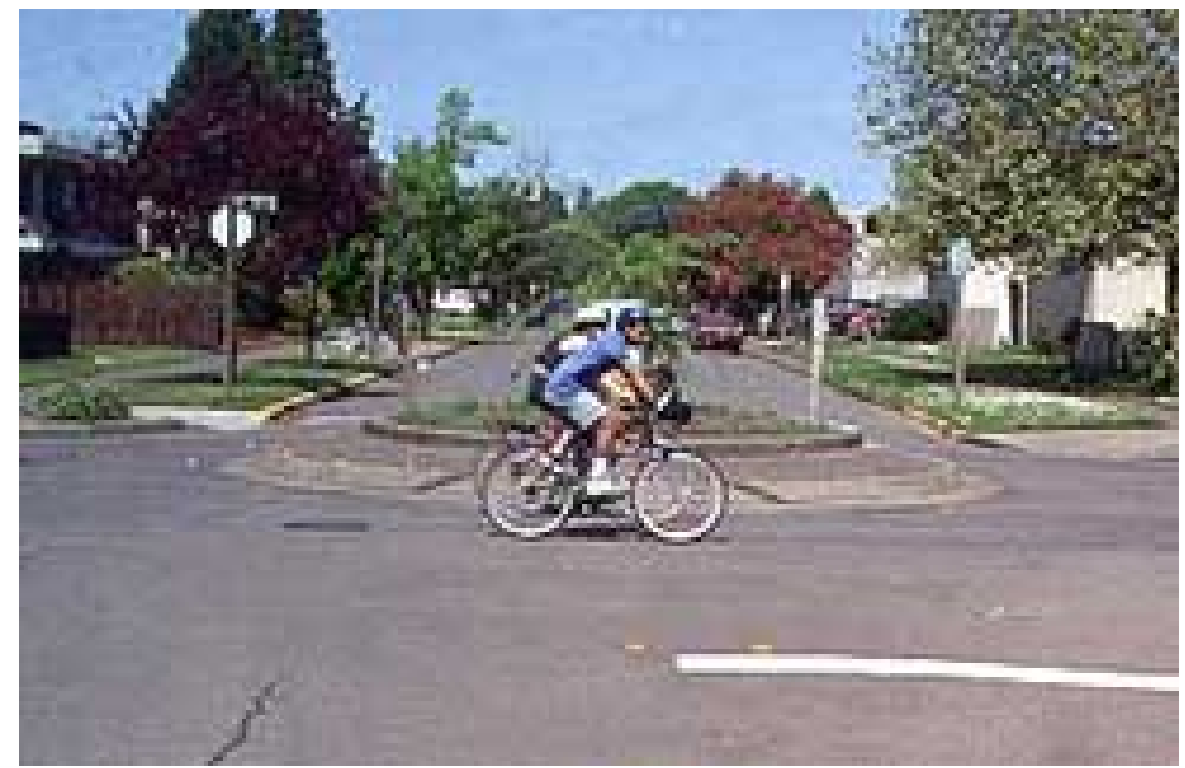

Fonte: Arquivo da autora. [YABIKU(1999)].

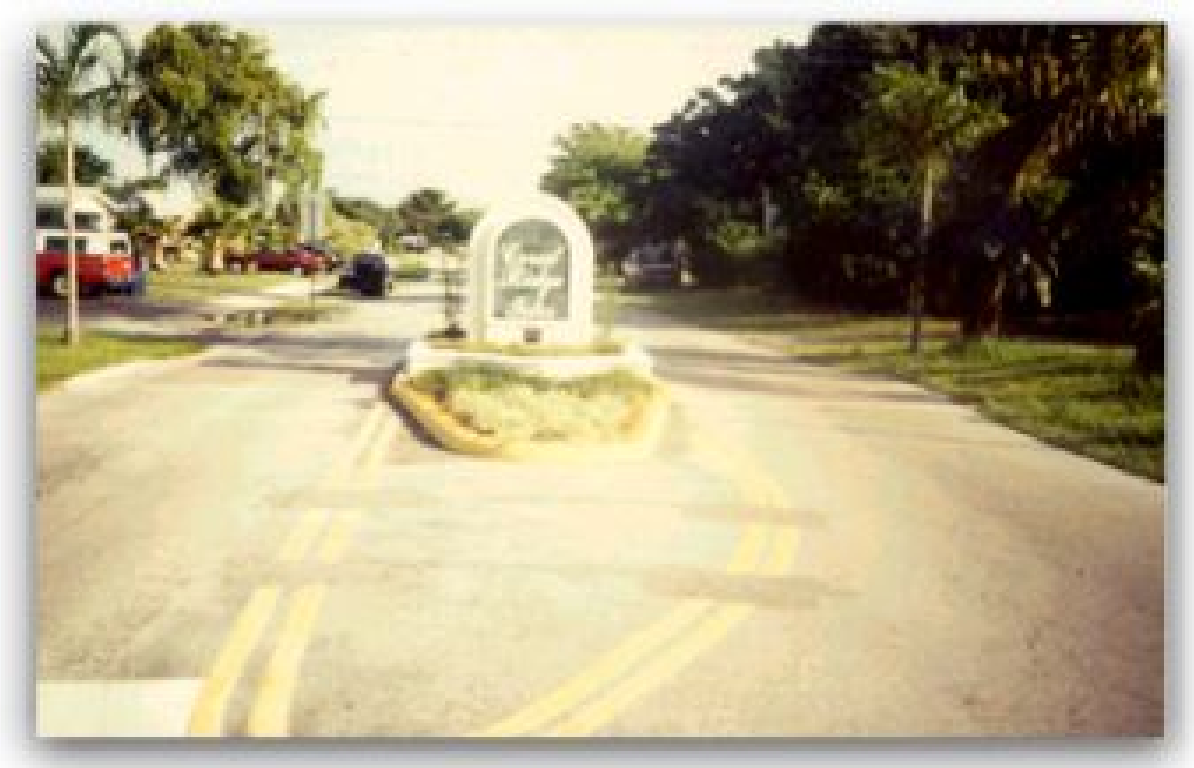

Fonte: Arquivo da autora. [YABIKU(1999)]. 


\section{SÍNTESE DO CAPÍTULO}

Neste capítulo foi apresentada a anatomia do atropelamento, isto é, os procedimentos que conduzem o veículo automotor e o pedestre a se confrontarem e culminarem com lesões, normalmente para a parte com menor massa inercial. Neste confronto, a probabilidade de sobrevivência dependerá de fatores, mas as lesões sobrevirão. Os grupos mais fragilizados, entre os pedestres, são os idosos e as crianças. Os idosos devido, principalmente, à dificuldade de recuperação das lesões e as crianças porque a fatalidade está mais presente, devido à grande possibilidade de lesões no segmento cefálico (cabeça e pescoço), motivadas pela pouca estatura em relação aos veículos.

A mortalidade por atropelamento, no município de São Paulo, é relatada em retrospectiva de três anos. O padrão de atropelamento, o comportamento e hábitos permanecem estáveis nas subregiões e demonstram a falta de políticas públicas na prevenção de atropelamentos, mesmo tendo as subregiões o controle da gestão de trânsito.

O custo de um acidente com o pedestre foi analisado tanto no atropelamento como na queda em calçadas e vias públicas.

No último item foram apresentadas medidas visando implementar segurança para pedestres. A intervenção urbana, como a implantação de “Zona 30" numa área de interesse e instalações de procedimentos de “traffic calming” em vias específicas.

É imprescindível aos técnicos conhecerem as necessidades da modalidade caminhar, inserindo-as nas intervenções urbanas, assim como os pedestres devem conhecer as regras de "sobrevivência”, para melhor transitar no espaço da cidade.

Assim devem ser propostas políticas específicas voltadas especificamente para a segurança dos pedestres (uma espécie de código de obra), tais como: 
- Identificar e desobstruir “corredores para circulação de pedestres”;

- Pavimentar, sinalizar e iluminar faixas e passarelas para pedestres;

- Estabelecer prioridade máxima para o pedestre no planejamento viário ou urbano.

- Enfatizar o espaço viário como um espaço de convivência e não um espaço de transição, passagem ou de movimento.

- Oferecer informação de boa qualidade para aqueles que caminham

- Integrar estratégias de pedestres com os projetos viários e urbanos.

- Melhorar o desenho urbano para incentivar e promover a modalidade de andar a pé. A incidência de queda de pedestres em vias públicas e seus custos mostram que os acidentes com pedestres sem envolvimento de veículos produzem perdas econômicas consideráveis.

E para os pedestres algumas componentes são reconhecidas no ato de caminhar (código do consumidor):

- Antes de atravessar uma via olhar para os dois lados da via.

- Cruzar sempre uma via pela faixa se pedestre (ou segurança) e em linha reta.

- Nunca cruzar uma via por entre os veículos parados.

- O pedestre deve, sempre, fazer-se visível.

- Conheça as sinalizações de trânsito.

E para os motoristas, a máxima:

- Motoristas respeitem os pedestres.

Enfim, a modalidade de caminhar é uma técnica científica e deve ser apreendida no seu todo e aplicável no conjunto do desenho urbano. 


\section{BIBLIOGRAFIA REFERENCIADA}

ALMEIDA, Marco Antonio Ramos. "São Paulo, o grande negócio”. Revista Urbs. N³9. dezembro2005/janeiro2006.

BHTRANS."Manual de Medidas Moderadoras do Tráfego”. Disponível em www.bhtrans.pbh.gov.br. Acessado em janeiro/2006.

CET. "Boletim Técnico nº 8, 17,19 -Áreas de Pedestres”. Companhia de Engenharia de Trânsito. São Paulo.1978.

CET. "Morte de Idosos por Atropelamento: uma proposta de educação para segurança da Terceira Idade no trânsito”. Companhia de Engenharia de Trânsito. São Paulo.1994.

CET. "Mortes em Acidentes de Trânsito no Município de São Paulo”. Companhia de Engenharia de Trânsito. São Paulo. 2005.

CTB. “Código de Trânsito Brasileiro”. Diário Oficial da União. Brasília. 1997.

DAROS, Eduardo José. “O risco de atropelamento”. Maio/2004. Disponível em www.pedestres.org.br/images conteudo/risco_de_atropelamento. Acessado em setembro/2005.

DETRAN. “Curiosidades”.2004. Disponível em www.detran.sp.gov.br. Acessado em setembro/2005.

DOTTA, Ático. “O Condutor Defensivo”. Ed. Sagra Luzzato. Porto Alegre. 2000.

FRANÇOSO, Lucimar Aparecida. "Avaliação das Seqüelas e suas Repercussões Sociais em Adolescentes Vítimas de Acidentes de Trânsito”. Dissertação de Mestrado. Escola de Medicina da Santa Casa da Misericórdia. 2004.

FRUIN, John J. “Pedestrian-Planning and Design”. New York. 1971.

GREVE, Júlia Maria D’Andréa . “Acidentes nas Calçadas”. Revista ABRAMET, Ano XXIV, número 47. 2006.

IBGE. “Síntese dos Indicadores Sociais-2002”. 2003. Disponível em www.ibge.gov.br. Acessado em setembro/2005

IPEA. "Impactos Sociais e econômicos dos acidentes de trânsito nas aglomerações urbanas”. Brasília. Junho 2003.

MCCOY,G.F;JOHNSTONE,R.A;DUTHIE,R.B. "Injury to the Elderly in Road Traffic Accidents”. The Journal of Trauma,vol 29. USA.1989.

METRO. "Síntese das Informações Domiciliar e Linha de Contorno. Pesquisa O/D/1997”. Companhia do Metropolitano. 1999. 
PLANEJAMENTO, Secretaria Municipal. "Dados Sócio-Econômicos”. Prefeitura Municipal de São Paulo. Disponível em www.prefeitura.sp.gov.br. Acessado em nov/2005.

PRO-AIM. “Mortalidade no Município de São Paulo”. Prefeitura de São Paulo. 2005.

PULIDO, Francisco. "La reconstrucción de accidentes de tránsito enfocada a los peatones”. II Seminário de Seguridad Vial. Colombia. 2001.

SEADE. “Demografia. Município de São Paulo. 2004”.Fundação Sistema Estadual de Análise de Dados. Disponível em www.seade.gov.br/produtos. Acessado em nov/ 2005.

TRANSPORTATION, Research Board. “HCM 2000”. National Research Council. Washington. D. C. 2000.

WAKSMAN, Renata Dejtiar. "Características epidemiológicas dos acidentes fatais de transporte em menores de quinze anos, São Paulo, setembro de 1990 a agosto de 1991”. Tese de doutorado. Faculdade de Medicina da USP. São Paulo. 1995.

YABIKU, Luiza. “O Pedestre”. Apostila do curso de Capacitação para Médicos Peritos Examinadores”. ABRAMET. São Paulo. 1999.

YABIKU, Luiza. “Os Motoristas de Terceira Idade e as Condições Não Amigáveis da Direção Veicular. O caso dos motoristas de terceira idade na cidade de São Paulo". Dissertação de Mestrado. FAUUSP. 2000. 


\section{CAPÍTULO IV}

\section{DESEMPENHO E NÍVEL DE SERVIÇO DAS INSTALAÇÕES PARA PEDESTRES}

\section{Apresentação:}

Neste capítulo será apresentado o método de avaliação do nível de serviço em instalações para pedestres. Esta metodologia foi lançada no compêndio da Highway Capacity Manual, do ano 2000. Concomitantemente serão feitas inserções de pesquisas de outros autores, assim como indicadas as divergências com o sistema de gerenciamento de trânsito no município de São Paulo.

A implantação de uma instalação para pedestres não deve ser somente a expressão de uma política vertical, mas também deve visar atender as necessidades do público alvo. Projetar implica em instrumentalizar-se técnica e esteticamente, incluindo-se o ajuste ao cliente e uma avaliação crítica do seu uso e satisfação. 


\section{CAPÍTULO IV \\ DESEMPENHO E NÍVEL DE SERVIÇO DAS INSTALAÇÕES PARA PEDESTRES}

\section{Sumário :}

1. CONCEITOS E DETERMINAÇÃO DE NÍVEL DE SERVIÇO

1.1 CONCEITO DE FLUXO DE PEDESTRE

1.2 CARACTERÍSTICA DOS DESLOCAMENTOS DE PEDESTRES

1.3 RELAÇÃO VELOCIDADE DO PEDESTRE E A DENSIDADE

1.4 RELAÇÃO DE FLUXO DE PEDESTRE E A DENSIDADE

1.5 RELAÇÃO VELOCIDADE DE CAMINHAR E O FLUXO DE PEDESTRE

1.6 RELAÇÃO ENTRE A VELOCIDADE DE CAMINHAR E O ESPAÇO

2. CARACTERÍSTICAS DOS PEDESTRES

2.1 ESPAÇO REQUERIDO PARA O PEDESTRE

2.2 VELOCIDADE DE CAMINHAR DO PEDESTRE

2.3 TEMPO DE TRAVESSIA E A CAPACIDADE

2.4 LARGURA EFETIVA DE UMA FAIXA DE PEDESTRE

2.5 TIPO DE PEDESTRE E MOTIVOS DE VIAJEM

3. MEDIÇÃO DE DESEMPENHO E NÍVEL DE SERVIÇO

3.1 FLUXO DE PEDESTRES

3.2 PELOTÕES DE PEDESTRES

3.3 DADOS DE ENTRADA REQUERIDOS E VALORES ESTIMADOS

4. ANÁLISE DE CAPACIDADE E NÍVEL DE SERVIÇO

4.1 TIPOS DE INSTALAÇÕES

4.2 METODOLOGIA

4.3 NÍVEL DE SERVIÇO

4.4 DETERMINAÇÃO DE VELOCIDADE DE CAMINHAR DOS PEDESTRES

4.5 DETERMINAÇÃO DA LARGURA EFETIVA DE UM PASSEIO

4.6 INSTALAÇÕES PARA FLUXOS NÃO INTERROMPIDOS

4.7 INSTALAÇÕES PARA PEDESTRES COM FLUXO INTERROMPIDO

5. FORMULÁRIOS E MEMÓRIA DE CÁLCULOS

6. LIMITAÇÕES DA METODOLOGIA E CONSIDERAÇÕES EM RELAÇÃO AO TRÂNSITO DA CIDADE DE SÃO PAULO

7. SÍNTESE DO CAPÍTULO

8. BIBLIOGRAFIA REFERENCIADA 


\section{DESEMPENHO E NÍVEL DE SERVIÇO DAS INSTALAÇÕES \\ PARA PEDESTRES}

Uma metodologia para avaliar a qualidade de serviço, foi lançada em 1971, por John J. Fruin [FRUIN(1971)], com seu livro "Pedestrian, planning and design", no qual fez uma analogia do trânsito de pedestres com os cálculos de engenharia de trânsito. Assim os níveis de serviço para os pedestres apresentavam conceitos similares aos do tráfego viário, resguardando as diferenças, como a flexibilidade de movimento dos pedestres. Portanto havia a nítida semelhança entre a metodologia de cálculo para os veículos e para os pedestres.

Com a crescente importância da presença do pedestre no sistema viário e urbano, no próprio Highway Capacity Manual atualizou-se a metodologia proposta por Fruin, conforme apresentado na edição do HCM 2000 - Highway Capacity Manual, edição do ano 2000 [TRANSPORTATION(2000)]. O compêndio HCM é tradicionalmente utilizado nos projetos viários pelos engenheiros e projetistas de trânsito, tanto nos projetos urbanos, como nas estradas rurais, auto-estradas e vias expressas. O seu interesse pelos pedestres demonstra a preocupação no trânsito da calçada e das áreas lindeiras.

Obviamente os dados apresentados no HCM foram testados em vias e áreas urbanas dos Estados Unidos da América do Norte, considerando a larga aplicação dessa metodologia nos projetos viários brasileiros, ressalvadas diferenças entre os Códigos de Trânsitos do Brasil [CTB(1997)] e dos Estados Unidos, seu conteúdo foi acolhido como aplicável nesta pesquisa. Essas diferenças serão objeto de observação e ajuste neste trabalho.

A unidade de medida adotada é o sistema métrico e decimal, preservadas as medidas sugeridas nas pesquisas dos autores, para compatibilizações com as equações. 


\section{CONCEITOS E DETERMINAÇÃO DE NÍVEL DE SERVIÇO}

Nível de Serviço (NS) é uma medida qualitativa que descreve as condições operacionais de uma corrente de trânsito, baseada em medidas de serviço tais como a velocidade e tempo de viagem, a liberdade para manobrar, as interrupções de fluxo viário, o conforto e a conveniência dos motoristas.

\subsection{Conceito de Fluxo de Pedestre}

Os conceitos em que se apóiam as medidas qualitativas do fluxo de pedestre são semelhantes àqueles usados para o fluxo veicular, tais como a liberdade de escolha da velocidade e de ultrapassagem. Outras medidas específicas, para o fluxo de pedestre, incluem a travessia do pedestre na corrente de trânsito, andar em direção oposta ao fluxo da maioria, manobrar, geralmente sem conflitos, mudar a velocidade de andar e a espera dos pedestres nas intersecções sinalizadas e não sinalizadas.

Fatores ambientais adicionais que contribuem à experiência de andar e assim perceber o nível de serviço são: o conforto, a conveniência, a segurança, a continuidade, a capacidade e economia do sistema.

O fator conforto inclui proteção ao tempo, controle do clima, arcadas, abrigos, etc. Estes fatores também podem ser considerados como influência nas atividades do pedestre.

O fator conveniência inclui distâncias de caminhar, demarcação de vias de pedestres, declividades, rampas, sinalização direcional, mapas e outras instalações que facilitam e descomplicam a viagem do pedestre.

A segurança é provida pela separação dos pedestres do trânsito veicular, no mesmo plano horizontal, com barreiras e verticalmente, acima ou abaixo, com passarelas ou 
passagem subterrâneas. Os dispositivos de controle de trânsito podem providenciar a separação entre pedestres e o trânsito veicular.

Aspectos de proteção incluem a iluminação, paisagem limpa e desimpedida e o grau e tipo de atividade desenvolvida na rua.

A economia em relação ao sistema urbano de pedestre refere-se ao custo que incorrem ao usuário pelos atrasos e inconveniências e pelos valores comerciais e locais motivados pelas instalações de trânsito de pedestres.

Esses fatores podem afetar as percepções dos pedestres de toda a qualidade de ambiente da rua. Apesar de usuários de automóveis terem razoável controle sobre a maioria destes fatores, o pedestre não tem qualquer controle sobre eles.

Este trabalho enfatiza a análise do Nível de Serviço para medir o fluxo de pedestres, tais como a velocidade, o espaço e o tempo de espera, conforme a metodologia preconizada pelo Highway Capacity Manual, do ano 2000. [TRANSPORTATION(2000)].

\subsection{Característica dos Deslocamentos de Pedestres}

Este item foi elaborado conforme "Pedestrian -Planning and Design", de John J. Fruin [FRUIN(1971)] e "Boletim Técnico - Áreas de Pedestres", da CET -São Paulo [CET(1978)]

VOLUME DE ESCOAMENTO ou FLUXO DE PEDESTRES - é o número de unidades de trânsito passando por uma seção, em uma unidade de tempo.

Para os pedestres é expresso em quantidade de pedestres numa seção de 1 metro de largura, circulando por minuto (60 s). É a mais importante característica de trânsito porque ajuda a determinar a largura das vias para pedestres.

VELOCIDADE - a velocidade de locomoção é expressa em distância por unidade de tempo, geralmente em metros por minutos ou segundos. 
DENSIDADE - é o número de unidade de trânsito por unidade de área. Para pedestres a unidade consiste no número de pedestres por metro quadrado.

INTERVALO - é o tempo e a distância entre unidades de trânsito, geralmente é difícil aplicar para pedestres.

FILA - expressa o número de unidades aguardando um serviço. O comprimento e duração das filas para pedestres variam muito e são explicadas por variáveis randômicas.

PELOTÃO - representa o efeito de flutuação de curto prazo de pedestres, ocasionado pela chegada aleatória a certo ponto onde devem esperar. A densidade dos pelotões é bem maior que a observada no fluxo normal.

A seguir relacionam-se as principais relações conceituais e matemáticas, visando ao processamento de cálculos para determinação de Níveis de Serviços. [TRANSPORTATION(2000)].

\subsection{Relação Velocidade, Densidade e Volume de Pedestres}

A relação fundamental entre a velocidade, a densidade e o volume para fluxo de pedestres é análoga à do fluxo de veículos. Com o aumento do volume e da densidade de pedestres diminui a sua velocidade. Com o aumento da densidade e o decréscimo do espaço do pedestre, o grau de mobilidade, que the é proporcionado, individualmente, diminui, assim como a velocidade da corrente de pedestres.

O gráfico IV-1, a seguir apresenta a relação entre a velocidade e a densidade para três classes de pedestres (estudantes, em trânsito e em compras). 


\section{Gráfico IV-1. Relação entre velocidade do pedestre e a densidade}

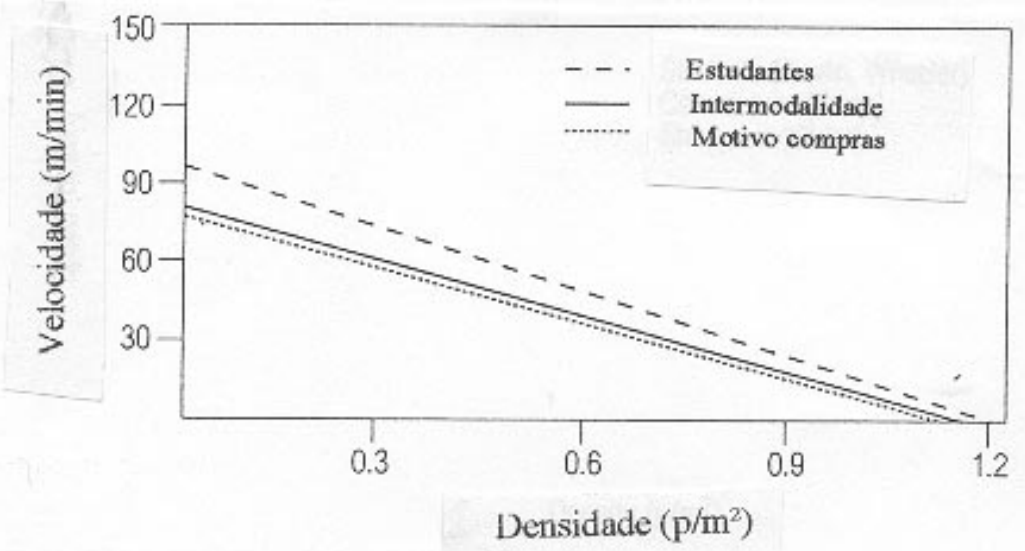

Fonte: HCM 2000 [TRANSPORTATION(2000)]

\subsection{Relação Fluxo de Pedestres, Densidade e Velocidade}

A relação entre densidade, velocidade e fluxo de pedestres é expressa pela equação 1:

$$
\text { Vped }=\text { Sped } * \text { Dped } \quad \text { (equação } 1)
$$

Onde: Vped = fluxo unitário $(\mathrm{p} / \mathrm{min} / \mathrm{m})$

Sped $=$ velocidade do pedestre $(\mathrm{m} / \mathrm{min})$

Dped $=$ densidade de pedestre $\left(\mathrm{p} / \mathrm{m}^{2}\right)$

Uma expressão alternativa, mais usada é a recíproca da densidade ou espaço:

$$
\text { Vped }=\text { Sped/M } \quad \text { (equação 2) }
$$

Sendo $M=$ espaço do pedestre $\left(\mathrm{m}^{2} / \mathrm{p}\right)$.

A relação básica entre fluxo e espaço, registrado por vários pesquisadores é a apresentada no gráfico IV-2.

A condição de máximo fluxo representa a capacidade da instalação-calçada. Do gráfico IV-2 observa-se que a unidade máxima de fluxo cai dentro a estreita faixa de densidade, com a média espacial por pedestre variando entre 0,4 e $0,9 \mathrm{~m}^{2} / \mathrm{p}$. Até o limite externo desta observação indica que o máximo fluxo ocorre nesta densidade.

Como o espaço é reduzido a menos de $0,4 \mathrm{~m}^{2} / \mathrm{p}$, o fluxo declina precipitadamente. 
$\overline{\text { Essa relação mostra que o trânsito de pedestre pode ser avaliado qualitativamente pelo }}$ uso do conceito de NS (Nível de Serviço), semelhante à análise de trânsito veicular. No fluxo próximo à capacidade, a média de 0,4 a $0,9 \mathrm{~m}^{2} / \mathrm{p}$ é requerida para cada movimento de pedestre. Entretanto, neste nível de fluxo, a limitada área disponível restringe a velocidade do pedestre e sua liberdade de manobra.

\section{Gráfico IV-2. Relação entre fluxo de pedestre e espaço.}

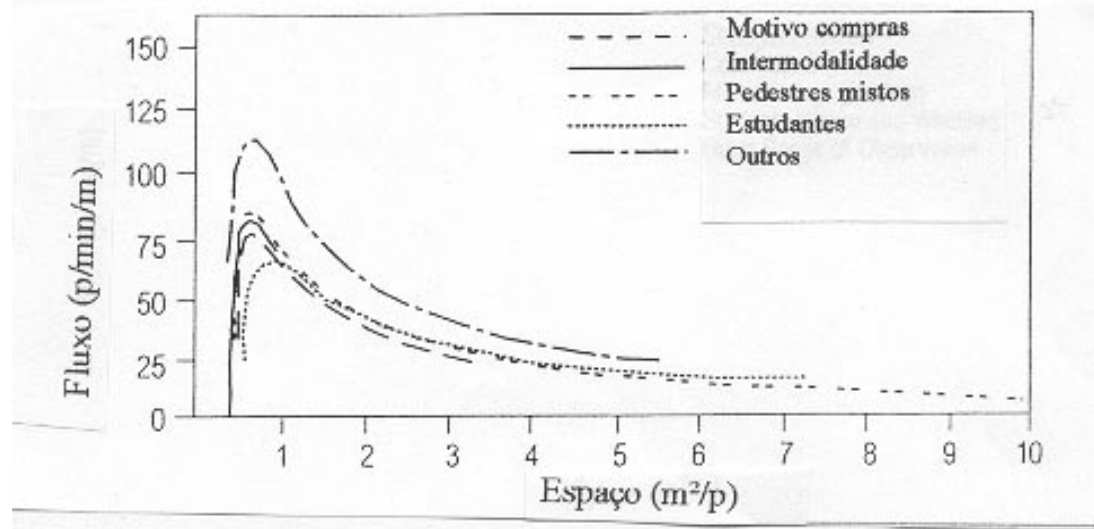

Fonte: HCM 2000 [TRANSPORTATION(2000)]

\subsection{Relação Velocidade de Caminhar e o Fluxo de Pedestre}

O gráfico IV-3 ilustra a relação ente velocidade dos pedestres e o seu fluxo. Esta curva é semelhante àquela do fluxo de veículos e relata que quando há pouco pedestre no passeio (isto é, baixo nível de fluxo), há espaço disponível para escolher a velocidade de caminhar, mesmo que alta. Conforme o fluxo cresce, a velocidade declina por causa da proximidade e interação entre pedestres. Quando o nível crítico de multidão ocorre, os movimentos tornam-se mais difíceis e tanto o fluxo como a velocidade declina. 


\section{Gráfico IV-3. Relação velocidade de caminhar e o fluxo de pedestre}

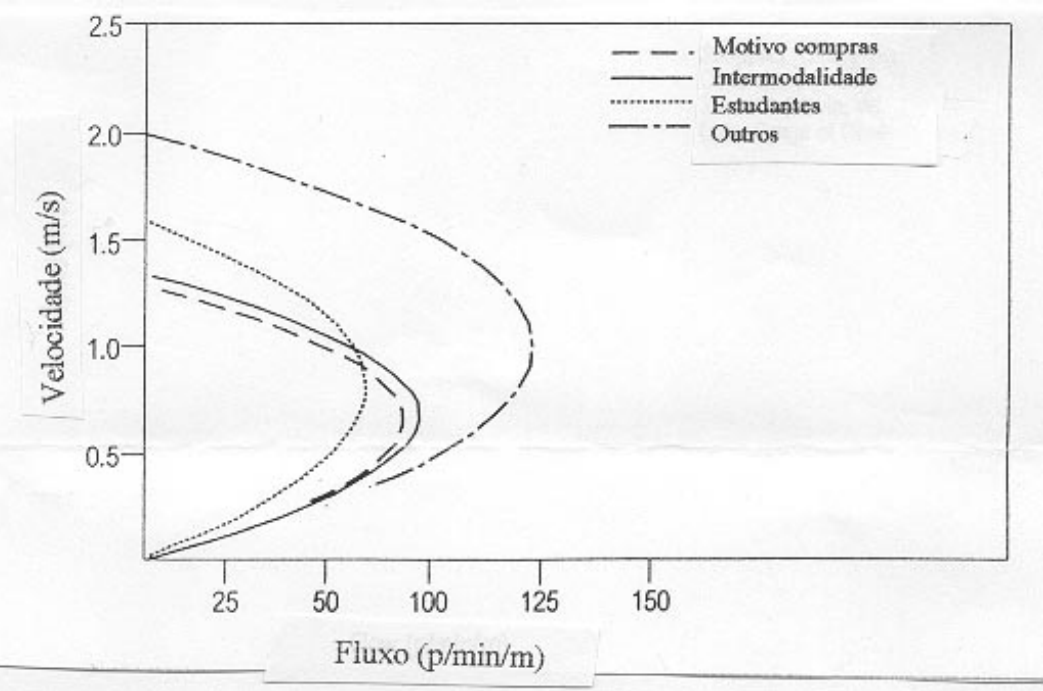

Fonte: HCM 2000 [TRANSPORTATION(2000)]

1.6 Relação entre a Velocidade de Caminhar e o Espaço

Gráfico IV-4. Relação entre velocidade do pedestre e o espaço.

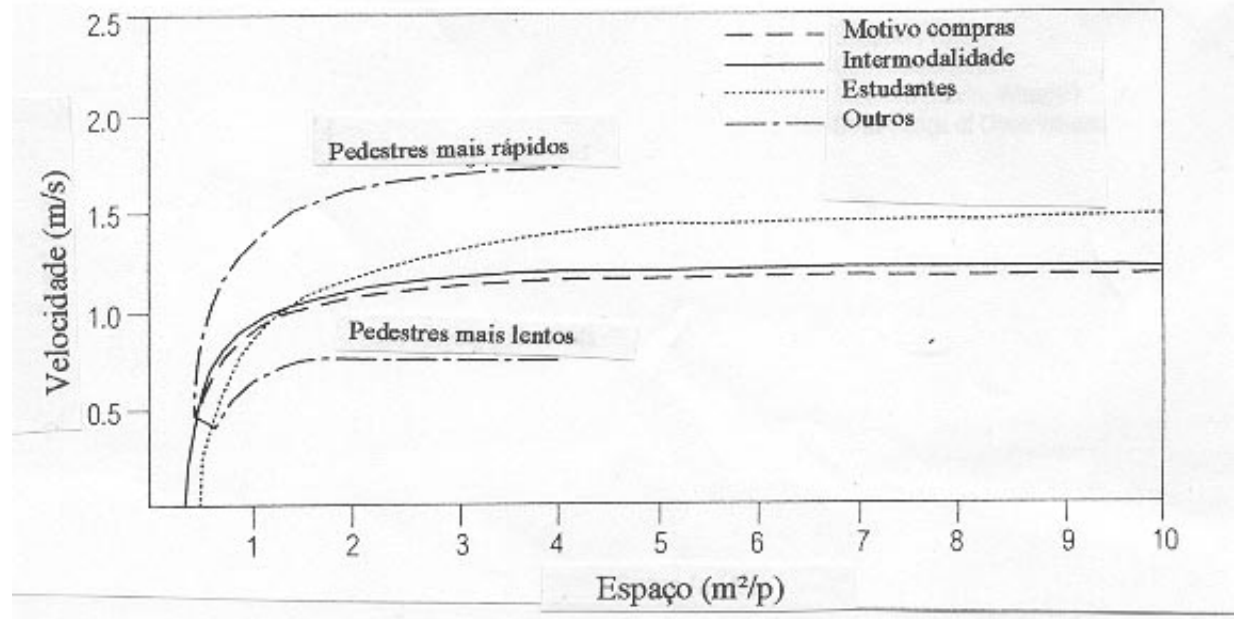

Fonte: HCM 2000 [TRANSPORTATION(2000)]

O gráfico IV-4 também confirma a relação de velocidade de andar e o espaço disponível, e sugere alguns pontos de demarcação para desenvolver os critérios de NS. O limite externo das observações apresentadas no gráfico IV-4 indica que no espaço médio de menos que $1,5 \mathrm{~m}^{2} / \mathrm{p}$, até o mais lento pedestre não pode aumentar a velocidade de seus passos. Pedestres rápidos, que caminham à velocidade de mais de $1,8 \mathrm{~m} / \mathrm{s}$, não podem desenvolver esta velocidade a menos do espaço médio de $4,0 \mathrm{~m}^{2} / \mathrm{p}$ ou mais. 


\section{CARACTERÍSTICAS DOS PEDESTRES}

\subsection{Espaço Requerido}

Os projetos de instalações para pedestres usam a profundidade do corpo e largura dos ombros como um espaço mínimo padrão. Uma simplificação do conceito de elipse do corpo de $0,50 \mathrm{~m} \times 0,60 \mathrm{~m}$, com área total de $0,30 \mathrm{~m}^{2}$, é usado como espaço básico para um pedestre, como na figura IV-1a. Isto representa um pedestre em pé. No cálculo de uma instalação para pedestre, uma área de $0,75 \mathrm{~m}^{2}$ é usada como uma zona de proteção para cada pedestre. Em Boueri [BOUERI(1999)] tem-se que a largura máxima do corpo no $95^{\prime}\left(95^{\circ}\right.$ percentil $)$, para homens é de $0,578 \mathrm{~m}$; e a profundidade máxima do corpo para homens no $95^{\prime}\left(95^{\circ}\right.$ percentil $)$ é de $0,330 \mathrm{~m}$.

Figura IV-1. Elipse do corpo e área para caminhar requerido para um pedestre
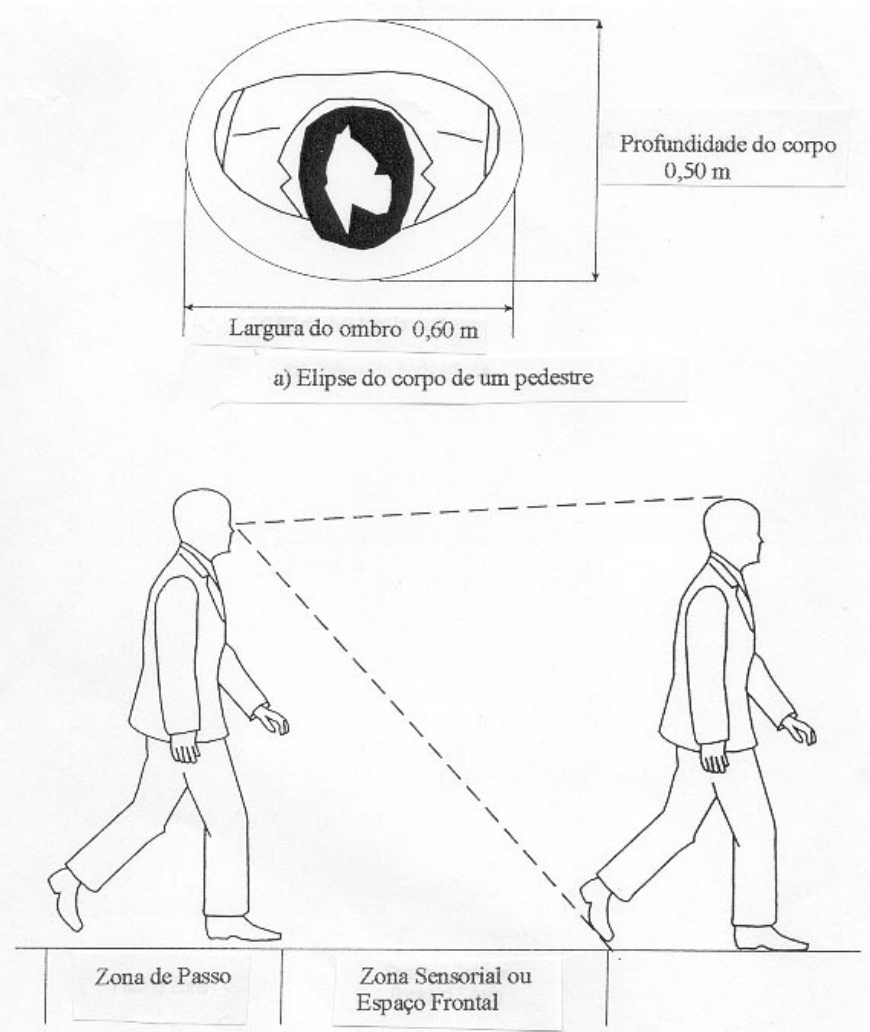

b) Espaço requerido para um pedestre caminhar

Fonte: HCM 2000. [TRANSPORTATION(2000)]. 


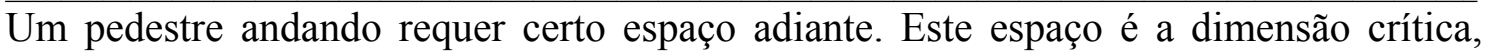
aquela que determina a velocidade do caminhar e o número de pedestres que ele é capaz de ultrapassar, num dado período de tempo. O espaço frontal (figura IV-1 b) representa uma zona de passo e uma zona sensorial.

\subsection{Velocidade de Caminhar do Pedestre}

A velocidade de caminhar do pedestre é maior dependendo da proporcionalidade de pedestres idosos (65 anos ou mais) na população de caminhantes. Se variar de 0 a $20 \%$ de pedestres idosos, a média da velocidade de caminhar é de $1,2 \mathrm{~m} / \mathrm{s}$ nas vias de pedestres. Se a população de idosos forem mais de $20 \%$ do total de pedestres a média de velocidade decresce para $1,0 \mathrm{~m} / \mathrm{s}$. Se a via sofrer acréscimo de $10 \%$ ou mais, a velocidade é reduzida em $0,1 \mathrm{~m} / \mathrm{s}$ para o caminhar. Nas calçadas, a velocidade do fluxo livre de pedestres é de aproximadamente $1,5 \mathrm{~m} / \mathrm{s}$. Há vários outros condicionantes que podem reduzir a média de velocidade do pedestre, tais como a alta porcentagem de crianças que caminham devagar na corrente de pedestres.

\subsection{Tempo de Travessia e a Capacidade}

Um tempo de $3 \mathrm{~s}$ é um valor médio razoável para calcular o tempo de travessia sinalizada. Uma capacidade de $75 \mathrm{p} / \mathrm{min} / \mathrm{m}$ ou $4500 \mathrm{p} / \mathrm{h} / \mathrm{m}$ é um valor razoável para uma instalação para pedestre se os dados locais não estiverem disponíveis. Na capacidade, a velocidade de caminhar de $0,8 \mathrm{~m} / \mathrm{s}$ é considerada um valor razoável. O gráfico IV-5 apresenta uma típica distribuição de velocidade de caminhar num fluxo livre num terminal de ônibus. 


\section{Gráfico IV-5. Distribuição típica da velocidade de caminhar num fluxo livre}

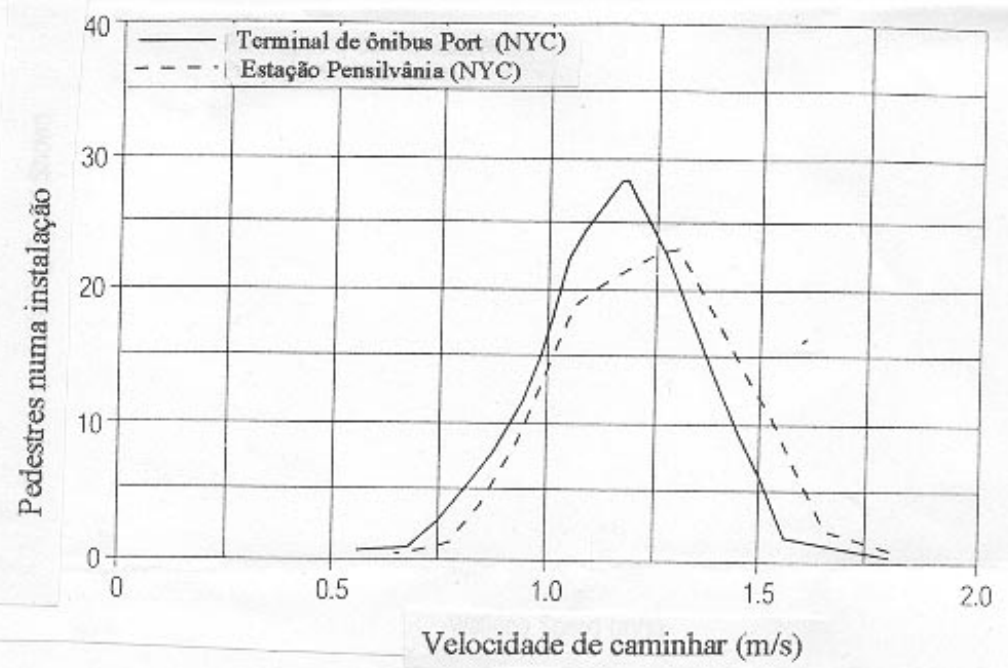

Fonte: HCM 2000 [TRANSPORTATION(2000)].

\subsection{Largura Efetiva de uma Faixa de Pedestre}

O conceito de faixa de pedestre tem sido usado para analisar o fluxo de pedestre, analogamente à análise de faixas de vias veiculares. Entretanto, o conceito de faixa não pode ser usado para análise de pedestre porque observações mostram que pedestres não caminham organizadamente em faixas. O conceito de faixa é observado somente em determinadas pessoas que podem caminhar em linha reta, numa dada largura de faixa, por exemplo, numa calçada estreita que permite somente 2 pedestres passarem por vez. Para evitar interferência quando 2 pedestres passam, cada um deve ter no mínimo 0,80 $\mathrm{m}$ de largura de faixa de pedestre. Quando os pedestres se conhecem um ao outro caminham próximos, cada um ocupando a largura de $0,70 \mathrm{~m}$, permitindo considerável probabilidade de contato devido às oscilações do corpo. Espaçamento menor que este somente ocorre em situações de multidão.

Uma largura livre de faixa de pedestre refere-se, portanto, à porção da faixa de pedestre que pode ser efetivamente usada para caminhar.Os pedestres evitam a proximidade dos meios-fios e não se pressionam em paredes e muros. Assim um espaço não útil deve ser descontado quando analisar uma instalação para pedestres. Igualmente deve-se 
considerar uma faixa vazia para pedestres próxima a construções ou próxima a obstruções físicas, tais como postes de iluminação, caixas de correios, boxes de telefones, etc.

O grau de influência nos movimentos dos pedestres devido a simples obstruções, tais como postes, sinalizações e hidrantes, reduzindo efetivamente a largura da faixa de caminhar, não foi extensivamente documentado. Ainda que um simples ponto de obstrução não possa reduzir efetivamente a largura de toda a calçada, ele terá um efeito nas vizinhanças imediatas.

\subsection{Tipo de Pedestres e Motivos de Viagem}

A análise do fluxo de pedestres, geralmente é baseada na média da velocidade de caminhar do grupo. Dentro do grupo ou entre grupos há consideráveis diferenças nas características de fluxos devido aos motivos de viagem, uso do solo, tipos de grupos, idade e outros fatores.

Pedestres costumam ir e vir a trabalho, usando as mesmas instalações dia após dia, andando em velocidade mais alta do que quando fazendo compras, conforme gráfico IV-1 (Relação entre velocidade de pedestre e a densidade). Pessoas idosas ou muito jovens tendem a andar mais devagar que outros grupos. Pessoas fazendo compras não apenas tendem a andar mais devagar que os que estão transitando em transbordos, assim como param nas frentes de vitrines e carregam pacotes. $\mathrm{O}$ analista pode ajustar $\mathrm{o}$ comportamento dos pedestres que desviam dos padrões regulares representados nas curvas de velocidade básica, volume e densidade. 


\section{MEDIÇÃO DE DESEMPENHO E NÍVEL DE SERVIÇO}

\subsection{Fluxo de Pedestres}

Os critérios de Nível de Serviço para fluxo de pedestre são baseados em medidas subjetivas, que podem se imprecisas. No entanto, é possível definir limites de espaço para pedestres, taxa de fluxos, e velocidades, que então podem ser usados para desenvolver critérios de qualidade de fluxo.

A velocidade é um importante critério para determinar o NS porque pode ser observada e mensurado facilmente e, também, porque descreve o serviço que o pedestre percebe. $\mathrm{Na}$ velocidade de $0,7 \mathrm{~m} / \mathrm{s}$ ou abaixo, muitos pedestres recorrem ao expediente de arrastar os pés. O gráfico IV-4 (Relação entre velocidade do pedestre e o espaço), mostra que esta velocidade corresponde ao espaço para pedestre nos limites de 0,6 a 0,7 $\mathrm{m}^{2} / \mathrm{p}$. Para $1,5 \mathrm{~m}^{2} / \mathrm{p}$ ou menos, até os mais vagarosos dos pedestres são forçados a diminuir a marcha. Os mais rápidos não podem atingir sua velocidade escolhida de 1,8 $\mathrm{m} / \mathrm{s}$, até que um espaço maior que $4 \mathrm{~m}^{2} / \mathrm{p}$ seja disponível. Como apresentado no gráfico IV-2 (Relação entre fluxo de pedestre e espaço), estes 3 valores espaciais: 0,6; 1,5 e 4 $\mathrm{m}^{2} / \mathrm{p}$, correspondem aproximadamente ao máximo fluxo da capacidade, ao $2 / 3$ da capacidade e 1/3 da capacidade, respectivamente.

Há outros significantes indicadores de NS. Por exemplo, a habilidade do pedestre em atravessar uma corrente de pessoas é prejudicada em espaço menor que $3,5 \mathrm{~m}^{2} / \mathrm{p}$, como apresentado gráfico IV-6. Acima deste nível a probabilidade de parar ou quebrar a ritmo de andar é reduzido a zero. Abaixo de $1,5 \mathrm{~m}^{2} / \mathrm{p}$, virtualmente toda tentativa de atravessar encontrará conflitos. Assim também, a habilidade de ultrapassar pedestres mais lentos é inalterada acima de $3,5 \mathrm{~m}^{2} / \mathrm{p}$, mas torna-se progressivamente mais difícil até o espaço alocado cair para $1,8 \mathrm{~m}^{2} / \mathrm{p}$, o ponto em que ultrapassar se torna virtualmente impossível. 


\section{Gráfico IV-6. Fluxo de trânsito numa travessia: probabilidade de conflito}

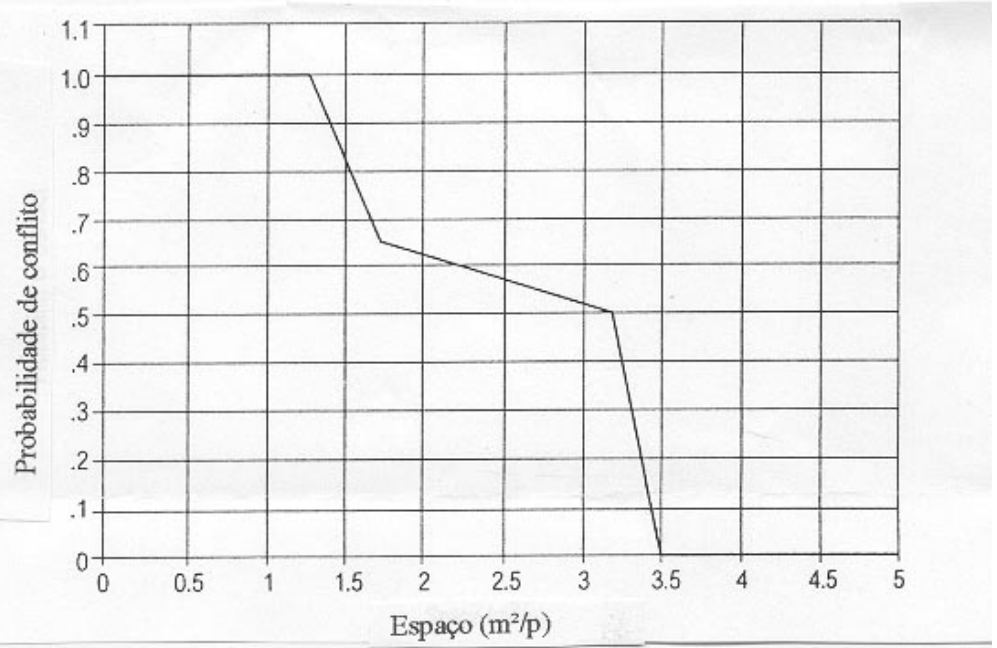

Fonte: HCM 2000 \{TRANSPORTATION(2000)].

Outro indicador de NS é a habilidade de manter o fluxo minoritário contrário ao fluxo principal. Para duas correntes, aproximadamente de igual valor e de fluxo de pedestres em direções contrárias, há uma pequena redução de capacidade na calçada, comparado com uma via de direção única, porque a corrente direcional tende a separar e ocupar uma divisão proporcional da calçada. Entretanto, se a direcional dividir-se em $90 \%$ contra $10 \%$, e o espaço é de $1,0 \mathrm{~m}^{2} / \mathrm{p}$, observou-se que há redução de capacidade em cerca de $15 \%$. Esta redução resulta da inabilidade do fluxo menor usar proporcionalmente a divisão da calçada.

Estudos fotográficos mostram que os movimentos dos pedestres na calçada são afetados por outros pedestres, mesmo quando o espaço for maior que $4 \mathrm{~m}^{2} / \mathrm{p}$. Em $6 \mathrm{~m}^{2} / \mathrm{p}$, observam-se pedestres andando em padrões de fila, andando um atrás do outro ou ao lado um do outro. Esta mesma observação sugere que são necessários acima de $10 \mathrm{~m}^{2} / \mathrm{p}$ para ocorrer a completa liberdade de movimento, sem conflitos; e que a partir de 13 $\mathrm{m}^{2} / \mathrm{p}$, os pedestres, individualmente, não são influenciados pelos outros pedestres. Agrupamentos ou pelotões não desaparecem completamente até o espaço de $50 \mathrm{~m}^{2} / \mathrm{p}$ ou mais. Ilustrações gráficas e descrições de NS de calçadas são apresentadas na figura IV- 
2. Estes critérios de NS são baseados no fluxo médio e não foi considerado o fluxo de pelotões.

O conceito de usar o espaço médio disponível ao pedestre como medida de NS de um passeio, também pode ser aplicado para filas e áreas de espera. Nestas áreas, o pedestre pára temporariamente ou espera ser atendido.

O NS de área de espera é considerado como a média do espaço disponível para cada pedestre e o grau de mobilidade admitido. Em lugares lotados, cheios, há pouco espaço para se movimentar, mas é possível uma circulação limitada, com o aumento da média dos espaços por pedestres.

Para áreas de filas (com pedestres em pé) os NS considerados são baseados na média dos espaços dos pedestres, conforto pessoal e grau de mobilidade interna, apresentados no figura IV-3. Áreas em pé no NS categoria $\mathrm{E}$ de 0,2 a $0,3 \mathrm{~m}^{2} / \mathrm{p}$ são encontradas somente nos mais lotados elevadores ou veículos coletivos. NS D no 0,3 a $0,6 \mathrm{~m}^{2} / \mathrm{p}$, também tipicamente traduzido por lotado, mas com algumas possibilidades de manobras. Isso comumente ocorre em calçadas quando grupos de pedestres esperam atravessar a esquina da rua. Áreas de espera, que requerem mais espaço para circulação, tais como saguão de teatros e plataformas de transportes coletivos, necessitam de NS mais altos. 
PEDESTRE:

MODALIDADE DE TRANSPORTE NA CIDADE UMA VISÃO ERGONÔMICA
Capítulo IV

Desempenho e Nível de Serviço das Instalações para Pedestres

\section{Figura IV-2. Nível de Serviço numa via de pedestre Fonte: HCM 2000 [TRANSPORTATION(2000)]}

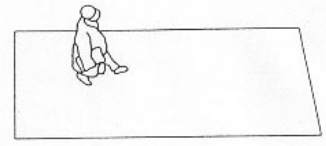

NS A

Espaço de pedestre $>5,6 \mathrm{~m}^{2} / \mathrm{p}$ Fluxo $\leq 16 \mathrm{p} / \mathrm{min} / \mathrm{m}$

No passeio com Nível de Serviço A, o pedestre escolhe a sua passada, sem alterar seus movimentos em função de outros pedestres. A velocidade de caminhar é livremente selecionada, e não há probabilidade de conflitos entre pedestres.

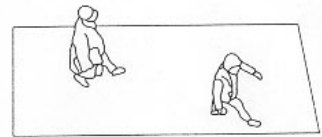

NS B

Espaço de pedestres $>3,7-5,6 \mathrm{~m}^{2} / \mathrm{p}$ Fluxo $>16-23 \mathrm{p} / \mathrm{min} / \mathrm{m}$

No Nível de Serviço B, há suficiente área para o pedestre selecionar a velocidade de caminhar livremente, para ultrapassar outros pedestres, e para evitar conflitos ao executá-lo. Neste Nível, o pedestre começa a se preocupar com outros pedestres, e a responder pela sua presença quando, for selecionar a velocidade de seus passos.

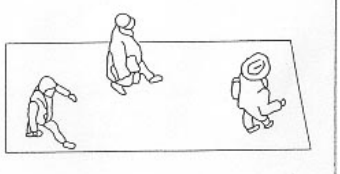

NS C

Espaço de pedestre $>2,2-3,7 \mathrm{~m}^{2} / \mathrm{p}$ Fluxo $>23-33 \mathrm{p} / \mathrm{min} / \mathrm{m}$

No Nível de Serviço C, o espaço é suficiente para uma velocidade normal de caminhar, e para ultrapassar outros pedestres numa corrente unidirecional principal.Andar em direção oposta ou os movimentos de cruzar o fluxo podem causar pequenos conflitos, e tanto a velocidade como o fluxo são mais baixa que nos níveis anteriores.

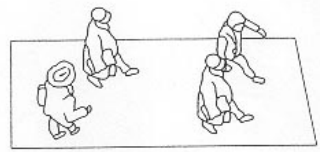

NS D

Espaço de pedestre $>1,4-2,2 \mathrm{~m}^{2} / \mathrm{p}$ Fluxo $>33-49 \mathrm{p} / \mathrm{min} / \mathrm{m}$

Neste Nível de Serviço D, a liberdade de selecionar uma velocidade de caminhar individual e de ultrapassar outros pedestres é restrita. Haverá grande probabilidade de conflito ao cruzar o fluxo ou andar em direção oposta, requerendo freqüente mudança de velocidade e posição. O Nível de Serviço provê razoável fluidez, mas é possível haver atritos (fricção) e interação entre pedestres.

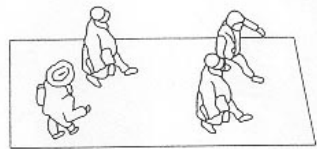

NS E

Espaço de pedestre $>0,75-1,4 \mathrm{~m}^{2} / \mathrm{p}$. Fluxo $>49-75 \mathrm{p} / \mathrm{min} / \mathrm{m}$

Neste Nível de Serviço E, virtualmente todos os pedestres restringem suas velocidades de caminhar, freqüentemente ajustando seu jeito. Numa limitada área, movimentos para frente é possível somente arrastando os pés. O espaço não é suficiente para ultrapassar pedestres mais lentos. Atravessar o fluxo ou andar em direção contrária são movimentos possíveis somente com extrema dificuldade. Projetar volumes, abordando o limite da capacidade do passeio, com paradas e interrupções do fluxo.

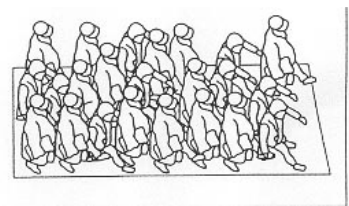

NS F

Espaço de pedestre $\leq 0,75 \mathrm{~m}^{2} / \mathrm{p}$ Fluxo variável $\mathrm{p} / \mathrm{min} / \mathrm{m}$

No Nível de Serviço F, as velocidades de caminhar são severamente restritas, e andar para frente somente arrastando os pés. È freqüente e inevitável o contato com outros pedestres. Atravessar ao fluxo ou andar em direção contrária são movimentos virtualmente impossíveis. O fluxo é esporádico e instável. O espaço é mais característico de filas de pedestres que de corrente em movimento. 
Figura IV-3.Nível de Serviço nas áreas de Filas.

Fonte: HCM 2000 [TRANSPORTATION(2000)]

NS A

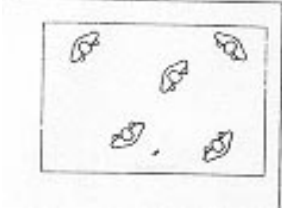

Espaço Médio de Pedestres $>1,2 \mathrm{~m}^{2} / \mathrm{p}$

Nesta situação é possível o pedestre, de pé, circular livre através da área de fila sem perturbar outras pessoas da fila.

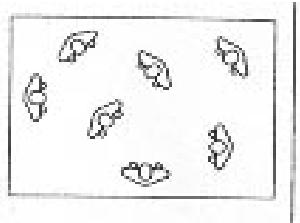

NS B

Espaço Médio de Pedestre $>0,9-1,2 \mathrm{~m}^{2} / \mathrm{p}$

O pedestre, de pé tem a circulação parcialmente restrita a fim de evitar perturbar outras pessoas da fila.

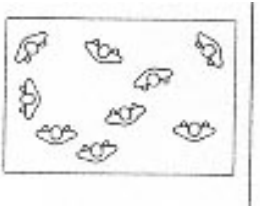

NS C

Espaço Médio de Pedestre $>0,6-0,9 \mathrm{~m}^{2} / \mathrm{p}$

O pedestre, de pé tem a circulação restrita através da área de fila, é possível haver perturbação as outras pessoas na fila: esta densidade está dentro do limite do conforto pessoal.

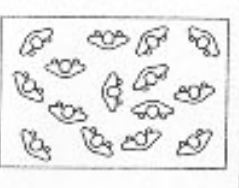

NS D

Espaço Médio de Pedestre $>0,3-0,6 \mathrm{~m}^{2} / \mathrm{p}$

É possível ficar de pé sem tocar nas pessoas: a circulação é severamente restrita dentro da fila e movimentos para frente só é possível como um grupo, isto é, todos movimentando-se em conjunto; um tempo de espera muito longo nesta densidade é desconfortável

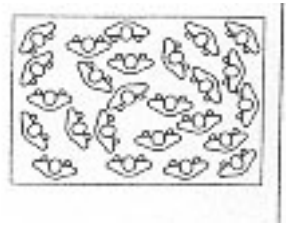

NS E

Espaço Médio de Pedestre $>0,2-0,3 \mathrm{~m}^{2} / \mathrm{p}$

De pé o contato físico com outras pessoas é inevitável: a circulação na fila não é possível; a fila pode somente ser sustentada por um curto período de tempo, sem sérios desconfortos.

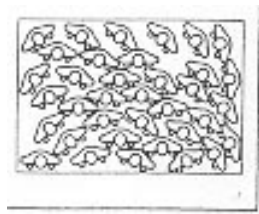

NS F

Espaço Médio de Pedestre $\leq 0,2 \mathrm{~m}^{2} / \mathrm{p}$

Virtualmente todas as pessoas dentro da fila estão de pé com contato físico um com outro; esta densidade é extremamente desconfortável; nenhum movimento é possível na fila; há potencial para pânico numa multidão nesta densidade. 


\section{Gráfico IV-7 Variação de fluxo de pedestre, minuto a minuto.}

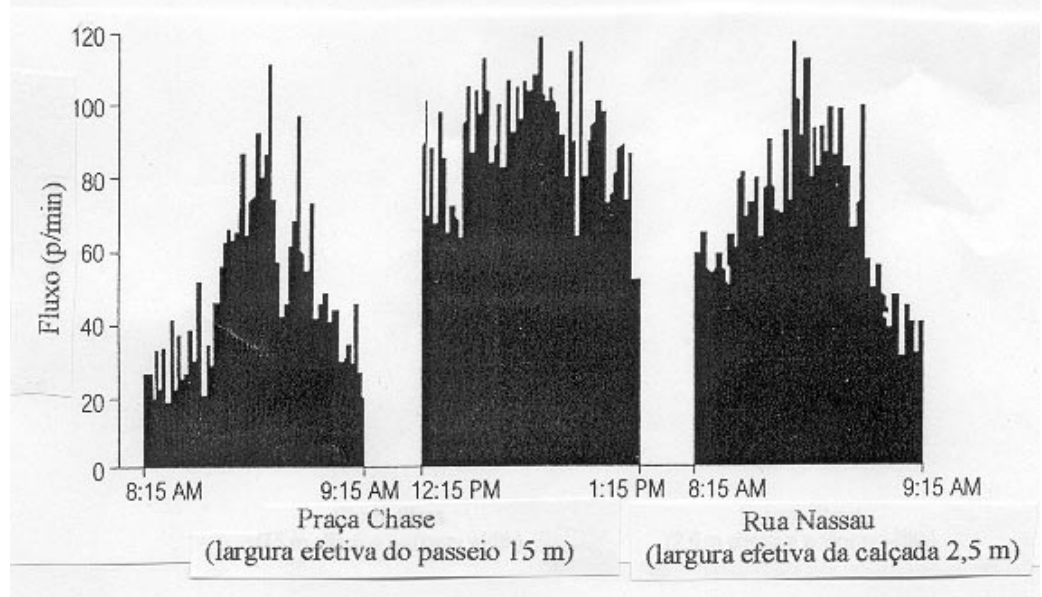

Fonte: HCM 2000 [TRANSPORTATION(2000)].

\subsection{Pelotões de Pedestres}

As taxas de fluxo médio nos diferentes Níveis de Serviço (NS) são de limitada utilidade, a menos de razoável intervalo de tempo especificados.

O gráfico IV-7 mostra que a taxa de fluxo médio pode ser enganosa. Os dados mostram dois locais na cidade de Nova York, mas o padrão é geralmente característica de distrito concentrado de negócios. A taxa máxima de fluxo de 15-min representa média de 4,5 e $6,0 \mathrm{p} / \mathrm{min} / \mathrm{m}$ na efetiva largura de calçada, durante o período mensurado. Entretanto, o gráfico IV-7 mostra que o fluxo durante o intervalo de 1-min pode ter mais que o dobro da taxa em outro, particularmente no relativo baixo fluxo. Até durante o pico do período de 15-min, a variação incremental de 50 a 100\% freqüentemente ocorre de 1 minuto para o próximo.

Dependendo dos padrões de trânsito, uma instalação projetada para um fluxo médio pode proporcionar baixa qualidade de fluxo para esta porção de trânsito de pedestre. No entanto não é prudente projetar para o extremo pico de fluxo de 1-min, que ocorre somente $1 \%$ ou $2 \%$ do tempo. Um significativo período de tempo pode ser determinado através de evolução aproximativa de flutuações de curto-termo do fluxo de pedestres. 
Flutuações de curto-termo aparecem em muitos fluxos de trânsito de pedestres não regulares, devido às chegadas randômicas dos pedestres. Nas calçadas, estas flutuações são exageradas pela interrupção de fluxos e formação de filas formadas pelas sinalizações e trânsito. Equipamentos de trânsito podem criar adicionais ondas adicionais na demanda devido à saída em grandes grupos de pedestres em intervalo curtos de tempo, seguidos de intervalos durante os quais não ocorre fluxo algum.

Até a sua dispersão, neste tipo de grupo, os pedestres movem-se juntos, como um pelotão. A figura IV-4 representa fluxos de pelotões numa travessia em intersecção. Pelotões também podem formar-se quando a ultrapassagem é impedida por causa de espaço insuficiente, pois pedestres mais rápidos são atrasados pelos mais lentos.

Apesar de magnitude e freqüência de pelotões poderem ser verificados pelo estudo de campo, o NS em pelotões geralmente está em patamar mais baixo que a média dos fluxos simples, exceto para alguns casos de NS "A" e "E", que envolvem um grande alcance de fluxo de pedestres.

Selecionar um projeto, para acomodar tanto a média dos fluxos sobre um longo período quanto de ondas em demanda ocorrendo em pelotões, requer uma avaliação de conveniência para pedestres, espaços disponíveis, custo e considerações políticas.

O diagrama de dispersão apresentado no gráfico IV-8 compara a taxa de fluxo de pelotão (i.é, a taxa de fluxo dentro de pelotões de pedestres) com a média da taxa de fluxo por período de 5 a 6 min de duração. A linha aproxima o limite superior do fluxo de pelotões observados. 
PEDESTRE:

MODALIDADE DE TRANSPORTE NA CIDADE UMA VISÃO ERGONÔMICA
Capítulo IV

Desempenho e Nível de Serviço das Instalações para Pedestres

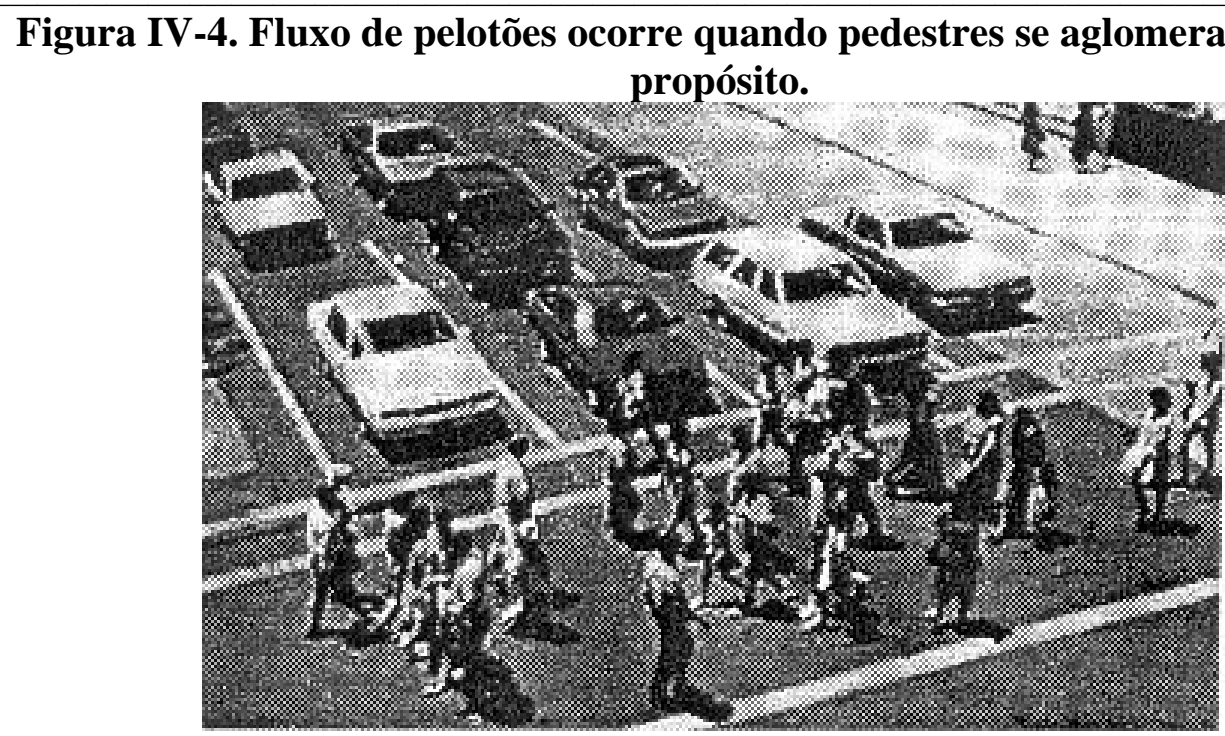

Fonte: HCM 2000 [TRANSPORTATION(2000)]

\section{Gráfico IV-8 Relação entre pelotões e fluxo médio}

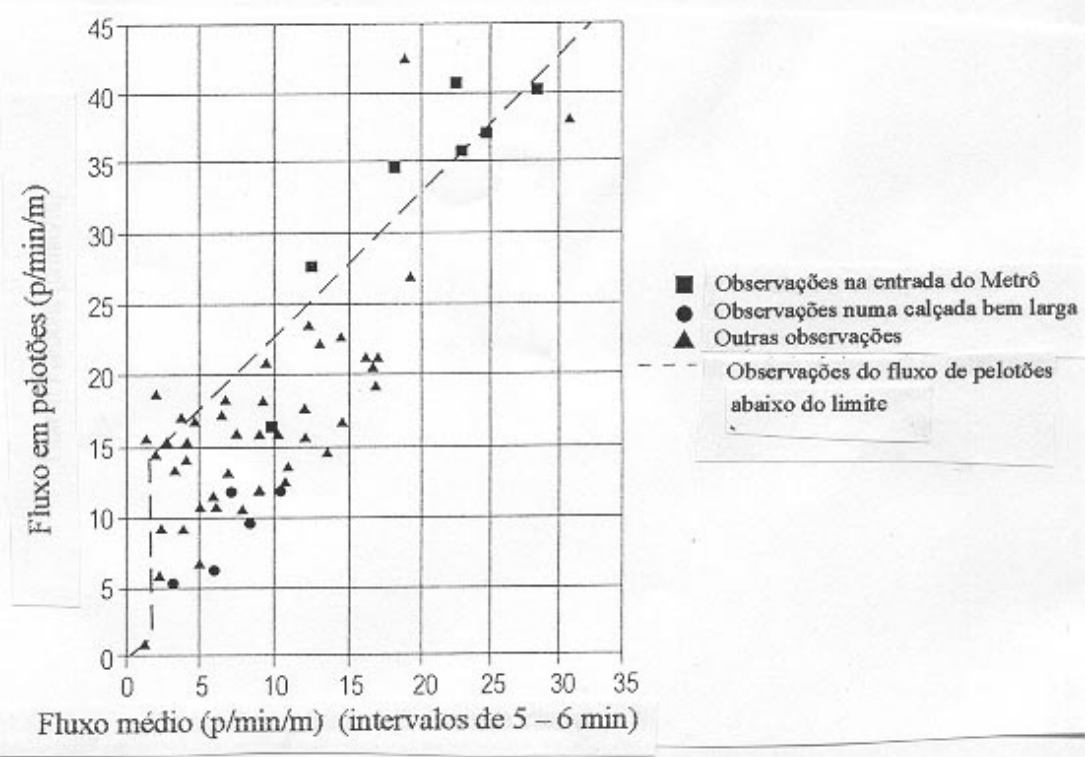

Fonte: HCM 2000 [TRANSPORTATION(2000)\}

3.3 Dados de Entrada Requeridos e Valores Estimados

A tabela IV-1 lista valores representativos que podem ser usados como parâmetros de entradas, na falta de dados locais. $\mathrm{O}$ analista pode notar que tomar medidas de campo para uso como entrada tem mais significado que adotar parâmetros com valores 
genéricos. Somente quando isto não é possível recomenda-se usar os valores representativos.

\section{Tabela IV-1 Dados de Entrada Requeridos e Valores Representativos para Pedestres}

\begin{tabular}{l|c}
\hline \multicolumn{1}{c|}{ Item } & Valores Representativos \\
\hline Dados Geométricos & - \\
Comprimento da calçada & $1,5 \mathrm{~m}$ \\
Largura efetiva & Tabela 4 \\
Raio de curvatura da esquina & - \\
Tamanho da travessia & \\
& \\
\hline Dados de Demanda & - \\
Período de análise & Equação 3 \\
Número de pedestres em pelotão & $1,2 \mathrm{~m} / \mathrm{s}$ \\
Velocidade de caminhar do pedestre & $3,0 \mathrm{~s}$ \\
Tempo de travessia do pedestre & \\
& \\
\hline Dados da Intersecção & Observação nas vias urbanas \\
\hline Vias Urbanas & \\
\hline Fonte: HCM 2000 [TRANSPORTATION(2000)]
\end{tabular}

Fonte: HCM 2000 [TRANSPORTATION(2000)]

\section{Comprimento de calçadas}

O comprimento das calçadas pode ser assumido como, aproximadamente, igual àquele utilizado nas calçadas das vias urbanas.

\section{Largura efetiva}

A American Association of State Highway and Transportation Officials (AASHTO) (citado em [TRANSPORTATION(2000)] ) recomenda que a largura da passagem livre deve ter 1,5 m no mínimo. Pode se necessária largura de 2,4 m ou maior, em áreas comerciais. Se houver equipamentos viários nas adjacências do meio fio da calçada, serão necessárias larguras adicionais para assegurar a passagem livre. Valores representativos listados em tabela IV-2 podem ser usados na ausência de dados locais. 


\section{Tabela IV-2 Largura representativa para calçadas}

\begin{tabular}{l|c}
\hline \multicolumn{1}{c|}{ Condição } & Largura (m) \\
\hline Zona de Proteção entre o meio-fio e a calçada & 1,5 \\
Sem zona de proteção entre o meio-fio e a calçada & 2,1 \\
\hline
\end{tabular}
Fonte: HCM 2000 [TRANSPORTATION(2000)].

A largura efetiva de travessias sinalizadas e não sinalizadas variam de acordo com os padrões locais. Se não se dispuser de dados locais os valores considerados de 3,6 m podem ser adotados como largura de travessia.

\section{Raio de curvatura de uma esquina de rua.}

O raio de curvatura de uma esquina de rua depende de vários fatores, incluindo a velocidade dos veículos, do ângulo de intersecção, os tipos de veículos que farão a curva, e limitações de conversão à direita, nas calçadas. Por exemplo, raios requeridos para caminhões e ônibus são mais longos do que aqueles para os veículos de passageiros. A tabela IV-3 lista os raios de curvatura que podem ser assumidos quando o analista não tem as medidas reais.

\section{Tabela IV-3 Raios de Curvatura de Esquinas Representativas}

\begin{tabular}{c|c}
\hline Composição de trânsito veicular & Raio de curvatura (m) \\
\hline Com conversão de caminhões e ônibus & 13,0 \\
Sem conversão de caminhões e ônibus & 7,3 \\
\hline
\end{tabular}

Fonte: HCM 2000 [TRANSPORTATION(2000)]

\section{Comprimento de travessia}

O comprimento de travessia é a soma das larguras das faixas de aproximação, a faixa propriamente dita e as linhas adjacentes.

\section{Período de Análise}

Planejamento, projeto, políticas e recursos, determinam o período de análise.A duração típica de um período de análise é 15 min. É difícil predizer os fluxos padrões, tais como 
os pelotões, baseados num período de análise muito longo. A calçada no meio do quarteirão pode contar com muitas variações diferentes nos períodos de 15 min durante o dia, estabelecendo variações nos fluxos direcionais.

\section{Número de Pedestres no Pelotão}

Numa travessia de intersecção sinalizada, o semáforo pode aumentar ou diminuir o tempo de espera do pedestre, dependendo do dimensionamento do tempo verde do sinal. Assim, o número de pelotões na intersecção sinalizada depende dos tempos de sinais e do dimensionamento do tempo verde.

O número de pedestres numa travessia de intersecção não sinalizada é determinado pelos pedestres e fluxo de veículos. Equação 3 pode ser usada para calcular o número de pedestres num pelotão:

$\mathrm{Nc}=\frac{V p \cdot e^{V p \cdot T c}+V \cdot e^{-V T c}}{(V p+V) \cdot e^{(V p-V) T c}}$

onde $\mathrm{Nc}=$ tamanho de um pelotão de pedestres típico numa travessia $(\mathrm{p})$.

$\mathrm{Vp}=$ taxa de fluxo de pedestre $(\mathrm{p} / \mathrm{s})$,

$\mathrm{V}=$ Taxa de fluxo veicular (veí/s),

$\mathrm{Tc}=$ intervalo crítico para um pedestre sozinho.

\section{Velocidade de caminhar de um pedestre}

Os pedestres apresentam um grande espectro na velocidade de caminhar, variando de $0,8 \mathrm{~m} / \mathrm{s}$ a $1,8 \mathrm{~m} / \mathrm{s}$. Os mais idosos geralmente caminham na faixa mais baixa do espectro. O Manual de Equipamentos de Controle de Tráfego Uniforme, assume a velocidade de caminhar de $1,2 \mathrm{~m} / \mathrm{s}$ para tempo sinalização de travessia. Velocidade de caminhar no meio do passeio é mais rápida que nas intersecções. Os homens também são mais velozes que as mulheres. A velocidade também é afetada pela declividade (subida), pela temperatura do ar, hora do dia, propósito da viajem, chuva e vento. 
$\overline{\text { Para trânsito livre sem fricções existe uma gama variada de velocidades de pedestres, }}$ conforme apresentado na tabela IV-4 abaixo, segundo Fruin [FRUIN(1971)].

Tabela IV-4. Média do fluxo livre de velocidade de pedestres

\begin{tabular}{c|c|c}
\hline Composição do Fluxo de Pedestres & \multicolumn{2}{|c}{ Velocidade } \\
\hline Homens & $94 \mathrm{~m} / \mathrm{min}$ & $1,6 \mathrm{~m} / \mathrm{seg}$ \\
\hline Mulheres & $77 \mathrm{~m} / \mathrm{min}$ & $1,3 \mathrm{~m} / \mathrm{seg}$ \\
\hline Misto & $81 \mathrm{~m} / \mathrm{min}$ & $1,4 \mathrm{~m} / \mathrm{seg}$ \\
\hline
\end{tabular}

Fonte: Fruin [FRUIN(1971)]

A redução por causa da idade não é muito significativa, estando em torno de $14 \%$ : de $84 \mathrm{~m} / \mathrm{min}$, para a idade de 20 a 25 anos, reduz-se para $66 \mathrm{~m} / \mathrm{min}$ para 81 a 87 anos.

O elemento que mais restringe a velocidade é a densidade, decrescendo em função da ocupação, de uma situação de parada para uma área de $0,23 \mathrm{~m}^{2} /$ ped a velocidade de $76,2 \mathrm{~m} / \mathrm{min}$ para áreas superiores a $4,65 \mathrm{~m}^{2} /$ ped.

\section{Tempo (duração) de uma travessia}

Pesquisadores têm estudado o tempo de uma travessia em mais de 4.000 voluntários pedestres. Pelotões não são afetados na travessia nem os idosos e nem os jovens pedestres. Valores representativos para a travessia são listados na tabela IV-5 e podem ser usados na ausência de dados locais. Um valor razoável de 3,0 s pode ser assumido na ausência de dados locais.

Tabela IV-5. Valores Representativos para Travessia

\begin{tabular}{l|c|c}
\hline \multirow{2}{*}{ Tipologia } & \multicolumn{2}{|c}{ Tempo de travessia (s) } \\
\cline { 2 - 3 } & $50^{\circ}$ percentil & $85^{\circ}$ percentil \\
\hline Homem jovem & 1,8 & - \\
Mulher jovem & 2,0 & - \\
Homem idoso & 2,4 & 3,7 \\
Mulher idosa & 2,6 & 4,0 \\
\hline
\end{tabular}

Fonte: HCM 2000 [TRANSPORTATION(2000)] 


\section{Tabela de Volume de Serviço}

A tabela IV-6 apresenta os Níveis de Serviço relativos ao volume de pedestres para uma calçada com $1,5 \mathrm{~m}$ de largura efetiva.

Tabela IV-6. Nível de Serviço para Volumes de Pedestres numa Calçada

\begin{tabular}{c|c}
\hline Nìvel de Serviço & Volume de Pedestres 15-Min \\
\hline A & 360 \\
\hline B & 525 \\
\hline C & 750 \\
\hline D & 1100 \\
\hline E & 1700 \\
\hline
\end{tabular}

Fonte: HCM 2000 [TRANSPORTATION(2000)]. 


\section{ANÁLISE DE CAPACIDADE E NÍVEL DE SERVIÇO}

\subsection{Tipos de Instalações}

Este tópico é destinado à análise de capacidade e nível de serviço das instalações para pedestres. Os procedimentos serão apresentados especificamente para determinados tipos de instalações para pedestres.

-Passeios e calçadas - instalações tais como terminais, calçadas, escadas e passagens designados exclusivamente para pedestres.

-Áreas de filas para pedestres - áreas onde pedestres permanecem em pé, temporariamente, enquanto esperam ser atendidos. Filas são encontradas em elevadores, plataformas de coletivos e travessia de ruas.

- Passagens compartilhadas - passagens fisicamente separadas do trânsito de estradas para uso de pedestres, bicicletas, skates e outros não motorizados.

- Travessia de pedestres - travessias sinalizadas e não-sinalizadas

- Instalações para pedestres ao longo das ruas - calçadas destinadas aos pedestres nas vias urbanas, incorrendo nos impactos tanto dos fluxos não interrompidos como nas interrupções fixas.

\subsection{Metodologia.}

A metodologia provê um esquema para a avaliação das instalações para pedestres. $\mathrm{O}$ analista poderá investigar os efeitos das bicicletas e das sinalizações de trânsito nas instalações para os pedestres, assim como os efeitos do volume de pedestres no fluxo e no Nível de Serviço (NS).

\subsection{Nível de Serviço - NS}

Os limites dos NS são dados pela análise de cada tipo de instalações para pedestres, porque as medidas de desempenho variam. 


\subsection{Determinação de Velocidade de Caminhar dos Pedestres}

A velocidade de caminhar depende da proporção de idosos (65 anos ou mais) na população de pedestres. Se 0 a $20 \%$ de pedestres são idosos, para fins de cálculo de passeios e calçadas a velocidade de $1,2 \mathrm{~m} / \mathrm{s}$. Se os idosos constituem mais de $20 \%$ de todos os pedestres a velocidade recomendada será de $1,0 \mathrm{~m} / \mathrm{s}$. Um acréscimo de $10 \%$ ou mais no número de idosos implicará reduzir a velocidade em $0,1 \% \mathrm{~m} / \mathrm{s}$.

\subsection{Determinação da Largura Efetiva de um Passeio}

A largura efetiva de um passeio é a porção do passeio que pode ser usada efetivamente pelos pedestres. Muitos tipos de obstruções de passeios tendem a dificultar os pedestres.

A largura efetiva do passeio pode ser composta usando a equação 4, abaixo;

$$
\mathrm{We}=\mathrm{Wt}-\mathrm{Wc} \quad(\text { equação } 4)
$$

Onde $\mathrm{We}=$ largura efetiva do passeio $(\mathrm{m})$

$\mathrm{Wt}=$ Largura total do passeio $(\mathrm{m})$

$\mathrm{Wc}=$ Soma das larguras das obstruções nos passeios e suas influências (m).

Um esquema típico de obstruções e largura estimado é apresentado na figura IV-5.

Figura IV-5. Larguras variáveis para obstáculos fixos.

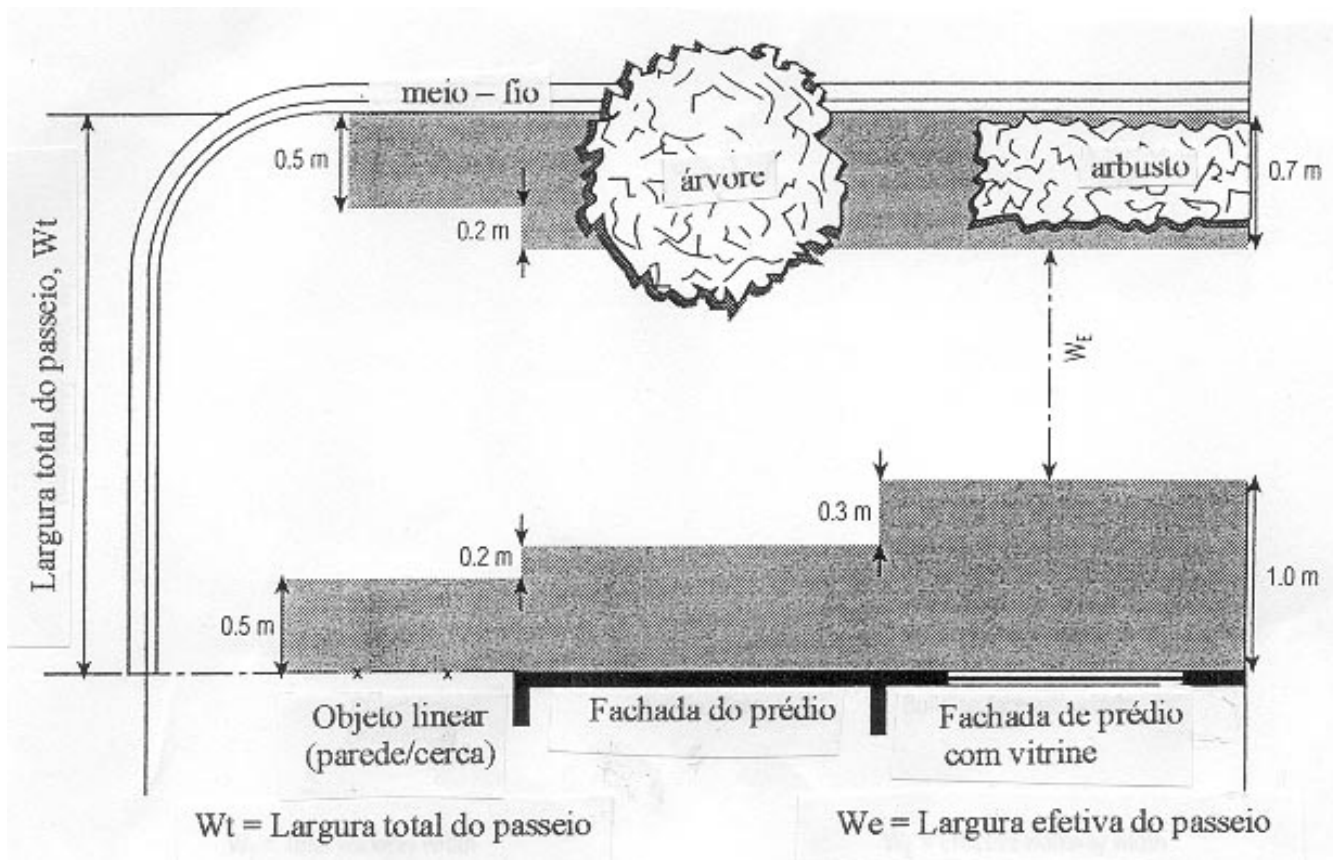

Fonte: HCM 2000 [TRANSPORTATION(2000)] 
$\overline{\text { A lista a seguir (tabela IV-7) apresenta largura de passeios com as obstruções devidas ao }}$ meio fio, construções ou objetos fixos. Os valores podem ser usados quando não estiverem disponíveis as configurações específicas. No capítulo II, desta tese, foi apresentado o "Decreto $\mathrm{n}^{\mathrm{o}} 45.904$ / 2005", que trata do dimensionamento e caracterização de calçadas, para as calçadas do município de São Paulo.[SÃO PAULO(2005)].

O comprimento efetivo de uma obstrução ocasional é assumido ser 5 vezes sua largura efetiva. A largura média resultante de obstruções ocasionais, tais como as árvores e postes, portanto, pode ser obtida pela média dos produtos de suas efetivas larguras pela proporção de seus efetivos comprimentos com a distância média entre eles.

Também, nas intersecções sinalizadas, o analista pode observar se a conversão à direita dos veículos ocupa parte da faixa de travessia durante a fase de travessia. Se a porção significativa da travessia não é usada pelos pedestres devido à conversão à direita dos veículos, pode ser computada uma largura de travessia efetiva pela subtração do apropriado tempo-espaço usado pelos veículos na conversão. 


\section{Tabela IV-7. Largura de obstáculos nas calçadas}

\section{Mobiliário Urbano \\ Tipos de Obstáculos}

Largura aproximada (m)

Poste de iluminação

Caixas e postes de sinalização de trânsito

Caixa de alarme de incêndio

Hidrante

Sinalização de trânsito

Equipamento para estacionamento

Caixa de correio $(0,5 \mathrm{~m} \times 0,5 \mathrm{~m})$

Telefones $(0,8 \mathrm{~m} \times 0,8 \mathrm{~m})$

Lixeiras

$$
\begin{gathered}
0,8-1,1 \\
0,9-1,2 \\
0,8-1,1 \\
0,8-0,9 \\
0,6-0,8 \\
0,6 \\
1,0-1,1 \\
1,2 \\
0,9 \\
1,5
\end{gathered}
$$

Bancos

\section{Acesso a metrôs subterrâneos}

Escadas subterrâneas

Grades de ventilação, aparentes

Grades de ventilação, com cobertura aparente

\section{Paisagismo}

Árvores

Cercado para plantas

$0,6-1,2$ 1,5

\section{Usos Comerciais}

Bancas de jornal

Quiosques de vendas

Displays de propagandas

Totem de displays

Café na calçada (2 mesas)

\section{Saliências de Construções}

Colunas

Porta de entrada com pequena varanda

Portas vai-e-vem

Respiradouros

Postes para toldos

Avanço para acostar caminhões

Entrada e saída de garagem

Passagem de veículos
$1,7-2,1$

$1,8+$

$1,5+$
$1,2-4,0$

variável

variável

variável 2,1

Fonte: HCM 2000 [TRANSPORTATION(2000)].

Nota: Para calcular a distância de segurança entre pedestres e obstáculos acrescenta-se 0,3 a 0,5 $\mathrm{m}$ da largura dos obstáculos individuais. As larguras são medidas a partir do meio fio até o limite do objeto, ou da face da construção ao limite do objeto. 


\subsection{Instalações para Fluxos Não Interrompidos de Pedestres}

Instalações para pedestres com fluxo não interrompidos incluem tanto os caminhos exclusivos como aqueles compartilhados, designados para uso de pedestres. Estas instalações são exclusivas para os pedestres, que não experimentam qualquer interrupção, exceto a interação com outros pedestres, e em caminhos compartilhados, com outros modos não motorizados de transportes.

\subsubsection{Passeios e Calçadas}

Passeios e calçadas são separados do trânsito de veículos motorizados e tipicamente não permitem bicicletas e outros usuários, que não os pedestres. Estas instalações são freqüentemente construídas para servir aos pedestres nas ruas das cidades, aeroportos, metrôs e terminais de ônibus.

Estas instalações de pedestres incluem seções determinadas de calçadas, terminais, escadas e áreas de travessias, por onde atravessam correntes de pedestres. Tais instalações acomodam os mais altos volumes de pedestres dentre os três tipos de instalações com fluxo não interrompido, aqui designado (passeios e calçadas, área de filas e instalações compartilhadas com bicicletas); também provêm os mais altos NS, porque os pedestres não compartilham as instalações com outras modalidades de viajem com maior velocidade.

Espaço pode ser diretamente observado no campo pela medição de amostras de áreas da instalação e determinação do máximo número de pedestres por um dado período de tempo. A velocidade também pode ser observada prontamente no campo e pode ser usado como critério suplementar para analisar o passeio ou a calçada. 
Para simplificar as observações de campo, a taxa de fluxo de pedestres pode ser usada como uma medida de serviço. A contagem de pico de 15 min e a efetiva largura do passeio é requerida para calcular a taxa de fluxo de acordo com a equação 5, abaixo:

$\mathrm{Vp}=\frac{V 15}{15 * W e} \quad($ equação 5$)$

Onde $\mathrm{Vp}=$ taxa de fluxo de pedestres $(\mathrm{p} / \mathrm{min} / \mathrm{m})$

$\mathrm{V} 15$ = Taxa de fluxo do pico de 15 minutos

$\mathrm{We}=$ Largura efetiva do passeio.

A razão do volume sobre a capacidade $(\mathrm{v} / \mathrm{c})$ pode ser calculada assumindo-se 75 $\mathrm{p} / \mathrm{min} / \mathrm{m}$ para a capacidade.

A tabela seguinte (tabela IV-8) lista o critério para NS dos pedestres nos passeios. Isto inclui as medidas de serviço do espaço e dos critérios suplementares de unidade de taxa de fluxo, velocidade e razão v/c.

Notar que os limites de NS resumidos nesta tabela não contam para fluxos de pelotões, mas assume a média de fluxo através de largura efetiva.

Tabela IV-8 Critério de NS para Fluxos Médios em Passeios e Calçadas

\begin{tabular}{|c|c|c|c|c|}
\hline NS & Espaço $\left(\mathrm{m}^{2} / \mathrm{p}\right)$ & $\begin{array}{c}\text { Taxa de Fluxo } \\
(\mathrm{p} / \mathrm{min} / \mathrm{m})\end{array}$ & $\begin{array}{c}\text { Velocidade } \\
(\mathrm{m} / \mathrm{s})\end{array}$ & Razão v/c \\
\hline A & $>5,6$ & $\leq 16$ & $>1,3$ & $\leq 0,21$ \\
\hline B & $>3,7-5,6$ & $>16-23$ & $>1,27-1,30$ & $>0,21-0,31$ \\
\hline $\mathrm{C}$ & $>2,2-3,7$ & $>23-33$ & $>1,22-1,27$ & $>0,31-0,44$ \\
\hline D & $>1,4-2,2$ & $>33-49$ & $>1,14-1,22$ & $>0,44-0,65$ \\
\hline $\mathbf{E}$ & $>0,75-1,4$ & $>49-75$ & $>0,75-1,14$ & $>0,65-1,0$ \\
\hline $\mathbf{F}$ & $\leq 0,75$ & Variável & $\leq 0,75$ & Variável \\
\hline
\end{tabular}

] Fonte: HCM 2000 [TRANSPORTATION(2000)]

É importante para o analista determinar se pelotões ou outros padrões de trânsito alteraram subliminarmente seus cálculos. Para tais casos recorrer aos estudos abaixo discriminados. 


\section{Efeito de pelotões em passeios e calçadas}

A tabela IV-9 resume os limites para a taxa de fluxo médio quando há formação de pelotões. Pesquisas indicam que o fluxo difícil começa com $49 \mathrm{~m}^{2} / \mathrm{p}$, que é equivalente a 1,6 p/min $/ \mathrm{m}$. Este valor é usado como limite para o NS “A”. A mesma pesquisa relata que aquele fluxo acumulado em pelotões inicia-se a $1,0 \mathrm{~m}^{2} / \mathrm{p}$, o que equivale a 59 $\mathrm{p} / \mathrm{min} / \mathrm{m}$. Este valor é usado como o limite de NS "F".

\section{Efeito de pelotões nos Terminais de Transporte}

Terminais de transporte apresentam um especial caso de fluxo de pelotões. São os verificados em aeroportos, terminais de ônibus e outros locais, onde o comportamento de pelotões é comum.

Tabela IV-9. Critérios de NS ajustados para pelotões em passeios e calçadas

\begin{tabular}{|c|c|c|}
\hline NS & Espaço $\left(\mathrm{m}^{2} / \mathrm{p}\right)$ & Taxa de fluxo* $(\mathrm{p} / \mathrm{min} / \mathrm{m})$ \\
\hline $\mathbf{A}$ & $>49$ & $\leq 1,6$ \\
\hline B & $>8-49$ & $>1,6-10$ \\
\hline $\mathbf{C}$ & $>4-8$ & $>10-20$ \\
\hline $\mathbf{D}$ & $>2-4$ & $>20-36$ \\
\hline $\mathbf{E}$ & $>1-2$ & $>36-59$ \\
\hline $\mathbf{F}$ & $\leq 1$ & $>59$ \\
\hline
\end{tabular}

Fonte : HCM 2000 [TRANSPORTATION(2000)]

\section{Escadas}

Pesquisa tem desenvolvido os limites de NS baseados no "Padrão de Escadas do Instituto de Engenharia de Transportes", que provê espaço e valores de fluxo listados na tabela IV-10,a seguir.

Estas modificações nos critérios de NS são para se certificar que as equações básicas de fluxo de trânsito estão satisfeitas. As razões volume sobre a capacidade v/c são baseadas na capacidade de $49 \mathrm{p} / \mathrm{min} / \mathrm{m}$. 


\section{Tabela IV-10. Os critérios de NS para Escadas}

\begin{tabular}{|cllll|}
\hline NS & Espaço $\left(\mathbf{m}^{2} / \mathbf{p}\right)$ & $\begin{array}{l}\text { Taxa de fluxo } \\
(\mathbf{p} / \mathbf{m i n} / \mathbf{m})\end{array}$ & $\begin{array}{l}\text { Veloc. Horiz. } \\
\text { Média }(\mathbf{m} / \mathbf{s})\end{array}$ & Razão v/c \\
\hline A & $>1,9$ & $\leq 16$ & $>0,53$ & $\leq 0,33$ \\
\hline B & $>1,6-1,9$ & $>16-20$ & $>0,53$ & $>0,33-0,41$ \\
\hline C & $>1,1-1,6$ & $>20-26$ & $>0,48-0,53$ & $>0,41-0,53$ \\
\hline D & $>0,7-1,1$ & $>26-36$ & $>0,42-0,48$ & $>0,53-0,73$ \\
\hline E & $>0,5-0,7$ & $>36-49$ & $>0,40-0,42$ & $>0,73-1,00$ \\
\hline F & $\leq 0,5$ & Variável & $\leq 0,40$ & Variável \\
\hline
\end{tabular}

Fonte: HCM 2000 [TRANSPORTATION(2000)]

\section{Fluxo de Travessia}

Um fluxo de travessia é um fluxo de pedestres que atravessa outro fluxo de pedestres aproximadamente em perpendicular. Em geral, o menor dos dois fluxos é submetido às condições do fluxo de travessia. Pesquisas notam que fluxos de travessia de pedestres ocorrem em saguões e corredores. O mesmo procedimento para estimar um passeio ou o espaço de uma calçada é usado para analisar as instalações para pedestres com fluxo de travessia. Os critérios de NS "A" a "D" são usados a partir da tabela IV-9. Se são observados pelotões, a partir da tabela IV-11. Além disso, a tabela IV-11 lista o NS "E" para instalações com fluxo de travessia.

Tabela IV-11. Critério de NS para fluxo de Pedestres com Travessia

\begin{tabular}{|ccccc|}
\hline NS & Espaço $\left(\mathbf{m}^{2} / \mathbf{p}\right)$ & $\begin{array}{c}\text { Fluxo } \\
(\mathbf{p} / \mathbf{m i n} / \mathbf{m})\end{array}$ & $\begin{array}{c}\text { Velocidade } \\
(\mathbf{m} / \mathbf{s})\end{array}$ & $\begin{array}{c}\text { Densidade } \\
\left(\mathbf{p} / \mathbf{m}^{2}\right)\end{array}$ \\
\hline $\mathbf{E}$ & $\geq 1,25$ & $\leq 75$ & $\geq 1,0$ & $\leq 0,8$ \\
\hline
\end{tabular}

Nota: Total de fluxos maior e menor

Fonte : HCM 2000 [TRANSPORTATION(2000)]

\subsection{2 Áreas de Filas}

O espaço médio disponível aos pedestres também pode ser aplicado como medida de serviço para as áreas de filas e áreas de espera. Os pedestres ficam em pé temporariamente nestas áreas, esperando serem atendidos. Os limites dos NS são 
$\overline{\text { listados na tabela IV-12, onde é apresentado o espaço médio para cada pedestre e para o }}$ grau de mobilidade permitido. Numa multidão em pé, há pouco espaço para se movimentar, mas uma circulação limitada é possível quando se aumenta a média dos espaços por pedestres.

Tabela IV-12. Critério de NS para áreas de filas para pedestres

\begin{tabular}{|cc|}
\hline NS & Espaço $\left(\mathbf{m}^{2} / \mathbf{p}\right)$ \\
\hline A & $>1,2$ \\
\hline B & $>0,9-1,2$ \\
\hline C & $>0,6-0,9$ \\
\hline D & $>0,3-0,6$ \\
\hline E & $>0,2-0,3$ \\
\hline F & $\leq 0,2$ \\
\hline
\end{tabular}

Fonte: HCM 2000 [TRANSPORTATION(2000)]

\subsubsection{Instalações compartilhadas entre pedestres e bicicletas}

Instalações compartilhadas são aquelas abertas ao uso de modos não motorizados, tais como bicicletas, skates e cadeiras de rodas. Os caminhos de uso compartilhados, freqüentemente são construídos para servirem áreas não-ruas da cidade e para promoverem oportunidades recreativas para o público. Estes caminhos são comuns nos campus universitários, onde o trânsito de veículos motorizados e estacionamentos são freqüentemente restritos. Nos Estados Unidos, há poucos caminhos exclusivos para pedestres; os mais comuns são os compartilhados.

Nas instalações compartilhadas, bicicletas - em razão de sua velocidade mais alta podem ter um efeito negativo na capacidade e NS para os pedestres. Entretanto, é difícil estabelecer um equivalente bicicleta-pedestre por causa das relações entre os dois, das diferenças em seus respectivos fluxos, da divisão direcional e de outros fatores (diferindo dos veículos pesados, para os quais há equivalências em veículos leves).

Para caminhos compartilhados, os NS são baseados nos eventos com possibilidades de acidentes. Pesquisas têm recomendado NS para pedestres e bicicletas, baseados na 
freqüência de passagem (fluxo na mesma direção) e de encontros (fluxos em direções opostas), em passeios de 2,4 m de largura. Como os pedestres ultrapassam poucas vezes outros pedestres, o NS para um pedestre, nos caminhos compartilhados, depende da freqüência com que a média de pedestres são ultrapassados pelas bicicletas. Entretanto, o analista pode observar o comportamento dos pedestres no campo, antes de assumir que não há interação pedestre-pedestre.

A equação abaixo é usada para calcular o número total de bicicletas passando na mesma direção e o número total de bicicletas em sentido oposto, por hora, para a média de pedestres no caminho compartilhado.

$$
\mathrm{Fp}=\mathrm{Qsb}\left(1-\frac{S p}{S b}\right) \quad \text { (equação 6) }
$$

$\mathrm{Fm}=\mathrm{Qob}\left(1+\frac{S p}{S b}\right)$

Onde $: \mathrm{Fp}=$ número de passagens na mesma direção (eventos/h)

$\mathrm{Fm}=$ número de passagens em direção oposta (eventos/h)

$\mathrm{Qsb}=$ taxa de fluxo de bicicletas na mesma direção (bicicletas/h)

Qob = taxa de fluxo de bicicletas em direção oposta (bicicletas/h)

$\mathrm{Sp}=$ velocidade principal dos pedestres no caminho $(\mathrm{m} / \mathrm{s})$

$\mathrm{Sb}=$ velocidade principal da bicicleta no caminho $(\mathrm{m} / \mathrm{s})$

O número total de eventos é calculado de acordo com a equação:

$$
\mathrm{F}=\mathrm{Fp}+0,5 \mathrm{Fm} \quad \text { (equação } 7)
$$

Onde $: \mathrm{F}=$ número total de eventos no caminho (eventos/h)

$\mathrm{Fp}=$ número de passagem na mesma direção (eventos/h)

$\mathrm{Fm}=$ número de eventos em direção oposta (eventos/h)

As passagens em sentidos opostos permitem contato visual direto, assim estas bicicletas tendem a causar menos transtornos aos pedestres.

Os valores adotados para a velocidade média para pedestres $(1,5 \mathrm{~m} / \mathrm{s})$ e para bicicleta $(6,0 \mathrm{~m} / \mathrm{s})$ aplicados na equação acima produzem um NS limite para caminhos de dois sentidos de direção. O volume de bicicletas indicado na tabela IV-13, vale para um 
caminho com divisão modal de 50/50 em passeios com largura 2,4 m. Observar que o

NS deve ser baseado no número total de eventos por hora. Para caminhos de sentido único não há encontros, assim o NS é determinado a partir do número de ultrapassagens, calculado com a equação 6 .

Tabela IV-13. Critério de NS para pedestres em caminhos de duas direções compartilhados.

\begin{tabular}{|ccc|}
\hline $\begin{array}{c}\text { NS } \\
\text { (pedestres) }\end{array}$ & $\begin{array}{c}\text { Quantidade de eventos } \\
\text { (número/h) }\end{array}$ & $\begin{array}{c}\text { Volume de bicicletas por direção } \\
\text { (bicicletas/h) }\end{array}$ \\
\hline A & $\leq 38$ & $\leq 28$ \\
\hline B & $>38-60$ & $>28-44$ \\
\hline C & $>60-103$ & $>44-75$ \\
\hline D & $>103-144$ & $>75-105$ \\
\hline E & $>144-180$ & $>105-131$ \\
\hline F & $>180$ & $>131$ \\
\hline
\end{tabular}

Fonte : HCM 2000 [TRANSPORTATION(2000)]

Notas: Largura do caminho de 2,4 m

Evento refere-se ao encontro ou ultrapassagem do pedestre por uma bicicleta.

Assumindo-se divisão de 50/50 para bicicletas.

\subsection{Instalações para Pedestres com Fluxo Interrompido}

Os procedimentos aqui focalizados são para determinar os NS para pedestres. Para os veículos os NS são determinados em outra instância.

\subsubsection{Interseções Sinalizadas}

Neste procedimento considera-se uma interseção sinalizada numa travessia com pelo menos uma aproximação. A análise de travessia de uma interseção sinalizada é mais complicada que uma travessia no meio do bloco, por que isto envolve intersecções de fluxo da calçada, pedestres atravessando a rua, e outras filas esperando a mudança de sinal. A medida de serviço é a média da espera experimentada pelo pedestre. Pesquisas indicam que a média de espera do pedestre nas travessias sinalizadas não é restrita pela 
capacidade, até que o fluxo de pedestres alcançe $5.000 \mathrm{p} / \mathrm{h}$. A média de espera por pedestres para a travessia é dada pela equação 8:

$$
. d p=\frac{0,5(C-g)^{2}}{C} \quad \text { (equação 8) }
$$

Onde $: \mathrm{dp}=$ tempo de espera pelos pedestres $(\mathrm{s})$

$\mathrm{g}=$ Tempo efetivo de verde para pedestres (s)

$\mathrm{C}=$ duração de ciclo $(\mathrm{s})$

A tabela IV-14 lista os NS para pedestres em intersecções sinalizadas, baseadas no tempo de espera do pedestre. Quando o pedestre espera mais que $30 \mathrm{~s}$, tornam-se impacientes e assume comportamentos arriscados. A tabela IV-14 inclui um guia para a probabilidade de desobediência (i.é, desrespeito aos sinais indicativos). Os valores da tabela IV-14 refletem conflitos de baixo para moderados. Nas interseções com alto conflito de volumes de veículos, os pedestres têm pouca escolha além de esperar abrir o sinal, e o número de observações de desobediência é reduzido.

\section{Tabela IV-14. NS para pedestres em intersecções sinalizadas}

\begin{tabular}{|ccc|}
\hline NS & $\begin{array}{l}\text { Tempo de espera } \\
\text { pedestres (s/p) }\end{array}$ & $\begin{array}{l}\text { Probabilidade de } \\
\text { desobediência }\end{array}$ \\
\hline A & $<10$ & Baixa \\
\hline B & $\geq 10-20$ & \\
\hline C & $>20-30$ & Moderada \\
\hline D & $>30-40$ & Alta \\
\hline E & $>40-60$ & Muito Alta \\
\hline F & $>60$ & \\
\hline
\end{tabular}

Fonte: HCM 2000 [TRANSPORTATION(2000)]

Ainda que o tempo de espera tenha impacto no tempo de viagem dos pedestres, isto não é considerado nas funções das esquinas de ruas e travessias, onde a circulação de pedestres e o espaço para as filas de pedestres aguardando travessia é que são relevantes. Uma esquina de rua sobrecarregada com uma travessia de pedestres pode 
afetar a operação veicular por requerer um tempo adicional de verde e retardar os movimentos de conversão.

\section{Área para pedestres requerida numa esquina}

Há dois tipos de áreas requeridas para pedestres numa esquina. Primeiro, a área de circulação, que é necessária para acomodar os pedestres atravessando no seu tempo verde e, obviamente, aos que se juntam àqueles que esperam no seu tempo vermelho e não atravessam a rua. Segundo, é preciso considerar uma área para acomodar aqueles pedestres que esperam durante a fase vermelha.

A metodologia descrita nas seções seguintes permite identificar problemas de locação, que podem requerer detalhes de campo e possíveis medidas reparadoras.

Medidas para incrementar melhorias podem incluir alargamento de calçadas, restrições adicionais às conversões de veículos, e mudança no tempo de sinalização. A figura IV-6 apresenta as variáveis requeridas para processar uma análise.

As figuras IV-7 e IV-8 mostram as condições de análise para esquinas e travessias. A condição 1 representa a fase de travessia de uma rua não preferencial, durante o tempo verde da rua preferencial, com as filas de pedestres do lado da rua preferencial, durante a fase vermelha da rua não preferencial. A condição 2 representa a fase de travessia da rua preferencial, com pedestres atravessando durante o tempo verde da rua não preferencial, e as filas do lado da rua não preferencial, durante a fase vermelha da rua preferencial.

A análise das esquinas de ruas e travessias compara o tempo disponível e espaço com a demanda de pedestres. O produto do tempo e espaço (ou tempo-espaço) é um parâmetro crítico, porque o projeto físico limita a disponibilidade espacial e o controle sinalizado limita a disponibilidade de tempo. 
Figura IV-6. Interseç̧ão em esquina e movimentos de pedestres

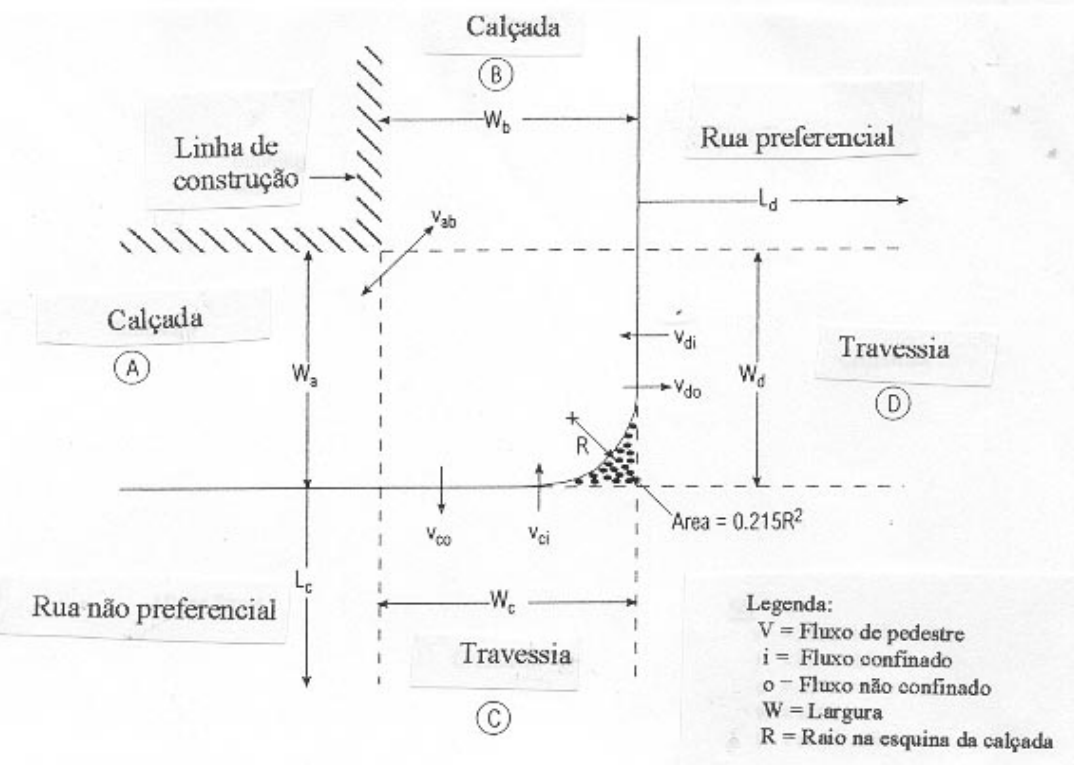

Fonte: HCM 2000 [TRANSPORTATION(2000)]

Figura IV-7. Condição 1 : Travessia na rua não preferencial

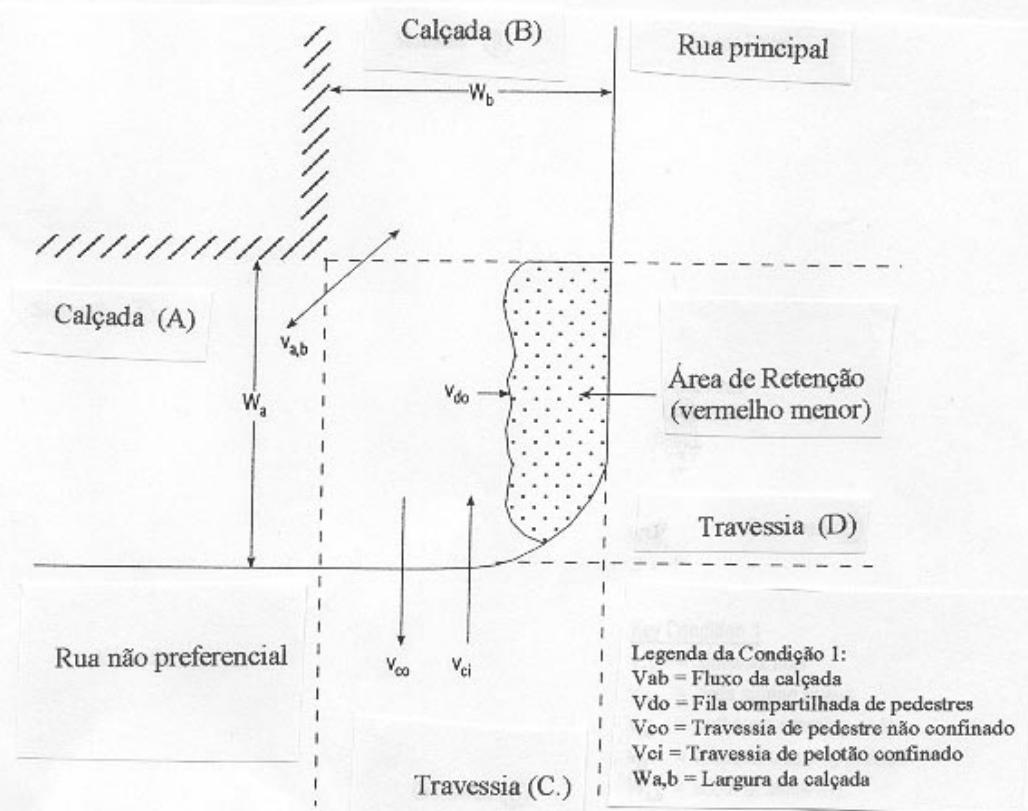

Fonte: HCM 2000 [TRANSPORTATION(2000)] 


\section{Figura IV-8. Condição 2 : Travessia na rua preferencial}

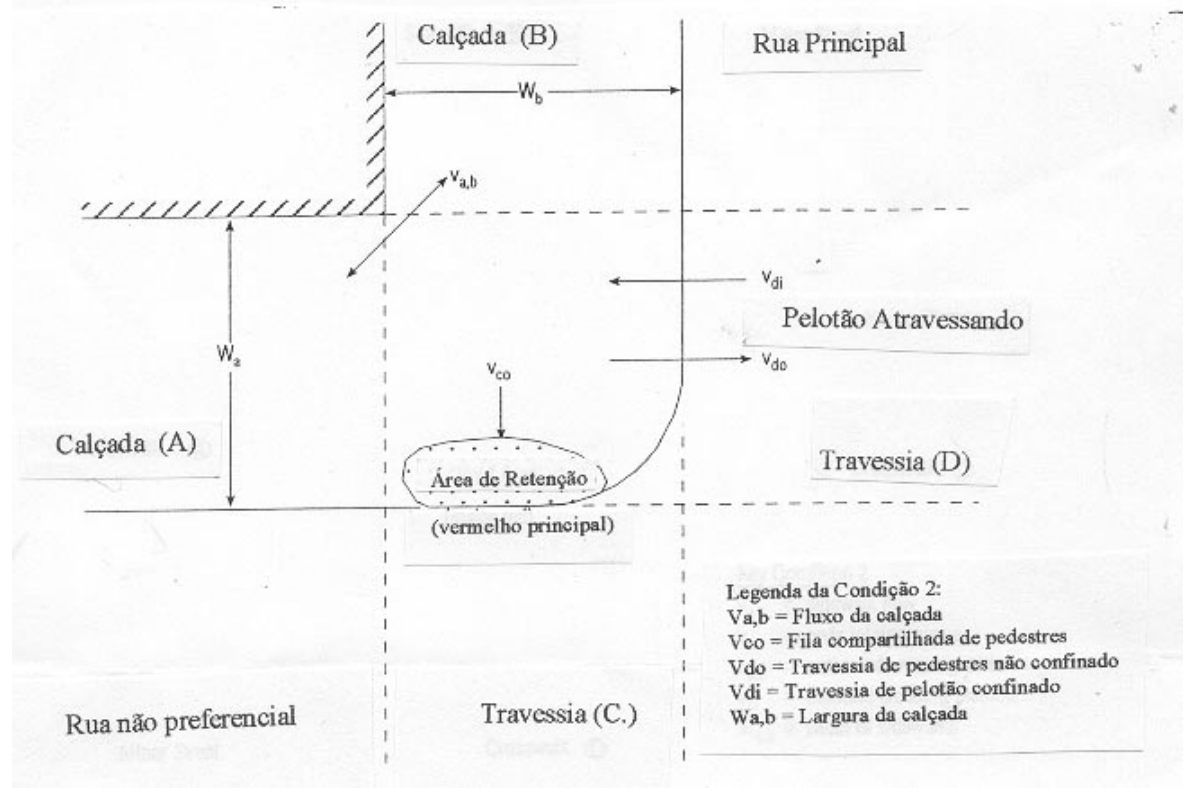

Fonte: HCM 2000 [TRANSPORTATION(2000)]

\section{Determinação Tempo-Espaço numa esquina de rua}

Tempo-Espaço disponível

A disponibilidade de tempo-espaço total para circulação e filas, nas interseções nas esquinas durante um período de análise, é o produto da área "líquida" efetiva e o período de análise. Para esquinas de ruas, o período de análise é um ciclo do sinal. A equação 9 é usada para calcular o tempo-espaço disponível numa interseção de esquina.

A figura IV-6 identifica as dimensões usadas na equação 9.

$$
\mathrm{TS}=\mathrm{C}\left(\mathrm{WaWb}-0,215 \mathrm{R}^{2}\right) \quad \text { (equação 9) }
$$

Onde: $\mathrm{TS}=$ tempo-espaço disponível $\left(\mathrm{m}^{2}\right.$-s)

$\mathrm{Wa}=$ largura efetiva da calçada a $(\mathrm{m})$

$\mathrm{Wb}=$ largura efetiva da calçada $\mathrm{b}(\mathrm{m})$

$\mathrm{C}=$ duração do ciclo (s)

\section{Área de retenção no tempo de espera}

Assumindo-se que as chegadas são uniformes nas filas de travessia, a média do tempo de retenção para os pedestres pode ser calculada usando a equações 10 e 11. Estas 
$\overline{\text { equações refletem a proporção do tempo de ciclo em que os fluxos são retidos, assim }}$ como seus tempos de retenção são o tempo de vermelho.

Para a condição 1 mostrados na figura IV-6 a equação 10 é usada para calcular o tempo de retenção.

Qtdo $=\frac{V d o \cdot R m i^{2}}{2 C} \quad$ (equação 10)

Onde:

Qtdo = tempo total dispendido pelo pedestre esperando atravessar a rua preferencial durante um ciclo (p-s)

$\mathrm{Vdo}=$ número de pedestres esperando atravessar da rua preferencial durante um ciclo, $\mathrm{p} / 15 \mathrm{~min} * 1 \mathrm{~min} / 60 \mathrm{~s} * \mathrm{C}(\mathrm{p} / \mathrm{ciclo})$

Rmi = Fase vermelha da rua não preferencial, ou a fase "não-atravesse" para pedestres. $\mathrm{C}=$ duração do ciclo.

Para a condição 2, como apresentado na figura IV-7, a equação 11 é usada para calcular o tempo de espera na área de retenção.

$$
\text { Qtco }=\frac{V c o \cdot R m j^{2}}{2 C} \quad \text { (equação 11) }
$$

Onde:

Qtco $=$ Tempo total dispendido pelos pedestres esperando atravessar a rua não preferencial durante um ciclo (p-s)

Vco $=$ o número de pedestres esperando atravessar a rua não preferencial durante um ciclo, $\mathrm{p} / 15 \mathrm{~min} * 1 \mathrm{~min} / 60 \mathrm{~s} * \mathrm{C}$ (p/ciclo)

Rmj = Fase vermelha da rua preferencial, ou a fase "não - atravesse" para sinais de pedestres.

$\mathrm{C}=$ duração do ciclo (s).

\section{Determinação da circulação tempo-espaço}

O tempo-espaço efetivo da esquina, disponível para circulação de pedestres, é o total disponível do tempo-espaço menos o tempo-espaço ocupado pelos pedestres esperando atravessar. A área de retenção requerida para pedestres esperarem é o produto do total de tempo de espera e da área usada pelos pedestres esperando. A equação 12 é usada para calcular o tempo-espaço disponível. 
$\mathrm{TSc}=\mathrm{TS}-[0,5(\mathrm{Qtdo}+$ Qtco $)]$

(equação 12)

Onde:

$\mathrm{TSc}=$ tempo-espaço total disponível para pedestres circularem $\left(\mathrm{m}^{2}-\mathrm{s}\right)$

$\mathrm{TS}=$ tempo-espaço total disponível $\left(\mathrm{m}^{2}\right.$-s)

Qtdo $=$ tempo total dispendido pelo pedestre esperando atravessar a rua preferencial durante um ciclo (p-s)

Qtco = Tempo-espaço dispendido pelo pedestre esperando atravessar na rua não preferencial durante um ciclo ( $\mathrm{p}-\mathrm{s})$.

\section{Espaço do pedestre}

Finalmente, o espaço requerido para circulação dos pedestres é calculado pela divisão do tempo-espaço total disponível para circulação de pedestres pelo tempo que o pedestre consome andando através da área de esquina - que é, a soma do volume de circulação multiplicado por 4s (média de tempo de circulação assumida). A área para cada pedestre, que é relatada nos limites dos NS para passeios, está na tabela IV-8.

A equação 13 é usada para cálculo dessa área para pedestre.

$\mathrm{M}=\frac{T S c}{4 v t o t} \quad$ (equação 13)

Onde:

$\mathrm{M}=$ área de circulação para pedestres $\left(\mathrm{m}^{2} / \mathrm{p}\right)$

$\mathrm{TS}=$ tempo-espaço total disponível para circulação de pedestres $\left(\mathrm{m}^{2}-\mathrm{s}\right)$

Vtot $=$ número total de pedestres circulando em um ciclo $=\mathrm{vci}+\mathrm{vco}+\mathrm{vdi}+\mathrm{vdo}+\mathrm{vab}$, como mostrado nas figuras 6 e 7 (p/ciclo)

\section{Determinação de tempo-espaço de travessia}

O tempo-espaço de uma travessia numa esquina é calculado conforme a equação 14 seguinte:

$$
\mathrm{TS}=\mathrm{LWe}\left[(\mathrm{WALK}+\mathrm{FDW})-\frac{L}{2 S p}\right]
$$

Ou :

$\mathrm{TS}=\mathrm{LWe}\left[\mathrm{G}-\frac{L}{2 S p}\right] \quad$ quando WALK + FDW não está instalado. 


\section{Onde:}

$\mathrm{TS}=$ tempo-espaço $\left(\mathrm{m}^{2}-\mathrm{s}\right)$

$\mathrm{L}=$ tempo de travessia $(\mathrm{m})$

$\mathrm{We}=$ comprimento efetivo de travessia $(\mathrm{m})$

$\mathrm{WALK}+\mathrm{FDW}=$ tempo verde efetivo para pedestre na travessia (s)

$\mathrm{Sp}=$ velocidade média do pedestre $(\mathrm{m} / \mathrm{s})$

$\mathrm{G}=$ tempo verde por fase, se WALK + FDW não tiver instalado(s)

A análise de tempo-espaço numa travessia requer um fluxo de pedestre durante o intervalo do ciclo. A equação 15 permite ao analista calcular o número de pedestres atravessando durante o intervalo do período do ciclo. O tempo total de travessia ou efetivo tempo verde requer uma travessia desimpedida e é calculado de acordo com a equação 16, que incorpora os efeitos de dispersão de pelotões com mais de 15 pedestres.

Nped $=\frac{V(C-G)}{C}$

(equação 15)

Onde:

Nped $=$ número de pedestres atravessando durante um intervalo $(\mathrm{p})$

$\mathrm{V}=$ volume de pedestre no passeio $(\mathrm{p} / 15 \mathrm{~min})$

$\mathrm{G}=$ fase do tempo verde, se WALK + FDW não estiver instalado

$\mathrm{T}=3,2+\frac{L}{S p}+\left[0,81 \frac{\text { Nped }}{W}\right] \quad$ para $\mathrm{W}>3,0 \mathrm{~m} \quad$ (equação 16)

.e:

$\mathrm{T}=3,2+\frac{L}{S p}+(0,27 \mathrm{Nped}) \quad$ para $\mathrm{W} \leq 3,0 \mathrm{~m}$

Onde:

$\mathrm{T}=$ tempo total de travessia $(\mathrm{s})$

$\mathrm{L}=$ tamanho da travessia $(\mathrm{m})$

$\mathrm{Sp}=$ velocidade média do pedestre $(\mathrm{m} / \mathrm{s})$

Nped $=$ número de pedestre atravessando durante o intervalo $(\mathrm{p})$

$\mathrm{W}=$ largura da travessia $(\mathrm{m})$

$3,2=$ tempo de largada na travessia do pedestre.

O tempo total ocupado em travessia é composto como um produto da média de tempo de travessia e o número de pedestres usando a travessia, durante um ciclo de sinal. A equação 17 é usada para este cálculo: 
$\mathrm{T}=(\mathrm{vi}+\mathrm{vo}) \mathrm{t} \quad$ (equação 17$)$

Onde:

$\mathrm{T}=$ Tempo total ocupado em travessia (p-s)

$\mathrm{Vi}=$ volume de pedestres dentro da faixa para esta travessia $(\mathrm{p} / \mathrm{ciclo})$

$\mathrm{Vo}=$ volume de pedestres fora da faixa para esta travessia ( $\mathrm{p} /$ ciclo)

$. t=$ tempo total de travessia da equação 15 (s)

O espaço de circulação provido para cada pedestre é determinado pela divisão do tempo-espaço disponível para a travessia pelo total de tempo ocupado, como na equação 18. Estes campos de áreas providos para cada pedestre, que é relatado nos limites do NS para passeios são listados na tabela IV-8

$\mathrm{M}=\frac{T S}{T} \quad$ (equação 18$)$

Onde:

$\mathrm{M}=$ área de circulação por pedestre $\left(\mathrm{m}^{2} / \mathrm{p}\right)$

$\mathrm{TS}=$ tempo-espaço $\left(\mathrm{m}^{2}-\mathrm{s}\right)$

$\mathrm{T}=$ Tempo total ocupado em travessia

O método de tempo-espaço permite uma aproximação estimativa do efeito de conversão de veículos nos NS de travessia durante a fase verde. Isto assume uma área ocupada pelo veículo na travessia, baseado no produto da trajetória (em curva) do veículo, tamanho da travessia e tempo estimado que o veículo esvazia o espaço. A trajetória (em curva) para a maioria dos veículos é $2,4 \mathrm{~m}$, e pode ser assumido que um veículo ocupa uma travessia por $5 \mathrm{~s}$. A equação 19 pode ser usada para estimar tempo-espaço ocupado por veículos em conversão, que é subtraído do valor de tempo-espaço obtido pela equação 14.

$\mathrm{TStv}=12 \mathrm{Ntv} \mathrm{We}$ (equação 19)

Onde:

TStv $=$ Tempo-espaço ocupado pelo veículo em conversão $\left(\mathrm{m}^{2}-\mathrm{s}\right)$

$\mathrm{Ntv}=$ Número de veículos durante a fase verde (veh)

$\mathrm{We}=$ largura efetiva da travessia $(\mathrm{m})$ 


\section{Determinação de tempo verde efetivo para o pedestre}

Um tempo verde mínimo e efetivo requerido para um fluxo de duas direções pode ser estimado usando a teoria de onda de choque e observações. Se há alto volume de pedestres, uma abordagem de onda de choque pode assegurar um cálculo mais adequado de tempo de travessia, para um fluxo intenso de pelotão em duas direções. Mas para condições de baixo volume, o tempo mínimo requerido pode ser determinado usando equação 9, que também leva em conta os fluxos de pelotões.

Pedestres usam tanto o tempo do foco "Siga" como os primeiros segundos do foco "Pare" para adentrar à intersecção. Para calcular esta demora, na equação 8 , o efetivo tempo verde é igual ao tempo de travessia mais os 4 s de piscante do foco "Pare".

\subsubsection{Interseções não sinalizadas}

Para travessia numa interseção não sinalizada, com pedestres contra uma corrente de trânsito livre, o procedimento é outro.

Entretanto, se na travessia da interseção não sinalizada houver faixa zebrada, o procedimento a seguir não se aplica, porque os pedestres têm o direito de passagem. Em vez disso, o tempo de espera dos pedestres podem ser estimados usando o método para intersecções controladas nos dois sentidos.

Aqui, também, a travessia da intersecção não sinalizada é mais complicada de ser analisada do que uma no meio do bloco, porque envolve interações de fluxos de pedestres na calçada com pedestres atravessando a rua e pedestres preenchendo os vazios.

A brecha crítica é o tempo em segundos abaixo do qual um pedestre não poderá tentar iniciar a travessia. Os pedestres usam seu próprio julgamento para determinar se a brecha disponível é longa o suficiente para uma travessia segura. Se a brecha disponível 
é maior que a brecha crítica, presume-se que o pedestre pode atravessar, mas se a brecha disponível é menor que a crítica, então o pedestre não deve atravessar.

Para um único pedestre, a brecha crítica é calculada com a equação 20, seguinte:

$\mathrm{Tc}=\frac{L}{S p}+\mathrm{Ts}$

(equação 20)

Onde:

$\mathrm{Tc}=$ brecha crítica para um único pedestre $(\mathrm{s})$

$\mathrm{Sp}=$ velocidade de caminhar média do pedestre $(\mathrm{m} / \mathrm{s})$

$\mathrm{L}=$ comprimento da travessia $(\mathrm{m})$

Ts = tempo de início e fim de travessia do pedestre (s)

Se for observado um pelotão no campo, então pode ser calculada uma distribuição espacial de pedestres usando-se a equação 21, para determinar a brecha crítica. Para calcular a distribuição espacial, o analista deve observar no campo ou estimar o tamanho do pelotão usando a equação 22. A brecha crítica para um grupo é determinada usando a equação 23. Se não há pelotão formado, assume-se o valor 1 para a distribuição espacial de pedestres.

$\mathrm{Np}=\mathrm{INT}\left[\frac{0,75(N c-1)}{W e}\right]+1$

(equação 21)

Onde:

$\mathrm{Np}=$ distribuição espacial de pedestres $(\mathrm{p})$

$\mathrm{Nc}=$ Número total de pedestres na travessia de pelotão $(\mathrm{p})$

$\mathrm{We}=$ largura efetiva da travessia $(\mathrm{m})$

$0,75=$ largura efetiva assumida, usado por um pedestre simples para evitar interferência quando ultrapassar outro pedestre.

$\mathrm{Nc}=\frac{V p \cdot e^{V p \cdot T c}+V \cdot e^{-V T c}}{(V p+V) \cdot e^{(V p-V) \cdot T c}}$

Onde:

$\mathrm{Nc}=$ tamanho de um típico pelotão de pedestres atravessando (p)

$\mathrm{Vp}=$ taxa de fluxo de trânsito $(\mathrm{p} / \mathrm{s})$ 
$\mathrm{V}=$ taxa de fluxo de trânsito (veí/s)

$\mathrm{Tc}=$ brecha crítica para pedestre sozinho $(\mathrm{s})$

$\mathrm{Tg}=\mathrm{Tc}+2(\mathrm{~Np}-1)$

(equação 23)

Onde:

$\mathrm{Tg}=$ brecha crítica de grupo (s)

$\mathrm{Tc}=$ brecha crítica para uma pessoa sozinha (s)

$\mathrm{Np}=$ distribuição espacial de pedestre $(\mathrm{p})$

A espera experimentada pelo pedestre é a medida de serviço. Pesquisas indicam que a média de espera numa travessia para pedestres numa intersecção não sinalizada depende da brecha crítica, do fluxo veicular desta travessia e do intervalo principal entre veículos. A média de espera para o pedestre atravessar é dada pela equação 24 .

$. \mathrm{dp}=\frac{1}{V}\left(\mathrm{e}^{V T g}-\mathrm{VTg}-1\right)$

(equação 24)

Onde :

$. d p=$ média de espera do pedestre (s)

$\mathrm{V}=$ taxa de fluxo veicular (vei/s)

$\mathrm{Tg}=$ brecha crítica para grupo, tirado da equação 22

A tabela IV-15 lista critério de NS para pedestre numa intersecção não sinalizada, baseada no tempo de espera do pedestre. A expectativa e tolerância para espera nos pedestres são menores numa interseção não sinalizada que numa interseção sinalizada. A tabela IV-15 inclui a probabilidade de o pedestre assumir um comportamento arriscado relativo ao NS. 
Tabela IV-15: NS para pedestres numa intersecção não sinalizada

\begin{tabular}{|ccc|}
\hline NS & $\begin{array}{c}\text { Média de espera por } \\
\text { pedestre (s) }\end{array}$ & $\begin{array}{c}\text { (a) Probabilidade de } \\
\text { comportamento de risco }\end{array}$ \\
\hline A & $<5$ & Baixa \\
\hline B & $\geq 5-10$ & Moderada \\
\hline C & $>10-20$ & Alta \\
\hline D & $>20-30$ & Muito Alta \\
\hline E & $>30-40$ & \\
\hline F & $>45$ & \\
\hline
\end{tabular}

(a) Probabilidade de aceitação de brechas curtas.

Fonte : HCM 2000 [TRANSPORTATION(2000)].

\subsubsection{Calçadas para pedestres em ruas urbanas}

Aqui focaliza-se a análise de extensões de instalações para pedestres com fluxos interrompidos e não interrompidos. A velocidade média de viagem dos pedestres, incluindo paradas, é o serviço medido. Esta velocidade média é baseada na distância entre dois pontos e da média entre o tempo requerido - incluindo paradas - para vencer a distância.

Calçadas para pedestres, ao longo das ruas, compreendem segmentos e interseções. O primeiro passo para analisar uma rua urbana é definir seus limites, assim segmentá-lo para análise. Cada segmento consiste de uma interseção sinalizada e uma corrente de pedestres na calçada, começando imediatamente depois da próxima corrente sinalizada ou não sinalizada numa interseção.

A velocidade média numa seção inteira é calculada de acordo com a equação 25 :

$$
. \mathrm{Sa}=\frac{L t}{\sum \frac{L i}{S i}+\sum d j}
$$

Onde :

$\mathrm{Lt}=$ comprimento total da rua urbana sob análise $(\mathrm{m})$

$\mathrm{Lt}=$ comprimento do segmento $\mathrm{i}(\mathrm{m})$

$\mathrm{Si}=$ velocidade de caminhar do pedestre no segmento $\mathrm{i}(\mathrm{m} / \mathrm{s})$

$. \mathrm{dj}=$ tempo de espera do pedestre na travessia $\mathrm{j}(\mathrm{s})$

$\mathrm{Sa}=$ velocidade média de travessia do pedestre $(\mathrm{m} / \mathrm{s})$ 
Há muitos fatores que afetam a velocidade do pedestre, incluindo atividades adjacentes no passeio, tipologia de ruas comerciais ou residenciais, obstruções laterais, declividade significante, largura efetiva da calçada e outros aspectos locais. Pesquisas têm sido insuficientes para produzir recomendações específicas nos efeitos individuais e coletivos. O tempo de espera nas interseções, entretanto, pode ser calculado, como já descrito.

Os critérios de NS baseados na velocidade de viagem do pedestre são listados na tabela IV-16. O critério geral assemelha-se aos critérios de NS dos veículos nas ruas urbanas; os limites são apresentados em semelhantes porcentagens da velocidade base.

Tabela IV-16: NS de calçadas para pedestres em ruas urbanas

\begin{tabular}{|cc|}
\hline NS & Velocidade Média (m/s) \\
\hline A & $>1,33$ \\
\hline B & $>1,17-1,33$ \\
\hline C & $>1,00-1,17$ \\
\hline D & $>0,83-1,00$ \\
\hline E & $\geq 0,58-0,83$ \\
\hline F & $<0,58$ \\
\hline
\end{tabular}

Fonte : HCM 2000 [TRANSPORTATION(2000)]. 


\section{FORMULÁRIOS E MEMÓRIAS DE CÁLCULOS}

Com base em HCM 2000 [TRANSPORTATION(2000)], foram elaborados alguns tipos de formulários, simplificando e adaptando para as condições das cidades brasileiras. Os formulários foram destacados conforme o tipo de instalação a ser analisado e objetivando facilitar a pesquisa de campo.

Os formulários sugeridos pelo HCM não são utilizados apenas como folhas de campo, mas também como memorial de cálculo, colocando fórmulas nas linhas, apresentando a seqüência de cálculos. É um formulário interessante para avaliações em grande escala, quando há uma bateria de calculistas, que auxiliam o analista na avaliação das instalações. Em pequena escala, ou em caráter didático, o memorial de cálculo pode ser destacado do formulário e apresentado à parte, para melhor reproduzir o fenômeno a ser analisado.

Para a análise total da instalação, além da visita ao campo é interessante, também, processar uma reprodução fotográfica, e um questionário para prospecção qualitativa da opinião pública, sobre a instalação em questão. 


\section{FORMULÁRIO PARA INSTALAÇÃO DE CALÇADAS E PASSEIOS}

\section{CALÇADAS E PASSEIOS}

\section{INFORMAÇÕES GERAIS}

Pesquisador:

Data:

Dia de semana:

Hora:

Tempo (clima):

\section{INFORMAÇÕES DO LOCAL}

Tipo de Instalação:

Local:

Observação ou croqui:

\section{VALORES LOCAIS}

Largura Total do passeio

$\mathrm{Wt}(\mathrm{m})$

Soma das larguras das obstruções e/ou distância de segurança(*) Wc (m)

Largura efetiva da travessia

We $(\mathrm{m})$

$\mathrm{We}=\mathrm{Wt}-\mathrm{Wc}$

Fluxo no pico de $15 \mathrm{~min}$

V15 (ambas as direções)

Fluxo unitário de pedestre

$\mathrm{Vp}(\mathrm{p} / \mathrm{min} / \mathrm{m})$

$\mathrm{Vp}=\frac{V 15}{15 x W e}$

NÍVEL DE SERVIÇO

(consultar tabela IV-8, IV-

9, IV-10 IV-11 ou IV-12 )

(*) Inclui largura de meio-fio, mobiliário urbano, vitrines, entradas de prédios, e todos os tipos de obstruções.
VALORES ASSUMIDOS ou CALCULADOS 


\section{FORMULÁRIO PARA INSTALAÇÃO COMPARTILHADA PEDESTRE -} BICICLETA

\section{INSTALAÇÃO COMPARTILHADA PEDESTRE - BICICLETA}

\section{INFORMAÇÕES GERAIS}

Pesquisador:

Data:

Dia de semana:

Hora:

Tempo (clima):

\section{INFORMAÇÕES DO LOCAL}

Tipo de Instalação:

Local:

Observação (ou croqui):

Velocidade principal de

pedestre, $\mathrm{Sp}(\mathrm{m} / \mathrm{s})$

Velocidade principal de

bicicleta, $\mathrm{Sb}(\mathrm{m} / \mathrm{s})$

Fluxo de bicicletas na

mesma direção, Qsb (bic/h)

Fluxo de bicicletas em

direção oposta, Qob (bic/h)

Número de ultrapassagens,

$\mathrm{Fp}$ (eventos/h)

$\mathrm{Fp}=\mathrm{Qsb}\left(1-\frac{S p}{S b}\right)$

Número de encontros, Fm

(eventos/h)

$\mathrm{Fm}=\mathrm{Qob}\left(1+\frac{S p}{S b}\right)$

Total de eventos, $\mathrm{F}($ even/h)

$\mathrm{F}=\mathrm{Fp}+0,5 \mathrm{Fm}$

NÍVEL DE SERVIÇO

(consultar tabela IV-13) 
FORMULÁRIO PARA TRAVESSIAS EM INTERSEÇÕES SINALIZADAS, NÃO SINALIZADAS E INSTALAÇÕES URBANAS.

INTERSEÇÕES SINALIZADAS, NÃO SINALIZADAS E INSTALAÇÕES URBANAS

\section{INFORMAÇÕES GERAIS}

Pesquisador:

Data:

Dia de semana:

Hora:

Tempo (clima):

\section{INFORMAÇÕES DO LOCAL}

Tipo de Instalação:

Local:

Observação:

\begin{tabular}{ll} 
VALORES LOCAIS & $\begin{array}{l}\text { VALORES ASSUMIDOS } \\
\text { ou CALCULADOS }\end{array}$ \\
\hline
\end{tabular}

TEMPO DE ESPERA DO PEDESTRE NA INTERSEÇÃO SINALIZADA

Tempo do ciclo $\mathrm{C}(\mathrm{s})$

Efetivo tempo verde para

pedestre, $\mathrm{g}(\mathrm{s})$

Tempo de espera médio,

$\mathrm{Dp}(\mathrm{s})$

$\mathrm{Dp}=\frac{0,5(C-g) 2}{C}$

NÍVEL DE SERVIÇO

(consultar tabela 14)

Tempo de Espera do Pedestre em Interseção Não Sinalizada

Velocidade de caminhar do

pedestre, $\mathrm{Sp}(\mathrm{m} / \mathrm{s})$

Tempo de largada do

pedestre, ts (s)

Comprimento da travessia,

$\mathrm{L}(\mathrm{m})$

Brecha crítica para

pedestre sozinho, tc (s)

.tc $=\frac{L}{S p}+\mathrm{ts}$

Número típico de pedestre

em pelotão na travessia, $\mathrm{Nc}$

(continua) 
(continuação)

Distribuição espacial do pedestre $(*) \mathrm{Np}(\mathrm{p})$

$\mathrm{Np}=$

$\operatorname{INT}\left[\frac{0,75(N p-1)}{W e}\right]+1$

Brecha crítica para grupos,

$\operatorname{tg}(\mathrm{s})$

$. \operatorname{tg}=\mathrm{tc}+2(\mathrm{~Np}-1)$

Fluxo veicular, v (veí/s)

Tempo de espera médio

para pedestre, dp (s)

$. \mathrm{dp}=\frac{1}{v}\left(\mathrm{e}^{v t}-\mathrm{vt}-1\right)$

NÍVEL DE SERVIÇO

(consultar tabela IV-15)

VELOCIDADE MÉDIA DE VIAGEM EM VIAS URBANAS

Comprimento da Via $(* *)$

$\mathrm{Lt}(\mathrm{m})$

Comprimento das seções

$\mathrm{Li}(\mathrm{m})$

Velocidade nas seções Si

$(\mathrm{m} / \mathrm{s})$

Tempo de espera nas

travessias Di(s)

Velocidade de viagem

média $\mathrm{St}(\mathrm{m} / \mathrm{s})$

$\mathrm{St}=\frac{L t}{\sum \frac{L i}{S i}+\sum D i}$

NÍVEL DE SERVIÇO

(consultar tabela IV-16)

Notas : (*) Se não houver pelotão, assumir $\mathrm{Np}=1$

(**) Comprimento da seção inclui comprimentos de calçadas e travessias. 
FORMULÁRIO PARA TRAVESSIA DE PEDESTRES EM INTERSEÇÕES SINALIZADAS, EM VIAS COM PRIORIDADES

\section{INTERSEÇÕES SINALIZADAS, EM VIAS COM PRIORIDADES}

\section{INFORMAÇÕES GERAIS}

Pesquisador:

Data:

Dia de semana:

Hora:

Tempo (clima):

\section{INFORMAÇÕES DO LOCAL}

Tipo de Instalação:

Local:

Observação:

\section{Dados de entrada:}

Tempo de ciclo, C. $\mathrm{S}$

Fase vermelha da via não preferencial, $\mathrm{Rm}$............................... $\mathrm{s}$

Fase vermelha de via preferencial, Rmj................................... $\mathrm{S}$

Fase verde efetiva da via não preferencial, gi............................ S

Fase verde efetiva da via preferencial, gj................................. $\mathrm{s}$

\begin{tabular}{l|l|l|l}
\hline & Fluxo 15 min & Fluxo $=\frac{p}{15 \mathrm{~min}}+\frac{1}{60}=\mathrm{pt}$ & Fluxo, $\mathrm{p} / \mathrm{s}^{*} \mathrm{C}$ \\
\hline Vci & & & \\
\hline Vco & & & \\
\hline Vdi & & & \\
\hline Vdo & & & \\
\hline Vab & & & \\
\hline Vtot & & & \\
\hline
\end{tabular}

\section{Dados geométricos}

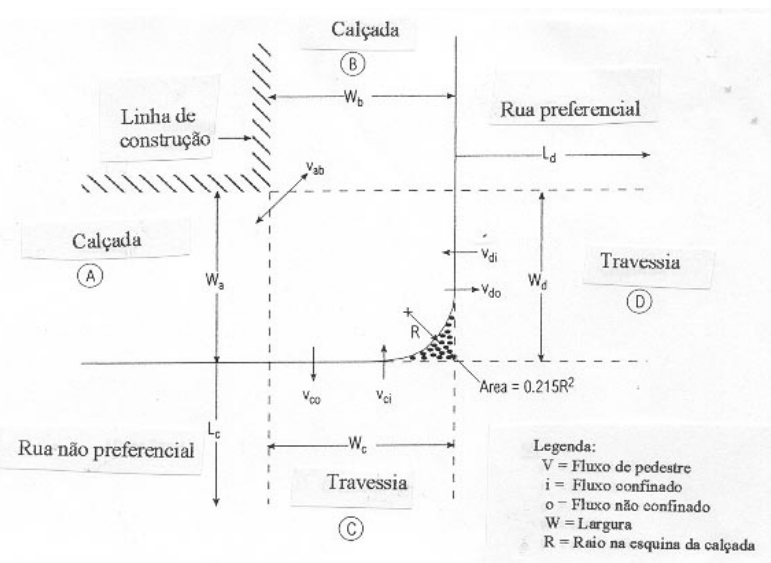

(continua) 
(continuação)

\section{ANÁLISE DE TEMPO-ESPAÇO DA ESQUINA}

Tempo - espaço total, TS

$\left(\mathrm{m}^{2}-\mathrm{s}\right)$

$\mathrm{TS}=\mathrm{C}\left(\mathrm{WaWb}-0,215 \mathrm{R}^{2}\right)$

Tempo despendido pelo

pedestre para atravessar a rua

principal, Qtdo (p-s)

Qtdo $=\frac{v d o \cdot R m^{2}}{2 C}$

Tempo-espaço total

disponível, TSc $\left(\mathrm{m}^{2}-\mathrm{s}\right)$

$\mathrm{TSc}=\mathrm{TS}-[0,5(\mathrm{Qtdo}+\mathrm{Qtco})]$

Área de circulação para

pedestre, $\mathrm{M}\left(\mathrm{m}^{2} / \mathrm{p}\right)$

$\mathrm{M}=\frac{T S C}{4 V m}$

\section{Nível de Serviço}

(consultar tabelaIV-8)

\section{ANÁLISE DE TEMPO-ESPAÇO DA TRAVESSIA}

\begin{tabular}{|c|c|c|}
\hline $\begin{array}{l}\text { Tempo de espera médio numa } \\
\text { interseção sinalizada }\end{array}$ & Travessia D & Travessia C \\
\hline \multicolumn{3}{|l|}{$\begin{array}{l}\text { Tempo de espera médio } \\
\text { dp (s) }\end{array}$} \\
\hline \multicolumn{3}{|l|}{$d p=\underline{0,5(C-g)^{2}}$} \\
\hline \multicolumn{3}{|l|}{$\begin{array}{l}\text { Nível de Serviço numa } \\
\text { interseção Sinalizada } \\
\text { (consultar tabela IV-14) }\end{array}$} \\
\hline \multicolumn{3}{|l|}{$\begin{array}{l}\text { Número de pedestre chegando } \\
\text { durante tempo vermelho, } \\
\text { Nped (p) } \\
(*)\end{array}$} \\
\hline $\begin{array}{l}\text { Velocidade média dos } \\
\text { pedestres, } \mathrm{Sp}(\mathrm{m} / \mathrm{s})\end{array}$ & & \\
\hline $\begin{array}{l}\text { Tempo total de travessia }(* *) \\
\text { T (s) }\end{array}$ & & \\
\hline
\end{tabular}


(continuação)
Tempo-espaço total,TS $\left(\mathrm{m}^{2}-\mathrm{s}\right)$
$\mathrm{TS}=\mathrm{LW}\left(\right.$ verde+verm- $\left.\frac{L}{2 S p}\right)$

Tempo total de travessia, $\mathrm{T}$

(p-s)

$\mathrm{T}=(v j+v g) \mathrm{t}$

Número de conflitos na

conversão à direita, Ntv(vei)

Tempo-espaço da conversão à

direita, TStv $\left(\mathrm{m}^{2}-\mathrm{s}\right)$

$\mathrm{TStv}=12 \mathrm{Ntv} . \mathrm{Wf}$

Tempo-espaço efetivo,

TS $f\left(m^{2}-s\right)$

$\mathrm{TSf}=\mathrm{TS}-\mathrm{TStv}$

Área de circulação para

pedestre, $\mathrm{M}\left(\mathrm{m}^{2} / \mathrm{p}\right)$

$\mathrm{M}=\frac{T S e}{T}$

NíVEL DE SERVIÇO

(consultar tabela IV-8)

Notas: $(*)$ Número de pessoas que chegam antes do sinal verde ou sai do meio-fio durante o verde ou chega na indicação Nped $=\frac{v(C-G)}{C}$

(**) Se $\mathrm{W}>3,0 \mathrm{~m}, \mathrm{t}=3,2+\frac{L}{S p}+\left(0,81 \frac{N p f}{W}\right) ;$ mas se $\mathrm{W} \leq 3,0 \mathrm{~m}, \mathrm{t}=3,2+\frac{L}{S t}+(0,27$ Nped) 


\section{QUESTIONÁRIO}

Como complementação da pesquisa numérica de campo, é importante a pesquisa qualitativa de campo, isto é, a auscultação da opinião dos usuários, os pedestres que estão utilizando a instalação em observação. A pesquisa qualitativa tem a finalidade de reproduzir o sentimento geral dos pedestres, uma opinião pública, não sendo uma pesquisa profunda, mas reflexiva das dificuldades individuais dos pedestres (tenho catarata, estou com o pé dolorido, sou idoso, mas estou em forma, etc). Este questionário foi baseado numa pesquisa semelhante, realizado pelos formandos do curso de especialização em Engenharia de Segurança do Trabalho da Universidade Federal de Santa Maria, RS, "Levantamento de riscos no trânsito de veículos e pedestres" [UFSM(1993)]. 
Entrevista com usuários da via, com amostragem qualitativa.

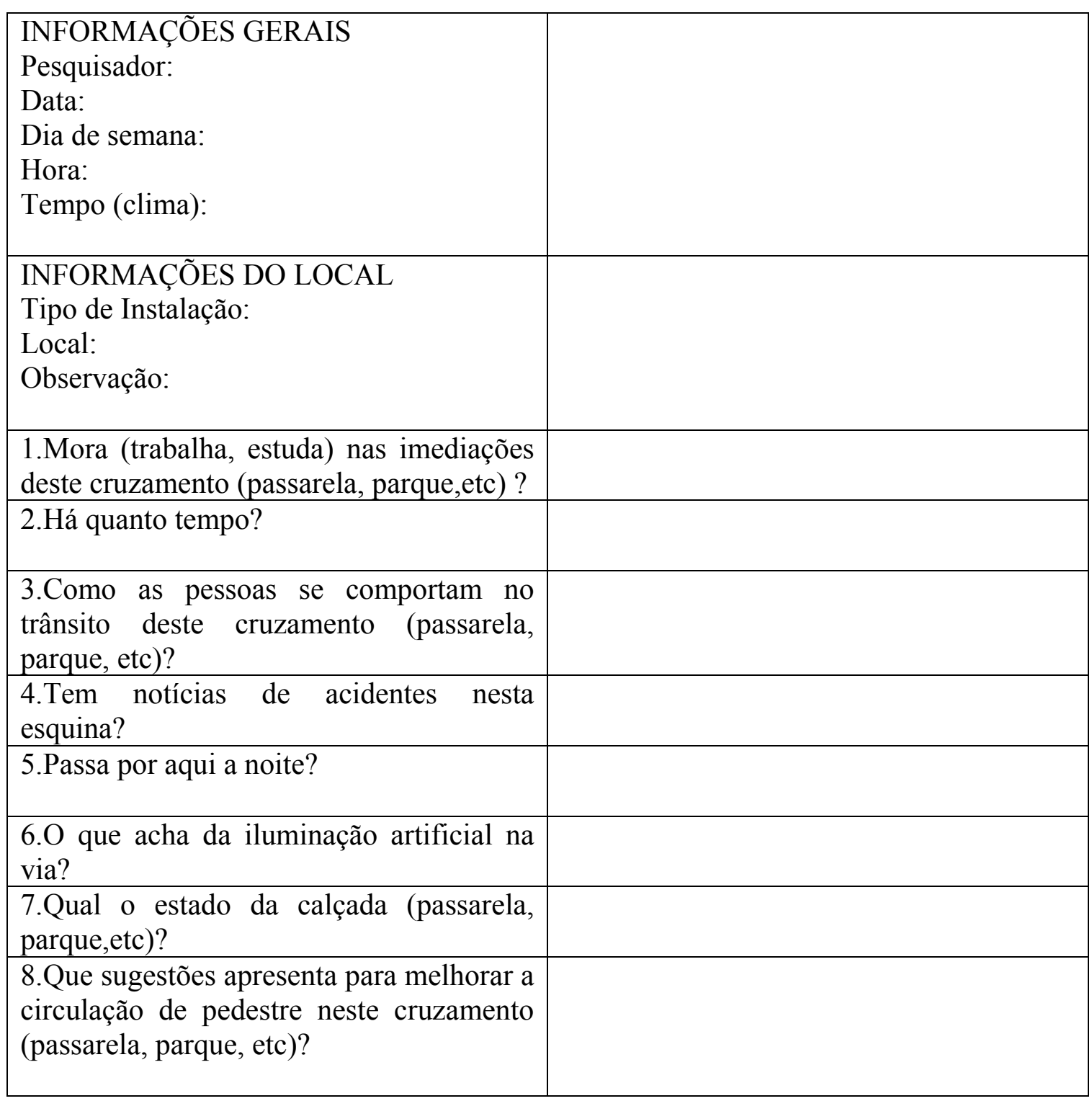




\section{LIMITAÇÕES DA METODOLOGIA E CONSIDERAÇÕES EM RELAÇÃO AO TRÂNSITO DA CIDADE DE SÃO PAULO}

\section{Limitações da metodologia}

Neste trabalho, cada instalação foi tratada do ponto de vista dos pedestres.

Esta metodologia não pode ser aplicada para o meio das calçadas devido a altos volumes de entrada e saídas de pedestres dos prédios ou estações de metrôs. Também não pode ser determinado o efeito de alto volume de veículos a motor entrando e saindo de um estacionamento e áreas de calçadas nas travessias. Além disso, a metodologia não considera a declividade, isto é, assumiu-se uma declividade de -3 a $+3 \%$; mesmo porque, os efeitos de declividades mais extremos não tem sido bem documentados.

\section{Considerações ao sistema de trânsito brasileiro.}

O trânsito brasileiro é legislado pelo Código de Trânsito Brasileiro, com a última reforma em 1997 [CTB(1997)]. Apesar de algumas regulamentações apresentadas pelo CONTRAN (Conselho Nacional de Trânsito) e DENATRAN (Departamento Nacional de Trânsito), há algumas flexibilidades regionais. Sendo assim em alguns Estados, até cidades, algumas medidas funcionais de caráter pontual são adotadas e adaptadas localmente.

No contexto geral, o trânsito, principalmente o de pedestres, não difere de região para região. O pedestre tem comportamento característico, personalidade e sentimento de liberdade. O que difere são os condicionamentos sociais, a educação de trânsito e a cultura do povo, conforme o "Manual de Segurança de Pedestres", editado pelo CONTRAN [CONTRAN(1979)]. 
O poder público ao construir instalações, nem sempre pergunta aos usuários, em potencial, se são as mais convenientes, seguras e apropriadas. Muitas instalações acabam não correspondendo à serventia a que foi destinada. Por exemplo, as passarelas. A mídia tem noticiado, com freqüência, atropelamentos, às vezes muito próximos de uma passarela. Costuma-se criticar os pedestres como sendo negligentes e mal educados; mas há todo um questionamento em relação à real segurança, o conforto e praticidade de uma passarela. O mais lógico, em relação ao dispêndio de energia, é que os pedestres circulem em nível, e os veículos transitarem em desnível. As travessias também apresentam um forte privilégio aos veículos motorizados. Os tempos de semáforo são calculados para favorecer maior fluidez da corrente de trânsito. Conseqüentemente, os pedestres têm tempo de espera maior que a paciência admite.

Sendo assim as instalações para pedestres nem sempre são satisfatórias.

A metodologia apresentada pelo HCM 2000 [TRANSPORTATION(2000)], é um instrumento para analisar a adequação dessas instalações e assim proporcionar melhor qualidade nas decisões sobre a realização de melhorias no sistema viário, incluindo a modalidade de caminhar.

Para a utilização da metodologia do Nível de Serviço, em relação às condições da cidade de São Paulo, é necessário prover algumas adaptações, por exemplo:

$1^{\circ}$ ) O tempo de semáforo do foco "Pare", por tempo intermitente ou tempo de amarelo, dependendo da condição do local. A fase "Pare" é adotada como 4 s, porém no Manual de Sinalização Urbana da CET-SP [CET(2001)], adota-se o tempo de "vermelho intermitente" de acordo com a largura da via, conforme Manual de Sinalização Semafórica - Critérios de Programação sobre o Vermelho Intermitente para Pedestre (Tabela IV-17) 


\section{Tabela IV-17 Programação do Tempo de Vermelho Intermitente para Pedestre}

\begin{tabular}{c|c}
\hline $\begin{array}{c}\text { Largura da travessia (L) } \\
(\mathbf{m})\end{array}$ & $\begin{array}{c}\text { Tempo de vermelho intermitente } \\
(\mathbf{s})\end{array}$ \\
\hline $\mathrm{L}<5,5 \mathrm{~m}$ & Inaplicável grupo focal para pedestre \\
\hline $5,5 \mathrm{~m} \leq \mathrm{L}<8 \mathrm{~m}$ & 3 segundos \\
\hline $8 \mathrm{~m} \leq \mathrm{L}<14 \mathrm{~m}$ & 4 segundos \\
\hline $14 \mathrm{~m} \leq \mathrm{L}<18 \mathrm{~m}$ & 5 segundos \\
\hline $18 \mathrm{~m} \leq \mathrm{L}$ & 6 segundos \\
\hline \multicolumn{2}{c}{ Fonte : Manual de sinalização. [CET (2001)] }
\end{tabular}

$2^{\circ}$ ) A largura da travessia de pedestres, no Manual de Sinalização Urbana, [CET(2001)], varia em $4,0 \mathrm{~m} ; 6,0 \mathrm{~m} ; 8,0 \mathrm{~m}$ e $16,0 \mathrm{~m}$, conforme a largura da pista e da demanda de transeuntes, sendo muito relativo, aplicado conforme o projeto local. O HCM 2000 [TRANSPORTATION(2000)] coloca a largura de 3,0m e maiores de 3,0m. Para cálculos, evidentemente utilizam-se as fórmulas para aquele com maiores de 3,0m; mas é interessante observar que o mínimo adotado é $3,0 \mathrm{~m}$, valor não considerado nos projetos brasileiros.

$\left.3^{\circ}\right)$ Pela Lei de Trânsito adotada na maioria dos estados dos Estados Unidos, a conversão à direita é permitida livremente, independente da sinalização vermelha. Pelo Código de Trânsito Brasileiro [CTB(1997)], isto não é permitido, a menos que o sinal esteja aberto a essa conversão. Com isso nas ruas de São Paulo há travessias de pedestres, em esquinas, tipo "carona" e "não carona". O tipo "carona" significa que, quando a sinalização for Verde para o fluxo de veículos, os pedestres podem atravessar livremente na mesma direção Verde, pois todos os veículos da pista perpendicular (Vermelhos) estarão parados. Os pedestres pegam "carona” na sinalização dos veículos. O tipo "não carona" é a travessia em que a conversão à direita é permitida, sendo assim a travessia, que em princípio não é permitida (o pedestre teria de esperar abrir sinal para si, ou aproveitar rapidamente o sinal Amarelo), mas na prática os pedestres atravessam nas brechas entre os veículos. Aqui as considerações do HCM 2000 
[TRANSPORTATION(2000)] ficam amplamente apoiadas, e as fórmulas para travessias com fluxo interrompido podem ser utilizadas, sem restrições.

$4^{\circ}$ ) Em São Paulo, é comum a utilização de Botoeiras pelos pedestres, para intervir no tempo de travessia. Botoeiras são dispositivos instalados em postes junto a algumas travessias, em que o pedestre acionando o botão estará solicitando um "estágio de pedestre", um tempo maior para a travessia, cerca de 68 segundos (contra 47s normais). Este "estágio de pedestre" ou "tempo de pedestre" também é chamado de "tempo morto" ou "tempo perdido", no jargão da engenharia de trânsito.

$5^{\circ}$ ) Estágio de pedestres

Com a vigência do Parágrafo Único do Artigo 38 do Código de Trânsito Brasileiro [CTB(1997)], deveria ocorrer mudança de conceito em relação ao estágio de pedestres. Referido parágrafo determina a prioridade de passagem quando o veículo manobrar para mudança de direção, explicitando a preferência do "pedestre, do ciclista e dos veículos que transitem em sentido contrário".

Hoje, o estágio de pedestres é utilizado para forçar artificialmente a abertura de uma brecha para a travessia de pedestres, pois estes não encontram brechas adequadas durante o estágio em que os veículos fazem a conversão e conflitam com eles.

$\mathrm{Na}$ realidade, o tempo do estágio de pedestres entra no cálculo do ciclo como tempo morto (pois é um tempo em que não anda nenhum veículo). O tempo de ciclo é diretamente proporcional ao tempo morto. Logo, quanto maior o tempo morto, maior deverá ser o ciclo.

$6^{\circ}$ ) No município de São Paulo está em vigor o decreto 45.904 / 2005 [SÃO PAULO (2005)], que legisla sobre a acessibilidade nas calçadas. O decreto traz uma série de novidades quanto à padronização dos passeios públicos na cidade, com destaque para a divisão das calçadas em três faixas: 
$\overline{\text { 1. faixa livre - área da calçada destinada exclusivamente à circulação de pedestres, } \mathrm{e}}$ que deverá ter largura mínima de 1,20 m e estar desobstruída de mobiliário urbano ou de qualquer outra interferência;

2. faixa de serviço - área destinada à colocação de objetos / elementos, mobiliário urbano e pequenas construções integrantes da paisagem urbana - implantada mediante a autorização do Poder Público, deve ter no mínimo 0,70 m de largura;

3. faixa de acesso - área destinada à acomodação de interferências temporárias como mesas e projeções de anúncios, sendo necessária autorização da Prefeitura e recomendável para passeios com mais de 2,0 $\mathrm{m}$ de largura, de forma a não interferir na faixa livre.

Os passeios devem incorporar dispositivos de acessibilidade nas condições especificadas na NBR 9050 [ABNT(2004)] ou norma técnica oficial que a substitua. Maiores detalhes no capítulo II desta tese.

A seguir são apresentadas ilustrações sobre algumas características do sistema viário paulista, visando a segurança do pedestre. (Figuras IV-9; IV-10; IV-11; IV-12; IV-13; IV-14 e IV-15).

Figura IV-9. Travessia de Pedestres Iluminada.

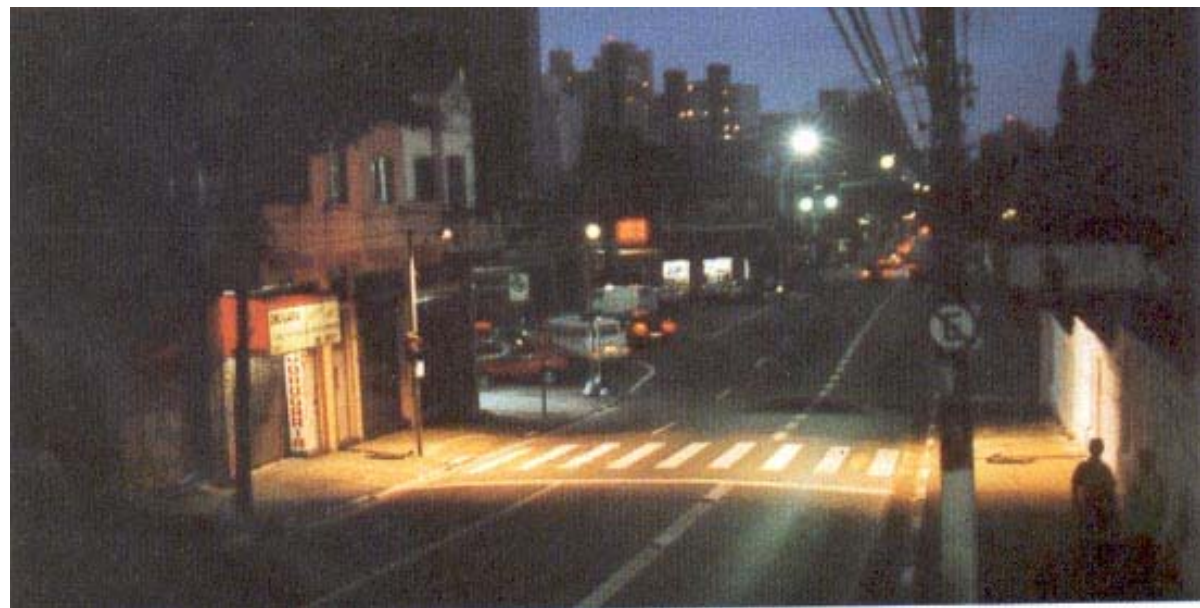

Fonte: [CET(2000)]

Houve considerável redução nos acidentes por atropelamento e por assaltos. 
Figura 10. Travessia com segurança

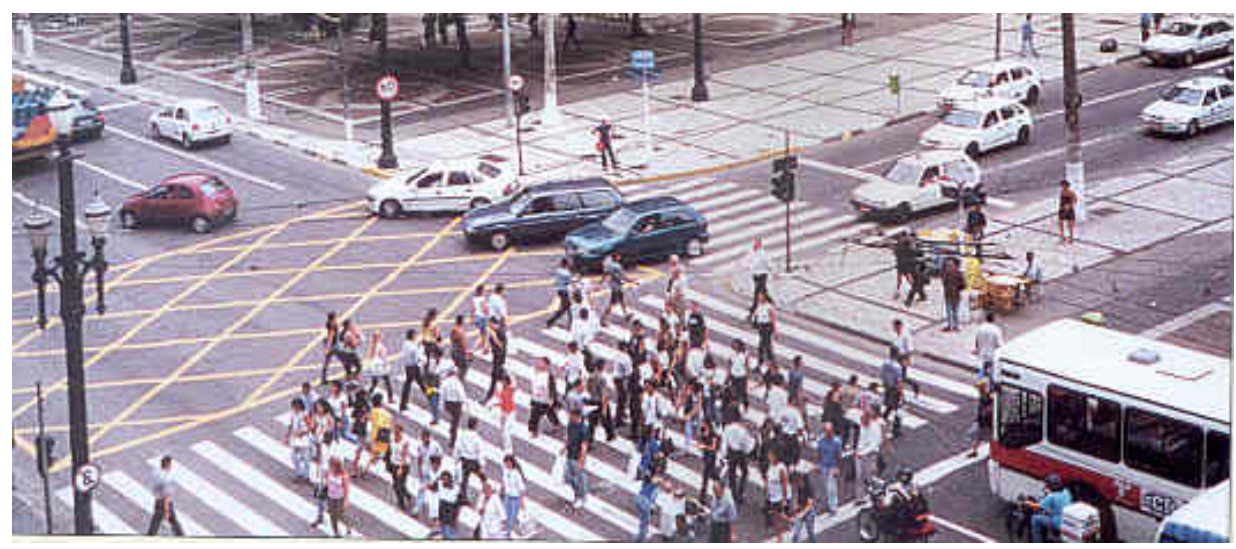

Fonte: Arquivo da autora [YABIKU(1999)].

À esquerda podemos notar o traçado em losangos alaranjados, que acentua .a obrigatoriedade de não fechar o trânsito, mesmo em hora de grande afluxo de veículos. Vemos uma travessia em pelotão. Observar que na calçada há pedestres com carrinhos aguardando a próxima travessia.

Figura 11. Viaduto do Chá

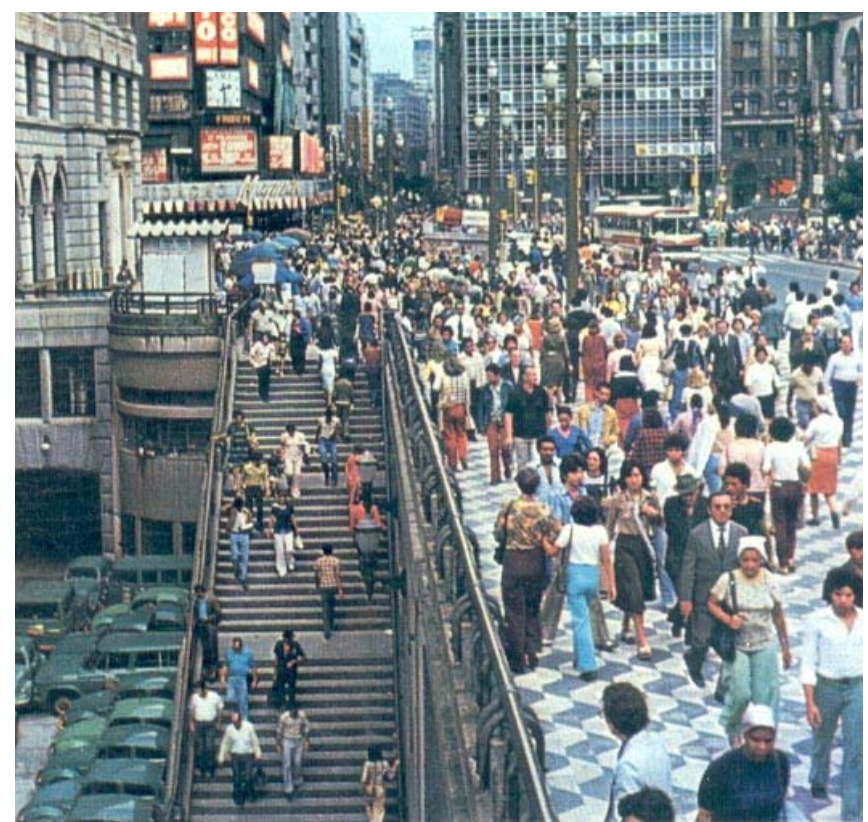

Fonte: [CET (1978)]

Viaduto do Chá, à direita e acesso em escada .para o Vale do Anhangabaú, à esquerda. 
Figura 12. Passarela para pedestres

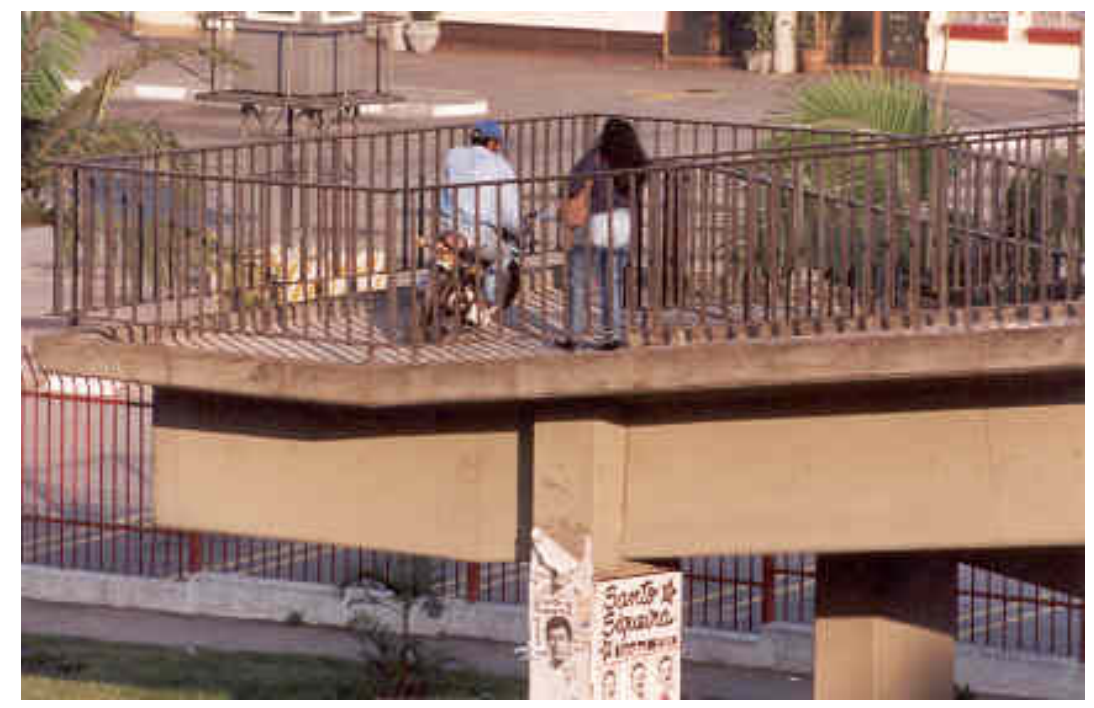

Fonte: Arquivo da autora [YABIKU(1999)]

Motoqueiro utilizando indevidamente a passarela para pedestres.

Figura 13. Complexo de passarelas

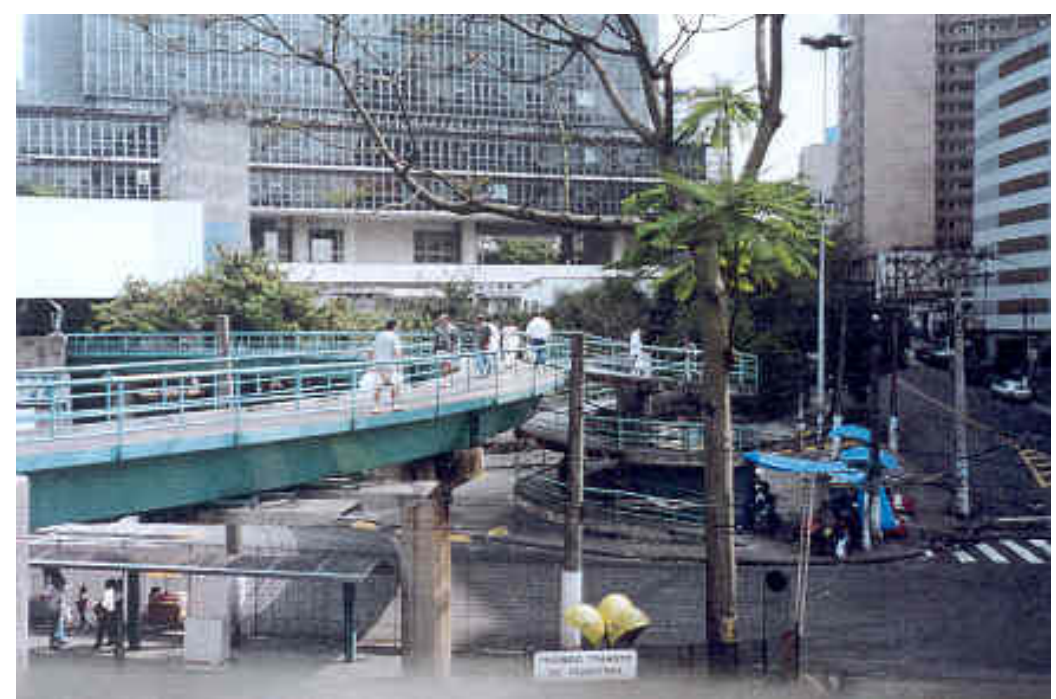

Fonte: Arquivo da autora [YABIKU(1999)]

Complexo de Passarelas no Terminal Praça da Bandeira

Estas passarelas constituem um sistema elevado de vias para o pedestre.

Estão ocupadas por camelôs e constituem-se no único acesso ao

Terminal de ônibus. 


\section{Figura 14. Segregação de pista para pedestre}

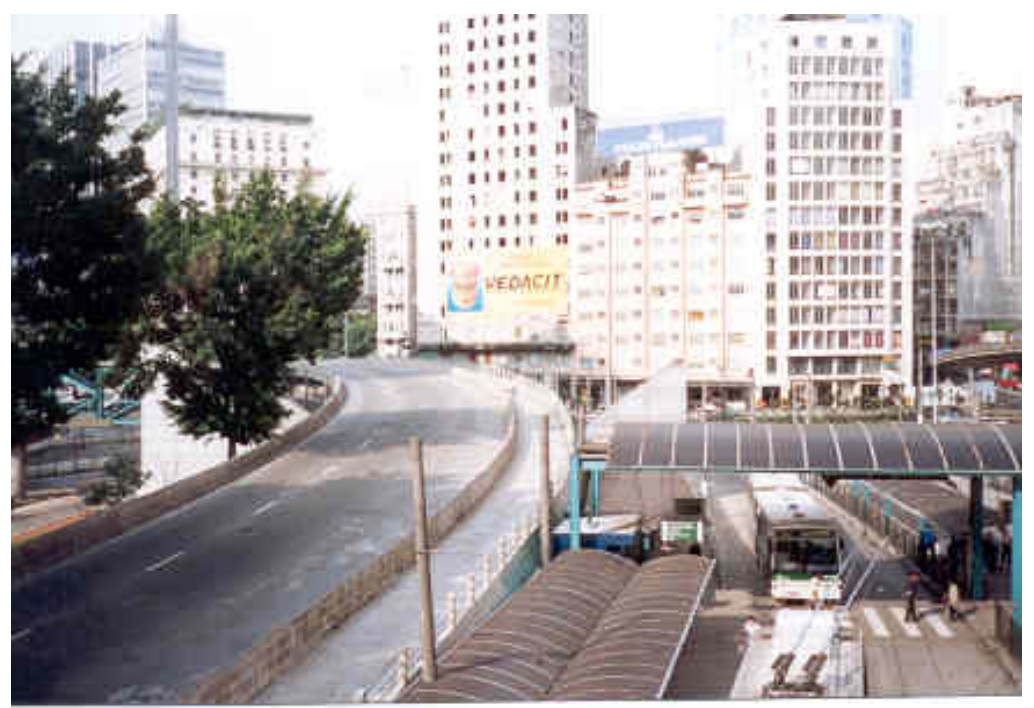

Fonte: Arquivo da autora [YABIKU(1999)]

À esquerda um viaduto com passagem para pedestre, segregada, .aumentando a segurança dos usuários. À direita o terminal de ônibus da Praça das Bandeiras.

Figura 15. Calçadão no centro da cidade

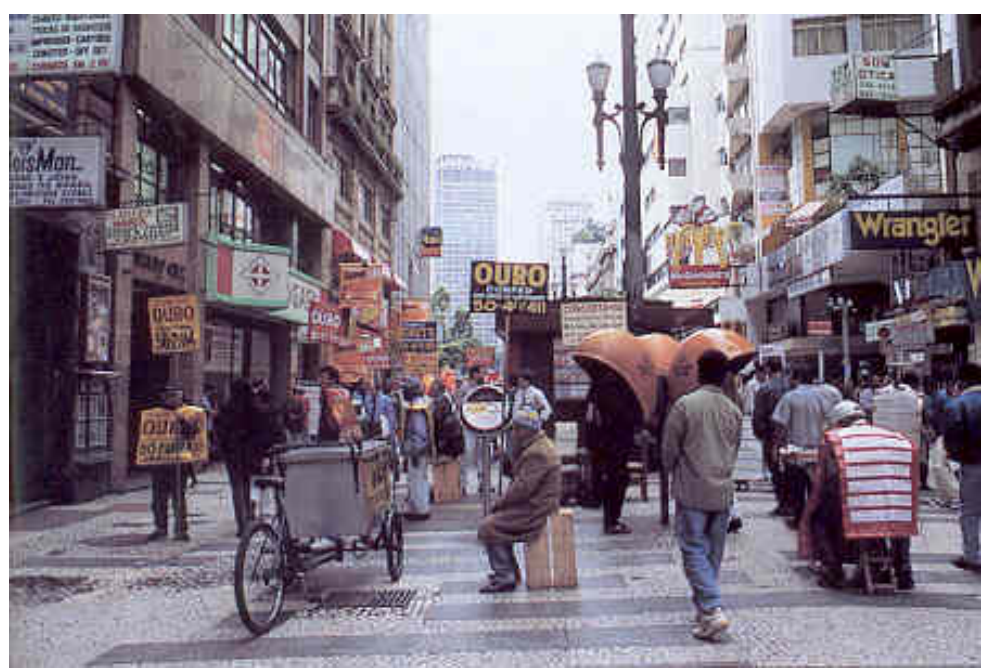

Fonte: Arquivo da autora.[YABIKU(1999)]

Ocupação do passeio (calçadão) por ambulantes, na região central.

Observar o excessivo apelo comercial, poluindo a paisagem urbana.

O espaço para o trânsito do pedestre fica comprometido. 


\section{SÍNTESE DO CAPÍTULO}

A primeira e a segunda parte deste capítulo contemplaram definições dos conceitos necessários para a compreensão das equações desenvolvidos na terceira e quarta partes. Alguns destes conceitos já foram apresentados nos capítulos anteriores, mas para a fluência e coerência de informações foram aqui repetidas. A quarta parte trata propriamente do método de cálculo do nível de serviço e na quinta parte foram apresentados os formulários e questionário para as pesquisas. As limitações da metodologia e as críticas foram apresentadas na sexta parte deste capítulo.

As condições para utilização deste método para avaliar as instalações para pedestres, na cidade de São Paulo revelam-se favoráveis, uma vez que a metodologia do HCM (Highway Capacity Manual) aplicada ao sistema viário já é prática comum nos projetos de engenharia de trânsito. Sempre salvaguardando as divergências entre as práticas e os códigos de trânsito dos dois países (Brasil e Estados Unidos, fonte desta metodologia). 


\section{BIBLIOGRAFIA REFERENCIADA}

ABNT. "Acessibilidade de pessoas portadoras de deficiência a edificações, espaço, mobiliário e equipamento urbano". NBR 9050. Set. 2004.

BOUERI, Jorge."Antropometria Aplicada à Arquitetura, Urbanismo e Desenho Industrial”. FAUUSP. São Paulo. 1999.

CET. "Boletim Técnico no 8, 17,19 -Áreas de Pedestres". Companhia de Engenharia de Trânsito. São Paulo.1978.

CET. "Fatos e Estatísticas de Acidentes de Trânsito em São Paulo". Companhia de Engenharia de Trânsito. São Paulo.2000.

CET- SP. "Manual de Sinalização Urbana - Semafórica". Cia de Engenharia de Trânsito. São Paulo. 2001.

CONTRAN. "Manual de Segurança de Pedestres”. 1979.

CTB."Código de Trânsito Brasileiro”. Diário Oficial da União. Imprensa Nacional. Brasília D.F. 1997.

FRUIN, John J. “Pedestrian-Planning and Design”. New York. DC. 1971.

SÃO PAULO, Prefeitura Municipal. "Decreto no 45.904 / 2005". Diário Oficial do Município.São Paulo. Maio 2005.

TRANSPORTATION, Research Board. "HCM 2000”. National Research Council Washington, D.C.2000

UFSM, Engenharia de Segurança do Trabalho. "Levantamento de riscos no trânsito de veículos e pedestres" Revista CIPA. São Paulo. 1993.

YABIKU, Luiza. "O Pedestre”. Apostila do curso de Capacitação para Médicos Peritos Examinadores. ABRAMET. São Paulo. 1999. 


\section{CAPÍTULO V}

\section{ESTUDO DE CASO}

\section{AVALIAÇÃO DE NÍVEL DE SERVIÇO E ADEQUAÇÃO ERGONÔMICA DAS INSTALAÇÕES PARA PEDESTRES NA CIDADE DE SÃO PAULO}

Apresentação:

Este capítulo apresenta a pesquisa de avaliação de Nível de Serviço das Instalações para Pedestres. O campo experimental da pesquisa foi a Zona Leste, selecionado a partir do cruzamento das informações sobre os "Pontos de Articulação" e suas localizações na Cidade de São Paulo e as mortes de Pedestres no Município de São Paulo. Para o conhecimento da área de interesse é elaborado um levantamento de dados sócioeconômicos, caracterização do seu sistema viário e pólos geradores de trânsito.

Com o levantamento de pontos críticos para pedestres, elaborados pela Companhia de Engenharia de Trânsito de São Paulo, situados nas proximidades dos "Pontos de Articulação" é levado a efeito a pesquisa e análise de campo, com a metodologia preconizada pela HCM 2000 e com a pesquisa qualitativa sobre a satisfação do usuário das instalações para pedestres. São configuradas as considerações finais com recomendações elaboradas a partir deste experimento. 


\section{ESTUDO DE CASO}

\section{AVALIAÇÃO DE NÍVEL DE SERVIÇO E ADEQUAÇÃO ERGONÔMICA DAS INSTALAÇÕES PARA PEDESTRES NA CIDADE DE SÃO PAULO}

\section{Sumário:}

1. SELEÇÃO DOS LOCAIS A SEREM ANALISADAS

1.1 Os "Pontos de Articulação" e suas localizações na Cidade de São Paulo

1.2 Mortes de Pedestres no Município de São Paulo

1.3 Relação entre os "Pontos de Articulação" e as regiões de maior mortandade de pedestres.

1.4 Conhecimento da região de interesse.

1.4.1 Dados Sócio-Econômicos

1.4.2 Caracterização do Sistema Viário

1.4.3 Pólos Geradores de Trânsito

1.5 "Pontos de Articulação" selecionados na escala do Pedestre

2. PESQUISA E ANÁLISE DOS LOCAIS SELECIONADOS

2.1 Critérios de pesquisa

2.2 Pesquisa e Análise das Instalações para Pedestres.

2.2.1 Bairro do Belém

2.2.2 Bairro da Mooca

2.2.3 Bairro do Tatuapé

2.2.4 Bairro da Vila Prudente

2.2.5 Bairro do Carrão

2.2.6 Bairro da Vila Esperança

2.2.7 Bairro da Penha

2.2.8 Considerações do item 2.2

2.3 Pesquisa e Análise de Campo.

2.3.1 Pesquisa Qualitativa sobre a Satisfação do Uso das Instalações para Pedestres

2.3.2 Considerações do item 2.3

3. SÍNTESE DO CAPÍTULO

4. BIBLIOGRAFIA REFERENCIADA 


\section{ESTUDO DE CASO}

\section{AVALIAÇÃO DE NÍVEL DE SERVIÇO E ADEQUAÇÃO ERGONÔMICA DAS INSTALAÇÕES PARA PEDESTRES NA CIDADE DE SÃO PAULO}

\section{SELEÇÃO DOS LOCAIS A SEREM ANALISADAS}

A cidade de São Paulo sem dúvida apresenta inúmeros locais de interesse para análise das instalações para pedestres. A fim de selecionar alguns pontos de interesse o critério adotado foi utilizar a análise elaborada pela Companhia do Metropolitano de São Paulo, denominada "Pontos de Articulação".

1.1 "Pontos de Articulação" e suas localizações na cidade de São Paulo

Os "Pontos de Articulação" foram na origem chamados de "Pontos de Rede" e com o desenvolvimento do trabalho sofreu essa renomeação. A determinação destes "Pontos" foi um extensivo trabalho elaborado pela Companhia do Metropolitano de São Paulo, coordenado pela arqa . Andreina Nigriello [NIGRIELLO(2002)], objetivando detectar pontos futuros que a curto, médio e longo prazo necessitariam de transporte coletivo mais eficazes.

O que é "Pontos de Articulação"?

É um modelo de planejamento de transportes que integram e interagem com o uso e ocupação do solo, ofertas de transportes coletivos e individuais, sistema viário e 
topografia. O "ponto de articulação" desenvolveu-se com o objetivo de agregar, ao processo de simulação da geração de viagens, maiores graus de conhecimento da cidade e de sensibilidade em relação à vida real urbana. Partindo-se da premissa de que alguns dos fatores, de difícil modelagem, podem ser trabalhados anteriormente à simulação, com o emprego de mecanismos auxiliares relativamente simples, que não envolvem volume de trabalho e recurso vultosos. Apresenta como vantagem operacional a espacialização e a visualização gráfica desses locais na malha urbana.

Em princípio pode-se conceituar o ponto de articulação como sendo lugares do espaço urbano com demanda de transporte e adensamento significativos, tanto numa situação presente como futura, em função do potencial de desenvolvimento a eles intrínseco. Neles a articulação entre a rede de transporte e a concentração de atividades merece especial atenção porque responde ao mesmo tempo a objetivos do planejamento urbano e do planejamento de transporte.

Assim, os "Pontos de Articulação" são locais com atributos espaciais que justifiquem a associação de rede de transporte de caráter estrutural com seu sistema de linhas alimentadoras e com os demais serviços e atividades necessárias à realização das funções urbanas. Estes atributos espaciais são:

-concentração de linhas de transporte público;

- concentração de atividades de comércio, serviço e/ou de produção;

- geração ou atração significativa de viagens;

- características físicas favoráveis ao acesso regional e local por vias coletoras arteriais e expressas;

- características físicas favoráveis ao adensamento do espaço edificado, graças á topografia plana ou pouco acidentada.

Resumo nas figuras (V-1), (V-2) e (V-3). 
Figura V-1. "Pontos de Articulação” - RMSP. Julho/99

Bolsões de Identificação 


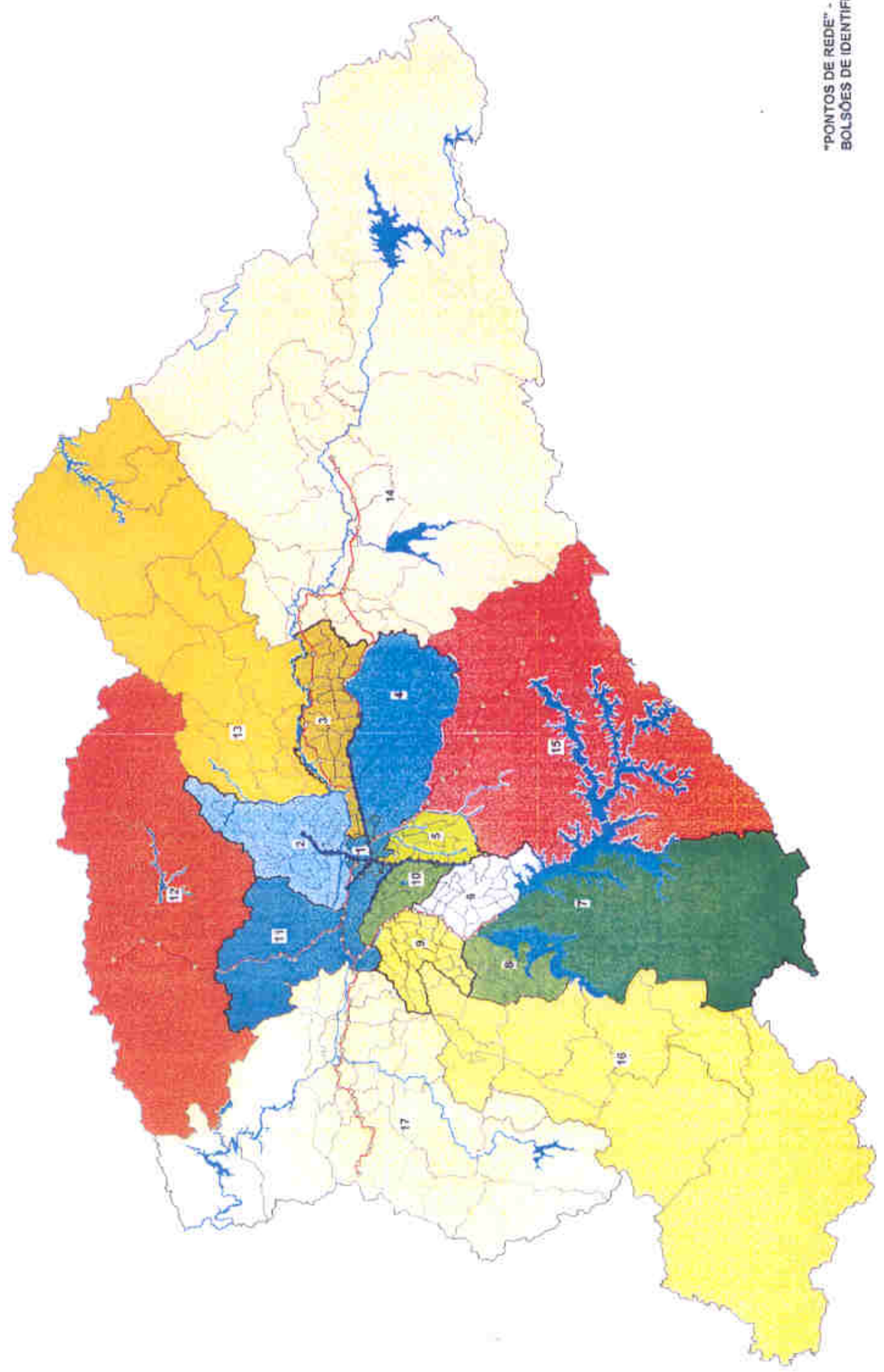

Fonte: "Estudo para Identificação dos “Pontos de Rede" na RMSP". [NIGRIELLO(1999)]. 
Figura V-2. “Densidade Populacional, Emprego e Viagens”. RMSP. Julho/99

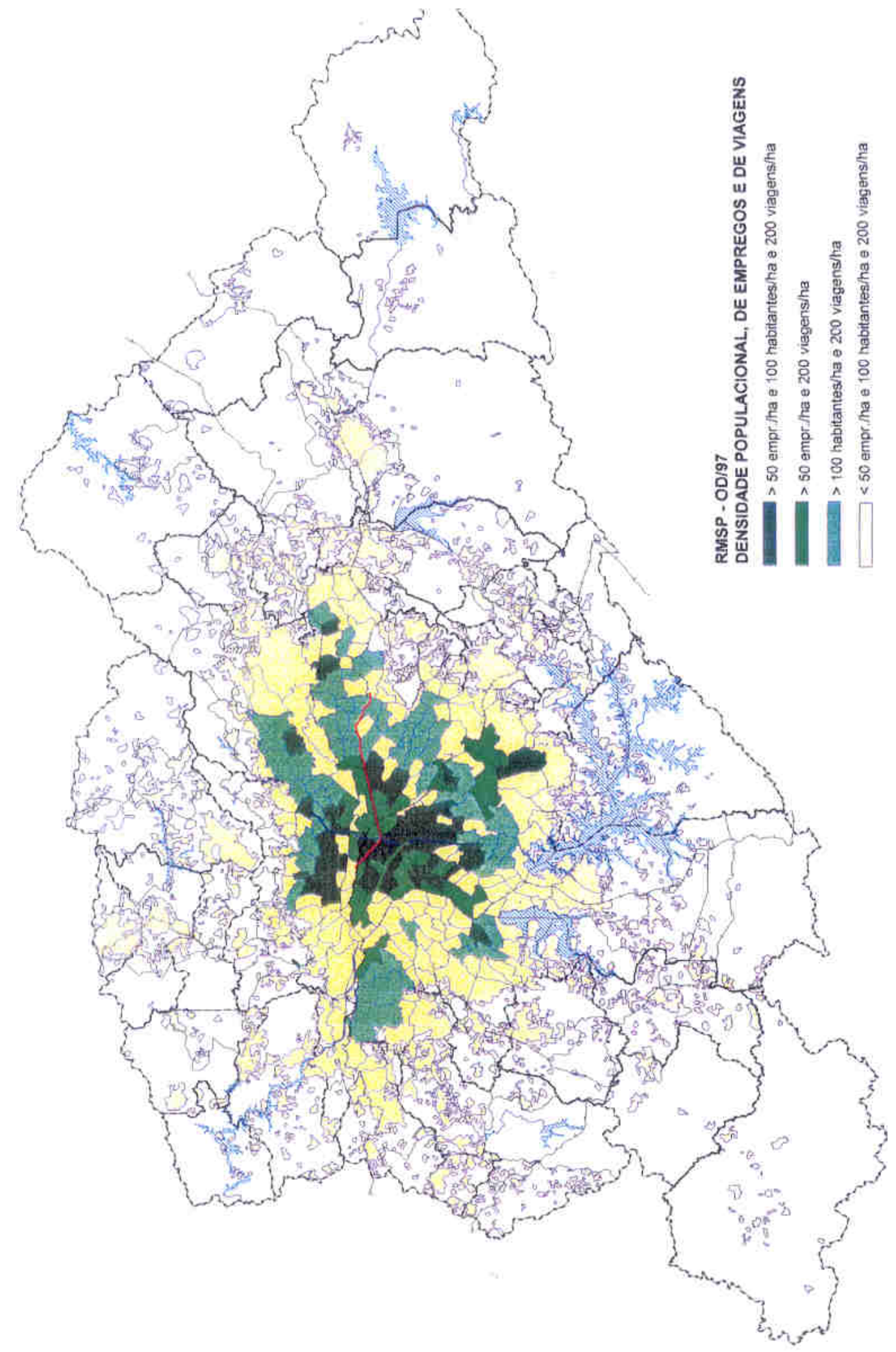

Fonte: “Estudo para Identificação dos “Pontos de Rede" na RMSP”. [NIGRIELLO(1999)]. 
Figura V-3. “Densidade de Viagens por Motivo Não Residencial”. RMSP. julho/99

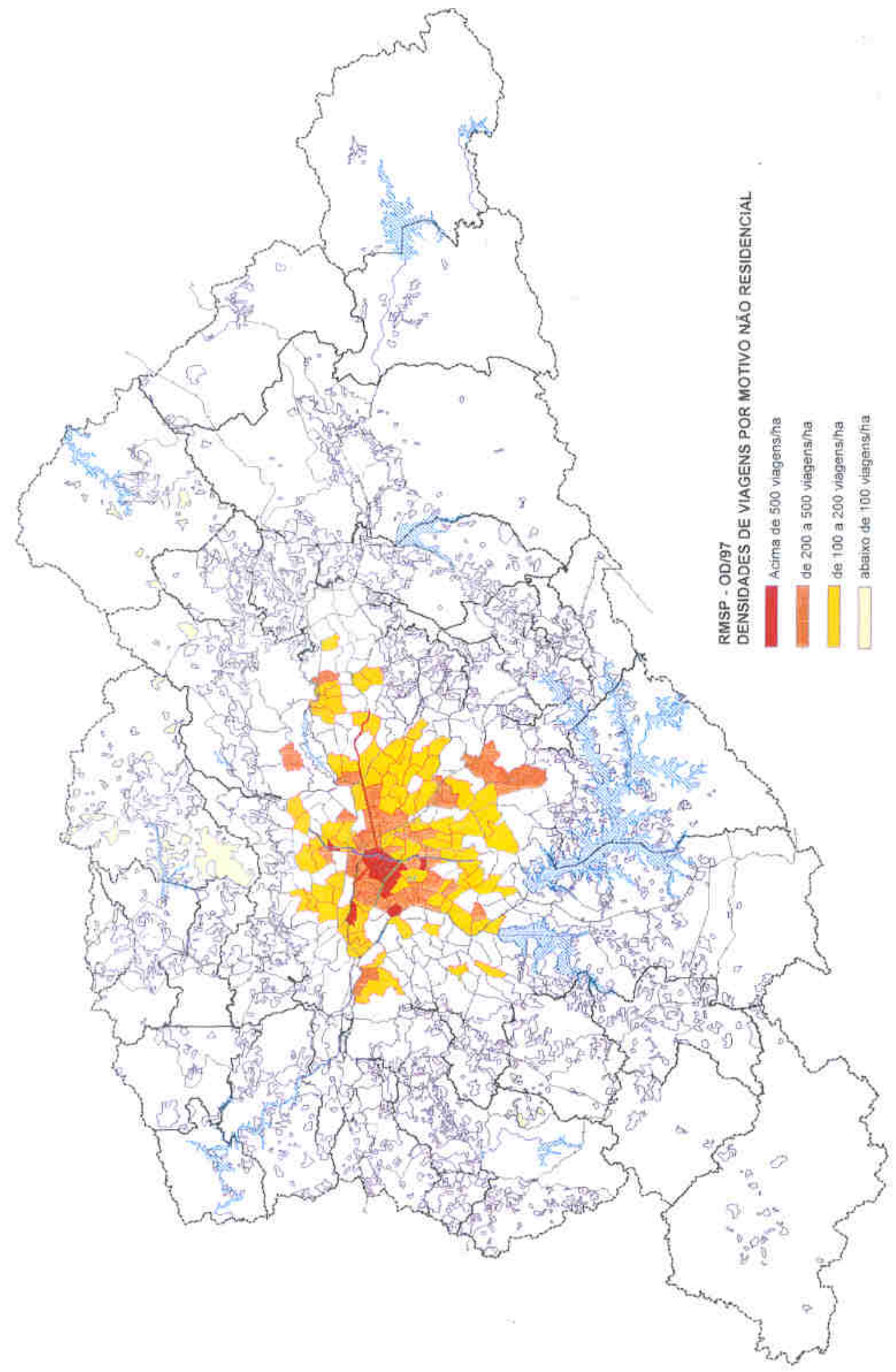

Fonte: “Estudo para Identificação dos “Pontos de Rede" na RMSP”. [NIGRIELLO(1999)]. 
Há "Pontos de Articulação" de diferentes categorias em função da quantidade de linhas de transporte, da concentração de atividades econômicas, da densidade de população, empregos e viagens das áreas onde estão localizados e da acessibilidade viária. Consideram-se quatro categorias de pontos de articulação. Nos locais onde há convergência de todos os atributos mencionados, identificam-se os pontos de $1^{\text {a }}$ categoria; aos de $2^{\text {a }}$ categoria correspondem os mesmos atributos, mas com menor escala; os pontos de $3^{\text {a }}$ categoria localizam-se em áreas menos densas, em termos de população e empregos e, portanto com menor geração ou atração de viagens; os pontos de $4^{\text {a }}$ categoria apresentam apenas alguns atributos, mas têm potencial para agregar, no futuro, características ausentes.

Porém estas categorias foram hierarquizadas, internamente, conforme a intensidade da presença dos atributos.

\section{Primeira Categoria:}

- Convergência de mais de 21 linhas de ônibus; acessíveis por vias arteriais expressas ou coletoras; topografia plana ou ondulada; localizados em zonas O/D com mais de 200 viagens/ha, realizadas por todos os motivos, excluído o de acesso à residência; localizados em zonas com mais de 200 viagens/ha e com mais de 50 empregos/ha e mais de 100 habitantes/ha.

- Convergência de mais de 21 linhas de ônibus; acessíveis por vias arteriais expressas ou coletoras; topografia plana ou ondulada; localizados em zonas O/D com mais de 200 viagens/ha, realizadas por todos os motivos, excluídos o de acesso à residência; localizados em zonas com mais de 200 viagens/ha e com mais de 50 empregos/ha.

- Convergência de mais de 30 linhas de ônibus; acessíveis por vias arteriais expressas ou coletoras; topografia plana ou ondulada; localizados em zonas O/D com mais de 200 
viagens/ha, realizadas por todos os motivos, excluídos o de acesso à residência; localizados em zonas com mais de 200 viagens/ha e com mais de 100 habitantes/ha.

ム Convergência de mais de 30 linhas de ônibus; acessíveis por vias arteriais expressas ou coletoras; topografia plana ou ondulada; localizados em zonas O/D com mais de 200 viagens/ha, realizadas por todos os motivos, excluídos o de acesso à residência; localizados em zonas com mais de 200 viagens/ha e com mais de 50 empregos/ha.

\section{Segunda Categoria:}

- Convergência de mais de 10 linhas de ônibus, até 20; acessíveis por vias arteriais expressas ou coletoras; topografia plana ou ondulada; localizados em zonas O/D com mais de 100 viagens/ha, realizadas por todos os motivos, excluídos o de acesso à residência; localizados em zonas com mais de 200 viagens/ha, e com mais de 50 empregados/ha e mais de 100 habitantes/ha.

- Convergência de mais de 10 linhas de ônibus, até 20, acessíveis por vias arteriais expressas ou coletoras; topografia plana ou ondulada; localizados em zonas O/D com mais de 100 viagens/ha, realizadas por todos os motivos, excluídos o de acesso à residência; localizados em zonas com mais de 200 viagens/ha e com mais de 50 empregos/ha.

- Convergência de mais de 10 linhas de ônibus, até 20; acessíveis por vias arteriais expressas ou coletoras; topografia plana ou ondulada; localizados em zonas O/D com mais de 200 viagens/ha, realizadas por todos os motivos, excluídos o de acesso à residência; localizados em zonas com mais de 200 viagens/ha e com mais de 100 habitantes/ha.

A Convergência de mais de 10 linhas de ônibus, até 20; acessíveis por vias arteriais expressas ou coletoras; topografia plana ou ondulada; localizados em zonas O/D com mais de 100 viagens/ha, realizadas por todos os motivos, excluídos o de acesso à 
residência; localizados em zonas com mais de 200 viagens/ha, e com mais de 100 habitantes/ha.

\section{Terceira Categoria:}

- Convergência de mais de 10 linhas de ônibus, até 20; acessíveis por vias arteriais expressas ou coletoras; topografia plana ou ondulada; localizados em zonas O/D com mais de 200 viagens/ha, realizadas por todos os motivos, excluídos o de acesso à residência e com mais de 50 empregos/ha e mais de 100 habitantes/ha.

- Convergência de mais de 10 linhas de ônibus, até 20; acessíveis por vias arteriais expressas ou coletoras; topografia plana ou ondulada; localizados em zonas O/D com mais de 200 viagens/ha realizadas por todos os motivos, excluídos o de acesso à residência e com mais de 50 empregos/ha.

- Convergência de mais de 10 linhas de ônibus, até 20; acessíveis por vias arteriais expressas ou coletoras; topografia plana ou ondulada; localizados em zonas O/D com mais de 200 viagens/há realizadas por todos os motivos, excluídos o de acesso à residência e com mais de 100 habitantes/ha.

$\boldsymbol{\Delta}$ Convergência de mais de 10 linhas de ônibus, até 20; acessíveis por vias arteriais expressas ou coletoras; topografia plana ou ondulada; localizados em zonas O/D com mais de 100 viagens/ha, realizadas por todos os motivos, excluídos o de acesso à residência.

\section{Quarta Categoria:}

${ }^{\text {o }}$ Convergência de mais de 10 linhas de ônibus; acessíveis por vias arteriais expressas ou coletoras e topografia plana ou ondulada.

Dessa forma, os "Pontos de Articulação" foram hierarquizados e ordenados em 63 de primeira, 109 de segunda, 37 de terceira e 82 de quarta categorias. Estes últimos (quarta categoria) são pontos que, nas condições atuais, ainda não correspondem totalmente aos 
valores determinados pelos indicadores que foram definidos para avaliar as concentrações espaciais de atividades econômicas.

Esta metodologia foi aplicada na Região Metropolitana de São Paulo em 1999, e foi detectado que os pontos de articulação de $1^{\mathrm{a}}, 2^{\mathrm{a}}$ e $3^{\mathrm{a}}$ categorias estão localizados no território de apenas sete municípios da metrópole: São Paulo, Osasco, Diadema. São Caetano, São Bernardo, Santo André e Guarulhos. Nestes sete municípios os pontos de articulação de $1^{\mathrm{a}}$ categoria estão concentrados em sua maioria no centro expandido e no sudoeste de São Paulo. Ainda em São Paulo há pontos de articulação de $1^{\mathrm{a}}$ categoria em Campo Limpo, Freguesia do Ó, Santana, Vila Guilherme, Vila Maria, Belém, Mooca, Tatuapé, Carrão, Penha, Vila Esperança, São Miguel e Vila Prudente. Os demais pontos de articulação de $1^{\mathrm{a}}$ categoria pertencem aos municípios de Osasco, Guarulhos, São Bernardo e Santo André.

Os pontos de articulação de $2^{\mathrm{a}}$ categoria são mais numerosos que os de $1^{\mathrm{a}}$ categoria e configuram uma coroa ao redor do centro expandido, localizados em sua maioria no município de São Paulo, em bairros como: Brooklim, Vila Santa Catarina, Freguesia do Ó, Santana, Vila Maria, Tucuruvi, Brasilândia, Vila Prudente, São Mateus, Guaianazes, São Miguel, Capão Redondo e Butantã.

Nos demais municípios da metrópole os pontos de articulação de $2^{\mathrm{a}}$ categoria localizamse nos municípios de Santo André, Guarulhos e Osasco.

Os pontos de articulação de $3^{\text {a }}$ categoria estão alinhados ao longo das marginais dos rios Tietê e Pinheiros e próximos às represas de Guarapiranga e Billings. Há também pontos de articulação desta categoria entremeados aos de $2^{\text {a }}$ categoria, em Santana, Tucuruvi, Penha, São Miguel, Itaim Paulista e Aricanduva.

O trabalho conclui que há desequilíbrio na distribuição dos "pontos de articulação" sobre o território metropolitano, destacando-se: 
- concentração de pontos de $1^{\mathrm{a}}$ categoria nas sub-regiões central e sudeste;

- áreas de grande oferta de transporte coletivo em locais com baixa concentração de atividades econômicas, como nas sub-regiões oeste, leste e extremo sul do município de São Paulo, áreas convencionalmente denominadas de "dormitórios".

- as maiores categorias são resultados da coincidência espacial de dois fatores:

1) uma oferta significativa de transporte coletivo (como ocorre ao longo das linhas de metrô).

2) uma infra-estrutura viária que garante a articulação dos pontos de rede a diversos locais de produção de viagens.

Isto confirma a interdependência da oferta de transporte com o uso do solo. E o trabalho conclui recomendando que ao planejar-se para 2020 seja considerando os desequilíbrios acima indicados, contemplando-se a oferta de transporte coletivo estrutural.

Localizações dos pontos na figura (V-4). 
Figura V-4. Localização dos “pontos de articulação”. RMSP. Julho/99

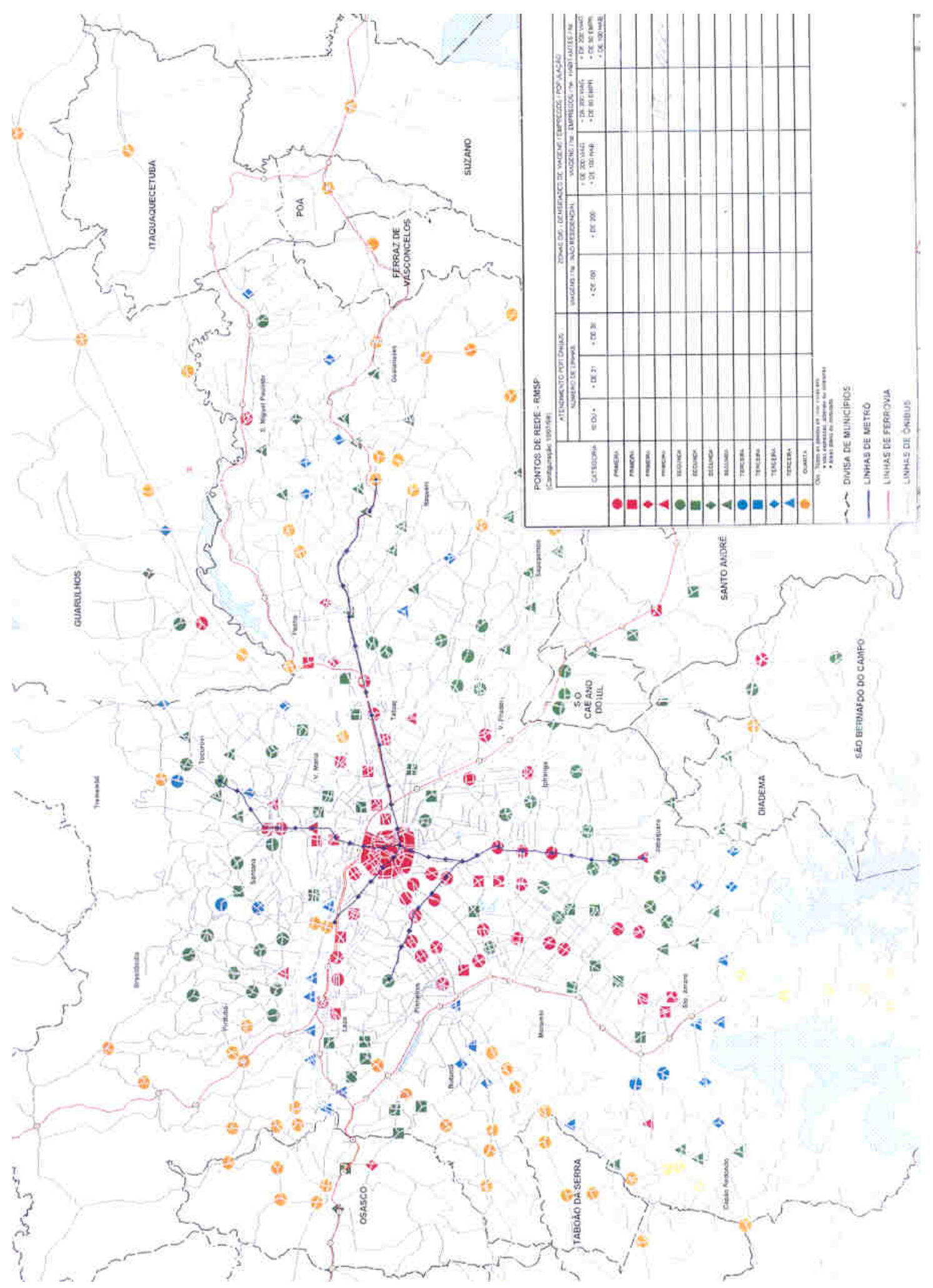


Fonte: "Estudo para Identificação dos "Pontos de Rede" na RMSP”. [NIGRIELLO(1999)].

1.2 Mortes de Pedestres no Município de São Paulo

Os "pontos de articulação" sendo locais com atributos específicos em concentração de linhas de transporte público, concentração de atividades de comércio, serviço e produção, geração ou atração significativa de viagens, acesso regional e local por vias coletoras, arteriais e expressas e condições físicas favoráveis ao adensamento de espaço confinado, são também locais favoráveis a acidentes de atropelamento, pois estes atributos são atrações de pessoas e veículos.

Os "pontos de articulação" de $1^{\text {a }}$ categoria são aqueles que atendem a todos os atributos. Assim, são potencialmente os mais críticos a atropelamentos. Tomando-se estes "pontos" e correlacionando-os com o números de óbitos por motivo de atropelamento, por região da Coordenadoria Regional de Saúde, lançado pelo PRO-AIM(*) Mortalidade no Município de São Paulo [PRO-AIM(2005)], demarcou-se as áreas de interesse desta pesquisa. A estatística de mortos por atropelamento nas regiões administrativas foi apresentada como Tabela III-18, no capítulo III, item 1.5 Morte por Atropelamento na Cidade de São Paulo. Aqui será reeditada como Tabela V- 1.

Tabela V-1.Morte por atropelamento, nas regiões administrativa de São Paulo, em retrospectiva anual.

\begin{tabular}{|l|c|c|c|c|}
\hline $\begin{array}{l}\text { Região Ano } \\
\text { Administrativa }\end{array}$ & Ano 2002 & Ano 2003 & Ano 2004 & $\begin{array}{c}\text { População } \\
\text { Total } \\
(2004)^{*}\end{array}$ \\
\hline Centro Oeste & $\mathbf{5 7}$ & $\mathbf{6 7}$ & $\mathbf{5 4}$ & 1.294 .720 \\
\hline Leste & $\mathbf{1 2 2}$ & $\mathbf{1 0 5}$ & $\mathbf{1 1 8}$ & 1.882 .362 \\
\hline Norte & $\mathbf{1 2 0}$ & $\mathbf{1 1 9}$ & $\mathbf{1 0 9}$ & 2.092 .360 \\
\hline Sudeste & $\mathbf{1 1 7}$ & $\mathbf{1 2 0}$ & $\mathbf{1 3 5}$ & 2.530 .920 \\
\hline Sul & $\mathbf{9 0}$ & $\mathbf{8 3}$ & $\mathbf{9 7}$ & 2.255 .452 \\
\hline
\end{tabular}




\begin{tabular}{|l|c|c|c|c|}
\hline Endereço Ignorado & $\mathbf{9 1}$ & $\mathbf{9 6}$ & $\mathbf{6 5}$ & ---- \\
\hline Total & $\mathbf{5 9 7}$ & $\mathbf{5 9 0}$ & $\mathbf{5 7 8}$ & 10.055 .814 \\
\hline
\end{tabular}

Fonte: Município de São Paulo. Sumário de Dados.[PRO-AIM(2005)]

* Sumário de Dados.Valores obtidos a partir do Censo Demográfico 2000, do IBGE.

(*) PRO-AIM, Programa de Aprimoramento das Informações de Mortalidade no Município de São Paulo.

Com a demarcação regional dos "pontos de articulação" de $1^{\text {a }}$ categoria conjugada com os óbitos por atropelamento por região administrativa da Secretaria da Saúde do Município de São Paulo, obteve-se a tabela V-2.

A Coordenadoria emite o número de óbitos por região, que é composta por determinados números de bairros que variam de acordo com os interesses da Coordenação de Saúde. O número de mortos foi relacionado com o total de mortos no ano de 2004, no município de São Paulo. Foram confrontados os bairros atendidos pelas regionais da Coordenadoria da Saúde com os locais evidenciados pelos “pontos de articulação", resultando na Tabela V-2. Relação de "Pontos de Articulação" com Número de Mortos por Atropelamento.

1.3 Relação entre os "Pontos de Articulação" e as regiões de maior mortandade de pedestres.

Tabela V-2. Relação de "Pontos de Articulação" com Número de Mortos por Atropelamento.

\begin{tabular}{|c|c|c|c|c|}
\hline $\begin{array}{l}\text { Ponto de } \\
\text { Articulação }\end{array}$ & \multicolumn{4}{|c|}{$\begin{array}{c}\text { PRO-AIM Mortalidade no Município de São Paulo } \\
\text { Atropelamento de Pedestres }\end{array}$} \\
\hline $1^{\mathrm{a}}$ Categoria & $\begin{array}{l}\text { Região da } \\
\text { Coord. Saúde }\end{array}$ & $\begin{array}{l}\text { Número de } \\
\text { mortes }(2004)\end{array}$ & $\begin{array}{l}\text { Número de } \\
\text { bairros/regional }\end{array}$ & $\begin{array}{l}\% \text { de } \operatorname{mortos}(*) \\
(\text { total }=578)\end{array}$ \\
\hline Campo Limpo & Sul & 97 & 6 & $17 \%$ \\
\hline
\end{tabular}




\begin{tabular}{|c|c|c|c|c|}
\hline Freguesia do Ó & Norte & \multirow{4}{*}{109} & \multirow{4}{*}{11} & \multirow{4}{*}{$19 \%$} \\
\hline Santana & Norte & & & \\
\hline Vila Guilherme & Norte & & & \\
\hline Vila Maria & Norte & & & \\
\hline Belém & Sudeste & \multirow{7}{*}{135} & \multirow{7}{*}{7} & \multirow{7}{*}{$23 \%$} \\
\hline Mooca & Sudeste & & & \\
\hline Tatuapé & Sudeste & & & \\
\hline Carrão & Sudeste & & & \\
\hline Penha & Sudeste & & & \\
\hline V. Esperança & Sudeste & & & \\
\hline V. Prudente & Sudeste & & & \\
\hline São Miguel & Leste & 118 & 7 & $20 \%$ \\
\hline
\end{tabular}

Fontes: "Pontos de Articulação". [NIGRIELLO(2002)]

"Mortalidade no Município de São Paulo". [PRO-AIM(2005)].

(*) Detalhamento da tabela do PRO-AIM encontra-se no capítulo III.

Observa-se que a região sudeste apresenta um alto índice de mortalidade por atropelamento (23\%) é o que apresenta maior número de "Pontos de Articulação", sete, o mesmo número de bairros que compõe a regional sudeste da Coordenadoria de Saúde. Correspondem aos bolsões 03 e 04, cores âmbar e azul, respectivamente, na figura (V5). Numa primeira aproximação teríamos cerca de 19 mortos por atropelamento por "Pontos de Articulação", em 2004, na região sudeste. Isto evidencia o alto potencial de morte nestes "pontos de articulação", uma vez que, são pólos de atração de pedestres e veículos. Este fato já fora observado em 1994, pela CET, em "Morte de Idosos por Atropelamento: uma Proposta de Educação para Segurança da Terceira Idade no Trânsito". [CET(1994)]. Neste trabalho constatou-se que a maior quantidade de mortes por atropelamento em corredores viários ocorreram na Avenida Alcântara Machado Radial Leste, sendo, na oportunidade, 124 atropelamentos com 21 mortes no primeiro semestre de 1993.

Observação: as várias instituições de serviços públicos dividem as suas regiões administrativas divergentes entre si, com a inclusão ou não de alguns bairros. Assim, para a Secretaria da Saúde do Município de São Paulo a região em foco neste trabalho é a Região Sudeste, quando para a Secretaria de Planejamento e para a Secretaria dos 
Transportes trata-se da Zona Leste; para a CET (Companhia de Engenharia de Tráfego)

e o DSV (Departamento do Sistema Viário), órgãos subordinados à Secretaria dos

Transportes, esta região é a GET-3, Gerência de Engenharia de Tráfego 3.

Figura V-5. “Pontos de Articulação” RMSP. Bolsão 3 e 4. Julho/99 
PEDESTRE:

MODALIDADE DE TRANSPORTE NA CIDADE UMA VISÃO ERGONÔMICA
Capítulo V

Avaliação de Nível de Serviço e Adequação Ergonômica das Instalações para Pedestres na Cidade de São Paulo

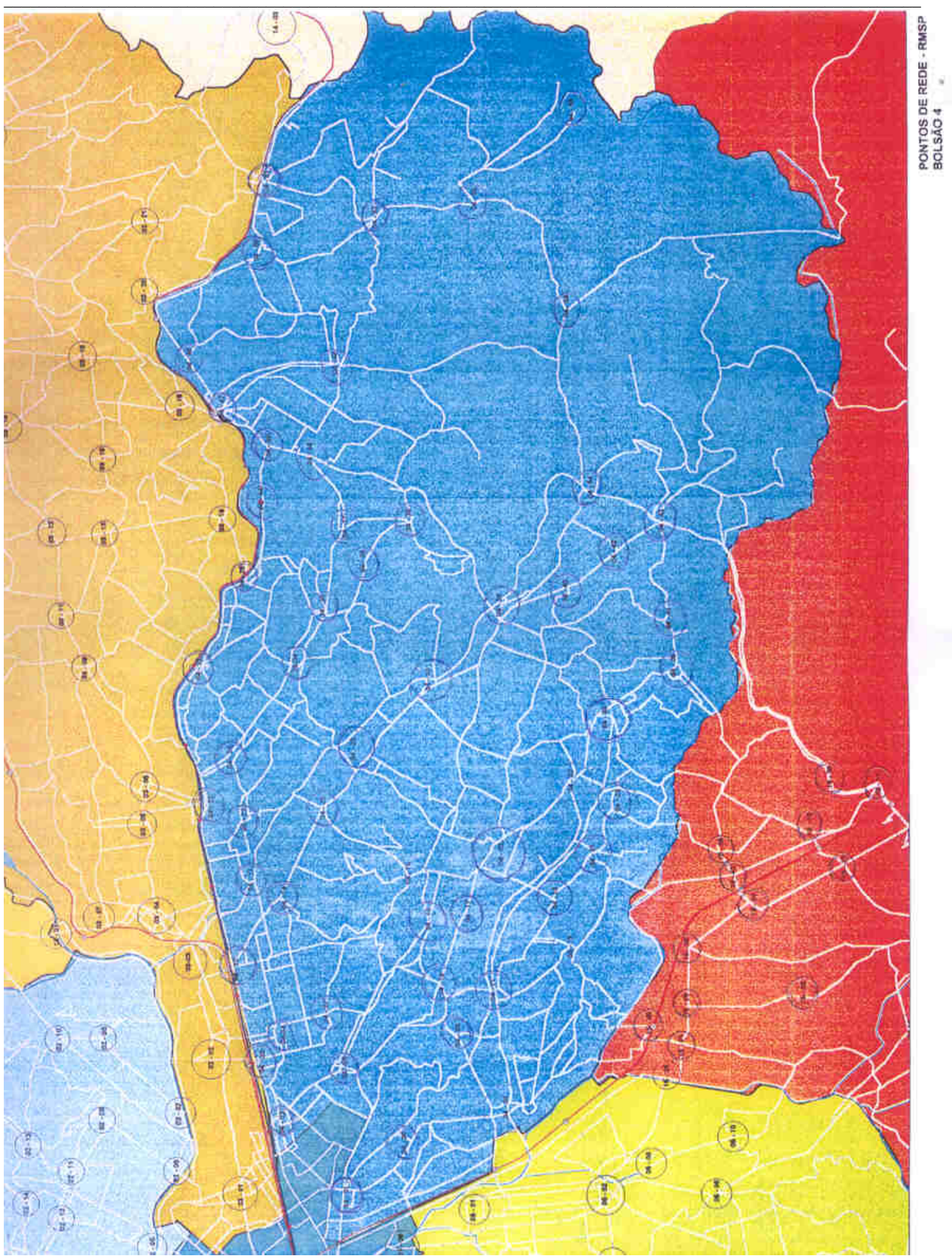

Fonte: "Estudo para Identificação dos "Pontos de Rede" na RMSP". [NIGRIELLO(1999)]. 
O interesse nesta área também pode ser justificado com a estatística de pedestres mortos em 2005, emitido pela CET-SP. [CET(2006)]. Gráfico V-1. Distribuição das Mortes por GETs.

\section{Gráfico V-1 Distribuição das Mortes de Pedestres por GETs (2005)}

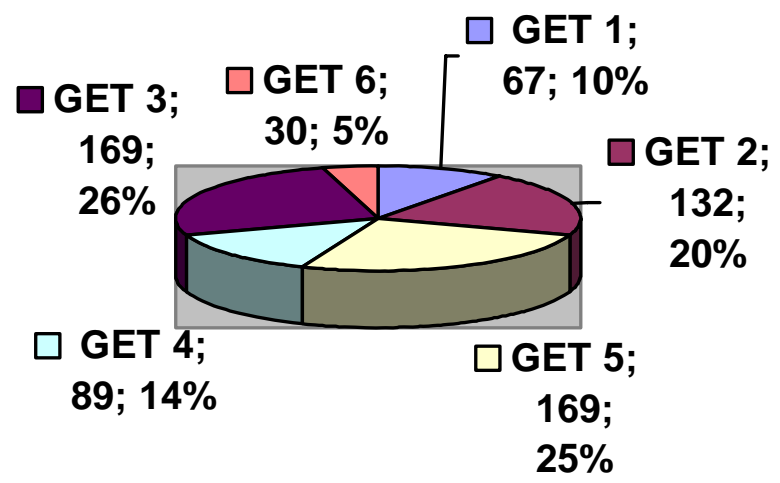

$\square$ GET $1 \square$ GET $2 \square$ GET $5 \square$ GET $4 \square$ GET $3 \square$ GET 6

Fonte: Mortes em Acidentes de Trânsito no Município de São Paulo. [CET(2006)]

Nota: GET 1 - Região Central, GET 2 - Região Norte, GET 3 - Região Leste, GET 4 - Região Sudeste, GET 5 - Região Sul, GET 6 - Marginais e Av. Bandeirantes.

A GET - 3, localizado na Zona Leste detém $26 \%$ das mortes de pedestres na Cidade de São Paulo, com 169 mortos em 2005. Os dados da PRO-AIM, em 2004, totalizou 135 mortos ou $23 \%$ na região sudeste. A ordem de grandeza é próxima, apesar das áreas abrangidas variarem em alguns bairros assim como a metodologia para a coleta de informações também variarem de instituição para instituição.

Assim, o enfoque da pesquisa concentrar-se-á nesta região.

1.4 Conhecimento da região de interesse.

\subsubsection{Dados Sócio- Econômicos}

Esta região é a mais populosa da cidade de São Paulo com cerca de 3,3 milhões de pessoas (33\%) do total paulistano e 17,7 \% da população da Região Metropolitana de São Paulo, segundo dados da Prefeitura da São Paulo, conforme Gilberto Dimenstein 
comentando as ações da SEBRAE na zona leste [DIMENSTEIN(2005)]. A população Economicamente Ativa (PEA) que vive na Zona Leste é composta de 1,7 milhões de pessoas o que representa $31 \%$ do município de São Paulo. Segundo Ministério do Trabalho existe 93 mil empresas formais, o que correspondem a $23 \%$ das empresas do Estado de São Paulo.

À título de comparação as cidades de Los Angeles (EUA), tem população de 3.600.000 habitantes, Montreal (Canadá) tem 3.300.000 habitantes e Buenos Aires (Argentina) tem 3.000.000 habitantes.

Esta região tem atraído vários Institutos de Ensino, sendo a mais recente a implantação da USP Leste, a Universidade de São Paulo, “campus” de Zona Leste, em 30 de agosto de 2004. A USP, tradicional universidade, renova seus propósitos com o assentamento de um novo "campus" universitário no bairro de Ermelino Matarazzo, próximo à rodovia Airton Senna e ao acesso ao aeroporto internacional Governador Franco Montoro, em Guarulhos e próximo às margens do Rio Tietê, conforme figuras (V-6), (V-7), (V-8) e (V-9). [USP LESTE(2004)]. 
Figura V- 6. Mapa de localização dos “campi” da USP, na Cidade de São Paulo.

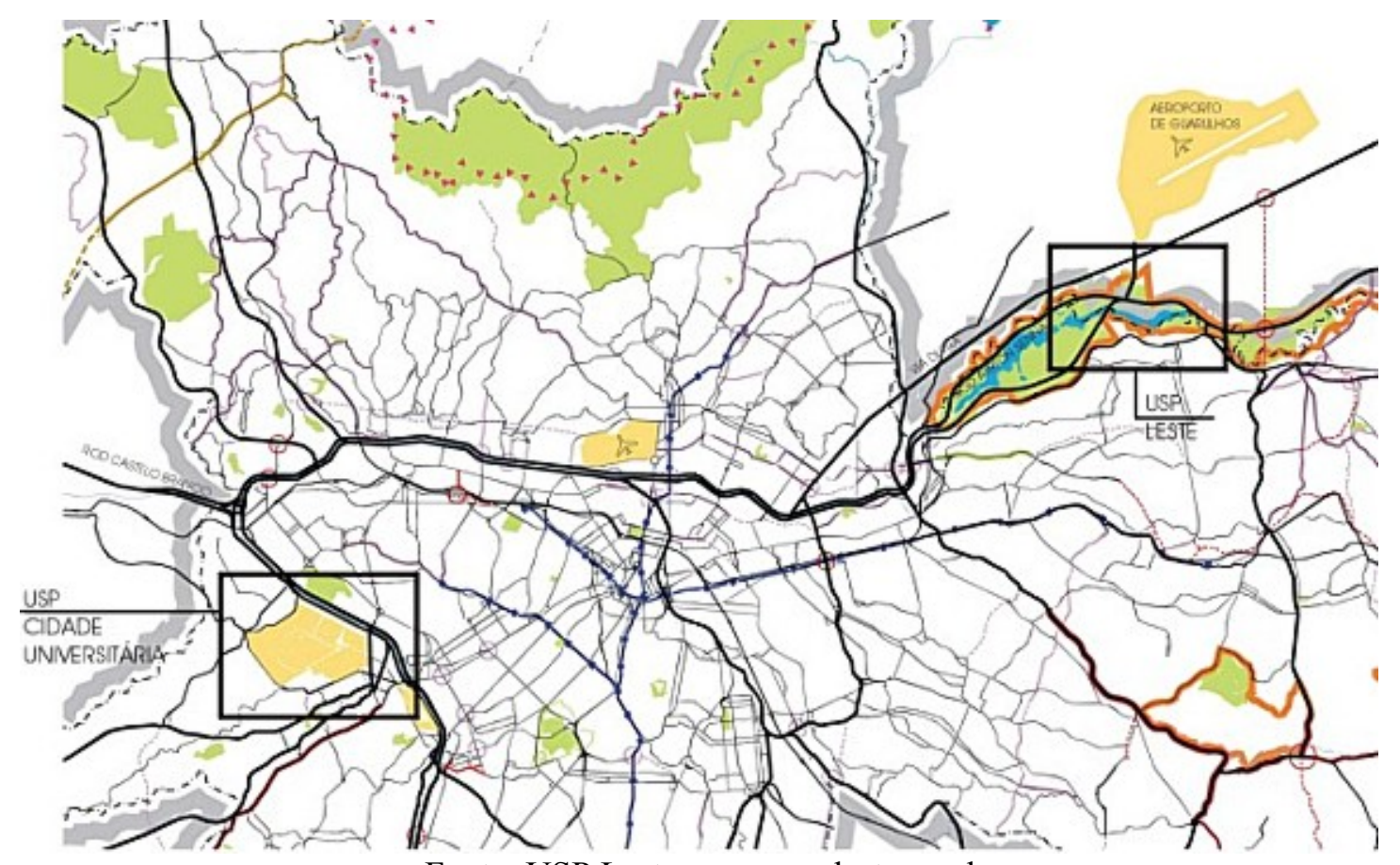

Fonte: USP Leste, www.uspleste.usp.br.

Figura V- 7. Mapa da USP Leste, Gleba 1 
PEDESTRE:

MODALIDADE DE TRANSPORTE NA CIDADE UMA VISÃO ERGONÔMICA
Capítulo V

Avaliação de Nível de Serviço e Adequação Ergonômica das Instalações para Pedestres na Cidade de São Paulo

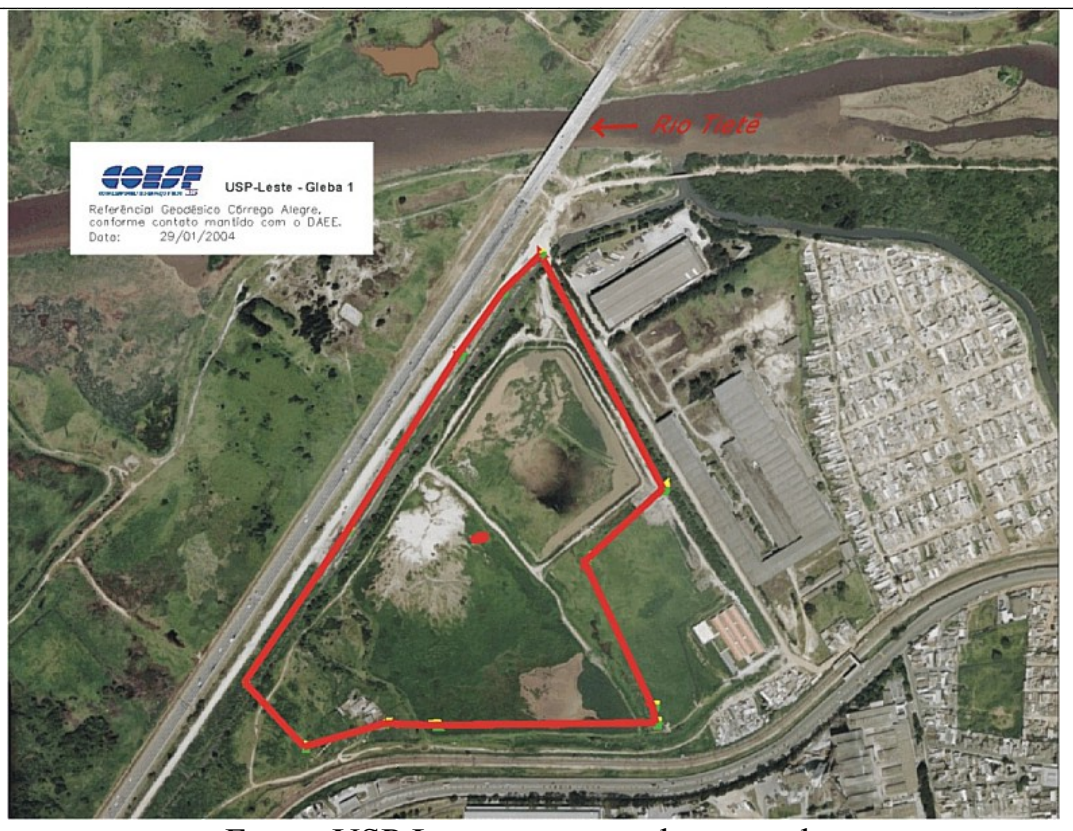

Fonte: USP Leste, www.uspleste.usp.br.

Figura V- 8. Mapa da USP Leste, Gleba 2

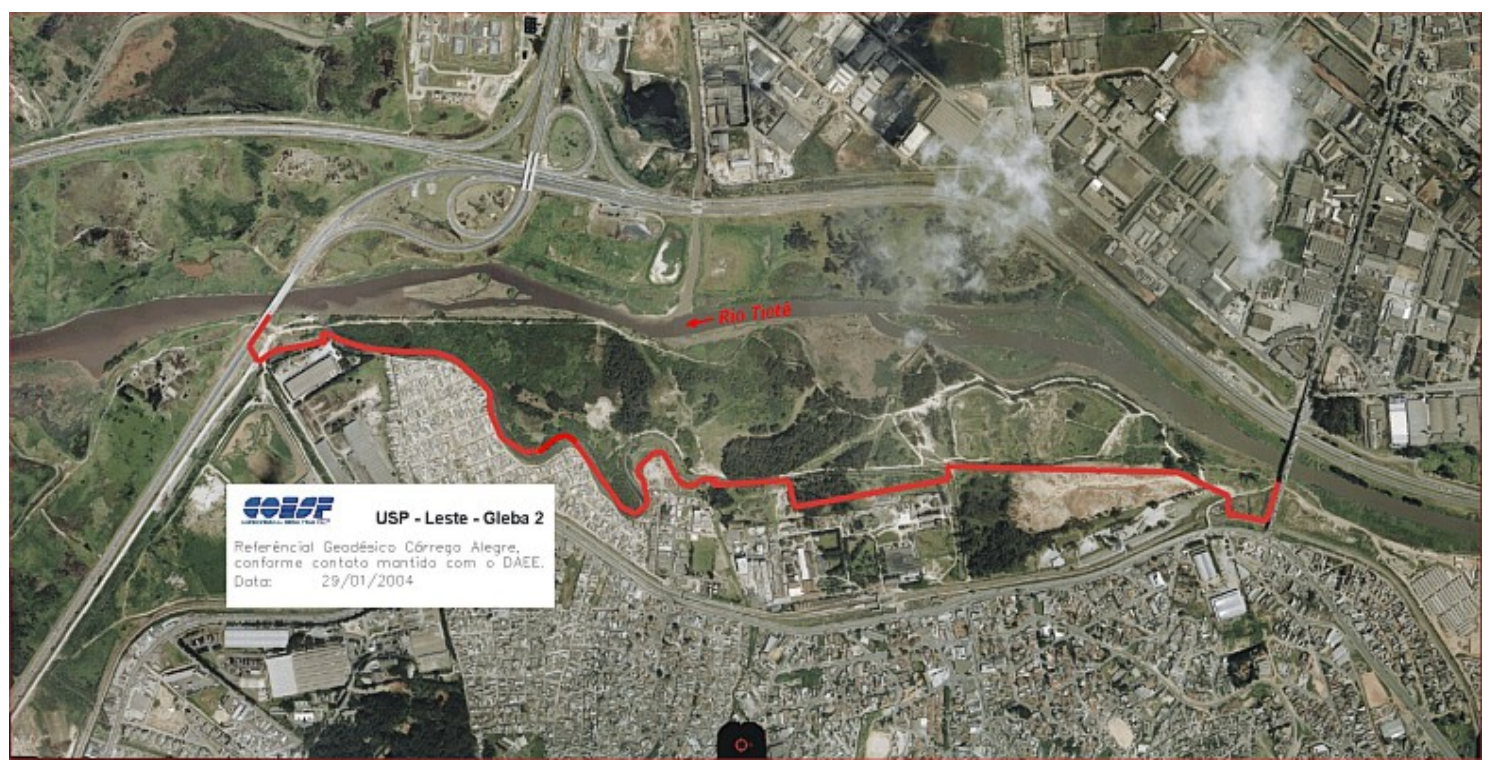

Fonte: USP Leste, www.uspleste.usp.br.

Figura V-9. Maquete do campus, Gleba 1. 


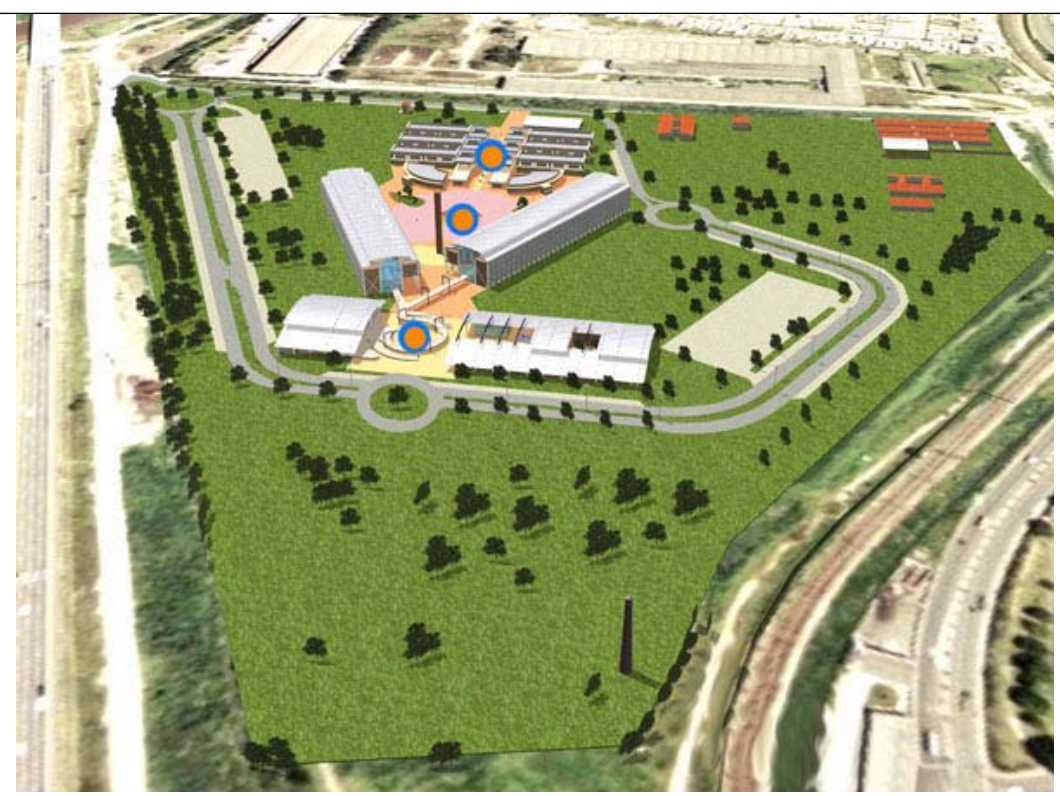

Fonte: USP Leste, www.uspleste.usp.br.

\subsubsection{Características do sistema viário}

No município de São Paulo o trânsito é gerenciado pala Companhia de Engenharia de Tráfego - CET. Para melhor monitoração deste empreendimento a CET dividiu o gerenciamento de trânsito em 6 Gerências, ou GETs. A região sudeste, objeto deste estudo, está compreendido na GET 3, a menos do "ponto de articulação" da Vila Prudente que está circunscrito nos limites entre as GET 3 e GET 4. As regiões compreendidas pelas GETs são: GET 1 região Central, GET 2 região Norte, GET 3 região Leste, GET 4 região Sudeste, GET 5 região Sul e GET 6 as marginais dos rios Tietê e Pinheiros e a avenida Bandeirantes. As GETs 1 e 2 compreendem a região Oeste da cidade.

A GET 3 compreende um território de $272 \mathrm{~km}^{2}$, com população de 3.200 .000 habitantes. [CET(2004)], cujo visualização encontra-se na figura (V-10).

Esta GET compreende $299 \mathrm{~km}$ de vias arteriais, $474 \mathrm{~km}$ de vias coletoras e $3.343 \mathrm{~km}$ de vias locais, totalizando $4.116 \mathrm{~km}$ de extensão do Sistema Viário. 
Há 989 cruzamentos semaforizados, sendo 731 com controladores semafóricos. Quanto ao tipo são 768 cruzamentos com semáforos convencionais (sendo 587 com controladores semafóricos), 185 cruzamentos com semáforos inteligentes (com 144 controladores semafóricos) e 36 cruzamentos com semáforos piscantes. Controladores são intervenções possíveis de realizar à longa distância, dentro do Centro Técnico, a fim de otimizar os tempos de cada fase de acordo com a necessidade do local, naquele instante.

A região também apresenta faixas de travessia para pedestres iluminadas. São 15 na Av. Celso Garcia, 1 no Largo da Concórdia, 1 na Av. Condessa Elizabete Robiano, 27 na Av Marechal Tito, 31 na Av. São Miguel, 8 na Av. Alcântara Machado, 2 na Av. João XXIII, 11 na Av. Paes de Barros, 1 na R. do Oratório, 2 na R. Melo Freire, 2 na Av Conde de Frontim, 14 na Av. Mateo Bei, e 12 na Av. Rio das Pedras.

\section{Figura V-10. Configuração geográfica do GET 3}

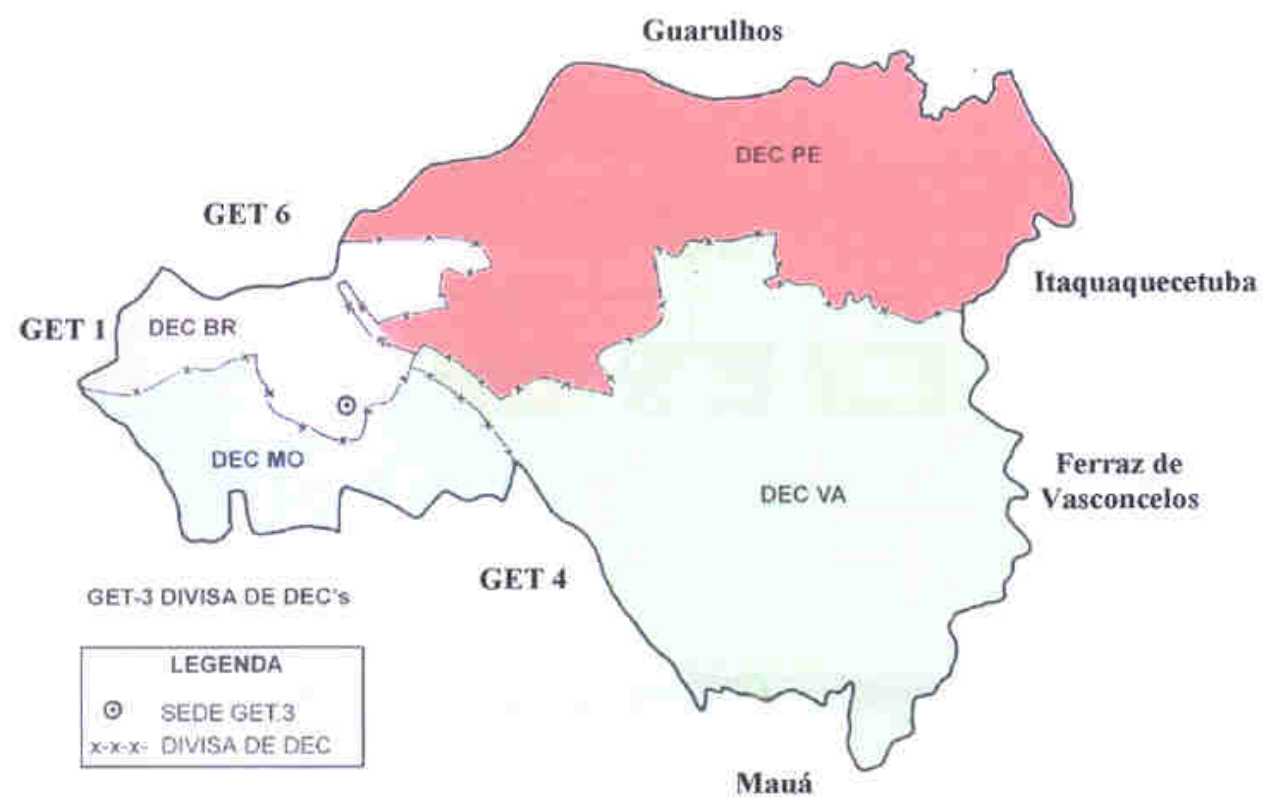

Fonte: "Perfil da Gerência GET 3" . [CET(2004)].

As subdivisões DEC referem-se aos Departamentos de Engenharia de Campo.

1.4.3 Pólos Geradores de Trânsito 
Pólos geradores são locais que atraem ou geram trânsito de veículos e pedestres, em grande quantidade, em períodos fixos ou não.

\section{Sistema de Transporte Coletivo.}

O sistema de transporte da área de interesse é composto basicamente por Metrô, Ferrovia, linhas de ônibus que se integram aos Terminais do Metrô e linhas de lotação.

As estações de metrô, de trens e terminais de ônibus (urbanos e rodoviários) se caracterizam como pólos geradores. Podemos visualizar a densidade destes pólos nas tabelas (V-3) estações de metrô, (V-4) estações de trem e (V- 5) terminais de ônibus urbano.

Tabela V-3. Estações de Metrô, compreendido na região do GET 3

$\begin{array}{ll}\text { - Brás } & \text { - Guilhermina Esperança } \\ \text { - Bresser } & \text { - Patriarca } \\ \text { - Belém } & \text { - Artur Alvim } \\ \text { - Tatuapé } & \text { - Itaquera } \\ \text { - Carrão } & \text { - José Bonifácio } \\ \text { - Penha } & \text { - Dom Bosco } \\ \text { - Vila Matilde } & \text { - Guaianazes }\end{array}$

Fonte: "Perfil da Gerência". [CET(2004)].

Tabela V-4. Estações de Trem (CBTU), compreendidos na região do GET 3

- Brás / Roosevelt

- Tatuapé

- Eng ${ }^{\mathrm{o}}$ Trindade

- Eng ${ }^{\circ}$ Goulart

- São Miguel Paulista

- Ermelino Matarazzo

- Itaim Paulista

- Moóca

- Itaquera

- Artur Alvim

Fonte: "Perfil da Gerência". [CET(2004)].

Tabela V - 5.Terminais de Ônibus Urbano, compreendidos na região do GET 3 - Metrô Brás - Metrô Guilhermina Esperança 
- Metrô Bresser

- Metrô Belém

- Metrô Tatuapé

- Metrô Carrão

- Metrô Penha

- Metrô Vila Matilde

- Terminal Aricanduva

- Terminal Penha
- Metrô Patriarca

- Terminal A. E. Carvalho

- Terminal Carrão

- Terminal São Mateus

- Metrô Itaquera

- Terminal Cidade Tiradentes

- Terminal Cidade Guaianazes

- Metrô Artur Alvim

Fonte: "Perfil da Gerência". [CET(2004)].

\section{Centros Comerciais}

Os centros comerciais são essencialmente atrações e geradores de trânsito de veículos e pedestres. Esta região caracteriza-se por possuir vários centros comerciais de rua, formando núcleos consolidados nos bairros, além de "shoppings centers" e hipermercados. Tabelas (V- 6), (V- 7) e (V- 8). Além destes grandes centros a região contém 272 ruas interditadas sistematicamente para promover as feiras livres semanais.

\section{Tabela V - 6. Relação de Centros Comerciais, na região do GET 3}

Principais bairros da área que apresentam centros comerciais

- Penha

- Tatuapé

- Brás

- Belém

- São Miguel

- Artur Alvim

- Vila Matilde

- Ermelino Matarazzo

- Itaim Paulista
- Ponte Rasa

- Vila formosa

- Mooca

- Água Rasa

- São Mateus

- Vila Carrão

- Itaquera

- Guaianazes

Fonte: "Perfil da Gerência". [CET(2004)].

Tabela V- 7. Relação de “Shoppings Centers”, na região do GET 3

- 25 de Março (R. Barão de Ladário)

- Center Penha (Centro da Penha)

- Polo Moda

- Anália Franco

- Tatuapé (R. Domingos Agostim)

- Center Chic (R. Antônio de Barros)

- Diretão (Av. Marechal Tito)

- Leste Aricanduva (Av. Aricanduva)

Fonte: "Perfil da Gerência". [CET(2004)].

Tabela V- 8. Relação de Hipermercados, na região do GET 3. 
- Pão de Açúcar (Av. Amador)

- Macro (Aricanduva)

- Pão de Açúcar (R. Serra do Japi)

- Carrefour (Av. Aricanduva)

- Sé ( Rua Coelho Lisboa)

- Carrefour (Pêssego)

- BIG (Av. Salim Farah Maluf)

- Extra Aricanduva

- D’ Avó (Av. Marechal Tito)

- Negreiros (Estrada do Iguatemi)

- BIG (Av. Dr. Custódio de Lima)

- Extra (Est. Itaquera/Guaianazes)

- D’ Avó (Av. São Miguel)

- Extra (Gov. Carvalho Pinto)

Fonte: "Perfil da Gerência". [CET(2004)].

\section{Outros Pólos}

Além do comércio, os grandes geradores são as fontes de lazer, instituições de ensino, hospitais e cemitérios. Não contabilizamos os bares, restaurantes e casas noturnas, que sem dúvida atraem pedestres e veículos, e estão presentes em quase toda a totalidade de ruas e avenidas da região, notadamente nos centros dos bairros. Assim como não foram contabilizadas as escolas de $1^{\circ}$ e $2^{\circ}$ graus, mas apenas as Faculdades e Universidades, devido ao seu porte e forte demanda de atração.

Tabelas (V- 9), (V- 10), (V- 11) e (V-12).

Tabela V- 9. Relação de Parques e Clubes, na região do GET 3.

- Esporte Clube Corinthians Paulista

- Centro Recreativo dos Trabalhadores (CERET)

- Parque do Piqueri (Rua Tuiuti)

- Centro Educacional e Esportivo do Tatuapé

- Clube Esportivo da Penha

- Parque Chico Mendes (Rua Cembira)

- Centro Esportivo do Sesi (Av. Esperantina)

- Parque Ecológico do Tietê

- Clube Atlético Juventus

- Sesc Belenzinho

- Aquário (Nova Trabalhadores)

- Sesc do Itaquera

- Parque do Carmo

- CT Corinthians (Itaquera)

Fonte: "Perfil da Gerência". [CET(2004)].

Tabela V- 10. Relação de Faculdades e Universidades, na região do GET 3

- UNIP (R. São Jorge)

- Faculdade Cantareira ( R. Marcos Arruda) 
- Faculdade Drumont (R. Prof. Pedreira de Freitas)

- Universidade Anhembi Morumbi (R. Dr Almeida Lima)

- UNICID

- Universidade Cruzeiro do Sul (UNICSUL)

- Universidade Capital (Av. Paes de Barros)

- Universidade São Judas Tadeu ( R. Taquari)

- Faculdade Brasília

- Universidade Cruzeiro do Sul (Av. Regente Feijó)

- UNIP (Av. Ver. Abel Ferreira)

- UNICASTELO (R. Carolina Fonseca)

- USP Leste (Arlindo Bettio, 1000, Ermelino Matarazzo)

Fonte: "Perfil da Gerência". [CET(2004)].

Tabela V-11. Relação de Hospitais, na região do GET 3

- Hospital Municipal do Tatuapé

- Hospital Nossa Senhora da Penha

- Hospital São José do Brás

- Hospital e Maternidade Leonor Mendes de Barros

- Hospital Municipal Tide Setúbal

- Hospital Municipal Dr. Alípio C. Neto (Ermelino Matarazzo)

- Hospital Geral Santa Marcelina (Av. Marechal Tito - Itaim Paulista)

- Hospital São Cristóvão

- Hospital Cema (R. do Oratório)

- Hospital João XXIII (R. Juventus)

- Hospital Municipal Prof. Waldomiro de Paiva

- Hospital Santa Marcelina (R. Sta. Marcelina)

Fonte: "Perfil da Gerência". [CET(2004)].

Tabela V- 12. Relação de Cemitérios, na região do GET 3

- Cemitério da Penha (Av. Amador Bueno da Veiga)

- Cemitério Quarta Parada

- Cemitério da Saudade (Av. Pires do Rio)

- Cemitério Municipal de Vila Formosa

- Cemitério do Carmo (R. Prof Hasegawa)

- Cemitério do Lajeado (Estrada do Lajeado)

- Cemitério de Itaquera (R. Serra de São Domingos)

Fonte: "Perfil da Gerência". [CET(2004)].

1.5 "Pontos de Articulação" na escala do Pedestre. 
Para reduzir a escala dos "pontos de articulação" à escala do pedestre, isto é, ruas, avenidas, instalações para pedestres, etc, recorreu-se às pesquisas realizadas pela CET SP referentes aos locais com fluxo de pedestres com mais complexidade na interação com o trânsito viário, nas proximidades dos "Pontos de Articulação" de $1^{\mathrm{a}}$ categoria da região sudeste. O resultado consta na Tabela V-13.

Tabela V-13. Correspondência entre "Pontos de Articulação" e locais com complexidade no trânsito de pedestres.

\begin{tabular}{|c|c|c|}
\hline Bairro & $\begin{array}{l}\text { (1) “Ponto de } \\
\text { Articulação" }\end{array}$ & $\begin{array}{l}\text { (2) Locais com complexidade no trânsito de } \\
\text { pedestres. }\end{array}$ \\
\hline \multirow[t]{3}{*}{ Belém } & $03-02$ & Av. Celso Garcia x Av. Salim Farah Maluf \\
\hline & $04-02$ & Av. Alcântara Machado x R. Dr Fomm \\
\hline & $04-03$ & Viaduto Guadalajara \\
\hline \multirow[t]{2}{*}{ Mooca } & $04-04$ & Av. Alcântara Machado x R. Hipódromo \\
\hline & $04-07$ & Viaduto Bresser \\
\hline \multirow[b]{2}{*}{ Tatuapé } & $04-12$ & Ponte Tatuapé \\
\hline & $04-05$ & $\begin{array}{l}\text { R. Acurui x R. Antonio de Barros x R. Emília } \\
\text { Marengo }\end{array}$ \\
\hline $\begin{array}{c}\text { Vila } \\
\text { Prudente } \\
\end{array}$ & $04-20$ & Travessia R. Montesima (Av. Salim F. Maluf) \\
\hline \multirow{3}{*}{ Carrão } & $04-14$ & R. Cantagalo x R. Gonçalo Nunes \\
\hline & $04-16$ & R. João XXIII x Av. Monsenhor Antonio Castro \\
\hline & $03-03$ & Ponte Aricanduva \\
\hline \multirow[t]{3}{*}{ Penha } & $03-04$ & Viaduto Cangaíba \\
\hline & $03-05$ & Av. São Miguel x R. Vigília \\
\hline & $03-06$ & Av. são Miguel x R. São Celso x R. Benfica \\
\hline $\begin{array}{c}\text { Vila } \\
\text { Esperança }\end{array}$ & 04- 24 & $\begin{array}{l}\text { Av. Amador Bueno da Veiga x R. Maria Carlota } \\
\text { Av. Amador Bueno da Veiga x R. Izabel }\end{array}$ \\
\hline
\end{tabular}

Fontes: (1)“Estudo para Identificação dos "Pontos de Rede" na RMSP”. [NIGRIELLO(1999)].

(2)“Pesquisa de Trânsito”. CET-SP. [CET(2005)] 


\section{PESQUISA E ANÁLISE DOS LOCAIS SELECIONADOS}

\subsection{Critérios de pesquisa}

A metodologia da pesquisa adotada foi detalhada no Capítulo IV. DESEMPENHO E NÍVEL DE SERVIÇO DAS INSTALAÇÕES PARA PEDESTRES.

Conforme a recomendação do método, as instalações para pedestres foram intensivamente observadas em campo. As medições no campo incluíram contagem do fluxo de pedestres, medidas físicas das calçadas, largura das vias, largura das travessias, conferência nos tempos de semáforos, ilustração fotográfica do local e visita aos arredores da instalação pesquisada.

As instalações para pedestres analisadas foram aquelas consideradas de maior complexidade no sistema viário pela CET-SP, tendo havido contagens de fluxo de pedestres desde 1997. Para os cálculos de nível de serviço destas instalações algumas destas contagens foram atualizadas, tanto pelas mudanças havidas no sistema de trânsito local de algumas das instalações como devido à distância no tempo de algumas contagens. Mas no contexto geral a ordem de grandeza não se alterou no tempo. Estas 
instalações compreenderam 4 travessias simples, 6 travessias em cruzamentos e 6 viadutos e pontes.

Os tempos de semáforo das instalações na Zona Leste são variáveis, sendo controlados à distância, na central de controle de tráfego. Dos 989 cruzamentos semaforizados 729 têm controladores à distância. Estes controles são instrumentos para atuar no trânsito em tempo real, porém seguem critérios estabelecidos no "Quadro: Resumo dos Tempos de Segurança" (tabelas V-14; V- 15; V-16;.V- 17):

“QUADRO: RESUMO DOS TEMPOS DE SEGURANÇA”

Tabela V-14. Cálculo do Tempo de Amarelo

\begin{tabular}{|l|c|}
\hline \multicolumn{2}{|c|}{ Tempo de Amarelo } \\
\hline $\begin{array}{c}\text { Velocidade } \\
\text { Regulamentada }\end{array}$ & $\begin{array}{c}\text { Tempo de } \\
\text { Amarelo }\end{array}$ \\
\hline Até $40 \mathrm{~km} / \mathrm{h}$ & $3 \mathrm{~s}$ \\
\hline $40 \mathrm{a} 60 \mathrm{~km} / \mathrm{h}$ & $4 \mathrm{~s}$ \\
\hline Acima de $80 \mathrm{~km} / \mathrm{h}$ & $5 \mathrm{~s}$ \\
\hline
\end{tabular}

Fonte: CET. "Perfil da Gerência. Visual GET-3". [CET(2004)] 
Tabela V-15.Cálculo do Tempo de Vermelho Geral (*)

\begin{tabular}{|c|}
\hline Vermelho Geral (**) \\
\hline Calcular pela fórmula: \\
Tvm $=3,6 \times(\mathrm{L}+\mathrm{c}) / \mathrm{V}$ \\
\hline $\mathrm{Tvm}=$ tempo de vermelho geral $(\mathrm{s})$ \\
\hline $\mathrm{L}=$ largura da via transversal $(\mathrm{m})$ \\
\hline$. \mathrm{c}=$ comprimento do veículo tipo $(\mathrm{m}) \pm 6,00 \mathrm{~m}$ \\
\hline $\mathrm{V}=$ velocidade da via $(\mathrm{km} / \mathrm{h})$ \\
\hline
\end{tabular}

(*) Tempo de varredura do estágio

(**) Calcular para cada aproximação

Fonte: CET. "Perfil da Gerência. Visual GET-3”. [CET(2004)]

Tabela V- 16.Cálculo do Tempo de Verde de Segurança(*) Tempo de Verde de Segurança

\begin{tabular}{|l|c|}
\hline \multicolumn{1}{|c|}{ Tipo de Via } & Verde de Segurança \\
\hline Arterial $(70 \mathrm{~km} / \mathrm{h})$ & $21 \mathrm{~s}$ \\
\hline Coletora $(50 \mathrm{~km} / \mathrm{h})$ & Entre 12 e $21 \mathrm{~s}$ \\
\hline Local $($ até $40 \mathrm{~km} / \mathrm{h})$ & $12 \mathrm{~s}$ \\
\hline
\end{tabular}

(*) Tempo antes de acionar a mudança de fase

Fonte: CET. "Perfil da Gerência. Visual GET-3". [CET(2004)]

Tabela V- 17. Cálculo de Tempo Verde Mínimo de Travessia

\begin{tabular}{|l|}
\hline \multicolumn{1}{|c|}{ Tempo Verde Mínimo de Travessia $\left(^{*}\right)$} \\
\hline \multicolumn{1}{|c|}{ Calcular pela fórmula: } \\
Ttrav $=\mathrm{L} / 1,2$
\end{tabular}

Fonte: CET. "Perfil da Gerência. Visual GET-3". [CET(2004)] 
Tabela IV- 8 Critério de NS para Fluxos Médios em Passeios e Calçadas(*)

\begin{tabular}{|lllll|}
\hline NS & Espaço $\left(\mathbf{m}^{2} / \mathbf{p}\right)$ & $\begin{array}{l}\text { Taxa } \\
\text { Fluxo(p/min/m) }\end{array}$ & $\begin{array}{l}\text { de } \\
\text { Velocidade }\end{array}$ & Razão v/c \\
\hline A & $>5,6$ & $\leq 16$ & $>1,3$ & $\leq 0,21$ \\
\hline B & $>3,7-5,6$ & $>16-23$ & $>1,27-1,30$ & $>0,21-0,31$ \\
\hline C & $>2,2-3,7$ & $>23-33$ & $>1,22-1,27$ & $>0,31-0,44$ \\
\hline D & $>1,4-2,2$ & $>33-49$ & $>1,14-1,22$ & $>0,44-0,65$ \\
\hline E & $>0,75-1,4$ & $>49-75$ & $>0,75-1,14$ & $>0,65-1,0$ \\
\hline F & $\leq 0,75$ & Variável & $\leq 0,75$ & Variável \\
\hline
\end{tabular}

Fonte: HCM 2000. [TRANSPORTATION(2000)]

(*) Tabela extraída do capítulo IV.

Tabela IV-14. NS para pedestres em intersecções sinalizadas (*)

\begin{tabular}{|ccc|}
\hline NS & $\begin{array}{l}\text { Tempo de espera } \\
\text { pedestres (s/p) }\end{array}$ & $\begin{array}{l}\text { Probabilidade de } \\
\text { desobediência }\end{array}$ \\
\hline A & $<10$ & Baixa \\
\hline B & $\geq 10-20$ & \\
\hline C & $>20-30$ & Moderada \\
\hline D & $>30-40$ & \\
\hline E & $>40-60$ & Alta \\
\hline F & $>60$ & Muito Alta \\
\hline
\end{tabular}

Fonte: HCM 2000 [TRANSPORTATION(2000)]

(*) Tabela extraída do capítulo IV.

\subsection{Pesquisa e Análise das Instalações}

\subsubsection{BAIRRO DO BELÉM}

Travessia de Pedestre na Avenida Alcântara Machado, próximo a Rua Dr. Fomm.

A avenida Alcântara Machado neste trecho tem três pistas de trânsito, sendo uma pista no sentido bairro com 5 faixas de rolamento, duas pistas no sentido centro, sendo uma pista expressa com 4 faixas, e uma pista local com 2 faixas de rolamento. Todas as 
$\overline{\text { pistas estão separadas com barreiras, conforme podem ser apreciadas nas figuras V- } 11}$, $\mathrm{V}-12$ e $\mathrm{V}-13$

\section{Figura V-11. Travessia de Pedestres na Avenida Alcântara Machado Visão panorâmica}

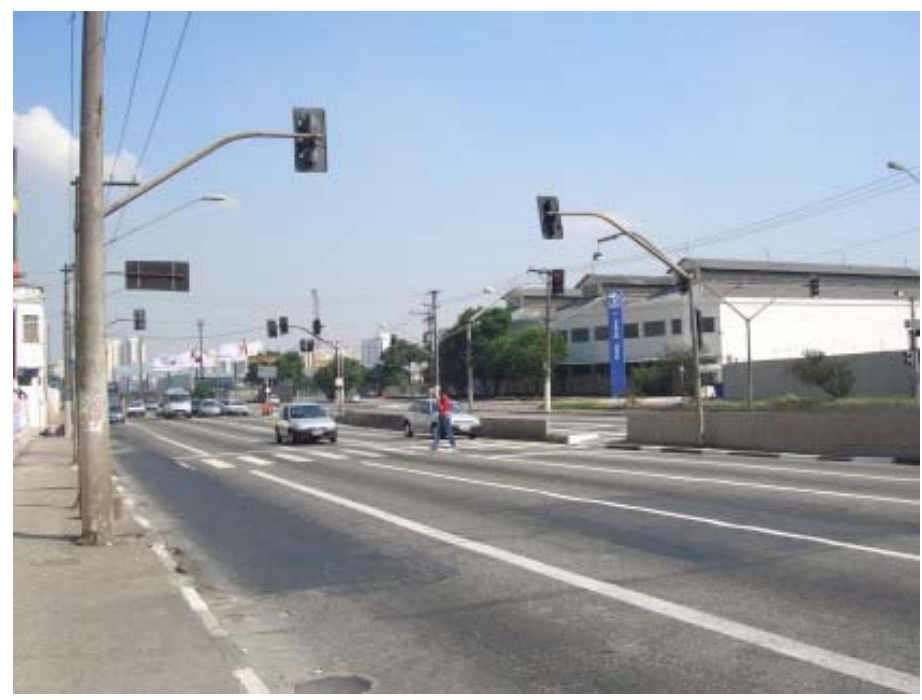

Fonte: Pesquisa da autora.

Observar que à direita da foto é o Pátio Belém, da METRÔ. À esquerda, onde localiza-se a rua Dr. Fomm tem-se o condomínio habitacional da CDHU, uma grande churrascaria, um centro de lazer com bingo, lojas de móveis e fábricas.

Figura V-12. Travessia de Pedestres na Avenida Alcântara Machado Detalhe da travessia 


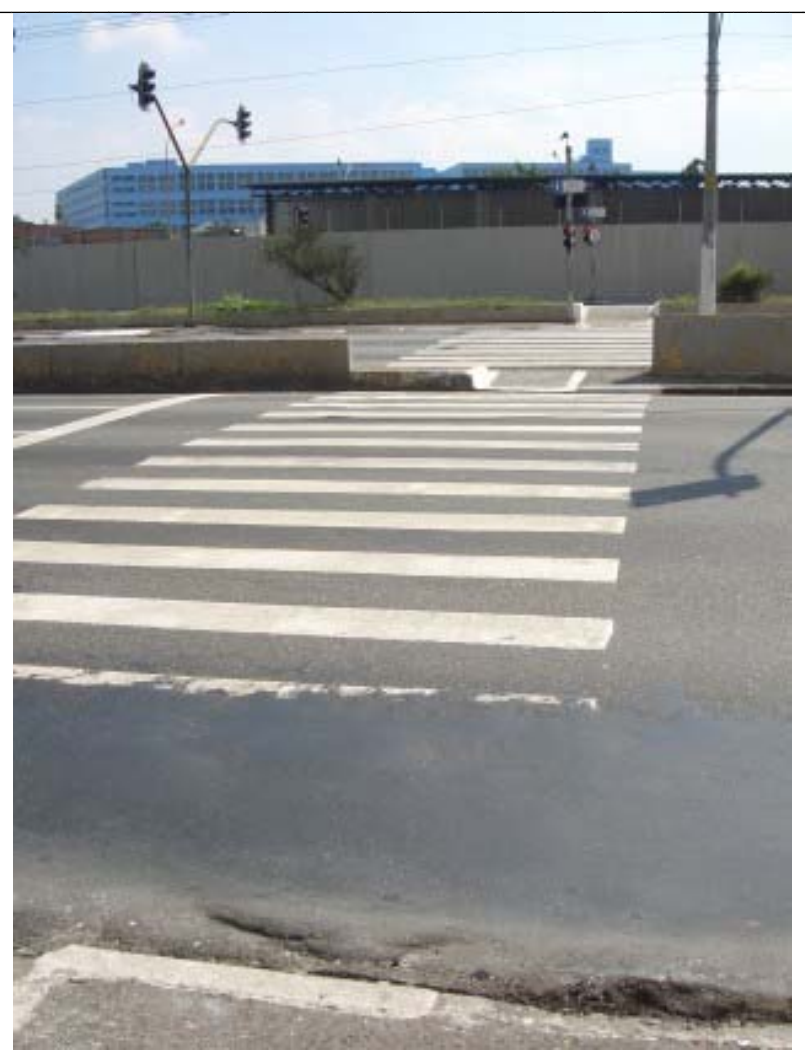

Fonte: Pesquisa da autora.

Observar as barreiras entre as pistas. Há um estreitamento no canteiro, em relação à faixa de pedestres, dificultando a travessia em pelotão. Essa travessia deve ser realizada em uma só passagem, pois permanecer em pé, esperando novo tempo de travessia, neste estreito canteiro, é altamente inseguro devido ao intenso trânsito de veículos. As barreiras servem mais para separar o trânsito do que resguardar a segurança do pedestre.

\author{
Cálculo dos Níveis de Serviço \\ Figura V-13. Esquema da Travessia da Av. Alcântara Machado
}




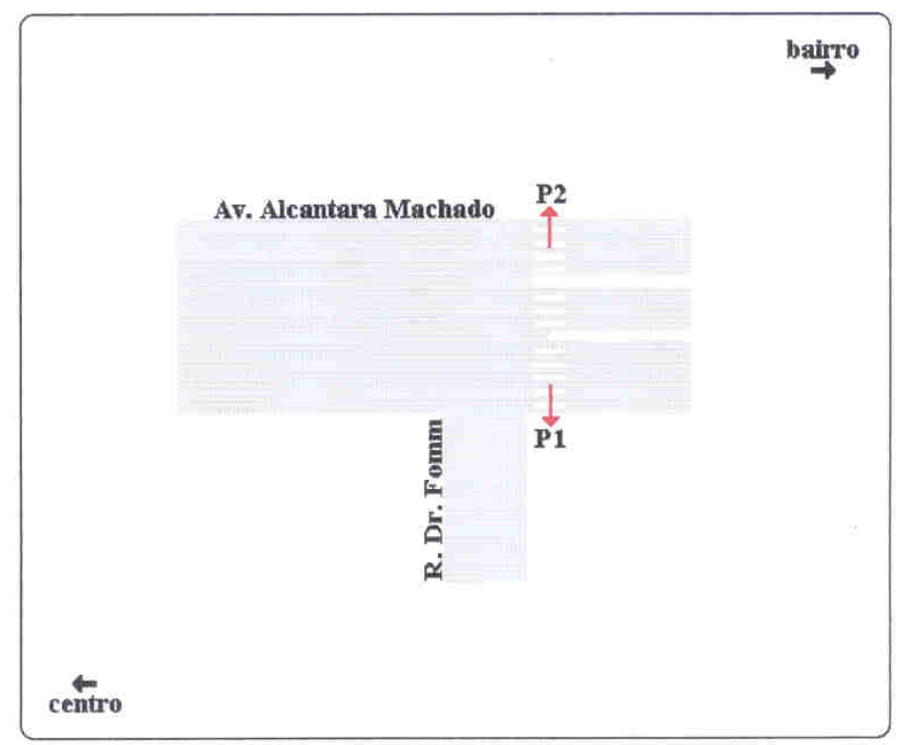

Fonte: CET. "Pesquisa de Trânsito". [CET(2005)].

1. Cálculo de tempo de espera do Pedestre na Interseção Sinalizada - Dp

Tempo de ciclo-C: $180 \mathrm{~s}$

Tempo Efetivo de verde para pedestre-g: $50 \mathrm{~s}$

$\mathrm{Dp}=\frac{0,5(C-g) 2}{C}$

$\mathrm{Dp}=\frac{0,5(180-50) 2}{180}=46,94 \mathrm{~s}$

Consultando a tabela IV-14 - NS para pedestres em interseções sinalizadas, para este tempo de espera o NS correspondente E, com Alta Probabilidade de Desobediência.

2. Cálculo do fluxo unitário de pedestre na calçada

Largura total do passeio - Wt : 2,50 m

Soma das larguras de obstruções - Wc: $0,50 \mathrm{~m}$

Largura efetiva da travessia: $\mathrm{We}=\mathrm{Wt}-\mathrm{Wc}=2,50-0,50 \mathrm{~m}$

Fluxo no pico de 15 minutos - V15:

Pico da Manhã: 152 pedestres entre as 7:00 às 7:15 h

Pico da Tarde: 40 pedestres entre 16:00 às 16:15 h

Fluxo unitário de pedestre $\mathrm{Vp}: \mathrm{Vp}=\frac{V 15}{15 \times W e}(\mathrm{p} / \mathrm{min} / \mathrm{m})$ 
Como a contagem em campo foi de 15 minutos, a fórmula se resume em $\mathrm{Vp}=\frac{V 15}{W e}$

Para o pico da manhã $\mathrm{Vp}=\frac{152}{2,0}=76(\mathrm{p} / \mathrm{min} / \mathrm{m})$

Consultando a tabela IV-8 Critérios de NS para Fluxos Médios em Passeios e

Calçadas, para este fluxo unitário, o NS correspondente é F.

Para o pico da tarde $\mathrm{Vp}=\frac{40}{2,0}=20(\mathrm{p} / \mathrm{min} / \mathrm{m})$

Consultando a tabela IV-8 Critérios de NS para Fluxos Médios em Passeios e

Calçadas, para este fluxo unitário, o NS correspondente é B.

3. Análise do Nível de Serviço calculado.

O tempo de espera do pedestre para atravessar a avenida é demorado e favorece a indução à desobediência à sinalização. No período de pico da manhã, entre 7:00 às 7:15 $\mathrm{h}$, o acúmulo de pedestres na calçada atinge o nível $\mathrm{F}$, tornando mais temerosa a conduta do pedestre devido a aproximação muito intensa entre eles, já no período da tarde o nível é B, o que corresponde a uma condição razoável.

A concentração de pedestres pela manhã pode ser explicada pelo horário de entrada de serviço coincidente entre os pedestres. O retorno às residências pode ser compreendido como movimento esparso, o que dilui o fluxo de pedestres.

\section{Viaduto Guadalajara}

Este viaduto atravessa a avenida Alcântara Machado, as linhas de trem da CPTM e a do Metrô e localiza-se próximo à travessia da avenida Alcântara Machado, próximo a rua Dr Fomm. Este viaduto faz a ligação entre o bairro da Mooca à Av. Celso Garcia, importante centro de comércio da região. Figuras V-14, V-15 e V-16.

Há calçadas em ambos os lados do viaduto, cuja largura é de 2,20 metros. 
Figura V-14.Viaduto Guadalajara Vista panorâmica

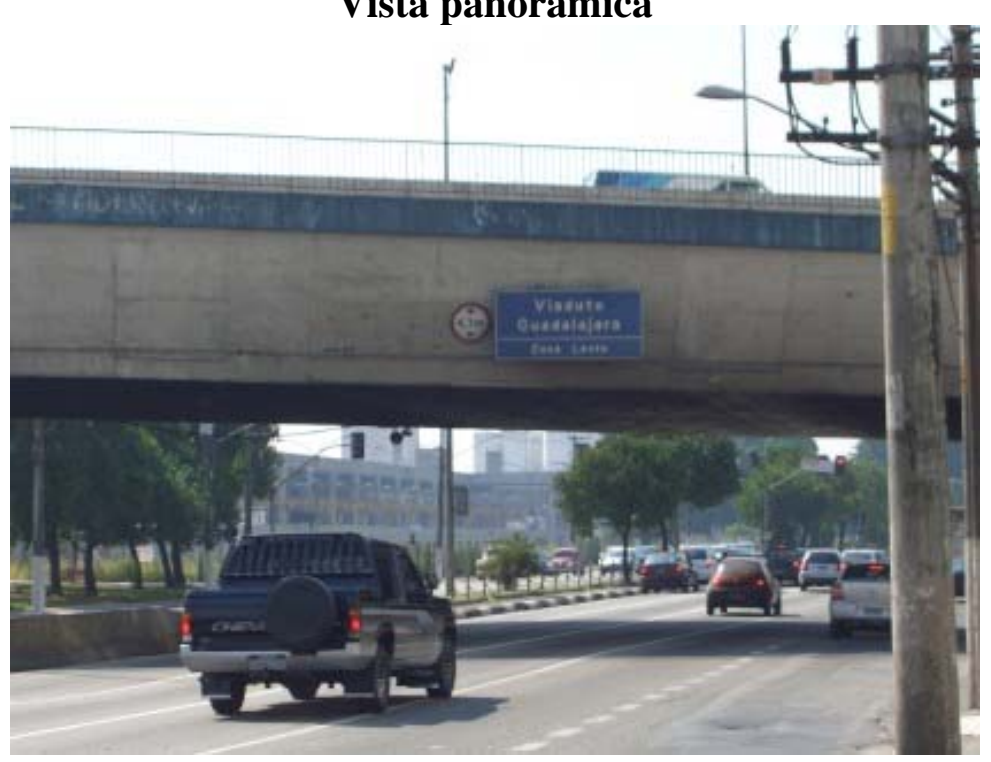

Fonte: Pesquisa da autora.

Visão do viaduto a partir da avenida Alcântara Machado.

Figura V-15.Viaduto Guadalajara Detalhe da calçada

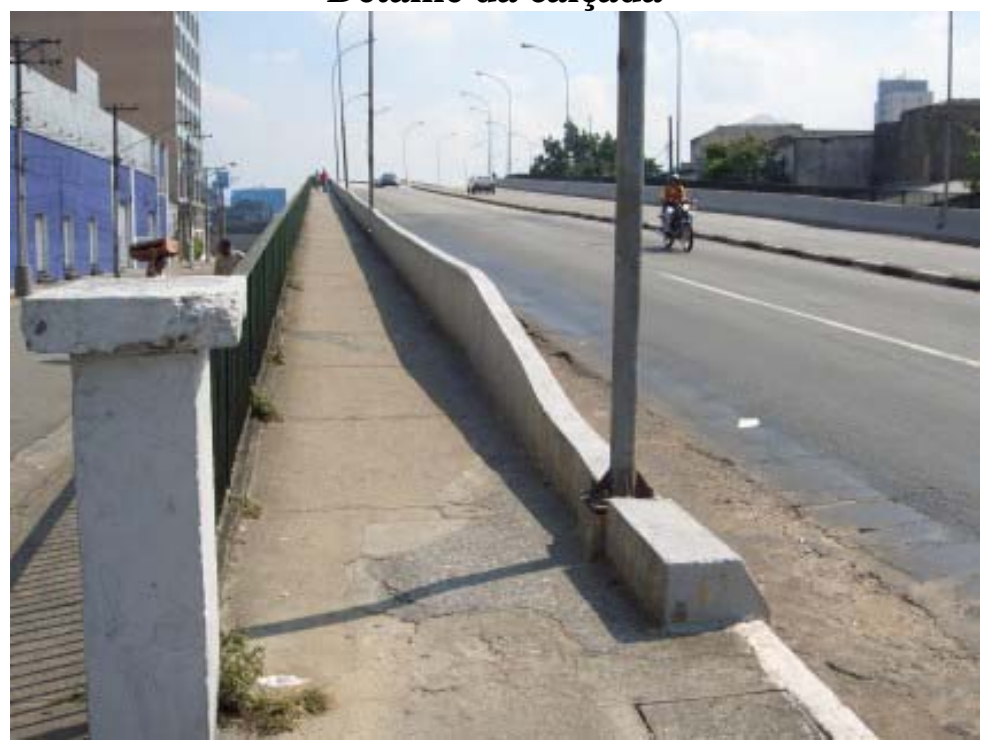


Fonte: Pesquisa da autora.

Observar a barreira de segurança separando o trânsito de pedestres com o sistema viário. A conservação desta passagem não está boa (plantas nascendo na beirada da passagem, desgaste do pavimento), mas todo o viaduto está nesse estado.

\section{Cálculo dos Níveis de Serviço}

\section{Figura V-16. Esquema da travessia do viaduto Guadalajara}

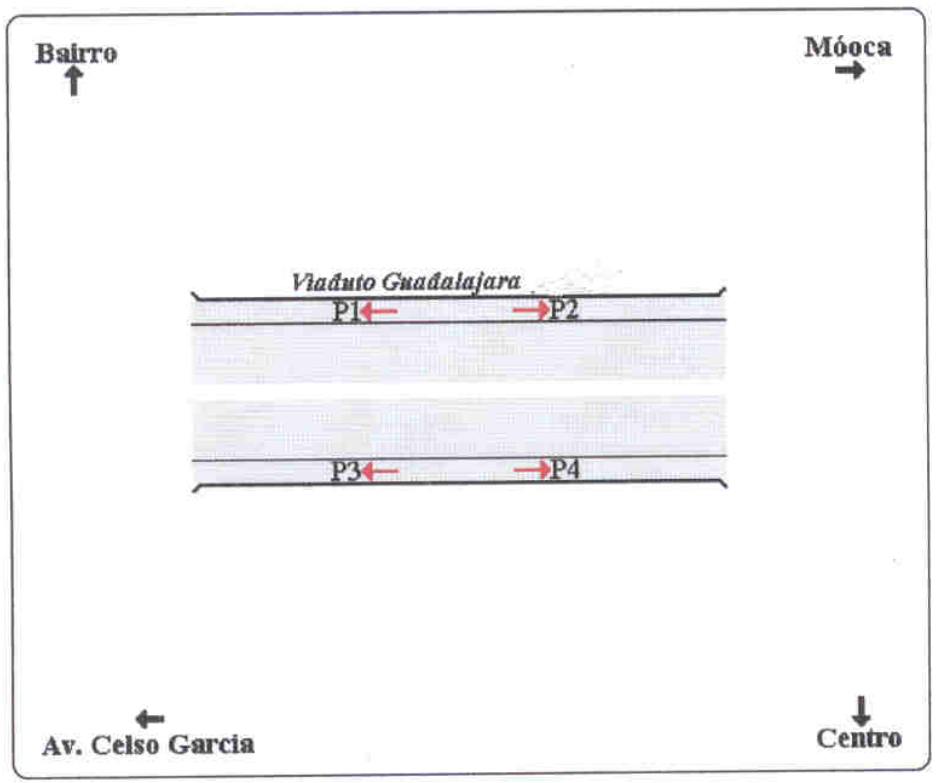

Fonte: CET. "Pesquisa de Trânsito". [CET(2005)].

Esta instalação será avaliada pelo fluxo unitário de pedestre, transitando nas calçadas do viaduto. $\mathrm{O}$ movimento $\mathrm{P} 1$ e $\mathrm{P} 2$ refere-se à calçada à direita, considerando o sentido Mooca a Av. Celso Garcia, e o movimento P3 e P4 à calçada à esquerda, neste mesmo sentido.

1. Cálculo do fluxo unitário de pedestre na calçada

Largura total do passeio - Wt : 2,20 m

Soma das larguras de obstruções - Wc: $0,50 \mathrm{~m}$

Largura efetiva da travessia: $\mathrm{We}=\mathrm{Wt}-\mathrm{Wc}=1,70 \mathrm{~m}$

Fluxo no pico de 15 minutos - V15:

Fluxo unitário de pedestre Vp: $\mathrm{Vp}=\frac{V 15}{15 \times W e}(\mathrm{p} / \mathrm{min} / \mathrm{m})$

Como a contagem em campo foi de 15 minutos, a fórmula se resume em $\mathrm{Vp}=\frac{V 15}{W e}$ 
Movimento P1 - P2

Pico da Manhã: 54 pedestres entre as $8: 30$ às $8: 45 \mathrm{~h}$

Pico da Tarde: 55 pedestres entre 17:00 às 17:15 h

Para o pico da manhã $\mathrm{Vp}=\frac{54}{1,70}=31,76(\mathrm{p} / \mathrm{min} / \mathrm{m})$

Consultando a tabela IV-8 Critérios de NS para Fluxos Médios em Passeios e

Calçadas, para este fluxo unitário, o NS correspondente é C.

Para o pico da tarde $\mathrm{Vp}=\frac{55}{1,70}=32,35(\mathrm{p} / \mathrm{min} / \mathrm{m})$

Consultando a tabela IV-8 Critérios de NS para Fluxos Médios em Passeios e

Calçadas, para este fluxo unitário, o NS correspondente é C.

Movimento P3 - P4

Pico da Manhã: 130 pedestres entre as 6:30 às 6:45 h

Pico da Tarde: 144 pedestres entre 17:00 às 17:15 h

Para o pico da manhã $\mathrm{Vp}=\frac{130}{1,70}=76,47(\mathrm{p} / \mathrm{min} / \mathrm{m})$

Consultando a tabela IV-8 Critérios de NS para Fluxos Médios em Passeios e

Calçadas, para este fluxo unitário, o NS correspondente é F.

Para o pico da tarde $\mathrm{Vp}=\frac{144}{1,70}=84,70(\mathrm{p} / \mathrm{min} / \mathrm{m})$

Consultando a tabela IV-8 Critérios de NS para Fluxos Médios em Passeios e

Calçadas, para este fluxo unitário, o NS correspondente é F.

2. Análise do Nível de Serviço calculado.

A calçada com o movimento P1 e P2 está oferecendo um bom nível de serviço (nível C), porém a calçada com o movimento P3 e P4, calçada à esquerda no sentido de direção à av. Celso Garcia está crítica, no horário de pico (nível F). Os pedestres mais vagarosos podem ser ultrapassados aos trancos, induzindo os mais ligeiros a um 
comportamento menos civilizados. Nestas circunstâncias esta instalação deve ter tratamento específico para sanar esta distorção.

\section{Travessias no cruzamento das avenidas Celso Garcia e Salim Farah Maluf}

O cruzamento destas duas avenidas tem como maior obstáculo para o pedestre a extensão das travessias. A avenida Salim Farah Maluf é acesso à avenida Marginal Tietê, o que a sobrecarrega de veículos, notadamente caminhões, que se originam ou se dirigem a Santo André, São Caetano, etc. e acessam a avenida Marginal Tietê.

A avenida Celso Garcia já foi um importante pólo comercial, mas nesta área, especificamente, o comércio é decadente, tendo muitas lojas encerradas suas funções, principalmente devido aos Hiper mercados, Shopping centers, etc, inaugurados nas proximidades da avenida Salim Farah Maluf. O entorno é constituído de residências de baixo custo e prédios comerciais vazios e à venda ou para alugar. Conforme depoimentos de moradores a própria implantação da avenida Salim Farah Maluf "matou” o comércio local, pois ficou difícil acessar as lojas com veículos, pois não sendo permitido estacionar na avenida Celso Garcia, estacionar nas redondezas também é desgastante, pois sempre que for manobrar o veículo, encara-se a avenida Salim F. Maluf. Ainda persistem algumas lojas de serviços, pequenos consertos, etc.

Alguns prédios de médio porte, tipo galpão, estão reciclando seu uso para o lazer, com atividades noturnas, tipo danceteria, forrós, festas, etc.

A avenida Celso Garcia neste trecho tem sentido único, centro-bairro, para veículos, com exceção de ônibus que trafegam nos dois sentidos.

Este cruzamento não tem alta incidência de pedestres, porém a extensão das travessias (larguras das avenidas), a quantidade de veículos, principalmente caminhões, na avenida 
$\overline{\text { Salim Farah Maluf e os ônibus na "contra-mão", na avenida Celso Garcia, dificultam a }}$ travessia segura dos pedestres. Figuras V-17, V-18, V-19, V-20 e V-21.

\section{Figura V-17.Cruzamento das avenidas Celso Garcia e Salim Farah Maluf} Visão panorâmica

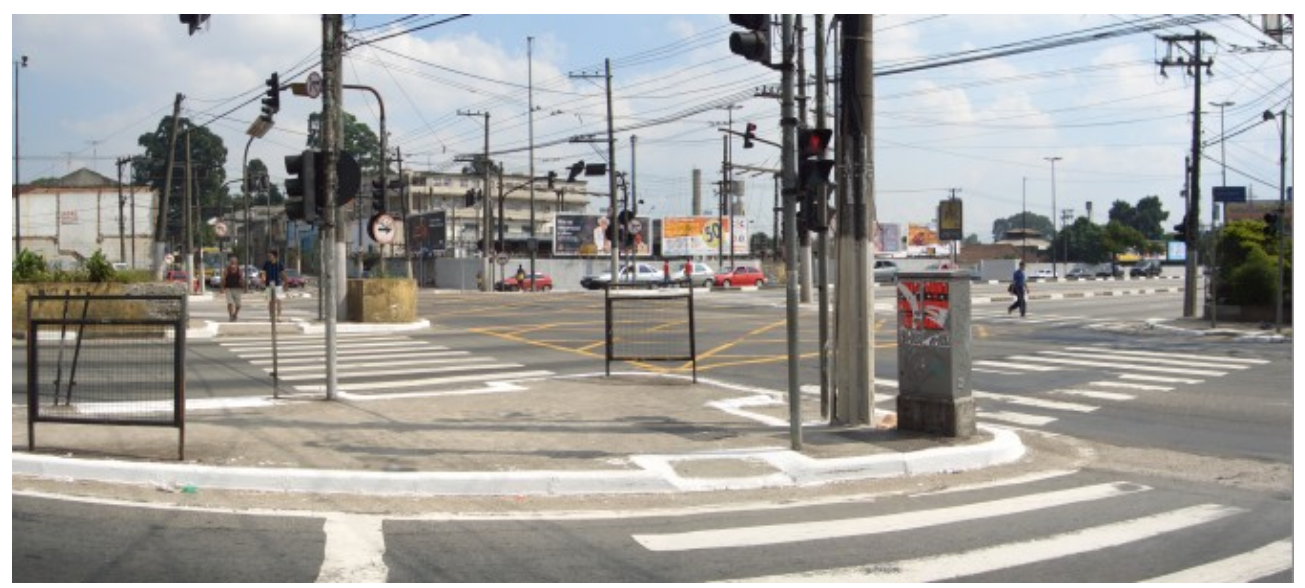

Fonte: Pesquisa da autora.

A via que atravessa longitudinalmente (da esquerda para a direita) da foto é a avenida Salim Farah Maluf, e a que atravessa transversalmente é a Celso Garcia. Observar a profusão de interferências tais como postes de luz, sinalização, barreiras para pedestres, etc. Observar que a travessia da avenida Salim Farah Maluf é transposta em três etapas, duas ilhas ao lado esquerdo.

Figura V-18.Cruzamento das avenidas Celso Garcia e Salim Farah Maluf 


\section{Detalhe 1.}

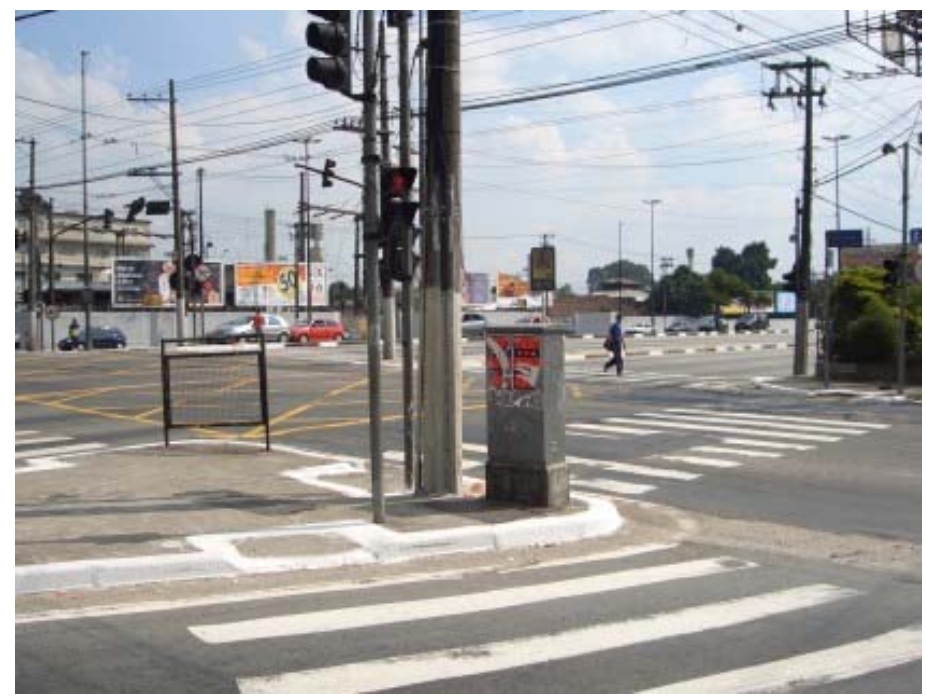

Fonte: Pesquisa da autora.

\section{Figura V-19.Cruzamento das avenidas Celso Garcia e Salim Farah Maluf Detalhe 2}

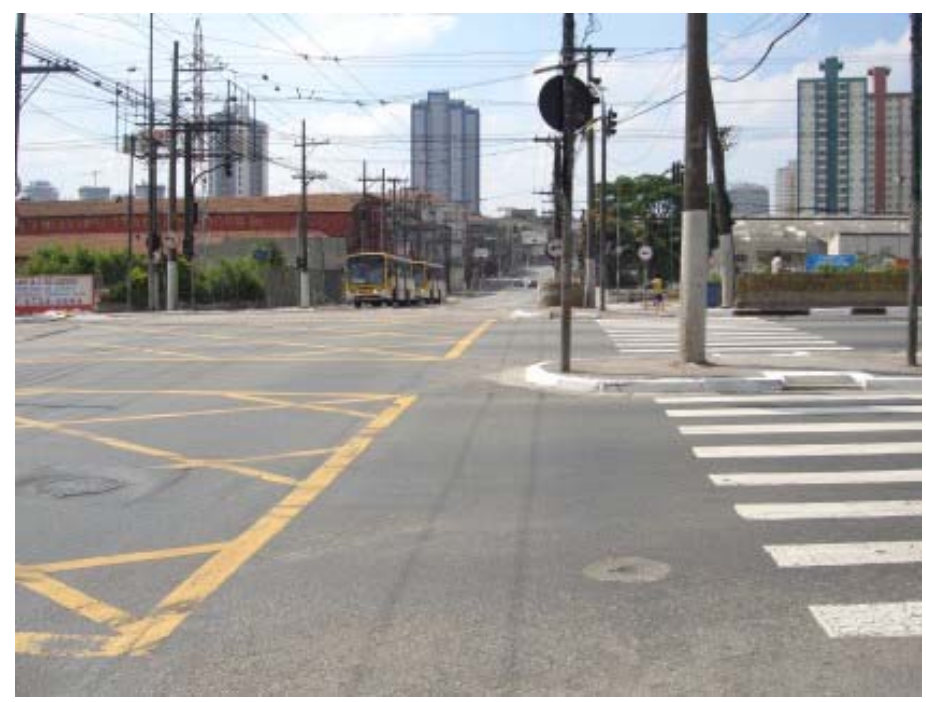

Fonte: Pesquisa da autora.

Observar os ônibus no sentido bairro/centro, em faixa exclusiva, na avenida Celso Garcia, pois o sentido da avenida é centro/bairro, com exceção aos ônibus que circulam nos dois sentidos.

Figura V-20.Cruzamento das avenidas Celso Garcia e Salim Farah Maluf Detalhe 3 


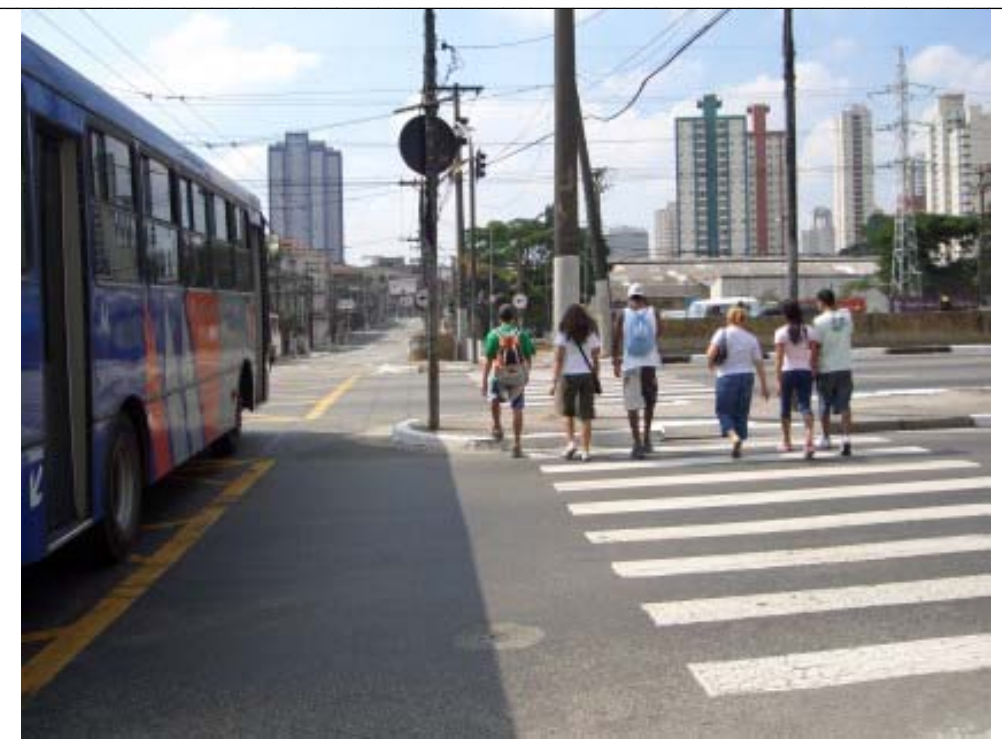

Fonte: Pesquisa da autora.

Observar ônibus no sentido centro/bairro, na avenida Celso Garcia. Os pedestres estão vencendo a primeira etapa da travessia. Observa-se mais duas etapas ao fundo.

\section{Cálculo dos Níveis de Serviço}

Figura V-21. Esquema de travessia no cruzamento nas avenidas Celso Garcia e Salim Farah Maluf

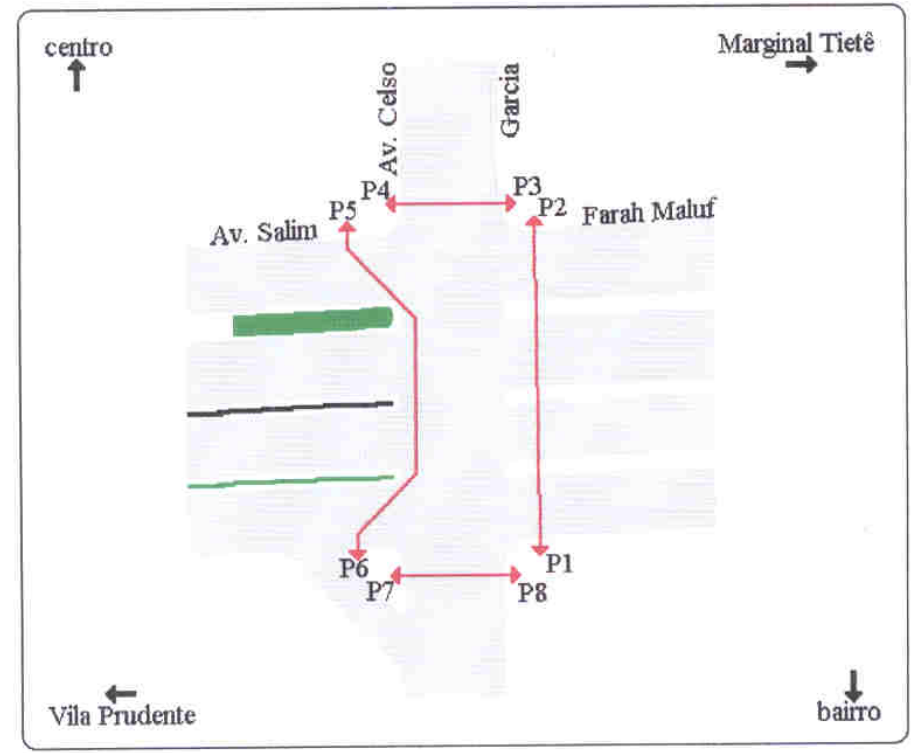

Fonte: CET. "Pesquisa de Trânsito". [CET(2005)]. 
Os movimentos P1 e P2 referem-se à travessia da avenida Salim Farah Maluf no vértice da direção da avenida Marginal Tietê; o movimento P3 e P4 trata-se da travessia da avenida Celso Garcia no vértice em direção do Centro da Cidade; o movimento P5 e P6 refere-se à travessia da avenida Salim Farah Maluf, no vértice em direção de Vila Prudente e finalmente os movimentos de P7 e P8 trata-se da travessia na avenida Celso Garcia no vértice em direção ao bairro de Tatuapé.

1. Cálculo de tempo de espera do Pedestre na Interseção Sinalizada - Dp

Tempo de ciclo-C: $160 \mathrm{~s}$

Tempo Efetivo de verde para pedestre-g: $80 \mathrm{~s}$

Os tempos de ciclo e de verde são igualmente divididos, ocorrendo nas duas avenidas (Celso Garcia e Salim F. Maluf).

Comprimento da travessia na av. Salim F. Maluf - L: 25,00 m

Comprimento da travessia na av. Celso Garcia: $10,00 \mathrm{~m}$

$$
\begin{aligned}
& \mathrm{Dp}=\frac{0,5(C-g) 2}{C} \\
& \mathrm{Dp}=\frac{0,5(160-80) 2}{160}=20,00 \mathrm{~s}
\end{aligned}
$$

Consultando a tabela IV-14 - NS para pedestres em interseções sinalizadas, para este tempo de espera o NS correspondente B, com Probabilidade Baixa a Moderada de

\section{Risco à Desobediência.}

Tempo de travessia individual: $\mathrm{T}=\frac{L}{v}$

Considerando a velocidade média de pedestre como $1,2 \mathrm{~m} / \mathrm{s}$, sendo L o comprimento da travessia temos:

Para a av. Salim Farah Maluf: $\mathrm{T}=\frac{25}{1,2}=20,8 \mathrm{~s}$

Para a av. Celso Garcia: $\mathrm{T}=\frac{10}{1,2}=8,33 \mathrm{~s}$

Portanto o tempo individual para a travessia é satisfatório, isto é, está dentro do tempo ofertado para a travessia. 
2. Cálculo do fluxo unitário de pedestre na calçada

\section{Travessias na avenida Salim Farah Maluf (movimentos P1, P2 e P5, P6)}

Largura total da calçada - Wt : 3,00 m

Soma das larguras de obstruções - Wc: Não foram consideradas as obstruções localizadas na calçada, por não interferirem na fluidez da caminhada.

Largura efetiva da calçada: $\mathrm{We}=\mathrm{Wt}-\mathrm{Wc}=3,00 \mathrm{~m}$

Fluxo no pico de 15 minutos - V15:

Fluxo unitário de pedestre $\mathrm{Vp}: \mathrm{Vp}=\frac{V 15}{15 \times W e}(\mathrm{p} / \mathrm{min} / \mathrm{m})$

Como a contagem em campo foi de 15 minutos, a fórmula se resume em $\mathrm{Vp}=\frac{V 15}{W e}$

Movimentos P1 e P2:

Fluxo no pico de 15 minutos - V15:

Pico da Manhã: 113 pedestres entre as 6:30 às 6:45 h

Pico da Tarde: 191 pedestres entre 17:15 às 17:30 h

Para o pico da manhã $\mathrm{Vp}=\frac{113}{3,0}=37,66(\mathrm{p} / \mathrm{min} / \mathrm{m})$

Consultando a tabela IV-8 Critérios de NS para Fluxos Médios em Passeios e

Calçadas, para este fluxo unitário, o NS correspondente é D.

Para o pico da tarde $\mathrm{Vp}=\frac{191}{3,0}=63,66(\mathrm{p} / \mathrm{min} / \mathrm{m})$

Consultando a tabela IV-8 Critérios de NS para Fluxos Médios em Passeios e

Calçadas, para este fluxo unitário, o NS correspondente é E.

Movimento P5 e P6:

Pico da Manhã: 85 pedestres entre as 6:30 e 6:45

Pico da Tarde: 84 pedestres entre as 17:45 e 18:00

Para o pico da manhã $\mathrm{Vp}=\frac{85}{3,0}=28,33(\mathrm{p} / \mathrm{min} / \mathrm{m})$

Consultando a tabela IV-8 Critérios de NS para Fluxos Médios em Passeios e

Calçadas, para este fluxo unitário, o NS correspondente é C.

Para o pico da tarde $\mathrm{Vp}=\frac{84}{3,0}=28,00(\mathrm{p} / \mathrm{min} / \mathrm{m})$ 
Consultando a tabela IV-8 Critérios de NS para Fluxos Médios em Passeios e

Calçadas, para este fluxo unitário, o NS correspondente é C.

\section{Travessias na avenida Celso Garcia (movimentos P3, P4 e P7, P8)}

Largura total da calçada - Wt : 2,50 m

Soma das larguras de obstruções - Wc: Não foram consideradas as obstruções localizadas na calçada, por não interferirem na fluidez da caminhada.

Largura efetiva da calçada: $\mathrm{We}=\mathrm{Wt}-\mathrm{Wc}=2,50 \mathrm{~m}$

Fluxo no pico de 15 minutos - V15:

Fluxo unitário de pedestre $\mathrm{Vp}: \mathrm{Vp}=\frac{V 15}{15 \times W e}(\mathrm{p} / \mathrm{min} / \mathrm{m})$

Como a contagem em campo foi de 15 minutos, a fórmula se resume em $\mathrm{Vp}=\frac{V 15}{W e}$

Movimentos P3 e P4:

Fluxo no pico de 15 minutos - V15:

Pico da Manhã: 39 pedestres entre as 7:00 às 7:15 h

Pico da Tarde: 89 pedestres entre 17:15 às 17:30 h

Para o pico da manhã $\mathrm{Vp}=\frac{39}{2,5}=15,60(\mathrm{p} / \mathrm{min} / \mathrm{m})$

Consultando a tabela IV-8 Critérios de NS para Fluxos Médios em Passeios e

Calçadas, para este fluxo unitário, o NS correspondente é A.

Para o pico da tarde $\mathrm{Vp}=\frac{89}{2,5}=35,60(\mathrm{p} / \mathrm{min} / \mathrm{m})$

Consultando a tabela IV-8 Critérios de NS para Fluxos Médios em Passeios e

Calçadas, para este fluxo unitário, o NS correspondente é D.

Movimento P7 e P8:

Pico da Manhã: 60 pedestres entre as 6:30 e 6:45

Pico da Tarde: 104 pedestres entre as 17:15 e 17:30

Para o pico da manhã $\mathrm{Vp}=\frac{60}{2,5}=24,00(\mathrm{p} / \mathrm{min} / \mathrm{m})$

Consultando a tabela IV-8 Critérios de NS para Fluxos Médios em Passeios e

Calçadas, para este fluxo unitário, o NS correspondente é C. 
Para o pico da tarde $\mathrm{Vp}=\frac{104}{2,5}=41,60(\mathrm{p} / \mathrm{min} / \mathrm{m})$

Consultando a tabela IV-8 Critérios de NS para Fluxos Médios em Passeios e

Calçadas, para este fluxo unitário, o NS correspondente é D.

3. Análise do Nível de Serviço calculado.

O tempo de espera do pedestre para atravessar a avenida é razoável e não induz os pedestres à desobediência à sinalização. $\mathrm{O}$ tempo dado à fase verde do pedestre é suficiente para a travessia individual.

Na avenida Salim Farah Maluf no movimento P5 e P6 há pouca concentração de pedestres na calçada (nível C), tanto no período da manhã como à tarde. Já no movimento P1 e P2 a concentração é próxima da crítica, sendo o nível D no pico da manhã às 6:30 h e nível E no pico da tarde às 17:15 h.

$\mathrm{Na}$ avenida Celso Garcia, no período da manhã, a travessia P3, P4 e P7,P8 estão com nível bom sendo A para P3, P4 e C na P7, P8. No pico da tarde o nível cai para D, próximo da crítica, nos dois movimentos.

Apesar do tempo de espera e do tempo para travessia serem favoráveis, há alguns acúmulos de pedestres nas calçadas, o que traduz em desconforto, mas não favorece comportamento de impaciência.

\subsubsection{BAIRRO DA MOÓCA}

\section{Travessias no cruzamento da avenida Alcântara Machado com a rua do}

\section{Hipódromo}

São três travessias neste cruzamento. A avenida Alcântara Machado só tem uma travessia de pedestres, no sentido bairro, enquanto a rua do Hipódromo tem travessias 
em ambos os lados da via, conforme representados nas figuras V-22, V-23, V-24, V-25

e V-26. Este cruzamento é uma confluência de duas importantes e movimentadas vias, tanto no sistema viário como em trânsito de pedestres. A área é densamente urbanizada, localizando-se comércios de grande porte, como atacadistas de materiais de construção (C \& C, Di Cicco), equipamentos de veículos (Roldão), igreja evangélica, lanchonete MacDonald, além de que a rua do Hipódromo ser o acesso à estação de Metrô Bresser.

Figura V-22. Cruzamento da avenida Alcântara Machado com a rua do Hipódromo. Vista panorâmica

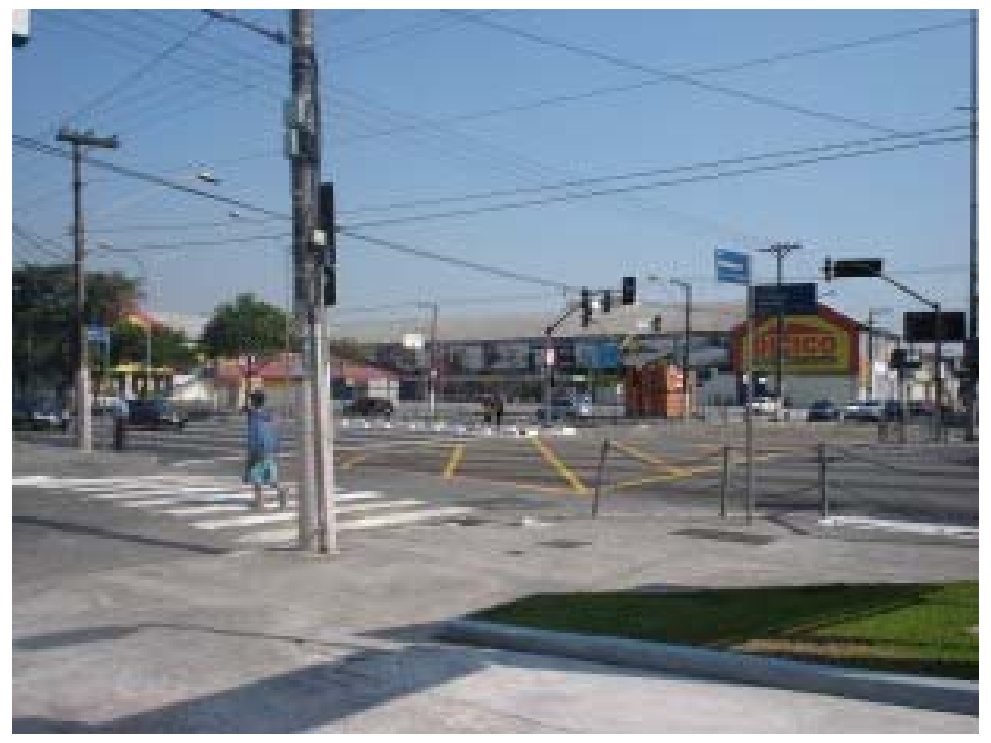


Fonte: Pesquisa da autora.

A via longitudinal da foto (da esquerda para a direita) é a avenida Alcântara Machado. A via transversal (onde um pedestre está atravessando) é a rua do Hipódromo. Observar que há um pedestre aguardando para atravessar a avenida Alcântara Machado, em local impróprio, inseguro e não regulamentado. Este comportamento é freqüente e caracteriza a impaciência dos pedestres, que os levam a tomarem atitudes inseguras.

\section{Figura V-23. Cruzamento da avenida Alcântara Machado com a rua do Hipódromo. Detalhe da travessia na avenida Alcântara Machado}

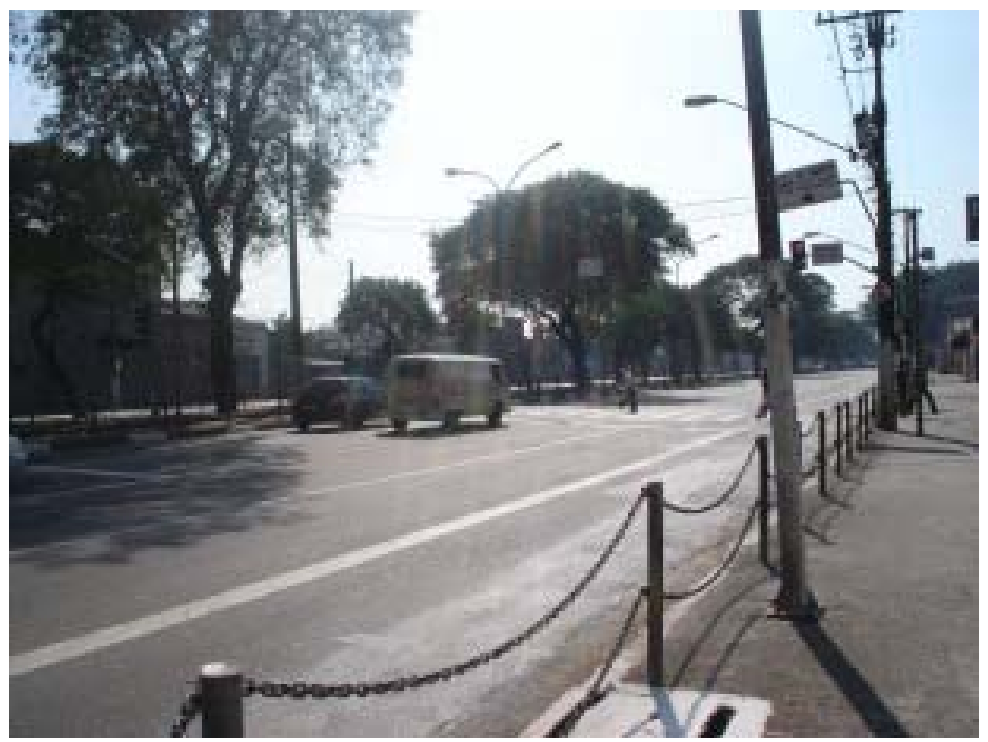

Fonte: Pesquisa da autora.

Observar a travessia na avenida Alcântara Machado. Há proteção (ou barreira) na esquina para induzir os pedestres a atravessarem dentro da faixa.

Figura V-24. Cruzamento da avenida Alcântara Machado com a rua do Hipódromo. Detalhe 1. 


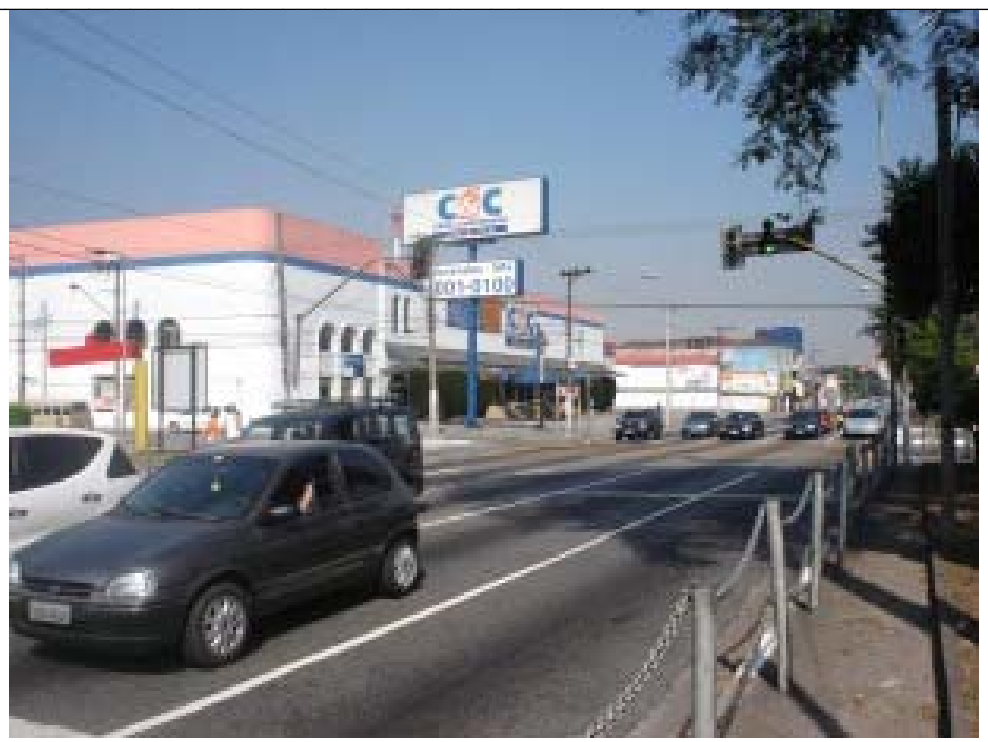

Fonte: Pesquisa da autora.

Observar que os veículos parados no primeiro plano estão aguardando a passagem dos pedestres, na avenida Alcântara Machado. Em primeiro plano também observam-se as correntes que induzem os pedestres a atravessarem na faixa.

\section{Figura V-25. Cruzamento da avenida Alcântara Machado com a rua do Hipódromo. Detalhe 2}

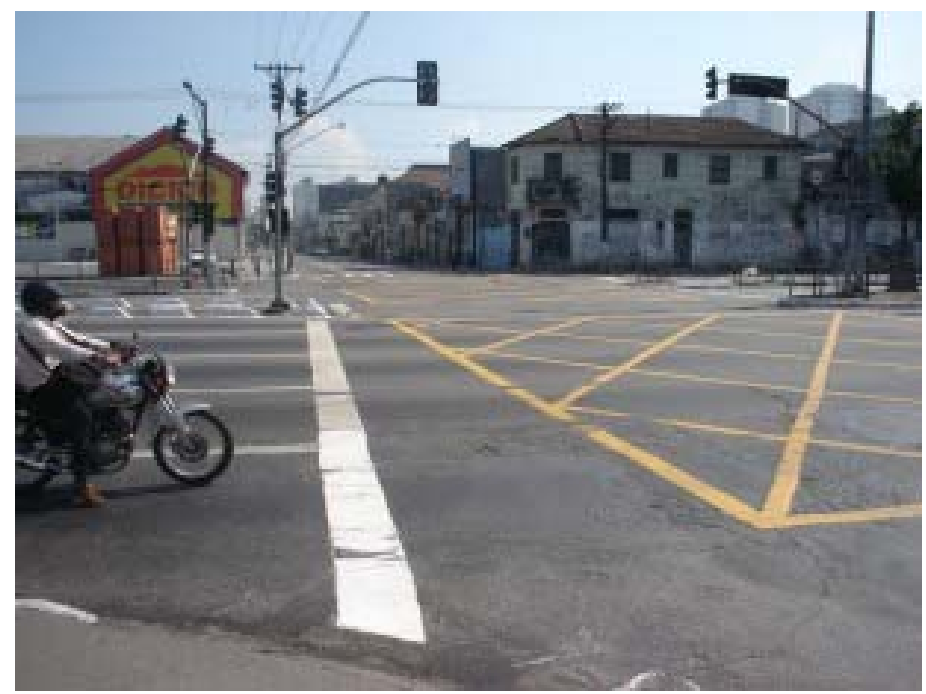

Fonte: Pesquisa da autora.

Detalhe da avenida Alcântara Machado onde não há travessia de pedestres.

\section{Cálculo dos Níveis de Serviço}

Figura V-26. Esquema da travessia na avenida Alcântara Machado 


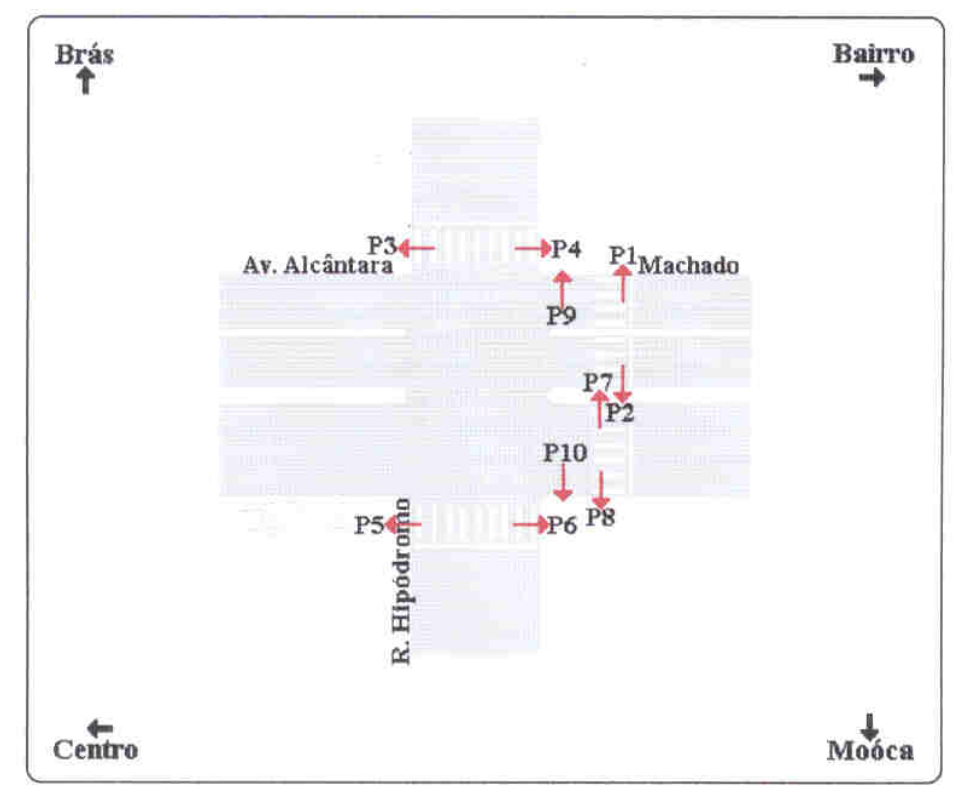

Fonte: CET. "Pesquisa de Trânsito". [CET(2005)].

Neste cruzamento a contagem de pedestre foi elaborado no período da tarde, pois no período da manhã há uniformidade na distribuição dos movimentos, não havendo nenhuma ocorrência negativa registrada.

A travessia da av. Alcântara Machado, representados no esquema como movimentos P1, P2, P7, P8, P9 e P10, para efeito de cálculo de fluxo unitário de pedestre, foram agrupados numa somatória e considerados movimentos P1 e P2.

Os movimentos P3 e P4 são representações da travessia da rua do Hipódromo no vértice em direção do bairro do Brás. Os movimentos P5 e P6, representam a travessia da mesma rua, na direção do bairro da Mooca.

\section{Travessia da avenida Alcântara Machado}

1. Cálculo de tempo de espera do Pedestre na Interseção Sinalizada - Dp

Tempo de ciclo-C: $180 \mathrm{~s}$

Tempo Efetivo de verde para pedestre-g: $50 \mathrm{~s}$

$\mathrm{Dp}=\frac{0,5(C-g) 2}{C}$ 
$\mathrm{Dp}=\frac{0,5(180-50) 2}{180}=46,94 \mathrm{~s}$

Consultando a tabela IV-14 - NS para pedestres em interseções sinalizadas, para este tempo de espera o NS correspondente E, com Alta Probabilidade à Desobediência.

2. Cálculo do fluxo unitário de pedestre na calçada

Largura total da calçada - Wt : 3,00 m

Soma das larguras de obstruções - Wc: Não foram consideradas as obstruções localizadas na calçada, por não interferirem na fluidez da caminhada.

Largura efetiva da calçada: $\mathrm{We}=\mathrm{Wt}-\mathrm{Wc}=3,00 \mathrm{~m}$

Fluxo no pico de 15 minutos - V15:

Fluxo unitário de pedestre $\mathrm{Vp}: \mathrm{Vp}=\frac{V 15}{15 \times W e}(\mathrm{p} / \mathrm{min} / \mathrm{m})$

Como a contagem em campo foi de 15 minutos, a fórmula se resume em $\mathrm{Vp}=\frac{V 15}{W e}$

Movimentos P1 e P2 (incluem P7, P8, P9 e P10)

Fluxo no pico de 15 minutos - V15:

Pico da Tarde: 1.608 pedestres entre 17:00 às 17:15 h

Para o pico da tarde $\mathrm{Vp}=\frac{1608}{3,0}=536(\mathrm{p} / \mathrm{min} / \mathrm{m})$

Consultando a tabela IV-8 Critérios de NS para Fluxos Médios em Passeios e

Calçadas, para este fluxo unitário, o NS correspondente é $\mathbf{F}$.

\section{Travessia na rua do Hipódromo}

Movimentos P3 e P4.

1. Cálculo de tempo de espera do Pedestre na Interseção Sinalizada - Dp

Tempo de ciclo-C: $180 \mathrm{~s}$

Tempo Efetivo de verde para pedestre-g: 130s

$$
\begin{aligned}
& \mathrm{Dp}=\frac{0,5(C-g) 2}{C} \\
& \mathrm{Dp}=\frac{0,5(180-130) 2}{180}=6,94 \mathrm{~s}
\end{aligned}
$$

Consultando a tabela IV-14 - NS para pedestres em interseções sinalizadas, para este tempo de espera o NS correspondente A, com Baixa Probabilidade à Desobediência. 
2. Cálculo do fluxo unitário de pedestre na calçada

Largura total da calçada - Wt : 2,50 m

Soma das larguras de obstruções - Wc: Não foram consideradas as obstruções localizadas na calçada, por não interferirem na fluidez da caminhada.

Largura efetiva da calçada: $\mathrm{We}=\mathrm{Wt}-\mathrm{Wc}=2,50 \mathrm{~m}$

Fluxo no pico de 15 minutos - V15:

Pico da Tarde: 43 pedestres entre 17:15 às 17:30 h

Para o pico da tarde $\mathrm{Vp}=\frac{43}{2,5}=17,2(\mathrm{p} / \mathrm{min} / \mathrm{m})$

Consultando a tabela IV-8 Critérios de NS para Fluxos Médios em Passeios e

Calçadas, para este fluxo unitário, o NS correspondente é B.

Movimento P5 e P6

1. Cálculo de tempo de espera do Pedestre na Interseção Sinalizada - Dp

Tempo de ciclo-C: $180 \mathrm{~s}$

Tempo Efetivo de verde para pedestre-g: 130s

$$
\begin{aligned}
& \mathrm{Dp}=\frac{0,5(C-g) 2}{C} \\
& \mathrm{Dp}=\frac{0,5(180-130) 2}{180}=6,94 \mathrm{~s}
\end{aligned}
$$

Consultando a tabela IV-14 - NS para pedestres em interseções sinalizadas, para este tempo de espera o NS correspondente A, com Baixa Probabilidade à Desobediência.

2. Cálculo do fluxo unitário de pedestre na calçada

Largura total da calçada - Wt : 2,50 m

Soma das larguras de obstruções - Wc: Não foram consideradas as obstruções localizadas na calçada, por não interferirem na fluidez da caminhada.

Largura efetiva da calçada: $\mathrm{We}=\mathrm{Wt}-\mathrm{Wc}=2,50 \mathrm{~m}$

Fluxo no pico de 15 minutos - V15:

Pico da Tarde: 150 pedestres entre 17:45 às 18:00 $\mathrm{h}$

Para o pico da tarde $\mathrm{Vp}=\frac{150}{2,5}=60,00(\mathrm{p} / \mathrm{min} / \mathrm{m})$ 
Consultando a tabela IV-8 Critérios de NS para Fluxos Médios em Passeios e

Calçadas, para este fluxo unitário, o NS correspondente é E.

3. Análise do Nível de Serviço calculado.

Nesta travessia têm-se três situações bem distintas. A travessia na avenida Alcântara Machado é crítica com nível de serviço E. A probabilidade de desobedecer as normas de segurança é verificada com os pedestres atravessando fora da faixa, ou em locais não regulamentados, como observados na figura acima. Quanto ao critério de fluxo de pedestres na calçada, o nível de serviço é F, caracterizando uma situação de acúmulo de pessoas criado pela demora na troca de sinalização para a travessia.

Na rua do Hipódromo, no movimento P3 e P4, o tempo de espera do pedestre para atravessar a avenida é boa e não induz os pedestres à desobediência à sinalização (nível A). Esta característica é própria da travessia "em carona", isto é, enquanto está verde para o trânsito na avenida, a travessia da rua secundária também está verde, e o fluxo de pedestres não é grande, portanto o tempo dado à fase verde do pedestre é suficiente para a travessia com tranqüilidade. O mesmo não ocorre no movimento $\mathrm{P} 5$ e $\mathrm{P} 6$, onde ocorre a travessia "em carona", mas o fluxo de pedestres é intenso no horário de pico atingindo o nível E, nível crítico, quando há muita acumulação de pedestres na calçada, favorecendo comportamento de pedestres atravessando fora da faixa.

\section{Viaduto Bresser}

Este viaduto atravessa a avenida Alcântara Machado, integrando o bairro da Mooca com a avenida Celso Garcia, importante região comercial. Este viaduto tem somente uma passagem de pedestre situado no lado direito de quem vai para a avenida Celso Garcia, conforme se observa na figura V-27, V-28 e V-29. Neste trecho da avenida Alcântara Machado localiza-se duas importantes instituições: a SENAI, instituição de ensino e o 
$\overline{\text { Instituto de Análise de Controle de Câncer, que administra tratamento de combate ao }}$ câncer. São duas instituições que atraem muitos pedestres diariamente.

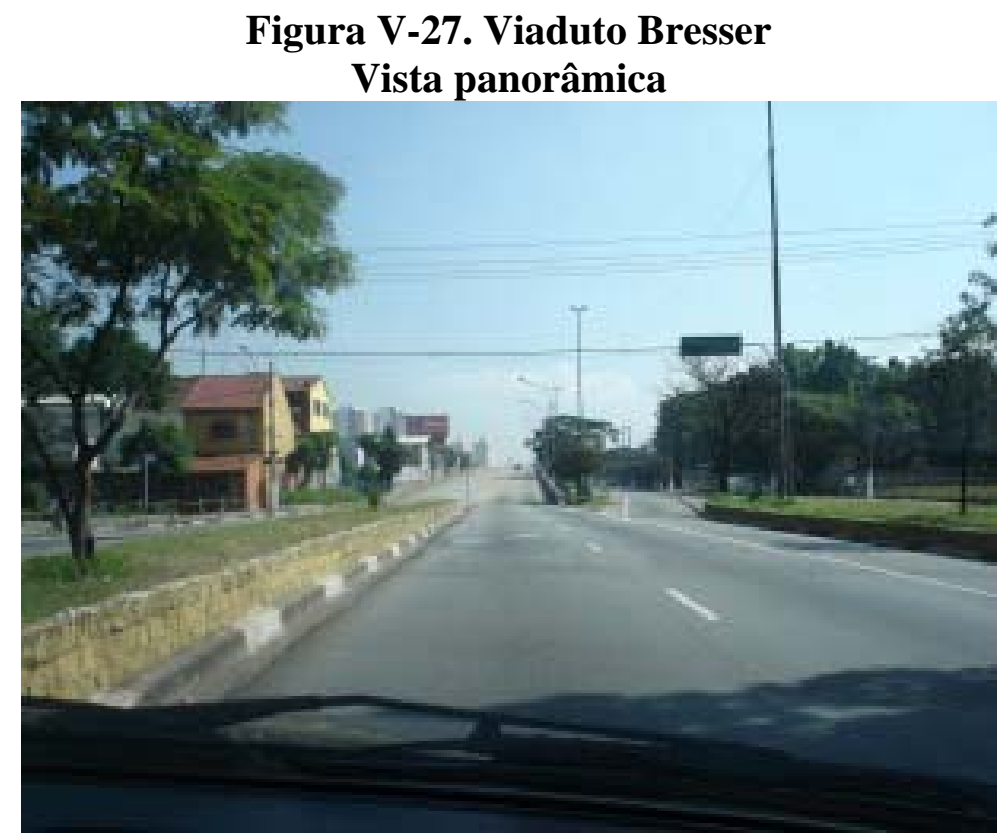

Fonte: Pesquisa da autora

Observar o viaduto no ponto de fuga da perspectiva panorâmica. Á direita da foto, onde há grande quantidade de árvores localiza-se o Instituto de Ensino do SENAI. À esquerda observam-se residências.

Figura V-28. Viaduto Bresser

Travessia de pedestres. Detalhes 1 e 2 .

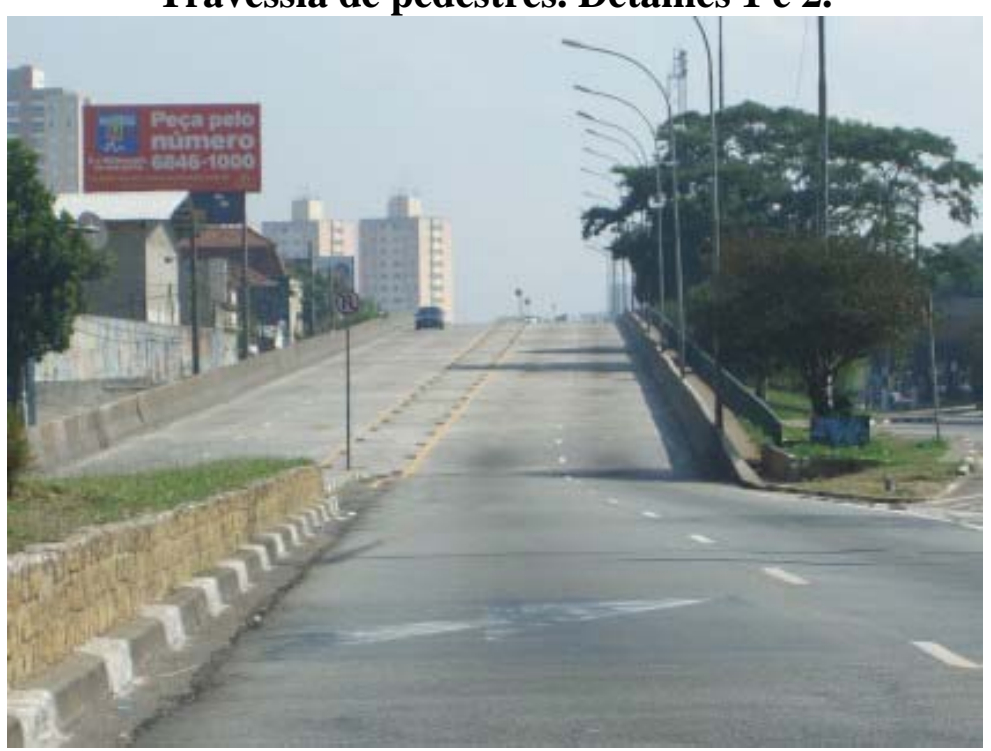

Detalhe 1. 


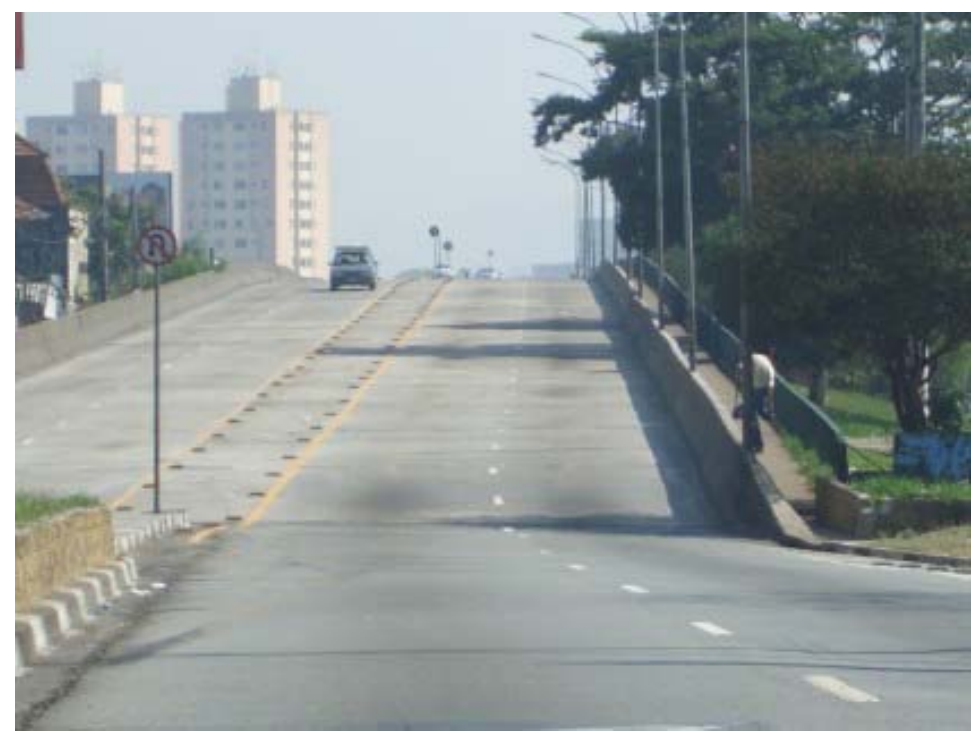

Detalhe 2.

Fonte: Pesquisa da autora

Observa-se que a travessia de pedestres é protegida com pequeno muro, de ambos os lados. Há postes de iluminação, apenas na calçada do lado direito da foto, mas a iluminação está voltada para a via, não para a passagem de pedestre. Observar o estreitamento da calçada no início da passagem. É uma interferência que restringe o fluxo de pedestres e atrapalha a pessoa que estiver portando volumes como carrinhos, sacolas, malas, etc. Considerando que próximo dali há uma instituição de ensino, onde se supõem que estudantes portem mochilas, malas, etc, esta restrição é indesejável.

\section{Cálculo dos Níveis de Serviço}

Figura V-29. Esquema de travessia no viaduto Bresser 


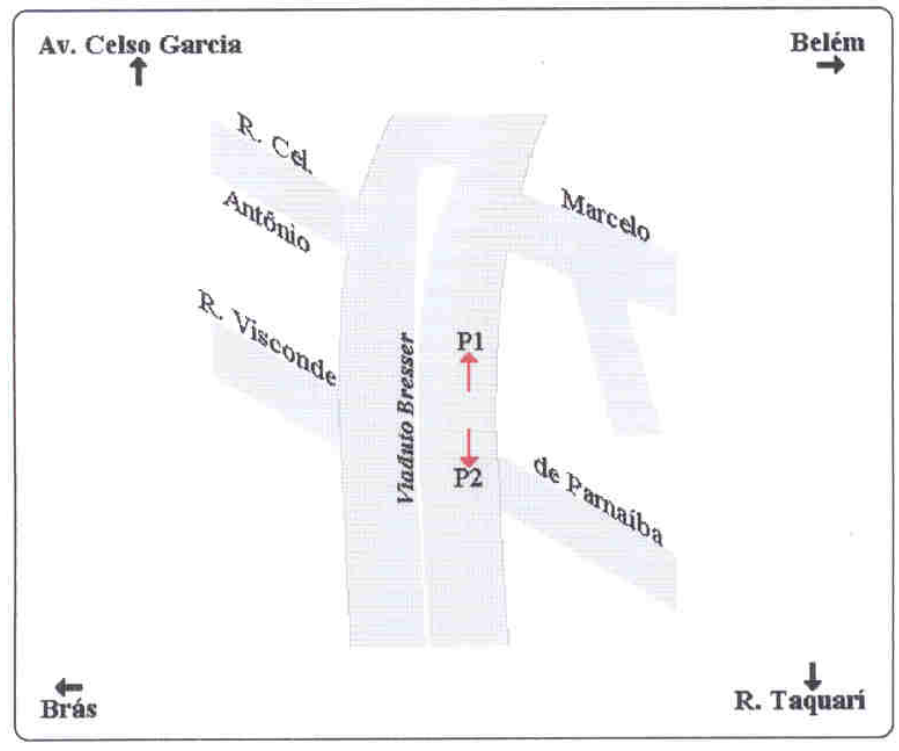

Fonte: CET. "Pesquisa de Trânsito". [CET(2005)].

Esta instalação será avaliada pelo fluxo unitário de pedestre, transitando na única calçada do viaduto. O movimento $\mathrm{P} 1$ e $\mathrm{P} 2$ refere-se à calçada à direita, considerando o sentido Mooca a Av. Celso Garcia.

1. Cálculo do fluxo unitário de pedestre na calçada

Largura total do passeio - Wt : $1,80 \mathrm{~m}$

Soma das larguras de obstruções - Wc: $0,50 \mathrm{~m}$

Largura efetiva da travessia: $\mathrm{We}=\mathrm{Wt}-\mathrm{Wc}=1,30 \mathrm{~m}$

Fluxo no pico de 15 minutos - V15:

Fluxo unitário de pedestre $\mathrm{Vp}: \mathrm{Vp}=\frac{V 15}{15 \times W e}(\mathrm{p} / \mathrm{min} / \mathrm{m})$

Como a contagem em campo foi de 15 minutos, a fórmula se resume em $\mathrm{Vp}=\frac{V 15}{W e}$

Movimento P1 - P2

Pico da Manhã: 57 pedestres entre as $6: 30$ às $6: 45 \mathrm{~h}$

Pico da Tarde: 83 pedestres entre 18:00 às 18:15 h

Para o pico da manhã $\mathrm{Vp}=\frac{57}{1,30}=43,84(\mathrm{p} / \mathrm{min} / \mathrm{m})$

Consultando a tabela IV-8 Critérios de NS para Fluxos Médios em Passeios e

Calçadas, para este fluxo unitário, o NS correspondente é D. 
Para o pico da tarde $\mathrm{Vp}=\frac{83}{1,30}=63,84(\mathrm{p} / \mathrm{min} / \mathrm{m})$

Consultando a tabela IV-8 Critérios de NS para Fluxos Médios em Passeios e

Calçadas, para este fluxo unitário, o NS correspondente é E.

2. Análise do Nível de Serviço calculado.

A calçada está operando num nível forçado, tanto no pico da manhã como à tarde. $\mathrm{O}$ fluxo de pedestres é intenso e haveria necessidade de uma reavaliação no sentido de uma travessia mais segura para os pedestres transporem a avenida Alcântara Machado.

\subsubsection{BAIRRO DO TATUAPÉ}

\section{Cruzamento das ruas Acurui, Emília Marengo e Antônio de Barros.}

Este cruzamento forma um $\mathrm{T}$, pois a rua Acurui é prolongamento da rua Emíla Marengo. A rua Antônio de Barros termina neste cruzamento. A rua Acurui é em declive acentuado, o que favorece aos veículos desenvolverem velocidades acima do permitido, ignorando semáforo, na descida para aproveitar o "embalo" e na subida para não perder o "embalo". A rua Emília Marengo é acesso à avenida Salim Farah Maluf e uma rua com intenso comércio de alto nível, pois é a borda do bairro de Anália Franco, bairro nobre da Zona Leste. A rua Antônio de Barros é tradicional rua comercial e interliga a parte alta de Tatuapé com a avenida Alcântara Machado (Radial Leste). A rua Acurui é mais residencial e apresenta alguns prédios de serviços como clínicas, restaurantes, salão de beleza, etc.

Há movimentação de pedestres em função das atividades comerciais destas ruas. Circulam linhas de ônibus na rua Emília Marengo e Acurui. Os pontos de ônibus estão deteriorados, sem conservação, alguns são somente postes de madeira, o que é motivo 


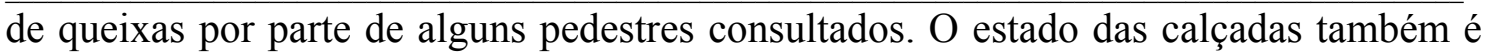
deplorável, principalmente em função do crescimento das árvores que "estouram" o calçamento. Figuras V-30 e V-31.

Os pedestres têm dificuldade na travessia devida, principalmente, à desobediência ao semáforo nas ruas Emíla Marengo e Acurui, por parte dos motoristas.

Figura V-30. Cruzamento r. Acurui x r. Antonio de Barros x r. Emília Marengo Vista panorâmica

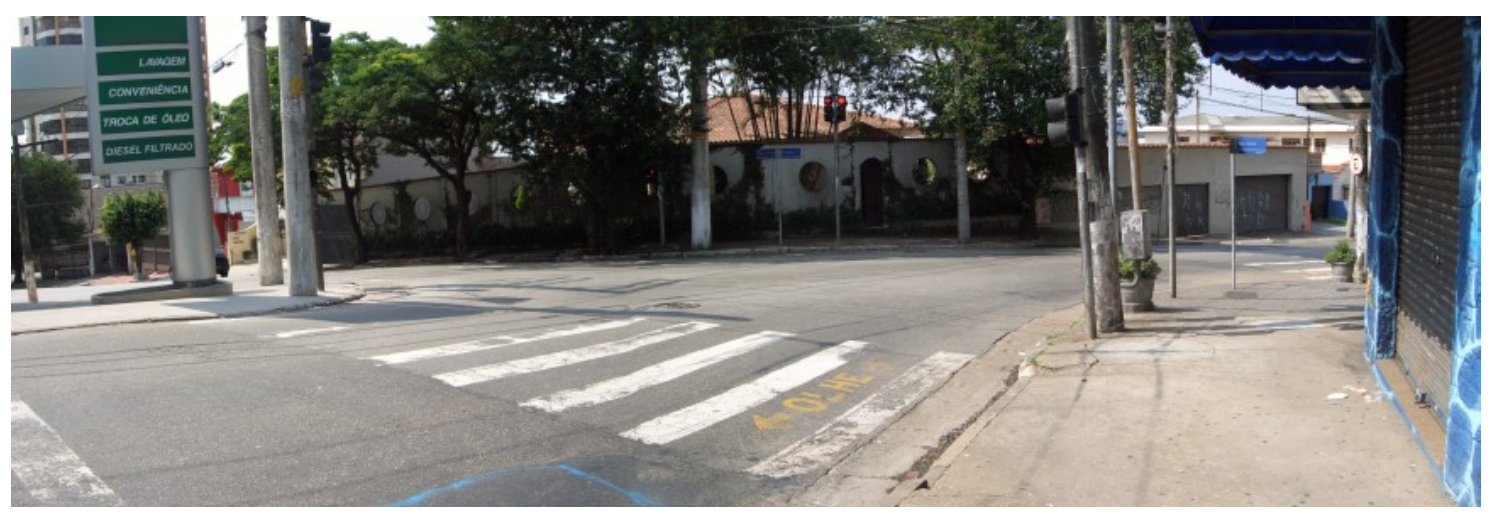

Fonte: Arquivo da autora

A rua Emília Marengo está em primeiro plano e segue à direita como rua Acurui. À esquerda e ao fundo vemos a esquina da rua Antônio de Barros, onde observamos um posto de combustível.

\section{Cálculo dos Níveis de Serviço}

Figura V-31. Esquema das travessias no cruzamento das ruas Acurui, Antonio de Barros e Emília Marengo 


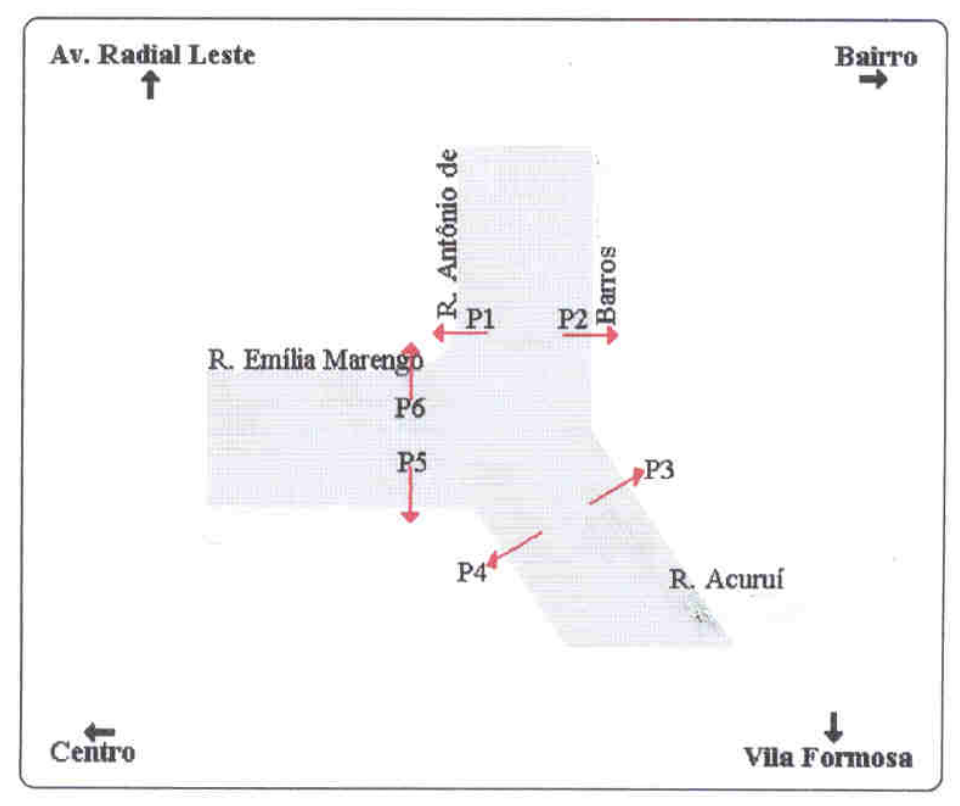

Fonte: CET. "Pesquisa de Trânsito". [CET(2005)].

O movimento P1 e P2 representam a travessia na rua Antônio de Barros, P3 e P4 a travessia na rua Acurui e P5 e P6 a travessia na rua Emília Marengo.

1. Cálculo de tempo de espera do Pedestre na Interseção Sinalizada - Dp

Tempo de ciclo-C: $60 \mathrm{~s}$

Tempo Efetivo de verde para pedestre-g: $30 \mathrm{~s}$

Os tempos de ciclo e de verde são igualmente divididos nas três ruas.

$\mathrm{Dp}=\frac{0,5(C-g) 2}{C}$

$\mathrm{Dp}=\frac{0,5(60-30) 2}{60}=7,5 \mathrm{~s}$

Consultando a tabela IV-14 - NS para pedestres em interseções sinalizadas, para este tempo de espera o NS correspondente A, com Baixa Probabilidade à Desobediência.

2. Cálculo do fluxo unitário de pedestre na calçada

\section{Travessias na rua Antônio de Barros (movimentos P1, P2)}

Largura total da calçada - Wt : 2,50 m

Soma das larguras de obstruções - Wc: Não foram consideradas as obstruções localizadas na calçada, por não interferirem na fluidez da caminhada. 
Largura efetiva da calçada: $\mathrm{We}=\mathrm{Wt}-\mathrm{Wc}=2,50 \mathrm{~m}$

Fluxo no pico de 15 minutos - V15:

Fluxo unitário de pedestre $\mathrm{Vp}: \mathrm{Vp}=\frac{V 15}{15 \times W e}(\mathrm{p} / \mathrm{min} / \mathrm{m})$

Como a contagem em campo foi de 15 minutos, a fórmula se resume em $\mathrm{Vp}=\frac{V 15}{W e}$

Fluxo no pico de 15 minutos - V15:

Pico da Manhã: 16 pedestres entre as 7:00 às 7:15 h

Pico da Tarde: 16 pedestres entre 17:00 às 17:15 h

Para o pico da manhã e pico da tarde $\mathrm{Vp}=\frac{16}{2,50}=6,40(\mathrm{p} / \mathrm{min} / \mathrm{m})$

Consultando a tabela IV-8 Critérios de NS para Fluxos Médios em Passeios e

Calçadas, para este fluxo unitário, o NS correspondente é A.

\section{Travessia da rua Acurui (movimentos P3 e P4)}

Largura total da calçada - Wt : 2,50 m

Soma das larguras de obstruções - Wc: Não foram consideradas as obstruções localizadas na calçada, por não interferirem na fluidez da caminhada.

Largura efetiva da calçada: $\mathrm{We}=\mathrm{Wt}-\mathrm{Wc}=2,50 \mathrm{~m}$

Fluxo no pico de 15 minutos - V15:

Pico da Manhã: 3 pedestres entre as 8:45 às 9:00 h

Pico da Tarde: 9 pedestres entre 17:45 às 18:00 h

Para o pico da manhã $\mathrm{Vp}=\frac{3}{2,50}=1,20(\mathrm{p} / \mathrm{min} / \mathrm{m})$

Consultando a tabela IV-8 Critérios de NS para Fluxos Médios em Passeios e

Calçadas, para este fluxo unitário, o NS correspondente é A.

Para o pico da tarde $\mathrm{Vp}=\frac{9}{2,50}=3,66(\mathrm{p} / \mathrm{min} / \mathrm{m})$

Consultando a tabela IV-8 Critérios de NS para Fluxos Médios em Passeios e

Calçadas, para este fluxo unitário, o NS correspondente é A.

\section{Travessia na rua Emília Marengo (movimentos P5 e P6)}

Largura total da calçada - Wt : 2,50 m

Soma das larguras de obstruções - Wc: Não foram consideradas as obstruções localizadas na calçada, por não interferirem na fluidez da caminhada.

Largura efetiva da calçada: $\mathrm{We}=\mathrm{Wt}-\mathrm{Wc}=2,50 \mathrm{~m}$

Fluxo no pico de 15 minutos - V15: 
Pico da Manhã: 22 pedestres entre as 7:00 às 7:15 h

Pico da Tarde: 25 pedestres entre 18:15 às 18:30 h

Para o pico da manhã $\mathrm{Vp}=\frac{22}{2,50}=8,80(\mathrm{p} / \mathrm{min} / \mathrm{m})$

Consultando a tabela IV-8 Critérios de NS para Fluxos Médios em Passeios e

Calçadas, para este fluxo unitário, o NS correspondente é A.

Para o pico da tarde $\mathrm{Vp}=\frac{25}{2,50}=10,00(\mathrm{p} / \mathrm{min} / \mathrm{m})$

Consultando a tabela IV-8 Critérios de NS para Fluxos Médios em Passeios e

Calçadas, para este fluxo unitário, o NS correspondente é A.

3. Análise do Nível de Serviço calculado.

Neste cruzamento têm-se três ruas em confluência, porém operacionalmente são duas pois a rua Emília Marengo é quase a continuação da rua Acurui, porém esta última tem declividade acentuada. O semáforo funciona simultaneamente para estas duas ruas (quando fecha para a rua Emília Marengo fecha também para a rua Acurui e abre para a rua Antônio de Barros).

Quanto à travessia de pedestres este cruzamento está operando em ótimas condições, com nível de serviço A, tanto em tempo de espera como no fluxo de pedestre na calçada.

O problema maior deste cruzamento é a parte operacional da via, pois a topografia desta favorece a desenvolvimento de velocidade por parte dos veículos. Devido a declividade da rua Acurui, os veículos que transitam no sentido da rua Emília Marengo para rua Acurui costumam prosseguir sem obedecer a sinalização. Por sua vez aqueles que sobem a rua Acurui, procuram desenvolver velocidade para vencer o aclive. Isto provoca alguns acidentes, notadamente, atropelamentos. Estas observações de campo são importantes para refinar os cálculos teóricos. 


\section{Ponte Tatuapé}

Esta ponte transpõe o rio Tietê e apresenta calçadas laterais para a travessia de pedestres. Esta ponte prolonga a avenida Salim Farah Maluf até a rodovia Presidente Dutra. Interliga os bairros de Belém à Vila Maria. Na região próxima à cabeceira da região de Belém há hospitais, FEBEM, residências e pequenos comércios. Na extremidade de Vila Maria também há residências, galpões industriais, garagem de ônibus e comércios. A circulação de pedestres é intensa devido a viagens de serviços, pequenos comércios e compras, pela população de baixa renda. Apesar da iluminação os pedestres usuários da ponte consideram a iluminação muito fraca, devido à altura da fonte luminosa que projeta muita sombra na calçada. Observar que o foco da iluminação é a via, conseqüentemente a calçada permanece na zona de penumbra. Figuras V-32, V-33 e V-34.

Figura V-32. Ponte Tatuapé

Vista panorâmica 


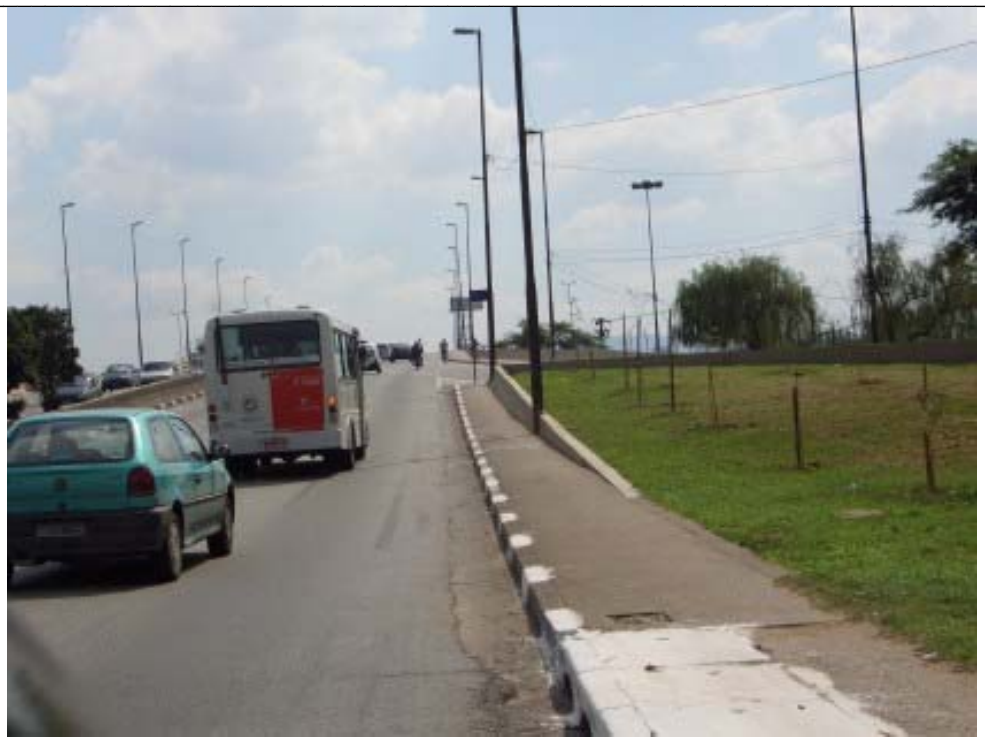

Fonte: Arquivo da autora

Observar que a ponte é iluminada, porém os pedestres consultados reclamaram que a iluminação não é suficientemente forte para ter uma caminhada segura à noite.

Figura V-33. Ponte Tatuapé

\section{Detalhe da calçada}

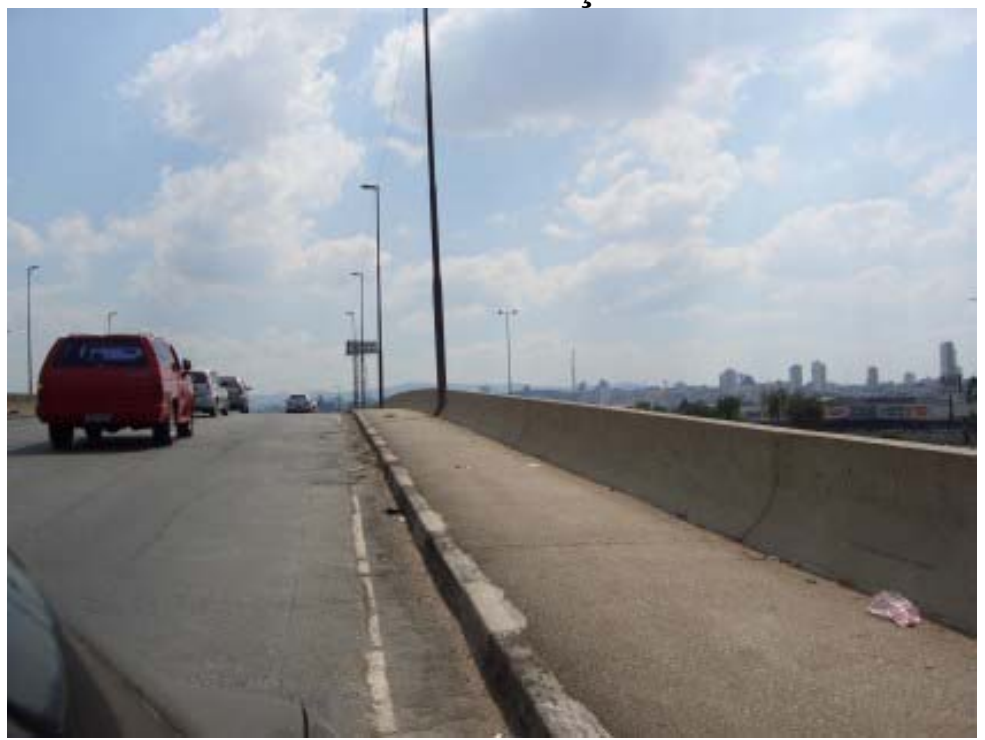

Fonte: Arquivo da autora

Observar que na ponte não há mureta de separação do tráfego viário e do pedestre. Este fato traz insegurança na travessia; a proximidade dos veículos em alta velocidade é um fator para acidentes.

\section{Cálculo dos Níveis de Serviço}




\section{Figura V-34. Esquema de travessia da ponte do Tatuapé}

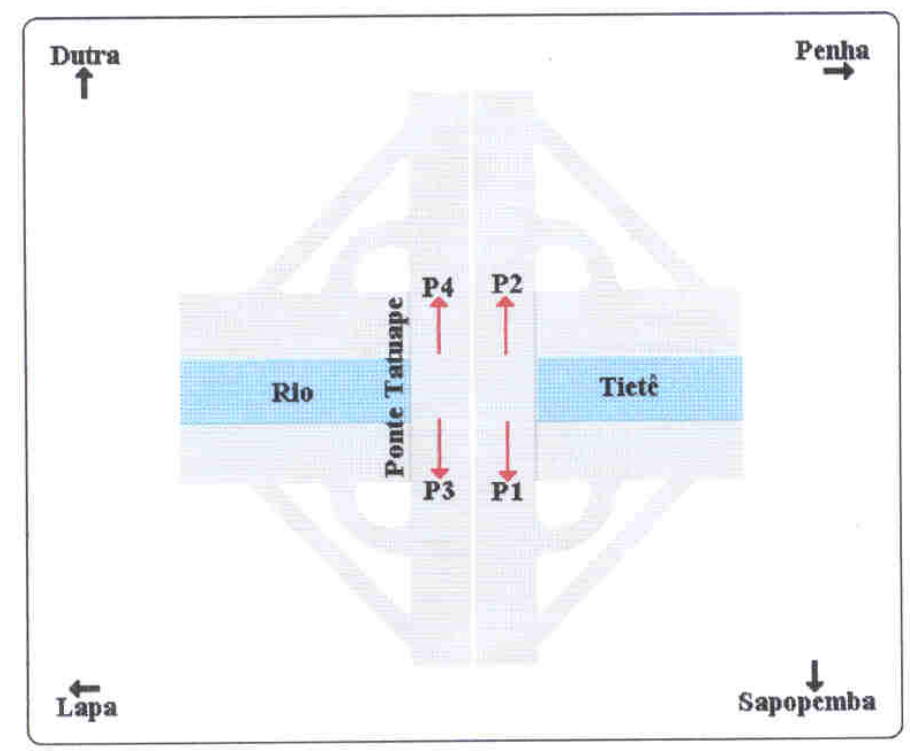

Fonte: CET. "Pesquisa de Trânsito". [CET(2005)].

Esta instalação será avaliada pelo fluxo unitário de pedestre, transitando nas calçadas da ponte. $\mathrm{O}$ movimento $\mathrm{P} 1$ e $\mathrm{P} 2$ refere-se à calçada à direita, considerando a direção da transposição do rio Tietê, em direção à rodovia Presidente Dutra, e o movimento P3 e P4 à calçada à esquerda.

1. Cálculo do fluxo unitário de pedestre na calçada

Largura total do passeio $-\mathrm{Wt}: 1,20 \mathrm{~m}$

Soma das larguras de obstruções - Wc: Não será considerado as obstruções da irregularidade das calçadas.

Largura efetiva da travessia: $\mathrm{We}=\mathrm{Wt}-\mathrm{Wc}=1,20$

Fluxo no pico de 15 minutos - V15:

Fluxo unitário de pedestre $\mathrm{Vp}: \mathrm{Vp}=\frac{V 15}{15 \times W e}(\mathrm{p} / \mathrm{min} / \mathrm{m})$

Como a contagem em campo foi de 15 minutos, a fórmula se resume em $\mathrm{Vp}=\frac{V 15}{W e}$

Movimento P1 - P2

Pico da Manhã: 138 pedestres entre as 6:30 às 6:45 h

Pico da Tarde: 67 pedestres entre 17:30 às 17:45 h 
Para o pico da manhã $\mathrm{Vp}=\frac{138}{1,20}=115,00(\mathrm{p} / \mathrm{min} / \mathrm{m})$

Consultando a tabela IV-8 Critérios de NS para Fluxos Médios em Passeios e

Calçadas, para este fluxo unitário, o NS correspondente é F.

Para o pico da tarde $\mathrm{Vp}=\frac{67}{1,20}=55,83(\mathrm{p} / \mathrm{min} / \mathrm{m})$

Consultando a tabela IV-8 Critérios de NS para Fluxos Médios em Passeios e

Calçadas, para este fluxo unitário, o NS correspondente é E.

Movimento P3 - P4

Pico da Manhã: 52 pedestres entre as 7:15 às 7:30 h

Pico da Tarde: 33 pedestres entre 17:00 às 17:15 h

Para o pico da manhã $\mathrm{Vp}=\frac{52}{1,20}=43,33(\mathrm{p} / \mathrm{min} / \mathrm{m})$

Consultando a tabela IV-8 Critérios de NS para Fluxos Médios em Passeios e

Calçadas, para este fluxo unitário, o NS correspondente é D.

Para o pico da tarde $\mathrm{Vp}=\frac{33}{1,20}=27,50(\mathrm{p} / \mathrm{min} / \mathrm{m})$

Consultando a tabela IV-8 Critérios de NS para Fluxos Médios em Passeios e

Calçadas, para este fluxo unitário, o NS correspondente é C.

2. Análise do Nível de Serviço calculado.

A calçada com o movimento P1 e P2 está com nível de serviço crítico (nível E e F), porém a calçada com o movimento P3 e P4, calçada à esquerda no sentido de direção da rodovia Presidente Dutra, está com serviço razoável, no horário de pico (nível C e D).

Como não há obstruções na calçada, nem muretinha de segurança, os pedestres mais ligeiros tentam ultrapassar os mais vagarosos, andando na via, comprometendo a sua segurança. Nestas circunstâncias esta instalação deve ter tratamento específico para sanar esta distorção. 


\subsubsection{BAIRRO DA VILA PRUDENTE}

\section{Travessia da rua Montesima}

Esta travessia transpõe a avenida Salim Farah Maluf. Na realidade a avenida Salim Farah Maluf percorre este trecho em corte, passando em desnível pala rua Montesima, que, portanto permanece integrado ao sistema viário original, assumindo a característica de um viaduto. Esta travessa está próxima da rua do Orfanato, um dos principais eixos da Vila Prudente, tradicional rua comercial; e a avenida Sapopemba, também tradicional via da Zona Sudeste. Interliga os bairros de Vila Prudente e Água Rasa. O entorno é basicamente área residencial, de classe média. No entorno da rua Montesima há empreendimentos comerciais, como padarias, bares, etc, além de escolas, academias, consultórios e outros empreendimentos de serviços. Sendo a avenida Salim Farah Maluf uma via expressa, esta travessa é importante, pois é a ligação entre as duas parte do bairro, cortadas pela avenida. Este viaduto tem duas calçadas, que são intensamente utilizadas, além das alças de acesso. FigurasV-35, V-36, V-37, V-38 e V-39. 


\section{Figura V-35.Travessia da rua Montesima. Cabeceira Água Rasa.}

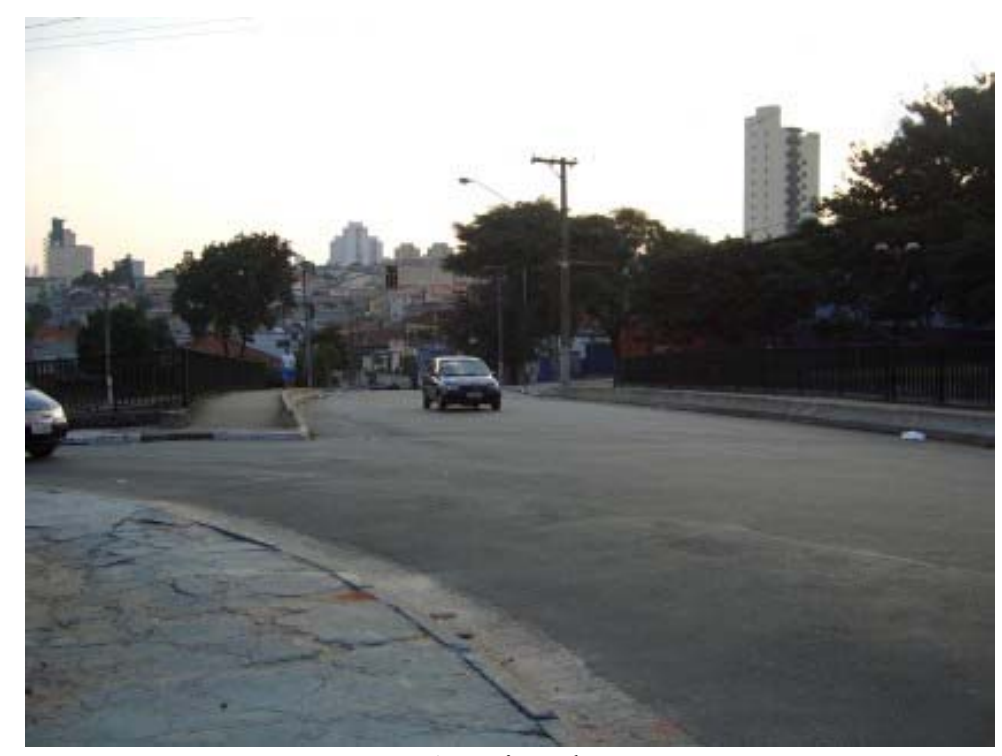

Fonte: Arquivo da autora

Á esquerda da foto observa-se a alça de acesso da avenida Salim Farah Maluf para a rua Montesima. Ao centro a travessa da rua Montesima.

Figura V-36.Travessia da rua Montesima. Cabeceira Vila Prudente.

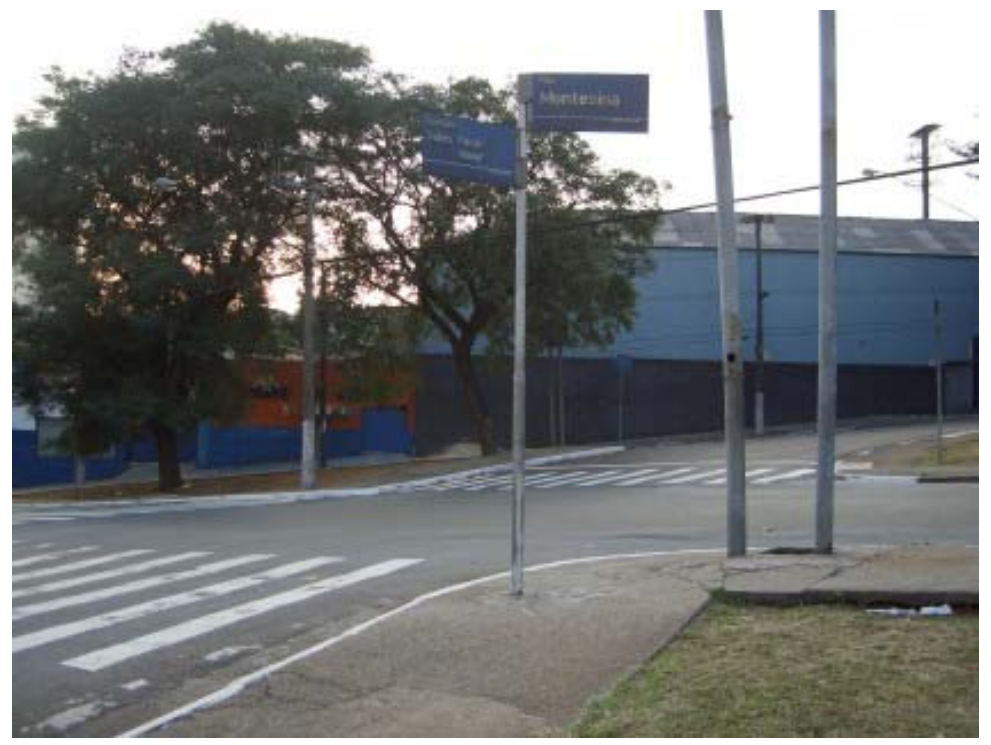

Fonte: Arquivo da autora

Vista da outra extremidade da travessia. Observar os postes colocados na calçada interferindo no livre fluxo de pedestres. 
Figura V-37.Travessia da rua Montesima. Detalhe 1.

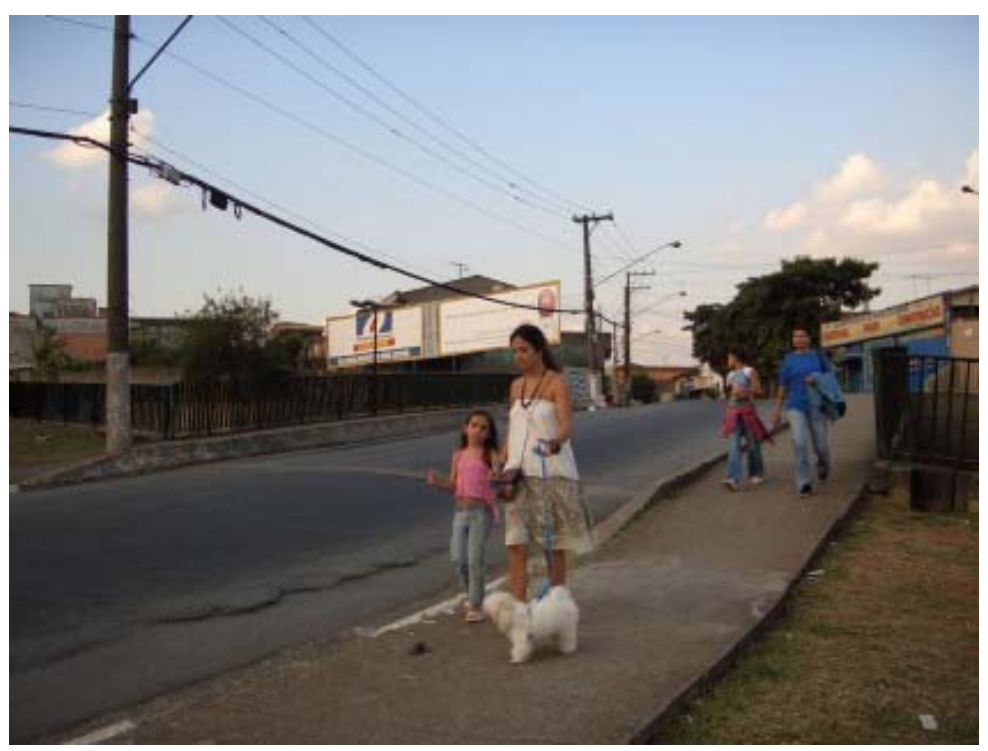

Fonte: Arquivo da autora

Observar que a travessia conta com uma barreira baixa separando o tráfego viário com o de pedestres.

Figura V-38.Travessia da rua Montesima Detalhe 2.

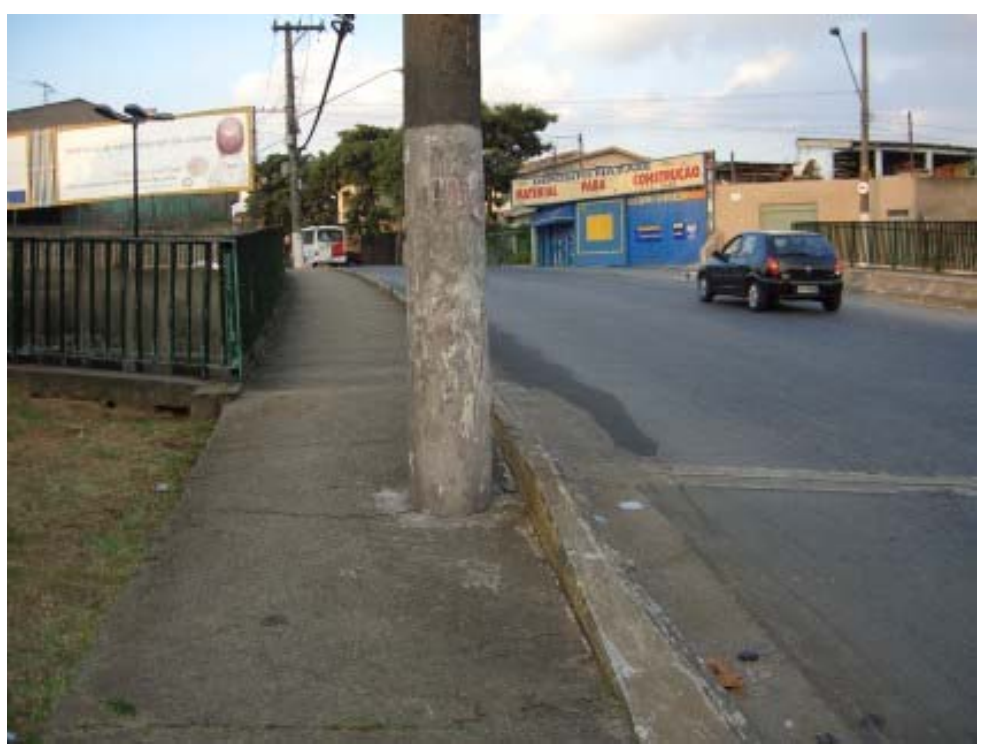

Fonte: Arquivo da autora

Postes colocados nas extremidades da calçada da travessa, interferindo na caminhada do pedestre. 


\section{Cálculo dos Níveis de Serviço}

\section{Figura V-39.Esquema da Travessia da rua Montesima}

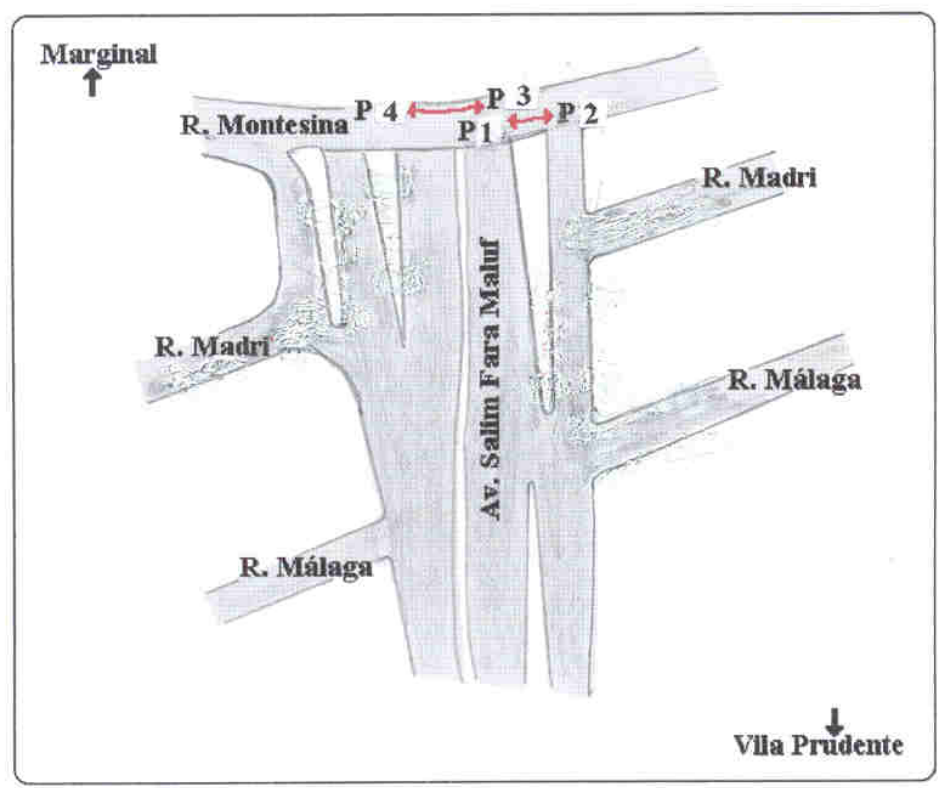

Fonte: CET. "Pesquisa de Trânsito". [CET(2005)].

Esta instalação será avaliada pelo fluxo unitário de pedestre, transitando nas calçadas do viaduto. $\mathrm{O}$ movimento $\mathrm{P} 1$ e $\mathrm{P} 2$ refere-se à calçada à direita, considerando o sentido de transposição da avenida Salim Farah Maluf em direção ao bairro do Água Rasa, e o movimento P3 e P4 à calçada à esquerda, no sentido Vila Prudente.

1. Cálculo do fluxo unitário de pedestre na calçada

Largura total do passeio $-\mathrm{Wt}: 2,00 \mathrm{~m}$

Soma das larguras de obstruções - Wc: $0,30 \mathrm{~m}$

Largura efetiva da travessia: $\mathrm{We}=\mathrm{Wt}-\mathrm{Wc}=1,70 \mathrm{~m}$

Fluxo no pico de 15 minutos - V15:

Fluxo unitário de pedestre Vp: $\mathrm{Vp}=\frac{V 15}{15 \times W e}(\mathrm{p} / \mathrm{min} / \mathrm{m})$

Como a contagem em campo foi de 15 minutos, a fórmula se resume em $\mathrm{Vp}=\frac{V 15}{W e}$

Movimento P1 - P2

Pico da Manhã: 103 pedestres entre as 7:00 às 7:15 h 
Pico da Tarde: 91 pedestres entre 17:00 às 17:15 h

Para o pico da manhã $\mathrm{Vp}=\frac{103}{1,70}=60,60(\mathrm{p} / \mathrm{min} / \mathrm{m})$

Consultando a tabela IV-8 Critérios de NS para Fluxos Médios em Passeios e

Calçadas, para este fluxo unitário, o NS correspondente é E.

Para o pico da tarde $\mathrm{Vp}=\frac{91}{1,70}=53,50(\mathrm{p} / \mathrm{min} / \mathrm{m})$

Consultando a tabela IV-8 Critérios de NS para Fluxos Médios em Passeios e

Calçadas, para este fluxo unitário, o NS correspondente é E.

Movimento P3 - P4

Pico da Manhã: 25 pedestres entre as 7:00 às 7:15 h

Pico da Tarde: 71 pedestres entre 17:00 às 17:15 h

Para o pico da manhã $\mathrm{Vp}=\frac{25}{1,70}=14,70(\mathrm{p} / \mathrm{min} / \mathrm{m})$

Consultando a tabela IV-8 Critérios de NS para Fluxos Médios em Passeios e

Calçadas, para este fluxo unitário, o NS correspondente é A.

Para o pico da tarde $\mathrm{Vp}=\frac{71}{1,70}=41,70(\mathrm{p} / \mathrm{min} / \mathrm{m})$

Consultando a tabela IV-8 Critérios de NS para Fluxos Médios em Passeios e

Calçadas, para este fluxo unitário, o NS correspondente é D.

2. Análise do Nível de Serviço calculado.

A calçada com o movimento P1 e P2 está com nível de serviço crítico(nível E), Nos dois picos do dia. A calçada com o movimento P3 e P4, calçada à esquerda no sentido de direção à Vila Prudente (rua do Orfanato), no horário de pico apresenta-se razoável com nível A no período da manhã e D no período da tarde.

Provavelmente a causa da preferência da calçada da direita seja porque esta não tem a obstrução representada pelos postes de iluminação na sua cabeceira, o que acontece com a calçada esquerda. 


\subsubsection{BAIRRO DO CARRÃO}

\section{Ponte Aricanduva}

Esta ponte transpõe o rio Tietê e faz a ligação entre os bairros de Carrão, Penha e Vila Maria. Na Vila Maria está localizado próximo do Hospital Municipal. Há residências e conjuntos habitacionais, comércios e locais de atividades recreativas (Clube do Corinthians, Clube Desportivo da Penha, etc). Devido a sua extensão e pelo trânsito intenso de veículos, esta ponte tem uma característica interessante: o retorno para pedestres. Nas cabeceiras da ponte há acesso para pedestre que contorna a ponte, por baixo, e interliga à outra direção da via. Porém este acesso não está em boas condições de uso, sendo inseguro em dias de chuva e à noite. Figuras V-40, V-41, V-42, V-43, V44 e V-45. Debaixo da ponte há um ponto de ônibus, mas não é iluminado, o que torna insegura a sua utilização à noite. As lotações costumam parar na alça de acesso, logo no término do retorno do pedestre (conforme ilustração abaixo). A ponte é iluminada, mas como o foco da iluminação é a via, a calçada permanece na zona de penumbra. Este fato foi motivo das reclamações dos pedestres usuários desta instalação, "a travessia é escura à noite". 


\section{Figura V-40.Ponte Aricanduva} Vista panorâmica

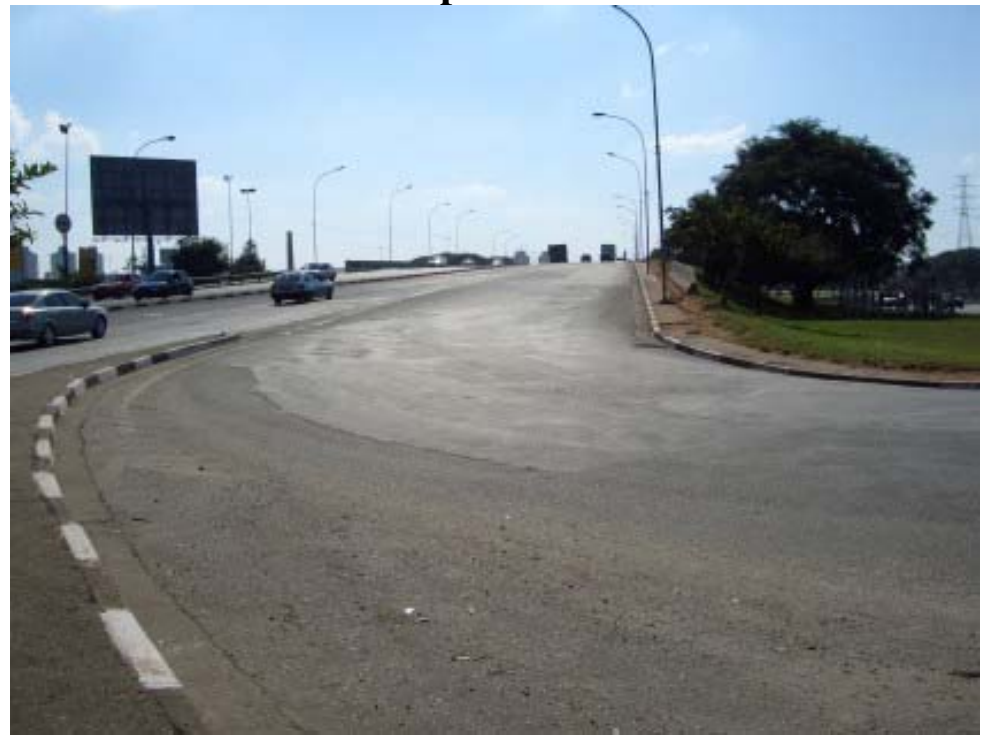

Fonte: Arquivo da autora

Ponte Aricanduva, no sentido Penha/ Vila Maria. Há tratamento paisagístico na alça de acesso, porém sem conservação ou manutenção. A calçada no contorno da alça está em mau estado. Não há separação de trânsito viário e de pedestre, a menos de um pequeno trecho, na cabeceira, no sentido Vila Maria/Penha, que não está representado nesta foto, mas numa outra mais adiante. Há iluminação voltada para a via.

\section{Figura V-41. Ponte Aricanduva \\ Detalhe da calçada}




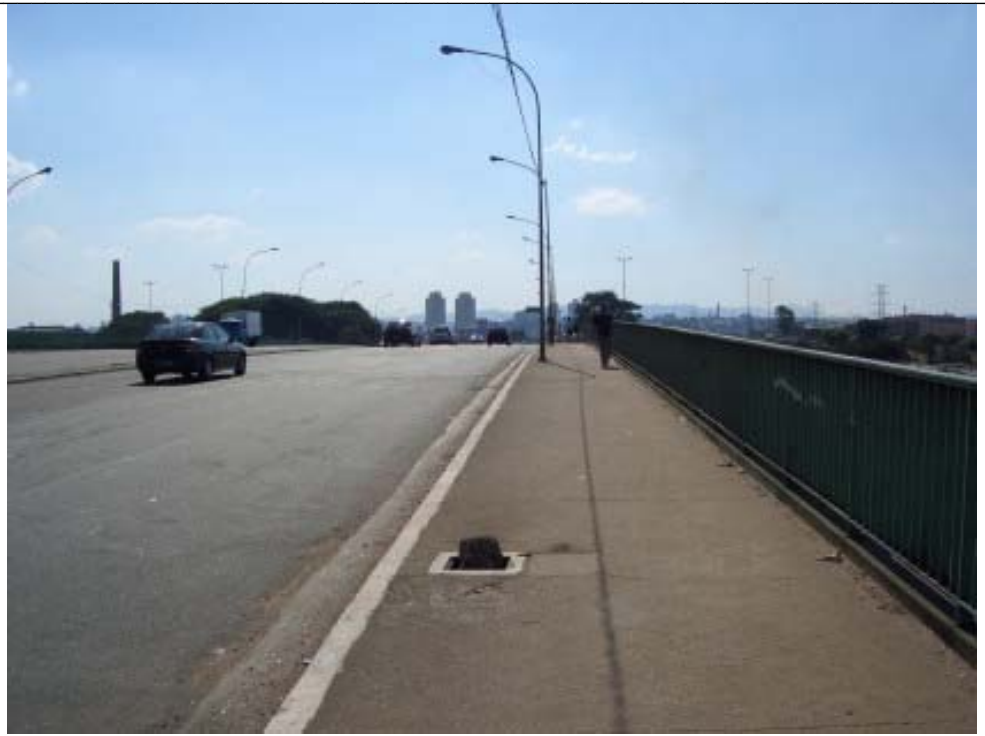

Fonte: Arquivo da autora

Observar a iluminação de boa qualidade (lâmpada de mercúrio, luz branca), mas muito alto, projetando sombras na calçada, à noite. Não há barreira separando o tráfego viário do pedestre, o que é inseguro para o pedestre. Há pequenos obstáculos na calçada por conta de instalações mal acabadas, como apresentado no primeiro plano.

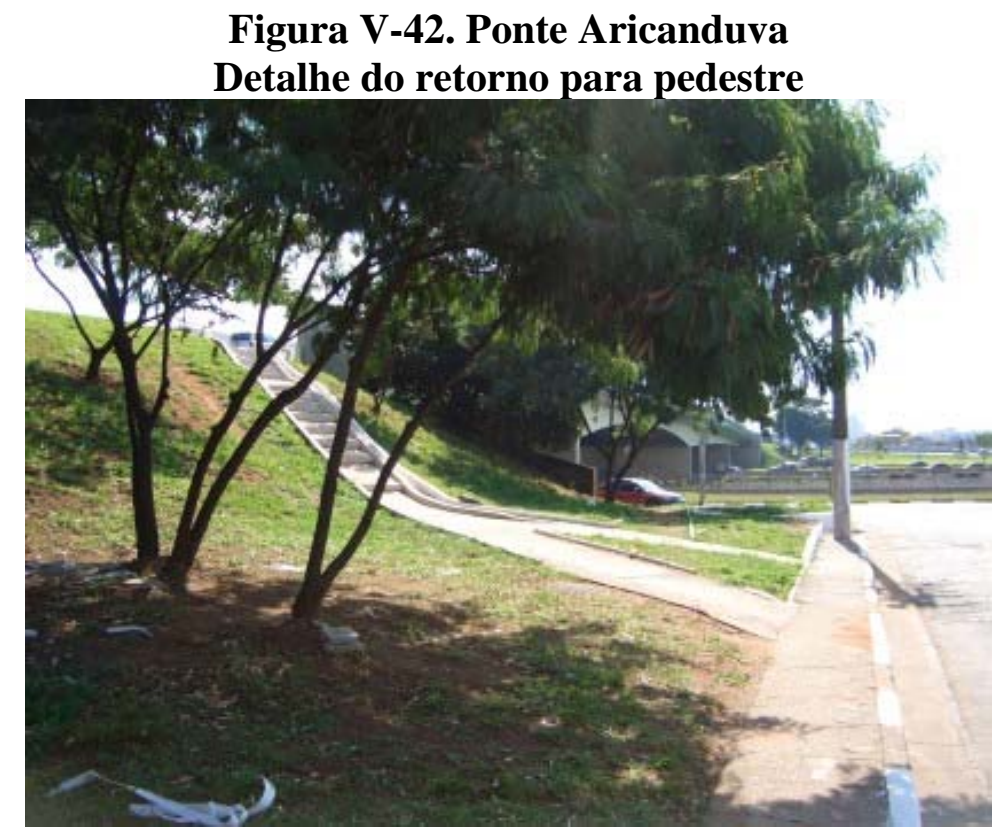

Fonte: Arquivo da autora

Observar a escadaria no meio do canteiro da alça de acesso. Trata-se do retorno do pedestre, isto é, a possibilidade de fazer o movimento de retorno à ponte, para o outro lado da via, sem cruzar o trânsito (movimento quase impossível e altamente perigoso). Após a escadaria observa-se um caminho em direção ao baixio da ponte, que irá contorná-lo, ligando-o a outra escadaria de acesso, no outro lado da ponte, mas na mesma cabeceira. Ao fim da escadaria é que os veículos de lotação costumam parar, pois debaixo da ponte é totalmente inviável, devido à falta de iluminação e segurança. Os ônibus de linha, no entanto, são obrigados a pararem debaixo da ponte, onde há um ponto regulamentado. 
Figura V-43.Ponte Aricanduva

Outro ângulo do detalhe do retorno para pedestre

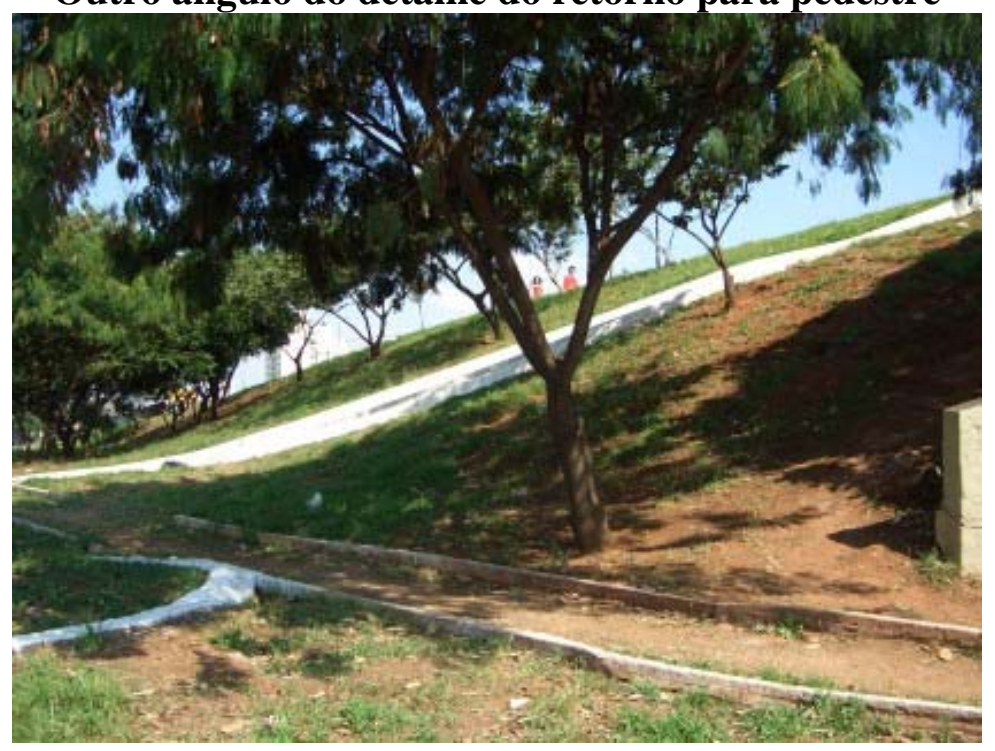

Fonte: Arquivo da autora

Em primeiro plano observa-se o caminho para retornar à ponte, após a descida da escadaria. $\mathrm{O}$ estado deste caminho é em terra solta, com alguns pedregulhos. Totalmente inundável em dias de chuva. Observar que não há iluminação neste local.

Figura V-44.Ponte Aricanduva Detalhe da travessia no sentido bairro-cidade

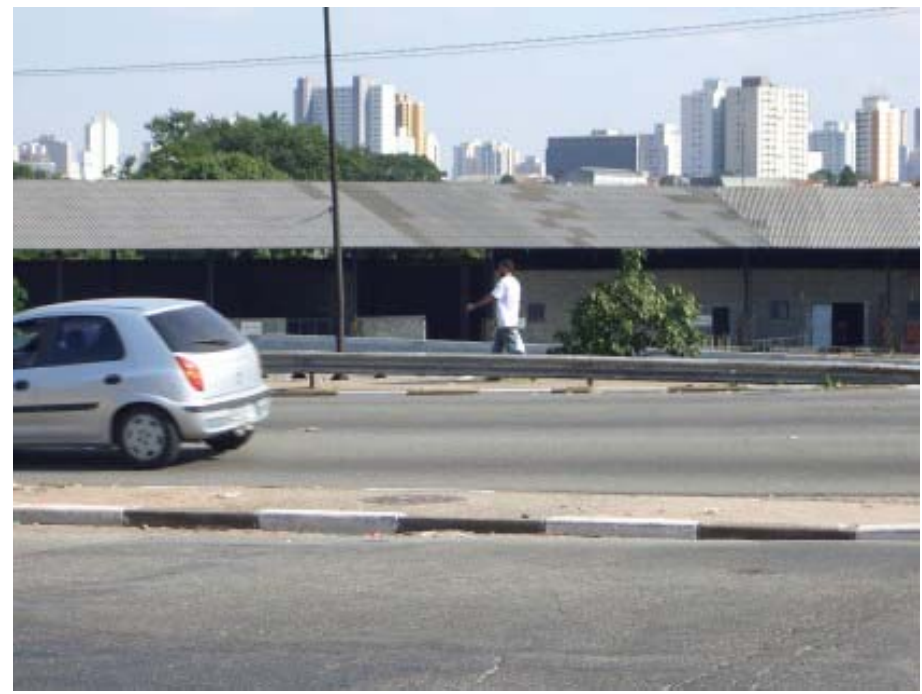

Fonte: Arquivo da autora

O pedestre do outro lado da via está próximo do acesso ao retorno do pedestre. Neste sentido (Vila Maria/Penha) na cabeceira da ponte foi colocado guard-rail, isto é, pequena barreira metálica, servindo de proteção ao pedestre. Do lado da ponte, sentido Penha/Vila Maria não há essa proteção, como pode ser visto na foto com vista panorâmica.

\section{Cálculo dos Níveis de Serviço}

Figura V-45. Esquema da travessia na ponte Aricanduva 


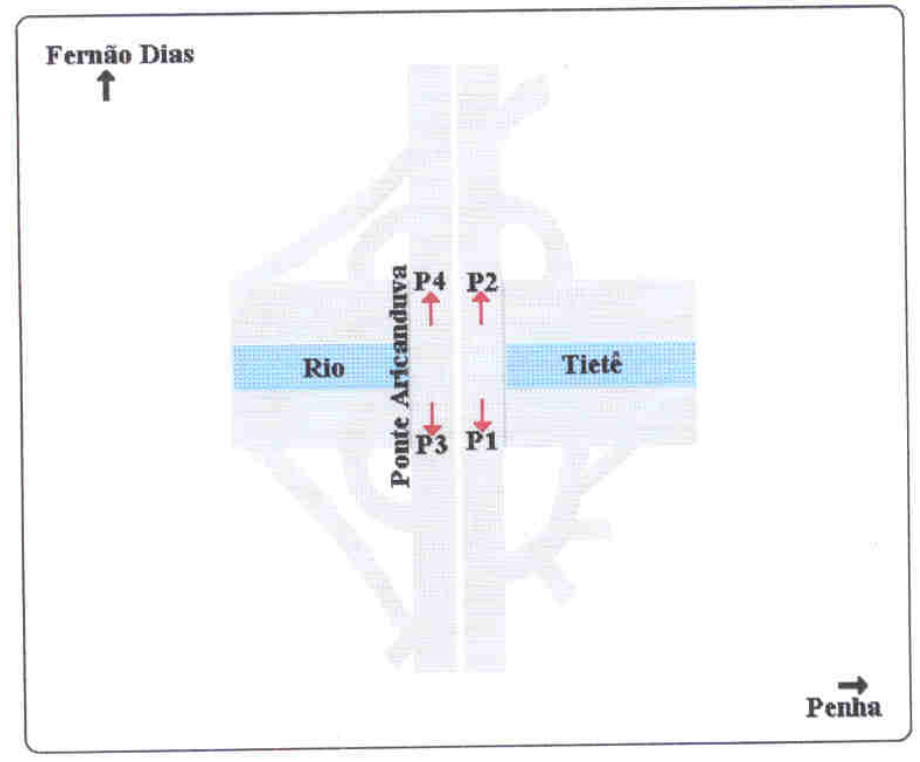

Fonte: CET. "Pesquisa de Trânsito". [CET(2005)].

Esta instalação será avaliada pelo fluxo unitário de pedestre, transitando nas calçadas da ponte. $\mathrm{O}$ movimento $\mathrm{P} 1$ e $\mathrm{P} 2$ refere-se à calçada à direita, considerando a transposição do rio Tietê na direção da rodovia Fernão Dias, e o movimento P3 e P4 refere-se à calçada da esquerda.

1. Cálculo do fluxo unitário de pedestre na calçada

Largura total do passeio - Wt : 2,80 m

Soma das larguras de obstruções - Wc: $0,50 \mathrm{~m}$

Largura efetiva da travessia: $\mathrm{We}=\mathrm{Wt}-\mathrm{Wc}=2,30 \mathrm{~m}$

Fluxo no pico de 15 minutos - V15:

Fluxo unitário de pedestre $\mathrm{Vp}: \mathrm{Vp}=\frac{V 15}{15 \times W e}(\mathrm{p} / \mathrm{min} / \mathrm{m})$

Como a contagem em campo foi de 15 minutos, a fórmula se resume em $\mathrm{Vp}=\frac{V 15}{W e}$

Movimento P1 - P2

Pico da Manhã: 45 pedestres entre as 6:45 às 7:00 h

Pico da Tarde: 86 pedestres entre 18:00 às 18:15 h

Para o pico da manhã $\mathrm{Vp}=\frac{45}{2,30}=19,56(\mathrm{p} / \mathrm{min} / \mathrm{m})$

Consultando a tabela IV-8 Critérios de NS para Fluxos Médios em Passeios e

Calçadas, para este fluxo unitário, o NS correspondente é B. 
Para o pico da tarde $\mathrm{Vp}=\frac{86}{2,30}=37,39(\mathrm{p} / \mathrm{min} / \mathrm{m})$

Consultando a tabela IV-8 Critérios de NS para Fluxos Médios em Passeios e

Calçadas, para este fluxo unitário, o NS correspondente é D.

Movimento P3 - P4

Pico da Manhã: 209 pedestres entre as 6:30 às 6:45 h

Pico da Tarde: 229 pedestres entre 17:30 às 17:45 h

Para o pico da manhã $\mathrm{Vp}=\frac{209}{2,30}=90,86(\mathrm{p} / \mathrm{min} / \mathrm{m})$

Consultando a tabela IV-8 Critérios de NS para Fluxos Médios em Passeios e

Calçadas, para este fluxo unitário, o NS correspondente é F.

Para o pico da tarde $\mathrm{Vp}=\frac{229}{2,30}=99,56(\mathrm{p} / \mathrm{min} / \mathrm{m})$

Consultando a tabela IV-8 Critérios de NS para Fluxos Médios em Passeios e

Calçadas, para este fluxo unitário, o NS correspondente é F.

2. Análise do Nível de Serviço calculado.

A calçada com o movimento P1 e P2 está oferecendo um nível de serviço razoável (nível $\mathrm{B}$ e D), porém a calçada com o movimento P3 e P4, calçada à esquerda na direção rodovia Fernão Dias está crítica, nos dois períodos de pico, manhã e tarde, nível F. Os pedestres mais ligeiros podem ultrapassar os mais vagarosos contornando-os pela via, levando-os a assumirem um comportamento não muito seguro. Nestas circunstâncias esta instalação deve ter tratamento específico para sanar esta distorção.

\section{Cruzamento das ruas Cantagalo com Gonçalo Nunes}

Este cruzamento está a uma quadra da avenida Conselheiro Carrão, importante eixo da Vila Carrão. Nos arredores há colégio de grande porte, um Hipermercado, no cruzamento, comércio de rua, em geral, e residências. A sinalização horizontal (pintura 
de faixa para pedestre) está muito desgastada, não sendo visível em dia de chuva intensa. Há profusão de postes nas esquinas (cerca de três a quatro por esquina).

Devido a proximidade com a avenida Conselheiro Carrão este cruzamento recebe o reflexo do seu congestionamento, o que repercute na travessia de pedestres. Sendo um local de grande afluência de pedestres, a travessia fica comprometida com o excesso de veículos, desrespeitando a velocidade e a sinalização. Figuras V-46, V-47 e V-48.

Figura V-46. Cruzamento das ruas Cantagalo com Gonçalo Nunes Vista panorâmica 


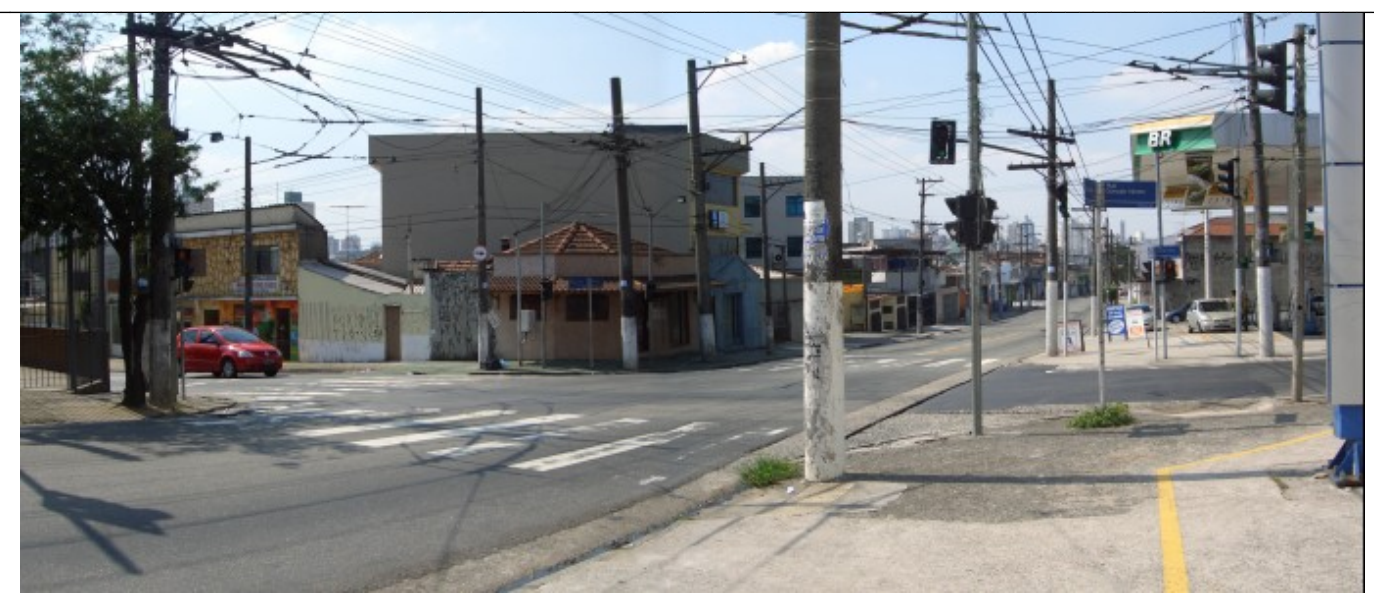

Fonte: Arquivo da autora

Figura V-47. Cruzamento das ruas Cantagalo com Gonçalo Nunes

\section{Detalhe}

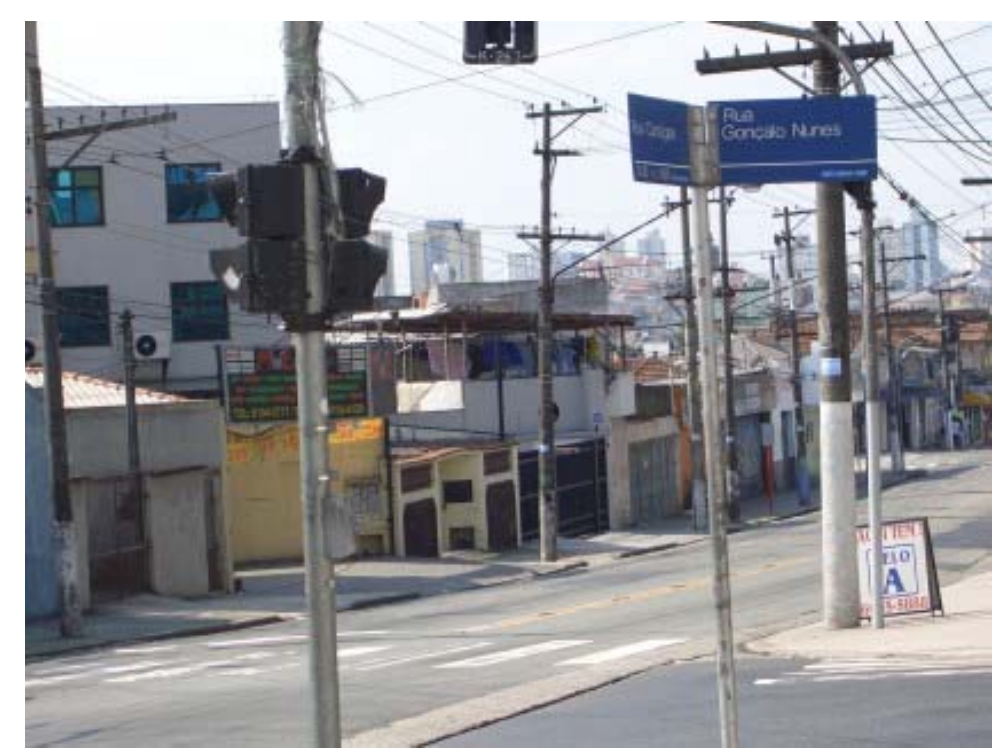

Fonte: Arquivo da autora

\section{Cálculo dos Níveis de Serviço}

Figura V-48. Esquema das travessias no cruzamento entre as ruas Cantagalo e Gonçalo Nunes 


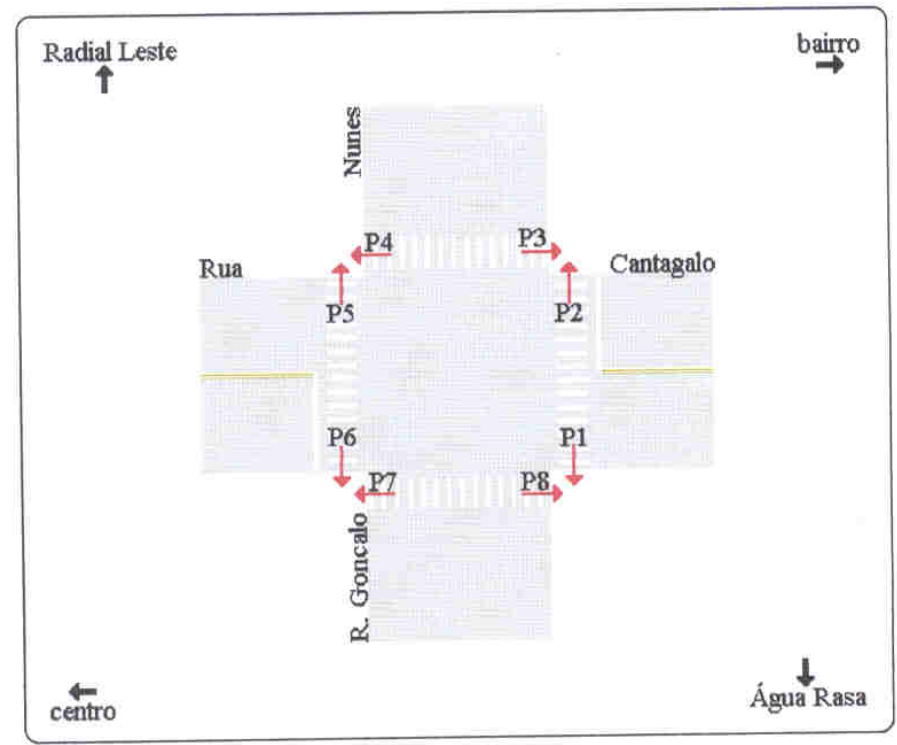

Fonte: CET. "Pesquisa de Trânsito". [CET(2005)].

Os movimentos $\mathrm{P} 1$ e $\mathrm{P} 2$ referem-se à travessia na rua Cantagalo, no vértice direcionado ao bairro. Os movimentos P5 e P6 representam a travessia na mesma rua, mas na direção centro da cidade. Os movimentos $\mathrm{P} 3$ e P4 referem-se à travessia na rua Gonçalo Nunes na direção à avenida Radial Leste, e os movimentos P7 e P8, na mesma rua na direção do bairro Água Rasa.

1. Cálculo de tempo de espera do Pedestre na Interseção Sinalizada - Dp

Tempo de ciclo-C: $60 \mathrm{~s}$

Tempo Efetivo de verde para pedestre-g: $30 \mathrm{~s}$

Os tempos de ciclo e de verde são igualmente divididos nas quatro ruas.

$\mathrm{Dp}=\frac{0,5(C-g) 2}{C}$

$\mathrm{Dp}=\frac{0,5(60-30) 2}{60}=7,5 \mathrm{~s}$

Consultando a tabela IV-14 - NS para pedestres em interseções sinalizadas, para este tempo de espera o NS correspondente A, com Baixa Probabilidade à Desobediência.

2. Cálculo do fluxo unitário de pedestre na calçada

Travessias na rua Cantagalo 
Largura total da calçada - Wt : 3,00 m

Soma das larguras de obstruções - Wc: Não foram consideradas as obstruções localizadas na calçada, por não interferirem na fluidez da caminhada.

Largura efetiva da calçada: $\mathrm{We}=\mathrm{Wt}-\mathrm{Wc}=3,00 \mathrm{~m}$

\section{Movimentos P1 e P2}

Fluxo no pico de 15 minutos - V15:

Fluxo unitário de pedestre $\mathrm{Vp}: \mathrm{Vp}=\frac{V 15}{15 \times W e}(\mathrm{p} / \mathrm{min} / \mathrm{m})$

Como a contagem em campo foi de 15 minutos, a fórmula se resume em $\mathrm{Vp}=\frac{V 15}{W e}$

Fluxo no pico de 15 minutos - V15:

Pico da Manhã: 30 pedestres entre as 6:30 às 6:45 h

Pico da Tarde: 47 pedestres entre 17:00 às 17:15 h

Para o pico da manhã $\mathrm{Vp}=\frac{30}{3,00}=10,00(\mathrm{p} / \mathrm{min} / \mathrm{m})$

Consultando a tabela IV-8 Critérios de NS para Fluxos Médios em Passeios e

Calçadas, para este fluxo unitário, o NS correspondente é A.

Para o pico da tarde $\mathrm{Vp}=\frac{47}{3,00}=15,66(\mathrm{p} / \mathrm{min} / \mathrm{m})$

Consultando a tabela IV-8 Critérios de NS para Fluxos Médios em Passeios e

Calçadas, para este fluxo unitário, o NS correspondente é A.

\section{Movimentos P5 e P6}

Fluxo no pico de 15 minutos - V15:

Pico da Manhã: 34 pedestres entre as 7:15 às 7:30 h

Pico da Tarde: 63 pedestres entre 18:00 às 18:15 h

Para o pico da manhã $\mathrm{Vp}=\frac{34}{3,00}=11,33(\mathrm{p} / \mathrm{min} / \mathrm{m})$

Consultando a tabela IV-8 Critérios de NS para Fluxos Médios em Passeios e

Calçadas, para este fluxo unitário, o NS correspondente é A.

Para o pico da tarde $\mathrm{Vp}=\frac{63}{3,00}=21,00(\mathrm{p} / \mathrm{min} / \mathrm{m})$

Consultando a tabela IV-8 Critérios de NS para Fluxos Médios em Passeios e

Calçadas, para este fluxo unitário, o NS correspondente é $\mathbf{B}$. 


\section{Travessia na rua Gonçalo Nunes}

Largura total da calçada $-\mathrm{Wt}: 3,00 \mathrm{~m}$

Soma das larguras de obstruções - Wc: Não foram consideradas as obstruções localizadas na calçada, por não interferirem na fluidez da caminhada.

Largura efetiva da calçada: $\mathrm{We}=\mathrm{Wt}-\mathrm{Wc}=3,00 \mathrm{~m}$

\section{Movimentos P3 e P4}

Fluxo no pico de 15 minutos - V15:

Pico da Manhã: 57 pedestres entre as 7:30 às 7:45 h

Pico da Tarde: 48 pedestres entre 17:45 às 18:00 h

Para o pico da manhã $\mathrm{Vp}=\frac{57}{3,00}=19,00(\mathrm{p} / \mathrm{min} / \mathrm{m})$

Consultando a tabela IV-8 Critérios de NS para Fluxos Médios em Passeios e

Calçadas, para este fluxo unitário, o NS correspondente é B.

Para o pico da tarde $\mathrm{Vp}=\frac{48}{3,00}=16,00(\mathrm{p} / \mathrm{min} / \mathrm{m})$

Consultando a tabela IV-8 Critérios de NS para Fluxos Médios em Passeios e

Calçadas, para este fluxo unitário, o NS correspondente é A.

\section{Movimentos P7 e P8}

Fluxo no pico de 15 minutos - V15:

Pico da Manhã: 35 pedestres entre as 6:45 às 7:00 h

Pico da Tarde: 44 pedestres entre 17:00 às 17:15 h

Para o pico da manhã $\mathrm{Vp}=\frac{35}{3,00}=11,66(\mathrm{p} / \mathrm{min} / \mathrm{m})$

Consultando a tabela IV-8 Critérios de NS para Fluxos Médios em Passeios e

Calçadas, para este fluxo unitário, o NS correspondente é A.

Para o pico da tarde $\mathrm{Vp}=\frac{44}{3,00}=14,66(\mathrm{p} / \mathrm{min} / \mathrm{m})$

Consultando a tabela IV-8 Critérios de NS para Fluxos Médios em Passeios e

Calçadas, para este fluxo unitário, o NS correspondente é A.

3. Análise do Nível de Serviço calculado. 
Neste cruzamento têm-se duas ruas de igual importância operacional em confluência.

Quanto à travessia de pedestres este cruzamento está operando em ótimas condições, com nível de serviço A em tempo de espera do pedestre, caracterizando baixa probabilidade de desobediência à sinalização; níveis $\mathrm{A}$ e $\mathrm{B}$ no fluxo de pedestre na calçada.

O problema maior deste cruzamento é a operação da via. Os veículos desenvolvem alta velocidade provocando acidentes, notadamente, atropelamentos. É recomendável um controle maior da velocidade. As observações de campo são importantes para refinar os cálculos teóricos.

\section{Travessia da avenida João XXIII, próximo a r. Monsenhor Antônio Castro}

Esta avenida contorna o Cemitério Municipal da Vila Formosa. Do lado oposto ao cemitério, há residências, comércios, posto de combustíveis, consultórios, revendedoras de veículos, etc. A rua Monsenhor Antônio Castro termina na avenida João XXIII. A travessia da avenida João XXIII é a que apresenta dificuldades para o pedestre.

A travessia da rua Monsenhor Antônio Castro (à direita da foto) não apresenta problemas para os pedestres, por ser uma travessia tipo "carona", isto é, quando o semáforo está fechado para o trânsito de veículos nesta rua o pedestre pode atravessá-lo sem dificuldade.

A travessia da avenida João XXIII apresenta problemas para os pedestres pois caracteriza três tempos para os pedestres, isto é, mesmo que o semáforo esteja fechado na avenida João XXIII, os pedestres não podem atravessar, pois é aberto para o trânsito dos veículos vindos da rua Monsenhor Antônio Castro. O desconhecimento destes movimentos aliados a demora na abertura de semáforo para pedestres são fatores de riscos para a travessia dos pedestres. Figuras V-49, V-50, V-51 e V-52. 
A avenida João XXIII é uma importante via onde trafegam ônibus, caminhões e automóveis. Por não haver cruzamentos, pois de um lado há a extensão do cemitério, à noite é comum aos veículos o desrespeito à sinalização semafórica.

Figura V-49. Travessia na av. João XXIII Vista panorâmica

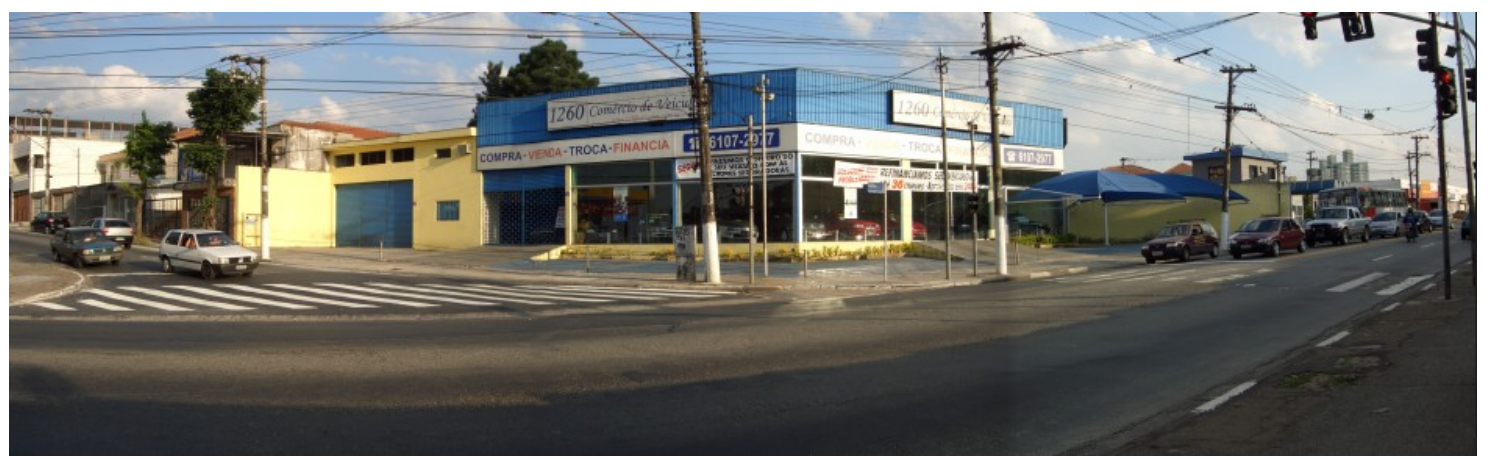

Fonte: Arquivo da autora

Vista a partir da calçada do Cemitério Municipal de Vila Formosa. À direita da foto vemos a travessia em questão. À esquerda a travessia da rua Monsenhor Antônio Castro.

\section{Figura V-50. Travessia na av. João XXIII Detalhe da travessia}

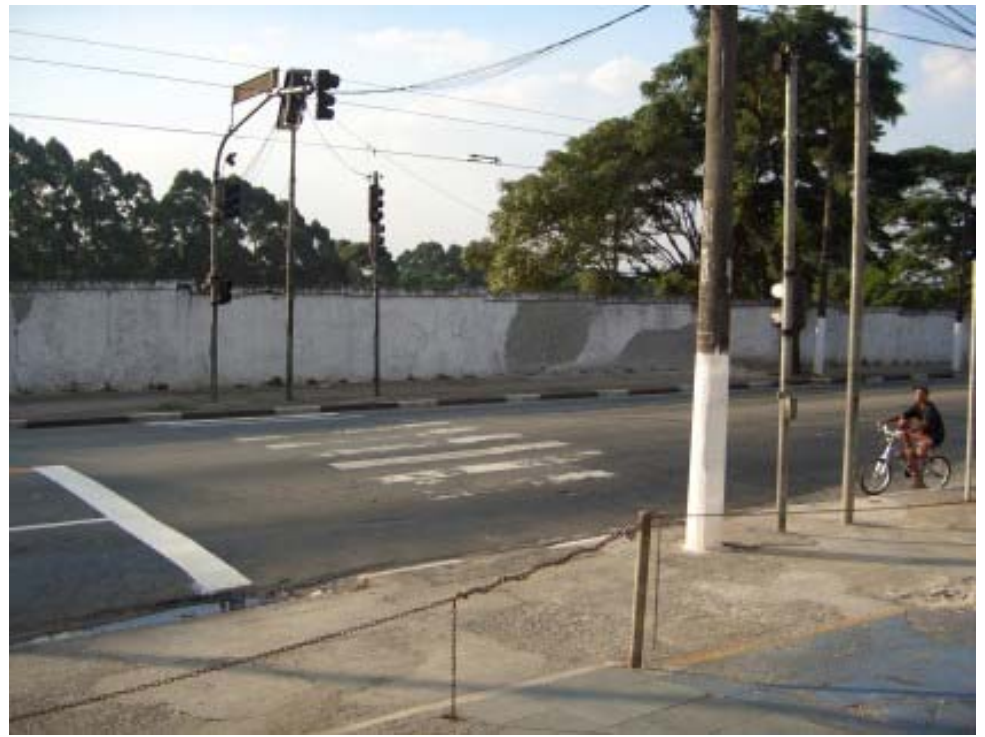

Fonte: Arquivo da autora

Pintura da faixa de pedestres em mau estado. Em dias de chuva estes se tornam invisíveis. Falta uma sinalização mais adequada ao pedestre, esclarecendo os tempos de espera ao pedestre. 


\section{Figura V-51. Travessia na av. João XXIII} Outro ângulo

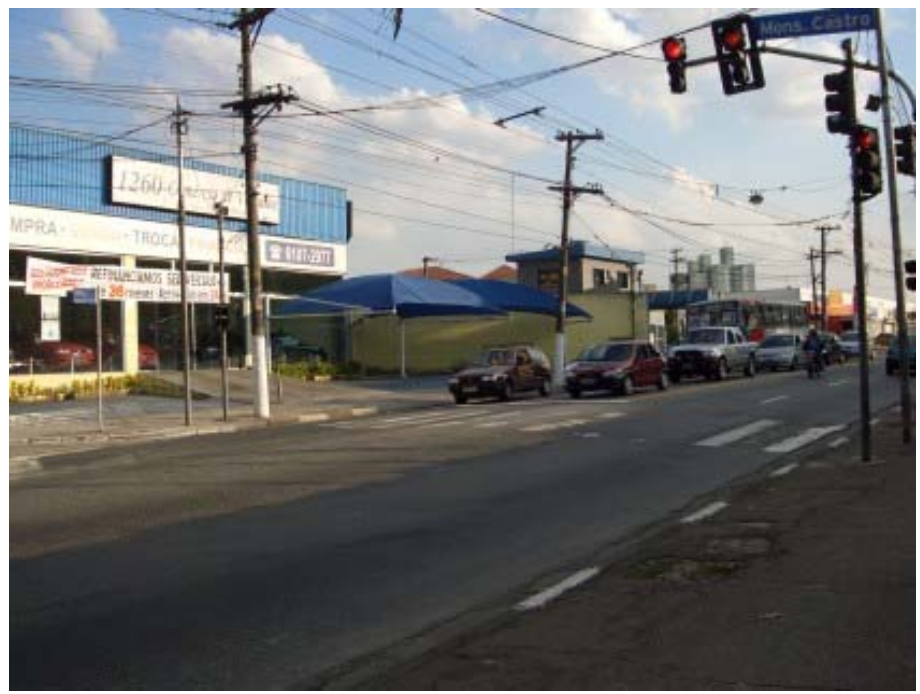

Fonte: Arquivo da autora

Na avenida João XXIII trafegam ônibus, caminhões e automóveis.

\section{Cálculo dos Níveis de Serviço}

Figura V-52. Esquema de travessia na av. João XXIII

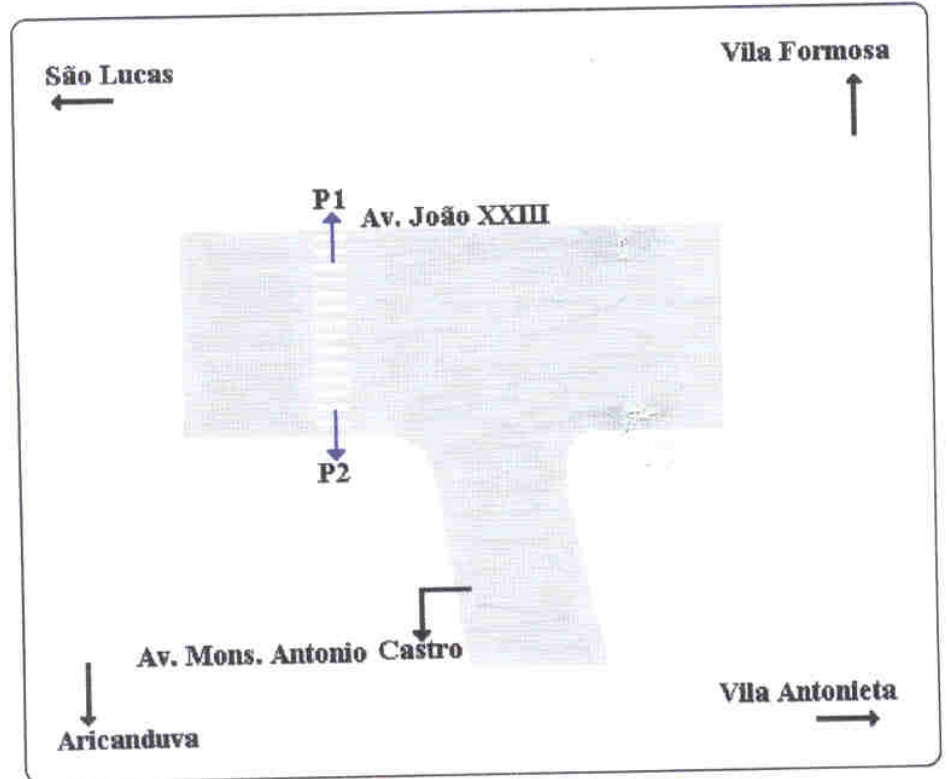

Fonte: CET. "Pesquisa de Trânsito". [CET(2005)]. 
1. Cálculo de tempo de espera do Pedestre na Interseção Sinalizada - Dp

Tempo de ciclo-C: $120 \mathrm{~s}$

Tempo Efetivo de verde para pedestre-g: $30 \mathrm{~s}$

$\mathrm{Dp}=\frac{0,5(C-g) 2}{C}$

$\mathrm{Dp}=\frac{0,5(120-30) 2}{120}=67,50 \mathrm{~s}$

Consultando a tabela IV-14 - NS para pedestres em interseções sinalizadas, para este tempo de espera o NS correspondente F, com Probabilidade de Desobediência Muito Alto.

2. Cálculo do fluxo unitário de pedestre na calçada

Largura total do passeio $-\mathrm{Wt}: 2,50 \mathrm{~m}$

Soma das larguras de obstruções - Wc: $0,50 \mathrm{~m}$

Largura efetiva da travessia: $\mathrm{We}=\mathrm{Wt}-\mathrm{Wc}=2,50-0,50 \mathrm{~m}$

Fluxo no pico de 15 minutos - V15:

Pico da Manhã: 71 pedestres entre as 6:45 às 7:00 h

Pico da Tarde: 48 pedestres entre 17:45 às 18:00h

Fluxo unitário de pedestre $\mathrm{Vp}: \mathrm{Vp}=\frac{V 15}{15 \times W e}(\mathrm{p} / \mathrm{min} / \mathrm{m})$

Como a contagem em campo foi de 15 minutos, a fórmula se resume em $\mathrm{Vp}=\frac{V 15}{W e}$

Para o pico da manhã $\mathrm{Vp}=\frac{71}{2,0}=35,5(\mathrm{p} / \mathrm{min} / \mathrm{m})$

Consultando a tabela IV-8 Critérios de NS para Fluxos Médios em Passeios e

Calçadas, para este fluxo unitário, o NS correspondente é D.

Para o pico da tarde $\mathrm{Vp}=\frac{48}{2,0}=24(\mathrm{p} / \mathrm{min} / \mathrm{m})$

Consultando a tabela IV-8 Critérios de NS para Fluxos Médios em Passeios e

Calçadas, para este fluxo unitário, o NS correspondente é C. 


\section{Análise do Nível de Serviço calculado.}

O tempo de espera do pedestre para atravessar a avenida é muito demorado e o pedestre pode assumir riscos com a desobediência à sinalização. Apesar de não haver alta concentração de pedestres nas calçadas (Nível de Serviço C e D), o tempo de espera é muito longa. Trata-se de um semáforo de três fases, o que corresponde a um ciclo semafórico muito amplo, mas desfavorável ao pedestre.

\subsubsection{BAIRRO DA VILA ESPERANÇA}

\section{Travessia no cruzamento das ruas Amador Bueno da Veiga e Maria Carlota}

A rua Amador Bueno da Veiga é um dos principais eixos da Vila Esperança e Penha. É uma rua antiga e estreita para suportar o volume de trânsito existente. A rua Maria Carlota termina na rua Amador Bueno da Veiga e é uma rua com grande declividade (a rua Amador Bueno da Veiga estende-se num espigão), e é um eixo para descer até a avenida Conde de Frontin (também conhecido como Radial Leste), serve de acesso à estação Vila Matilde de Metrô e é acesso ao centro da cidade, alternativa à rua Amador Bueno da Veiga. Figuras V-53, V-54 e V-55.

As travessias são duas, uma na rua Maria Carlota, outra na Amador Bueno da Veiga, próxima à rua Pico do Papagaio. Não há travessia na rua Amador Bueno da Veiga no lado oposto à travessia legalizada. Tanto a rua Amador Bueno da Veiga quanto a rua Maria Carlota permitem trânsito nos dois sentidos de direção. O semáforo é de três tempos, isto é, mesmo quando o semáforo está fechado para o fluxo centro/bairro na rua Amador Bueno da Veiga, ele está aberto para o sentido bairro/centro, não permitindo a travessia de pedestres na rua Amador Bueno da Veiga. A travessia na rua Maria Carlota só é possível quando está aberto o trânsito na rua Amador Bueno da Veiga, mas sempre há o perigo de veículos desta via, no sentido centro/bairro, entrar na rua Maria Carlota. 
No outro sentido os veículos devem esperar a terceira fase. Portanto a travessia dos pedestres está comprometida.

A região é residencial e há grande expansão de condomínios verticais. Os grandes lotes residenciais antigos estão sendo adquiridos por incorporadoras que estão verticalizando a área. A rua Amador Bueno da Veiga é uma rua comercial, com grande oferta de lojas de serviços, bancos, etc.

Os pedestres na maioria são moradores que circulam para fazer compras, ir aos consultórios médicos, cabeleireiros, etc. Unanimamente reclamam desta travessia e a da rua Izabel, que é paralela à Maria Carlota.

Figura V-53. Travessia no cruzamento das ruas Amador Bueno da Veiga e Maria Carlota

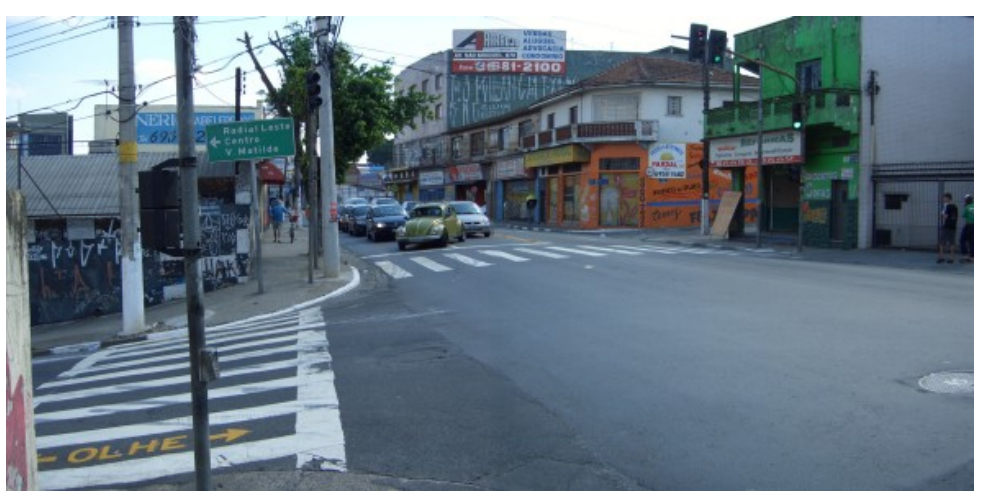

Fonte: Arquivo da autora

A rua Maria Carlota é a rua em declive observada à esquerda da foto. A rua Amador Bueno da Veiga é a rua que ocupa a parte central da foto. Observar as duas travessias em questão.

\section{Figura V-54.Travessia no cruzamento das ruas Amador Bueno da Veiga e Maria Carlota. Outro ângulo}




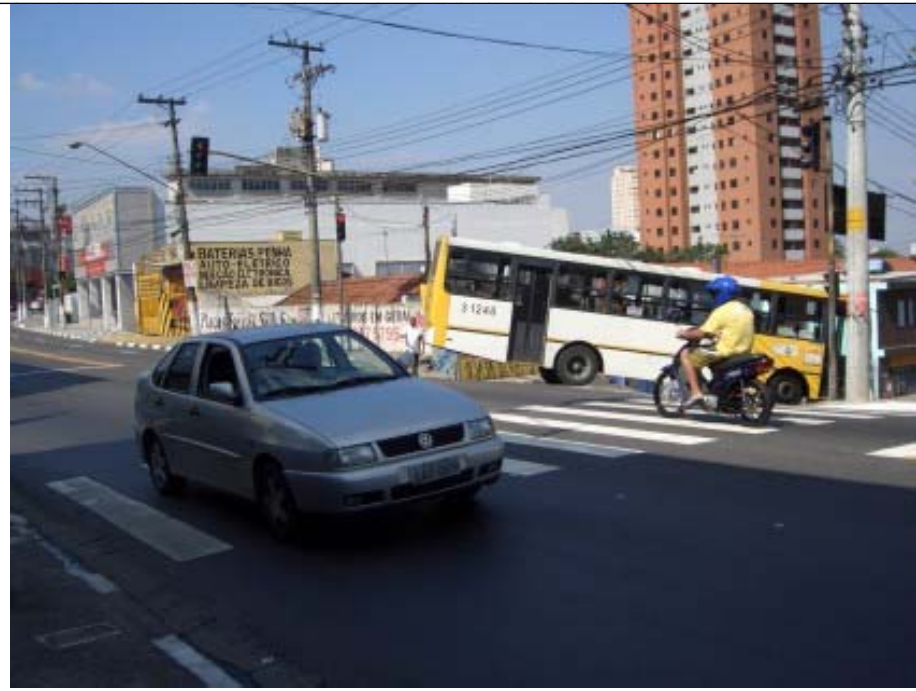

Fonte: Arquivo da autora

Observar o ônibus entrando na rua Maria Carlota e um veículo prosseguindo na rua Amador Bueno da Veiga no sentido bairro/centro. Neste momento o pedestre não pode fazer a travessia na rua Amador Bueno da Veiga, aliás observar que um motociclista está parado na faixa de pedestre.

\section{Cálculo dos Níveis de Serviço}

\section{Figura V-55. Esquema de travessia das ruas Amador Bueno da Veiga e} Maria Carlota

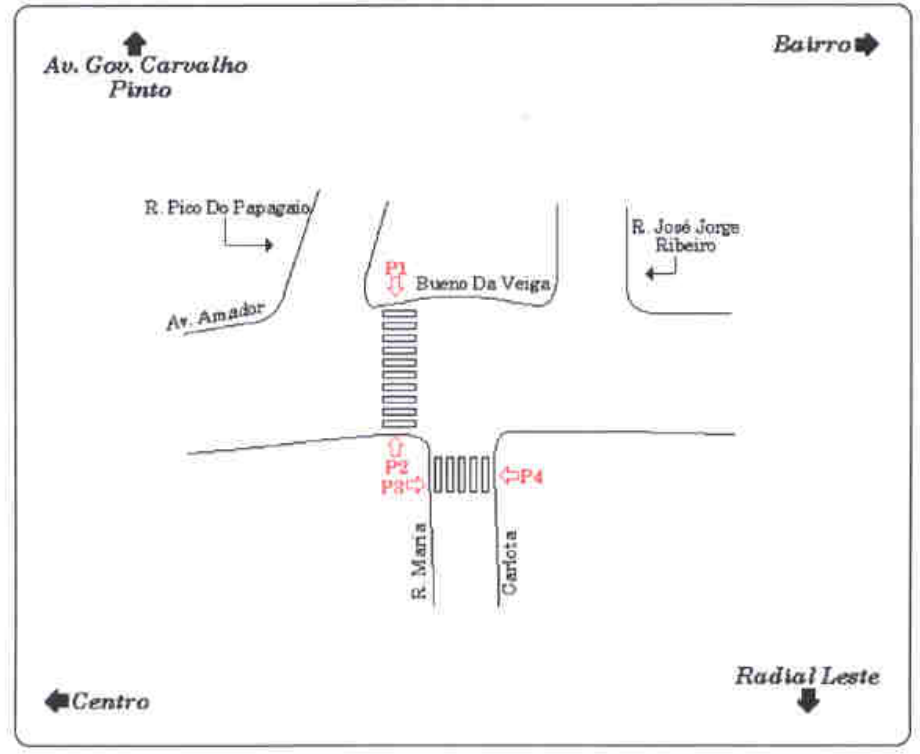

Fonte: CET. "Pesquisa de Trânsito". [CET(2005)].

Neste cruzamento a rua Amador Bueno da Veiga apresenta apenas uma travessia, representado pelos movimentos P1 e P2. A travessia da rua Maria Carlota é 
representado pelos movimentos P3 e P4. A operação semafórica é de três tempos, para a possibilitar a conversão da rua Amador Bueno da Veiga, direção bairro-centro à rua Maria Carlota (sentido Radial Leste).

\section{Travessia Amador Bueno da Veiga (movimentos P1 e P2)}

1. Cálculo de tempo de espera do Pedestre na Interseção Sinalizada - Dp

Tempo de ciclo-C: $100 \mathrm{~s}$

Tempo Efetivo de verde para pedestre-g: $30 \mathrm{~s}$

$$
\begin{aligned}
& \mathrm{Dp}=\frac{0,5(C-g) 2}{C} \\
& \mathrm{Dp}=\frac{0,5(100-30) 2}{100}=24,50 \mathrm{~s}
\end{aligned}
$$

Consultando a tabela IV-14 - NS para pedestres em interseções sinalizadas, para este tempo de espera o NS correspondente C, com Probabilidade Moderada de

\section{Desobediência.}

2. Cálculo do fluxo unitário de pedestre na calçada Largura total da calçada $-\mathrm{Wt}: 3,00 \mathrm{~m}$

Soma das larguras de obstruções - Wc: Não foram consideradas as obstruções localizadas na calçada, por não interferirem na fluidez da caminhada.

Largura efetiva da calçada: $\mathrm{We}=\mathrm{Wt}-\mathrm{Wc}=3,00 \mathrm{~m}$

Fluxo no pico de 15 minutos - V15:

Fluxo unitário de pedestre $\mathrm{Vp}: \mathrm{Vp}=\frac{V 15}{15 \times W e}(\mathrm{p} / \mathrm{min} / \mathrm{m})$

Como a contagem em campo foi de 15 minutos, a fórmula se resume em $\mathrm{Vp}=\frac{V 15}{W e}$

Fluxo no pico de 15 minutos - V15:

Pico da Manhã: 94 pedestres entre 7:45 às 8:00 h

Pico da Tarde: 115 pedestres entre 17:00 às 17:15 h

Para o pico da manhã $\mathrm{Vp}=\frac{94}{3,00}=31,33(\mathrm{p} / \mathrm{min} / \mathrm{m})$

Consultando a tabela IV-8 Critérios de NS para Fluxos Médios em Passeios e

Calçadas, para este fluxo unitário, o NS correspondente é C. 
Para o pico da tarde $\mathrm{Vp}=\frac{115}{3,00}=38,33(\mathrm{p} / \mathrm{min} / \mathrm{m})$

Consultando a tabela IV-8 Critérios de NS para Fluxos Médios em Passeios e

Calçadas, para este fluxo unitário, o NS correspondente é D.

\section{Travessia da rua Maria Carlota (movimentos P3 e P4)}

1. Cálculo de tempo de espera do Pedestre na Interseção Sinalizada - Dp

Tempo de ciclo-C: $100 \mathrm{~s}$

Tempo Efetivo de verde para pedestre-g: $40 \mathrm{~s}$

$$
\begin{aligned}
& \mathrm{Dp}=\frac{0,5(C-g) 2}{C} \\
& \mathrm{Dp}=\frac{0,5(100-40) 2}{100}=18,00 \mathrm{~s}
\end{aligned}
$$

Consultando a tabela IV-14 - NS para pedestres em interseções sinalizadas, para este tempo de espera o NS correspondente $\mathbf{B}$, com Probabilidade de Baixa à Moderada de

\section{Desobediência.}

2. Cálculo do fluxo unitário de pedestre na calçada

Largura total da calçada - Wt : 3,00 m

Soma das larguras de obstruções - Wc: Não foram consideradas as obstruções localizadas na calçada, por não interferirem na fluidez da caminhada.

Largura efetiva da calçada: $\mathrm{We}=\mathrm{Wt}-\mathrm{Wc}=3,00 \mathrm{~m}$

Fluxo no pico de 15 minutos - V15:

Pico da Manhã: 108 pedestres entre 7:00 às 7:15 h

Pico da Tarde: 189 pedestres entre 16:30 às 16:45 h

Para o pico da manhã $\mathrm{Vp}=\frac{108}{3,00}=36,00(\mathrm{p} / \mathrm{min} / \mathrm{m})$

Consultando a tabela IV-8 Critérios de NS para Fluxos Médios em Passeios e

Calçadas, para este fluxo unitário, o NS correspondente é D.

Para o pico da tarde $\mathrm{Vp}=\frac{189}{3,00}=63,00(\mathrm{p} / \mathrm{min} / \mathrm{m})$

Consultando a tabela IV-8 Critérios de NS para Fluxos Médios em Passeios e

Calçadas, para este fluxo unitário, o NS correspondente é E.

3. Análise do Nível de Serviço calculado. 
Neste cruzamento têm-se duas ruas de igual importância operacional em confluência.

Considerando o tempo de espera do pedestre, a avenida Amador Bueno da Veiga está operando com o nível C, indicando um serviço demorado; propiciando ao pedestre um risco moderado de desobediência às regras de trânsito. Na rua Maria Carlota o nível apresentado é B, considerado de risco entre baixo e moderado para haver contravenção às leis de trânsito, por parte dos pedestres. Em se tratando de fluxo de pedestres, nas calçadas da avenida Amador Bueno da Veiga o serviço é considerado próximo do crítico, níveis C e D. Na rua Maria Carlota a acumulação de pedestres é crítica atingindo os níveis D para o pico da manhã e E para o pico da tarde. O semáforo de três fases não favorece a travessia de pedestres, pois confunde os pedestres que, além de impaciente, não percebe que o sinal fechado para o trânsito em um sentido pode estar aberto para outro sentido. Uma sinalização mais adequada, mais educativa tanto para os pedestres como para os motoristas seria parte de uma solução. Dar um tempo específico só para o trânsito de pedestres, sem movimentação dos veículos, em ambas as vias, também seria uma outra forma de priorizar a travessia de pedestres.

\section{Travessias das ruas Amador Bueno da Veiga com Izabel / Samuel Jorge Ribeiro}

A rua Izabel é paralela a rua Maria Carlota. A sua importância no sistema viário é a mesma da rua Maria Carlota. As três travessias neste cruzamento estão situadas na rua Samuel Jorge Ribeiro, na rua Izabel e na rua Amador Bueno da Veiga, próximo à rua Samuel Jorge Ribeiro. A rua Izabel não permite a conversão dos veículos da rua Amador Bueno da Veiga, sentido bairro-centro, tendo sinalização e obstáculos impedindo este movimento. Figuras V-56, V-57, V-58, V-59, V-60 e V-61.

Figura V-56.Travessias das ruas Amador Bueno da Veiga, Izabel e Samuel Jorge Ribeiro. Vista panorâmica 


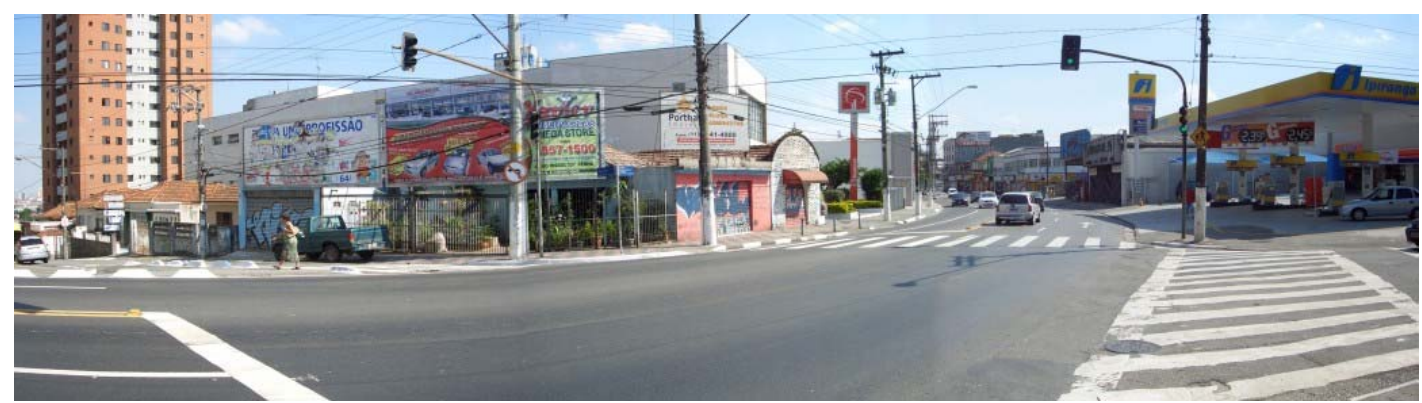

Fonte: Arquivo da autora

A rua Amador Bueno da Veiga é aquela que ocupa a parte central da foto. A rua Samuel Jorge Ribeiro é a observada à direita da foto. Do lado esquerdo é possível observar a rua Izabel, é aquela em que há uma senhora atravessando a rua.

Figura V-57.Travessias das ruas Amador Bueno da Veiga, Izabel e Samuel Jorge Ribeiro. Detalhe 1.

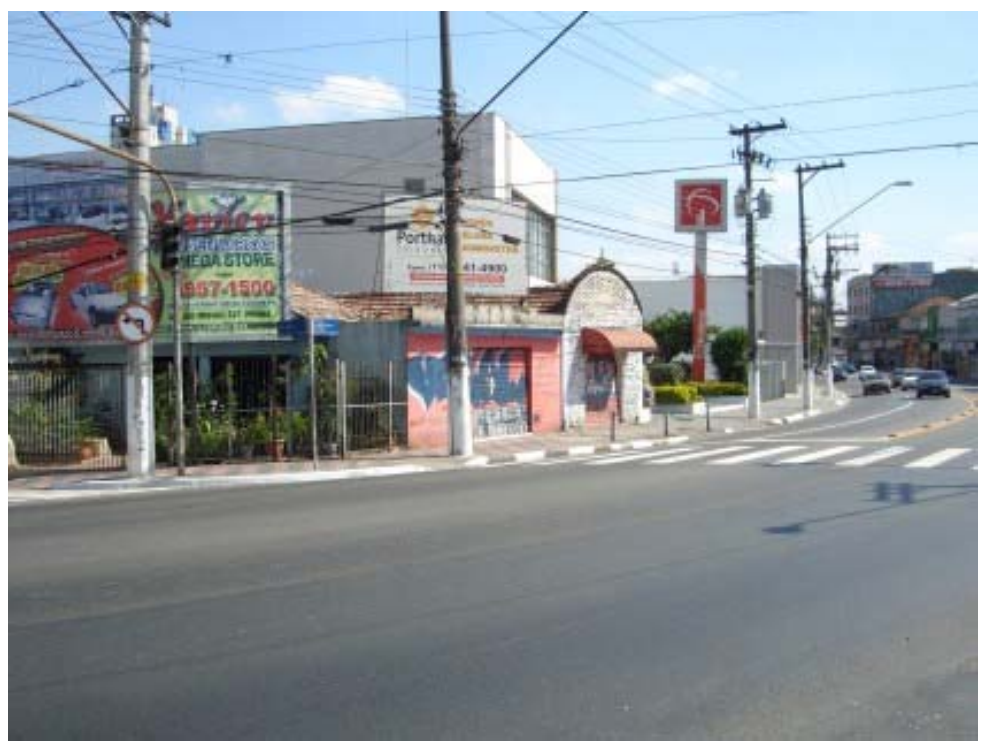

Fonte: Arquivo da autora

Ângulo de visão da rua Amador Bueno da Veiga

Figura V-58.Travessias das ruas Amador Bueno da Veiga, Izabel e Samuel Jorge Ribeiro. Detalhe 2. 


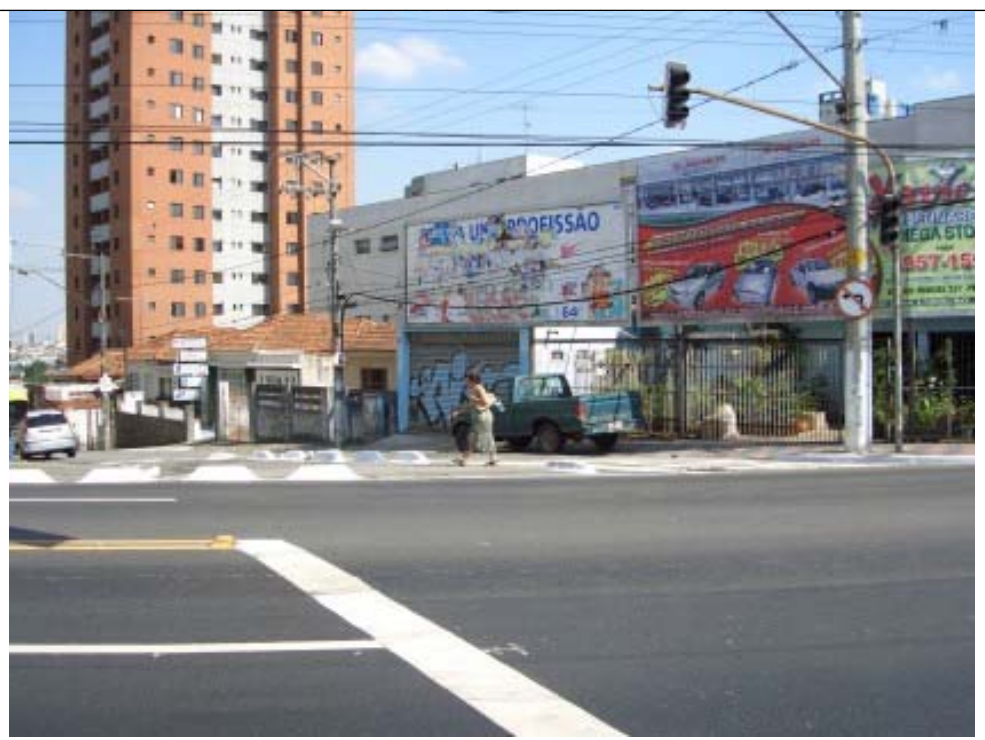

Fonte: Arquivo da autora

Vista da travessia da rua Izabel. Observar que esta travessia está bloqueada na sua metade, a fim de canalizar o fluxo de veículos. Os veículos na rua Amador Bueno da Veiga, sentido bairro/centro não podem fazer a conversão para acessar a rua Izabel. Esta só pode ser acessada no sentido centro/bairro. Porém para os pedestres os obstáculos (também chamados de "picolés") são transtornos para o livre trânsito.

\section{Figura V-59.Travessias das ruas Amador Bueno da Veiga, Izabel e Samuel Jorge Ribeiro. Ângulo de visão da rua Izabel}

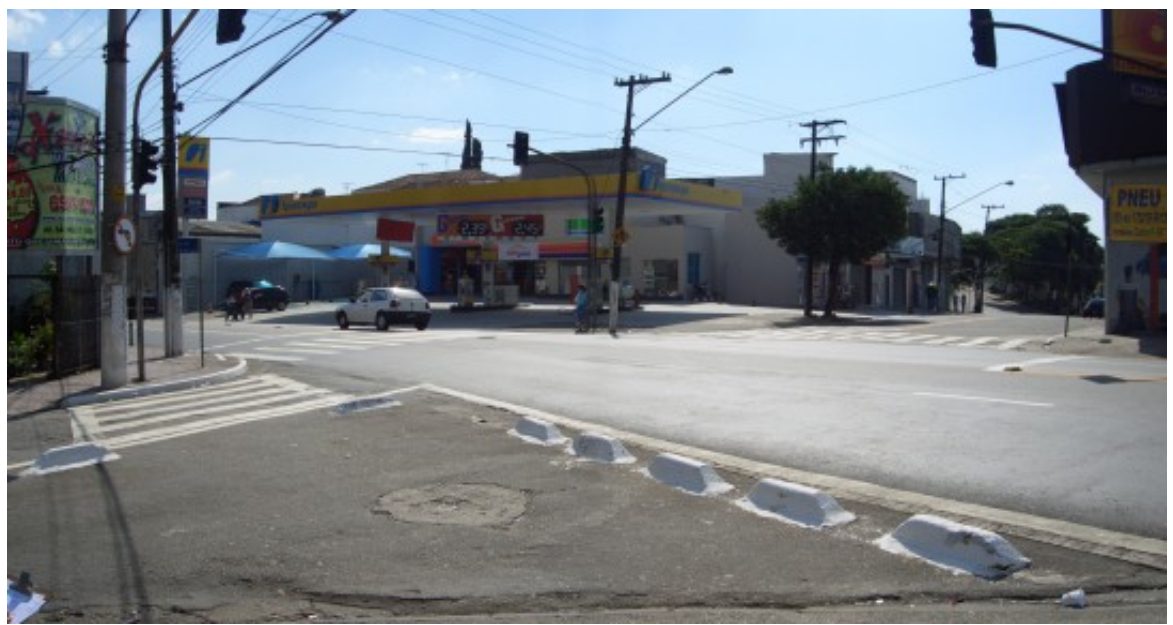

Fonte: Arquivo da autora

Outro ângulo da travessia da rua Izabel. Apesar de respeitarem a travessia não colocando os obstáculos junto à faixa, quando há muitos pedestres as dificuldades surgem. Observar que este "canteiro" não está bem conservado, com buraco no centro, provavelmente uma caixa de inspeção de alguma instituição de serviço público.

Figura V-60.Travessias das ruas Amador Bueno da Veiga, Izabel e Samuel Jorge Ribeiro. Visão da rua Samuel Jorge Ribeiro 


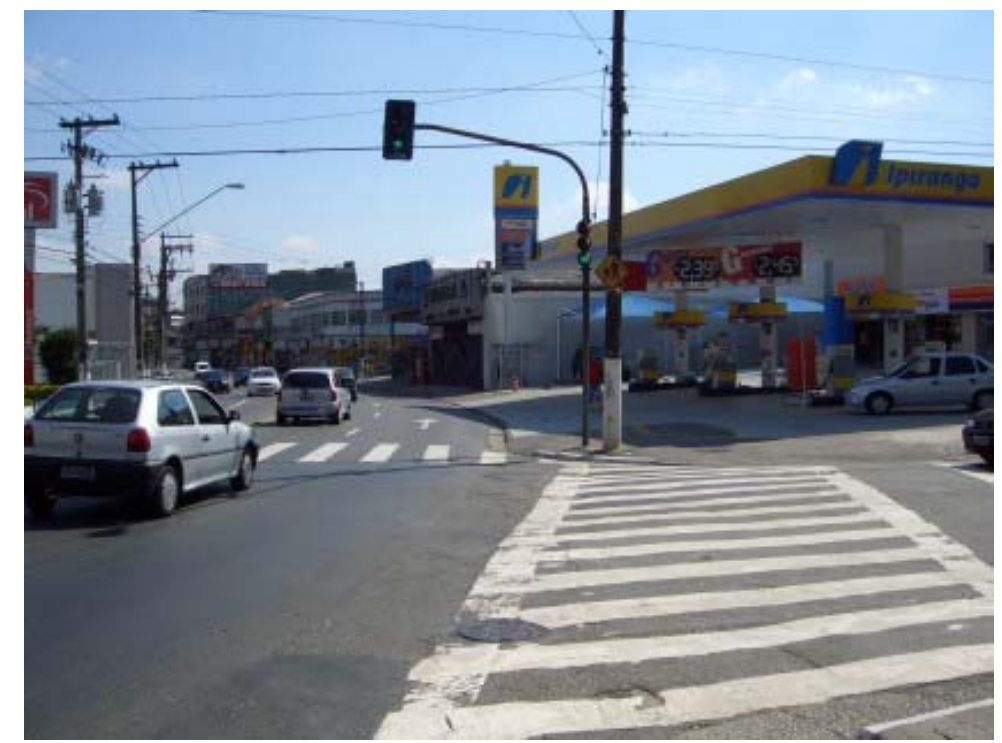

Fonte: Arquivo da autora

\section{Cálculo dos Níveis de Serviço}

Figura V-61. Esquema das travessias das rua Amador Bueno da Veiga, Izabel e Samuel Jorge Ribeiro

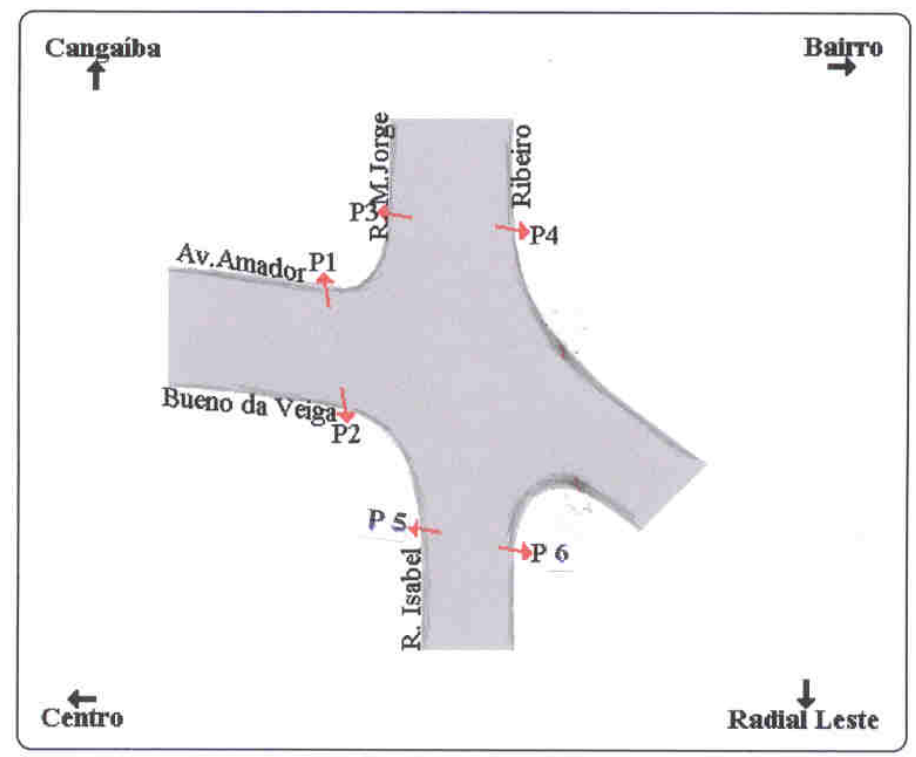

Fonte: CET. "Pesquisa de Trânsito". [CET(2005)]. 
A rua Amador Bueno da Veiga neste cruzamento apresenta apenas uma travessia, representado pelos movimentos $\mathrm{P} 1$ e $\mathrm{P} 2$. Os movimentos $\mathrm{P} 3$ e $\mathrm{P} 4$ representam a travessia na rua Samuel Jorge Ribeiro. A travessia na rua Izabel é representada pelos movimentos P5 e P6.

\section{Travessia da rua Amador Bueno da Veiga (movimentos P1 e P2)}

1. Cálculo de tempo de espera do Pedestre na Interseção Sinalizada - Dp

Tempo de ciclo-C: $100 \mathrm{~s}$

Tempo Efetivo de verde para pedestre-g: $30 \mathrm{~s}$

$$
\begin{aligned}
& \mathrm{Dp}=\frac{0,5(C-g) 2}{C} \\
& \mathrm{Dp}=\frac{0,5(100-30) 2}{100}=24,50 \mathrm{~s}
\end{aligned}
$$

Consultando a tabela IV-14 - NS para pedestres em interseções sinalizadas, para este tempo de espera o NS correspondente C, com Probabilidade Moderada de

\section{Desobediência.}

2. Cálculo do fluxo unitário de pedestre na calçada Largura total da calçada - Wt : 3,00 m

Soma das larguras de obstruções - Wc: Não foram consideradas as obstruções localizadas na calçada, por não interferirem na fluidez da caminhada.

Largura efetiva da calçada: $\mathrm{We}=\mathrm{Wt}-\mathrm{Wc}=3,00 \mathrm{~m}$

Fluxo no pico de 15 minutos - V15:

Fluxo unitário de pedestre Vp: $\mathrm{Vp}=\frac{V 15}{15 \times W e}(\mathrm{p} / \mathrm{min} / \mathrm{m})$

Como a contagem em campo foi de 15 minutos, a fórmula se resume em $\mathrm{Vp}=\frac{V 15}{W e}$

Fluxo no pico de 15 minutos - V15:

Pico da Manhã: 379 pedestres entre 9:00 às 9:15 h

Pico da Tarde: 240 pedestres entre 17:30 às 17:45 h

Para o pico da manhã $\mathrm{Vp}=\frac{379}{3,00}=126,33(\mathrm{p} / \mathrm{min} / \mathrm{m})$

Consultando a tabela IV-8 Critérios de NS para Fluxos Médios em Passeios e

Calçadas, para este fluxo unitário, o NS correspondente é F. 
Para o pico da tarde $\mathrm{Vp}=\frac{240}{3,00}=80,00(\mathrm{p} / \mathrm{min} / \mathrm{m})$

Consultando a tabela IV-8 Critérios de NS para Fluxos Médios em Passeios e

Calçadas, para este fluxo unitário, o NS correspondente é F.

\section{Travessia na rua Samuel Jorge Ribeiro (Movimentos P3 e P4).}

1. Cálculo de tempo de espera do Pedestre na Interseção Sinalizada - Dp

Tempo de ciclo-C: $100 \mathrm{~s}$

Tempo Efetivo de verde para pedestre-g: $70 \mathrm{~s}$

$$
\begin{aligned}
& \mathrm{Dp}=\frac{0,5(C-g) 2}{C} \\
& \mathrm{Dp}=\frac{0,5(100-70) 2}{100}=4,50 \mathrm{~s}
\end{aligned}
$$

Consultando a tabela IV-14 - NS para pedestres em interseções sinalizadas, para este tempo de espera o NS correspondente A, com Baixa Probabilidade à Desobediência.

2. Cálculo do fluxo unitário de pedestre na calçada

Largura total da calçada $-\mathrm{Wt}: 3,00 \mathrm{~m}$

Soma das larguras de obstruções - Wc: Não foram consideradas as obstruções localizadas na calçada, por não interferirem na fluidez da caminhada.

Largura efetiva da calçada: $\mathrm{We}=\mathrm{Wt}-\mathrm{Wc}=3,00 \mathrm{~m}$

Fluxo no pico de 15 minutos - V15:

Pico da Manhã: 318 pedestres entre 9:00 às 9:15 h

Pico da Tarde: 207 pedestres entre 17:30 às 17:45 h

Para o pico da manhã $\mathrm{Vp}=\frac{318}{3,00}=106,00(\mathrm{p} / \mathrm{min} / \mathrm{m})$

Consultando a tabela IV-8 Critérios de NS para Fluxos Médios em Passeios e

Calçadas, para este fluxo unitário, o NS correspondente é F.

Para o pico da tarde $\mathrm{Vp}=\frac{207}{3,00}=69,00(\mathrm{p} / \mathrm{min} / \mathrm{m})$

Consultando a tabela IV-8 Critérios de NS para Fluxos Médios em Passeios e

Calçadas, para este fluxo unitário, o NS correspondente é E.

\section{Travessia rua Izabel (movimentos P5 e P6)}


1. Cálculo de tempo de espera do Pedestre na Interseção Sinalizada - Dp

Tempo de ciclo-C: $100 \mathrm{~s}$

Tempo Efetivo de verde para pedestre-g: $70 \mathrm{~s}$

$$
\begin{aligned}
& \mathrm{Dp}=\frac{0,5(C-g) 2}{C} \\
& \mathrm{Dp}=\frac{0,5(100-70) 2}{100}=4,50 \mathrm{~s}
\end{aligned}
$$

Consultando a tabela IV-14 - NS para pedestres em interseções sinalizadas, para este tempo de espera o NS correspondente A, com Baixa Probabilidade à Desobediência.

2. Cálculo do fluxo unitário de pedestre na calçada

Largura total da calçada $-\mathrm{Wt}: 3,00 \mathrm{~m}$

Soma das larguras de obstruções - Wc: Não foram consideradas as obstruções localizadas na calçada, por não interferirem na fluidez da caminhada.

Largura efetiva da calçada: $\mathrm{We}=\mathrm{Wt}-\mathrm{Wc}=3,00 \mathrm{~m}$

Fluxo no pico de 15 minutos - V15:

Pico da Manhã: 421 pedestres entre 9:00 às 9:15 h

Pico da Tarde: 312 pedestres entre 17:30 às 17:45 h

Para o pico da manhã $\mathrm{Vp}=\frac{421}{3,00}=140,33(\mathrm{p} / \mathrm{min} / \mathrm{m})$

Consultando a tabela IV-8 Critérios de NS para Fluxos Médios em Passeios e

Calçadas, para este fluxo unitário, o NS correspondente é F.

Para o pico da tarde $\mathrm{Vp}=\frac{312}{3,00}=104,00(\mathrm{p} / \mathrm{min} / \mathrm{m})$

Consultando a tabela IV-8 Critérios de NS para Fluxos Médios em Passeios e

Calçadas, para este fluxo unitário, o NS correspondente é F.

3. Análise do Nível de Serviço calculado.

Neste cruzamento têm-se três ruas de igual importância operacional em confluência.

Considerando o tempo de espera do pedestre, a avenida Amador Bueno da Veiga está operando com o nível $\mathrm{C}$, indicando um serviço demorado; propiciando ao pedestre um 
$\overline{\text { risco moderado de desobediência às regras de trânsito. Nas ruas Samuel Jorge Ribeiro e }}$ Izabel o nível apresentado é A, considerado ótimo.

No entanto nas calçadas há acumulação de pedestres na hora do pico, nas três vias, caracterizando nível de serviço crítico (nível F). Há uma grande demanda de pedestres, e seria mais recomendável a instalação de outro local de travessia exclusiva para pedestres no meio da rua, a fim de melhor distribuição desta demanda.

\subsubsection{BAIRRO DA PENHA}

\section{Viaduto Cangaíba}

O viaduto Cangaíba é a transposição da avenida Governador Carvalho Pinto, vindo da avenida Cangaíba. A ocupação do entorno deste viaduto é residencial de baixa renda, apesar da região ser de renda média. A avenida Governador Carvalho Pinto é uma avenida relativamente nova, com a proposta de ocupar seu canteiro central com área de lazer, campos de futebol, árvores, bancos e mesas para "pic-nics", caminhadas, etc.

Ao longo desta avenida observa-se vários restaurantes, bares, sorveterias, etc, freqüentadas pela classe média da região. Figuras V-62, V-63, V-64, V-65 e V-66.

Os pedestres que utilizam este viaduto são preferencialmente os residentes do entorno. Apesar de contar com iluminação os usuários reclamam da escuridão na calçada, à noite e de madrugada (muitos saem às quatro ou cinco horas da manhã para trabalharem). A avenida Cangaíba é importante eixo que une os bairros de Cangaíba e Penha.

Figura V-62. Viaduto Cangaíba Vista Geral 


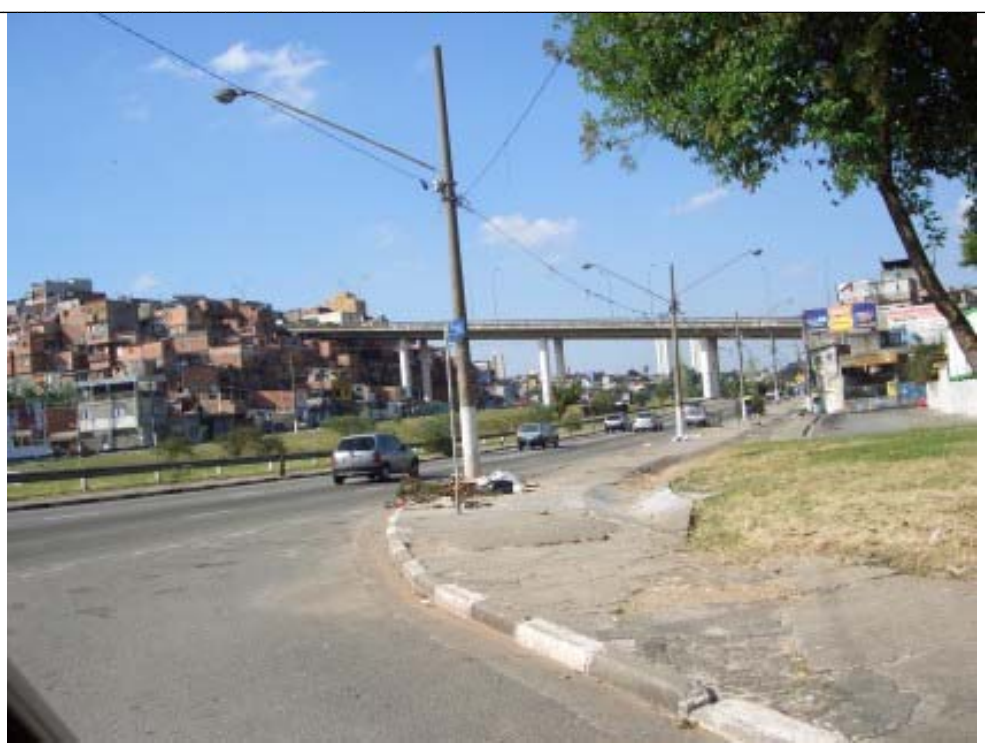

Fonte: Arquivo da autora

O viaduto é em declive. A parte alta é o bairro de Cangaíba e a parte baixa é o bairro da Penha. A avenida observada é a Governador Carvalho Pinto, sendo avenida de fundo de vale é larga e seu canteiro central foi aproveitado para uso de lazer.

Observar as habitações de baixa renda à esquerda da foto. Provavelmente são ocupações não regulamentadas.

Figura V-63. Viaduto Cangaíba Vista do viaduto e a passagem de pedestre 
Fonte: Arquivo da autora

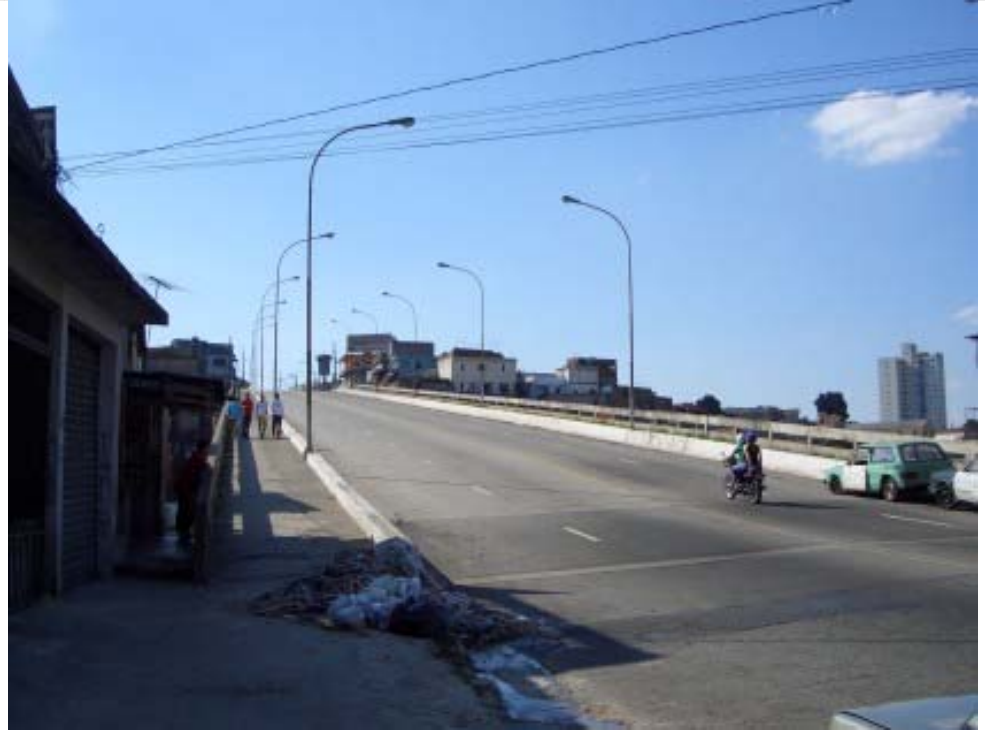

O viaduto comporta iluminação de mercúrio e obstáculo separando o trânsito viário do pedestre. A iluminação sendo voltada para a via projeta sombra na calçada, à noite. Todas as duas cabeceiras do viaduto estão ocupadas com residências de baixa renda, tipo favelas, e contam com a organização caótica, incluindo lojas e bares.

\section{Figura V-64. Viaduto Cangaíba Detalhe da ocupação do entorno do viaduto}

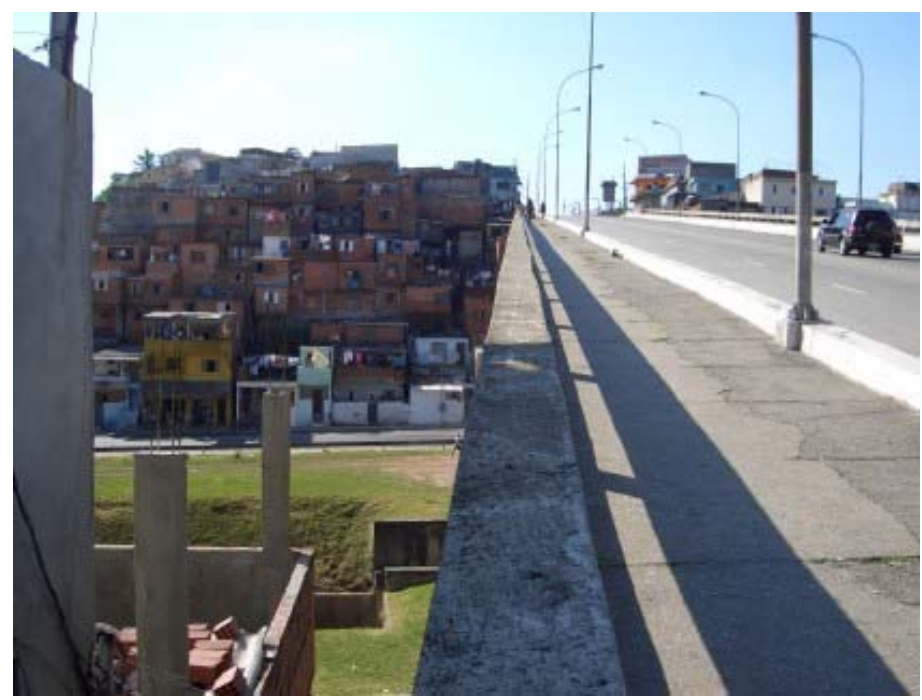

Fonte: Arquivo da autora

Observa-se a ocupação por favelas nas duas cabeceiras. $O$ intervalo entre o viaduto e a construção ainda em alicerces, é devido a uma escadaria improvisada que é o acesso da favela ao viaduto. Este tipo de acesso existe nos quatro cantos do viaduto. 


\section{Figura V-65. Viaduto Cangaíba Outro ângulo do viaduto}

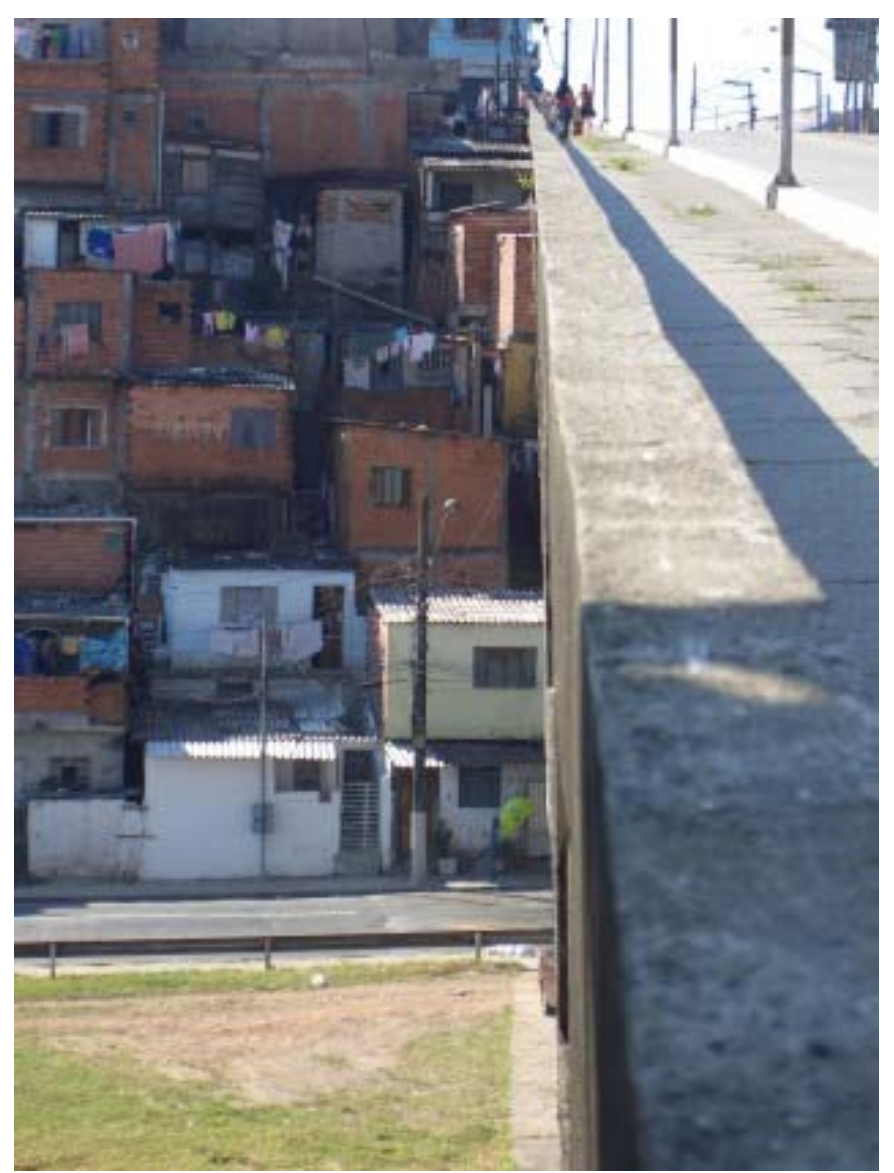

Fonte: Arquivo da autora

Observar o obstáculo de separação de trânsito viário do pedestre (muretinha branca). A calçada não está em boa conservação podendo ser observado plantinhas nascendo, o que caracteriza o empoçamento de águas de chuva e acumulação de sujeiras e detritos.

À esquerda da foto pode-se observar as residências tipo favela.

\section{Cálculo dos Níveis de Serviço}




\section{Figura V-66. Esquema da travessia do viaduto Cangaíba}

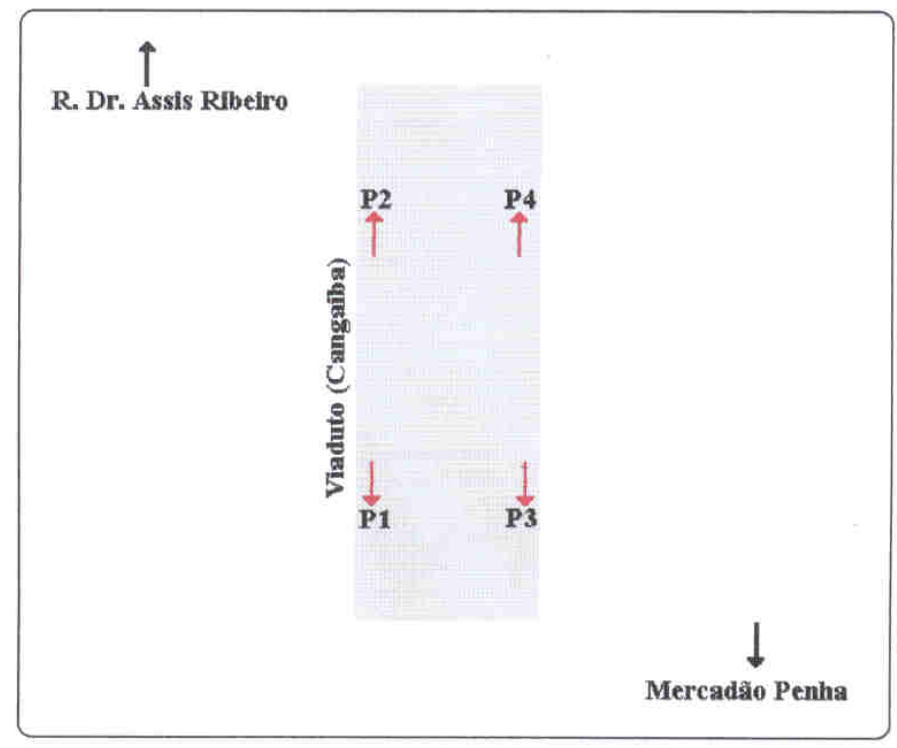

Fonte: CET. "Pesquisa de Trânsito". [CET(2005)].

Esta instalação será avaliada pelo fluxo unitário de pedestre, transitando nas calçadas do viaduto. $\mathrm{O}$ movimento $\mathrm{P} 1$ e $\mathrm{P} 2$ refere-se à calçada à esquerda, considerando o viaduto na direção para a rua Dr. Assis Ribeiro, e o movimento P3 e P4 refere-se à calçada da direita, nesta mesma direção.

\section{Cálculo do fluxo unitário de pedestre na calçada}

Largura total do passeio $-\mathrm{Wt}: 2,40 \mathrm{~m}$

Soma das larguras de obstruções - Wc: $0,50 \mathrm{~m}$

Largura efetiva da travessia: $\mathrm{We}=\mathrm{Wt}-\mathrm{Wc}=1,90 \mathrm{~m}$

Fluxo no pico de 15 minutos - V15:

Fluxo unitário de pedestre $\mathrm{Vp}: \mathrm{Vp}=\frac{V 15}{15 \times W e}(\mathrm{p} / \mathrm{min} / \mathrm{m})$

Como a contagem em campo foi de 15 minutos, a fórmula se resume em $\mathrm{Vp}=\frac{V 15}{W e}$

Movimento P1 - P2

Pico da Manhã: 87 pedestres entre as $8: 30$ às $8: 45 \mathrm{~h}$ Pico da Tarde: 100 pedestres entre 18:00 às 18:15 h

Para o pico da manhã $\mathrm{Vp}=\frac{87}{1,90}=45,79(\mathrm{p} / \mathrm{min} / \mathrm{m})$ 
Consultando a tabela IV-8 Critérios de NS para Fluxos Médios em Passeios e

Calçadas, para este fluxo unitário, o NS correspondente é D.

Para o pico da tarde $\mathrm{Vp}=\frac{100}{1,90}=52,63(\mathrm{p} / \mathrm{min} / \mathrm{m})$

Consultando a tabela IV-8 Critérios de NS para Fluxos Médios em Passeios e

Calçadas, para este fluxo unitário, o NS correspondente é E.

Movimento P3 - P4

Pico da Manhã: 53 pedestres entre as 7:30 às 7:45 h

Pico da Tarde: 89 pedestres entre 16:00 às 16:15 h

Para o pico da manhã $\mathrm{Vp}=\frac{53}{1,90}=27,89(\mathrm{p} / \mathrm{min} / \mathrm{m})$

Consultando a tabela IV-8 Critérios de NS para Fluxos Médios em Passeios e

Calçadas, para este fluxo unitário, o NS correspondente é C.

Para o pico da tarde $\mathrm{Vp}=\frac{89}{1,90}=46,84(\mathrm{p} / \mathrm{min} / \mathrm{m})$

Consultando a tabela IV-8 Critérios de NS para Fluxos Médios em Passeios e

Calçadas, para este fluxo unitário, o NS correspondente é D.

2. Análise do Nível de Serviço calculado.

A calçada com o movimento P1 e P2 está oferecendo um nível de serviço próximo do crítico (nível D e E), porém a calçada com o movimento P3 e P4, calçada à direita do viaduto na direção da rua Dr. Assis Ribeiro, no horário de pico o serviço é razoável (nível C e D). Este viaduto conta com uma muretinha de segurança separando a calçada da via. Por ser um viaduto muito longo e em aclive, seu uso é limitado à população carente, residente nas proximidades. 


\section{Travessia na av. São Miguel, próximo às ruas Vigília e Luis Asson}

A avenida São Miguel é um importante eixo do bairro da Penha e conecta este ao bairro de São Miguel Paulista. É uma via de quatro faixas com canteiro central, e dois sentidos de direção. É uma avenida comercial, porém há muitas residências, principalmente em prédios. A região é predominantemente residencial, e como há muitas ofertas de residências antigas em grandes lotes, estes estão passando para as incorporadoras, que produzem os condomínios residenciais. Há escolas, bancos, comércios e serviços.

As ruas Vigília e Luis Asson não formam cruzamento com a avenida São Miguel, pois não acessam esta avenida no mesmo ponto (elas são esconsas em relação à avenida). Este fato explica a travessia de pedestres simples, que seria favorável aos pedestres, não fosse o pouco tempo dado à travessia, para não comprometer a fluidez do intenso trânsito de veículos. Não há iluminação especial para a travessia. Os usuários da via reclamam que a iluminação da avenida não é suficiente para os motoristas verem os pedestres à noite. Figuras V-67, V-68, V-69 e V-70. Há muita circulação de pedestres, residentes ou trabalhadores nos entornos desta travessia.

Figura V-67.Travessia de pedestre na Av. São Miguel. Vista 1.

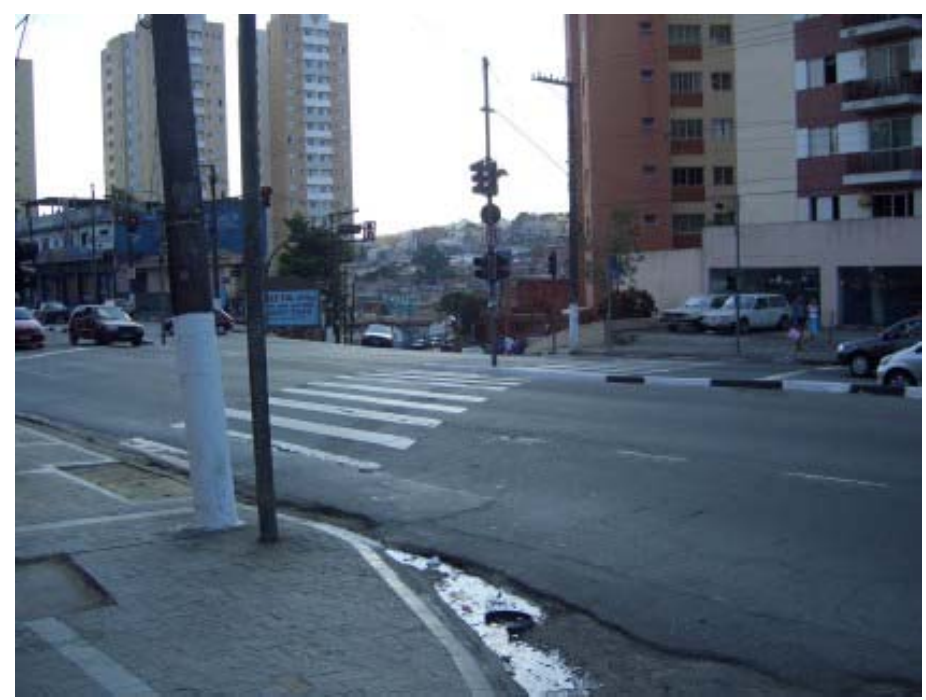

Fonte: Arquivo da autora 
Vista da avenida São Miguel. Ao fundo observa-se a rua Vigília. A câmera está posicionada na rua Luis Asson.

Figura V-68. Travessia de pedestre na Av. São Miguel. Vista 2.

Fonte: Arquivo da autora

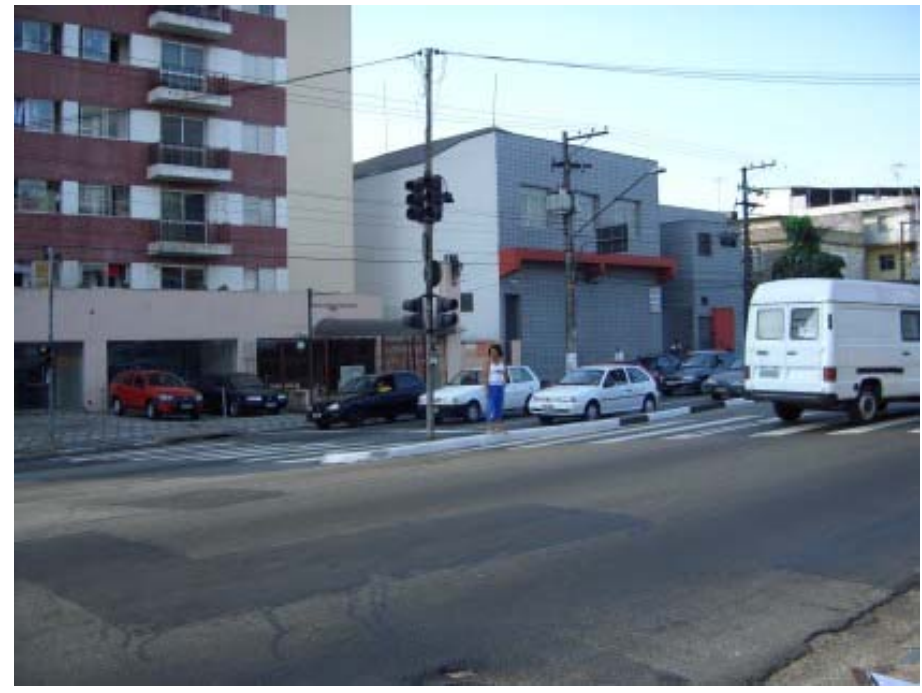

Devido ao pouco tempo dado à travessia de pedestre este só consegue atravessar a avenida em duas etapas. Observar que o canteiro central é inseguro para a espera do pedestre, principalmente se forem crianças ou idosos, ou mesmo para aqueles que estejam com sensibilidade no labirinto auditivo ou problemas de equilíbrio.

Figura V-69.Travessia de pedestre na Av. São Miguel Detalhe da vista 2.

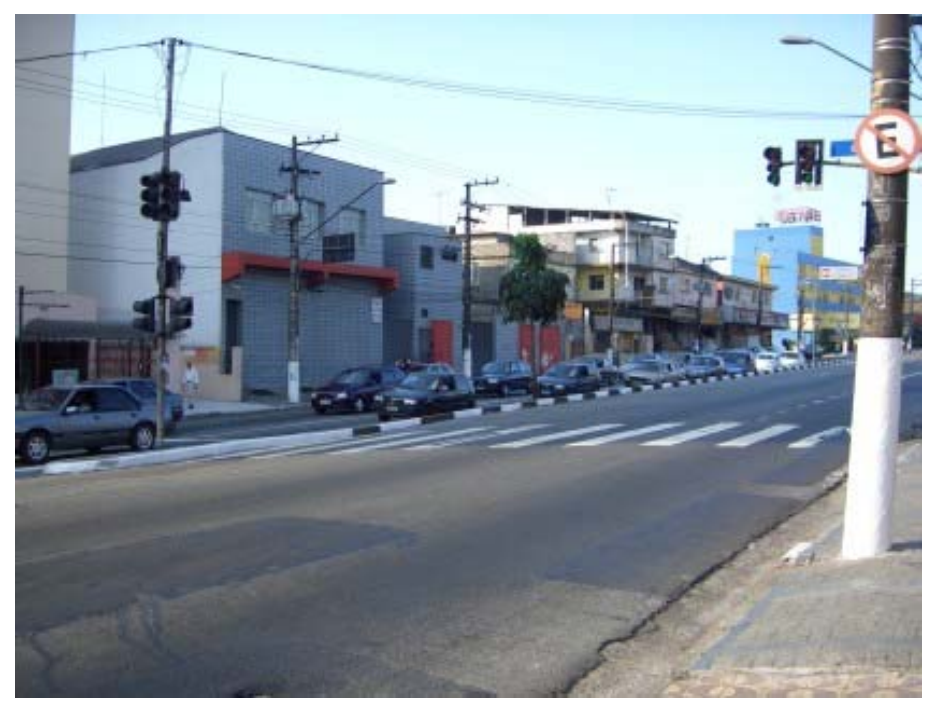

Fonte: Arquivo da autora

Outro ângulo da travessia. 


\section{Cálculo dos Níveis de Serviço}

Figura V-70. Esquema da travessia na av. São Miguel / r. Vigília/ r. Luis Asson

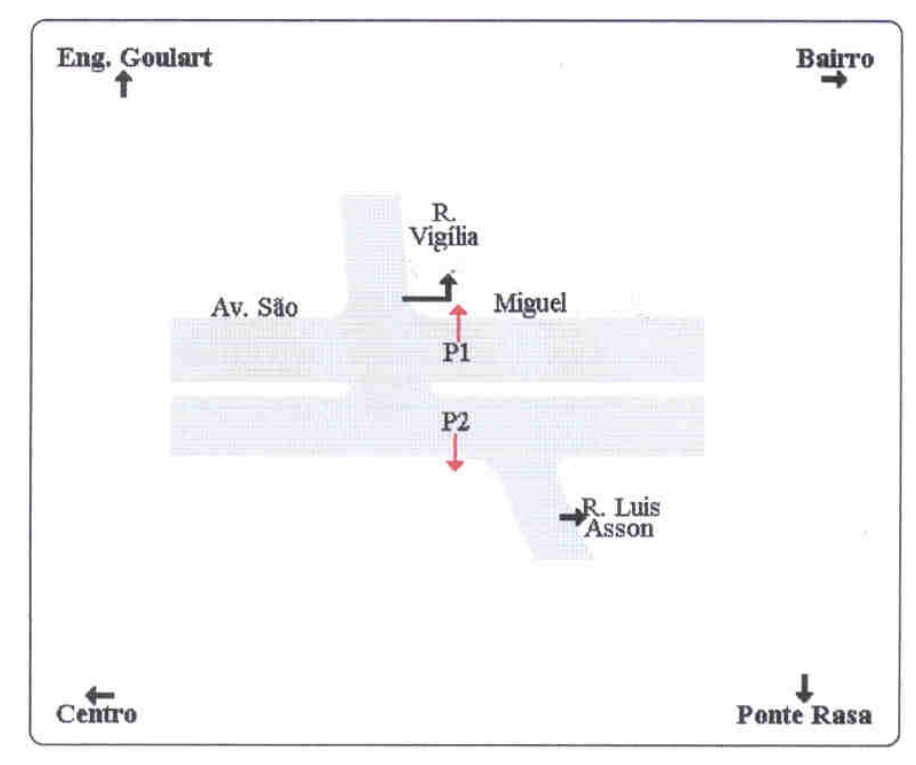

Fonte: CET. "Pesquisa de Trânsito". [CET(2005)].

1. Cálculo de tempo de espera do Pedestre na Interseção Sinalizada - Dp

Tempo de ciclo-C: $100 \mathrm{~s}$

Tempo Efetivo de verde para pedestre-g: $30 \mathrm{~s}$

$\mathrm{Dp}=\frac{0,5(C-g) 2}{C}$

$\mathrm{Dp}=\frac{0,5(100-30) 2}{100}=24,50 \mathrm{~s}$

Consultando a tabela IV-14 - NS para pedestres em interseções sinalizadas, para este

tempo de espera o NS correspondente C, com Risco Moderado em Probabilidade de

\section{Desobediência.}

2. Cálculo do fluxo unitário de pedestre na calçada

Largura total do passeio - Wt : 2,50 m

Soma das larguras de obstruções - Wc: $0,50 \mathrm{~m}$

Largura efetiva da travessia: $\mathrm{We}=\mathrm{Wt}-\mathrm{Wc}=2,50-0,50 \mathrm{~m}$

Fluxo no pico de 15 minutos - V15: 
Pico da Manhã: Não detectado pico neste período.

Pico da Tarde: 73 pedestres entre 17:00 às 17:15 h

Fluxo unitário de pedestre $\mathrm{Vp}: \mathrm{Vp}=\frac{V 15}{15 \times W e}(\mathrm{p} / \mathrm{min} / \mathrm{m})$

Como a contagem em campo foi de 15 minutos, a fórmula se resume em $\mathrm{Vp}=\frac{V 15}{W e}$

Para o pico da tarde $\mathrm{Vp}=\frac{73}{2,0}=36,50(\mathrm{p} / \mathrm{min} / \mathrm{m})$

Consultando a tabela IV-8 Critérios de NS para Fluxos Médios em Passeios e

Calçadas, para este fluxo unitário, o NS correspondente é D.

3. Análise do Nível de Serviço calculado.

O tempo de espera do pedestre para atravessar a avenida não é suficientemente demorado e a indução à desobediência à sinalização é moderada. No período de pico da tarde o nível é $\mathrm{D}$, o que corresponde a uma condição instável. Os pedestres podem apresentar comportamento de intolerância devido à proximidade entre eles.

\section{Travessia na av. São Miguel nas proximidades das ruas Benfica de Minas e São Celso}

Esta travessia fica próxima da travessia da rua Vigília. As características viárias e de entorno são iguais, porém aqui ainda predomina as residências unitárias. A avenida São Miguel permanece uma via comercial.

As ruas São Celso e Benfica de Minas não formam cruzamento com a avenida São Miguel (elas são esconsas em relação à avenida). Assim sendo a travessia de pedestres é uma travessia simples, o que acarreta em prejuízo ao pedestre, pois o tempo dado para a travessia é pouco, para não comprometer a fluidez dos veículos na avenida São Miguel. Esta travessia não conta com iluminação específica de travessia, apenas a iluminação da avenida. Os usuários lamentam este fato, pois à noite dificilmente os veículos respeitam 
$\overline{\text { a travessia e os pedestres são obrigados a correrem, por sabem que podem não serem }}$ vistos. Figuras V-71 e V-72.

Figura V-71. Travessia na av. São Miguel / r. Benfica de Minas / r. São Celso

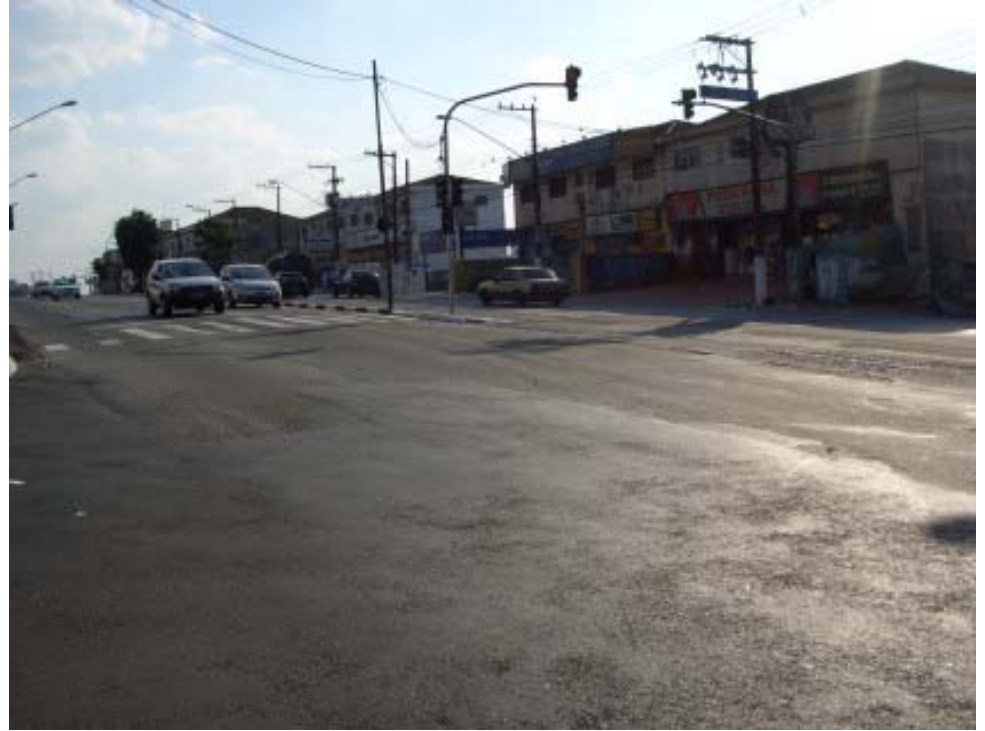

Fonte: Arquivo da autora

Observar que a pintura da faixa de pedestres não está em bom estado. Em dias de chuvas esta faixa desaparece para os veículos. A iluminação da avenida é insuficiente para a travessia à noite.

\section{Cálculo dos Níveis de Serviço}

Figura V-72. Esquema de travessia na av. São Miguel / r. Benfica de Minas / r. São Celso 


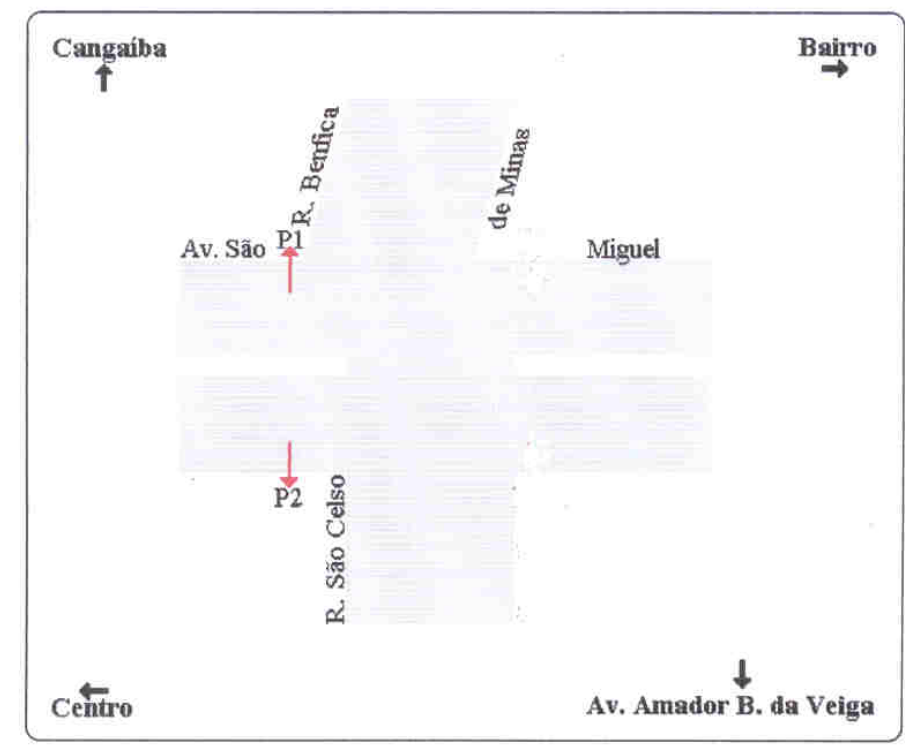

Fonte: CET. "Pesquisa de Trânsito". [CET(2005)].

1. Cálculo de tempo de espera do Pedestre na Interseção Sinalizada - Dp

Tempo de ciclo-C: $100 \mathrm{~s}$

Tempo Efetivo de verde para pedestre-g: $30 \mathrm{~s}$

$\mathrm{Dp}=\frac{0,5(C-g) 2}{C}$

$\mathrm{Dp}=\frac{0,5(100-30) 2}{100}=24,50 \mathrm{~s}$

Consultando a tabela IV-14 - NS para pedestres em interseções sinalizadas, para este tempo de espera o NS correspondente C, com Risco Moderado de Probabilidade de

\section{Desobediência.}

2. Cálculo do fluxo unitário de pedestre na calçada

Largura total do passeio $-\mathrm{Wt}: 2,50 \mathrm{~m}$

Soma das larguras de obstruções - Wc: $0,50 \mathrm{~m}$

Largura efetiva da travessia: $\mathrm{We}=\mathrm{Wt}-\mathrm{Wc}=2,50-0,50 \mathrm{~m}$

Fluxo no pico de 15 minutos - V15:

Pico da Manhã: Não foi detectado pico horário neste período.

Pico da Tarde: 157 pedestres entre 18:15 às 18:30 h

Fluxo unitário de pedestre Vp: $\mathrm{Vp}=\frac{V 15}{15 \times W e}(\mathrm{p} / \mathrm{min} / \mathrm{m})$ 
Como a contagem em campo foi de 15 minutos, a fórmula se resume em $\mathrm{Vp}=\frac{V 15}{W e}$

Para o pico da tarde $\mathrm{Vp}=\frac{157}{2,0}=78,50(\mathrm{p} / \mathrm{min} / \mathrm{m})$

\section{Consultando a tabela IV-8 Critérios de NS para Fluxos Médios em Passeios e}

Calçadas, para este fluxo unitário, o NS correspondente é F.

3. Análise do Nível de Serviço calculado.

O tempo de espera do pedestre para atravessar a avenida não é suficientemente demorado e a indução à desobediência à sinalização é moderada. Porém, a acumulação de pedestres na calçada no pico horário atinge o nível $\mathrm{F}$, correspondente ao pior nível de serviço. Os pedestres assim agrupados podem desenvolver atitudes de intolerância e extrapolar a área da calçada, que não os comportam.

\subsubsection{Considerações do item 2.2 .}

Tomando-se por referência a avaliação de nível de serviço mais baixo por instalação analisada, deduzimos as seguintes considerações:

Das instalações pesquisadas, no horário de pico, todos os viadutos e pontes estão com nível de serviço $\mathrm{E}$ ou $\mathrm{F}$, caracterizando um dimensionamento não compatível com a demanda de pedestres, colocando-os em risco na sua jornada. Sendo transposições de grandes avenidas ou do rio Tietê, estes pedestres não têm outra opção de travessia. Talvez seja o momento de repensar numa outra possibilidade de travessia, exclusiva para pedestres, salvaguardando a segurança e integridade dos pedestres.

Das travessias de pedestres analisadas $50 \%$ operam no nível D e outros $50 \%$ em nível F, o que caracteriza um mal serviço, isto é, os pedestres têm de esperar muito tempo para poder atravessar a via e assim há acumulação de pedestres na calçada, incentivando 
pedestres a transgredirem as regras de trânsito, tais como, atravessar fora da faixa, atravessar correndo quando houver brecha entre os veículos e o semáforo ainda não abriu para os pedestres, atravessar correndo para aproveitar o último segundo do semáforo, etc.

Os cruzamentos apresentam uma característica interessante. Dos cruzamentos analisados 34\% apresentam níveis de serviços A e B, o que representam estar com bom dimensionamento para os pedestres. Porém, são cruzamentos considerados preocupantes do ponto de vista da operação viária, devido a acidentes entre veículos e até alguns atropelamentos, devido a alta velocidade desenvolvida pelos veículos e pela desobediência aos sinais semafóricos por parte dos motoristas. Os restantes $66 \%$ operam com níveis de serviço E e F, o que é considerado crítico, induzindo os pedestres a comportamentos de desobediência às regras de trânsito.

Das travessias e cruzamentos analisados e na consulta à população usuária a condição mais desfavorável à segurança do pedestre são as operações semafóricas em três fases, pois não há suficiente instrução ou sinalização tanto aos pedestres como aos motoristas, o que os levam a cometerem transgressões às regras de trânsito.

É importante observar que as análises dos Níveis de Serviço das instalações não prescindem de uma análise de observação local, nem uma consulta aos usuários da instalação.

No contexto total das instalações analisadas, no horário de pico, 6\% operam com nível de serviço A e outros 6\% em nível $\mathrm{B}, 13 \%$ em nível $\mathrm{D}, 31 \%$ em nível $\mathrm{E}$ e, finalmente 44\% em nível F. Como estas instalações estão próximas dos "Pontos de Articulação" observados, as premissas destes "Pontos" estão confirmadas, pois realmente há demanda de pessoas, ao ponto de haver saturação em muitas das instalações, 
necessitando de novas intervenções urbanas, sejam com características de equipamentos urbanos, sistema viários ou com operação de transporte urbano.

\subsection{Pesquisa e Análise de Campo}

\subsubsection{Pesquisa Qualitativa sobre a Satisfação do Uso das Instalações para Pedestre}

As instalações para pedestres que apresentaram maiores problemas com a interação viária, na Zona Leste, conforme indicação da CET-SP, foram classificadas em três tipos:

- viaduto ou ponte, onde o pedestre caminha longitudinalmente, no sentido do movimento, sem cruzá-la, até o término da instalação.

- travessia, local onde o pedestre caminha no sentida transversal ao movimento, atravessando a via, sem ser cruzamento de vias.

- cruzamento, onde o pedestre atravessa a via, transversalmente ao movimento, sendo o local caracterizado como um cruzamento de via.

Para cada tipo de instalação foram entrevistados 15 pedestres (alguns ciclistas), que efetivamente são usuários destas instalações.

As perguntas foram:

1. Mora (trabalha ou estuda) nas imediações deste viaduto (travessia ou cruzamento)?

2. Há quanto tempo?

3. Como você acha que as pessoas se comportam neste viaduto (travessia ou cruzamento)?

4. Tem tido notícias de acidentes neste viaduto (travessia ou cruzamento)?

5. Passa por aqui à noite?

6. O que acha da iluminação artificial aqui? 
7. Como você avalia esta calçada aqui?

8. Que sugestões você apresenta para melhorar a circulação de pedestre neste viaduto (travessia ou cruzamento)?

Para a primeira pergunta "Mora, trabalha ou estuda próximo deste local" as respostas foram: Trabalham 50\%; Moram e Trabalham 22,5\%; Moram 17,5\% e Estavam de passagem $10 \%$.

Esta relação constata não apenas a atração do local como mercado de trabalho, mas a atração para morar, já que moram $40 \%$ dos entrevistados.

Para a segunda pergunta, sobre o tempo que mora ou trabalha, as respostas foram: $12,5 \%$ a menos de um ano; $32,5 \%$ entre 1 e 2 anos; $12,5 \%$ entre três e cinco anos; $12,5 \%$ entre 6 e 10 anos; $22,5 \%$ entre 11 e 20 anos e 7,5\% temporários (passagem).

Esta relação constata que $45 \%$ dos entrevistados moram ou trabalham há menos de dois anos e 57,5\% há pelo menos cinco anos e que há uma grande população fixa na região (22,5\% estão estabelecidos entre 11 a 20 anos ou mais).

A terceira pergunta refere-se a opinião do pedestre entrevistado sobre o comportamento de demais pedestres e dos motoristas de veículos, que utilizam a instalação.

\section{VIADUTO}

As respostas foram sintetizadas em expressões dos próprios entrevistados.

Pedestres:

- Tem muita gente carregando muito peso (sacola, botijão de gás, etc) ou empurrando carrinho (feira, pipoqueiro, etc). Assim passa um por vez e bem devagar.

- Passa muita gente com bicicletas, o que atrapalha muito.

- Tem muito pedestre ladrão, principalmente à noite.

Ciclistas entrevistados: 
"Sei que estou atrapalhando, mas não tem jeito, não dá para andar na via, porque os veículos passam por cima da gente".

Motoristas de veículos:

"Em dias de chuva os veículos passam em velocidade nas poças de água suja e espirram nos pedestres. Os jatos de água passam por cima das muretinhas. É uma água suja e a gente está com roupa para trabalhar”.

\section{TRAVESSIA}

Pedestres:

- 46\% acreditam que os pedestres respeitam o semáforo, mas passam correndo porque o sinal fecha rápido.

- 27\% acreditam que os pedestres respeitam o semáforo: "até param no canteiro central”.

- $27 \%$ acreditam que os pedestres não respeitam nem o semáforo nem a faixa de travessia.

A credibilidade do pedestre em outros pedestres está assegurada, pois $73 \%$ acreditam no respeito ao semáforo, mesmo que tenham que correr para atravessar.

Motoristas de veículos:

Os pedestres entrevistados acreditam que $67 \%$ dos motoristas respeitam o semáforo e $33 \%$ não respeitam o semáforo da travessia.

Frase característica: "Pedestre não pode vacilar".

\section{CRUZAMENTO}

Pedestres:

- Respeitam o semáforo: $20 \%$ disseram que sim.

- Não respeitam o semáforo: $80 \%$ disseram que não.

Motoristas de veículos: 
- Respeitam o semáforo: 33\% disseram que sim.

- Não respeitam o semáforo: $67 \%$ disseram que não.

$\mathrm{Na}$ opinião dos pedestres entrevistados, há um grande desrespeito à sinalização pelo semáforo, tanto da parte dos pedestres como dos motoristas, diferentemente dos entrevistados nas travessias de pedestres, que acreditavam mais na obediência à sinalização do semáforo.

Frases características:

"Pedestre vê uma brecha e atravessa, porque o tempo de verde é muito curto para ele". "Pedestre atravessa entre os carros, nem sempre na faixa, como deveria".

"Semáforo de três fases é complicado. Os pedestres não sabem que não é a sua vez de passar, apesar do sinal estar fechado para outro lado, mas pode vir os veículos que viram a rua, ou até os que não viram. Os motoristas também não sabem quando pode ir ou não, eles pensam que o semáforo está quebrado".

A questão quatro refere-se ao conhecimento de acidentes na instalação em questão.

Nos viadutos e pontes $80 \%$ não tinham conhecimento de acidentes no local $20 \%$ relataram algum acidente.

Nas travessias $33 \%$ souberam de algum acidente e $67 \%$ desconheciam.

Nos cruzamentos $73 \%$ tinham conhecimento de acidentes e $27 \%$ não.

Por esta amostra os cruzamentos aparentam ser foco de muitos acidentes, ou que os acidentes são marcantes e muito comentados. Porém, se confrontarmos esta informação com a questão três, sobre o comportamento dos pedestres e motoristas, os cruzamentos são aqueles que apresentam mais contraventores de semáforos que aqueles das travessias, o que responderia esta questão sobre acidentes.

Na questão cinco, se o pedestre utiliza a instalação à noite, as respostas foram:

Viadutos e pontes: 
- $30 \%$ passam à noite

- 70\% não passam à noite

Travessias:

- 60\% utilizam a travessia á noite

- 40\% não a utilizam

Cruzamentos:

$-53 \%$ utilizam a travessia à noite

- 47\% não o utilizam.

Os viadutos e pontes aparentam ser instalações inseguras para os pedestres, à noite. $\mathrm{Na}$ questão três, muitos entrevistados chamaram a atenção sobre os assaltos que ocorrem nos viadutos e pontes. Por sua vez, as travessias e os cruzamentos, são utilizados à noite, sem muita restrição. Os viadutos e pontes pesquisados são longos, e apesar de ligar dois pontos de interesse (dois bairros distintos, atravessam o rio Tietê, etc), aparentemente os pedestres têm opção de atravessar a instalação por meio de ônibus. Já uma travessia ou um cruzamento é uma instalação curta, inserida no percurso, portanto difícil de evitá-los.

A questão seis refere-se à iluminação artificial sobre a instalação ou arredores, que a iluminem.

Nos viadutos e pontes $20 \%$ consideraram a iluminação boa; $40 \%$ má e $40 \%$ não souberam responder.

Nas travessias 27\% classificaram a iluminação como boa; $67 \%$ má e $6 \%$ não souberam responder.

Nos cruzamentos $33 \%$ responderam que a iluminação é boa; $47 \%$ que é má e $20 \%$ não tinham opinião. 
Os usuários dos viadutos à noite são cerca de $30 \%$ dos entrevistados e $20 \%$ consideram a iluminação boa. São respostas compatíveis.

Já nas travessias apesar de $60 \%$ utilizarem-nas à noite, $67 \%$ consideram a iluminação má. Portanto estes pedestres estão utilizando as travessias conscientes dos riscos de não serem vistos pelos motoristas.

Nos cruzamentos, aparentemente, a iluminação é tanto percebida como boa como má, com ligeira vantagem na condição de má iluminação.

Os comentários sobre algumas travessias é que há muitas árvores no canteiro central que encobrem a iluminação.

Outra observação é sobre a iluminação amarela que, dizem, não ilumina o suficiente.

O estado das calçadas foi questionado no item sete.

Para os usuários de viadutos e pontes $20 \%$ consideram as calçadas em bom estado; $30 \%$ razoável e 50\% em mau estado.

Para os pedestres das travessias 13\% consideram em bom estado; $13 \%$ razoável e $74 \%$ em mau estado.

Para aqueles que utilizam cruzamentos $27 \%$ consideram-no em bom estado; $27 \% \mathrm{em}$ estado razoável e $46 \%$ em mau estado.

O mau estado das calçadas parece ser consenso entre os entrevistados. As alegações foram várias:

- Muitas rachaduras e falhas formando degraus nas calçadas. No pavimento da via há algumas ondulações.

- Há buracos sem tampas, nas calçadas.

- As calçadas são utilizadas por carros fortes.

- Alguns ônibus sobem na calçada para fazerem a curva.

- Calçadas estreitas (tem gente com bicicletas, carrinhos, etc). 
$\overline{\text { Interessante observar que em torno de } 20 \% \text { dos entrevistados consideram as calçadas }}$ em bom estado, mesmo estando em pé numa calçada com rachaduras e desniveladas, durante a entrevista. Aparentemente, a resignação de certa parte da população torna-os indiferentes aos serviços oferecidos, não despertando a crítica ou mesmo comentários.

O item oito versa sobre as sugestões possíveis para melhorar a instalação.

\section{VIADUTO E PONTES:}

- Fazer uma boa reforma nos viadutos e pontes.

- Pintura de gradis e do viaduto em si.

- Alargar as calçadas, por conta das bicicletas e carrinhos que ocupam as calçadas também.

- Melhorar a drenagem da via, para não formar poças de água, quando chover.

- Melhorar a iluminação.

- Policiamento à noite, e à pé, por conta dos assaltos nos viadutos e pontes.

\section{TRAVESSIAS:}

- Dar tempo maior no semáforo para o pedestre.

- Substituir a travessia por uma passarela.

- Iluminação melhor da travessia. Eliminar a iluminação amarela.

- Fechar os semáforos próximos ao mesmo tempo, porque se não sempre tem veículo querendo atravessar.

- Presença de policiamento.

-Reforçar pintura da faixa. À noite ou quando chove não se enxerga a faixa.

- Aumentar a fiscalização de trânsito.

- Melhorar as calçadas.

- Podar as árvores dos canteiros centrais.

CRUZAMENTOS: 
- Fiscalização de trânsito, principalmente de manhã, quando os veículos desenvolvem maiores velocidades.

- Melhorar as calçadas.

- Aumentar o tempo de verde para o pedestre.

- Implantar o "marcador de tempo" do semáforo para os pedestres, a fim de saberem quanto tempo ainda tem para atravessar com segurança.

- Colocar "lombada eletrônica" ou radares na avenida, para diminuir a velocidade dos veículos.

- Melhorar a iluminação.

- Policiamento da via.

- Implantar semáforo inteligente para multar infratores que queimam o tempo vermelho.

- Melhorar transporte público.

- Alargar a avenida.

- Implantar travessias de pedestres um pouco longe do cruzamento e tirar a possibilidade de travessia do cruzamento.

- Presença de polícia ou agente de trânsito, pelo menos nas horas de pico, nos cruzamentos com semáforos de três fases, para disciplinar os movimentos.

\subsubsection{Considerações do item 2.3}

Por meio destas entrevistas pode-se avaliar o nível de satisfação dos pedestres em relação às instalações em questão. Em princípio, o perfil do usuário destas instalações é a de uma pessoa que trabalha nas proximidades, há um ou dois anos. Usa intensamente a instalação e é crítico quanto à sua qualidade. A opinião sobre os pedestres e motoristas dos veículos, dada pelos usuários dos cruzamentos é de que há um grande desrespeito à sinalização pelo semáforo, comportamento diferente observado pelos 
usuários das travessias de pedestres, que acreditam mais na obediência à sinalização do semáforo. As instalações são utilizadas por muitos pedestres portadores de volumes pesados e alguns empurram carrinhos, outros pedalam bicicletas entre os pedestres, por não se sentirem seguros circulando nas vias. Estes segmentos de pedestres diminuem a fluidez e o tempo no caminhar. Apesar de serem mais observados nos viadutos e pontes, também são comuns as suas presenças nas calçadas de vias. As irritações devido às suas presenças aparentam não terem maiores conseqüências além de alguns impropérios. As poças d'água, nos viadutos e pontes; as árvores frondosas nos canteiros centrais das travessias são interferências ambientais que podem ser manejados a baixo custo e rapidamente. A iluminação melhor e reforço na pintura das faixas de travessias são medidas que demandam certa programação orçamentária, mas são factíveis. As melhorias nas calçadas fazem parte de um programa da municipalidade. Este programa foi relatado no capítulo II, desta tese. Caberia às subprefeituras uma intensa fiscalização no cumprimento das regras de calçamentos. Reprogramar os tempos de semáforos para privilegiar a travessia dos pedestres é a reivindicação constante dos pedestres entrevistados. Se não for viável, por afetar a fluidez do sistema viário, então é caso de estudar as possibilidades de se instalar travessias aéreas ou subterrâneas. Mas a instalação de "marcador de tempo" para o pedestre é factível, dependendo da programação orçamentária. A fiscalização por agente de trânsito e o policiamento ostensivo parece ser uma solução desejada por todos, mas está sujeita à estratégia das corporações e sofre as limitações de seu contingente. Mas não deve ser descartada a sua atuação mais intensa, mesmo em sistema de rodízio temporários, por instalações.

A viabilidade de implantação de "lombadas eletrônicas", radares e semáforos inteligentes podem ser estudados e, se viável, serem orçadas e programadas as suas instalações. Os cruzamentos devem passar por uma reciclagem de caráter mais amplo, 
incluindo outras instalações ao redor, e solucionado sua funcionalidade, principalmente, em se tratando de cruzamento com semáforo de três fases. Os pedestres apresentaram sugestões para a reciclagem destes cruzamentos.

Já o alargamento das calçadas de viadutos e pontes, assim como o alargamento das avenidas são sugestões de difícil execução, pois envolve o remanejamento de todo o sistema urbano da região.

A melhoria do transporte público é a meta e desafio de todos os prefeitos. Tendo esta solução os transportes individuais serão reduzidos e a qualidade de vida, sem dúvida, será melhor para todos, principalmente para os pedestres. 


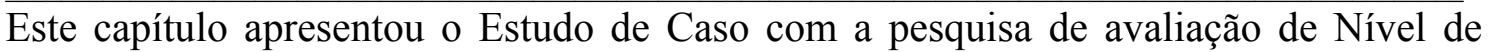
Serviço das Instalações para Pedestres. O campo experimental da pesquisa foi a Zona Leste do Município de São Paulo. A eleição desta região partiu do cruzamento das informações sobre os "Pontos de Articulação" e suas localizações na Cidade de São Paulo e as mortes de Pedestres no Município de São Paulo. O Estudo para Identificação dos "Pontos de Articulação" é uma metodologia apresentada pela Companhia do Metropolitano de São Paulo. Em princípio pode-se conceituar o "Ponto de Articulação" como sendo lugares do espaço urbano com demanda de transporte e adensamento significativos, tanto numa situação presente como futura, em função do potencial de desenvolvimento a eles intrínseco. Como este princípio admite a presença de pedestres como principal ator, uma vez que o transporte e o adensamento urbano está voltado ao uso do espaço urbano, então a morte por atropelamento é a conseqüência de uma oferta de serviços de má qualidade. O cruzamento destes parâmetros (densidade, transporte, oferta de espaço e morte) elegeu a região Leste como a região crítica do Município de São Paulo. A seguir foram obtidas as instalações com complexidade no trânsito para pedestres, detectadas pela Companhia de Engenharia de Trânsito de São Paulo, situados nas proximidades dos "Pontos de Articulação". A estas instalações foram aplicadas, as metodologias preconizadas pela HCM 2000, para cálculo do Nível de Serviço, e levantadas as pesquisas qualitativas sobre a satisfação do usuário destas instalações para pedestres. A metodologia HCM 2000 foi apresentada no capítulo IV. As instalações foram observadas "in loco", analisado o seu entorno e levantados as dimensões das instalações.As contagens de número de pedestres e indicação do horário de pico foram levantadas pela Companhia de Engenharia de Trânsito, e atualizados pela autora. A seguir foram determinados os Níveis de Serviço, teoricamente, com a aplicação da metodologia, para cada instalação e elaborado suas análises. Das instalações 
pesquisadas, no horário de pico, todos os viadutos e pontes estão com nível de serviço $\mathrm{E}$ ou F, caracterizando um dimensionamento não compatível com a demanda de pedestres, colocando-os em risco na sua jornada. Sendo transposições de grandes avenidas ou do rio Tietê, estes pedestres não têm outra opção de travessia, à menos que uma nova possibilidade de travessia, exclusiva para pedestres seja instalado, salvaguardando a segurança e integridade dos pedestres. Das travessias de pedestres analisadas $50 \%$ operam no nível D e outros $50 \%$ em nível F, o que caracteriza um mal serviço, isto é, os pedestres têm de esperar muito tempo para poder atravessar a via e assim há acumulação de pedestres na calçada, incentivando pedestres a transgredirem as regras de trânsito, tais como, atravessar fora da faixa, atravessar correndo quando houver brecha entre os veículos e o semáforo ainda não abriu para os pedestres, atravessar correndo para aproveitar o último segundo do semáforo, etc. Os cruzamentos apresentam uma característica interessante. Dos cruzamentos analisados 34\% apresentam níveis de serviços $\mathrm{A}$ e $\mathrm{B}$, o que representam estar com bom dimensionamento para os pedestres. Porém, são cruzamentos considerados preocupantes do ponto de vista da operação viária, devido a acidentes entre veículos e até alguns atropelamentos, devido a alta velocidade desenvolvida pelos veículos e pela desobediência aos sinais semafóricos por parte dos motoristas. Os restantes $66 \%$ operam com níveis de serviço $\mathrm{E}$ e $\mathrm{F}$, o que é considerado crítico, induzindo os pedestres a comportamentos de desobediência às regras de trânsito. Paralelamente à determinação dos Níveis de Serviço foram entrevistados os usuários dessas instalações, em amostragem, para avaliação do nível de satisfação dos pedestres em relação às instalações em questão. 
Em princípio, o perfil do usuário destas instalações é a de uma pessoa que trabalha nas proximidades, há um ou dois anos. Usa intensamente a instalação e é crítico quanto à sua qualidade. A opinião sobre os pedestres e motoristas dos veículos, dada pelos usuários dos cruzamentos é de que há um grande desrespeito à sinalização pelo semáforo, comportamento diferente observado pelos usuários das travessias de pedestres, que acreditam mais na obediência à sinalização do semáforo.

As instalações são utilizadas por muitos pedestres portadores de volumes pesados e alguns empurram carrinhos, outros pedalam bicicletas entre os pedestres, por não se sentirem seguros circulando nas vias. Estes segmentos de pedestres diminuem a fluidez e o tempo no caminhar. Apesar de serem mais observados nos viadutos e pontes, também são comuns as suas presenças nas calçadas de vias. As irritações devido às suas presenças aparentam não terem maiores conseqüências além de alguns impropérios.

É importante observar que as análises dos Níveis de Serviço das instalações não prescindem de uma análise de observação local, nem uma consulta aos usuários da instalação. Das observações no local e depoimentos dos usuários elaborou-se algumas recomendações básicas:

- As poças d'água, nos viadutos e pontes e as árvores frondosas nos canteiros centrais das travessias são interferências ambientais que podem ser manejados a baixo custo e rapidamente.

- A iluminação nas travessias deve ser melhorada, colocando-a abaixo das copas das árvores, para não ocorrer o sombreamento nas travessias.

- Reforço na pintura das faixas de travessias é uma medida que demanda certa programação orçamentária, mas é factível. 
- As melhorias nas calçadas fazem parte de um programa da municipalidade. Este programa foi relatado no capítulo II, desta tese. Caberia às subprefeituras uma intensa fiscalização no cumprimento das regras de calçamentos.

- Reprogramar os tempos de semáforos para privilegiar a travessia dos pedestres é a reivindicação constante dos pedestres entrevistados. Se não for viável, por afetar a fluidez do sistema viário, então é caso de estudar as possibilidades de se instalar travessias aéreas (passarelas) ou subterrâneas. A instalação de "marcador de tempo" para o pedestre é factível, dependendo da programação orçamentária.

- A fiscalização por agente de trânsito e o policiamento ostensivo parece ser uma solução desejada por todos, mas está sujeita à estratégia das corporações e sofre as limitações de seu contingente. Mas não deve ser descartada a sua atuação mais intensa, mesmo em sistema de rodízio temporários, por instalações.

- A viabilidade de implantação de "lombadas eletrônicas", radares e semáforos inteligentes podem ser estudados e, se viável, serem orçadas e programadas as suas instalações.

- Os cruzamentos devem passar por uma reciclagem de caráter mais amplo, incluindo outras instalações ao redor, e solucionado sua funcionalidade, principalmente, nos cruzamento com semáforo de três fases. Das travessias e cruzamentos analisados e na consulta à população usuária a condição mais desfavorável à segurança do pedestre são as operações semafóricas em três fases, pois não há suficiente instrução ou sinalização tanto aos pedestres como aos motoristas, o que os levam a cometerem transgressões às regras de trânsito.

- O alargamento das calçadas de viadutos e pontes, assim como o alargamento das avenidas são sugestões de difícil execução, pois envolve o remanejamento de todo o sistema urbano da região. 
- A melhoria do transporte público é a meta e desafio de todos os prefeitos. Tendo esta solução os transportes individuais serão reduzidos e a qualidade de vida, sem dúvida, será melhor para todos, principalmente para os pedestres.

No contexto total das instalações analisadas, no horário de pico, 6\% operam com nível de serviço A e outros 6\% em nível $\mathrm{B}, 13 \%$ em nível D, 31\% em nível $\mathrm{E}$ e, finalmente 44\% em nível F. Como estas instalações estão próximas dos "Pontos de Articulação" observados, as premissas destes "Pontos" estão confirmadas, pois realmente há demanda de pessoas, ao ponto de haver saturação em muitas das instalações,

necessitando de novas intervenções urbanas, sejam com características de equipamentos urbanos, sistema viários ou com operação de transporte urbano.

\section{Gráfico V-2 NS das Instalações para Pedestres próximos dos "Pontos de Articulação”.}

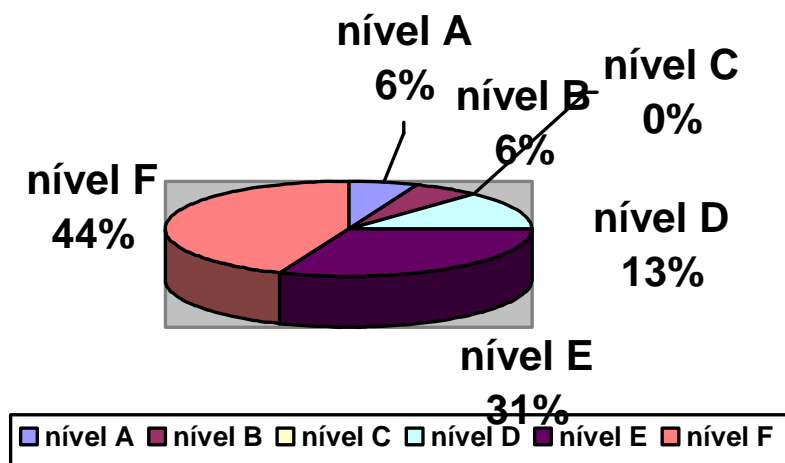

Os Níveis de Serviço das instalações de pedestres, juntamente com observações no campo e pesquisa de opinião do usuário, formam juntos Parâmetros para Qualificar o Ambiente Urbano na Escala do Pedestre. Esta Escala deve ser considerado na elaboração de um projeto ou planejamento urbano. 


\section{BIBLIOGRAFIA REFERENCIADA}

CET. "Mortes em Acidentes de Trânsito no Município de São Paulo". Companhia de Engenharia de Tráfego. São Paulo. 2006.

CET. "Perfil da Gerência. Visual GET-3". Companhia de Engenharia de Tráfego. São Paulo. 2004.

CET. "Morte de Idosos por Atropelamento: uma proposta de educação para segurança da Terceira Idade no trânsito”. São Paulo.1994.

CET. "Pesquisa de Trânsito: Pedestres, de 1997 à 2005". Gerência de Planejamento e Pesquisa. Companhia de Engenharia de trânsito. São Paulo. 2005.

DIMENSTEIN, Gilberto. "Ações da SEBRAE na Zona Leste”. Disponível na Folha On Line de 03/06/2005. Acessado em 15/03/2006.

NIGRIELLO, Andreina. "Pontos de Articulação". Revista ANTP. São Paulo. 2002.

NIGRIELLO, Andreina. "Estudo para Identificação dos Pontos de Rede na RMSP". Relatório. Cia do Metropolitano de São Paulo. São Paulo. 1999.

PRO-AIM. "Mortalidade no Município de São Paulo”. Prefeitura de São Paulo. 2005.

USP LESTE. Disponível em www.uspleste.usp.br, 30/08/2004. Acessado em $15 / 03 / 2006$. 
PEDESTRE:

MODALIDADE DE TRANSPORTE NA CIDADE UMA VISÃO ERGONÔMICA
Capítulo V

Avaliação de Nível de Serviço e Adequação Ergonômica das Instalações para Pedestres na Cidade de São Paulo 


\section{BIBLIOGRAFIA}

ABATE, Tânia Piestzschke. "Ergonomia da Criança. Aspectos ergonômicos da criança e o projeto da pré-escola no Estado de São Paulo”. Dissertação de Mestrado. FAUUSP.2004.

ABCP. "Galeria de fotos". 2005. Disponível em www.abcp.org.br. Acessado em 15/02/2006.

ABNT. "Acessibilidade de pessoas portadoras de deficiência a edificações, espaço, mobiliário e equipamento urbano”. NBR 9050. Set. 2004.

ABNT. "Acessibilidade à pessoa portadora de deficiência em ônibus e trolebus, para atendimento urbano e intermunicipal”. NBR 14022. Dez 1997 / 2006.

ABRASPE. “Manual de Orientação do Pedestre”. São Paulo. 1998.

ALEXANDER, Christopher. "Tres aspectos de matematica y diseño y la estrutura del medio ambiente”. Barcelona.1980

ALMEIDA, Marco Antonio Ramos. "São Paulo, o Grande Negócio”. Revista URBS n³9. Dezembro2005/Janeiro2006.

ANGELO, Cléon. “Accessibilité des voires”. ANLH asbl.Paris .1999.

ARGAN, Giulio Carlo. “A História da Arte como História da Cidade”. São Paulo. Martins Fontes. 1993.

BACHELARD, Gaston. “A Poética do Espaço”. Rio de Janeiro.

BENJAMIN, Walter. "Passage”. Editions du Seuil. Paris. 1987.

BHTRANS."Manual de Medidas Moderadoras do Tráfego”. Disponível em www.bhtrans.pbh.gov.br. Acessado em janeiro/2006.

BOUERI, Jorge.“Antropometria Aplicada à Arquitetura, Urbanismo e Desenho Industrial”. FAUUSP. São Paulo. 1999.

CET. "Boletim Técnico nº 8, 17,19 -Áreas de Pedestres”. Companhia de Engenharia de Trânsito. São Paulo.1978.

CET. "Morte de Idosos por Atropelamento: uma proposta de educação para segurança da Terceira Idade no Trânsito”. Companhia de Engenharia de Trânsito. São Paulo. 1994.

CET. "Fatos e Estatísticas de Acidentes de Trânsito em São Paulo". Companhia de Engenharia de Trânsito. São Paulo. 2000. 
CET- SP. "Manual de Sinalização Urbana - Semafórica”. Companhia de Engenharia de Trânsito. São Paulo. 2001.

CET. "Perfil da Gerência. Visual GET 3". Companhia de Engenharia de Trânsito. São Paulo. 2004.

CET. "Pesquisa de Trânsito: Pedestres, de 1997 à 2005”. Gerência de Planejamento e Pesquisa. Companhia de Engenharia de Trânsito. São Paulo. 2005.

CET. "Mortes em Acidentes de Trânsito no Município de São Paulo”. Companhia de Engenharia de Trânsito. São Paulo. 2005.

CHILDE, Gordon. “O que aconteceu na história”. Ed. Zahar.São Paulo. 1966.

COLMEIA. “Repensando a Vila Olímpia”. Movimento Colméia. São Paulo. 2003.

CONTRAN-DENATRAN. “Manual de Segurança de Pedestres”. 1979.

CRONEY, John.“Anthropometrics for Desingers”.B.T. Batford. London. 1971.

CTB. “Código de Trânsito Brasileiro”. Diário Oficial da União. Imprensa Nacional. Brasília D. F. 1997.

CUCCI NETO, João. “Aplicação da Engenharia de Tráfego na Segurança dos Pedestres”. CET. 1996.

CULLEN, Gordon. “A paisagem urbana”. Lisboa Edições. 1983.

CZAJA, Sara J. "Human Factors Research Needs for an Aging Population”. National Research Council. Washington D. C. 1990.

DAROS, Eduardo José. "O risco de atropelamento”. Maio/2004. Disponível em www.pedestres.org.br/imagesconteudo/risco_de_atropelamento. Acessado em setembro/2005.

DETRAN. “Curiosidades”. 2004. Disponível em www.detran.sp.gov.br. Acessado em setembro/2005.

DIMENSTEIN, Gilberto. “Ações da SEBRAE na Zona Leste”. Disponível na Folha On Line de 03/06/2005. Acessado em 15/03/2006.

DOTTA, Atico. “O condutor defensivo”. Ed Sagra. Porto Alegre.1998.

DREYFUSS, Henry. “The Measure of Man and Woman”. New York. 1993.

ENCICLOPEDIA BRITANICA.”Micropedia volume I”. 1973.

EPM. "Curso de Pediatria. O crescimento da criança”. Disponível em www.virtual.epm.br/material/tis.2003. Acessado em 9/2/2006. 
FERRARA, Lucrecia D’Allésio. “Os Significados Urbanos”. Edusp. 2000.

FERRARA, Lucrecia D’Allésio. “Ver a Cidade”. Nobel. 1988.

FORBES, T. W. “Human Factors in Highway Traffic Safety Research”.NY.1972.

FRANCO, Maria de Assunção Ribeiro. “Desenho Ambiental”.

FRANÇOSO, Lucimar Aparecida. "Avaliação das Sequelas e suas Repercussões Sociais em Adolescentes Vítimas de Acidentes de Trânsito”. Dissertação de Mestrado. Escola de Medicina da Santa Casa da Misericórdia. 2004.

FRUIN, John J. “Pedestrian-Planning and Design”. New York. DC. 1971.

GRANDJEAN, Etienne. “Fitting the Task to the Man”. London. 1980.

GREVE, Júlia Maria D’Andréa . “Acidentes nas Calçadas”. Revista ABRAMET, Ano XXIV, número 47. 2006.

GUIA MAIS. “Guia de Ruas do Município de São Paulo!. TPI. 2005.

HALL, Edward T. “A Dimensão Oculta”. Rio de Janeiro. 1966.

HUNT, JOHN. "Crossing the road: a method of assessing pedestrian crossing difficuty”. Traffic Engineering+Cccontrol. November 1993.

IBGE. “Síntese dos Indicadores Sociais-2002”. 2003. Disponível em www.ibge.gov.br. Acessado em setembro/2005.

IIDA, Itiro. “Ergonomia. Projeto e Produção”. Ed. Blucher. São Paulo. 1990.

IPEA. "Impactos Sociais e Econômicos dos Acidentes de Trânsito nas Aglomerações Urbanas”. Brasília. Junho. 2003.

JACOBS, Jane. “Morte e vida de grandes cidades”. Ed. Martins Fontes. 2000.

KELLY, P.L.; KROEMER, K.H. E. "Anthropometry of the Elderly: Status and Recommendations”. The Journal of Human Factors, 32(5). 1990.

LAUX, Lila. “Aging Techniques”. U.S. West Technologies. Washington D.C. 1996.

LE CORBUSIER. “Carta de Atenas / Le Corbusier”. Hucitec. São Paulo. 1993.

LYNCH, Kevin. “Buena Forma de la Ciudad”. Editora Gili. Barcelona. 1985.

LOGIT. “Centro Acessível”. Associação Viva o Centro. São Paulo. 1993. 
MCCOY,G.F.; JOHNSTONE,R.A; DUTHIE,R. B. "Injury to the Elderly in Road Traffic Accidents”. The Journal of Trauma, vol 29. USA. 1989.

MELHEN, J. "Projeto Passeio Livre”. Fórum Paulistano de Passeio Livre. São Paulo.Maio. 2005.

MELLO, José Carlos. “Planejamento dos Transportes”. Mc Graw-Hill. S. P. 1975.

METRO. "Síntese das Informações Domiciliar e Linha de Contorno. Pesquisa O/D/1997” . Companhia do Metropolitano.São Paulo.1999.

MINAYO-GOMEZ, Carlos. "Crianças e adolescentes trabalhadores: um compromisso para a saúde coletiva”. Caderno da Saúde Pública. 1997. Disponível em http://www.scielo.br. Acessado e, 9/02/2006.

MINAYO, Maria Cecília de Souza. "Violência contra idosos”. Revista Ciência \& Saúde Coletiva. Ministério da Justiça. Brasília. 2005.

MISLEH, Soraia. “Subsolo carece de Mapa Unificado”. Jornal do Engenheiro. Fevereiro. 2006.

NIGRIELLO, Andreina. “Pontos de Articulação”. Revista ANTP. São Paulo. 2002.

NIGRIELLO, Andreina. “Estudo para Identificação dos Pontos de Rede na RMSP”. Relatório. Companhia do Metropolitano de São Paulo. São Paulo. 1999.

PANERO, Julius; ZELNIK, Martin. "Human Dimension \& Interior Space”. Whitney Library of Design. London. 1979.

PLANEJAMENTO, Secretaria Municipal. "Dados Sócio-Econômicos”. Prefeitura Municipal de São Paulo. Disponível em www.prefeitura.sp.gov.br. Acessado em novembro/2005.

PRO-AIM. “Mortalidade no Município de São Paulo”. Prefeitura de São Paulo. 2005.

PULIDO, Francisco. "La reconstrucción de accidentes de tránsito enfocada a los peatones”. II Seminário de Seguridad Vial. Colombia. 2001.

PUSHKAREV, B; ZUPAN, J. “Urban Space for Pedestrian”. MIT Press. 1975.

ROBIN, Jacques. “La sécurité de l’ enfant à biciclette”. INPSE. France.2005.

RUANO, Miguel. "Ecourbanism, Sustainable Human Settlements: 60 case studies" Ed Gustavo Gili. Barcelona. 1999.

SÃO PAULO, Prefeitura Municipal. “Decreto $n^{\circ}$ 45.904/2005”. Diário Oficial do Município. São Paulo. Maio. 2005. 
SÃO PAULO, Prefeitura Municipal. "Programa Passeio Livre”. 2005. Disponível em http://portal.prefeitura.sp.gov.br. Acessado em 15/02/2006.

SAKAGUCHI, Maria Akemi. "Da medicina ao urbanismo, as origens do primado da mobilidade”. Dissertação de Mestrado. FAUUSP. 1998.

SANTOS, Milton. “A natureza do espaço. Técnica e Tempo, Razão e Emoção”. São Paulo. HUCITEC. 1996.

SANTOS, Milton. “Pensando o espaço do homem”. São Paulo. HUCITEC. 1996.

SANTOS, Prefeitura Municipal. "História e Lenda de Santos”. 2004. Disponível em http://www.novomilenio.inf.br/santos/h0264.htm. Acessado em 17/02/2006.

SEADE. "Demografia. Município de São Paulo.2004”. Fundação Sistema Estadual de Análise de Dados. Disponível em www.seade.gov.br/produtos. Acessado em novembro/2005

SERRA, Geraldo. “O Espaço Natural e a Forma Urbana”. Nobel.

SCHERRER, J. “Physioligie du Travail”. Masson \& C Editeurs. Paris. 1967.

SCHNEIDER, Bernard; ROBIN, Jacques. "L' enfant dans la rue”. Paris. 2003.

SILVA, Paulo. “Calçado para Crianças”. 2005. Disponível em http://calcadodesportivo.no.sapo.pt. Acessado em 9/02/2006.

TILLEY, Alvin R. “The measure of man and woman”. Human Factors in Design. 1993.

TRANSPORTATION, Research Board. "HCM 2000”. National Research Council Washington, D.C.2000

TUAN, Yi-Fu. "Espaço e Lugar. A perspectiva da experiência”. S. P. DIFEL 1983

UFSM, Engenharia de Segurança do Trabalho. "Levantamento de riscos no trânsito de veículos e pedestres”. Revista CIPA. São Paulo. 1993.

USP LESTE. Disponível em www.uspleste.usp.br, 30/08/2004. Acessado em 15/03/2006.

VIANNA, Edison de Oliveira. "Passeios, calçadas e infra-estrutura para o tráfego de pedestres em São Paulo”. FAUUSP. 2001.

WAKSMAN, Renata Dejtiar. "Caracterísitcas epidemiológicas dos acidentes fatais de transporte em menores de quinze anos, São Paulo, setembro de 1990 a agosto de 1991”.Tese. Faculdade de Medicina USP. São Paulo. 1995

YABIKU, Luiza. “O Pedestre”. Apostila do curso de Capacitação para Médicos Peritos Examinadores. ABRAMET. São Paulo. 1999. 
YABIKU, Luiza. "Os motoristas da Terceira Idade e as Condições Não Amigáveis da Direção Veicular. O caso dos motoristas de terceira idade na cidade de São Paulo”. Dissertação de Mestrado. FAUUSP. 2000.

YAZIGI, Eduardo. “O mundo das calçadas”. Tese de Doutorado.USP. 2001. 